UNIVERSIDAD DE SALAMANCA - USAL

Facultad de Filología

Departamento de Lengua Española

Doctorado en Cuestiones de Lengua, Sociolingüística y Crítica

Textual Españolas/Curso: 2004-12

\title{
EL DISCURSO PUBLICITARIO EN EL TURISMO
}




\section{EL DISCURSO PUBLICITARIO EN EL TURISMO}

Tesis presentada al Departamento de Lengua Española de la Facultad de Filología de la Universidad de Salamanca como instrumento parcial para la conclusión del curso de Doctorado en Cuestiones de Lengua, Sociolinguiística y Crítica Textual Españolas en su Contexto Histórico y Filológico y, por consiguiente, la obtención del título de doctor.

Directores: Dra ${ }^{\text {. }}$ Mercedes Marcos Sánchez

Dr. Javier de Santiago Guervós 
DEDICATORIA

A mi familia 


\section{AGRADECIMIENTOS}

El matiz del color con el que se imprimió esta tesis ha sido logrado por medio de la mezcla de mucho sacrificio, trabajo, esfuerzo, dedicación, persistencia y constancia. Corresponde al color de mis ideas y de una gran lucha a favor de mis ideales. Por eso, concluir esta tesis doctoral es todo un reto para mi vida personal y profesional. Agradezco grandemente a todos los que creyeron en mis ideas, han luchado por lo que he creído y que contribuyeron para que eso se concretara como una realidad: a Dios, por ser la gran diferencia en mi historia de vida; a mi familia, por apoyarme en mis estudios; a mi directora, Doctora Mercedes Marcos Sánchez, por acompañarme e instruirme sabiamente desde la génesis de este trabajo en 2005; a mi director, Doctor Javier de Santiago Guervós, por la atención y empeño desde que comenzó a codirigir este trabajo en 2009; a Lourdes, cuyas clases de informática me han ayudado bastante; a la Universidad de Salamanca (USAL); al Departamento de Lengua Española de la Facultad de Filología de la USAL, especialmente a Dr. Bartol Hernández; a la Universidade do Estado do Rio Grande do Norte (UERN); al Departamento de Letras Extranjeras de la UERN; al gran intelectual y eterno profesor Manuel Gilson de Almeida de la Faculdade de Letras de la UERN; al departamento, a los profesores y a los alumnos del curso de turismo del Campus Avançado de la UERN en Natal; a la Blumen serviços editoriais, especialmente, a Anacyara, Cristina, Rodrigo y Vinícius; a la Secretaria Estadual de Turismo do RN (SETUR); a todos del Colegio Mayor Inés Luna Terrero; a Celia, por la amistad y la dedicación en la revisión de esta tesis doctoral; a mis grandes amigas Elaíne y Jéssica por apoyarme y animarme cuando más lo necesité; a mis amigos Hilda, Mineko, Virginia, Juan Gregorio, David Castillo, Sonia, Solange y Shu, que me acompañaron y me apoyaron, durante la elaboración de este trabajo; a Ana Kočman, mi amiga y compañera de doctorado, por inspirarme con su ejemplo de empeño y dedicación a los estudios. En fin, mil gracias a todos los que, directa o indirectamente, me ayudaron a alcanzar este sueño. 
"Chega mais perto e contempla as palavras.

Cada uma

tem mil faces secretas sob a face neutra

e te pergunta, sem interesse pela resposta,

pobre ou terrível, que lhe deres:

Trouxeste a chave?"

(Carlos Drummond de Andrade) 


\section{RESUMEN}

La sociedad moderna disfruta del llamado bienestar social que modificó las costumbres contemporáneas. La publicidad y el turismo son productos de ese estado social y económico, tienen orígenes históricos muy semejantes, además, juegan un papel muy importante en la sociedad de nuestro tiempo. La lingüística textual también es un evento contemporáneo y el análisis de los textos publicitarios desde el punto de vista de la lingüística ganó cada vez más relieve en los últimos años. Tomando esto como base, este estudio tiene como objetivo buscar una intersección entre el turismo, la publicidad y la lingüística textual, además de identificar características textuales que clasifiquen el texto publicitario o su nivel de "publicitariedad". Para la realización de este trabajo, además de una investigación bibliográfica y documental, fue adoptado el estudio de caso como forma principal de diseño metodológico. Los resultados evidenciaron que es factible relacionar los campos de conocimientos del turismo, la publicidad y la linguiística textual, también corroboraron que hay características inherentes al discurso publicitario, como el carácter expresivo (todo lo que se refiere al uso del lenguaje); el carácter comunicativo (todo que particulariza la comunicación en la publicidad); el carácter retórico (todo lo que se refiere a la perpetuación de la retórica en el texto publicitario); el carácter persuasivo (lo publicitario como un discurso fundamentalmente persuasivo); y, por último, el carácter pragmático (las cuestiones pragmáticas que permean la publicidad). Esas características sirven para caracterizar y particularizar el discurso publicitario, lo que a la vez le distingue de otros tipos discursivos. Por último, es importante destacar que este trabajo tiene un carácter abierto para que pueda ser mejorado y/o ampliado por futuros investigadores a quienes les interese este tema.

Palabras clave: Lingüística textual, discurso escrito y discurso publicitario. 


\begin{abstract}
The modern society lives the called well been way of life that changes the contemporary habits. The advertisement and the truism are product of this type of society and its economy, all of that started by the same history facts, besides, have the same roll of importance in our society. Textual linguistics is also a contemporary event and publicity texts analyses in a linguistic point of view started to have even more importance in the latest years. Based on this, our thesis is about the similarity among truism industry, advertisement and text linguistics. We have tried to establish texts characteristics that identify an advertisement text and its level of "publicitarity". To finish this study we made a bibliographic and documents research, and we have adopt the design of case studies as methodology. Finally, some results show us up that is possible create a relation among tourism knowledge, advertisement and text linguistics and also that there are some characteristics of publicity discourse, like its expressive character (all about its usage of language); its communicative character (all things that make the publicity a particular act of communication); its rhetoric character (the rhetoric in publicity discourse); its persuasive character (the persuasion inside publicity discourse); and its pragmatic character (the pragmatic in publicity), that gives a particular character and distinguish a publicity text of others. It's important to tell that this research is open to other students and researchers to get it better and improve this type of researches in the future.
\end{abstract}

Key Words: Text Linguistics, write discourse and publicity discourse. 


\section{ÍNDICE}

CAPÍTULO I - INTRODUCCIÓN................................................................................. 11

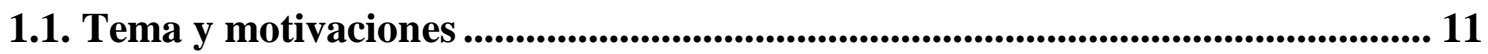

1.2. Antecedentes y cuadro referencial ............................................................................ 12

1.3. Problemas, objetivos e hipótesis .................................................................... 13

1.4. Viabilidad y originalidad .......................................................................................................... 16

1.5. Diseño metodológico ....................................................................................... 17

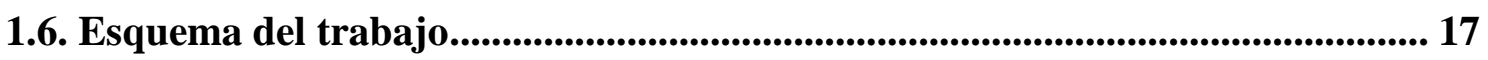

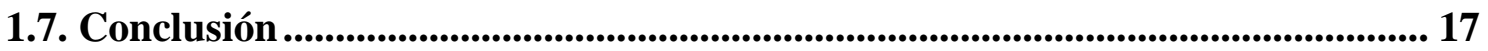

CAPÍTULO II - TURISMO, COMUNICACIÓN TURÍSTICA, PUBLICIDAD Y

LINGÜÍSTICA TEXTUAL: TEMAS CONVERGENTES........................................ 19

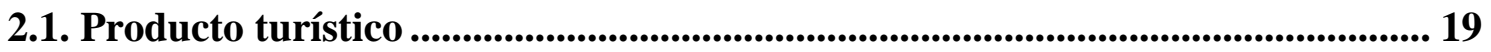

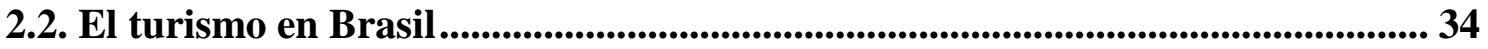

2.3. El turismo en Rio Grande do Norte .................................................................. 44

2.4. El marketing y la comunicación turística................................................................ 50

2.5. La comunicación turística y la publicidad ............................................................ 54

2.6. La comunicación turística y la lingüística textual ................................................. 63

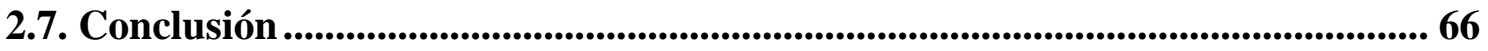

CAPÍTULO III - ESTUDIO DE CASO: EL CORPUS, LA METODOLOGÍA, EL DISEÑO Y LA TEORÍA DEL ACTO DE COMUNICACIÓN PUBLICITARIO 70

3.1. Metodología y diseño experimental .................................................................................. 70

3.2. Objetivos e hipótesis ....................................................................................... 75

3.3. Selección del corpus, recogida y tratamiento de los datos ............................... 76

3.4. Grado de innovación previsto.............................................................................................. 77

3.5. Plan de trabajo y cronograma................................................................................... 78

3.6. Investigación bibliográfica y documental...................................................... 78

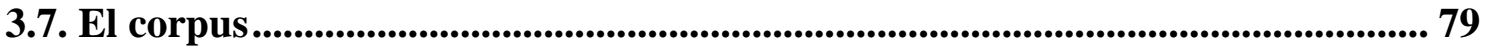




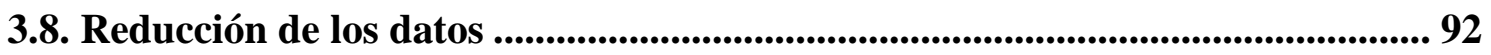

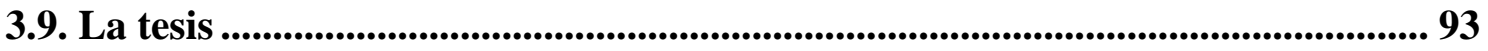

3.10. La teoría del acto de comunicación publicitario ........................................................ 94

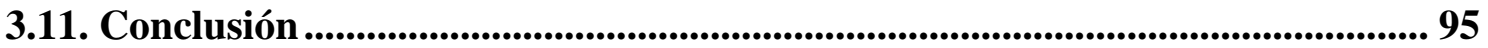

CAPÍTULO IV - PUBLICIDAD TURÍSTICA: UN ACTO DE COMUNICACIÓN

ESPECÍFICO ................................................................................................................... 98

4.1. La publicidad: conceptualización ........................................................................... 98

4.2. Publicidad y propaganda .............................................................................. 143

4.3. La palabra en la publicidad .................................................................... 153

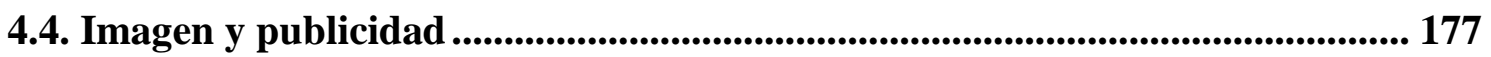

4.5. Lenguaje en la publicidad .......................................................................................... 186

4.6. El sistema comunicativo en la publicidad ..................................................... 219

4.7. El acto de habla en la publicidad ...................................................................... 229

4.8. Conclusión ................................................................................................................... 246

CAPÍTULO V - PUBLICIDAD TURÍSTICA: ASPECTOS RETÓRICOS.......... 248

5.1. La retórica y su definición ........................................................................................... 248

5.2. La retórica y sus orígenes históricos .......................................................................... 253

5.3. Retórica, discurso y persuasión ............................................................................... 258

5.4. La retórica en la publicidad............................................................................ 278

5.5. La publicidad y la literatura......................................................................................... 297

5.6. La persuasión publicitaria ............................................................................................. 311

5.7. La argumentación publicitaria.................................................................................... 383

CAPÍTULO VI - EL TEXTO PUBLICITARIO: ASPECTOS SEMIÓTICOS Y

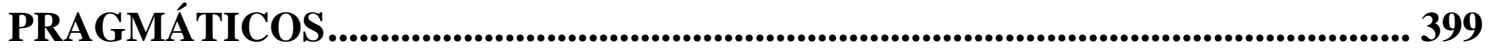

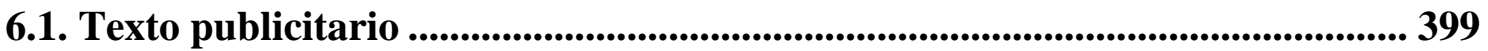

6.2. El eslogan en la publicidad .................................................................................................. 433

6.3. La publicidad: un texto híbrido .......................................................................440 
6.4. Semiótica y publicidad turística ............................................................................ 442

6.5. La imagen en la publicidad turística ....................................................................... 449

6.6. Publicidad turística: lenguaje escrito y visual ...................................................... 452

6.7. Publicidad y pragmática ..................................................................................................... 465

CAPÍTULO VII - CONCLUSIONES...................................................................... 474

7.1. La Publicidad Turística .............................................................................. 474

7.2. La disposición de capítulos ........................................................................ 477

7.3. Las cuestiones estudiadas....................................................................... 479

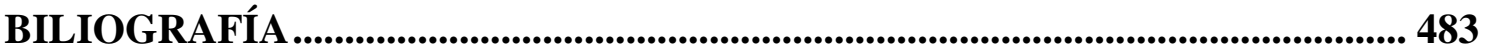

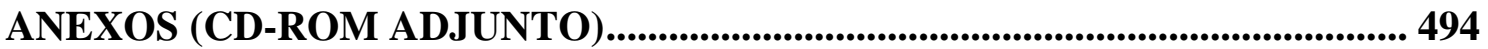




\section{Capítulo I}

\section{INTRODUCCIÓN}

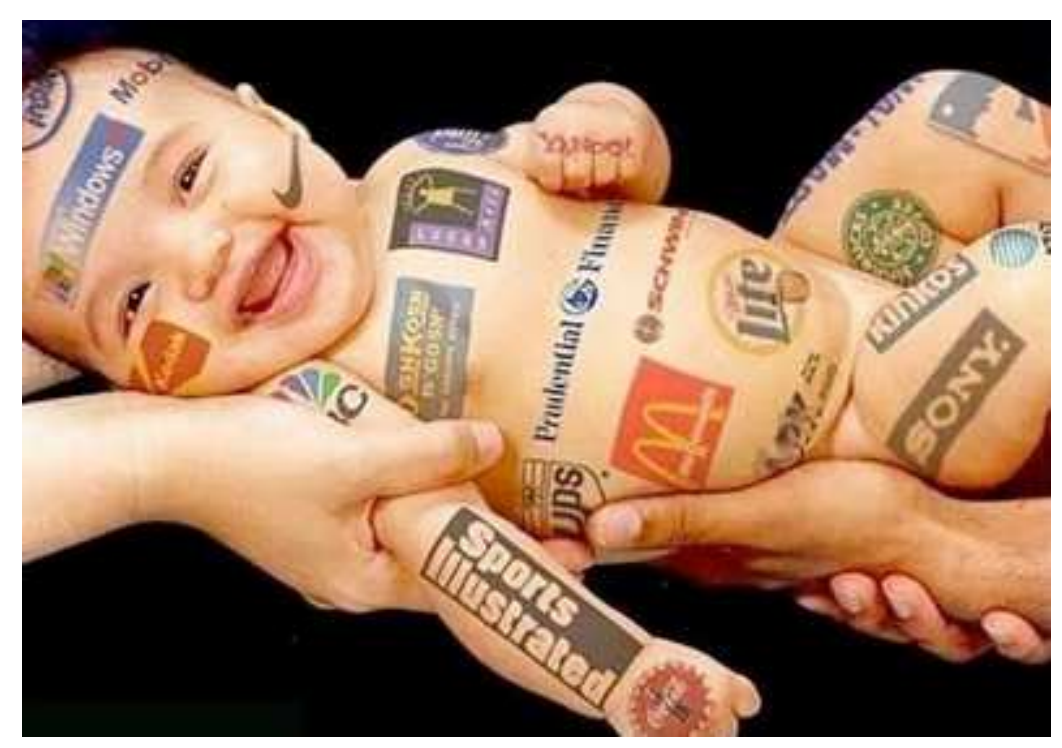

"Quien deja de hacer publicidad para ahorrar dinero, es como si parara el reloj para ahorrar el tiempo".

(Henry Ford) 


\section{CAPÍTULO I - INTRODUCCIÓN}

Este primer capítulo de nuestra investigación científica posee un carácter introductorio. Está dividido en siete apartados, a saber: tema y motivaciones; antecedentes del estudio y cuadro referencial; problemas, objetivos e hipótesis; viabilidad y originalidad del estudio; diseño metodológico; esquema del trabajo; y, por último, la conclusión. Trata, básicamente, de las cuestiones inherentes al tema elegido como objeto de estudio y de las motivaciones que subyacen a esa elección y a la elaboración de dicha investigación.

\subsection{Tema y motivaciones}

Con nuestro trabajo pretendemos aportar un instrumento útil para los estudiantes del lenguaje, especialmente para los que se dedican al análisis del discurso, más específicamente del discurso publicitario. De modo que elaboraremos un instrumento de estudio y registro para quienes se interesan por comprender los complejos mecanismos que subyacen al uso de la palabra y a los procesos de elaboración e interpretación de los enunciados en un texto escrito.

Esta investigación busca estudiar la publicidad turística, tomando como base el caso de la publicidad turística, escrita, distribuida por las agencias de viajes de Natal asociadas a la Asociación Brasileña de Agencias de Viaje (ABAV). Intenta, a través de ello, encontrar elementos comunes, en el corpus del estudio, que sirvan para identificar un texto publicitario y distinguirlo del texto literario y del no literario. En ese sentido se busca establecer el reconocimiento del discurso publicitario desde un abordaje lingüístico/textual.

Así, esta investigación se configura a partir de tres puntos que apoyan la relevancia de su realización, a saber: la importancia socioeconómica del segmento del turismo, la importancia de la publicidad para este sector económico y la importancia de los estudios lingüísticos sobre la publicidad en el contexto contemporáneo.

Se parte, para ello, de un análisis del contexto socioeconómico global y local en el que el turismo actúa como un factor de desarrollo económico. Basados en esa importancia 
de la industria del turismo se apoyan unos de los aspectos más relevantes de la realización de este trabajo.

Creemos, pues, que una de las grandes aportaciones de este trabajo reside en la invitación a los investigadores de la lingüística textual a estudiar la publicidad turística, además de invitar a los investigadores de cualquier campo de investigación a la elaboración de estudios interdisciplinarios que puedan estar relacionados con el desarrollo de algún aspecto de la sociedad a la que pertenecen. Y así, reforzamos esa invitación con nuestra creencia en la importancia de la realización de estudios sobre el lenguaje y la comunicación para cualquier sector, sea científico, social, político y económico de todos los países, incluso para el del turismo brasileño.

\subsection{Antecedentes y cuadro referencial}

Al empezar este trabajo de investigación en el año de 2004, no hemos encontrado ningún trabajo que trate de la publicidad turística desde un punto de vista de la lingüística. Tampoco hemos encontrado trabajos de investigación que estudien la publicidad turística de Natal. Por eso, en la elaboración de esta investigación no hemos podido adoptar ningún otro trabajo que trate del mismo tema como un parámetro para nuestro estudio.

La publicidad, enfocada desde una perspectiva lingüística o comunicativa, es tema de estudio de muchos investigadores. Hay diversos trabajos sobre el discurso publicitario que es tema de obras como La Argumentación Publicitaria: Retórica del Elogio y de la Persuasión (2000), de Adam \& Bonhomme; Lenguaje Publicitario (2005), de Juan de los Ángeles; Realce y Apelación en el Lenguaje de la Publicidad (2004) y Sintaxis Publicitaria (2005), ambos de Sara Robles Ávila; A Evolução do Texto Publicitário (1999) de João A. Carrascoza; Publicidade: A linguagem da Sedução (2000), de Nelly de Carvalho; Jogos Polissêmicos no Discurso Publicitário (2002), de Rosa Lídia Coimbra; entre otros.

En nuestra investigación, la publicidad será tratada como un acto de comunicación, en ese sentido, estamos de acuerdo con Sara Robles (2004:12) cuando dice que el discurso publicitario consiste en "un acto intencional producido por un emisor para lograr un fin 
predeterminado". Trataremos también de abordar una temática estrictamente linguíistica en esta investigación, como también lo defiende esta misma autora cuando trata en su obra los aspectos lingüísticos de la publicidad, prioritarios y distintivos, para ella, y que todavía no han sido exhaustivamente trabajados.

Sara Robles (2004) habla de las clases de palabras y las subdivide en los cuantificadores; los adjetivos; los artículos; los posesivos; los sustantivos; los verbos; los adverbios y las conjunciones. Además, dedica la segunda parte de su trabajo a los enunciados publicitarios de apelación y de realce, subdivididos en imperativos; exclamativos; desiderativos; interrogativos y enunciativos. También, en la tercera parte de su obra, trata de las estructuras sintácticas de apelación y realce, ordenadas en las estructuras nominales; la oración simple; la yuxtaposición; las oraciones coordinadas y la oración compleja.

Seguiremos, pues, el ejemplo de esta autora en el sentido de tratar el objeto de estudio de la publicidad desde una perspectiva lingüística, aunque consideramos necesario el desarrollo de trabajos de investigación sobre la publicidad que aborden más bien las características puramente textuales y pragmáticas y, en eso, nos distinguimos de la estudiosa mencionada anteriormente, que trata de elementos más bien gramaticales, estructurales y semióticos, como la mayoría de los investigadores de este campo de estudio.

\subsection{Problemas, objetivos e hipótesis}

El problema central de esta investigación gira en torno de las siguientes preguntas: ¿Hay elementos inherentes al discurso publicitario que determinan si un texto es publicitario o no? ¿Qué elementos textuales están presentes en todos o casi todos los textos publicitarios? ¿Hay alguna característica común en la publicidad que defina su grado de "publicitariedad" o que caracterice un texto publicitario como tal? Con esa finalidad se han planteado las siguientes cuestiones de estudio:

1- ¿Cuál es la importancia del turismo a nivel mundial y local?

2- ¿Cuáles son las especificidades de este producto?

3- ¿Cuáles son las particularidades de la industria del turismo? 
4- ¿Cuál es la importancia del marketing y de la comunicación para esa industria?

5- ¿Cómo se constituye la publicidad del producto turístico?

6- ¿Qué se comprende por publicidad?

7- ¿Qué importancia tiene la publicidad en el contexto contemporáneo?

8- ¿Cuáles son las especificidades de la publicidad desde un punto de vista lingüístico?

9- ¿Se pueden identificar elementos comunes a todos los textos publicitarios que los determinen como publicitarios y no como literario o no literario?

A partir de la formulación de esas preguntas/problemas el objetivo general de este trabajo se configura en: estudiar los elementos textuales presentes en la publicidad turística, tomando como punto de partida el caso de Natal, y con ello intentar identificar esos elementos que hacen que un texto publicitario sea caracterizado como tal. En función de ese objetivo general se derivan los objetivos específicos expuestos a continuación:

1- Contextualizar e identificar la importancia del turismo para Natal;

2- Evaluar la importancia del marketing y de la comunicación turística para la industria del turismo;

3- Configurar un modelo de estudio de la publicidad y sus especificidades desde una perspectiva lingüística.

4- Determinar los elementos textuales propios de la publicidad turística a partir del caso de Natal.

El estudio del caso de Natal fue elegido tomando como base la importancia que el producto turístico tiene para esta ciudad y cómo eso condiciona la producción de su publicidad turística y la delimitación de su público objetivo. Además de la necesidad de este tipo de estudio que, aunque posea un carácter puramente linguiístico, puede tener alguna aplicabilidad directa para esa sociedad.

El mayor interés por la composición de este estudio fue la necesidad de ampliación de la cantidad de estudios sobre la publicidad, desde una perspectiva puramente de la lingüística textual y, en especial, de la publicidad turística, como un elemento inherente a muchas sociedades que perciben parte de su facturación a través de esta industria. 
Además de la aplicabilidad lingüística de este trabajo, podremos contribuir, a partir de los estudios lingüísticos propuestos, al desarrollo de aportaciones como estas para el turismo en Natal. Esto corrobora aún más la importancia de dicho trabajo en el contexto actual, puesto que el turismo es uno de los sectores más dinámicos de la economía, ya que genera casi $10 \%$ del Producto Interior Bruto (PIB) mundial. A partir de ello, señalamos la importancia lingüística, social y económica que un trabajo como este puede tener, dado que pone en relieve las innovaciones en las humanidades con estudios interdisciplinarios, propuestos en el VIII (octavo) congreso internacional sobre el discurso artístico, realizado por la Universidad de Oviedo, en marzo de 2001.

Una investigación que tiene como objetivo estudiar las características fundamentales del discurso publicitario a partir del caso de Natal, más bien de la publicidad escrita de esta ciudad como destino turístico, contribuye a las investigaciones lingüísticas en el análisis del discurso escrito allí, hecho que se hace necesario en su actual proceso de desarrollo educativo, político, social y económico.

También, sirve para crear un corpus de investigación en publicidad turística de Natal. Así, contribuiremos al desarrollo del campo lingüístico, objeto de nuestro estudio, en el turismo de la capital del Rio Grande do Norte. Con eso, no desvirtuaremos el proyecto del gobierno brasileño para el desarrollo del turismo en Brasil, para que eso pueda mejorar la calidad de algunos sectores económicos y sociales del mayor país de América Latina.

Hemos partido, por un lado, de la hipótesis de que se puede relacionar la industria del turismo con la publicidad y, por otro, de que a partir del análisis del discurso publicitario del turismo se pueden establecer elementos que configuren un texto publicitario como tal, o sea, elementos que determinen lo que llamaremos de "publicitariedad".

Por lo tanto, esta investigación tiene como contexto la publicidad turística e intenta con ello establecer el nexo entre el turismo, la publicidad y la lingüística textual para estudiar los elementos propios de los textos publicitarios. Uno de los principales planteamientos de este estudio consiste en la búsqueda de informaciones sobre el 
fenómeno publicitario desde una perspectiva lingüística y, sobre todo, de las estrategias pragmáticas presentes en el acto de comunicación establecido en este tipo de publicidad.

\subsection{Viabilidad y originalidad}

Esta investigación se hace viable a partir del momento en que Natal pasa a ser un centro turístico en Brasil y hace campañas publicitarias para la promoción de su turismo a niveles nacional e internacional. También, porque el turismo necesita de la publicidad para vender sus productos. Frente a eso, podemos decir que esta investigación puede poseer una aplicabilidad social directa, ya que puede ser usada para el desarrollo de la publicidad para el turismo de allí.

Como ya hemos mencionado, no hemos encontrado ningún trabajo sobre el tema de la publicidad turística, ni tampoco respecto a la configuración de este tipo de texto, sus características fundamentales y distintivas. Quizás eso ocurra porque se trata de un campo de estudio interdisciplinario, que puede ser abordado desde la perspectiva de la administración como parte del marketing, desde un punto de la comunicación social o como un campo de la lingüística. Todo ello elucida aún más la importancia de la realización de esta investigación y le atribuye un carácter original, al mismo tiempo que justifica la elección del tema. Además de ser un trabajo pionero en el ámbito de Natal y en eso también reside su originalidad.

El carácter innovador de este estudio está en la creación de este campo de investigación en el municipio de Natal, además de trabajar aspectos de la lingüística textual y hacer un puente de esta área del conocimiento con el turismo y la publicidad. 


\subsection{Diseño metodológico}

La investigación empírica se caracteriza por poseer una naturaleza cualitativa de exploración y descriptiva, cuyo diseño metodológico consiste en el estudio de caso. El modelo de segmentación de la publicidad para su posterior análisis fue elaborado acorde con la investigación teórica de este estudio.

\subsection{Esquema del trabajo}

Este trabajo está estructurado en siete capítulos: el primero consiste en la introducción; el segundo es una revisión bibliográfica que sirve para establecer una convergencia temática entre el turismo, la comunicación turística, la publicidad y la lingüística textual; en el tercer capítulo abordamos la metodología, el diseño del estudio y $L a$ Teoría del Acto de Habla Publicitario; ya el cuarto, el quinto y el sexto capítulos consisten en el análisis de los datos a partir de la óptica de la publicidad como un acto de comunicación, de los aspectos retóricos de la publicidad, además de la semiótica y la pragmática en los textos publicitarios; por último, en el séptimo capítulo presentamos las conclusiones de nuestro estudio.

\subsection{Conclusión}

A partir de este capítulo se busca cumplir el objetivo de presentar de modo general el trabajo que nos hemos propuesto llevar a cabo. También se pretende justificar la necesidad de la existencia del siguiente capítulo que tratará del turismo y su relación con la comunicación turística, la publicidad y la lingüística textual. Con ello intentamos evitar cualquier incongruencia textual o temática, además de defender que se pueden relacionar estos campos de estudio en la elaboración de una investigación de carácter puramente lingüístico. 


\section{Capítulo II}

\section{TURISMO, COMUNICACIÓN TURÍSTICA, PUBLICIDAD Y LINGÜÍSTICA TEXTUAL: TEMAS CONVERGENTES}

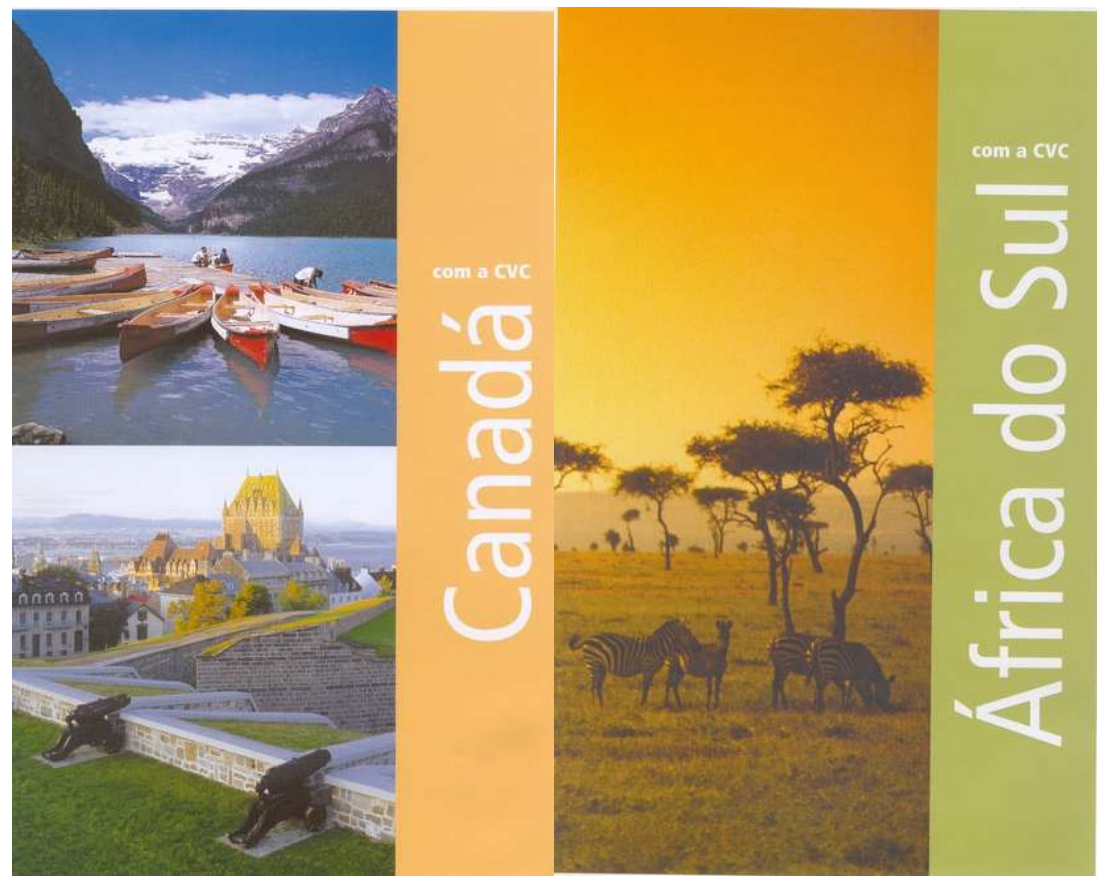

"La propaganda turística divulga un producto de consumo inmaterial. La realización de un viaje turístico constituye una experiencia, la realización de un sueño - aspectos subjetivos, cuya intensidad varía de acuerdo con las motivaciones del comportamiento turístico".

(Meene Ruschmann) 


\section{CAPÍTULO II - TURISMO, COMUNICACIÓN TURÍSTICA, PUBLICIDAD Y LINGÜÍSTICA TEXTUAL: TEMAS CONVERGENTES}

El segundo capítulo de nuestro estudio tiene como objetivo establecer las especificidades del producto turístico y mostrar que eso condiciona la producción de la publicidad turística. También defiende la industria del turismo como un elemento de desarrollo socioeconómico en Natal y muestra cómo esa industria puede estar relacionada con el Marketing turístico, con la publicidad y con el análisis del discurso publicitario. Para ello trata cuestiones como la definición del producto turístico, su especificidad y su marketing. Por último presenta cuestiones como la publicidad turística y su análisis según las leyes de la lingüística, más específicamente, el análisis del discurso publicitario.

\subsection{Producto turístico}

Para la realización de un estudio sobre la publicidad turística hace falta, a priori, elaborar una configuración del producto turístico y de todos los elementos que forman parte de esta industria, puesto que el turismo no es un bien industrializado y eso condiciona la elaboración de su publicidad. Así que para el estudio de la publicidad turística es fundamental tener en cuenta lo que expondremos a continuación.

Una de las actividades de mayor crecimiento en el planeta es el turismo. Este sector crece $2,7 \%$ en 2002, trasladándose 714,6 millones de turistas por los cinco continentes. Para un $40 \%$ de los países, las actividades turísticas constituyen la principal fuente de divisas. El capital gastado por los visitantes entra en las cuentas de la nación (en la balanza de servicios) como resultados de la exportación de bienes.

El turismo es un objeto de estudio multidisciplinar y todavía no se ha configurado como una disciplina autónoma con una dinámica propia. En los estudios en el campo del turismo varias disciplinas como la lingüística, la psicología, la antropología, la sociología, la economía, la administración, la geografía, el derecho, la educación, la estadística, las nuevas tecnologías, la ecología, la arquitectura, la ingeniería, la gastronomía, etc. pueden estar relacionadas directa o indirectamente. Así, "el turismo no es una ciencia social entendida como cuerpo de doctrina metódicamente ordenado [...] 
constituye una disciplina en desarrollo que emplea métodos y conceptos de la mayoría de las ciencias sociales ya consolidadas" (Maneti Dencker, 2003:28). Desde este punto de vista, el turismo sigue la tendencia actual del abordaje interdisciplinar y multidisciplinar en casi todos los campos del conocimiento. Para Álvarez Valdés (2003:13):

\begin{abstract}
El sector del turismo resume en sí mismo la gran evolución económica y sociocultural que se hace presente en el mundo actual. Su impacto en el desarrollo de la humanidad llega más allá de su papel dinamizador de las economías, pues representa un componente catalizador de la globalización, en el ámbito de la cultura y del intercambio entre la población de cualquier latitud.
\end{abstract}

En las palabras de Maneti Dencker (2003:184), el producto turístico "es el conjunto de bienes y servicios que se ofrecen al mercado para un confort material y espiritual del turista”. En este sentido se configura como un producto bastante complejo, ya que no se trata de un bien industrializado y del comercio, además, se distingue de los otros tipos de servicios puesto que se trata de un producto intangible, como menciona Meene Ruschmann (1999:11) cuando dice que:

\begin{abstract}
El producto turístico está compuesto por un conjunto de bienes y servicios unido por relaciones de interacción e interdependencia que le tornan extremamente complejo. Sus singularidades le distinguen de los bienes industrializados y del comercio, como también de los demás tipos de servicios. Una de sus características más destacadas es que se trata de un producto inmaterial - intangible - cuyo residuo, después del uso, es una experiencia vivencial. ${ }^{1}$
\end{abstract}

Al referirse a las grandes transformaciones en la sociedad contemporánea y a la dinamicidad del turismo en esa sociedad, Álvarez Valdés (2003:26) dice que "se vive en tiempos de transición, en los cuales lo que hoy sirve y es consumido, mañana ya se volverá obsoleto, no atendiendo, por lo tanto, a las necesidades que originalmente satisfacían".

Y como en el mundo contemporáneo el turismo asume un papel preponderante en las actividades económicas y sociales, "el estudio del turismo es de fundamental importancia en función del papel económico y social que las actividades ligadas al ocio

\footnotetext{
${ }^{1}$ Traducción de la autora.
} 
y al turismo vienen asumiendo en el mundo contemporáneo" (Maneti Dencker, $2003: 22)^{2}$

Una vez establecida la configuración del producto turístico, proponemos una visión diacrónica del origen y desarrollo de la industria turística en el occidente y con ello esperamos comprender mejor este producto y la elaboración de su publicidad.

\title{
El turismo y su legado histórico
}

Se puede decir que el origen de la actividad turística en Europa se remonta a las civilizaciones de Grecia y Roma. Los viajes realizados durante los siglos XV, XVI, XVII y XVIII pueden ser considerados como la génesis de la actividad turística moderna. Sin embargo, hasta finales del siglo XVIII y durante el siglo XIX el turismo no adquirió un carácter más popular y pasó a ser una actividad más asequible a un mayor número de personas, convirtiéndose, así, en una actividad realizada por la burguesía emergente en este período histórico y dejando de ser privilegio de la aristocracia. Concerniente a eso, Rob Davidson (1988:24) defiende que:

\begin{abstract}
Aunque también otros sectores de la sociedad participaron sin duda en alguna forma de viaje de placer (sobre todo visitas a amigos y parientes), no fue hasta finales del siglo XVIII y en el XIX cuando el turismo se hizo accesible a otros niveles sociales. Para entonces, los destinos incluidos en el Gran Viaje habían empezado a atraer a las emergentes clases burguesas, que contaban con los medios para unirse a la aristocracia viajera de su tiempo. Entretanto, fueron surgiendo en toda Europa destinos turísticos especializados, al intentar las ciudades balneario y lugares turísticos alpinos y costeros establecerse como lugares de descanso y ocio, primero para la aristocracia y más tarde para los visitantes de clase media.
\end{abstract}

El origen del turismo organizado se remonta a épocas como el siglo XIX, sigue durante el siglo XX y se transforma en actividad masiva en la década de 1950. Para Godoi Trigo (1993:17) "el turismo empezó a organizarse a mediados del siglo XIX, sin embargo, solamente a partir de la década de 1950 se transformó en una actividad de masas bastante significativa, en términos socioeconómicos y culturales". ${ }^{3}$

\footnotetext{
2 Idem.

${ }^{3}$ Taducción de la autora.
} 
Durante los últimos años del siglo XIX y los primeros del siglo XX hubo una sustancial aceleración en el aumento de las actividades con fines turísticos realizadas por los europeos, hecho que puede ser visto como consecuencia de: las conquistas de los trabajadores; el aumento de los ingresos; el desarrollo tecnológico, principalmente del sector de transportes; y del surgimiento del aumento de tiempo libre y por consiguiente la posibilidad del ocio. Según Rob Davidson (1988:24):

\begin{abstract}
A finales del siglo XIX y principios del XX el crecimiento de las actividades turísticas emprendidas por los europeos se vio acelerado por dos factores fundamentales: las mejoras tecnológicas en los transportes y el revolucionario aumento del tiempo libre y de los ingresos de libre uso. La llegada del ferrocarril fue un factor de gran importancia en la aceleración del crecimiento del turismo. La red viaria convirtió en realidad el turismo de masas poco tiempo después de su puesta en servicio como forma de viajar y se desarrolló con rapidez.
\end{abstract}

La historia del origen de la industria del turismo está íntimamente relacionada con el inicio del desarrollo y el crecimiento del sistema capitalista. Para Godoi Trigo (1999:19) "la industria turística empezó a desarrollarse con el perfeccionamiento del capitalismo". A partir de la década de 1960, la población mundial se dio cuenta de que visitar los sitios donde sucedieron grandes hitos de la historia mundial podría figurar como una opción de ocio y, por consiguiente, un tipo de actividad turística.

Referente al desarrollo de las actividades turísticas, podemos afirmar que la revolución industrial, seguida por las innovaciones tecnológicas, proporcionó la consolidación de esta reciente actividad económica. Según Geraldo Castelli (1990:19) "El turismo empezó a ganar cada vez más adictos gracias a las innovaciones proporcionadas por la revolución industrial en los campos tecnológicos, políticos, económicos y sociales".

El principal precursor de esta nueva actividad fue el inglés Thomas Cook, puesto que, todavía en el siglo XIX, empezó el proceso de comercialización del turismo. Dicho proceso proporcionó el surgimiento de las primeras empresas relacionadas directamente con el turismo. En cuanto a las actividades turísticas, la revolución industrial, seguida por las innovaciones tecnológicas, proporcionó la consolidación de esta reciente actividad económica. Según Geraldo Castelli (1990:19) "El turismo empezó a ganar 
cada vez más adictos gracias a las innovaciones proporcionadas por la revolución industrial en los campos tecnológicos, políticos, económicos y sociales”.

Junto al inglés Thomas Cook, el alemán Louis Stangen y otro inglés, Thomas Bennet, vislumbraron la posibilidad de prosperidad comercial por medio de la actividad turística. Esa perspectiva comercial proporcionó a las personas mencionadas anteriormente el hecho de dar inicio a la actividad comercial del turismo en Europa. Thomas Bennet se destacó en ese contexto por su modo de comercialización, a partir de la selección de turistas. Este personaje fue responsable de la ruptura de paradigmas turísticos y la formación de grupos selectos de turistas, proporcionando una forma de atención diferenciada y específica.

\section{La expansión de la actividad turística}

Meene Ruschmann (1999) desarrolla un estudio del Marketing Turístico en el que tiene como finalidad trabajar las características del producto turístico y evidenciar el modo en el que presentan este producto en las acciones publicitarias promocionales. Su trabajo está dividido en dos partes: la primera aborda los vehículos y los contenidos de los mensajes publicitarios en turismo, la segunda trata del proceso de investigación científica usado para obtener resultados que sirvan para la elaboración de una propuesta de planificación específica en la divulgación turística. En este trabajo, Meene Ruschmann (1999:13) afirma que:

La expansión del turismo moderno está ligada, indudablemente, al progreso económico, a la concentración urbana, a las facilidades de circulación y al desarrollo de los transportes, que contribuyen para la reorganización de este fenómeno, el que pasó a ser objeto de atención de los gobernantes en virtud de su importancia socioeconómica. ${ }^{4}$

Pues bien, esta afirmación sirve para corroborar la importancia del turismo en la sociedad mundial contemporánea como un mercado económico en expansión, que a su vez presenta un alto índice de competencia, lo que conlleva dedicar una atención doble

\footnotetext{
${ }^{4}$ En la fuente original: “A expansão do turismo moderno está ligada de forma indubitável ao progresso econômico, à concentração urbana, às facilidades de circulação e ao desenvolvimento dos transportes, contribuindo para o redimensionamento do fenômeno, que passou a ser objeto de atenção dos governos diante de sua importância socioeconômica”.
} 
sobre la estrategia de comunicación en este tipo de industria que debe tener siempre en cuenta la alta competencia del mercado y tomar su posicionamiento frente a ello.

El turismo puede resultar de los más variados objetivos, como los comerciales, los deportivos, congresos, ocio, etc. El crecimiento de esta actividad muestra que el estado de movimiento del hombre de un sitio a otro es casi una constante en la sociedad contemporánea. Eso resulta de las particularidades de esta sociedad que dispone de los beneficios de las nuevas tecnologías, además del desarrollo de los medios de transporte y comunicación que conlleva más facilidad, seguridad y velocidad en el desplazamiento de un sitio a otro.

Lo cierto es que se llega a creer que el turismo es una de las actividades económicas más significativas en el siglo XXI, siendo uno de los sectores más dinámicos de la economía mundial, y que llega a generar cerca del 10\% del Producto Interior Bruto (PIB) del mundo. Es más, en algunos países, la industria turística consiste en la principal fuente de recursos económicos.

El turismo moderno surge como consecuencia del desarrollo económico, tecnológico y social vivido por sociedades post-industriales. En Godoi Trigo (1993:18-19) podemos constatar que "el turismo moderno tuvo su origen sobre el año de 1840 (surgimiento de la Abreu Turismo en Porto, Portugal) y 1841 (primera excursión de Thomas Cook, de Leicester a Loughborough, Reino Unido)". 5

El producto turístico de Europa resulta de un largo proceso de inversiones y creaciones que posibilitó el desarrollo de la actividad turística en este continente. Como consecuencia de ello fue posible crear espacios de interés turístico y mejorar la infraestructura de los destinos turísticos ya consolidados en cada país del continente europeo. Así, la diversidad del producto turístico fue estructurada durante muchos años, sobre todo del siglo XX.

\footnotetext{
${ }^{5}$ En la fuente original: "O turismo moderno, cuja origem pode ser datada de 1840 (surgimento da Abreu Turismo no Porto, Portugal) e 1841 (primeira excursão de Thomas Cook, de Leicester a Loughborough, Reino Unido)".
} 
A lo largo del tiempo, el turismo se organizó en torno a una actividad de desplazamiento geográfico y físico con los viajes, sumados a los paseos y/o estancias en ambientes con grande flujo de individuos, beneficiados con la práctica del ocio organizado de forma creativa. La actividad turística primeramente recurre a la acción de desplazamiento, un alejamiento de la vida cotidiana por medio de las prácticas de ocio. Esa distinción es marcada por la ruptura de la rutina, el alejamiento de acciones rutinarias, teniendo como objetivo la ampliación de las percepciones de mundo y el cambio en función de los estímulos que se distinguen del ritual diario. Según la definición de John Urry (1996:17) "el turismo es una actividad de ocio [...] constituye una manifestación de cómo el trabajo y el ocio son organizados".

La actividad turística internacional en Europa procede de dos grandes grupos de turistas: los europeos y los visitantes provenientes de otros continentes. Ha sido desarrollada en un ambiente poco favorable por la economía fluctuante y las altas tasas de desempleo. En relación a ello, Rob Davidson (1998:27) dice que:

\begin{abstract}
Durante los noventa, el turismo se desarrolló en un entorno de rendimientos económicos fluctuantes y con la persistencia de tasas de desempleo relativamente elevadas en los principales países industrializados. Sin embargo, a pesar del entorno económico, en algunos casos en recesión, tanto en Europa como en algunos de los principales mercados europeos en otros continentes, el gasto en viajes y turismo se ha mantenido extraordinariamente estable. En la actualidad viaja cada vez más gente, sin que les intimide, al parecer, el terrorismo, los desastres naturales o las dificultades económicas y políticas tanto de sus países como del extranjero.
\end{abstract}

En el ámbito empresarial, la actividad turística se mantiene como líder en el sector internacional y se conserva de forma relativamente estable, dado que los gastos en viajes y turismo son constantes. Su popularidad tiene origen, desde un punto de vista internacional, en los últimos años de la década de 1990, cuando todos los lugares del mundo pasaron a disfrutar de los beneficios provenientes de los desplazamientos turísticos y de la expansión de la industria del turismo. Esa realidad se mantiene hasta el período contemporáneo, aunque de forma desigual. Actualmente, Europa y Estados Unidos lideran el mercado de visitas turísticas internacionales.

Europa constituye el $57 \%$ del mercado, pero es importante resaltar que los EUA continúan siendo el líder mundial en el sector, presentando unos ingresos de 67 billones 
de dólares, seguidos por España, Francia e Italia, con unos ingresos de 27 billones a 34 billones de dólares al año.

Aún así, el sector turístico todavía presenta un bajo índice de estudios por parte de los campos de investigación de las ciencias sociales, pero forma parte de una industria que lleva a cabo un impacto cada vez mayor en la economía mundial. Resulta del proceso de desarrollo económico, social y cultural vivido por el mundo contemporáneo e incide directamente en la formación humana global y en el intercambio de culturas, además de su papel en la economía del actual mercado globalizado.

\section{Un nuevo estilo de vida}

El advenimiento de la revolución industrial insertó en la sociedad nuevas formas de creación y producción. A partir de ello, el hombre que antaño vivía en la zona rural se trasladó a los centros urbanos, donde las industrias eran medios de trabajos atractivos y promovían el desplazamiento de los trabajadores del campo para la ciudad.

La formación de urbes, los trabajos en las industrias y la conquista de los derechos laborales, sumados a la disminución de la jornada de trabajo y al capital excedente, proporcionaron la aparición de la necesidad del ocio y de la inversión de tiempo libre en la vida social. Para Kurt Krapf (1953:26) "ante el formidable crecimiento de los viajes que siguió el desarrollo industrial y a la revolución en las técnicas de transportes en el siglo XIX, la economía política se vio obligada a no seguir ignorando el turismo" como un instrumento propulsor de la economía.

Con la alta carga horaria a la que los trabajadores estaban sometidos, aumentaba el interés de invertir en tiempo libre como una fuga de la jornada de trabajo semanal de 8 horas durante un año entero. Geraldo Castelli (1990:27) afirma que "se buscaba vivir nuevas experiencias, conocer nuevos modos de vida, nuevas culturas y pueblos, descubrir un mundo distinto del que se estaba obligado a vivir artificialmente".

Más todavía, el desarrollo de los medios de transporte, como el ferrocarril y el barco, junto a la adopción y popularización del uso del avión como medio de transporte, marcaron definitivamente la aceleración de la industria turística después de la Segunda 
Guerra Mundial. A partir de ello, fue posible la modernización de esta industria y su configuración estructural moderna.

Esta actividad del sector terciario engloba las esferas de la economía, la política, la sociedad y la cultura, siempre de acuerdo con el contexto de cada época. En el inicio del siglo XX la actividad del turismo presentó un determinado desarrollo durante la Primera Guerra Mundial (1914-1918). No obstante, solamente a partir de 1919 empezó como turismo de masas.

En el año de 1929, esa actividad sufrió con los reflejos de la caída de la Bolsa de Nueva York. En 1933, el turismo dio un nuevo salto en la escala de desarrollo que se extendió hasta el año de 1939, cuando estalló la Segunda Guerra Mundial. Durante el período que comprendió ese conflicto bélico la actividad turística fue bruscamente interrumpida.

Pasadas las tensiones de la guerra, en 1949, Europa asistió a una nueva realidad de práctica del turismo cuando registró un promedio de 9 millones de viajeros curiosos por encontrar en el viejo mundo las regiones afectadas por el conflicto. Ese número aumentó a 23 millones en 1953, luego creció más del doble, a aproximadamente 55 millones de personas. Ese dato es coherente con lo que afirma Godoi Trigo (1993:64), cuando dice que "en la contemporaneidad, el turismo se estableció como un fenómeno mundial".

Con el desenlace de la Segunda Guerra Mundial, la actividad turística adquirió una nueva importancia, sobre todo en países que tuvieron su economía afectada por este conflicto bélico. A causa de la necesidad de reestructuración de la economía de algunos países, se buscó en la industria turística una forma estructurada de reorganización económica.

Las transformaciones sociales, económicas y culturales promovidas por las actividades generadas por esa industria propiciaron las mejoras de diversos servicios. En relación con ello, Geraldo Castelli (1990:21) afirma que "existió el desarrollo de los medios de transporte, los medios de alojamiento, las agencias de turismo, la infraestructura de base de las ciudades turísticas, etc." 
Así que la inserción de las nuevas tecnologías en la vida del hombre proporcionó cambios profundos en la cultura y en la sociedad. En el período contemporáneo, esas transformaciones fueron marcadas por la expansión de las comunicaciones de masas, sumadas a las artes y la ciencia que también absorbieron las nuevas técnicas provenientes de la tecnología. Los mass media, a través de la radio, la televisión, la publicidad, los periódicos e internet, influenciaron el modo de vida de las sociedades modernas. Dentro de esa perspectiva, el fenómeno turístico se insertó en el contexto post-industrial, ganando relieve dentro de las actividades económicas. Para John Urry (1996:21) "ese proceso envuelve justamente nuevas formaciones económicas que, con el auxilio de las nuevas tecnologías, produjeron nuevos estilos de vida en el mundo entero".

\section{El turismo y la política de relaciones internacionales}

La actividad del turismo se volvió, con el tiempo, sobre todo a partir de la década de 1960, fuente de desarrollo económico, social y cultural. Lo cual según Geraldo Castelli (1990:46), "incontestablemente, el turismo, una de las formas de ocio, se configuró en el siglo XX como un fenómeno de destaque. Y, por ello, llama la atención de estudiosos, hombres de negocios y gobernantes".

Además de eso, las transformaciones a partir de esa actividad de prestación de servicios funcionan como base que sostiene la economía y la progresión económica de muchos países, principalmente los que disponen de bellezas naturales y culturales, abarcando países desarrollados y en desarrollo. Esta misma idea es encontrada en Kurt Krapf (1953:26) cuando afirma que "cada vez más, los viajes al extranjero se situaron bajo un régimen de compensación económica recíproca”.

La movilidad espacial, cultural y lingüística, consiste en bienes que pueden ser adquiridos a través de la actividad turística. Otro punto positivo de la industria turística es el aumento de divisas en el lugar receptor. Por eso muchos países limitan la cantidad de sus habitantes que pueden irse al exterior como una medida para evitar la salida de divisas. Además de eso, incentivan el turismo interno, es decir, dentro del mismo país, pues de este modo el flujo de capital puede seguir dentro del país. 
En la época contemporánea se ha vuelto casi inviable el mantenimiento de un país sin el establecimiento de relaciones exteriores. La política, la economía, los deportes, la cultura y el turismo pertenecen a este amplio contexto de relaciones internacionales. El turismo acompaña el desarrollo de las actividades económicas y culturales, auxiliando a los más diversos países en el conocimiento mutuo de distintas naciones. Según Geraldo Castelli (1990:103), "al analizar el turismo en las relaciones internacionales, parece indispensable enfocar este tema bajo dos prismas: intercambio comercial e intercambio cultural". Eso está de acuerdo con Kurt Krapf (1953:47) cuando afirma que "el turismo sirve de intercambio para las relaciones económicas con el exterior en beneficio del prestigio cultural y político de una nación”.

\section{Una actividad económica en ascenso}

A partir de la década de 1960 el turismo internacional pasó a ser un mercado masificado y Europa movía un gran número de turistas, pero en los últimos años este número ha sufrido un descenso. Quizás dicha caída en el aumento del turismo internacional europeo pueda ser atribuida al hecho de que hubo un desarrollo del turismo internacional en otras partes del mundo. Referente a eso, Rob Davidson (1998:29) afirma que:

\footnotetext{
La incorporación de nuevos destinos, sobre todo en Asia y el Caribe, ha traído consigo una diversificación general del turismo en el mundo y una marcada redistribución regional de los desplazamientos turísticos a escala mundial. En las últimas décadas estas regiones han sido testigo de unas tasas de crecimiento del turismo internacional muy por encima de las europeas. $\mathrm{Y}$ en la competencia global por el segmento de viajeros a quienes les gusta viajar entre continentes por placer o negocios, que crece a buen ritmo, no existe duda sobre qué regiones del mundo están ganando.
}

No obstante, Europa sigue siendo uno de los destinos turísticos internacionales más visitados y, a la vez, el europeo es uno de los más provisores consumidores del turismo internacional. Ese posicionamiento es confirmado en Rob Davidson (1998:36) cuando asegura que "de la misma forma que Europa es el destino de la mayor parte del turismo internacional mundial, los europeos son a su vez importantes generadores de gasto turístico internacional". 
Lo cual nos lleva a creer que, en este contexto, es importante resaltar que los países que dominan el gasto en el turismo internacional, sumando un total de $50 \%$ de los gastos en el segmento del turismo internacional mundial, son países como Alemania, Reino Unido, Italia, Francia, EUA y Japón. Los turistas europeos también representan un gran porcentaje de consumidores del turismo internacional y se puede decir que gracias a ellos y a sus viajes a larga distancia sube la demanda por destinos de viajes novedosos en diversas partes del mundo.

Países como Austria, Noruega, Bélgica, Suiza, Polonia, Suecia, España, Dinamarca, Grecia y Portugal también son apuntados como posibles consumidores de los viajes turísticos internacionales. Otro factor importante es que para los europeos, sus principales destinos turísticos internacionales son los países pertenecientes al propio continente Europeo. En lo que concierne a las tendencias contemporáneas para el turismo en Europa, las perspectivas para este mercado son positivas.

Se cree en una perspectiva de progreso para este sector durante los primeros años del siglo XXI, en relación a los factores más notables que ejercerán una determinada influencia en el mercado del turismo en Europa a un plazo medio. Según Rob Davidson (1998:42), "en términos generales, la mayoría de los analistas son optimistas respecto al siglo XXI. La mayoría basan lo positivo de sus expectativas fundamentalmente en una combinación favorable de factores tanto del lado de la demanda como del de la oferta".

De todo ello se puede inferir que el turismo es un sector de la economía mundial que está en ascenso. Este progreso del segmento del turismo está íntimamente relacionado con los sueldos, el bienestar en la calidad de vida, el derecho a vacaciones remuneradas, el aumento de tiempo libre, el desarrollo de la industria del ocio, la mejora de los medios de comunicación y transportes, además de la adquisición de mejores niveles educativos. Eso es coherente con la idea expuesta por Rob Davidson (1998:42) en la que dice que "unos ingresos más elevados, más tiempo libre y mejores niveles educativos contribuyen a que más gente viaje y explore nuevas regiones". 
Una de las tendencias del mercado turístico contemporáneo es el aumento de la cantidad de turistas con más de 50 años y jubilados, que disponen de un buen poder adquisitivo y son muy exigentes. Entre este grupo están los aficionados y defensores de la naturaleza preocupados con el entorno natural que eligen el turismo ecológico. Esta idea coincide con el marketing turístico actual que dirige los anuncios de este tipo de producto buscando atender las exigencias y demandas del grupo de consumidores mencionado antes. En relación a eso Rob Davidson (1998:46) afirma que:

\begin{abstract}
Los responsables del marketing turístico, y de gran cantidad de otros productos de consumo, se han dado cuenta hace mucho de que el interés por el medio ambiente no es ya, como antaño se percibía, territorio de excéntricos y radicales. Para un número creciente de personas, la definición de una experiencia de calidad durante las vacaciones ha pasado a incluir la necesidad de un turismo respetuoso con el entorno y, con toda seguridad, la importancia de este factor continuará aumentando.
\end{abstract}

Además se reconocen los beneficios económicos del turismo, sobre todo, en movimientos internacionales "de capitales y en la balanza de pagos (rentas turísticas). Las entradas de divisas que generan los gastos de los turistas se convirtieron rápidamente en un importante factor de desarrollo económico y de rentabilidad del turismo" (Kurt Krapf, 1953:26).

\title{
Tipos de turismo
}

Los destinos turísticos son vendidos por las agencias de viajes como productos. En realidad lo que se pone en venta son las experiencias que se pueden encontrar en los lugares a donde son ofertados paquetes de viajes turísticos. Esas experiencias se configuran, básicamente, en cuatro modos de turismo: el receptivo, el emisivo, el interno y el social, como afirma Maneti Dencker (2003:161) cuando dice que "hay cuatro modos de turismo, a saber: el turismo receptivo, el emisivo, el interno y el social".

Esos modos de turismo organizan los diversos tipos de turismo existentes, como el turismo de sol y playa, el turismo cultural, el turismo lingüístico, el turismo rural (senderismo), el turismo deportivo, el turismo gastronómico, el turismo de salud (balnearios, hoteles, spas, etc.), el turismo religioso y el turismo de negocios. 
Dentro de estos tipos de turismo están los que ofrecen menos beneficios para el Estado, además, el modo de turismo positivo es el receptivo, mientras el emisivo es considerado como negativo. Así que todos esos tipos de turismo son positivos en el sentido receptivo, porque "por positivo se entiende el turismo receptivo; lo negativo indica el turismo emisivo" (Maneti Dencker, 2003:175).

\section{Incidentes internacionales y los Organismos Oficiales del Turismo (OOT)}

Los atentados terroristas del 11 de septiembre de 2001 en los Estados Unidos (EUA) provocaron una retracción en este sector de la economía, pues se ha dudado de la seguridad de los aviones y aeropuertos, pero las expectativas para los próximos años, según la Organización Mundial de Turismo (OMT), son favorables. Datos de la OMT demuestran que la crisis provocada por los atentados de 11 de septiembre en Estados Unidos pierde su fuerza que intimidaba a los turistas.

También problemas económicos internacionales como la crisis económica mundial de los años 2008-2012; de salud, como la pandemia de gripe del cerdo (2009); y algunos accidentes aéreos, como el del vuelo 447 de la Air France (2009) afectan indirectamente al turismo e intimidan a los viajeros, pero no llegan a provocar una crisis en este sector industrial.

En virtud de la consolidación de la industria del turismo y de todas las actividades de ocio relacionadas a ese tipo de negocio, es inevitable la acción y participación de los poderes públicos vigentes en este sector de la economía. Así, todas las actividades relacionadas a este sector económico pasaron a tener mucha importancia dentro de los departamentos de los poderes públicos, tanto municipal, estatal y federal. Hasta el punto del Estado promocionar activamente su política turística.

La implicación del poder público en este sector de la economía es favorable a su desarrollo económico y de su progresión social. No obstante, la posición del poder público no es central en la industria del turismo porque se mantiene al margen de los negocios y de las acciones del sector privado, subsidiando y complementando las actividades. 
Desde el año de 1963, en la Conferencia de las Naciones Unidas, en Italia, fueron determinados los Organismos Oficiales de Turismo (OOT) para cumplir medidas en relación a los trabajos de incentivo y concatenación de las prácticas nacionales de turismo. Se determinó que la responsabilidad de esas instituciones era subsidiar las tareas necesarias para el trabajador en el crecimiento, además de la divulgación del turismo local y mundial. También, se propuso estimular las acciones de estrategias políticas que empleen el desarrollo económico, promoviendo la integración con la población autóctona.

Como punto positivo de ese tipo de industria se puede destacar la preocupación que los gobiernos asumieron en la preservación del patrimonio histórico y cultural de cada Estado, sobre todo los que tienen el turismo como una importante fuente de recursos económicos. Con el aumento de la demanda por determinados productos turísticos, surgieron en algunos países los órganos gubernamentales dedicados a ese campo, además de los internacionales coordinados por la Organización de las Naciones Unidas para la Cultura, Ciencia y Educación (Unesco), como la Organización Mundial del Turismo (OMT), con sede ubicada en Madrid.

\section{El Ministerio del Turismo y el Instituto Brasileño de Turismo (EMBRATUR)}

La actividad turística en Brasil está bajo el comando de entidades gubernamentales como el Ministerio del Turismo y el Instituto Brasileño de Turismo (EMBRATUR), en un ámbito nacional. Este fue creado en el año de 1966 y su misión consistía, a priori, en la promoción de la industria nacional de turismo como un medio de entrada de divisas, creación de nuevos puestos de trabajo y la consecuente mejora de la economía del país.

No obstante, en el año de 2003 fue instituido el Ministerio del Turismo brasileño, que absorbió esas responsabilidades y se firmó como una entidad gubernamental responsable del turismo nacional, su desarrollo sostenible, su generación de divisas y su creación de puestos de trabajos, por medio de políticas públicas y sociales que mejoren la calidad de esta industria en Brasil.

Por eso, desde entonces la Embratur se ocupa de la promoción del marketing y de la comercialización de Brasil como un producto turístico en el exterior. Esto evidencia la 
importancia del marketing y de la publicidad para la industria del turismo en Brasil, que tiene los Estados Unidos, el Reino Unido, Canadá, Argentina, Chile, Perú, Alemania, Portugal, España, Francia, Holanda e Italia como destinos prioritarios de sus campañas publicitarias.

El gobierno nacional, a través del Ministerio del Turismo, ha elaborado diversos proyectos para desarrollar el turismo brasileño, entre estos proyectos figuran los de Planificación y Gestión; Información y Estudios Turísticos; Logística y Transportes; la Regionalización del Turismo; el Fomento a la Iniciativa Privada; la Infraestructura Pública; la Cualificación de los Equipamientos y Servicios Turísticos; la Promoción y el Apoyo a la Comercialización y el Programa Turismo Sostenible e Infancia, todos tienen el objetivo de mejorar la calidad del producto turístico brasileño. El Ministerio del Turismo actúa para promocionar y fortalecer el mercado turístico brasileño en los ámbitos nacional e internacional, en este último, tiene como objetivo aumentar la demanda y mejorar la imagen de Brasil como producto turístico en el exterior.

Este es un mercado muy importante para la economía brasileña y según los datos estadísticos de la Embratur, más de $85 \%$ de los turistas que llegan a Brasil provenientes de otros países superan sus expectativas del país; más de $80 \%$ de eses turistas volverían al país; más de un 50\% volverían para conocer otro destino turístico brasileño y más de 90\% indicarían Brasil como un lugar interesante para visitar.

\subsection{El turismo en Brasil}

Frente a la presentación de los aspectos más significativos para la comprensión del producto turístico y su industria, desde una perspectiva general, conviene destacar las particularidades de esta industria en Brasil y, más específicamente, en Natal, para una mejor comprensión de la publicidad turística de esta ciudad brasileña.

Brasil es un país de dimensiones continentales, el quinto más extenso del mundo, con 8.547.403 $\mathrm{km}^{2}$, que corresponde a 47,9\% del territorio de América del Sur, y posee la primera economía de esta región. La mayoría de los 26 estados brasileños, un total de 17, están bañados por el océano Atlántico, eso permite que este país posea un escenario de paraíso tropical, formado por un litoral de playas de arena blanca, con una extensión 
de 7.400 Km. Además, en la parte central del país hay unos 34 parques nacionales, 70 ciudades históricas y diversas reservas biológicas.

Aunque disponga de un enorme potencial turístico natural, la participación brasileña no llega a $1 \%$ del mercado. También, aunque el país aproveche poco su potencial turístico, los números de la última década muestran una expansión acelerada. De 1994 a 1999, Brasil salta del $43^{\mathrm{a}}$ al $29^{\mathrm{a}}$ lugar en el ranking mundial de los destinos para el turismo más solicitados, según la OMT. En 2002 entran en el país 3,1 billones de dólares en divisas generadas por esta actividad, contra 1,3 billón facturado en 1992. En 2002, cerca de 3,8 millones de turistas extranjeros entraron en territorio brasileño, contra 1,7 millón en 1992.

De acuerdo con las informaciones del ministerio del trabajo, en 2001 había en el país 159 mil establecimientos ligados al turismo, que emplean a 1,3 millón de personas. El impacto económico del turismo no beneficia solo a las empresas directamente ligadas al sector. Favorece también a la creación de varios empleos indirectos. Según estudios del Instituto Brasileiro de Geografia e Estatística (IBGE), sumando las 52 actividades productivas relacionadas al sector, el número de empleos llega a 4,9 millones.

Para aprovechar mejor el enorme potencial del país en el sector, el gobierno brasileño preparó un plan nacional para el turismo ejecutado entre 2003 y 2007. Las metas eran crear condiciones para generar 1,2 millón de empleos y ocupaciones, aumentar a 9 millones el número de turistas extranjeros en Brasil, generar 8 billones de dólares en divisas y aumentar a 65 millones el movimiento de pasajeros en vuelos domésticos.

El turismo representa uno de los sectores de la economía que muestra constantes subidas en un contexto global, por eso países con recursos naturales para la promoción de actividades turísticas, como Brasil, suelen invertir en esa industria como una forma de aumentar la entrada de divisas y generar el aumento de puestos de trabajo. 
Cabe resaltar que el número de turistas extranjeros en Brasil es superior al número de turistas nacionales, hecho que beneficia a la economía brasileña por recibir divisas de países extranjeros por medio de los gastos de esos turistas. Y de los 10 países que más emiten turistas para Brasil, 5 tienen el español como lengua oficial, es decir, un total de casi $50 \%$ de los turistas extranjeros que llegan a Brasil hablan el español como lengua materna, a saber: Argentina, Uruguay, Paraguay, España y Chile, como se puede ver en la tabla siguiente:

\begin{tabular}{|c|c|}
\hline \multicolumn{2}{|c|}{ PAÍSES QUE MÁS EMITEN VISITANTES A BRASIL (2005) } \\
\hline PAÍSES & \% DE TURISTAS \\
\hline Argentina & $\mathbf{2 2 , 3}$ \\
\hline EUA & $\mathbf{1 7 , 8}$ \\
\hline Portugal & $\mathbf{8 , 0}$ \\
\hline Uruguay & $\mathbf{7 , 7}$ \\
\hline Alemania & $\mathbf{6 , 9}$ \\
\hline Italia & $\mathbf{6 , 8}$ \\
\hline Francia & $\mathbf{5 , 7}$ \\
\hline Paraguay & $\mathbf{5 , 6}$ \\
\hline España & $\mathbf{3 , 9}$ \\
\hline Chile & $\mathbf{3 , 8}$ \\
\hline
\end{tabular}

Fuente: Ministerio del Turismo y Organización Mundial del Turismo. 
Brasil está en el $34^{\circ}$ lugar en el ranking mundial de los países que más reciben turistas en el mundo, siendo los diez primeros colocados de ese ranking:

\begin{tabular}{|c|c|}
\hline \multicolumn{2}{|c|}{ PAÍSES MÁS VISITADOS MUNDIALMENTE (2005) } \\
\hline RANKING & PAÍSES \\
\hline $1^{\mathbf{0}}$ & Francia \\
\hline $\mathbf{2}^{\mathbf{0}}$ & España \\
\hline $3^{\mathbf{0}}$ & EUA \\
\hline $\mathbf{4}^{\mathbf{0}}$ & China \\
\hline $\mathbf{5}^{\mathbf{0}}$ & Italia \\
\hline $\mathbf{6}^{\mathbf{0}}$ & Reino Unido \\
\hline $\mathbf{7}^{\mathbf{0}}$ & México \\
\hline $\mathbf{8}^{\mathbf{0}}$ & Alemania \\
\hline $\mathbf{9}^{\mathbf{0}}$ & Turquía \\
\hline $\mathbf{1 0}^{\mathbf{0}}$ & Austria \\
\hline
\end{tabular}

Fuente: Ministerio del Turismo y Organización Mundial del Turismo.

\section{Brasil como un producto turístico}

Cada sitio trae consigo símbolos que los individuos asocian favorable o negativamente a la imagen de un lugar. En Brasil la representación que la mayoría de las personas hace primero remite al país de los carnavales. En este mercado los turistas compran las imágenes de los productos, que son intangibles y consisten básicamente en la experiencia de un viaje. Para Rosana Bignani (2002:12) "los factores históricos y sociales predominantes, la posición geográfica, el clima y, en gran escala, la comunicación, crean la imagen de un lugar, en general, bien definida en la mente de la

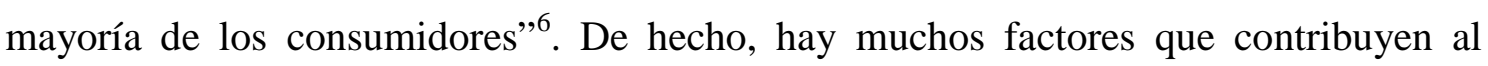

\footnotetext{
${ }^{6}$ Traducción de la autora.
} 
desarrollo del turismo en una determinada localidad, como apunta Maneti Dencker (2003:203-204):

\begin{abstract}
Factores que por naturaleza no poseen relación con el turismo, pero su fuerza de atracción original se tornan objetos turísticos son los factores naturales (situación geográfica, topografía, paisaje, vegetación, fauna, clima); factores de existencia y de la actividad humana: idiomas, mentalidad, hospitalidad, usos y costumbres, folklore, cultura (religión, arte, ciencia), política, economía; infraestructura general: transportes y comunicación, estructura e imagen de la localidad, otros factores de la infraestructura, como el abastecimiento de agua, vallas fluviales y cloacas, energía eléctrica, telecomunicación, etc.
\end{abstract}

Según la Embratur, bellos paisajes; cosas distintas para ver; coste razonable; condiciones sanitarias; fraternidad de la gente; seguridad personal; coste de la tarifa aérea; cosas diferentes para hacer; lugares históricos; clima; atmósfera política; comidas típicas; museos y galerías de arte; lugares exóticos; música y danza; playas y pesca submarina; compras; vida nocturna y cultura primitiva constituyen los factores considerados importantes para la destinación de viajes.

A partir de factores como esos se ha hecho uso de diversas imágenes de Brasil como artificio para atraer la visita de turistas internacionales. Por eso es común que este país esté asociado a la idea de paraíso salvaje, playas, incluyendo abundancia de riquezas naturales, vegetación, fauna, flora y clima, sobre todo con imágenes de la floresta Amazónica. Esos son los mensajes que dominan la retórica de la publicidad que es creada para los turistas extranjeros. La gran cantidad de divulgación del país se da a través de reportajes, folletos y catálogos de las agencias de viajes.

La misma publicidad que tiene como objetivo generar una imagen positiva del país para atraer al turista extranjero, deja espacio a connotaciones sensuales en la imagen de las playas brasileñas, también asociada a la liberación sexual y, consecuentemente, al turismo sexual. Eso resulta, desde un punto de vista social, un problema, ya que el turismo de sol y playa asociado al turismo sexual genera más inconvenientes que beneficios para cualquier Estado y su respectiva sociedad.

Para Godoi Trigo (1998:31) "el turismo se desarrolla mejor en zonas donde hay estabilidad. Las personas son sensibles a determinados problemas en viajes, 
especialmente a los que afectan a su seguridad". ${ }^{7}$ Los discursos que contemplan el multiculturalismo del país, por ser un lugar democrático, con buena receptividad, cordialidad y creatividad de la gente quedan, muchas veces, subyacentes a las ideas despreciativas.

Rio de Janeiro es considerada la postal de Brasil, pero convive con los problemas de la violencia urbana. Eso no afecta solamente al estado carioca sino a todo el país dentro del escenario internacional, dado que acaba por ser asociado, en su totalidad, a esta problemática. El turismo nacional acaba sufriendo las consecuencias y repercusiones de esos hechos. Como contestación a ese estereotipo los demás estados pasaron a invertir en publicidad para desmitificar la idea de la violencia generalizada en Brasil, en especial el sector turístico de la región Nordeste.

\section{El impacto social del turismo}

Según los datos del gobierno federal, el turismo comporta un promedio de 204 millones de personas trabajando en este sector alrededor del globo, siendo 6 millones referentes a los puestos de trabajo creados en Brasil. Además de ello, la actividad turística corresponde al 10\% del PIB mundial. En el año 1995, casi 2 millones de turistas extranjeros desembarcaron en el país. Dos años después, ese número había aumentado a 2,75 millones. Aun así, Brasil correspondía a solamente $0,3 \%$ de la preferencia de los viajes de la población mundial de aquél año. Ese dato retrata la pequeña participación del país en el turismo externo. Los números que la Embratur informa registran que en 1995, del total de los visitantes extranjeros que llegaron al país, un 90\% de ellos tenían como destino la región Nordeste. Por consiguiente, el turismo se transformó en una de las principales actividades económicas de esa región.

De acuerdo con las informaciones registradas en el documento de divulgación del Programa de Desarrollo del Turismo (PRODETUR), financiado por el Banco Nacional de Desarrollo Económico y Social (BNDES), se calcula que cerca del 5\% del PIB de la región proviene del sector del turismo. En 1997, los beneficios del turismo llegaron a la marca de 3 billones de dólares, solamente en la región Nordeste. Los puntos de interés

\footnotetext{
${ }^{7}$ En la fuente original: "O turismo desenvolve-se melhor onde há estabilidade nessas áreas. As pessoas são sensíveis a determinados problemas em viagens, especialmente aos que afetam sua segurança”.
} 
turístico más visitados del Nordeste fueron los estados de Bahia y Ceará. Esos dos estados atrajeron, ya en 1995, una cantidad que corresponde a casi $14 \%$ del mercado turístico brasileño. Otra razón para que esa región atraiga aun hoy tantos visitantes son los escenarios paradisíacos de sus playas, además de un folclore muy arraigado.

La prueba cabal de que el turismo en Brasil y en el mundo puede traer beneficios para la economía local es que la regionalización de las Actividades Características del Turismo (ACT) significó para los estados de São Paulo y Rio de Janeiro una suma de 63,53\% de los ingresos brutos de los servicios relacionados a esta actividad; el 48,43\% de la gente empleada en esta área y el 58,90\% de los sueldos de los profesionales que tratan con el turismo. Al lado del Distrito Federal, Pará, Amazonas y Tocantins, aquellos dos estados fueron los únicos de Brasil que consiguieron presentar mayor índice de generación de renta que los índices de empleo en turismo.

El turismo doméstico en Brasil creció en los últimos años, pero, aun así, está todavía lejos de ser lo ideal para un país con tantos escenarios que conocer. Entre 2002 y 2003 , las familias brasileñas gastaron $\mathrm{R} \$ 17$ millones con viajes de ocio. A pesar de la cifra millonaria, ese valor es estimado solamente en $1,66 \%$ de los gastos totales de esas familias. De ese total, un poco más de la mitad se gastó en cuestiones básicas del turismo: transporte, hostelería y alimentación. Solamente el ítem combustible de vehículos, incluso en los transportes, alcanzó casi un cuarto de los gastos, lo que significa que el turismo brasileño tiene la necesidad de viabilizar nuevas formas de transporte.

Natal posee una industria turística consagrada a nivel regional, nacional e internacional. La estructura de esta actividad económica tiene el apoyo del sector público de la Secretaria Estadual de Turismo (SETUR), a nivel del estado; además de la Secretaria Especial de Comércio, Indústria y Turismo (SECTUR), a nivel municipal. El gobierno del estado y el federal apoyan la industria del turismo por medio de proyectos como el Programa de Ação para o Desenvolvimento do Turismo no Nordeste (PRODETUR) y el Aquarela, porque comprenden la actividad turística como una forma rápida de cambiar los indicadores económicos de la población natalense. Además, la industria del turismo es un campo de la economía que mueve muchos recursos financieros y genera diversos puestos de trabajo en ese estado. 
En el año 2005, en Brasil, más de 8 millones de personas trabajaban en el sector turístico, que es muy importante en la creación de puestos de trabajo en este país. El estado de Rio Grande do Norte es uno de los estados brasileños beneficiados con el desarrollo del sector turístico para la mejora de sus índices económicos y sociales. Gracias a la industria turística ese estado pasó a obtener beneficios turísticos de 416 millones de dólares en 2005, que en el año de 2002 llegaban a solamente 284 millones de dólares.

En reconocimiento a la importancia de la actividad turística para la economía local, la Secretaría Estadual de Turismo (SETUR) destinó en el año 2008 más de 6,3 millones de su facturación para la promoción de la publicidad de este estado en niveles nacionales e internacionales. El principal foco de la expresión comercial de ese estado fuera de Brasil es Europa, países como Portugal, España, Holanda, Inglaterra, Noruega, Italia y Alemania.

Así como en todo el país, las políticas públicas dirigidas para las ACTs solamente pasaron a ser pensadas en el estado brasileño de Rio Grande do Norte a partir de una coyuntura mundial de recesión económica. El elevado índice de desempleo obligó al Gobierno Federal a pensar en nuevas formas de generar divisas y disminuir las desigualdades sociales que existían en Brasil. Fue con esta intención que se creó la Empresa Brasileña de Turismo (Embratur), a mediados de la década de 1980. Sin embargo, cabe resaltar que en 1971 el Rio Grande do Norte ya tenía su propia Empresa de Promoción y Desarrollo del Turismo (Emproturn). Por un período de más de una década esa empresa funcionó como una estructura subutilizada por el estado en lo que se refiere al intento de atraer turistas.

Las acciones de la Emproturn pasaron a ser efectivas solamente cuando las esferas del poder público estatal y federal actuaron en el sistema de acciones coordinadas entre ellos. A partir de 1984, en función de una serie de hechos, Natal tuvo su sector del turismo acelerado. Entre dichos hechos, se destaca la buena presentación de la ciudad en el congreso de la Associación Brasileña de Agentes de Viajes (Abrav); la creación de la Via Costeira, con una extensión de $8 \mathrm{~km}$, aproximando la playa de Ponta Negra a las demás playas urbanas del municipio; además de la creación del Centro de Convenções de Natal. Todos esos hechos, asociados a la perspectiva de instalación de hoteles con 
patrón internacional en la Via Costeira, hicieron que el turismo en el estado fuera activado desde su etapa inicial.

El resultado del incremento de la actividad es que el $36 \%$ del número total de los medios de hospedajes de Brasil están situados, ya en este mismo año, en Bahía. La expectativa es que la creciente demanda de visitantes, en los más variados puntos del Nordeste, hizo que esa región conquistase inversiones en otros sectores de la economía y no solamente en el turismo. Los datos que constan en la Embratur afirman que el segmento de la hostelería en el Nordeste consiguió, en 1995, R \$ 967.643 dentro de un total de R $\$ 5.734 .735$ de la recaudación brasileña en turismo. Sin mencionar un promedio de R $\$ 500$ millones pagados en impuestos por el segmento, además de las cargas en otros tributos. Otro dato que corrobora la información de que el turismo en Nordeste es fundamentalmente importante es el hecho de que la actividad en el ámbito regional ocupa un $24 \%$ de los trabajadores brasileños especializados y no especializados en esta área.

\section{Turismo interno}

Según el teórico del turismo Godoi Trigo (1998:35), en su libro Turismo Básico, "Brasil, aunque sea la décima economía capitalista del mundo, tiene una distribución de rentas y riquezas bastante irracional" ${ }^{\prime 8}$. El sector del turismo es uno de los más afectados por los problemas sociales de Brasil, dado que gran parte de la población brasileña no tiene las condiciones financieras necesarias para pagar una actividad de ocio como el turismo.

Para llenar el espacio creado por las disparidades socioeconómicas entre ricos y pobres en Brasil y desarrollar proyectos turísticos para el país, se creó el proyecto VAI BRASIL, surgido por medio del Ministerio del Turismo en colaboración con la Asociación Brasileña de Agencias de Viaje (ABAV). Este proyecto tiene la finalidad de disponer de un considerable número de ofertas de paquetes de viajes, en rutas diversas, con el objetivo de suplir los períodos de baja temporada en el turismo. Además de tales disponibilidades, el proyecto está enfocado para servir los deseos de la sociedad brasileña en general. Con precios asequibles y una estructura solidificada, actúa de

\footnotetext{
${ }^{8}$ Traducción de la autora.
} 
forma activa en el fortalecimiento del sector turístico, además de servir como importante generador de divisas y desarrollo social.

\section{El Prodetur y el Plan Acuarela}

En 1995, el gobierno federal, buscando desarrollar la actividad de forma ordenada, planeada y en colaboración con los estados y municipios, de acuerdo con las necesidades de cada localidad, creó el Programa de Desarrollo del Turismo (PRODETUR). Su principal meta era invertir en la integración de mano de obra y prestación de servicios con calidad. El sector de la hostelería no fue el único contemplado por este programa del gobierno federal. El presupuesto inicial del Prodetur fue estimado en US\$ 800 millones, de los cuales la mitad venía del Banco Interamericano de Desenvolvimento (BID). Gran parte de esos recursos financieros fue destinada a las actividades de generación de trabajo, saneamiento básico, provisión del agua y creación y reconstrucción de carreteras, además de la recuperación del patrimonio histórico. Otros sectores contemplados fueron los referentes a la preservación del medio ambiente, a la manutención de aeropuertos y a la estructuración de órganos del gobierno para recibir mejor a los turistas.

Hasta marzo de 1999, cerca de US\$ 506 millones habían sido aplicados en 52 proyectos ya concluidos por el país, además de otros 130 proyectos que estaban en curso en aquél año. En el área de preservación ambiental, por ejemplo, la meta era mantener conservado 24.679 hectáreas. La red de saneamiento contemplaba 34 proyectos, los cuales al final beneficiarían 462 mil personas oriundas de la población de diferentes localidades de Brasil. En relación a la infraestructura básica para el turismo, el Prodetur había previsto la ampliación de ocho aeropuertos, 46 carreteras (un total de $555 \mathrm{~km}$ ), dos atracaderos y un terminal hidroviario. Eso demuestra que los beneficios alcanzados en función del turismo agregan valor en la calidad de vida de la población local.

Se ha invertido mucho en el sector del turismo del estado brasileño de Rio Grande do Norte que recibió recursos financieros del gobierno federal provenientes de proyectos como el Prodetur I y II, además del Plan Acuarela (2005-2014). Dichos planes de desarrollo del turismo brasileño, han sido fundamentales para el desarrollo del Nordeste de Brasil y actuaron en campos como la mejora de la infraestructura de los polos 
turísticos, la capacitación de profesionales y el marketing, en especial en campañas publicitarias a nivel nacional e internacional.

Los países que hacen frontera con Brasil son, según la Embratur, los proveedores de un $80 \%$ de los visitantes de los puntos turísticos brasileños. Este mismo órgano del gobierno federal tuvo la previsión de que en el 2008 las divisas provenientes del sector del turismo llegarían a sumar 5,5 billones de dólares, esas cifras superaron los 4,9 billones de divisas del año anterior. La actividad turística es el principal ítem de servicios de exportación y ha crecido en relación a años anteriores, ocupando, entonces, un puesto muy importante en la economía nacional.

El Plan Acuarela está dividido en etapas: la primera (2005-2006), la segunda (20072010) y la tercera (2011-1014) y apuesta, sobre todo, en campañas publicitarias de Brasil en el exterior ya que casi 3\% de Producto Interior Bruto (PIB) brasileño procede de este sector de la economía. La Embratur también invierte en campañas publicitarias que sirven para construir una imagen positiva del país en el exterior.

Natal fue elegida para la divulgación del inicio de la segunda etapa del Plan Acuarela por ser un ejemplo nacional en el desarrollo del turismo, que a su vez modificó gran parte de la infraestructura de esta ciudad y generó diversos puestos de trabajo, formales e informales. Además, Brasil será la sede del mundial de fútbol en el año de 2014, hecho que servirá para acelerar el proceso de desarrollo de las ciudades y del turismo en ese país. Natal será beneficiada directamente con este hecho por formar parte de las ciudades brasileñas donde habrá partidos de fútbol durante esta competición internacional.

\subsection{EI turismo en Rio Grande do Norte}

Hace más de tres décadas que Natal, capital del estado brasileño de Rio Grande do Norte, es beneficiada económicamente por la industria del turismo. Esa localidad está relacionada con el turismo a nivel nacional e internacional. En Brasil, la consolidación de la actividad turística organizada económicamente surge entre los años 1966 y 1988. En esa época este estado brasileño fue privilegiado con incentivos financieros y fiscales para invertir en esa actividad tanto en ámbitos públicos como privados. 
A partir de esa época, Natal empieza a recibir inversiones en su infraestructura para ordenar la actividad turística una vez que se tiene notificación de que este tipo de actividad económicamente organizada necesita de una infraestructura, eventos y marketing para ser lucrativa. Con ello desde la década de 1960 hasta la de 1970 hubo un progreso en la infraestructura en la red de hoteles natalenses para beneficiar el turismo como se puede ver en la siguiente tabla:

\begin{tabular}{|l|c|c|}
\hline \multicolumn{1}{|c|}{ HOTELES } & AÑO & EMPRESARIOS RESPONSABLES \\
\hline Hotel Tirol & 1968 & Sr. Pacheco \\
\hline Ampliación del Hostal Samburá & 1973 & Sr. Firmino Moura \\
\hline Motel Tahiti & 1975 & Sra. Alcione Dowsley \\
\hline Pousada do Sol & 1974 & Sr. João Veríssimo \\
\hline Hotel Ducal & 1976 & União das Empresas Brasileiras (UEB) \\
\hline Sol Hotel & 1977 & Sr. Fernando Paiva \\
\hline
\end{tabular}

Fuente: SOUZA, Itamar. Turismo no RN antes da Via Costeira. Diário do RN, nº 11, 03/08/1999. 
A partir de la década de 1970 se aceleró el proceso de creación de obras que beneficiaron la infraestructura del turismo en Natal. Se cree que la consolidación del turismo natalense se dio a partir de la década de 1980 con la construcción de la Via Costeira. Y desde esta época hasta el año 1995, hubo un vertiginoso aumento en la actividad turística como se puede ver en la tabla a continuación:

\begin{tabular}{|c|c|c|}
\hline \multirow{2}{*}{ AÑOS } & \multicolumn{2}{|c|}{ NÚMERO DE HUÉSPEDES } \\
\cline { 2 - 4 } & $\begin{array}{c}\text { NÚMERO DE HOTELES } \\
\text { CLASIFICADOS }\end{array}$ & EN TODAS LAS MODALIDADES \\
\hline 1987 & 112.779 & 343.624 \\
\hline 1988 & 118.855 & 392.421 \\
\hline 1989 & 135.268 & 436.421 \\
\hline 1990 & 115.288 & 418.070 \\
\hline 1991 & 153.997 & 455.044 \\
\hline 1992 & 136.364 & 401.071 \\
\hline 1993 & 205.561 & 587.318 \\
\hline 1994 & 222.603 & 618.342 \\
\hline 1995 & 265.453 & 737.367 \\
\hline
\end{tabular}

Fuente: Secretaria Estadual de Turismo - SETUR, 1996.

Otro factor que contribuyó al aumento de la actividad del turismo en Natal fue la creación del Carnatal, carnaval fuera de temporada, realizado durante el mes de diciembre y creado en la década de 1990. En el año 1996, Natal ya contaba con 34 hoteles. También con el turismo hubo un aumento del número de establecimientos de las actividades económicas (comercio, industria y servicios) en Natal. Y el turismo, que es una actividad económica de prestación de servicios, está en crecimiento, sobre todo, en las últimas décadas.

Del año 1999 al 2003 hubo un aumento de visitantes extranjeros a Natal, lo que sirvió para sumar unos ingresos de US\$ 77.716 .364 (setenta y siete millones, setecientos y dieciséis mil, trescientos sesenta y cuatro dólares) en el año de 2003. 
En la segunda mitad de la década de 1960, la Prefeitura Municipal do Natal creó la Secretaria Municipal de Turismo (SEMTUR), que actuó, primeramente, en la divulgación y promoción de eventos en la ciudad. En la década de 1970 fue instituida la Empresa de Promoção e Desenvolvimento do Turismo do Rio Grande do Norte (EMPROTURN), que fue formada para promover la divulgación y desarrollo turístico a nivel del estado. Su surgimiento estuvo ligado al movimiento conjunto de los demás estados de la región Nordeste. Durante el final de la década de 1970 e inicio de la de 1980, fue caracterizado por los proyectos de promoción, divulgación y estructuración del desarrollo de la infraestructura, buscando la subida de la industria del turismo en el estado, sobre todo en Natal.

En el año 2000, el Prodetur convirtió a Natal en el quinto destino más visitado de Brasil, detrás solamente de São Paulo, Rio de Janeiro, Fortaleza e Salvador. La capital del Rio Grande do Norte recibió el 1,17\% de los turistas nacionales que viajan por el país. Entre 1996 y 2000, la SETUR había registrado un crecimiento de la actividad del 127,35\%, con el aumento de visitantes nacionales del $113 \%$ e internacionales del 544,41\%. La principal vía de acceso de esos visitantes al estado fue el Aeropuerto Internacional Augusto Severo, cuyas obras de ampliación quintuplicaron su área de embarque, permitiendo que solamente esa obra proporcionara un aumento del $66 \%$ en los desembarques anuales de turistas.

\section{Turismo en Natal}

A partir de la década de 1980, el turismo pasó a ejercer un papel fundamental en las metas de prioridades del gobierno del Estado do Rio Grande do Norte, que buscaba el desarrollo socioeconómico y cultural, además de la generación de divisas e inversiones. Para la promoción del turismo en este estado, se hacía uso de Natal como su principal propaganda. Para empezar el gobierno del estado pasó a invertir en la infraestructura de la ciudad, buscando realizar perfeccionamientos a través de los incentivos financieros del Banco Interamericano de Desarrollo (BID).

Natal posee las condiciones ampliamente favorables al desarrollo de la actividad turística, gracias a su ubicación privilegiada próxima al litoral, que le hace disponer de escenarios naturales exuberantes. La ciudad de Natal se está destacando en el ámbito del 
sector turístico nacional y, sobre todo, en la región Nordeste, no sólo por las potencialidades del litoral, también por los dispositivos específicos que la capital potiguar dispone en su estructura turística. Para Lopes Júnior (1997:242) "La capacidad cinegética de la actividad es traducida no solo en la emergencia de una significativa economía cultural en la ciudad, sino también en la producción de paisajes como lugares de consumo que son ahora referencias importantes". 9

En esta misma línea de razonamiento Lopes Júnior (1997:243) afirma que "el turismo funciona como un vector modernizador, haciendo emerger diferentes redes de informaciones e instituciones locales de cooperación económica". ${ }^{10}$ La actividad de ese campo ha proporcionado la generación de empleos directos e indirectos en la ciudad. Las empresas del turismo y negocios ligadas al área (alimentos, transportes, construcción civil, vestuario, etc.) vienen absorbiendo un considerable número de mano de obra no especializada y especializada, proporcionando crecimiento económico.

El aumento del índice de empleo y de divisas son los principales elementos generados por la actividad turística en la ciudad. Los medios de hospedaje son los mayores empleadores de este sector. Los beneficios generados en este campo también son distribuidos entre los otros sectores de la economía en la ciudad. Sectores de la industria alimentaria, del vestuario, de la construcción civil y transportes se benefician con el aumento de las actividades turísticas.

La hostelería genera muchos puestos de trabajo, ya que la necesidad de unidades habitacionales es cada vez más necesaria para acoger tanta demanda de turistas nacionales e internacionales. Los sectores ligados a la alimentación y a las bebidas presentan una significativa cantidad de empleados y tienen una perspectiva de crecimiento.

No obstante, Natal, como otras capitales del nordeste brasileño, figura en la ruta del turismo sexual del país. Eso es considerado un serio problema social que genera intranquilidad y molestias en la población local. Esta preocupación hizo que los sectores relacionados con el turismo se movilizaran en campañas contra este tipo de turismo,

\footnotetext{
${ }^{9}$ Traducción de la autora.

${ }^{10}$ Traducción de la autora.
} 
como se puede ver a continuación a partir del sello creado para la propaganda contra el turismo sexual en Brasil.

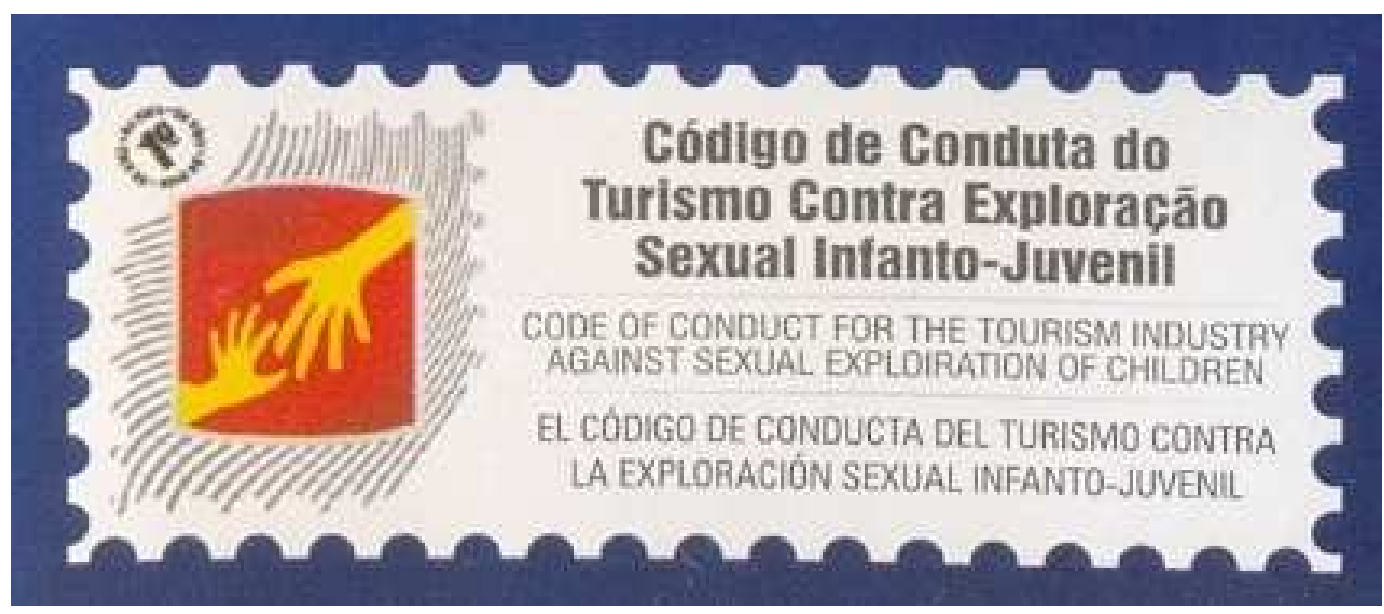

La publicidad de Natal como destino turístico

Frases como "Natal: ciudad del sol” y "Natal: novia del sol” caracterizan el espíritu de la ciudad a través de los medios de divulgación. Son diversos los tipos de divulgación de la ciudad de Natal. Y las empresas de turismo venden esta ciudad como un destino de primera clase. Según la divulgación de esas empresas, Natal proporciona un tipo de ocio extraordinariamente atractivo para quienes planean visitarla.

Nacionalmente, la ciudad fue divulgada a través de anuncios en periódicos y revistas de gran circulación en el país. Sin embargo, fue con la campaña de televisión con la que la ciudad pasó a tener mayor relieve como destino turístico. Telenovelas de la Rede Globo de Televisión como Cambalacho (1986), Despedida de Solteiro (1992-1993) y Tieta (1989-1990), fueron divisores de aguas de las campañas publicitarias divulgativas del turismo potiguar, es decir, del Rio Grande del Norte. Los documentales sobre el ecosistema de Natal también contribuyeron a vender Natal como destino turístico. En el escenario internacional, el estado participó, en conjunto con los demás estados de la región Nordeste, de una campaña para argentinos, en la que la presentadora de programa infantil, Xuxa, invitaba a los hermanos del país vecino a una aventura por el litoral brasileño. También la empresa estadounidense de chicles Adam's eligió las dunas del litoral norte del estado como escenario de campañas publicitarias. 
La ACT del Rio Grande do Norte, además, hizo uso en el inicio de su actuación de una serie de problemas de seguridad pública por los cuales pasaban Rio de Janeiro y otras capitales brasileñas. En función de ello, mientras los medios de comunicación presentaban imágenes negativas de esos bienes turísticos, Natal sobresalía al ser vendida como una ciudad tranquila. Pontes Fonseca (2005:128), en su investigación de doctorado, afirma que "a ejemplo de Natal, otras ciudades podrían recibir más visitantes si les fueran dirigidos más recursos para tal finalidad". 11

\subsection{El marketing y la comunicación turística}

Es casi imposible abordar el tema de la publicidad sin hablar de marketing. Éste actúa orientándose hacia la dimensión estratégica y la operativa, en función de la satisfacción del consumidor y del orientador de mercado, como afirma Manuel Rey (2004:17) cuando dice que "la orientación hacia la satisfacción conjunta de consumidores y organizadores implica la existencia de dos dimensiones en la gestión del marketing, una estratégica y otra operativa". El marketing turístico funciona como un punto de intersección entre las técnicas y las estrategias del marketing y la industria turística.

\footnotetext{
${ }^{11}$ Traducción de la autora.
} 
Entre las varias actividades más visibles del marketing están la publicidad y las ventas, puesto que el marketing significa el contentamiento recíproco entre los intereses de una organización, de un grupo empresarial o simplemente una empresa, además de la demanda de su clientela o público objeto. Todo aquello en lo que consiste el marketing no actuaría como una función propiamente dicha en una empresa sino como una filosofía de procedimiento de la empresa inserta en un determinado mercado industrial. Según Manuel Rey (2004:19):

\begin{abstract}
El marketing, como se expone en esta obra, es algo más complejo, pero que persigue el objetivo de fácil comprensión: la satisfacción conjunta de los requerimientos de la empresa u organización y las necesidades y deseos de sus clientes. Desde este punto de vista el marketing no es una nueva campaña de publicidad, ni el seguimiento de las ventas del mes, ni tan siquiera la creación de la imagen de la empresa. En realidad, no se debe considerar como una función de la empresa, sino como una filosofía, una forma de hacer negocios que tiene que impregnar a toda la organización, empezando por la dirección y terminando por los empleados de último nivel.
\end{abstract}

Sobre el año 1910 el término marketing fue incorporado a la economía, desde entonces adquirió varias definiciones que se adaptaron a la sociedad de cada época, lo que aporta a este término un significado dinámico en lo que concierne al hecho de acompañar y adaptarse a las condiciones del mundo circundante susceptible de constantes cambios.

La Asociación Americana de Marketing (1960:15) dice que el "marketing es la ejecución de actividades empresariales que dirigen el flujo de mercancías y servicios desde el productor hasta el cliente o usuario". Posteriormente, este concepto fue perfeccionado por Mazur (1967) y Kotler (1988).

El concepto de marketing propuesto por Philip Kotler, en los años 80, considera el marketing como un proceso social y empresarial por medio del que los individuos cubren sus necesidades y deseos a través del cambio de productos y su valoración, creando así un sistema circular entre las necesidades, deseos y demandas; el producto; la satisfacción y utilidad; y, por fin, el intercambio.

A lo largo de la historia del concepto de marketing hubo tres momentos fundamentales para que se llegase a la formulación de Kotler. Una de sus bases fue la corriente del marketing denominada de "marketing relacional". Para Manuel Rey (2004:22) ese 
enfoque organiza y defiende la estructuración del concepto de marketing en torno a los siguientes elementos de fundamental importancia para la industria del turismo:

a) La relación;

b) La interactividad entre las partes;

c) El largo plazo.

La relación existente entre la oferta y la demanda en todo mercado por medio de la cual se puede establecer un intercambio y la promoción de la satisfacción equitativa es alzada en las economías de mercado por el marketing a través de dos actividades dirigidas a la distribución y a la comunicación.

A partir de ello podemos inferir la importancia que la comunicación ejerce frente al marketing turístico. El proceso de comunicación se ordena de forma que conlleve un doble flujo de información entre productores y consumidores. A través de la organización de las dos actividades mencionadas anteriormente, se puede concretar la función del marketing en la economía como observa Manuel Rey (2004:27):

La función del marketing en la economía queda concretada. Se trata de crear un flujo de información que permita conocer las necesidades y deseos de la sociedad, confeccionar los productos que puedan satisfacer esas necesidades, organizar la distribución de los mismos para ponerlos en manos de los consumidores y, por último, articular un flujo de información que permita a la oferta comunicar de forma persuasiva a la demanda qué productos y en qué condiciones tiene a su disposición y conocer el grado de satisfacción que los mismos le proporcionan.

El marketing posee tres ideas básicas que son: la filosofía, la dimensión estratégica y la dimensión operativa. Su filosofía gira en torno a una subdivisión en seis posiciones filosóficas presentadas a continuación:

1- Orientación hacia la producción;

2- Orientación hacia el producto;

3- Orientación hacia la venta;

4- Orientación hacia el consumidor;

5- Orientación al marketing social; 
6- Orientación al mercado.

Como ya hemos visto anteriormente, la creciente búsqueda de ocio y negocios comerciales han configurado la industria del turismo en una posición de líder económico en el mercado mundial. Sin embargo, todos los cambios sufridos por la industria turística y su coyuntura industrial, que está orientada hacia las exigencias de un consumidor sofisticado, vehiculan el proceso y la aplicación del marketing turístico al concepto de turismo, como explica Manuel Rey (2004:35) cuando afirma que "la aplicación del marketing al turismo debe hacerse con cautela, pues son muchas las peculiaridades y elementos distintivos del mismo. Por lo tanto, y antes de delimitar el contenido del marketing turístico, se hace necesario partir de una adecuada definición del término turismo".

Según la Organización Mundial de Turismo (OMT), el término turismo se refiere a "las actividades que realizan las personas durante sus viajes y estancias en lugares distintos al de su entorno habitual, por un periodo de tiempo inferior a un año con fines de ocio, negocio y otros". Sin embargo, la amplitud del vocablo "actividades" dificulta la definición estricta del producto turístico distribuido por medio de los siguientes subsectores: alojamiento, restaurantes, atracciones turísticas, infraestructura local, medios de transportes y viajes organizados, entre otros. Solamente después de tomar como base la definición de turismo, es factible discurrir sobre el marketing turístico, que para Manuel Rey (2004:37):

Será la parte del marketing encargada de guiar la comercialización de los productos y servicios de las organizaciones que integran el sector. Para ello, deberá estudiar al consumidor turístico y sus necesidades y deseos, las características de los mercados y entornos que rodean al marketing en estas organizaciones y las estrategias y acciones de marketing relevantes para las empresas del sector. La dificultad estriba, precisamente, en encontrar pautas de gestión de marketing comunes para todo el sector, dada la heterogeneidad propia del mismo (dentro del sector se integra una gran variedad de organizaciones, públicas y privadas, de tamaños y condiciones de producción muy dispares como restaurantes, hoteles, patronatos, grandes líneas aéreas. 


\subsection{La comunicación turística y la publicidad}

Siempre que hablamos de publicidad turística hacemos referencia al marketing turístico y a la comunicación persuasiva, como si fueran elementos interrelacionados. Hay dos enfoques básicos para el proceso de comunicación para las organizaciones: la interna y la externa o comunicación comercial. De acuerdo con esta idea Manuel Rey (2004:320) defiende que:

El concepto de comunicación en el contexto de las organizaciones tiene dos enfoques iniciales. Se puede establecer una comunicación interna entre los diferentes miembros o grupos que forman parte de una organización, y una comunicación externa entre la propia organización y los individuos y grupos que son ajenos a la misma.

El producto turístico mantiene muchas incertidumbres comerciales por sus especificidades y por el entorno comercial lleno de competitividad, en ese contexto es necesario exponer los servicios ofrecidos, sus características, ventajas y otras particularidades capaces de adquirir la confianza de los clientes. En virtud de eso, el proceso de comunicación turística debe englobar una información más bien interesada en dar a conocer un determinado producto y a la vez convencer al público potencial a producir la acción de compra del producto anunciado. En este caso el proceso de comunicación consiste en una serie de señales difundidas por una empresa a un determinado público en función de la obtención de una respuesta positiva al mensaje emitido. En ese tipo de proceso comunicativo los elementos fundamentales de la comunicación (emisor, código, mensaje, medio o canal de difusión, receptor, posibles ruidos y la retroalimentación) necesitan estar previamente definidos.

Todos esos elementos presentes en el proceso de comunicación sirven para apoyar una empresa en cómo proceder en la planificación de lo que desea comunicar, cómo, y para quién será producido el mensaje y cuáles los medios de difusión comunicativa más apropiados para ello. 
Como elementos de comunicación turística están la publicidad, las ferias de eventos turísticos, las promociones de ventas, las relaciones públicas, el patrocinio y el marketing directo. Respecto de los instrumentos de comunicación turística Manuel Rey (321-322) dice que:

\begin{abstract}
Las actividades de comunicación comercial de la empresa turística están basadas en la utilización de varios instrumentos para transmitir sus mensajes al público objetivo. Todos ellos forman parte de la estrategia de comunicación de manera integrada [...]. Los mecanismos que se usan ampliamente en el sector turístico son los siguientes: publicidad, promoción de ventas, relaciones públicas, ferias turísticas, venta promocional, patrocinio y marketing directo. La combinación de estos mecanismos va a depender [...], de las situaciones específicas de cada empresa, pero cada uno de ellos puede desempeñar un papel determinado [...], dependiendo de cuatro factores principales: el tipo de mercado, el tipo de producto, la estrategia de comunicación y el grado de implicación del comprador.
\end{abstract}

La prioridad de un determinado instrumento de comunicación turística en relación a otro será definida a partir de factores como si se tratara de mercados de consumo o mercados organizacionales, el tipo de producto ofrecido, el ciclo de vida del producto, la estrategia de comunicación: push (presión) o pull (aspiración) y el grado de implicación del consumidor, su género, su edad, su grupo socioeconómico y su nivel educativo y cultural. En general, en muchos de esos factores se hace necesario el uso de la publicidad como instrumento de comunicación turística. Para Manuel Rey (2004:323):

\footnotetext{
La publicidad consiste en el envío de mensajes no individualizados y pagados por el emisor a un público objetivo seleccionado, con el propósito de dar a conocer y recordar productos o marcas e influir en sus actividades y comportamientos. Por lo tanto, la publicidad es un instrumento de comunicación que se utiliza para transmitir mensajes de forma impersonal y simultánea mediante medios de comunicación masivos remunerados y que van dirigidos a un amplio conjunto de clientes potenciales.
}

Los anuncios publicitarios conllevan un determinado precio para el receptor $\mathrm{y}$, sobre todo, para el emisor que no es anónimo e implica siempre el respaldo de la fiabilidad de quien emite los mensajes. Dichos mensajes son limitados por el precio que se paga por espacios y tiempos predeterminados y limitados. Son difundidos por los medios de comunicación social masivos, usados como préstamo por la comunicación comercial. Los medios de comunicación social más usados son la televisión, la radio, la prensa, el cine y los medios electrónicos. 
La publicidad, por ser una de las estrategias de comunicación del turismo más importantes, merece una atención especial en lo que concierne a sus procedimientos, que son:

1- La estrategia publicitaria;

2- El plan de medios de soporte publicitario;

3- La identificación y la selección de medios publicitarios;

4- Las decisiones sobre los soportes de publicidad;

5- La evaluación del plan de medios y soportes en la publicidad.

Las estrategias publicitarias son delimitadas por los objetivos de la empresa y por su marketing propiamente dicho. Son difundidos a partir de la estrategia creativa, encargada de la creatividad en la elaboración de mensajes publicitarios, además de la estrategia de difusión, responsable por la selección del lugar, la fecha y la forma de difusión del mensaje de la publicidad.

Los medios de comunicación elegibles para una campaña publicitaria son los convencionales tradicionalmente, como la prensa (diarios y revistas); los audiovisuales, como el cine y la televisión; los radiofónicos, como las emisoras de radio; además de la publicidad expuesta en medios exteriores, como la que se expone en las vías públicas. Sumado a eso, existen los medios no convencionales que consisten, sobre todo, en las ventas en el ámbito de páginas electrónicas on line.

La venta personal también actúa como elemento de marketing para la industria turística. Sirve para establecer un contacto directo entre el personal representante de esa industria y el cliente, además transmite el tipo de imagen que la empresa quiere pasar a sus clientes. 
El producto turístico es peculiar en el sentido de que no se trata de un bien de consumo tangible y por ello no puede ser evaluado materialmente, de ahí la importancia de la forma por la cual el producto es presentado y representado a su público, por medio de promociones publicitarias. Concerniente a eso Meene Ruschmann (1999:11-12) dice que:

Por tratarse de un bien de consumo abstracto, no puede, al contrario de los bienes tangibles, ser evaluado de acuerdo con su tamaño, peso, formato o color. Es representado a los consumidores potenciales por medio de descripciones y fotos, y lo que induce al cliente a su compra son las promesas de satisfacción. La manera por la que el producto es presentado, o la promesa es retratada, en acciones publicitarias y promocionales, es fundamental para la decisión de compra del turista. ${ }^{12}$

La publicidad turística debe ser muy llamativa y presentar imágenes tan reales a punto de despertar en el interlocutor el deseo de visitar el sitio anunciado. Por eso "el turismo hace llamadas por medio de la grafía y de la imagen, que deben ser bastante evocativas, para hacer nacer el deseo en quien las ve de visitar el local divulgado" (Meene Ruschmann, 1999:60). ${ }^{13}$

En esta misma línea de pensamiento, es importante resaltar que la publicidad turística juega con el carácter subjetivo de sus mensajes, para ello hace falta conocer a los posibles perfiles de los consumidores del producto anunciado, ya que el público receptor de la expresión comercial del turismo es, fundamentalmente, heterogéneo, tal como afirma Meene Ruschmann (1999:63-64) a continuación:

La propaganda turística divulga un producto de consumo inmaterial. La realización de un viaje turístico constituye una experiencia, la realización de un sueño - aspectos subjetivos, cuya intensidad varía de acuerdo con las motivaciones del comportamiento turístico. Así como las motivaciones, es necesario conocer, minuciosamente, al público objeto de una campaña publicitaria que en el turismo es altamente heterogéneo en lo que se refiere a los gustos, costumbres, deseos, necesidades, además de las diferentes nacionalidades e idiomas, en el caso del turismo internacional. ${ }^{14}$

La publicidad turística es el elemento que actúa en la persuasión de los posibles consumidores de este tipo de producto, además de difundir y crear la necesidad de la

\footnotetext{
${ }^{12}$ Traducción de la autora.

${ }^{13}$ Traducción de la autora.

${ }^{14}$ Traducción de la autora.
} 
actividad turística. En fin, "la propaganda turística es considerada la actividad que influencia y se esfuerza en persuadir y habituar a las personas a viajar, proponiéndoles motivos que despierten el deseo de conocer un determinado local" (Meene Ruschmann, 1999:70). ${ }^{15}$

Todavía concerniente a la importancia de la expresión comercial del turismo, se puede destacar que el proceso de comunicación turística es bastante complejo por establecer el nexo entre el productor y el consumidor de la comunicación, o sea, la oferta y la demanda como afirma Meene Ruschmann (1999:85) a continuación:

\begin{abstract}
La comunicación publicitaria en el turismo es un proceso bastante complejo. Es considerada elemento de ligación entre la oferta y la demanda y, por eso, la conquista de mercados solo tendrá éxito cuando los productos turísticos estén adaptados a las necesidades y deseos de la demanda y si es realizada por medio de una acción publicitaria coordinada y direccionada. ${ }^{16}$
\end{abstract}

En este contexto es fundamental la fiabilidad del mensaje divulgado para mostrar el destino turístico de forma atractiva sin presentar o prometer lo que no existe porque es "necesario enseñar el producto turístico de la forma más llamativa posible, resaltando los aspectos distintivos de una atracción o equipamiento, sin embellecerlos o divulgar lo inexistente" (Meene Ruschmann, 1999:62). ${ }^{17}$

En suma, la credibilidad de un mensaje publicitario perteneciente a la industria turística es un factor preponderante en el sentido de que los clientes compran bienes intangibles, puesto que lo que se compra por medio de una actividad turística consiste en una "experiencia - intangible e imposible de ser evaluada antes de efectivamente vivida. Por lo tanto, la credibilidad de los mensajes enviados por medio de la propaganda y de las

\footnotetext{
${ }^{15}$ En la fuente original: “A propaganda turística é considerada a atividade que influencia e se esforça em persuadir e habituar as pessoas a viajar, propondo-lhes motivos que despertem o desejo de conhecer um determinado local".

${ }^{16}$ En la fuente original: “A comunicação publicitária no turismo é um processo bastante complexo. É considerada elemento de ligação entre a oferta e a demanda e, por isso, a conquista de mercados só terá sucesso quando os produtos turísticos estiverem adaptados às necessidades e desejos da demanda e se for realizada por meio de uma ação publicitária coordenada e direcionada".

${ }^{17}$ En la fuente original: "É preciso mostrar o produto turístico da forma mais atraente possível, ressaltando os aspectos diferenciais de uma atração ou equipamento, sem embelezá-los ou divulgar o que não existe".
} 
promociones es un aspecto fundamental de su comercialización" (Meene Ruschmann, 1999:113). ${ }^{18}$

\title{
El folleto turístico
}

El material impreso como los folletos, catálogos, libros y revistas funcionan como la variable de la comunicación en un programa de marketing-mix de una empresa. En general desempeña las funciones complementares de la publicidad, además de remplazar el producto turístico; auxiliar en el acto de ventas; representar acciones publicitarias y servir de apoyo a ellas; funcionar como un documento que asegura la calidad de un determinado producto y, por lo tanto, actúa como una especie de elemento contractual que asegura la garantía del servicio que será comprado.

Además de eso, el material impreso sirve de motivación para la compra de un producto turístico y desempeña un papel informativo. En este sentido trabaja como un tipo de orientación educativa con respecto al producto turístico. A lo dicho anteriormente Manuel Rey (2004:347) añade que:

\begin{abstract}
Los folletos turísticos actúan como sustitutos del producto turístico, dado que se caracteriza por su intangibilidad y por la imposibilidad de separar su producción de su consumo. Este material se convierte en una pieza fundamental a la hora de hacer tangible el producto, ofreciendo al cliente la oportunidad de conocer con mayor profundidad sus cualidades a través de una combinación adecuada de texto y fotografías. Esto hace que su diseño sea lo suficiente atractivo como para captar la atención del consumidor potencial.
\end{abstract}

Además de servir para describir el producto turístico y para reforzar otros tipos de acciones comunicativas, ya que son útiles para detallar los productos anunciados mediante otros recursos comunicativos, también transmiten las informaciones principales sobre un determinado destino turístico, tales como el clima, la gastronomía, la cultura y las costumbres locales.

La tipología de los folletos no es fija, sin embargo es posible establecer una clasificación de este tipo de material a partir de la adopción de algunos criterios como

\footnotetext{
${ }^{18}$ En la fuente original: "Experiência - intangível e impossível de ser avaliada antes de efetivamente vivida. Portanto, a credibilidade das mensagens enviadas por meio da propaganda e das promoções é um aspecto fundamental da sua comercialização".
} 
por ejemplo el contenido del material impreso. Manuel Rey (2004:348-349) propone una clasificación según este criterio, a partir de ello sugiere una división clasificativa en tres grandes grupos, a saber: los folletos informativos; los folletos orientativos y destinados a ventas; y los folletos libros. Tomando esa clasificación como punto de partida, veremos abajo en qué consiste cada uno de estos grupos.

\section{Los folletos informativos}

Son los que sirven para informar respecto del producto turístico de forma accesible y simple, por medio de textos y fotos. No obstante, no incorporan los precios. Como ejemplo de ese tipo textual se puede citar las guías turísticas y los consejos de viajes como el que podemos ver a continuación.

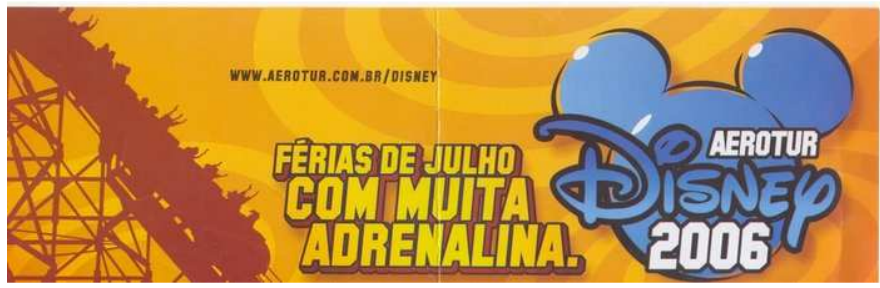

Anverso de un folleto publicitario informativo

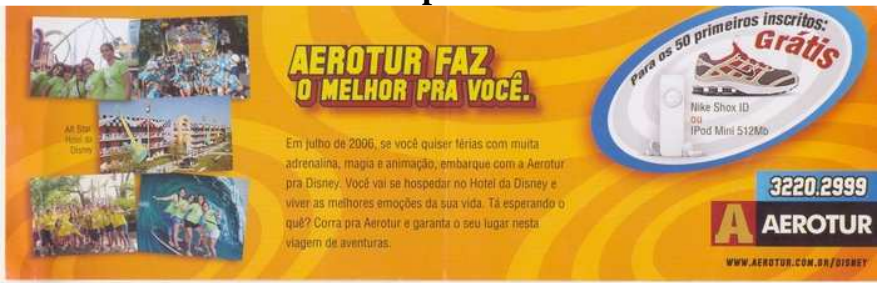

Verso de un folleto publicitario informativo 
Este tipo es más objetivo, menos informativo y descriptivo, en él hay presencia de tarifas, formas de pago y su obsolescencia. Eso es lo que podemos observar en el ejemplo de folleto orientativo y destinado a venta expuesto abajo.

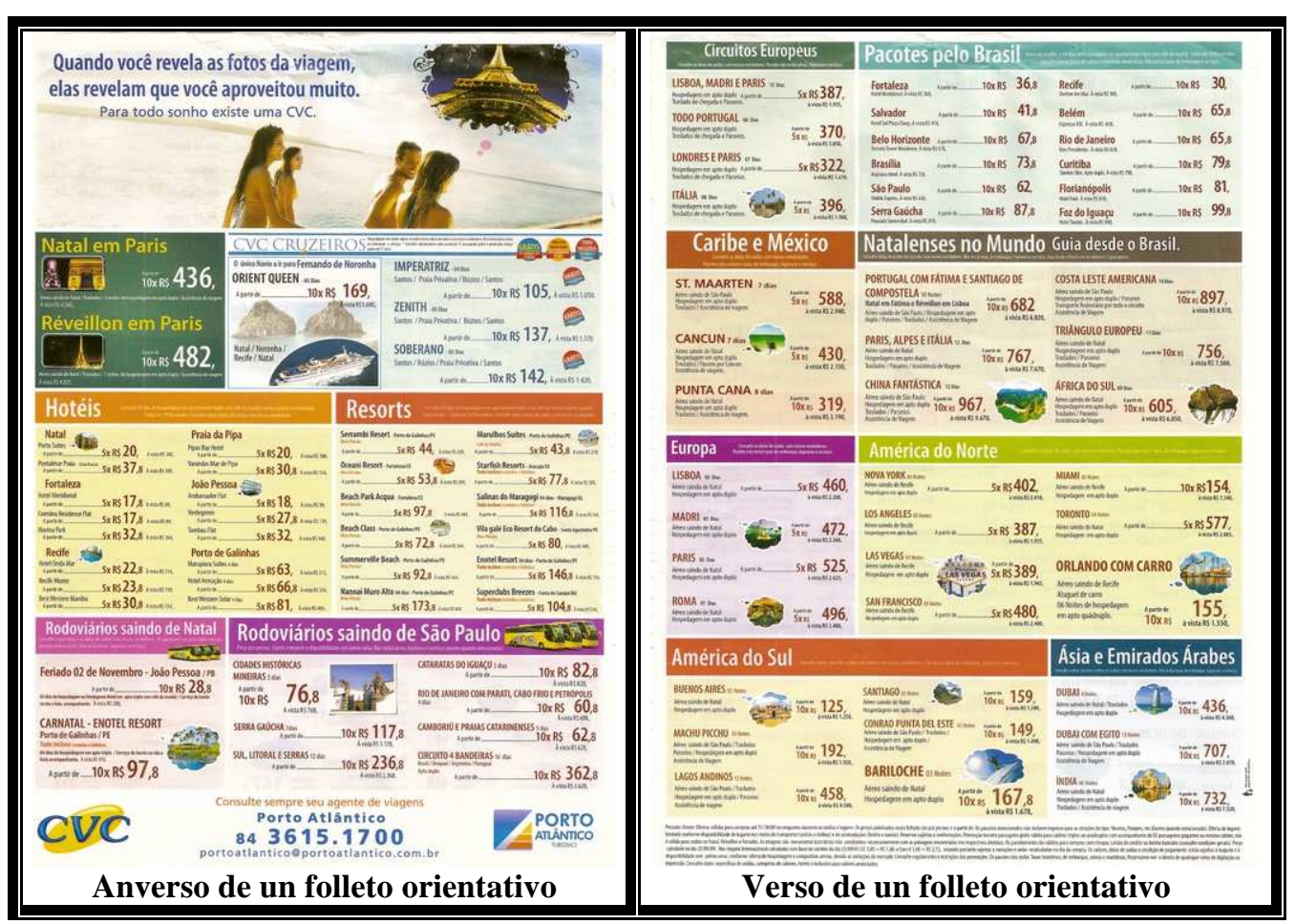


Por último, el tercer tipo consiste en folletos extensos con el formato de un libro, son ediciones limitadas, con más contenido y más amplitud. Además de tener más calidad, que implica el alto coste y su consecuente limitación. Son generalmente producidas por localidades turísticas para tratar con exuberancia sus propios destinos turísticos.

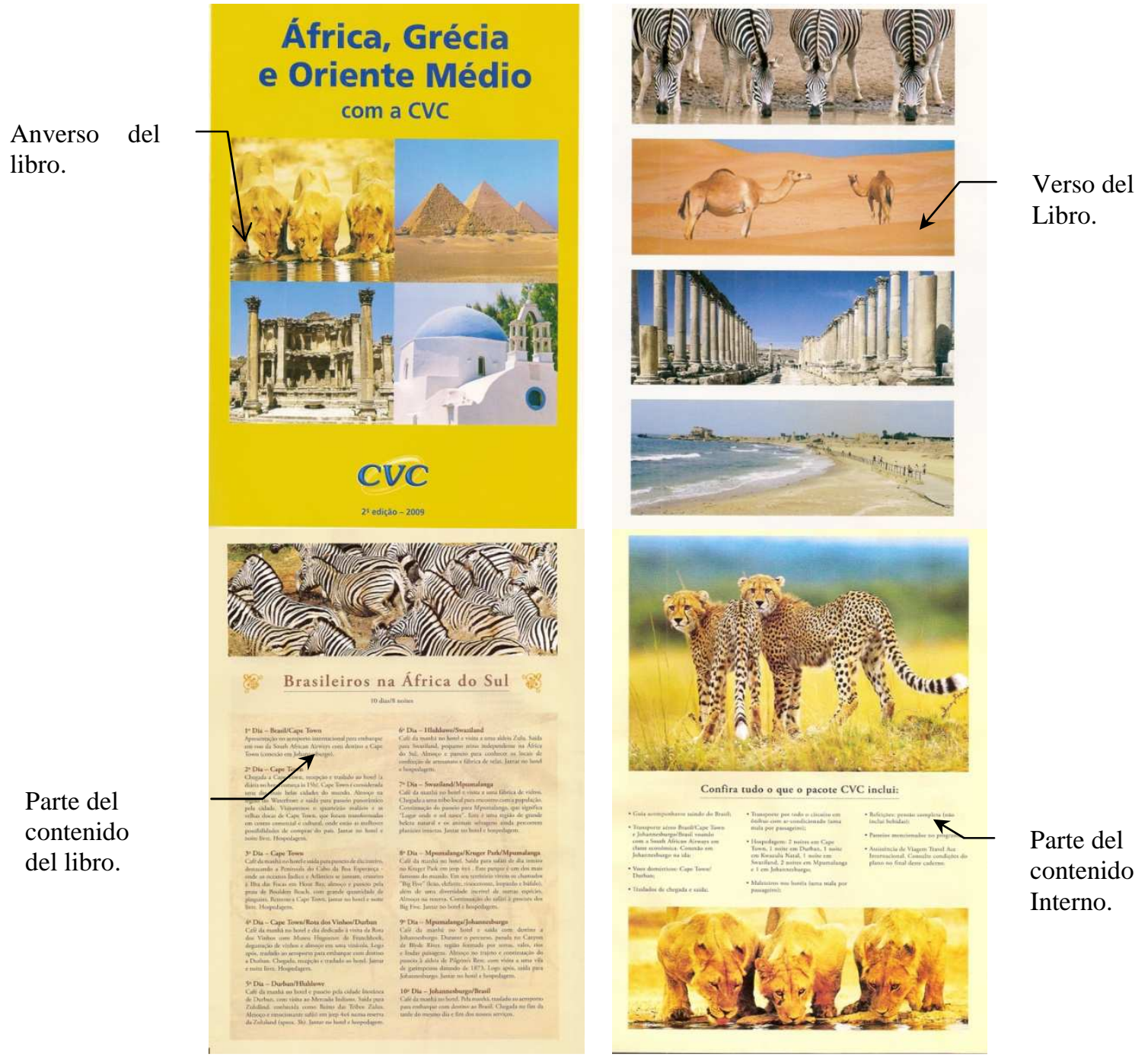

Además de los tres tipos grandes grupos presentados por Manuel Rey (2004) y expuestos arriba, otra alternativa sería establecer la clasificación de los folletos a partir de su destinatario o mezclar el primer tipo con el segundo modo de clasificación, lo que resulta en la tendencia más contemporánea de folletos mixtos. 


\subsection{La comunicación turística y la lingüística textual}

En las últimas décadas ha aumentado el interés por el análisis del discurso y sus aplicaciones pragmáticas. Por eso es cada vez más frecuente el aumento de la relevancia de este campo de estudio frente a la comunidad científica. Además de ello, muchas profesiones que se dedican al trato personal con contacto directo como negociaciones, marketing, discusión o correspondencia ocupan un lugar destacado en el ámbito profesional que, actualmente, se ha preocupado más de la importancia de transmitir mensajes y recibir la respuesta esperada del interlocutor o la audiencia de dicho mensaje.

La relevancia y la atención científica dedicadas al análisis del discurso y a la lingüística textual, en la segunda mitad del siglo XX e inicio del XXI, están directamente relacionadas con la realidad contemporánea, que está regida por un sistema económico en el que la comunicación es fundamental. Además, esa misma sociedad disfruta del desarrollo de los medios de difusión de la palabra y la comunicación, es decir, los mass media, de una forma general.

Sumado a eso es cada vez más común la existencia del contacto directo entre distintas naciones o culturas. En este contexto, la necesidad de aclarar la misma idea para personas de culturas distintas se hace importante para evitar los malentendidos de incomprensión o demagogia que en muchas situaciones comunicativas pueden generar diversos problemas. También se puede añadir aquí el hecho de que el mundo de los negocios, como es el caso de la industria del turismo, depende del acto comunicativo eficaz, ya que en muchas negociaciones, sus fracasos o éxitos dependen de trasmisiones exitosas de información.

Así que, a partir de esa realidad, aumenta la inversión financiera, científica y tecnológica en la preparación de profesionales de las diversas esferas profesionales concernientes al habla y a la escrita. Además, aumenta la demanda de las grandes empresas por profesionales de la comunicación, bien calificados y con competencia lingüística apropiada para atender las exigencias del mercado laboral. Junto a eso, parece ser que los estudios sobre publicidad están aumentando poco a poco, pero todavía hay pocos estudios sobre publicidad desde un punto de vista de la linguiística, 
como menciona Robles Ávila en su libro Realce y Apelación en el Lenguaje de la Publicidad (2004:11) cuando dice que, en ese ámbito, las investigaciones más actuales "se han concentrado en temas y aspectos más bien vinculados a cuestiones de publicidad general, estrategias comerciales, imagen publicitaria, etc. ajustándonos a la realidad, se puede decir que los aspectos lingüísticos parecen desecharse”.

El lenguaje publicitario explora todos los recursos lingüísticos posibles en la elaboración de un mensaje y el dominio de la semántica es fundamental en la elección del léxico para la producción del mensaje publicitario, como afirma Robles Ávila (2004:13) cuando dice que el lenguaje publicitario:

\begin{abstract}
Tiene que explotar al máximo el rendimiento de los elementos lingüísticos que utiliza en la configuración de los mensajes, siendo la semántica la disciplina que se sitúa en el centro de la diana para el creativo. Como cualquier emisor, el proceso que seguirá el publicitario en la creación del mensaje será onomasiológico y partirá de los conceptos para llegar a las palabras que los representan. Las palabras que se seleccionen deben ser las más eficaces desde el punto de vista de su significado, deben ajustarse con exactitud a los conceptos que se quieren transmitir.
\end{abstract}

\title{
La importancia de la lingüística textual para la publicidad
}

La publicidad, a su vez, ha conquistado bastante significación en lo que concierne al campo laboral de los negocios, además de los estudios y aplicaciones de este campo de la lingüística textual. Muchas veces ya no se percibe la presencia de la publicidad en todos los sitios y en todos los medios de comunicación, pues ya se ha convertido en algo cotidiano.

Es más, en la sociedad contemporánea, el elemento publicitario desempeña un papel fundamental en todos los tipos de empresas tanto de prestación de servicios como de elaboración y comercialización de productos. Eso torna difícil imaginar una realidad sin los colores, la creatividad y las innovaciones de los anuncios que están por todas partes, aunque uno no se fije en ellos.

En este contexto el discurso publicitario desempeña un papel fundamental en nuestra actual constitución social y económica, puesto que es producto de un grupo consumista 
y al mismo tiempo se vuelve sobre este grupo social para hacerlo público objetivo de campañas publicitarias que instigan al consumo.

Por eso existe la necesidad de estudios sobre los textos publicitarios, para que se consiga aclarar sus condiciones de producción textual, cuáles son sus principales características y en qué consiste específicamente el discurso publicitario. Además de cómo se produce un buen texto publicitario, también cómo se forma y actúa un buen publicista.

Un simple folleto de texto publicitario es uno de los ejemplos más claros de lo complicado que es el discurso y el texto escrito. Es una forma de comunicación que requiere el dominio de todas las técnicas de escritura, al mismo tiempo que hace uso de una cuidadosa creatividad. El manejo de la lengua a favor de la comunicación con fines persuasivos es muy complejo y por eso preocupa a los profesionales que se dedican al fenómeno publicitario.

En la publicidad es necesaria la producción de textos que presenten las ideas del emisor de manera clara, para que el interlocutor pueda acceder al mensaje transmitido con mucha facilidad. Además de ello, los textos publicitarios deben ser producto de una creatividad artística y textual que proporcionen a la vez una fácil comprensión y, sobre todo, llamen la atención de la audiencia, para persuadirla.

Sin embargo, en esta investigación no trataremos de la publicidad de cualquier producto ya que nos dedicaremos solamente a la publicidad del producto turístico, o sea, la publicidad turística. De ese modo se intentará realizar un estudio lingüístico de este tipo de publicidad, en el que se intentará establecer una relación entre la industria del turismo y el lenguaje publicitario, aplicando los conceptos del análisis del discurso y la lingüística textual tan fundamentales para la publicidad y para cualquier mercado económico que dependa directa o indirectamente del lenguaje y de un acto de comunicación eficaz para vender su producto.

A partir de ello se abogará en este estudio que la publicidad turística trabaja elementos lingüísticos en la elaboración de sus mensajes y los difunde por los medios de comunicación social masivos, usados como préstamo por la comunicación comercial en 
el marketing turístico. Eso quiere decir que los elementos lingüísticos y textuales constituyen la base para la publicidad de la que se ocupan los medios de comunicación masivos de los cuales el marketing turístico hace uso. Y, por lo tanto, muestra que hay una íntima relación entre el sector del turismo con su marketing, la comunicación social, por medio de la publicidad, y la linguística textual, sin la cual toda esta cadena de la comunicación turística no sería establecida.

\subsection{Conclusión}

Al fraguar la organización de nuestro trabajo de investigación, nos hemos dado cuenta de la importancia de la existencia de un capítulo que relacione nuestra temática y a la vez aclare algunos elementos y conceptos fundamentales para nuestro estudio. Así que este capítulo ha sido elaborado en virtud de la necesidad del establecimiento del nexo entre la industria del turismo; su importancia como un factor de desarrollo económico y social; el marketing turístico; la comunicación publicitaria; la lingüística textual; y la publicidad. Así, lo que hemos visto anteriormente nos deja claro que:

1- El turismo es un producto intangible y multidisciplinar;

2- La industria del turismo se desarrolló con el perfeccionamiento del capitalismo;

3- El turismo y la publicidad se relacionan con la revolución industrial;

4- El marketing turístico funciona como un punto de intersección entre las técnicas y las estrategias del marketing y la industria del turismo;

5- La publicidad, por su parte, es una de las actividades más visibles del marketing;

6- El marketing funciona como una filosofía de procedimiento empresarial, inserto en un determinado mercado industrial;

7- La comunicación es una de las actividades por medio de las cuales el marketing establece la relación existente entre la oferta y la demanda, en todo mercado, por medio de la que se puede establecer un intercambio y la promoción de la satisfacción equitativa alzada en las economías de mercado;

8- La aplicación del marketing turístico está vinculada al concepto de turismo;

9- La publicidad turística es uno de los elementos de la comunicación turística;

10- La publicidad turística es el elemento que actúa en la persuasión de los posibles consumidores de este tipo de producto, además de difundir y crear la necesidad de la actividad turística; 
11- La publicidad turística es bastante compleja porque establece el nexo entre la oferta y la demanda de un producto intangible;

12- Los folletos turísticos actúan como sustitutos del producto turístico;

13- El folleto turístico hace tangible al producto turístico por medio de una combinación adecuada de texto e imagen;

14- La tipología de los folletos turísticos no es fija;

15- La industria del turismo depende del acto comunicativo eficaz;

16- La lingüística textual estudia los actos de comunicación;

17- El texto publicitario desempeña un papel fundamental en la sociedad contemporánea;

18- El turismo es un fenómeno contemporáneo;

19- La comunicación de masas es un fenómeno contemporáneo;

20- La lingüística textual es un fenómeno contemporáneo;

21- La publicidad es un fenómeno contemporáneo;

22- La publicidad es un acto de comunicación.

Tomando, pues, estos postulados como referencia, no cabe duda de que el turismo, la comunicación turística, la publicidad y la lingüística textual son temas convergentes, sobre todo en lo que toca a la esfera de lo contemporáneo, dado que todos ellos son fenómenos de nuestro tiempo, dependen de la comunicación y tienen el origen de su actual desarrollo vinculado a la revolución industrial y al desarrollo del capitalismo. Así que partimos de esta premisa para dar continuación a este trabajo. 


\section{Capítulo III}

\section{ESTUDIO DE CASO: EL CORPUS, LA METODOLOGÍA, EL DISEÑO Y LA TEORÍA DEL ACTO DE COMUNICACIÓN PUBLICITARIO}
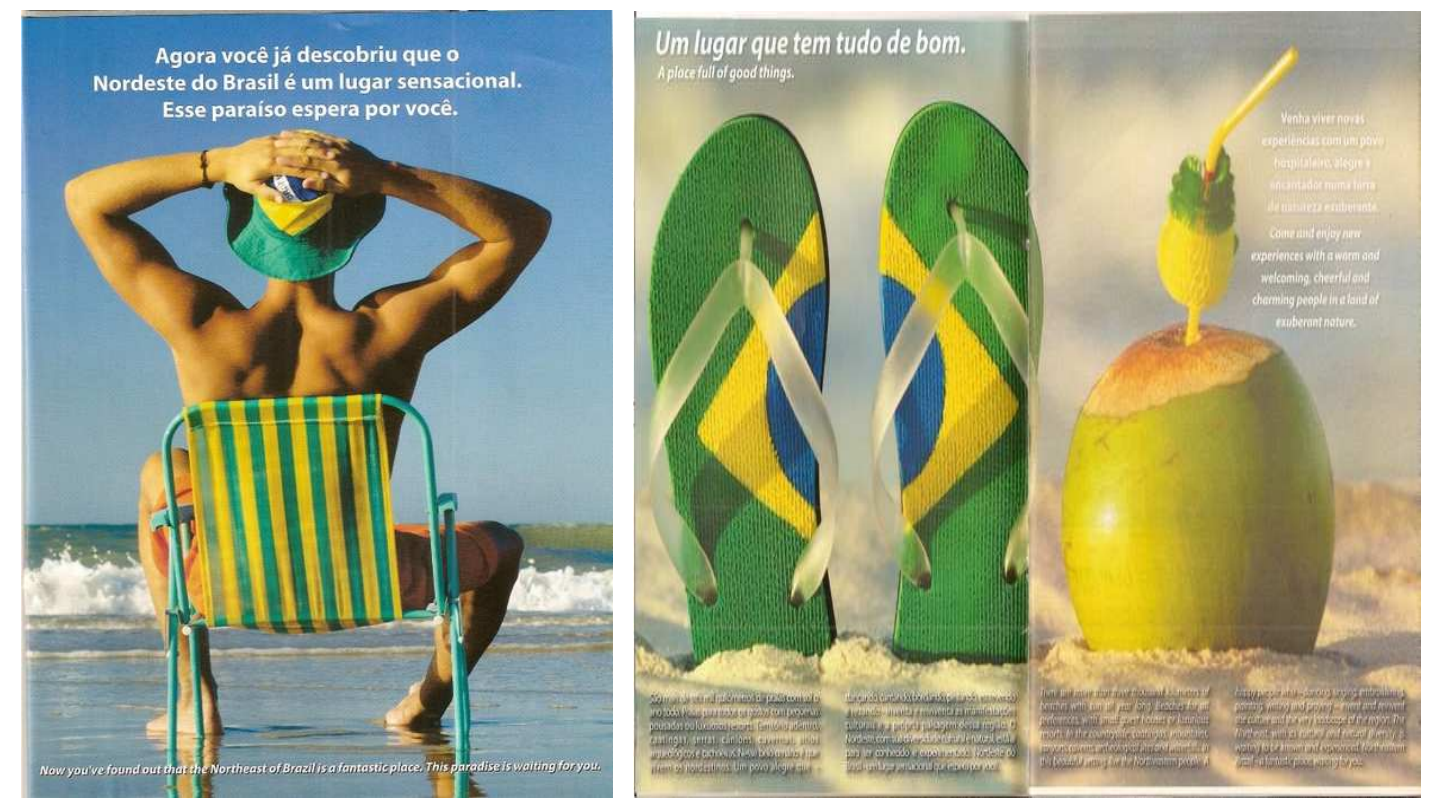

"Las características de cualquier cuestión social son: provisoriedad, dinamismo y especificidad, pues el objeto de las ciencias sociales es histórico".

(Maneti Dencker) 


\section{CAPÍTULO III - ESTUDIO DE CASO: EL CORPUS, LA METODOLOGÍA, EL DISEÑO Y LA TEORÍA DEL ACTO DE COMUNICACIÓN PUBLICITARIO}

El tercer capítulo de nuestro trabajo está dedicado a la presentación de nuestro corpus del estudio de caso, la metodología de la investigación empírica adoptada como modelo operacional de procedimiento, el diseño metodológico utilizado en la investigación y nuestra Teoría del Acto de Comunicación Publicitario. Está constituido por doce temas, entre los cuales figuran la metodología y diseño experimental; objetivos e hipótesis; selección del corpus, recogida y tratamiento de los datos; grado de innovación previsto; plan de trabajo y cronograma; investigación bibliográfica y documental; el corpus; reducción de los datos; la tesis; la teoría del acto de comunicación publicitario; la publicitariedad; y, por último, la conclusión del capítulo.

\subsection{Metodología y diseño experimental}

Una investigación científica resulta de una curiosidad y un esfuerzo por encontrar respuestas y nuevas informaciones al respecto de un determinado objeto de estudio. Para Maneti Dencker (2003:266), de ese modo se puede "encontrar soluciones para los problemas humanos y contribuir para la mejora de las condiciones de vida de todos, colocando al hombre como prioridad mayor".

Para el establecimiento de una clasificación para las investigaciones científicas es necesaria la adopción de parámetros de referencia a partir de elementos como la clasificación de ciencia y la clasificación de investigación. La ciencia puede ser clasificada en ciencias formales (lógica y matemática); y ciencias factuales (naturales, culturales, sociales o humanas). De ese modo, por un lado, la física, la química, la biología, la geología, la astronomía, etc. constituyen las llamadas ciencias naturales. Y, por otro, entre las llamadas ciencias culturales, sociales o humanas figuran la lingüística, la antropología, la sociología, la economía, la política, la historia, la psicología y otras. Por eso nuestra investigación en lingüística textual forma parte de los estudios de las ciencias factuales, más específicamente, de las ciencias culturales, sociales o humanas. Para Maneti Dencker (2003:20) "las características de cualquier cuestión social son: provisoriedad, dinamismo y especificidad, pues el objeto de las ciencias sociales es histórico". 
La clasificación de una investigación está establecida en relación a sus objetivos, a su forma de estudio y a su objeto de estudio. La investigación científica, en cuanto a sus objetivos, puede ser: investigación teórica, metodológica, empírica y práctica o acción; por otro lado, la investigación en cuanto a su forma de estudio puede ser: investigación exploratoria, descriptiva y explicativa; por último, está la investigación según su objeto de estudio, clasificada en bibliográfica, experimental y de campo. Desde este punto vista, nuestra investigación puede ser clasificada como teórica y práctica, en relación a sus objetivos; exploratoria y descriptiva, según su forma de estudio; y, bibliográfica y de campo, en relación al objeto de estudio.

A partir de eso, cabe añadir que un estudio científico también puede ser clasificado en relación a sus procedimientos técnicos y esa es una parte muy importante de una investigación porque remite al marco teórico establecido para su aproximación conceptual, aunque necesite de un modelo conceptual $\mathrm{u}$ operativo, o sea, de un delineamiento. En la presente investigación hubo una parte bibliográfica, asociada a una investigación documental.

El delineamiento de un estudio de caso consiste en un estudio profundo de forma exhaustiva de un número reducido de objetos para su amplio detallamiento. En las ciencias sociales este delineamiento de una investigación "es considerado como un delineamiento más adecuado para la investigación de un fenómeno contemporáneo dentro de su contexto real, donde los límites entre el fenómeno y el contexto no son claramente percibidos" (Yin, 2001, apud Carlos Gil, 2002:54).

En razón de ello hemos elegido el estudio de caso como delineamiento predominante para nuestro estudio científico. También se han adoptado para esta investigación los métodos cualitativos, puesto que, como afirma Santos Asensi (2008:304-305), las características de la investigación cualitativa son:

1- Inductiva (recoger datos para confirmar una hipótesis);

2- Rigurosa;

3- Realista y humanista;

4- Ideográficas e interactivas;

5- Enfocada en la producción de conocimiento; 
6- Actitud transdisciplinar;

7- Capacidad de adaptación al entorno;

8- Compromiso ético con el tema y el contexto de investigación;

9- Pluralidad metodológica;

10- Facilitar la comprensión.

No obstante lo anterior, algunos aspectos han sido detallados de modo cuantitativo, en el caso de los datos obtenidos en las agencias de viaje que forman parte del caso estudiado, pero en general hemos seguido un modelo de investigación cualitativo.

Para llevar a cabo esa actividad de corroboración y ampliación de los postulados existentes se utilizan como base los paradigmas ya existentes. Esta investigación hizo uso de las bases teóricas a respecto del análisis del discurso y más específicamente el discurso publicitario a partir del estudio del caso de la publicidad distribuida por las agencias de viaje de Natal asociadas a la Asociação Brasileira de Agências de Viagens (ABAV). Por ello la primera etapa de la organización metodológica de esta investigación consiste en la actualización de los conceptos acumulados sobre el turismo y su relación con la publicidad. Para eso hemos tomado en consideración que:

El estudio del turismo, como de las otras ciencias, se procesa dentro del paradigma dominante en el momento de la investigación. Lo que se observa es que ese paradigma, en el momento actual, pasa a incorporar variables cualitativas y elementos subjetivos como complementación e incluso como sustitución de las técnicas estadísticas y análisis cualitativos (Maneti Dencker, 2003:265).

\section{Estudio de Caso}

Tomando como base la clasificación de la investigación de acuerdo con sus objetivos generales, el establecimiento de su marco teórico (aproximación conceptual) es facilitado a partir del planeamiento de un modelo operativo de investigación, también conocido por disign o delineamiento, es decir, el planeamiento detallado de la investigación. 
En este sentido, el marco de referencia teórico de nuestro estudio se extiende sobre una problemática presente en nuestra realidad y puede ser clasificado como un estudio de caso. Concerniente al delineamiento de una investigación Carlos Gil (2002:43) afirma que:

\begin{abstract}
Como el delineamiento expresa en líneas generales el desarrollo de la investigación, con énfasis en los procedimientos técnicos de la recogida y análisis de los datos, se torna posible, en la práctica, clasificar las investigaciones según su delineamiento. El elemento más importante para la identificación de un delineamiento es el procedimiento adoptado para la colecta de datos. Así, pueden ser definidos dos grandes grupos de delineamientos: aquellos que se valen de las llamadas fuentes de "papel" y aquellos cuyos datos son fornecidos por personas.
\end{abstract}

\title{
Problema y unidad caso
}

La elección del tema es un factor decisivo en la elaboración de una tesis, pues, a partir de ello, se puede tener un tema más preciso o más panorámico. También la tesis puede estar ligada directamente a intereses políticos y sociales, y eso no le hará menos científica. Una vez que el carácter científico de una investigación se apoya en el cumplimiento de definición de un objeto de estudio, se requiere decir sobre este objeto algo que todavía no haya sido dicho, ofrecer utilidad a los demás a través del estudio, presentar hipótesis y suministrar elementos para la verificación y refutación de ellas.

La etapa inicial de ese tipo de investigación consiste en la formulación del problema a ser estudiado. Esa formulación requiere una lectura previa y la observación de que la mayor utilización de estudios de caso ocurre en estudios exploratorios y descriptivos. Para Dencker (2003:97) "la observación de los fenómenos sociales, hecha de manera intensiva, que implica la participación del investigador en el universo de ocurrencia de esos fenómenos, es una metodología de tipo cualitativo". Para esta misma autora:

\footnotetext{
En general, la mayoría de las investigaciones cualitativas se propone rellenar los espacios vacíos en el conocimiento, teniendo carácter descriptivo o exploratorio, y pocas se organizan para situaciones en que la teoría no es suficiente para solucionar el problema y el investigador necesita buscar en campo las variables que serán consideradas en el análisis (Maneti Dencker, 2003:98).
} 
La indagación central que motivó este estudio corresponde a la importancia que la comunicación publicitaria cobra en la sociedad contemporánea, sobre todo en sectores como el turismo. En suma, la estrategia y el método de esta investigación establecen una relación con la formulación del problema, objeto de esta investigación, y puede ser expresado, como hemos visto anteriormente, a través de las siguientes preguntasproblemas:

1- ¿Hay elementos inherentes al discurso publicitario que determinan si un texto es publicitario o no?

2- ¿Qué elementos textuales están presentes en todos o casi todos los textos publicitarios?

3- ¿Hay alguna característica común en la publicidad que defina su grado de "publicitariedad" o que caracterice un texto publicitario como tal?

Con esa finalidad han sido planteadas las siguientes cuestiones de estudio:

1- ¿Cuál es la importancia del turismo a nivel mundial y local?

2- ¿Cuáles son las especificidades de este producto?

3- ¿Cuáles son las particularidades de la industria del turismo?

4- ¿Cuál es la importancia del marketing y de la comunicación para esa industria?

5- ¿Cómo se constituye la publicidad del producto turístico?

6- ¿Qué se comprende por publicidad?

7- ¿Qué importancia tiene la publicidad en el contexto contemporáneo?

8- ¿Cuáles son las especificidades de la publicidad desde un punto de vista lingüístico?

9- ¿Se pueden identificar elementos comunes a todos los textos publicitarios que los determinen como publicitarios y no como literarios y no literarios?

La selección de un caso es realizada de acuerdo con el propósito de la investigación. Es más, "la elección del contexto y de los participantes, en las investigaciones cualitativas, es intencional" (Maneti Dencker, 2003:102). Además, las modalidades de los estudios de caso pueden ser de orden intrínseca (cuando el caso es el propio objeto de estudio), instrumental (cuando el estudio es desarrollado visando el conocimiento de un problema sin interés específico en el caso) y colectiva (cuando se estudian las características de una población). 
En este punto conviene resaltar que dentro de los métodos de investigación científica el inductivo consiste en el método de las humanidades por antonomasia, dado que las ciencias humanas son ciencias inductivas. Por lo tanto es posible afirmar que los humanistas nos movemos entre el método inductivo y el hipotético-deductivo, a saber: en un estudio en el campo de la sintaxis y fonología, que son más científicas, entonces, el método empleado será hipotético-deductivo; en un estudio sobre el análisis del discurso, lexicología y pragmática, el método inductivo es más apropiado.

El método inductivo en lingüística trabaja con hipótesis y muestras y consiste en un punto de vista de la realidad, por la que se llega a una hipótesis (H1) que será contrastada con una muestra más grande y para que se pueda llegar a una nueva hipótesis (H2), que será contrastada con una muestra más grande y de ahí se obtiene una tercera hipótesis (H3) y, así, sucesivamente hasta que lleguemos a resultados estables.

\subsection{Objetivos e hipótesis}

El mayor interés por la composición de este estudio fue la necesidad de ampliación de la cantidad de estudios sobre la publicidad, desde una perspectiva puramente de la lingüística textual y, en especial, de la publicidad turística, como un elemento inherente a muchas sociedades que perciben parte de su facturación a través de esta industria. Al formular las preguntas-problemas el objetivo general del trabajo se configura en: estudiar los elementos textuales presentes en la publicidad turística, tomando como punto de partida el caso de Natal, y con ello intentar identificar esos elementos que hacen con que un texto publicitario sea caracterizado como tal.

De eso se derivan los objetivos específicos de crear una relación entre la industria del turismo y la comunicación publicitaria desde la linguiística textual intentando contextualizar e identificar la importancia del turismo para Natal; evaluar la importancia del marketing y de la comunicación turística para la industria del turismo; configurar un modelo de estudio de la publicidad y sus especificidades desde una perspectiva lingüística; y determinar los elementos textuales propios de la publicidad turística a partir del caso de Natal. 
Hemos partido, por un lado, de la hipótesis de que se puede relacionar la industria del turismo con la publicidad y, por otro, de que a partir del análisis del discurso publicitario del turismo se pueden establecer elementos que configuren un texto publicitario como tal. Como conclusión de lo señalado, para la evaluación de nuestras hipótesis hemos considerado que la hipótesis 1 sería confirmada si se encuentra un $60 \%$ o más de los textos publicitarios catalogados con la misma configuración textual.

\subsection{Selección del corpus, recogida y tratamiento de los datos}

El corpus de esta investigación ha sido constituido por materiales bibliográficos, documentos, y publicidades escritas distribuidas por las agencias de viaje de Natal afiliadas a la ABAV, además de alguna publicidad distribuida por la SETUR. Para especificar la descripción de los instrumentos fueron elaboradas algunas tablas constituidas por ítems cuyas informaciones ofrezcan la clasificación textual de la publicidad analizada. En la aplicación de los instrumentos esas fueron rellenadas por el ejecutor de la investigación a medida que fueron consultados los documentos y las fuentes de información. La recogida y el análisis de los datos poseen un carácter cualitativo y los ítems de las tablas fueron analizados tomando como base la parte teórica de este estudio.

Los resultados finales han sido expuestos por medio de gráficos y el tratamiento de los datos obtenidos, a través de las tablas, se han comparado con la finalidad de verificar la relación entre lo que está dicho por nuestras propuestas teóricas sobre el discurso publicitario y cómo eso se presenta en el material analizado.

La recogida de datos en los estudios de caso se vale siempre de más de una técnica, distinguiéndose, pues, de la mayoría de las investigaciones. Para Carlos Gil (2002:141):

Se puede decir que, en términos de recogida de datos, el estudio de caso es el más completo de todos los delineamientos, pues se vale tanto de datos de gente cuanto de datos de papel. De hecho, en los estudios de caso los datos pueden ser obtenidos mediante análisis de documentos, entrevistas, observación espontánea, observación participante y análisis de artefactos físicos. 
De acuerdo con la visión de Maneti Dencker (2003:102), "en las investigaciones cualitativas el proceso de recogida e interpretación de los datos es hecho de modo interactivo durante todo el proceso de investigación". Así que para la recolección de los datos hemos adoptado métodos interactivos como los de internet y multimedia. Además de eso, hemos seguido la orientación que Maneti Dencker (2003:89) nos presenta de que "todos los datos recogidos deben poseer relación con la cuestión que se pretende aclarar".

Para el tratamiento de los datos escritos hemos escaneado una parte representativa que sirva como una muestra de nuestro corpus de estudio. También hemos elaborado fichas que contengan los datos más relevantes, tales como el título y número; la fecha de obtención; el origen del documento; el recolector; el tipo de documento; una breve descripción de su contenido; el interés para el análisis; además de otras observaciones necesarias. También, durante la etapa de tratamiento de los datos y el establecimiento del corpus de estudio, hemos dedicado especial atención a la cantidad de textos recogidos y analizados. En el comentario lingüístico del corpus hemos mencionado los elementos implícitos en los textos y sus presuposiciones.

El análisis de los datos carece de sistematización y organización. En esa fase de ese tipo de investigación "es natural admitir que el análisis de los datos sea de naturaleza predominantemente cualitativo" (Carlos Gil, 2002:141). Los ítems de las tablas fueron analizados tomando como base la parte teórica de este estudio. Con eso se pudo exponer los resultados por medio de gráficos.

\subsection{Grado de innovación previsto}

Esta investigación se hace viable a partir del momento en que Natal pasa a ser un centro turístico en Brasil y hace campañas publicitarias para la promoción de su turismo a niveles nacional e internacional, también, porque el turismo necesita de la publicidad para vender sus productos. Frente a eso, hay la posibilidad de afirmar que esta investigación puede poseer una aplicabilidad social directa, ya que es posible usarla para el desarrollo de la publicidad para el turismo de allí. 
Además, otro factor de innovación de este trabajo reside en el hecho de que no hemos encontrado ningún trabajo sobre el tema de la publicidad turística, ni con respecto de la configuración de este tipo de texto, sus características fundamentales y distintivas. Quizás eso ocurra porque se trata de un campo de estudio interdisciplinario, que puede ser abordado desde la perspectiva de la administración como parte del marketing, desde un punto de la comunicación social o como un campo de la lingüística.

Todo ello elucida aún más la importancia de la realización de esta investigación y le atribuye un carácter original, al mismo tiempo que justifica la elección del tema, por ser un trabajo pionero en el ámbito de Natal y en eso también reside su originalidad. En fin, el carácter innovador de este estudio está en la creación de este campo de investigación en el municipio de Natal, además de trabajar aspectos de la linguística textual y hacer un puente de esta área del conocimiento con la publicidad y el turismo.

\subsection{Plan de trabajo y cronograma}

Para la realización de este trabajo hemos seguido el orden de las etapas más importantes para el delineamiento de un estudio de caso. De este modo, la etapa inicial de nuestra investigación consiste en la formulación del problema a ser estudiado; en segundo lugar viene la definición de la unidad-caso; luego, la determinación del número de casos a ser estudiados consiste en la tercera parte de este estudio; la cuarta etapa para la concretización de nuestra investigación es la elaboración del protocolo que sirve como un documento que institucionaliza el instrumento de colecta de datos a ser adoptado, bien como la conducta para su consecuente aplicación; la quinta etapa es la recogida de datos y el análisis de los datos consiste en la sexta etapa del proceso de elaboración de esta investigación científica; la redacción final del trabajo de la investigación consiste en su última etapa de elaboración.

\subsection{Investigación bibliográfica y documental}

Así que para concretar este trabajo se parte de una investigación bibliográfica en la que se utilizan artículos científicos y libros, además de una investigación que posee un carácter documental (la publicidad turística). En la presente investigación hubo una parte bibliográfica, asociada a una investigación documental, que es bastante semejante 
a la investigación bibliográfica, distinguiéndose de aquella por medio de la naturaleza de sus fuentes porque "la investigación documental se vale de materiales que no recibieron todavía un tratamiento analítico, o que pueden ser reelaborados de acuerdo con los objetivos de la investigación" (Carlos Gil, 2002:45). Así que una de las principales etapas del estudio propuesto es la conceptualización del modelo teórico referencial, que consiste en la etapa de procesamiento de los conceptos básicos pertinentes al problema, a partir de una revisión bibliográfica con respecto al tema.

\subsection{El corpus}

Dentro del análisis del discurso todo y cualquier evento lingüístico es pasible a estudios desde que sea llevado en consideración su contexto. Para Calsamiglia \& Tusón (2002:353) "desde la perspectiva del análisis del discurso interesa todo tipo de manifestaciones verbales - orales o escritas - siempre que se tomen en consideración los factores contextuales en los que esas muestras verbales se producen”.

En este sentido, cabe resaltar que el corpus está formado por textos completos para que, a partir de eso, adquiera un carácter más verdadero y fiable en los resultados a los que se pueda llegar. Velásquez Garza (2007:25), al hablar de los corpus de referencia y sus generalidades, afirma que un corpus de referencia "es un conjunto de textos codificados en formato electrónico constituidos para servir de materia básica en el desarrollo de proyectos como pueden ser la creación de diccionarios, gramáticas, bases de datos y sistemas de traducción por ordenador, entre otros".

Frente a las dificultades existentes a la hora de definir un corpus y sus criterios metodológicos, desde un punto de vista de la Linguiística de Corpus, Giovanni Parodi (2010:25) presenta su definición de corpus por medio de la que propone que:

\footnotetext{
Un corpus es una colección o un conjunto de textos que está formado por al menos dos o más textos (dicho de otro modo, corpus aquí sería algo así como corpus textuales). En este sentido un corpus debe contener un número importante de textos que comparten ciertos rasgos definitorios, limitado solo por características inherentes a la naturaleza de los mismos.
}

En torno a cada una de esas definiciones presentadas anteriormente es importante destacar que el corpus de referencia al que se refiere Velásquez Garza se distingue del 
concepto de corpus adoptado por Parodi, puesto que Velásquez Garza (2007:25) hace una diferencia entre archivos digitales y corpus, clasificando los primeros como archivos electrónicos constituidos por texto, imagen y sonido, a la vez que clasifica el corpus como archivos de textos, orales o escritos. Tomando como base esas concepciones de corpus, hemos llevado a cabo la recolección de nuestros datos y la configuración de nuestro corpus de estudio.

\section{Diseño y organización del corpus}

La lingüística de corpus "constituye un enfoque metodológico para el estudio de las lenguas y que presenta oportunidades revolucionarias para la descripción, análisis y enseñanza de discursos de todo tipo" (Giovanni Parodi, 14:2010). Concerniente a eso, hemos intentado diseñar y recolectar un corpus, cuya muestra fuera representativa para, a partir de ello, crear una teoría fundamentada en datos empíricos.

El corpus de este trabajo es compuesto por una colección de textos publicitarios escritos, seleccionados y ordenados según el siguiente criterio: año de recolecta del corpus, agencias de viajes, tipo de publicidad y lugar de la recolecta. De ese modo, el corpus está compuesto por el universo de los textos publicitarios distribuidos por las agencias de viajes de Natal afiliadas a la ABAV, como ya hemos visto anteriormente. El universo estudiado está constituido por la publicidad que esas agencias disponían y la muestra analizada fue formada por los textos de tipo folletos informativos de Natal como destino turístico.

Pese a las dificultades para diseñar y recolectar un corpus textual y adoptar criterios metodológicos para esta investigación en el marco de la lingüística de corpus (LC), hemos intentado seguir la definición de corpus presentada por Giovanni Parodi (2010:25) en la que "un corpus es una colección o un conjunto de textos que está formado por al menos dos o más textos, dicho de otro modo, corpus aquí sería algo así como corpus textuales". Así que, desde este punto de vista, hemos recolectado un corpus con un número representativo de textos publicitarios del turismo vehiculados por medio de la modalidad escrita de la lengua. 
La muestra usada para nuestro estudio está compuesta por los anuncios, recogidos en el año de 2005, divididos según los tipos de vehículos de publicidad turística, a saber: folletos informativos; folletos orientativos y destinados a ventas; folletos libros; y, por último, folletos mixtos. Para ello fueron visitadas 61 agencias de viajes de las cuales 27 no disponían de publicidad impresa y 6 ya no estaban ubicadas en la dirección presentada por la ABAV, mientras 28 usaban publicidad impresa para la divulgación del producto turístico. Para complementar y actualizar este corpus, en el año de 2009, hemos recogido más anuncios divididos según los tipos de vehículos de publicidad turística anteriormente presentados, además de folletos informativos en nuevas tecnologías: DVD (fueron recogidos 4 DVDs), 3 periódicos y 2 revistas. Para eso hemos visitado 58 agencias de viajes de las cuales 35 disponían de publicidad impresa, 16 no disponían de publicidad impresa y 7 había cambiado de dirección y por ello no fueron localizadas.

El corpus de textos recogidos para esta investigación está formado por un total de 514 vehículos de textos publicitarios para el turismo. Hemos preferido adoptar este término, dado que la mayoría de la publicidad estudiada anuncia diversos productos turísticos, de modo que funciona más como un soporte publicitario que simplemente un anuncio o publicidad.

Cabe destacar que el material recopilado atiende al criterio de ser textos originales y completos para que, a partir de eso, adquieran un carácter más verdadero y fiable en los resultados a los que se pueda llegar. Para ello hemos organizado y digitalizado el corpus que fue escaneado y consta en el DVD adjunto con los anexos de este trabajo. Además, otro dato que merece ser registrado durante la recogida de nuestra muestra de estudio es el hecho de que, en general, la mayoría de las agencias de viaje no poseen una publicidad propia, sino que hacen uso de la publicidad elaborada por las grandes operadoras de turismo, por las cadenas de hoteles o por alguna institución pública. 
Folletos

Los folletos analizados suman una cantidad de 347 unidades. En lo que se refiere al idioma en el que están codificados este tipo de publicidad hemos encontrado los datos que expondremos en la secuencia. Del total de folletos encontrados, 300 están en lengua portuguesa; 41 son presentados en portugués e inglés; 2 en lengua portuguesa, lengua inglesa y lengua española; 2 en portugués, inglés y francés; 1 en portugués, inglés y alemán; y, por último, 1 en alemán.

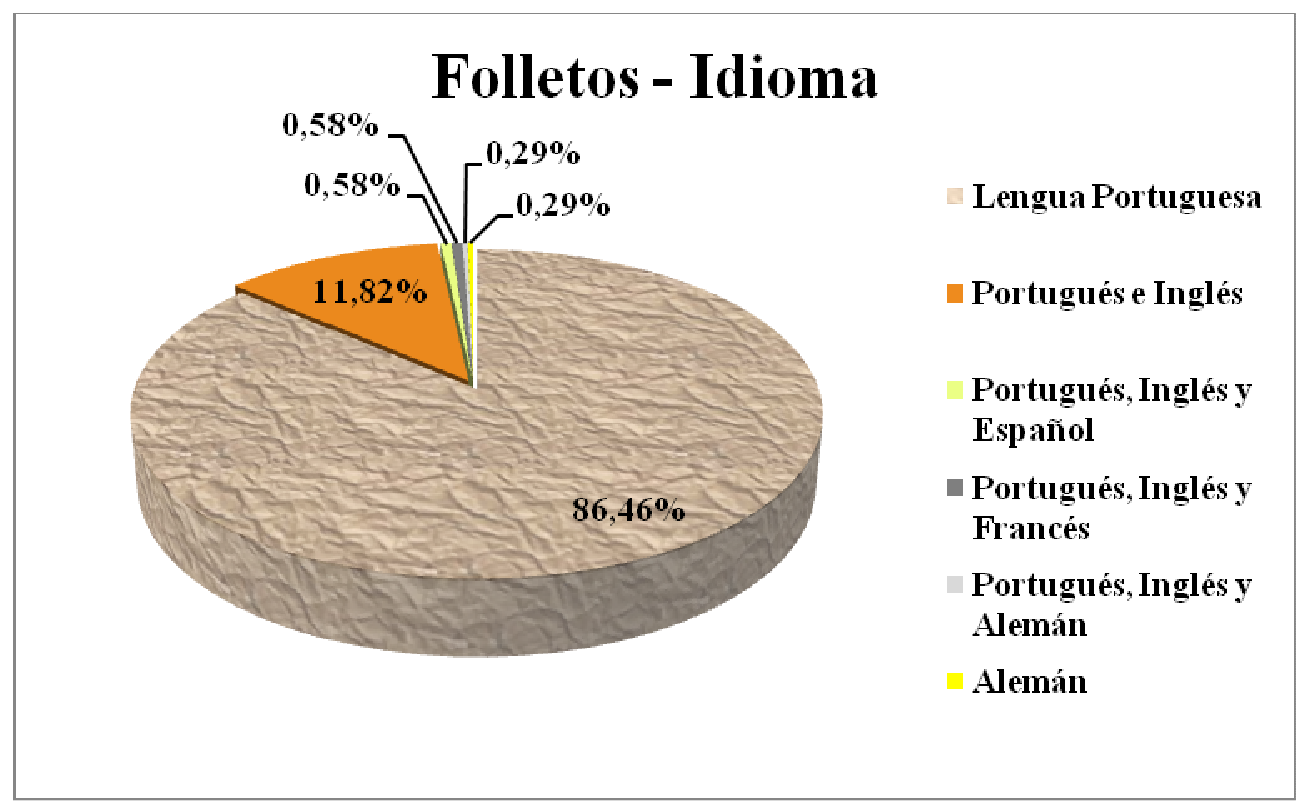

Gráfico 1

El modo de turismo anunciado por esos folletos está dividido en modo de turismo receptivo y modo de turismo emisivo. Del total de folletos analizados, 203 consisten en folletos publicitarios de turismo receptivo, mientras que 144 de esos folletos anuncian el turismo emisivo. 


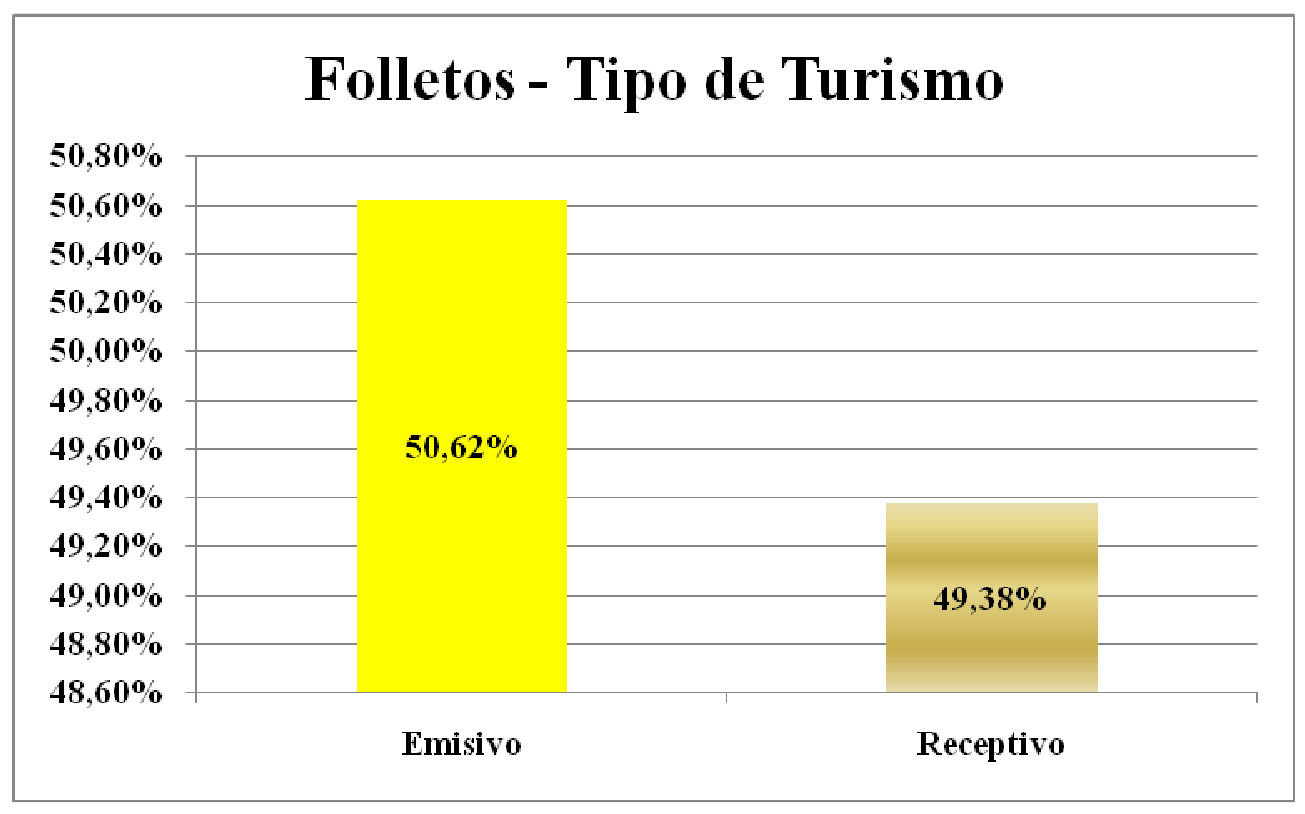

Gráfico 2

En lo que toca a la calidad del papel que sirve como soporte para este tipo de publicidad, 3 de los folletos analizados están en dina 4; 18 en papel reciclado; y un total de 316 folletos están elaborados con papel de alta calidad de impresión.

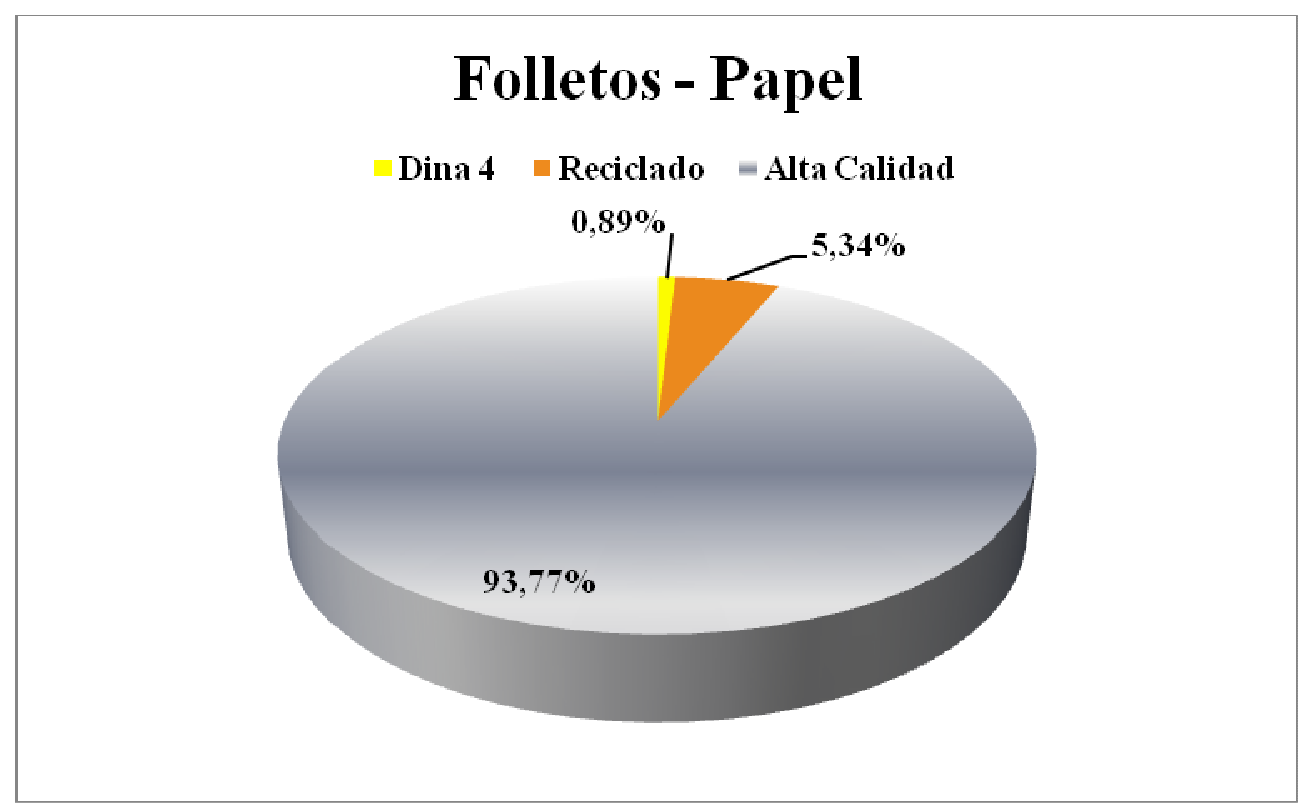

Gráfico 3

La institución que financia la elaboración de los soportes publicitarios para el turismo se configuran en hoteles, 138; agencias de viajes, 147; operadoras de turismo, 35; instituciones públicas, 17. 


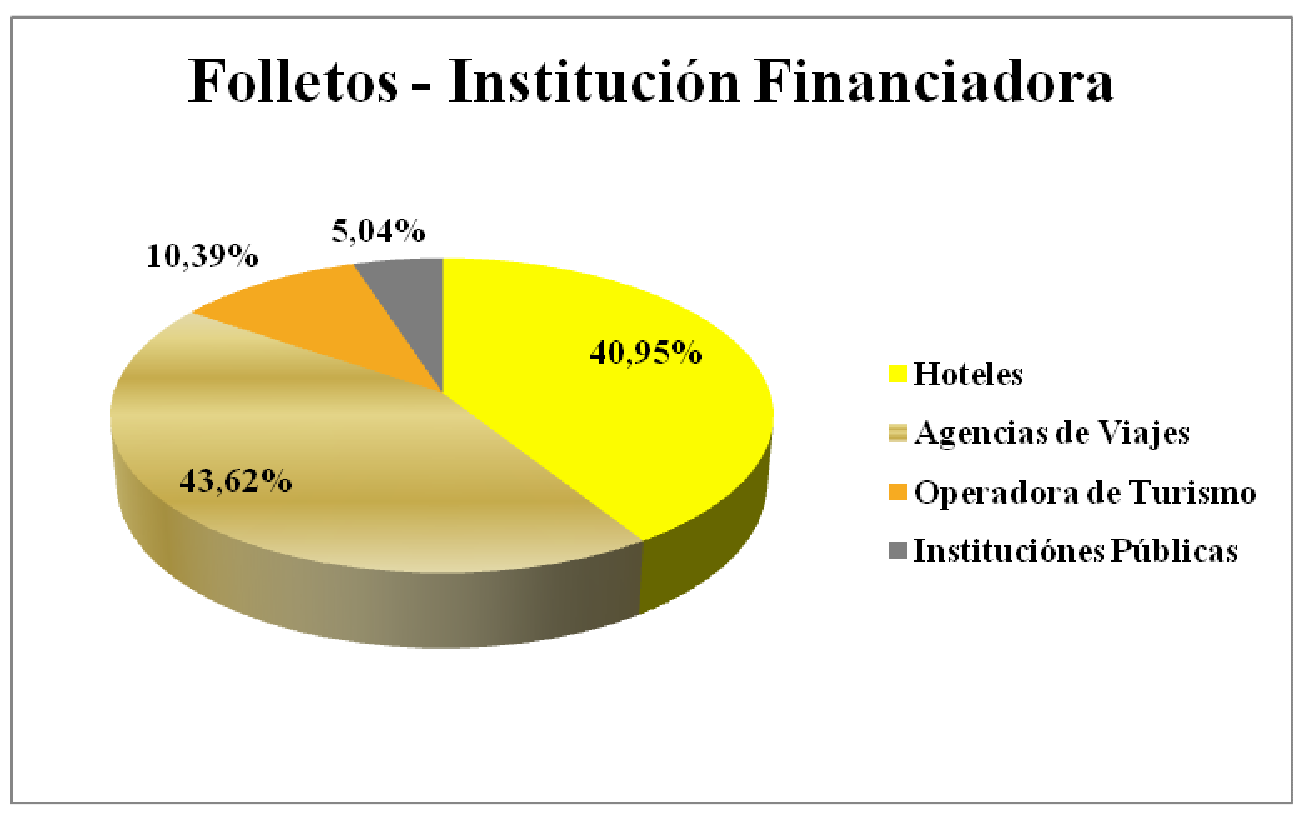

Gráfico 4

Folletos mixtos

Hemos analizado un total de 64 folletos mixtos. En lo concerniente al idioma en los que fueron escritos estos folletos, hemos observados la siguiente situación: 64 folletos escritos solamente en portugués; 0 escritos en portugués e inglés; 0 producidos en portugués, inglés y español; tampoco había en cualquier otro idioma.

Los tipos de soportes publicitarios por característica del tipo de turismo consisten en 11 folletos mixtos destinados al turismo receptivo y 43 folletos destinados al turismo emisivo. Parece ser que en este tipo de anuncio publicitario está destinado, sobre todo, a los habitantes locales. 


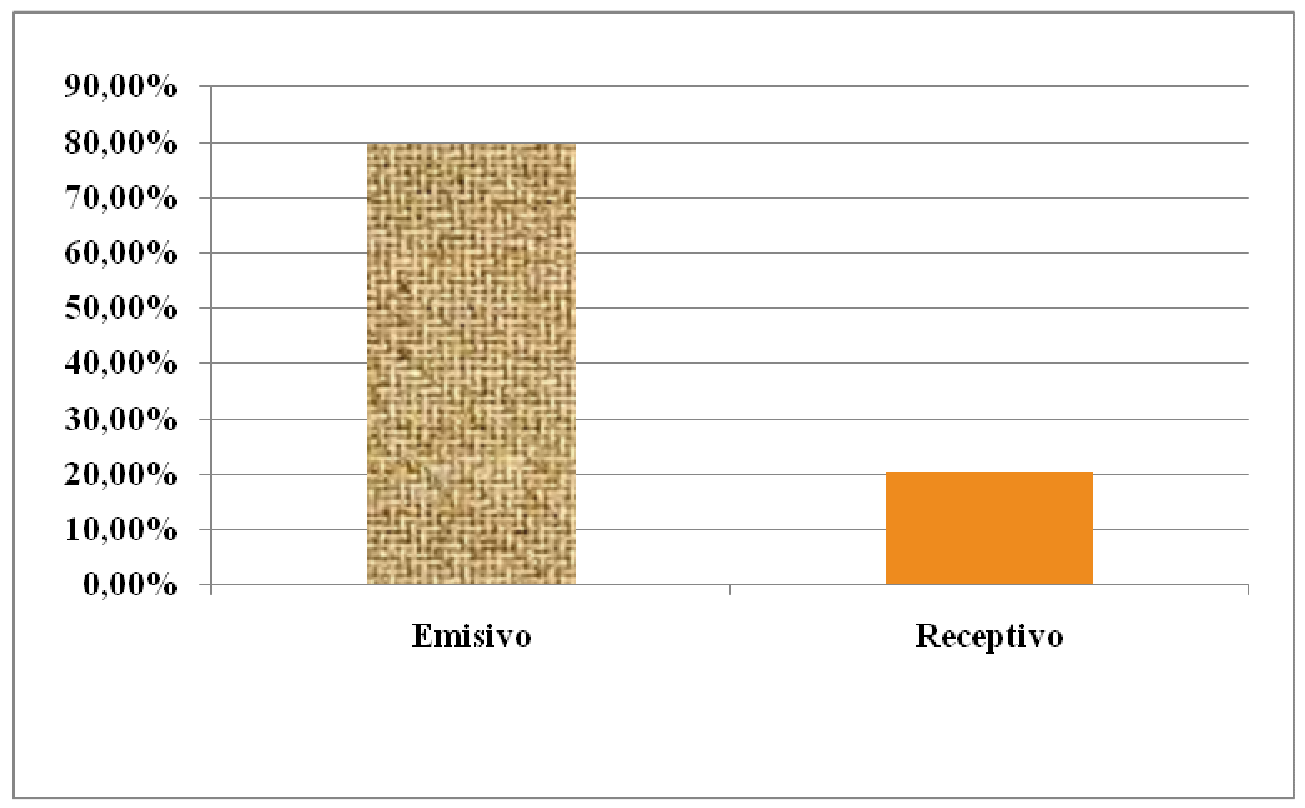

\section{Gráfico 5}

En relación a la calidad del papel en la que se presentan los folletos mixtos, fue observado que 14 de esos anuncios están en papel dina 4; 1 en papel reciclado; contra 39 en papel de alta calidad de impresión.

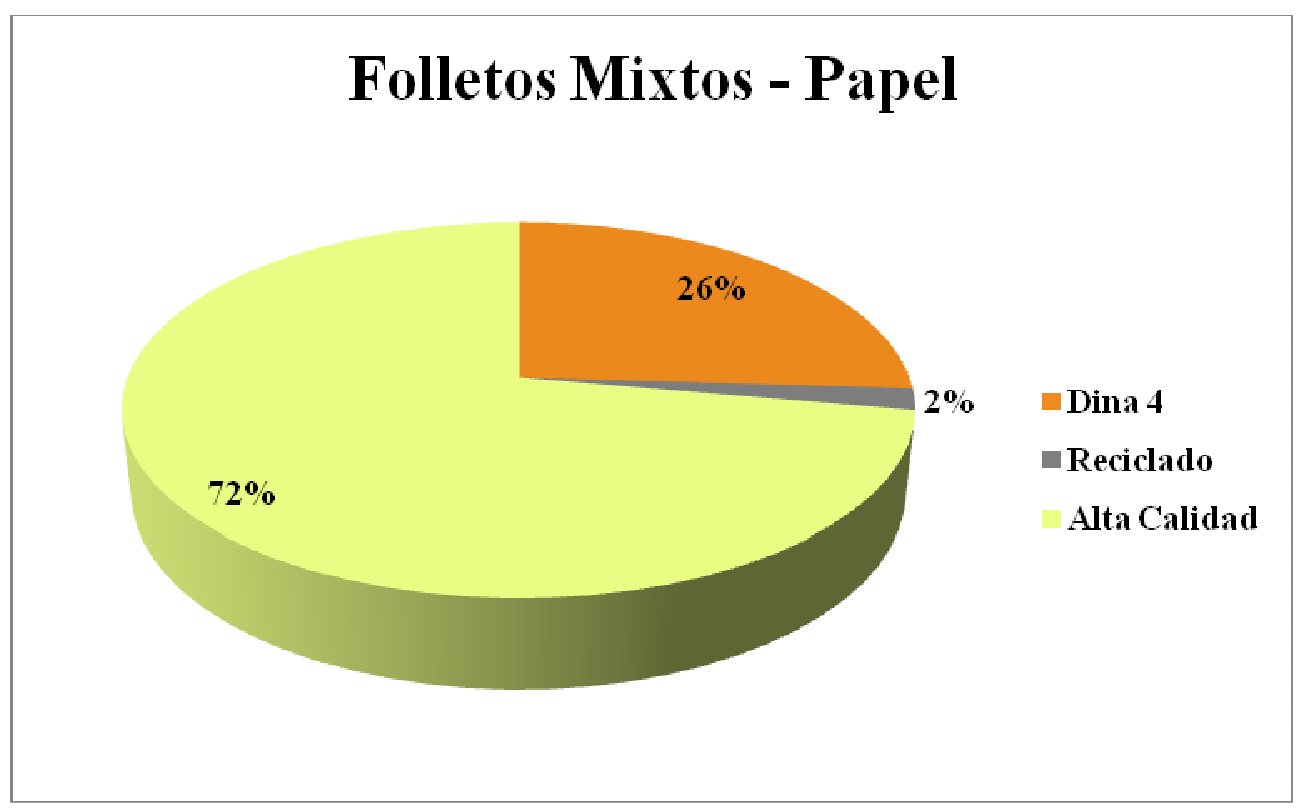

\section{Gráfico 6}

Una vez más en lo que se refiere a la cantidad de producto por folleto mixto, la publicidad que anuncia varios productos a la vez quedó con la mayoría, dado que 7 de los folletos mixtos estudiados anunciaban solamente 1 producto, mientras 47 anuncian varios productos a la vez. 


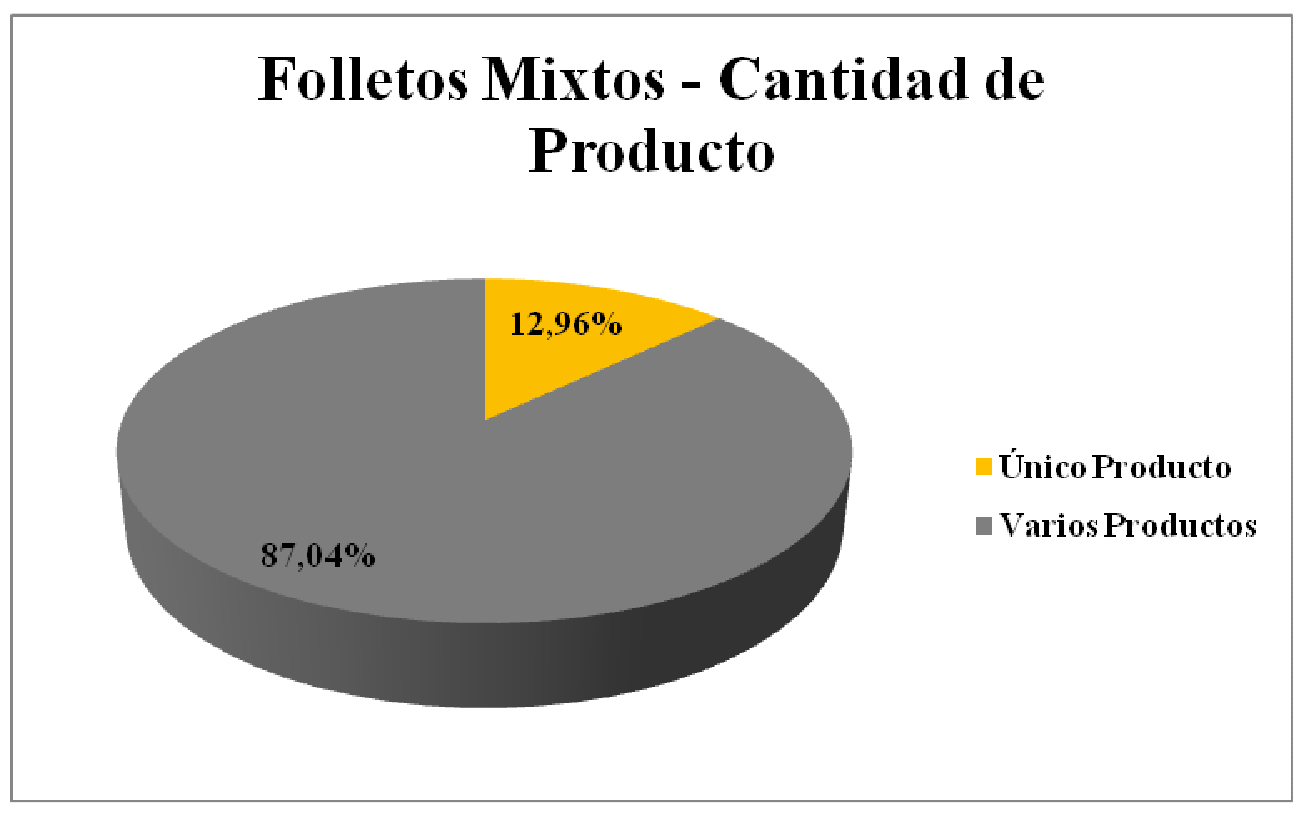

Gráfico 7

Entre las instituciones que financian la elaboración de los folletos mixtos hemos visto que 6 de ellos fueron elaborados por hoteles; 30 por agencias de viaje; 18 por operadoras de turismo; y ninguno ha sido financiado por alguna institución pública.

\section{Folletos Mixtos - Institución Financiadora}

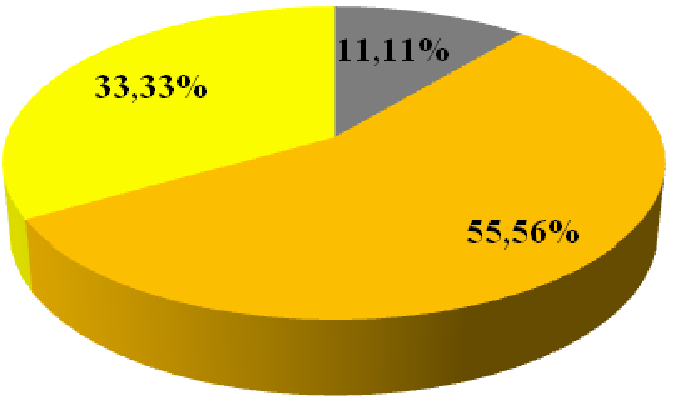

Hoteles

Agencias de Viajes

Operadora de Turismo

Gráfico 8 
Libros

De un total de 49 libros que forman parte de nuestro corpus de estudio, 24 están escritos en legua portuguesa; 11 en portugués e inglés; 1 en portugués, inglés y español; 2 en inglés y holandés, y 1 está escrito solamente en holandés.

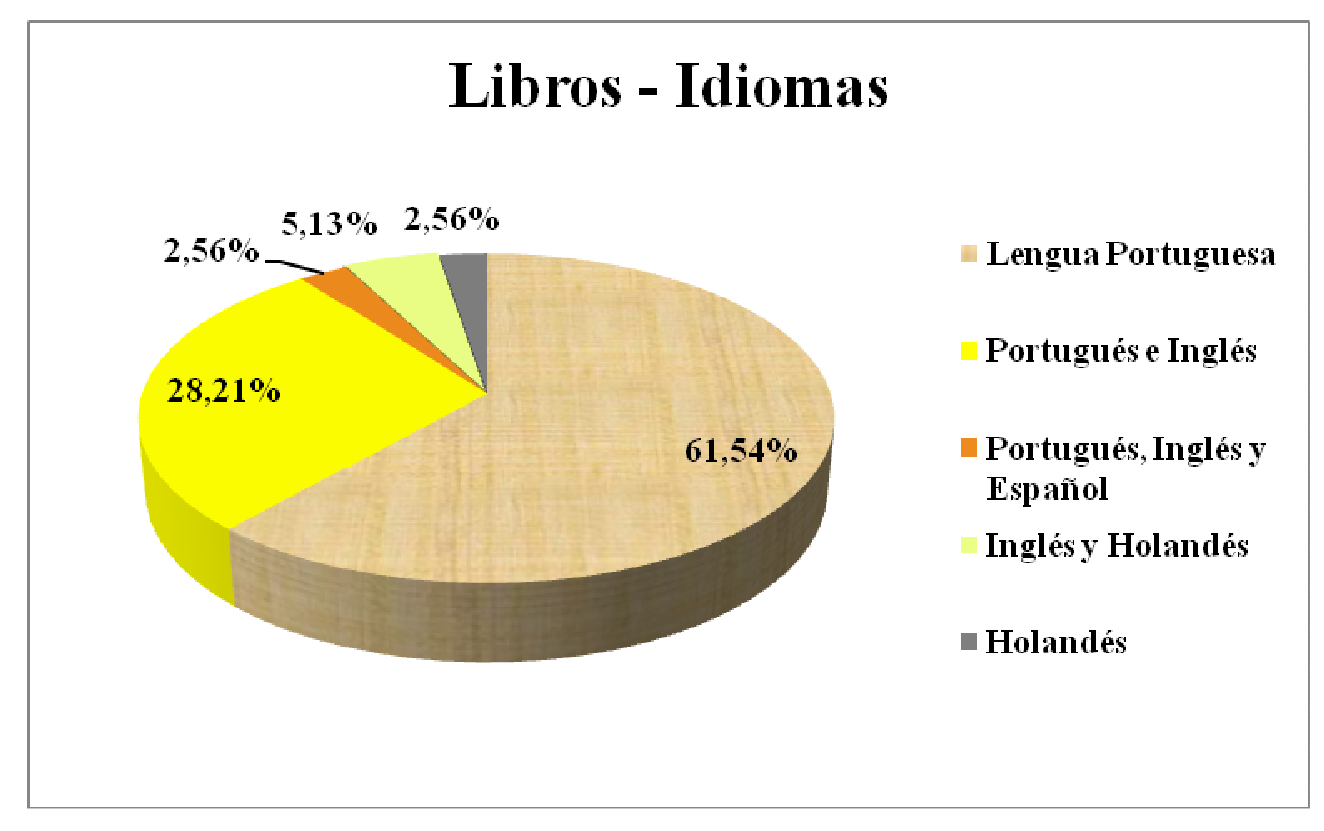

Gráfico 9

Referente a los colores en los que fueron imprimidos estos libros, hemos encontrado los 39 libros estudiados coloridos. De ese total 13 se destina al turismo receptivo y 26 al turismo emisivo. 


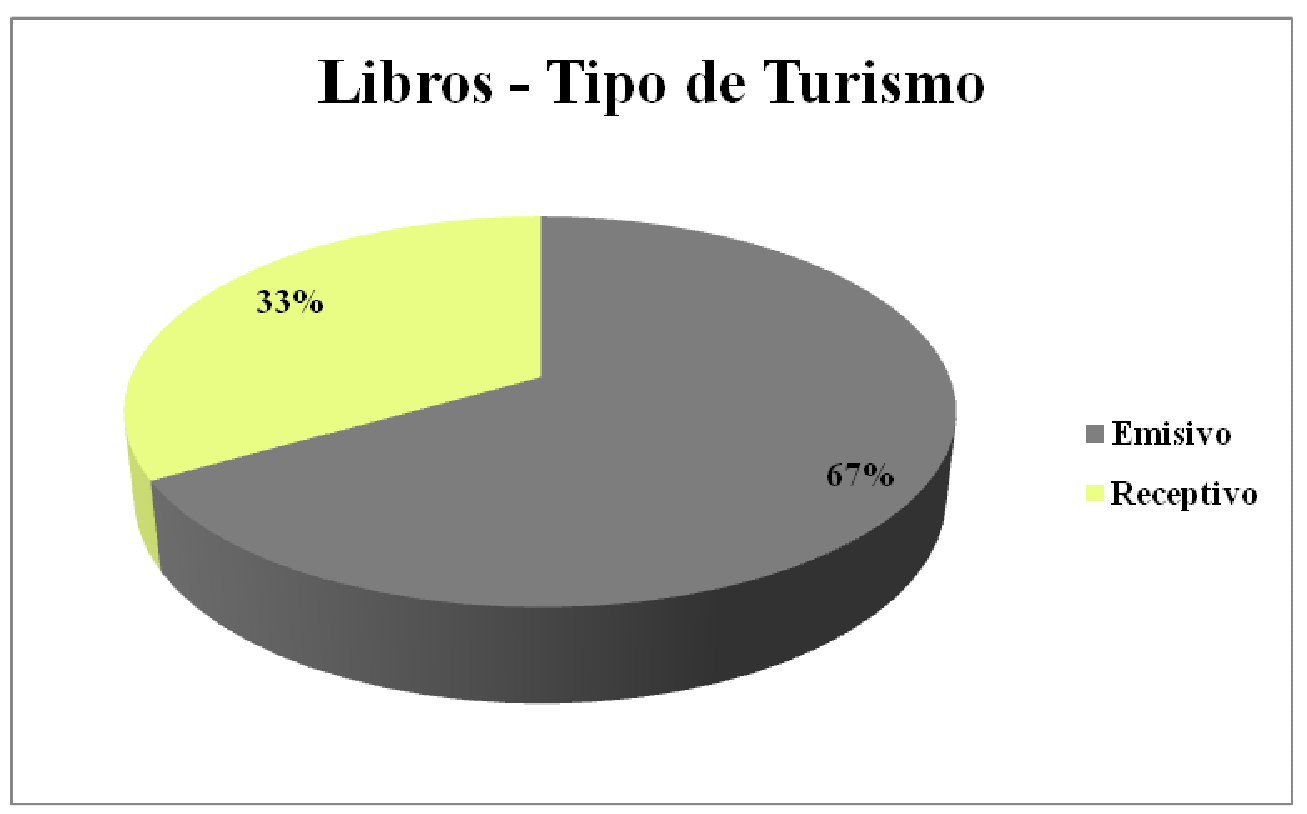

Gráfico 10

De los 39 libros analizados, 1 está impreso en papel dina 4; 2 en papel reciclado; y 36 en papel de alta calidad de impresión. Del valor total de los libros que hemos encontrado, los 39 se refieren a anuncios de varios productos. 


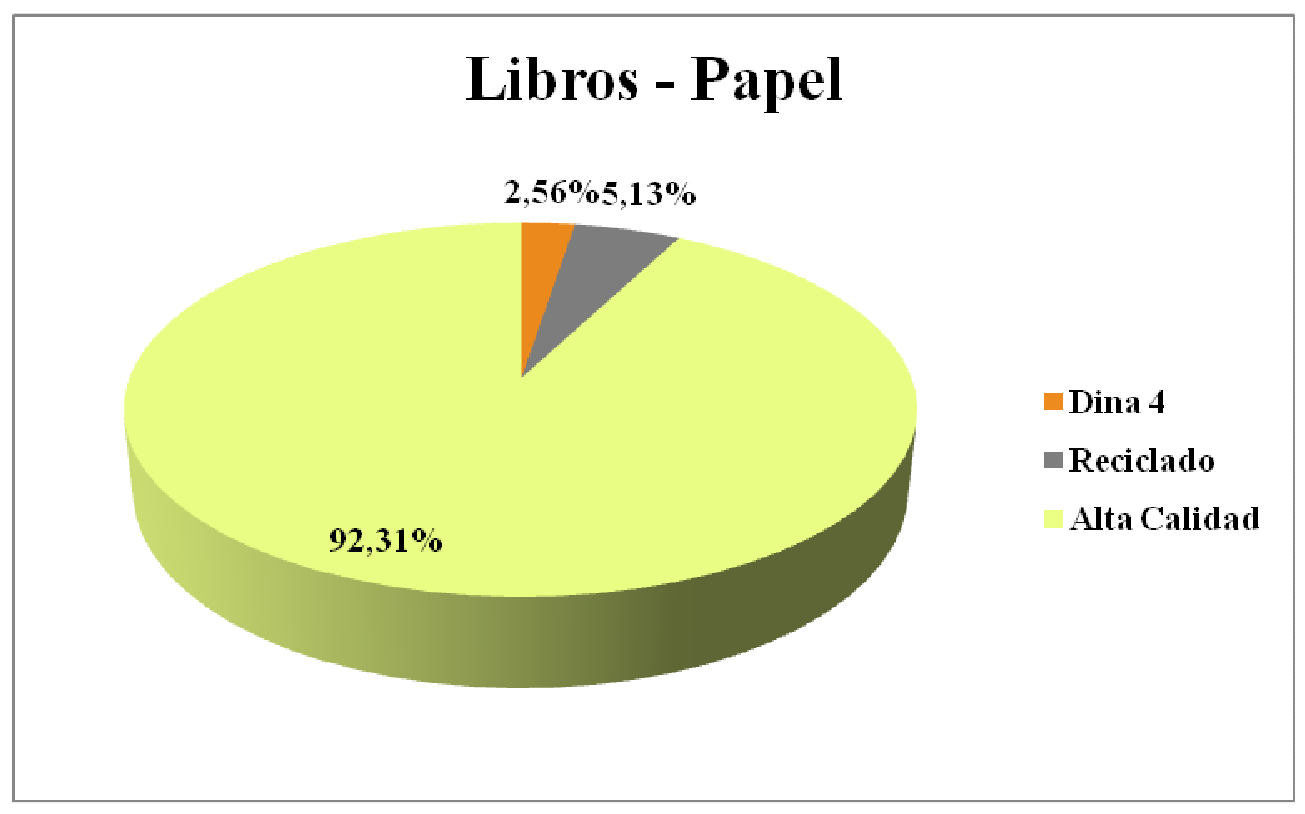

Gráfico 11

De las instituciones que financian la elaboración de este tipo de publicidad turística, es importante destacar que 3 fueron financiadas por hoteles; 10 por agencias de viajes; 15 por operadoras de turismo y 10 por instituciones públicas.

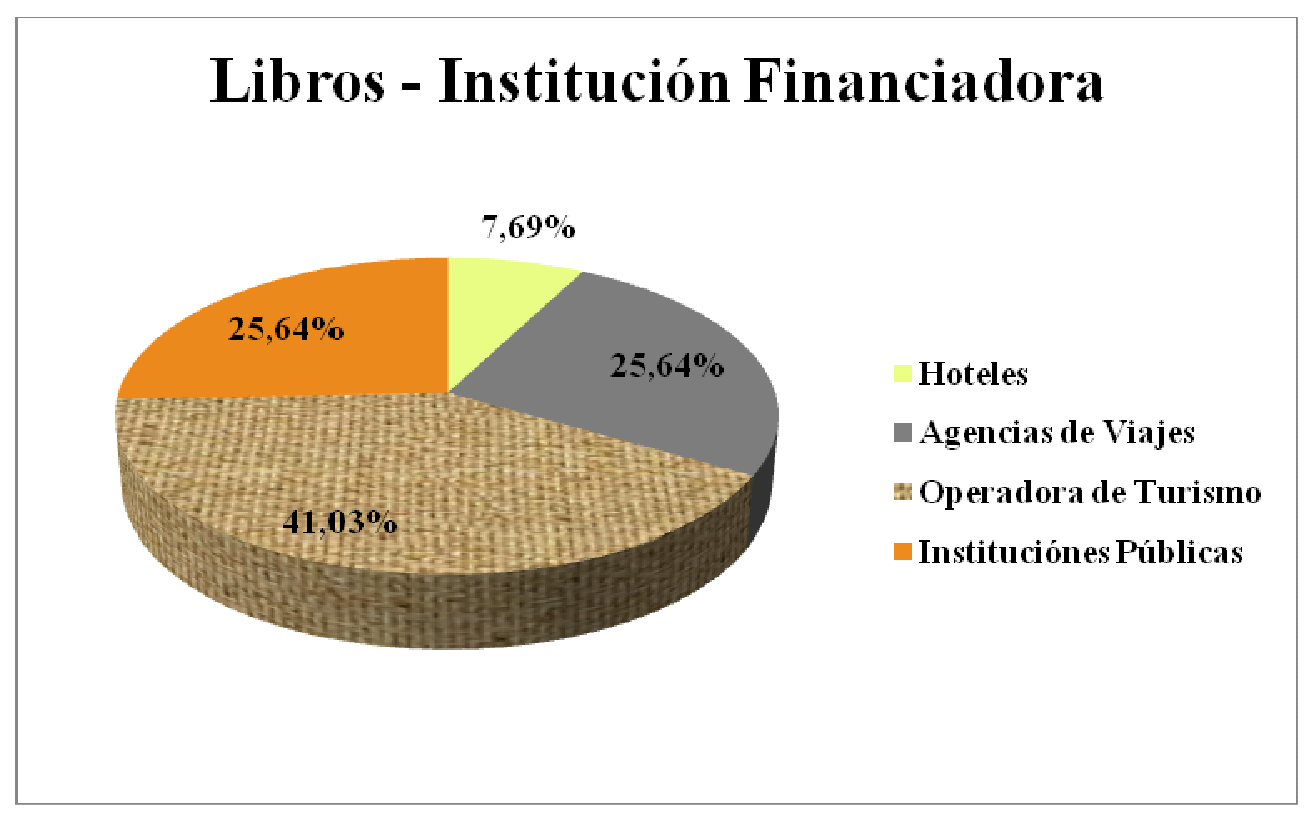

Gráfico 12 
En nuestro estudio hemos analizados un total de 45 libros mixtos de los cuales 43 fueron escritos en lengua portuguesa; y 2 en lengua española.

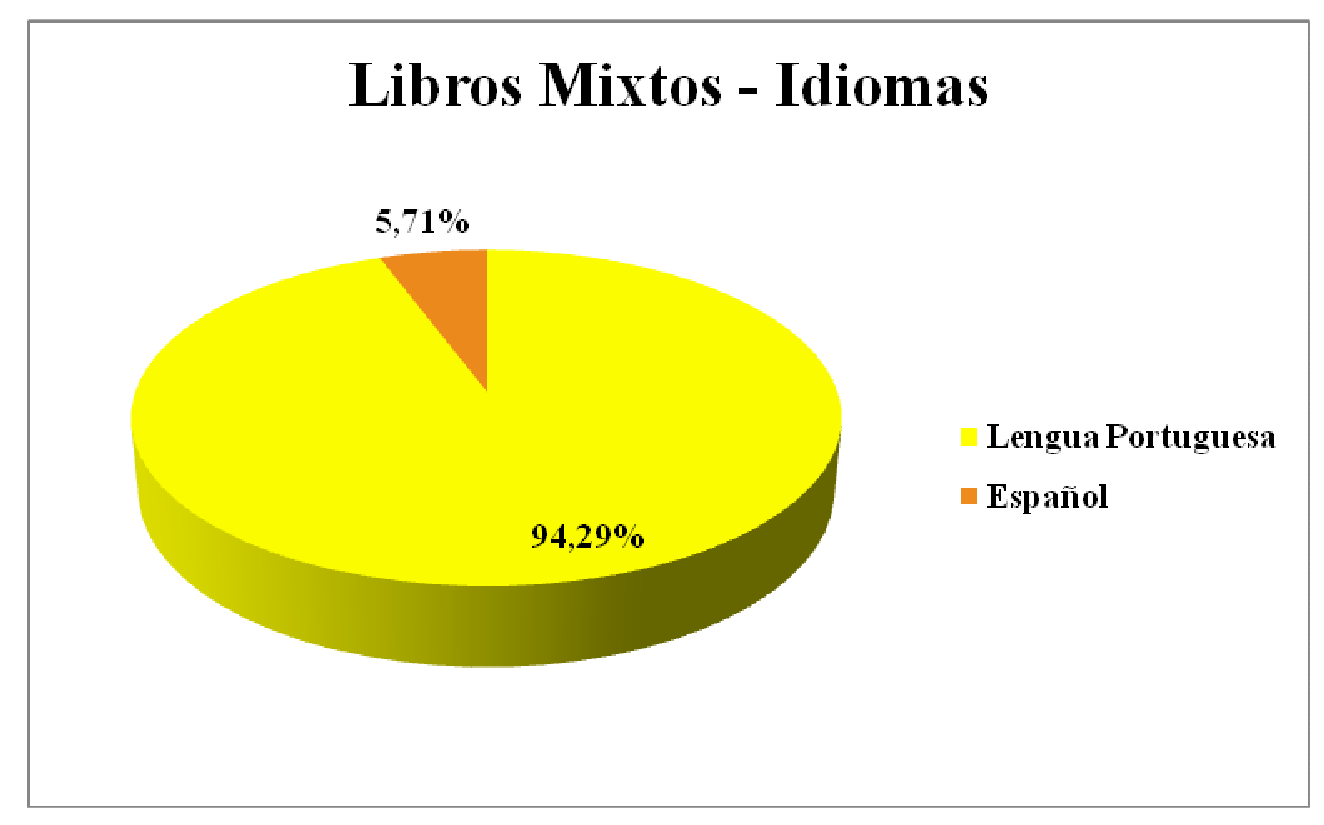

Gráfico 13

En lo que respecta al tipo de turismo, hemos observado que los 35 anuncios son destinados al turismo emisivo, mientras que no hemos encontrado ningún libro mixto destinado al anuncio publicitario del turismo receptivo.

En relación a la calidad del papel en el que se vehicula la publicidad turística en libros mixtos, hemos descubierto que 1 de los libros estaban en dina 4; 2 en papel reciclado y 42 libros mixtos estaban impresos en papel con alta calidad. 


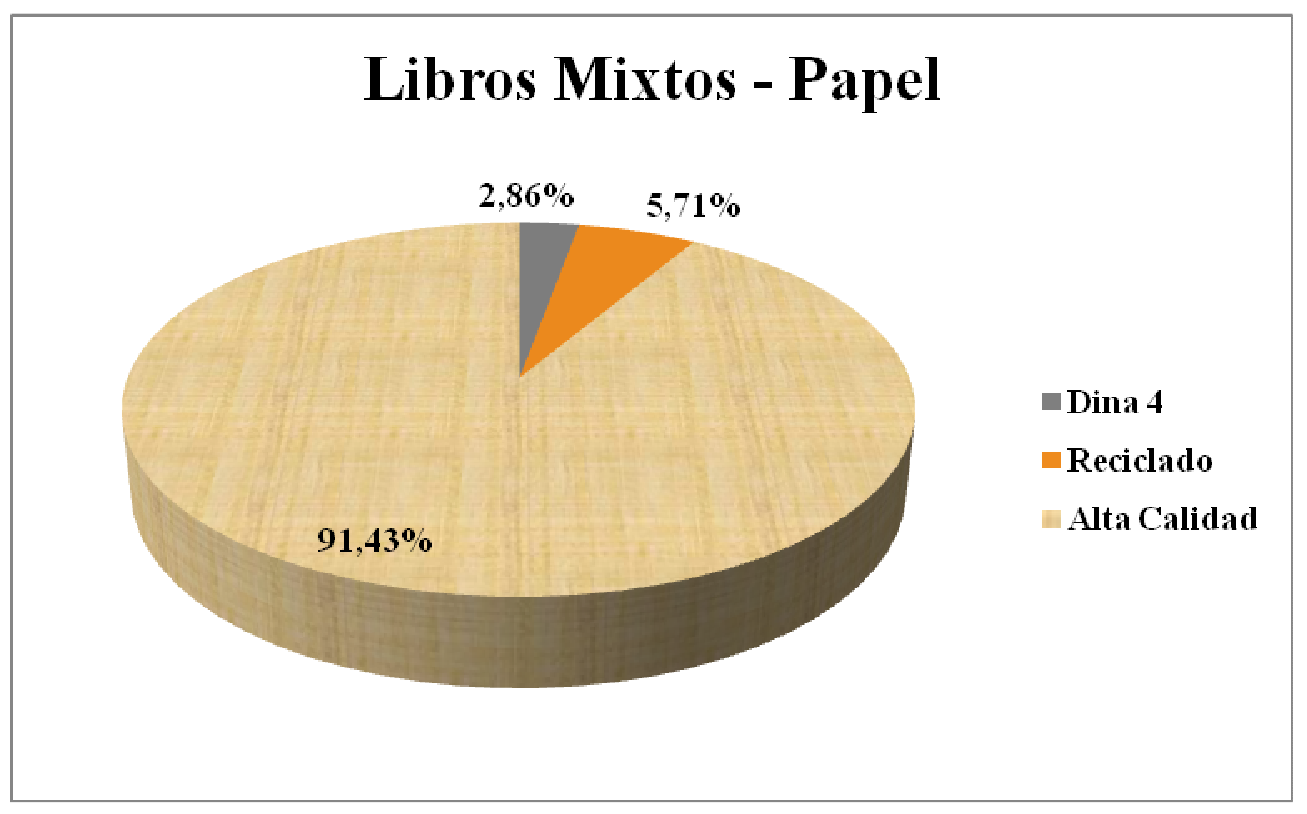

Gráfico 14

De esos libros no hemos encontrado ninguno que se refiriera a publicidad de un único producto, con lo cual los 35 libros analizados anunciaban varios productos a la vez. De ese total de libros mixtos, 6 tuvieron su elaboración financiada por agencias de viaje; y 29 por operadoras de turismo.

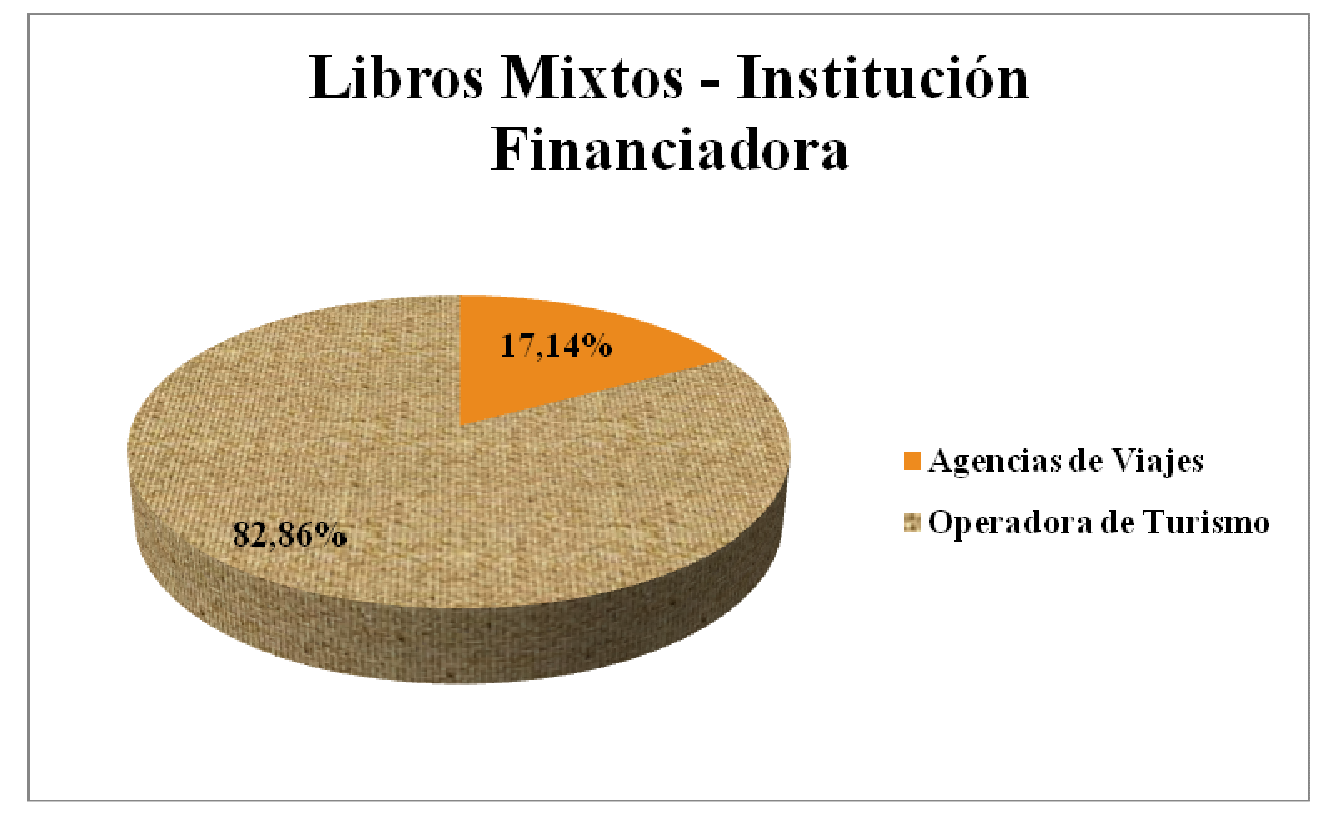

Gráfico 15 


\section{Revistas, periódicos y publicidad electrónica}

En nuestro corpus de análisis también hemos encontrado periódicos y revistas como vehículo que funciona como soporte para la publicidad turística. Un total de 3 periódicos y 2 revistas, todos escritos en lengua portuguesa y en colores. De estos, 2 estaban dedicados al turismo receptivo, mientras 3 de ellos estaban dirigidos hacia el turismo emisivo.

El tipo de calidad del papel en el que estaban impresos esos periódicos y revistas era muy alta. La publicidad vehiculada por esos soportes anunciaba diversos productos a la vez. En relación con la institución financiadora de la elaboración de ese tipo de publicidad, hemos visto que los 3 periódicos y las 2 revistas fueron financiados por instituciones públicas.

Cada día es más frecuente la publicidad electrónica o por internet, tanto que el Instituto de Lenguas Modernas Aplicadas (IULMA), en Valencia, dispone de un grupo de investigadores que empezaron un proyecto en el año de 2009 sobre el discurso turístico $\mathrm{y}$, como resultado de los trabajos del grupo de investigadores del IULMA, fueron publicados algunos artículos en el libro Discurso Turístico e Internet (2012). Ese hecho corrobora la importancia del discurso turístico en red en la actualidad.

Nuestro corpus de estudio muestra eso cuando hemos encontrado 4 DVDs como soporte de publicidad turística. Todos están en tres idiomas (portugués, inglés y español) y 3 fueron financiados por hoteles, mientras 1 por instituciones públicas. Además de eso, muchas operadoras de turismo, agencias de viajes, hoteles, e instituciones públicas tienen su propia página en internet, por medio de la que propagan su publicidad e incluso realizan ventas, es más, parece ser que, actualmente, la página en internet forma parte de la propia imagen corporativa de las empresas.

\subsection{Reducción de los datos}

En virtud de la numerosa cantidad de anuncios publicitarios recogidos para la constitución del corpus de estudio, hemos visto la necesidad de acotación del corpus para que fuera factible realizar los análisis textuales necesarios para formular la 
contestación a nuestras preguntas-problemas. A partir de ello hemos tenido que adoptar criterios objetivos para realizar una reducción de los datos para el análisis.

En un principio hemos escaneado ejemplos de los folletos, libros y libros mixtos para formar parte de la muestra seleccionada a partir del corpus de estudio. Esa muestra sería usada como la publicidad usada para ilustrar la parte teórica de nuestro trabajo y para la realización del análisis. No obstante, por la cantidad de publicidad escaneada, constituida por 1.332 páginas digitalizadas (ver en los anexos), no sería posible trabajar con una muestra tan numerosa para el análisis. Por eso hemos tenido que encontrar otro criterio para disminuir y escoger nuestra muestra de estudio.

Así, para formar una muestra de publicidad turística para servir como objeto de análisis textual hemos elegido analizar solamente la publicidad en forma de folleto turístico, sobre todo de Natal como producto turístico. Este criterio nos pareció prudente, ya que los folletos turísticos predominan en relación a otro tipo de publicidad y están integralmente escaneados. Además, Natal consiste en un producto turístico de proporción nacional e internacional y es la cuidad donde hemos recogido nuestro corpus de estudio. Dicho esto, la muestra final para el análisis está compuesta por 293 páginas escaneadas que constituyen un total de 110 folletos publicitarios y anuncian, principalmente, Natal como destino turístico y los productos propios de este tipo de industria.

\subsection{La tesis}

La redacción del informe o del trabajo final de la investigación consiste en la etapa final del estudio de caso. Para ello se adoptan técnicas para unificar el estilo del texto, referente a eso Maneti Dencker (2003:239) afirma que:

Para que la comunicación científica sea eficiente, es necesario un cierto grado de padronización. Esa padronización es obtenida mediante la observación de las normas de la International Organization for Standardization (ISO), a nivel internacional; de la Associação Brasileira de Normas Técnicas (ABNT), en nivel nacional; y de la institución en que se realiza la investigación, en un nivel más específico. 
En virtud de eso hemos adoptado esas técnicas en la elaboración del estilo adoptado en el formateo de la redacción final de nuestra investigación. Cabe añadir que este tipo de texto es comúnmente de carácter narrativo, aunque últimamente presente una estructura igual a la de cualquier otro trabajo científico. Es importante observar que "considerando que el estudio de caso es un delineamiento más flexible que los demás, es natural que la elaboración del informe pueda ser caracterizado por un grado de formalidad menor que el requerido en relación a otras investigaciones" (Carlos Gil, 2002:141).

\subsection{La teoría del acto de comunicación publicitario}

Con nuestro estudio hemos llegado a lo que llamamos de La teoría del Acto de Comunicación Publicitario, en la que se parte del presupuesto de que el texto publicitario establece un acto de habla propio de este género textual y eso, por lo tanto, lo distingue de los demás tipos de textos. Usamos el término publicitariedad para designar las características inherentes al discurso publicitario que lo distingue de los textos literarios y no literarios. De ese modo la publicitariedad sería la característica que define un texto como publicitario y lo distingue de los textos literarios y los no literarios.

Dichas características consisten en el carácter expresivo, es decir, todo lo que se refiere al uso del lenguaje; el carácter comunicativo, mejor dicho, todo que particulariza la comunicación en la publicidad; el carácter retórico, o sea, todo lo que se refiere a la perpetuación de la retórica en el texto publicitario; el carácter persuasivo, es decir, la persuasión en el discurso publicitario; y, por último, el carácter pragmático de la publicidad.

El carácter pragmático del acto de comunicación publicitario consiste en el hecho de que todos los elementos participantes del acto de habla se manifiestan de forma específica en el acto de comunicación publicitario. Además, el texto publicitario tiene siempre como acto perlucutivo la compra o la adquisición del producto anunciado.

Así, apoyamos nuestra Teoría del Acto de Comunicación Publicitario en cinco ejes, a saber: el carácter expresivo, el carácter comunicativo, el carácter retórico, el carácter persuasivo y el carácter pragmático. Esos elementos en su totalidad constituyen lo que 
hemos llamado de publicitariedad y pueden ser encontrados en todos o casi todos los textos que forman parte de nuestro corpus de estudio.

En eso consisten nuestro argumentamos presentados juntamente con nuestra muestra de publicidad analizada en los capítulos IV, V y VI de esa tesis doctoral. Este análisis sirve como un medio para ejemplificar los cinco ejes en los que se apoya nuestra Teoría del Acto de Comunicación Publicitario, que se preocupa por caracterizar el texto publicitario como tal y a la vez lo distingue de otros géneros textuales.

\subsection{Conclusión}

Con todo ello, constatamos que hacer una tesis es enfrentarse a un proceso de madurez personal, intelectual y profesional del que se puede sacar mucho provecho. Por eso el período dedicado a la elaboración de este tipo de trabajo científico debe ser tomado con mucho gusto por la experiencia de descubrir la respuesta para la pregunta que, mientras doctorando, uno se plantea al iniciar su investigación.

Además, se debe aprender con cada paso dado en dirección a la conclusión de este trabajo, que será inolvidable para su productor. Eso es lo que afirma Eco (2005:233) cuando dice que "podrá suceder que volváis a vuestra tesis incluso decenas de años más tarde. Pues habrá sido como vuestro primer amor y os resultará difícil de olvidarla. En el fondo, habrá sido la primera vez que hacéis un trabajo científico serio y riguroso, lo cual como experiencia no es poco".

Así, de lo expuesto se puede concluir que la experiencia de producir una tesis es casi inolvidable, además de ser muy intensa. Por eso, con nuestro tercer capítulo presentamos el diseño científico usado como un instrumento teórico para configurar nuestro estudio, a partir del que definimos los principales puntos del ámbito epistemológico de este trabajo, su corpus, su organización metodológica y, por último, nuestra Teoría del Acto de Comunicación Publicitario, la cual defenderemos por medio del análisis del corpus presentado en los capítulos IV, V y VI de este trabajo de investigación científica, presentados a continuación. 


\section{Capítulo IV}

\section{PUBLICIDAD TURÍSTICA: UN ACTO DE COMUNICACIÓN ESPECÍFICO}

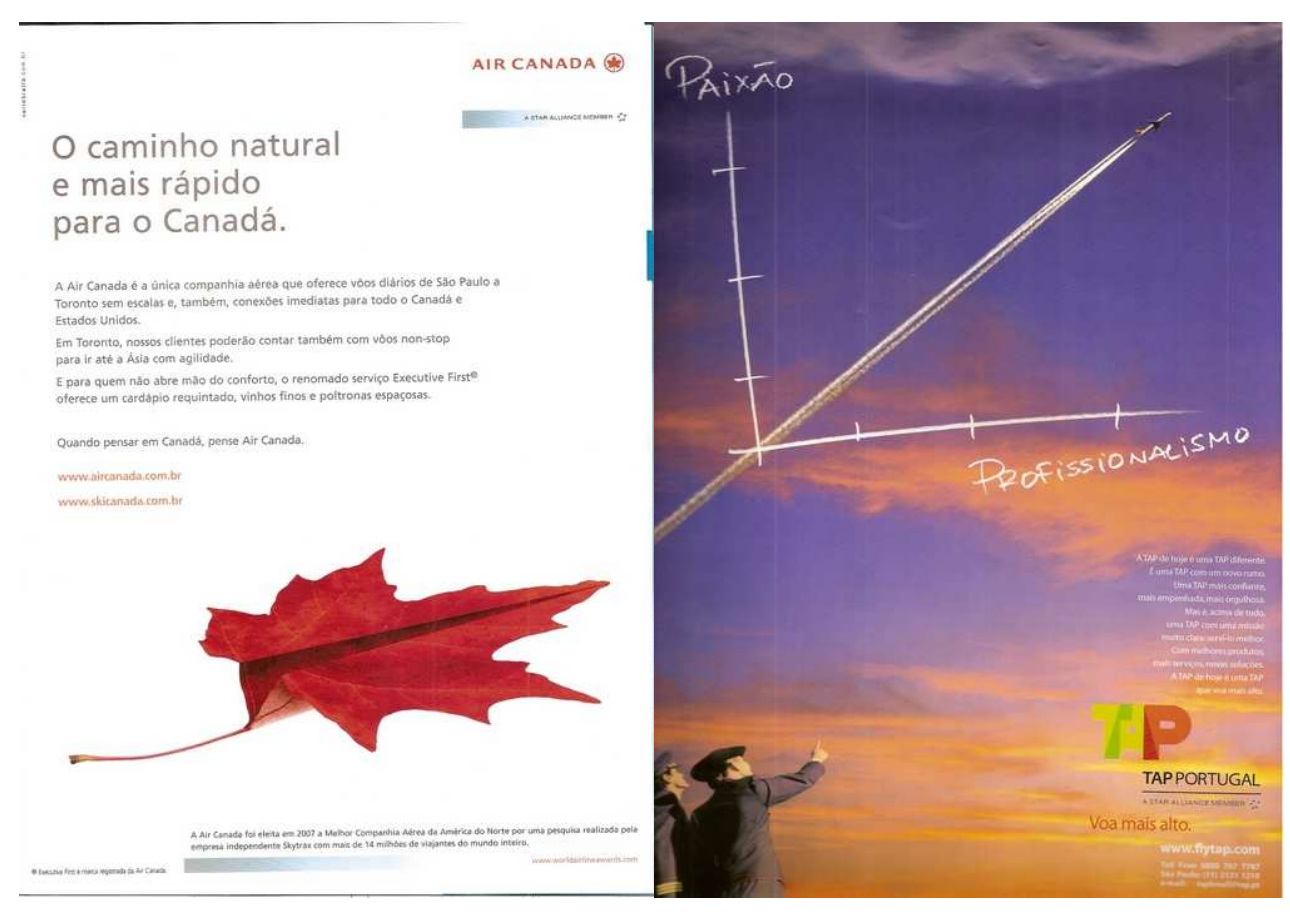

"El lenguaje publicitario sirve a la sociedad de masas, cuya cultura (cultura de masas) está dominada por los medios masivos de comunicación, que transmiten incesantemente los símbolos, los mitos y las imágenes que mejor se adaptan a los valores prácticos de una sociedad de consumo".

(López Eire) 


\section{CAPÍTULO IV - PUBLICIDAD TURÍSTICA: UN ACTO DE COMUNICACIÓN ESPECÍFICO}

En nuestro cuarto capítulo, empezamos el análisis del corpus de estudio para defender la Teoría del Acto de Comunicación Publicitario. Postulamos aquí que la publicidad y, por consiguiente, la publicidad turística, consiste en un proceso comunicativo del que participan determinados elementos que, sin embargo, se comportan distintamente de otros procesos de comunicación, dadas las especificidades de la publicidad, en especial, de la publicidad turística. Eso es lo que hemos denominado carácter comunicativo del texto publicitario. Así pues, en este capítulo, hemos elaborado nuestra conceptualización de la publicidad turística de modo que sirva para plasmar la premisa de la que partimos, esto es, la publicidad, desde un punto de vista textual, se debe estudiar de modo que se ponga de relieve su concepto, su origen, la relación entre la publicidad y la propaganda, el uso de la palabra en la publicidad, el uso de la imagen en la publicidad, el lenguaje publicitario y su proceso comunicativo específico.

\subsection{La publicidad: conceptualización}

A principios del siglo XXI, paradójicamente a una realidad en la que se cultivan pocos valores humanísticos en contraste con el predominio de los tecnológicos, de la apariencia y posesión material, la publicidad triunfa como un arte asequible a cualquier público lector. Es un arte más bien poético, difundido por todas partes y que llega a conmover, subjetivamente, a su público objetivo por medio de un lenguaje artísticamente elaborado.

Partiendo de este presupuesto, quizás fuera posible afirmar que el discurso publicitario encajaría en el grupo de los textos literarios, pero esta conclusión es precipitada si no intentamos comprender, previamente, en qué consiste lo publicitario. Ante la necesidad de definir qué sería y en qué consistiría el fenómeno publicitario, Kurt Spang (2005:30) hace referencia a su propia traducción del concepto de O. W. Haseloff, el cual afirma que la "publicidad comercial es comunicación, persuasión y orientación de decisiones económicamente eficaces". Veamos un ejemplo: 
ANTIBES RESIDENCE Sen Lugar mum paraiso Tropical

Your place in a tropical pertedise Nated. Brazil

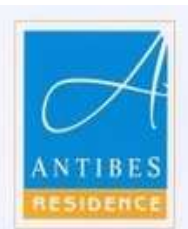

Prava de Ponto Negra

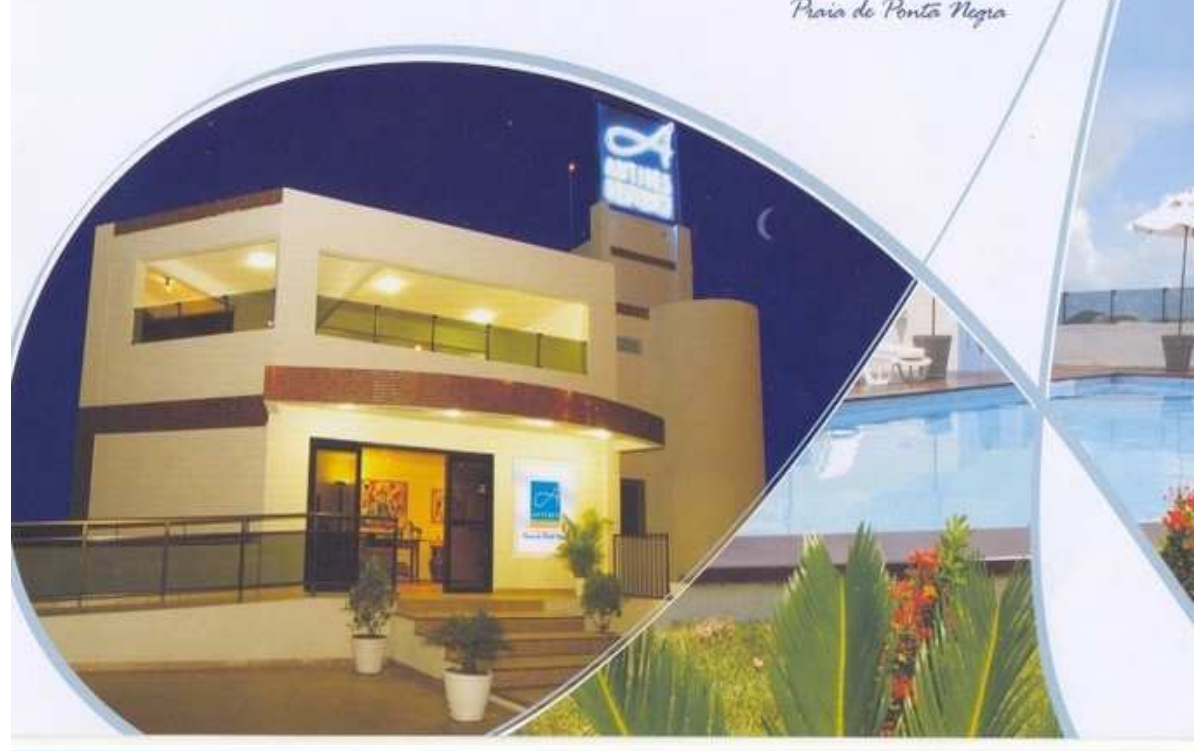

Antibes Residence

Rua Eliá Barros, 9104 - Praia de Ponta Negra

Natal/RN - Cep: 59092-360

reservas@antibesresidence.com.br wiww.antibesresidence.com.br

Tel:- 55 (84) 4009.2700 Fax: 55 (84) 4009.2749

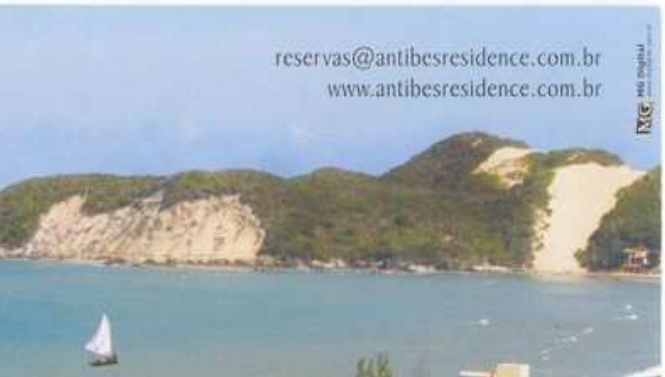

4

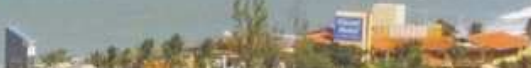
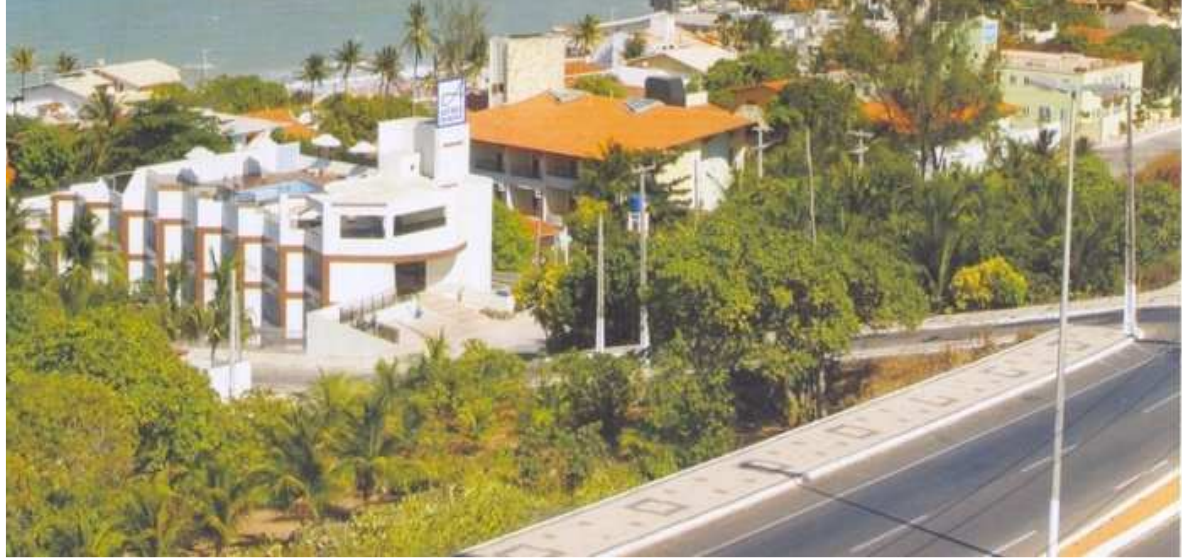


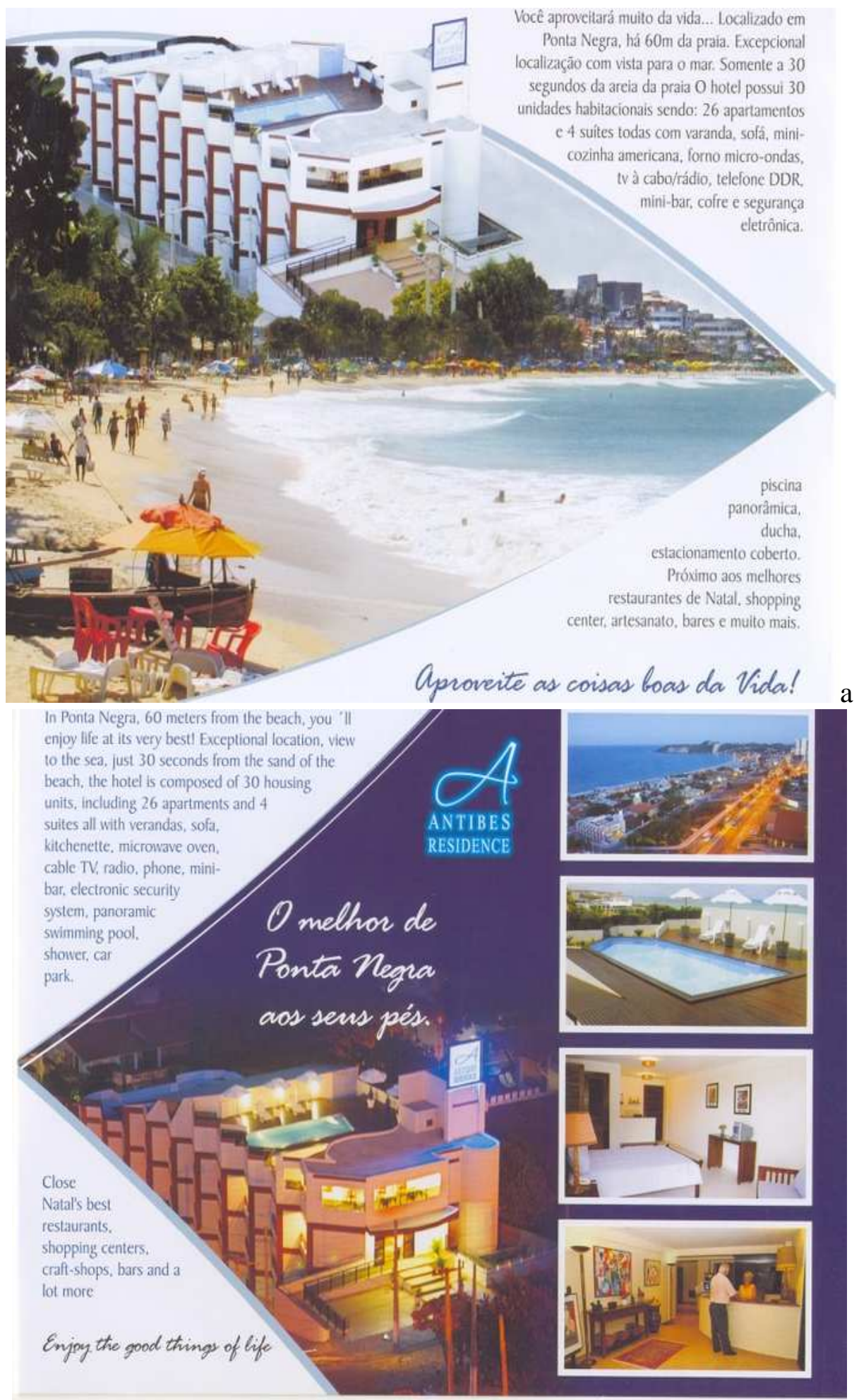

Texto 1

La publicidad suele destacar la calidad de un determinado producto para promover su venta por medio del argumento de excelencia. Si observamos este anuncio desde el punto de vista del receptor, vamos a ver la imagen de un hotel cerca de la playa, imágenes de la playa y de las instalaciones del hotel. En la primera página del folleto publicitario hay una frase destacada en cursiva que dice: "Tu lugar en un paraíso 
tropical". La última palabra, es decir, "tropical”, se destaca dentro de la oración por el tamaño de la fuente que es superior a la fuente de los otros sintagmas que forman parte de la frase expuesta anteriormente, con lo cual, el lector debe fijarse en esta última palabra cuyo tamaño le aporta más relevancia.

A partir de aquí, la curiosidad del receptor de este anuncio se despierta para intentar descubrir qué lugar es este que es suyo y está ubicado en un paraíso tropical, algo que descubriría fácilmente al seguir la secuencia de lectura occidental de la izquierda a la derecha, ya que, un poco más adelante depara en una logomarca con el nombre "Antibes Residence". La inferencia, pues, conduce a: el lugar anunciado como producto turístico debe ser visitado porque es un paraíso tropical, donde ya tengo un lugar para quedar, el Antibes Residense.

Aquí no se habla de costes, ni de medios de transporte para llegar al destino turístico anunciado. Y, objetivamente, las dos primeras páginas de este folleto publicitario se limitan a presentar el producto anunciado, su ubicación y formas de contacto. Luego, en la tercera página aparece el texto: Disfrutarás mucho de la vida...ubicado en Ponta Negra, $60 \mathrm{~m}$ de la playa. Excepcional localización con vistas al mar. Solamente a 30 segundos de la arena de la playa el hotel posee 30 habitaciones [...] ;disfruta de las cosas buenas de la vida!

Y en la última página de este folleto está la traducción del texto presentado anteriormente al inglés y la frase "lo mejor de Ponta Negra a tus pies". En ninguna parte del texto dice que el interlocutor debe hospedarse en el Antibes Residence. Y, por lo tanto, en la macroestructura de este texto figura simplemente la descripción del hotel, la presentación de su localización, y los puntos de interés turísticos que están próximos a este Hotel.

Es importante fijarnos en el hecho de que este anuncio es lo más neutro posible en el sentido de que una persona de cualquier lugar lo puede decodificar con más o menos las mismas informaciones. Eso ocurre porque la publicidad turística está dirigida a una amplia audiencia, incluso es común encontrar el mismo anuncio vehiculado en diferentes idiomas, como lo podemos comprobar por medio del texto 1. 
Una de las características de la publicidad turística es anunciar un producto intangible, una experiencia adquirida durante un viaje. Por eso, la imagen del producto anunciado es casi más importante que la descripción de este producto. Si observamos en el folleto presentado anteriormente, por lo menos $90 \%$ del texto está formado por imagen, con lo cual el procesamiento de la información textual exige un menor coste de energía cognitiva ya que va a depender de lo que cada receptor interprete de las imágenes.

El producto visual consiste en la propia imagen del "Antibes Residence", sus instalaciones internas y su vista privilegiada del mar. Existe un mensaje manifiesto de un lugar elegante y tranquilo para la instalación del turista y el mensaje latente es de un lugar acogedor, confortable, relajado, como en "paraíso tropical", que el propio eslogan ya lo anticipaba en la afirmación: “Tu lugar en un paraíso tropical”.

En el marco del vocabulario adoptado en este texto, observamos el uso léxico de paraíso tropical, disfrutar, excepcional, cosas buenas y lo mejor. No cabe duda que las ideas presentadas por el locutor del texto están fraguadas por medio de un vocabulario positivo, usado por el persuasor para lograr sus objetivos al producir este mensaje: la venta del producto anunciado. Y desde un punto de vista de la pragmática éste es el acto de habla perlocutivo instituido por el proceso comunicativo establecido por texto en cuestión.

Otro punto que merece ser destacado en este texto es un tuteo que no es casual, como todo en la publicidad. Sirve para crear una intimidad, una proximidad entre el ente productor del mensaje y el receptor, ya que, como muy bien apunta Santiago Guervós (2008:23) “el tuteo aleja las distancias, acerca los sentimientos, aporta confianza”.

Que este texto es persuasivo no cabe la menor duda, pero ¿por qué persuade? Es un texto que puede ser decodificado sin un gran esfuerzo cognitivo, va dirigido más a la emoción que a la razón, adopta un lenguaje positivo, limpio y de fácil comprensión. Es memorable porque usa frases muy comunes como "disfruta lo mejor de la vida"; hace uso de una organización del contenido, la forma, la tipología y los colores tan coordinada que todo significa. 
Jean-Michel Adam \& Marc Bonhomme, por su parte, en la obra La Argumentación Publicitaria: Retórica del Elogio y de la Persuasión (2000:28), postulan que "el discurso publicitario constituye un género blando, débilmente definido, heterogéneo e inestable, cuya única línea directiva es incitar al consumo comercial”.

Frente a ello, se puede llegar al postulado de que la publicidad figura entre los textos que hacen uso de diversos géneros textuales $y$, por este motivo, no posee características propias. Ante todo, no se puede negar que la marca definitiva de la publicidad es su carácter persuasivo, como afirman Adam \& Bonhomme (2000:182) cuando dicen que:

La publicidad se distingue por una predilección por las formas textuales tomadas de los ámbitos discursivos más diversos. Extendiéndose de esta manera hacia géneros diferentes, que parecen tener poca relación directa con sus funciones fundamentales - persuadir al público, describir y contar el producto -, la publicidad parece negarse a sí misma como género autónomo.

Albert D. Lasker, considerado el padre de la publicidad moderna, fue defensor de la idea de John E. Kennedy de que la publicidad actúa como un "vendedor impreso". En la sociedad de masas, la publicidad actúa como un elemento preponderante en la creación de símbolos, mitos, imágenes y valores. Por eso, el lenguaje publicitario refleja la sociedad a la que va dirigido. En las palabras de López Eire (1998:37):

\begin{abstract}
El lenguaje publicitario sirve a la sociedad de masas, cuya cultura (cultura de masas) está dominada por los medios masivos de comunicación, que transmiten incesantemente los símbolos, los mitos y las imágenes que mejor se adaptan a los valores prácticos de una sociedad de consumo que se deja llevar muy fácilmente por el flujo de lo sentimental. Por eso el lenguaje publicitario se identifica con las tendencias de sus receptores fundamentalmente a la hora de presentar un producto de consumo como deseable a base de identificarlo y definir con mucho gancho y atractivo sus específicas propiedades y cualidades.
\end{abstract}

Si la publicidad es un tipo de texto heterogéneo y se niega como un género autónomo, ¿cómo se clasificaría el texto publicitario frente a la dicotomía textual de textos literarios y no literarios? Para encontrar una respuesta, intentemos comprender, previamente, todo el proceso del fenómeno publicitario en la comunicación desde su origen. 


\section{El discurso publicitario}

El lenguaje es un constructo social del que los seres humanos hacen uso para comunicar sus pensamientos y sentimientos. En este sentido, es dinámico y acompaña a los cambios sociales, económicos, históricos y culturales de una determinada comunidad. Los diversos tipos de lenguaje existentes pueden ser configurados y estudiados desde una perspectiva discursiva, a partir de la cual se forman dos grandes grupos del discurso, a saber: el oral y el escrito.

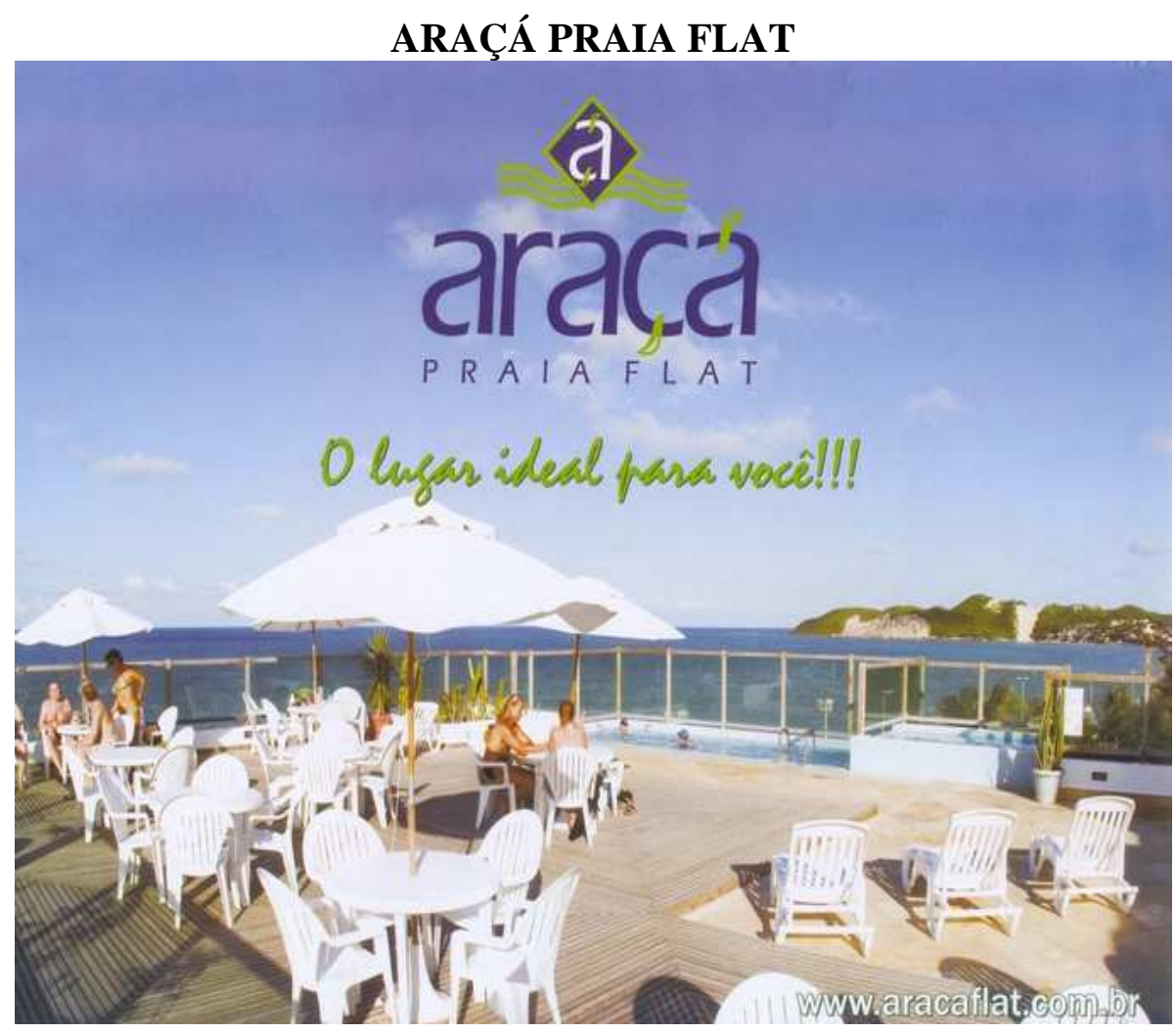




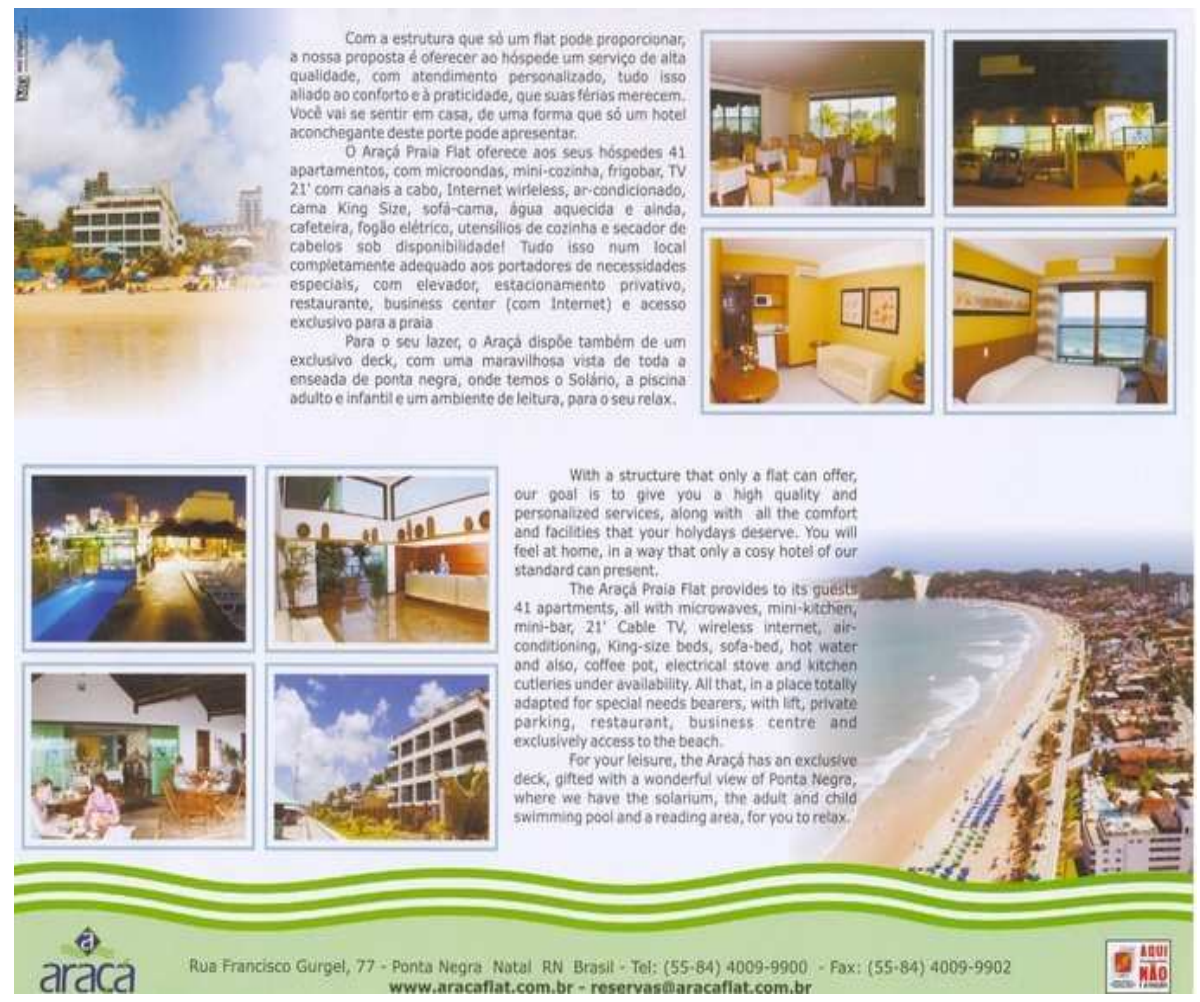

Texto 2

Este anuncio publicitario del Araçá Praia Flat figura en el grupo del discurso escrito. Sin embargo, no hace uso solamente del lenguaje verbal, ya que el texto está compuesto por el código verbal y visual. En el texto publicitario ese uso de códigos diferentes en la constitución del mismo texto es más una regla que una excepción, sobre todo en la publicidad turística que materializa un producto intangible por medio de folletos publicitarios. En este sentido, la imagen desempeña un papel fundamental. Observemos que este folleto publicitario está compuesto por dos páginas: la primera, en su mayor parte, consiste básicamente en imagen, mientras la segunda posee un $80 \%$ de lenguaje visual frente a un $20 \%$ del contenido fraguado por medio del lenguaje verbal.

Desde un punto de vista formal, la primera página describe, por medio de imagen, un ambiente de sol y playa muy tranquilo, con algunas personas disfrutando de un momento de ocio. El lector atento infiere rápidamente que este ambiente es el Araçá Praia Flat y luego, bajo el nombre, viene el eslogan: Un lugar ideal para ti. Y realmente este pasa a ser un lugar ideal para quien busca un destino turístico de sol y playa que corresponda a la imagen del texto. Así que esta imagen pasa a tener la función de gancho para despertar en el lector el interés de seguir leyendo el anuncio que expone a continuación el siguiente texto: Con una estructura que solamente un flat puede 
proporcionar, nuestra propuesta es ofrecer al visitante un servicio de alta calidad, con atendimiento personalizado, todo eso unido al confort y a la practicidad, que tus vacaciones merecen. Vas a sentirte en casa, de un modo que solo un hotel acogedor como este puede proporcionar. El Araçá Praia Flat ofrece a sus huéspedes 41 pisos, con [...]. Para tu ocio, el Araçá dispone también de un exclusivo deck, con una vista maravillosa de la playa de Ponta Negra. Donde tenemos el solárium, la piscina para adultos y niños y un ambiente de lectura para tu relajación.

En la macroestructura de este texto publicitario figura la descripción del "Araçá Praia Flat", la presentación de su localización y su vista privilegiada de la playa de Ponta Negra. Con lo cual, la progresión temática de este texto puede ser definida como siendo de progresión de tema constante. Las personas del discurso presentes son el "nosotros", como emisor que presenta un tipo de cortesía desde un punto de vista retórico, además de la inscripción del "você", en portugués de Brasil, que tiene la fuerza semántica del "tú" en español, presentando así un carácter de proximidad entre el emisor y el destinatario.

En el uso léxico podemos encontrar sintagmas como: lugar ideal, alta calidad, atendimiento personalizado, confort, practicidad, hotel acogedor, vista maravillosa, ocio y relajación, con lo cual tenemos la presencia de un vocabulario positivo en el que figuran sustantivos acompañados de adjetivos y sustantivos que forman parte de un campo léxico del bienestar.

Ahora bien, sabemos que este texto pertenece a los textos escritos, más bien al discurso publicitario y por eso es persuasivo por excelencia, pero ¿por qué persuade? Es un texto de fácil comprensión cuyo proceso de decodificación exige el más mínimo esfuerzo cognitivo. Además, el acto de habla locutivo consiste en el discurso constituido por el lenguaje verbal escrito y el lenguaje visual; el ilocutivo en la descripción del producto turístico ofertado y su ubicación; y el perlocutivo en la estrategia de persuasión publicitaria que tiene como finalidad recibir del interlocutor la confirmación en forma de un acto de compra del producto turístico anunciado.

Desde un punto de vista de la tipología textual, posee una secuencia dominante de texto argumentativo, ya que la descripción funciona más bien como un recurso persuasivo, 
para despertar en el lector/consumidor el deseo de consumir el producto ofertado. El producto visual consiste en la propia imagen del "Araçá Praia Flat", sus instalaciones internas y su vista privilegiada del mar, cuyo mensaje manifiesto es de un lugar elegante y tranquilo para la instalación del turista y el mensaje latente es de un lugar acogedor, confortable, relajado e ideal, como el propio eslogan afirma: “el lugar ideal para ti”.

En ese contexto, vale recordar que tanto el discurso oral como el escrito pueden ser divididos, por dicotomía, en literarios y no literarios. La distinción entre lo que sería el texto literario y el no literario es tema de estudio de muchos investigadores del lenguaje. En este sentido, Proença Filho (1995:36) afirma que "el código en el que se pauta el discurso literario guarda una íntima relación con el código del discurso común. Sin embargo, presenta, en relación a este, distinciones sigularizadoras". Para este autor, dichas distinciones serían la complejidad, la multisignificación, el predominio de connotación, la libertad creativa, el énfasis en el significante $\mathrm{y}$, por último, la variabilidad.

Ya el discurso publicitario presenta características comunes al código del discurso literario y, a la vez, al código del discurso no literario. Puede presentar textos informativos, denotativos, objetivos e invariables como el discurso no literario, pero también presenta textos complejos, multisignificativos, connotativos, con libertad creativa, con énfasis en el significante y variable. Por eso, algunas de nuestras indagaciones en este trabajo de investigación consisten en: ¿a qué tipo discursivo pertenece el discurso publicitario? ¿Es la publicidad un texto literario o no literario? Con el objetivo de contestar a tales preguntas, intentemos comprender primeramente qué es publicidad y en qué consiste lo publicitario desde una perspectiva estrictamente comunicativa y textual.

\section{Un proceso de comunicación específico}

Para delinear las especificidades del texto publicitario escrito y clasificarlo frente a la dicotomía textual de literario y no literario, es necesario adentrarse en este tema y partir de cuestiones básicas como el tipo de texto y el proceso comunicativo establecido por él. A partir del texto expuesto más abajo, intentemos comprender qué tipo de texto 
comprende lo publicitario y cuál es el proceso comunicativo establecido a través de este tipo textual:

SHOPPING DO ARTESANADO POTIGUAR

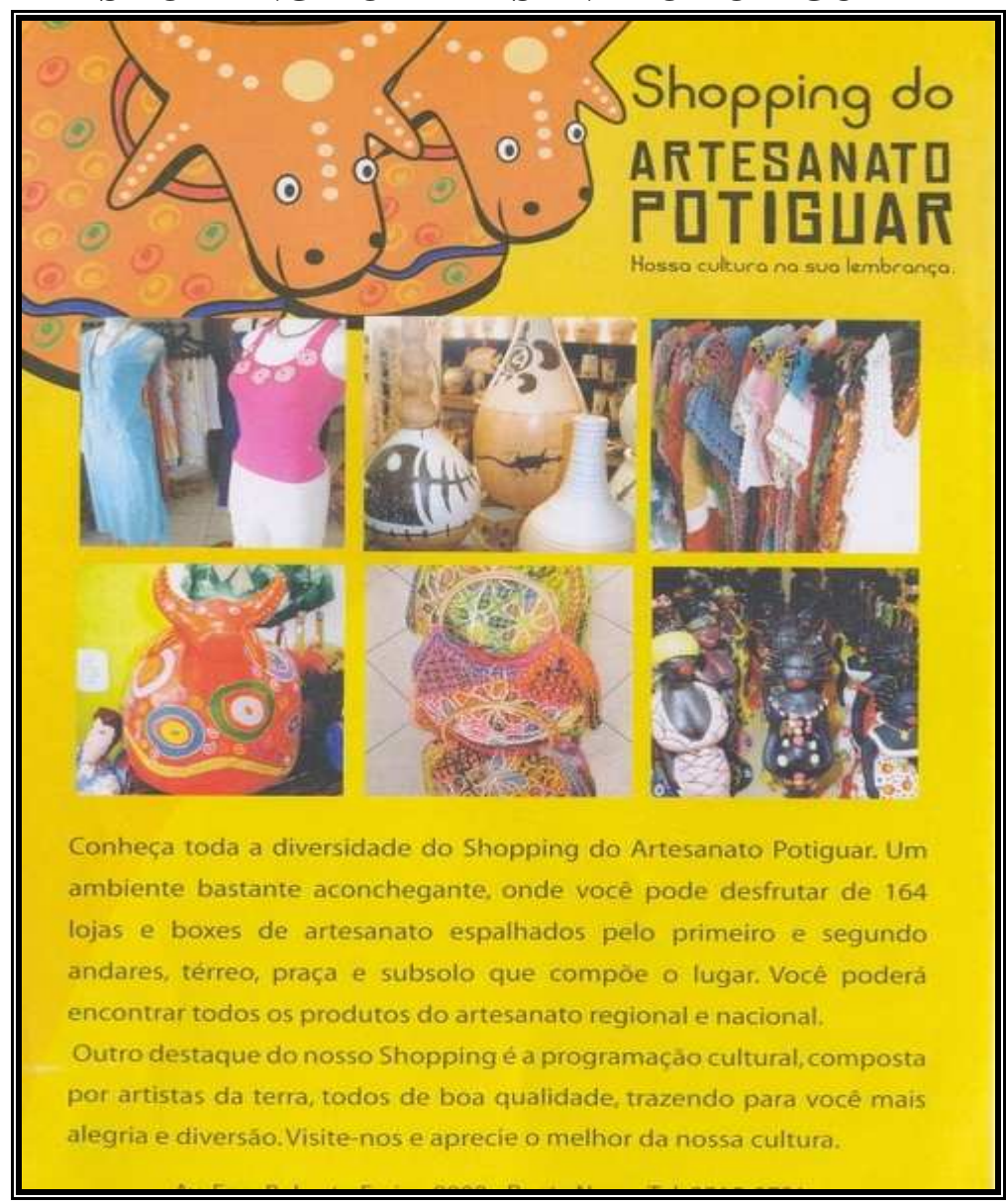

Texto 3

En el tercer texto de nuestra muestra de análisis figura el anuncio de un centro comercial cuya especialidad es la venta de recuerdos para turistas. Luego, en las primeras líneas del anuncio, se lee: shopping do artesanato potiguar. Este enunciado está destacado de forma distinta desde un punto de vista tipográfico, puesto que la fuente cambia de tamaño y de formato. El adjetivo potiguar está en una fuente más grande que los otros lexemas de la frase. Esto ya significa que este adjetivo tiene más importancia, en realidad es lo que particulariza el tipo de artesanía, que no es la de otro sitio sino la potiguar, y eso le atribuye un carácter particular, una calidad especial, una determinada excelencia. 
A continuación de la lectura se lee el eslogan nuestra cultura en tus recuerdos, donde recuerdos posee un sentido ambiguo, ya que corresponde tanto a la acepción correspondiente a recuerdos guardados en la memoria de uno como al sustantivo que designa los objetos comprados durante un viaje que sirven para recordarlo.

Un $70 \%$ del texto corresponde a imágenes de los productos anunciados, que en este caso son productos tangibles, como ropas, bolsos, objetos de cerámica para decoración y un buey que es uno de los símbolos del folklore brasileño. También merece destacarse la combinación cromática del anuncio y el uso de un amarillo fuerte como color dominante en el folleto publicitario. El mensaje manifiesto del producto visual es la presentación de ropas, muñecos, esculturas, pinturas y bolsos; y el mensaje latente es de un lugar inspirado en el arte, muy original, con presencia de artistas; el mensaje latente de esta imagen es de carácter persuasivo, pues las imágenes de los productos funcionan como el atractivo para despertar el interés por la compra de esos productos artesanales.

En su macroestructura figura la descripción del "Shopping do Artesanato Potiguar", sus productos y eventos. Así, la progresión temática de este texto puede ser definida como de progresión de tema constante. El texto es el siguiente: Conoce toda la variedad del centro comercial de la artesanía potiguar. Un ambiente muy acogedor, donde puedes disfrutar de 164 tiendas y casetas de artesanía ubicadas en las tres plantas del local. Puedes encontrar todos los productos de artesanía regional y nacional. Otro destaque del centro comercial es la programación cultural, compuesta por artistas locales muy bien calificados, lo que te proporcionará más alegría y diversión. Ven a visitarnos y disfruta lo mejor de nuestra cultura.

En el marco léxico de este texto es importante destacar los sintagmas ambiente muy acogedor, disfrutar, muy bien calificados, más alegría, más diversión, lo mejor. Sin duda, todas estas construcciones, como es habitual en el lenguaje publicitario, condensan una selección léxica absolutamente positiva, crea un estereotipo positivo. En ese texto se usa el argumento de la excelencia del producto lo mejor, además del argumento de cantidad 164 tiendas y dice que vas a alegrarte y disfrutar más de tu viaje de turismo. Aquí hay una determinada suspensión del principio de sinceridad, ya que no se puede saber a ciencia cierta si eso es cierto o no. 
Ese texto pertenece al género del discurso publicitario y, desde un punto de vista de la tipología textual, posee una secuencia dominante de texto argumentativo, ya que la descripción funciona más bien como un recurso persuasivo. En la textura discursiva es importante destacar el uso de verbos en el modo imperativo, como en "conoce", "ven" y "disfruta”, que tienen más bien una función de consejo que de una orden.

El mismo Kurt Spang (2005:30) añade que, frente a las exigencias de la sociedad contemporánea, el concepto de publicidad, presentado en el primer párrafo, puede recibir un matiz distinto, dado que en las tendencias actuales de publicidad se podría llegar a añadir que "el afán de informar sobre el producto o el servicio tiende a escasear aumentando considerablemente la apelación masiva a los sentimientos y aspiraciones personales y sociales de los potenciales compradores". Aquí podríamos inferir que la publicidad tiene como finalidad la seducción de su público y para ello parte del principio de incorporación de los valores de cada época y de cada sociedad para aproximarse a su audiencia. Así, el arte publicitario consistiría en una herramienta seductora de un determinado público.

La publicidad de cualquier producto es tangible, puesto que anuncia un producto que puede ser visto antes de su adquisición, mientras que la publicidad de servicios es intangible porque ofrece un producto que no puede ser visto ni probado antes de su consumo. Dicho esto, como hemos visto anteriormente, el turismo consiste en un producto inmaterial, pero hay actividades comerciales dentro de esta industria que puede ser la venta de productos. Por ejemplo, la publicidad anterior anuncia productos materiales como ropa, bolsos, objetos de cerámica, con lo cual es un anuncio publicitario de un producto, mientras que cuando se anuncia el turismo, un bien intangible.

No es novedad afirmar que la publicidad ocupa un puesto importante en la sociedad actual, además, crea neologismos y los difunde. También forma diccionarios de sus palabras más usadas, inmortaliza eslóganes y mantiene una relación muy estrecha con la sociedad de consumo. Ferrer Rodríguez (1994:235) considera que hay dos factores que dominan el mensaje publicitario: "la naturaleza mudable del ser humano y el imperio persistente de las leyes del mercado". Por eso comprendemos la publicidad como un 
"producto social" y parte constitutiva del marco de referencia de una sociedad, aún siendo un "fenómeno económico".

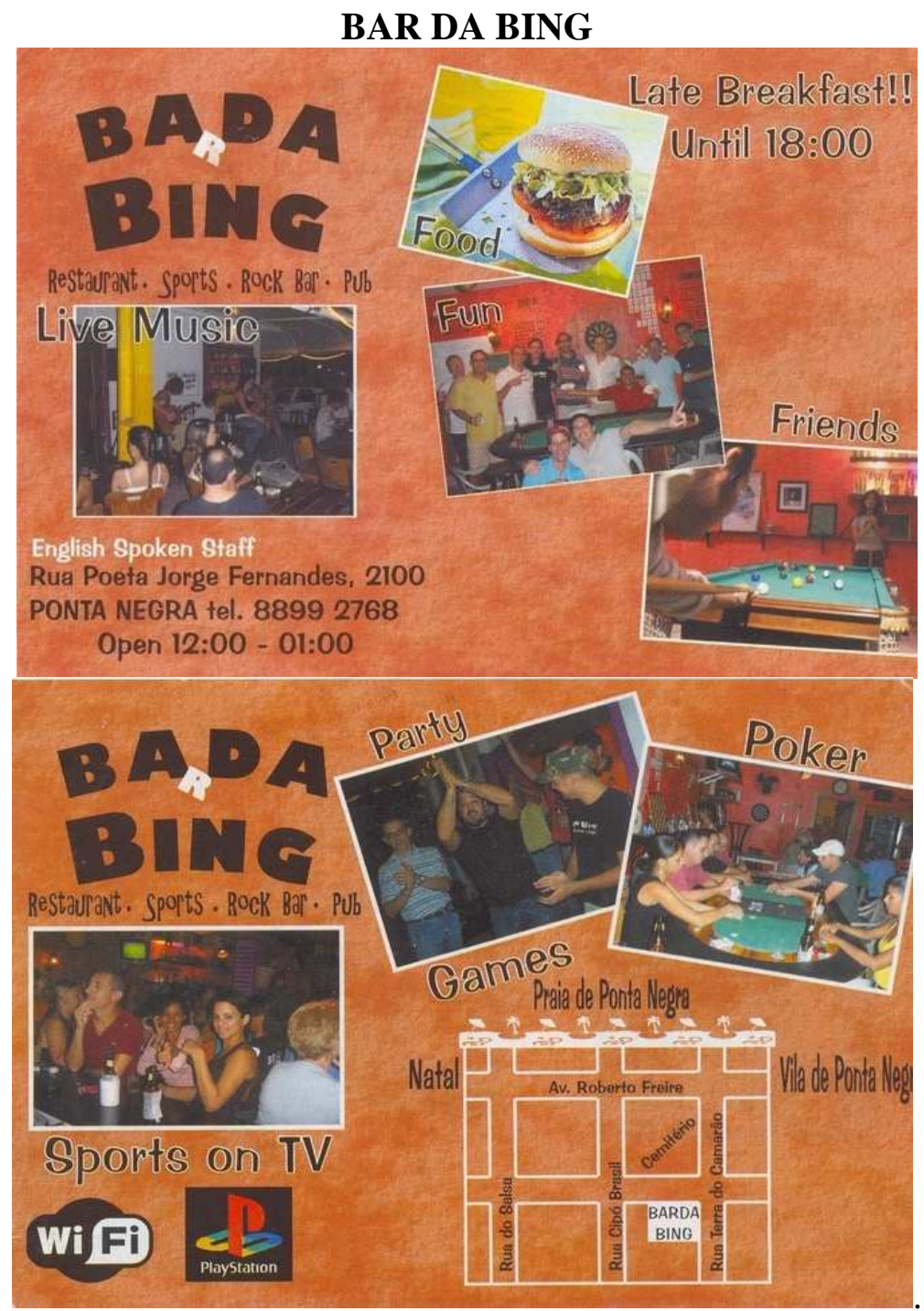

Texto 4

El folleto publicitario expuesto arriba realiza toda una expresión textual por medio de las imágenes, y el contenido verbal posee una función de anclaje. En su macroestructura figura la descripción del "Bar da Bing”, la presentación de su localización y lo que uno puede encontrar allí: comida, música en directo, diversión, amigos, fiesta, juegos y los partidos deportivos exhibidos por la televisión. Este mensaje puede ser inferido por el lector sin mucho esfuerzo cognitivo a partir de la unión del producto visual con el verbal. 
El texto es completamente impersonal y tiene función de enumeración, por eso no existe la presencia de personas del discurso. El producto visual consiste en la propia imagen del "Bar da Bing" y el mapa de cómo llegar a ese bar, cuyo mensaje manifiesto es una invitación a visitarlo y el mensaje latente es de un lugar joven, de fiesta y con mucha vida nocturna”.

La parte verbal del texto está escrita en inglés, con lo cual podemos inferir que este bar está pensado para turistas extranjeros. Aunque no excluye a los jóvenes brasileños de clase media y alta que pueden comprender perfectamente la parte textual en lengua inglesa, porque todo el léxico forma parte de su vocabulario cotidiano, ya que el uso de extranjerismos como bar, breakfast, restaurant, sports, rock, pub, food, fun, friends, party, poker, games, TV, playstation y wifi forma parte del léxico disponible de este público de brasileños y, a la vez, le aporta status, modernidad y juventud por ser un léxico de alto prestigio lingüístico.

Si volvemos a ver el léxico que figura en este anuncio, podemos observar que todo el contenido verbal consiste en palabras como bar, desayuno, restaurante, deporte, rock, pub, comida, diversión, fiesta, poker, juegos, tele, consola y wifi. Es decir, todo un campo léxico perteneciente a actividades de ocio. Por eso, ese texto es persuasivo, no aporta grandes dificultades a la hora de decodificarlo, tiene imágenes agradables a la vista, un léxico positivo y alegre, que va direccionado más a la emoción que a la razón del interlocutor. En definitiva, un texto estándar de publicidad.

Como hemos visto hasta este punto de nuestra investigación, el arte publicitario hace uso de todos los artificios posibles para actuar directamente sobre los sentidos humanos (audición, olfato, tacto, gusto, visión y emoción) para convencer al interlocutor, ya que uno de sus objetivos fundamentales es motivar a su público emocionalmente, como señala Kurt Spang (2005:30) cuando dice que la publicidad "trata de despertar instintos y pasiones y llevarlos a una reacción impulsiva e irracional”.

\section{El arte de la publicidad}

La producción publicitaria contemporánea es más bien la producción de una obra de arte en la que la forma de presentar lo que se quiere decir es elaborada con el ingenio 
del artista que emplea su total creatividad para sensibilizar a su interlocutor. Así, el publicista podría ser considerado un artista, un reproductor de la sociedad, del espacio y del tiempo en el que vive. En ese sentido Piratininga (1994:68) dice que "los artistas son, como las otras personas de su época, seres sociales, producto y productores de su sociedad; es decir, ni personas completamente independientes y autocráticas, ni aisladas y desenraizadas"19.

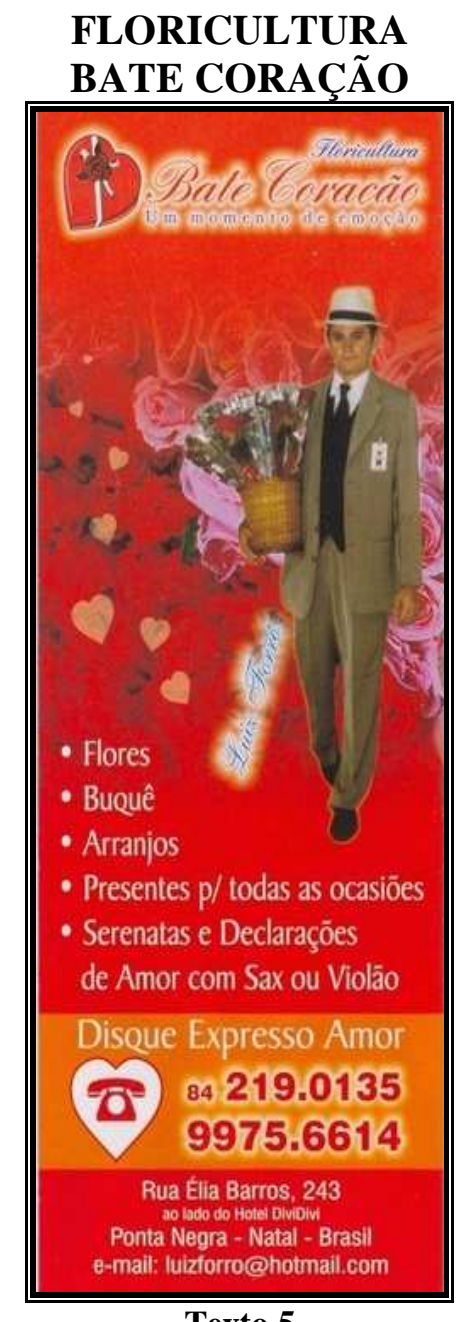

Por un lado, eso aproxima la publicidad al arte y el publicista al artista, puesto que la publicidad ejerce un papel ideológico en la sociedad por medio de sus mensajes estéticamente elaborados. Esto también es característico del discurso literario, así que, una vez más, podríamos concluir que el texto de la publicidad es un texto muchas veces literario.

\footnotetext{
${ }^{19}$ En la fuente original: "os artistas são, como as outras pessoas de sua época, seres sociais, produtos e produtores de sua sociedade; quer dizer, nem pessoas completamente independentes e autocráticas, nem, à partida, isoladas e desenraizadas".
} 
El anuncio presentado anteriormente fue elaborado por medio de un arte digital de edición y sobreposición de imágenes, incluso el nombre de quien lo creó, Luiz Forró, figura en el anuncio de forma muy discreta, del mismo modo que el nombre de un pintor aparece en sus cuadros.

El texto publicitario en cuestión es el anuncio de una floristería, lo que queda muy claro desde la primera línea del texto verbal "floricultura late corazón". Al seguir la lectura, desde un punto de vista occidental, es decir, de izquierda para la derecha y de arriba abajo, el lector atento encuentra el eslogan "un momento de emoción". Aquí es importante observar dos cosas: la rima entre el corazón y emoción, y el uso de fonemas predominantemente bilabiales en la construcción sintáctica del eslogan. A partir de ahí, podemos decir que hubo un cuidado estético, desde un punto de vista lingüístico, en la elaboración de este texto.

En su macroestructura figura la descripción de la "floricultura bate coração", la presentación de su localización y formas de contacto. Así, la progresión temática de este texto puede ser definida como de progresión de tema constante. No hay ninguna persona del discurso presente y la cohesión y coherencia del texto son creadas en la mente del lector por procesos cognitivos simples, a partir de la unión del discurso de la imagen con el discurso verbal.

El producto visual consiste en la imagen de un chico vestido con traje y corbata, con un sombrero adornando su cabeza. El personaje lleva un ramo de flores en la mano derecha y el fondo de la imagen es rojo con dibujos de corazones y rosas. Para una mejor compresión de lo que puede representar esta imagen, y toda esa simbología, entra en juego el uso de los supuestos culturales por parte del lector, que necesita saber previamente que el rojo es el color que representa el amor y la pasión; las rosas y los corazones también son símbolos representativos del enamoramiento. Además, la cultura brasileña es una cultura considerada machista, con lo cual quien regala flores es el hombre a la mujer, de ahí que en el anuncio quien regala y entrega las flores es un chico y no una chica.

El personaje del anuncio está vestido de una forma elegante dentro del contexto social, cultural y económico en el que el anuncio es distribuido. La expresión facial del 
personaje es seria, serena, elegante y confiable, como la propia ocasión lo exige. Este anuncio deja claro que en la sociedad brasileña este tipo de demostración de amor romántico, que en algunas culturas puede parecer cursi u hortera, es un hecho especial y muy emocionante en la vida de una persona. Por último, el mensaje manifiesto es el simple anuncio de una floristería y sus productos y el mensaje latente es de un hombre caballeroso y enamorado que regala flores a su amor.

El campo léxico que enumera los productos y servicios ofertados por la "floricultura bate coração" presenta palabras como: corazón, emoción, flores, ramos, regalos, serenatas y declaraciones de amor, con lo que no pertenece solamente al léxico de una floristería, sino del campo de regalos para ocasiones especiales de una pareja.

No obstante, toda la preocupación con la estética del texto, tanto de su contenido de la imagen como verbal, todavía es demasiado pronto para llegar a la conclusión de que un texto publicitario es un texto artístico y por lo tanto literario, dado que hace falta tocar muchos otros temas relacionados con el fenómeno publicitario.

Otro factor importante que se puede encontrar en el texto en cuestión es el hecho de que es un reflejo de la sociedad contemporánea, en la que es muy común la existencia de una dirección física y otra electrónica, además del uso del teléfono para realizar compras. De eso también se puede inferir el nivel socioeconómico del público objeto de este anuncio: hombres de clase media y alta.

A partir de ahí, está claro que el texto publicitario ejerce una función explícitamente ideológica, típica de toda manifestación cultural y, sobre todo, de los discursos periodísticos, elaborados al servicio de los grupos económicos que detienen la hegemonía política y/o económica en una sociedad de masas y en su economía de mercado.

Con este último dato añadido, también se podría concluir que el discurso publicitario se hace explícito por medio de un tipo de texto no literario de forma que perdura la duda ¿se puede clasificar el texto publicitario como literario o no literario? Para encontrar la respuesta a esta pregunta, sigamos con nuestra línea de razonamiento. 
Un arte efímero

Desde el comienzo de este trabajo se viene afirmando que la publicidad es un arte, un arte efímero en la búsqueda del cambio constante para acompañar la velocidad de las mutaciones de valores humanos de la sociedad actual, proceso natural y propio de la comunicación. Así, la publicidad comprendida como un arte no pertenece, pues, al grupo de arte transcendental, o por lo menos no trataría de temas transcendentales.

\section{BEACH RESORT NATAL}

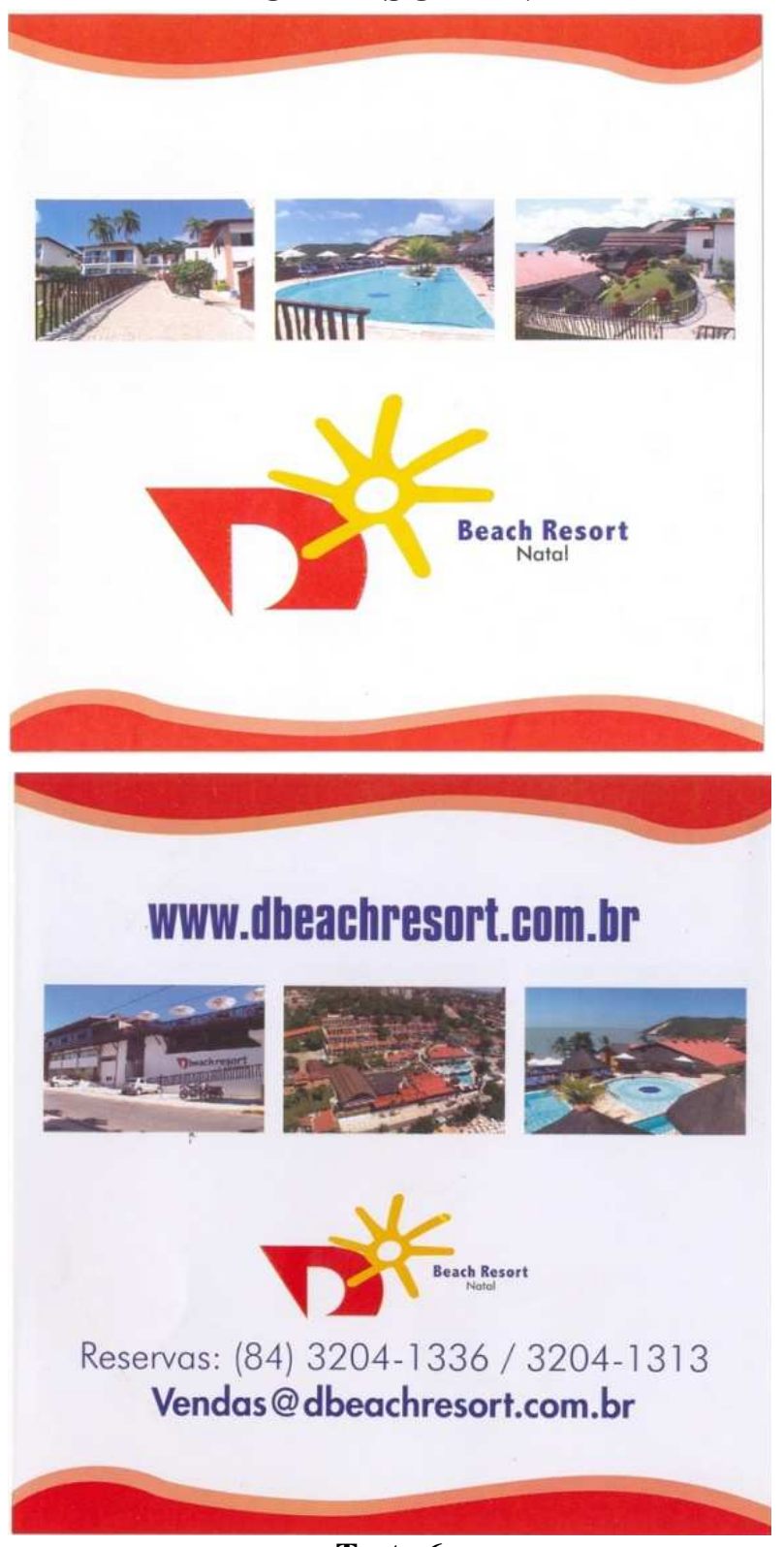

Texto 6

Betés Rodríguez (2005:124) también defiende la idea de lo efímero cuando afirma que "la variable tiempo nos recuerda la fugacidad del mensaje publicitario", que por eso 
puede ser muy efímero y caducar poco tiempo después de su producción. Fernández Gómez (2005:99) señala que:

\begin{abstract}
Esta fugacidad publicitaria es algo natural, consustancial al fenómeno mismo de la publicidad; los públicos cambian, los productos adquieren nuevas características, las actitudes se modelan; en definitiva, el mercado no es un todo inamovible y estable, sino un entramado fluctuante y voluble. Y con él debe moverse la publicidad: en función de las necesidades, motivaciones o deseos de los consumidores; de los avances, cambios o novedades en materia de producción, y por supuesto, del entorno.
\end{abstract}

En el texto 6 se puede ver, desde un punto de vista formal, un texto que sigue el formato de un texto electrónico, es la portada de un DVD. Este tipo de publicidad es todavía muy novedoso en la venta de servicios turísticos y hace unos 10 años era impensable promover la publicidad de un servicio por medio del hipertexto, un canal que no era tan popular como lo es actualmente. En esto podemos encontrar el cambio de paradigmas y el cambio de valores en una determinada sociedad de consumo.

El anuncio del "D Beach Resort" en el actual momento de la coyuntura turística en Natal es muy novedoso y moderno, pero dentro de algunos años, por la dinamicidad de la economía y del mercado consumidor, puede no serlo. Y en eso reside el cambio fluctuante y voluble en el que se mueve la publicidad. Es decir, el prestigio que este tipo de publicidad promueve por su novedad no es fijo y puede cambiar a lo largo del tiempo.

El acto de habla locutivo del texto en cuestión consiste en el discurso constituido por el lenguaje verbal escrito y el lenguaje visual; el ilocutivo en la presentación del producto turístico ofertado y formas de contactos: número de teléfono, correo, y web; y el perlocutivo parece ser el acceso a las informaciones del este producto turístico contenidas en el DVD y, por consiguiente, la adquisición del producto anunciado.

El producto visual consiste en seis imágenes panorámicas del Resort anunciado y su logomarca, cuyo mensaje manifiesto es de un lugar muy sofisticado y elegante y el mensaje latente es de un lugar acogedor, confortable y muy amplio. En ninguna parte aparece propuesta de compra o venta de los servicios turísticos de este Resort, solamente la presentación de lo que se quiere vender de forma seductora, y en eso 
consiste su carácter persuasivo que va más dirigido a la emoción que a la razón por medio de imágenes deslumbrantes a cualquier mirada.

Por lo tanto, es cierto, como afirman Betés Rodríguez (2005) y Fernández Gómez (2005), que la fugacidad es una característica inherente a la publicidad, que presenta tres tipos básicos de anuncios, a saber: el impreso, el radiofónico y el televisivo. Cada uno de ellos tiene su especificidad y su forma propia de presentación que divergen desde las técnicas empleadas en su creación y presentación hasta el código que los vehicula. Independiente de esto, también están condicionados al cambio dentro del mismo tipo por causa de la edad, el género y el grupo social de su audiencia; además de los productos anunciados, los servicios ofrecidos y los valores sociales, económicos y culturales del público destinatario. Todo eso delimita la forma de presentación de un determinado tipo de anuncio.

\section{Un texto camaleón}

En este punto se puede pensar que el texto publicitario, aunque pueda ser clasificado como artístico, se aleja del texto literario por no poseer la característica de ser clasificado como transcendental, pero si es estético, es estético y camaleónico, se adapta al contexto, al cambio para sobrevivir como un género del discurso eficaz. Por eso la publicidad cambia según la época, el espacio, el público, el género, la edad, el tipo de mensaje, el lenguaje, el código, el canal, etc. 


\section{BELLO MARE HOTEL}

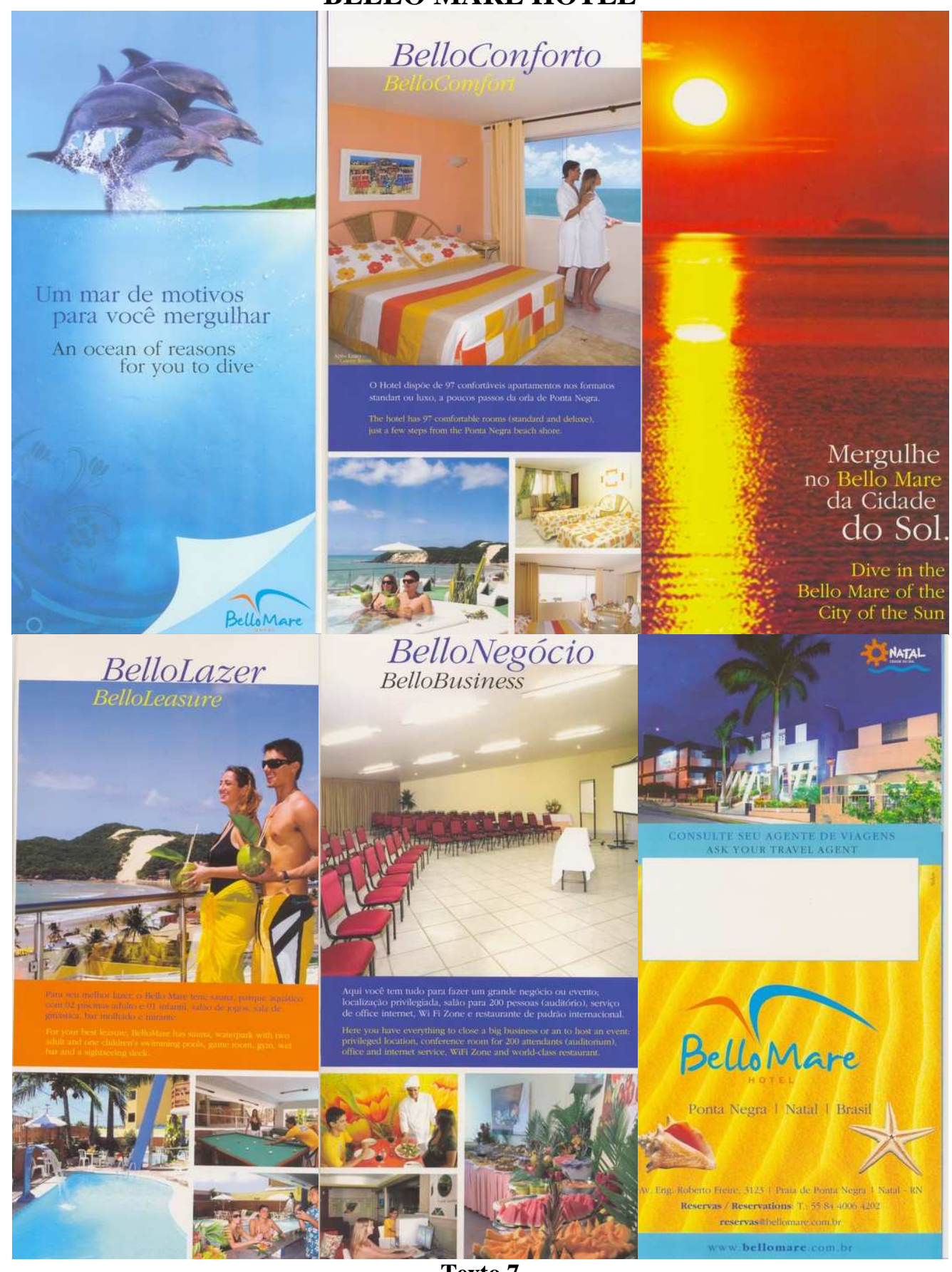

Texto 7

El texto 7 presenta un buen ejemplo de cambio y adaptación de un texto publicitario a su público objeto, o sea, es un ejemplo típico de un texto camaleón. Desde un punto de vista formal, este texto sigue el formato propio del texto publicitario, creado como un híbrido de lenguaje verbal y visual. En su macroestructura, figura la descripción del "Bello Mare Hotel”, la descripción de sus instalaciones, servicios y su localización. 
La progresión temática de este texto puede ser definida de progresión de tema constante. El folleto publicitario está formado por seis páginas. En la primera se puede ver cuatro delfines saltando a punto de bucear en un mar de aguas azules y trasparentes. Luego, el eslogan, un mar de motivos para que bucees, y en el lado derecho de la página, el nombre del producto turístico ofertado: Bello Mare Hotel acompañado de una indicación de que se debe seguir la lectura y para ello hay que cambiar de página.

La persona del discurso presente es la inscripción del "você", en portugués de Brasil, que tiene la fuerza semántica del "tú" en español, presentando así un carácter de proximidad entre el emisor y el destinatario. Como hemos visto anteriormente, este recurso acota las distancias entre los interlocutores y aporta más proximidad.

En la segunda página presenta el enunciado bello confort como el titular, seguido de una cadena de elementos que muestran el confort que uno puede encontrar en el hotel: imágenes de una habitación de matrimonio con una pareja mirando por la ventana hacia el mar; una habitación doble; una pareja muy alegre sentada delante del mar tomando agua de coco verde; y una pareja desayunando en la habitación.

Por último, el contenido verbal del texto dice que el hotel dispone de 97 apartamentos confortables en los formatos estándar y de lujo, a pocos metros de la orla de Ponta Negra. La palabra clave aquí es confort porque consiste en el primer gran motivo que uno tiene para hospedarse (bucear) en el hotel Bello Mare.

La tercera parte de este anuncio contiene la imagen de una bella puesta del sol en el mar y el enunciado bucee en el bello mare de la ciudad del sol. O sea, venga al hotel Bello Mare de Natal, considerando que esta ciudad es vendida como destino turístico por el atributo de estar soleada durante todo el año, hecho que le dio el título de ciudad del sol.

En el cuarto folio aparece el titular bello ocio y cuatro imágenes que intentan corroborar la excelencia de la calidad del ocio encontrado en el hotel. Eso es lo que se puede ver por medio de la imagen de una pareja relajada y mirando hacia el mar desde el hotel; la piscina del hotel; la sala de juegos del Bello Mare con la pareja jugando al billar; y una pareja en el bar acompañada por el camarero. A la mitad de esta parte del anuncio hay un texto escrito que dice para que tengas un mejor ocio, el bello mare tiene sauna, 
parque acuático con dos piscinas para adulto y una infantil, sala de juegos, sala de gimnasia, bar mojado y mirante.

La quinta página se compone de un pequeño texto con cuatro imágenes bajo el titular bello negocio. En las imágenes se puede ver una sala de reuniones, una sala con ordenadores, la mesa para el desayuno y un bufet libre. El texto afirma que aquí tienes todo para hacer un gran negocio o evento: ubicación privilegiada, sala para doscientas personas (auditorio), servicio de internet, zona de wifi y restaurante con un patrón mundial.

Concluye con la frase consulte tu agente de viajes, además de las formas de entrar en contacto con el personal del hotel por medio de dirección física y electrónica. Así, el anuncio presenta su "mar de motivos para uno bucear en el bello mare". Dichos motivos son: el confort; la ubicación, es decir, Natal, la ciudad del sol; la variedad de sus actividades de ocio; y su ambiente de negocio organizado para realizar cualquier tipo de evento empresarial.

En resumen, el lector llega más o menos al siguiente enunciado: el Bello Mare hotel es confortable, moderno, bien ubicado, dispone de muchas actividades de ocio, posee ambiente para eventos empresariales y la gente que frecuenta este ambiente es adulta, joven, educada, guapa, bien sucedida y feliz. El lector/consumidor que sea vulnerable a esta seducción del anuncio llamará al hotel para hacer su reserva, o la suya y de su pareja.

El producto visual consiste en la propia imagen del "Bello Mare Hotel", sus instalaciones internas y su vista privilegiada del mar, cuyo mensaje manifiesto es de un lugar elegante y completo; y el mensaje latente es de un lugar bello, confortable, de ocio, de negocios, y restaurante, en fin: "un mar de motivos para bucear" como el propio eslogan afirma. En suma, se vende la propia felicidad.

Este folleto publicitario tiene un lenguaje neutro y estándar y está adaptado a un determinado público objeto, a personas de más de 25 años y menos de 40 años, que no tengan hijos, quizás a parejas de ejecutivos, como está reflejado en los personajes que aparecen en los anuncios. Además de tener un estilo deportista y aparentar ser una parte 
de la sociedad con muy buena condición socioeconómica. Ambos reflejan la alegría y el éxito en todas las imágenes, con lo cual, además del hotel y la ciudad de Natal como producto turístico este anuncio también vende una ideología dominante, permeada por valores hedonistas como confort, modernidad, ocio, juventud, belleza y felicidad. Todo eso es pasible a cambios dependiendo de una variedad de factores que ya hemos mencionado anteriormente porque la publicidad es un tipo de texto efímero.

En lo que concierne al carácter efímero de la publicidad, destacamos el anuncio impreso como lo menos efímero, porque es un documento de fácil acceso al interlocutor, que puede, de cierta forma, decidir cuándo leerlo o no, eso es lo que Kurt Spang (2005:31) expone cuando pone de relieve las particularidades del anuncio impreso, dado que en este tipo de anuncio se permite al lector decidir cómo y cuándo acceder a la información presentada pues "una de las particularidades destacadas de este tipo es que potencialmente el receptor puede dosificar el tiempo de recepción, puede detenerse en la lectura el tiempo que quiera".

Aquí podríamos afirmar que el anuncio impreso, como herramienta de análisis, merece una atención especial, frente a los demás tipos de anuncios, dado que es un registro escrito y, por lo tanto, un documento que es menos vulnerable a pérdidas de contenido. Eso posibilita el análisis objetivo, desde un punto de vista formal, de este tipo de mensaje.

En este punto de lo expuesto sobre la publicidad, se puede llegar a una noción básica sobre la importancia y el nivel de dificultad que hay en el trabajo de un publicista, dado que, además de ser muy creativo, este profesional debe saber muy bien lo que está haciendo y, sobre todo, para quien lo hace, para que a partir de ello pueda encontrar las directrices y criterios que deben seguirse en la elaboración de un anuncio. También hay que tener en cuenta que el trabajo del publicitario es, ante todo, persuasivo con objetivos pragmáticos y/o comerciales bien definidos.

También, el concepto de contexto y la importancia de la audiencia son fundamentales en la publicidad, comprendida como un acto comunicativo codificado en un determinado tipo de lenguaje, con sus particularidades culturales y sociales. En toda comunicación están presentes elementos como la lengua, la cultura y la sociedad. Quizás por ese 
motivo Rodríguez Ferrer (1994:13) concibe la publicidad en las dimensiones del lenguaje, la cultura y la sociedad. También creemos factible la concepción de la publicidad por medio de esas dimensiones, sin embargo, es importante resaltar que todas ellas forman parte de un proceso más amplio: la comunicación humana.

En el siglo XIX empezó la gran difusión de anuncios y su categórica sistematización. Se dice que la primera institución organizada dedicada a la publicidad surgió en Francia. Sin embargo, se sabe de la existencia de la publicidad en tiempos remotos en lugares como Babilonia, China y Pompeya. Según Adam \& Bonhomme (2000:14), “del siglo XVII al XIX, con el desarrollo de la imprenta y el nacimiento de la prensa, se fraguaron las bases de la retórica publicitaria escrita”. Durante esa época, la publicidad adquiere su estructura y función contemporáneas. Sobre ello esos mismos autores dicen que:

La sistematización de los anuncios de pago tomó tres formas: el anuncio
uniforme, definido por su brevedad y su simplicidad; el anuncio cartel, más
largo, con un esbozo de artificios tipográficos, y la propaganda propiamente
dicha, que constituye un anuncio disfrazado de artículo (Adam \&
Bonhomme, 2000:14).

Ya en el siglo XX, la publicidad pasó a tener mucha importancia para el mercado financiero. En muchos periódicos y revistas de esta época, entre un 35\% y un $70 \%$ de sus ganancias derivaban de esta estrategia comercial. A lo largo de estos siglos, la publicidad, conocida antaño por términos como aviso o propaganda, se desarrolló para configurarse en lo que se entiende hoy en día por lo que llamamos de arte publicitario.

Todavía para Adam \& Bonhomme (2000) el desarrollo de la estructura compleja del discurso publicitario se caracteriza por dos grandes fenómenos: la organización tipográfica del texto/imagen y la imagen/texto. En el siglo XIX la imagen se adoptó con un protagonismo referente a la segunda parte del sistema semiológico en publicidad. A partir del siglo XX, la imagen pasa a cobrar un cierto protagonismo en los anuncios, y pasa a tener una determinada importancia como elemento constitutivo del discurso publicitario. Eso puede ser corroborado con una observación atenta del anuncio publicitario de la Galería Beco do Adobe expuesto a continuación. 


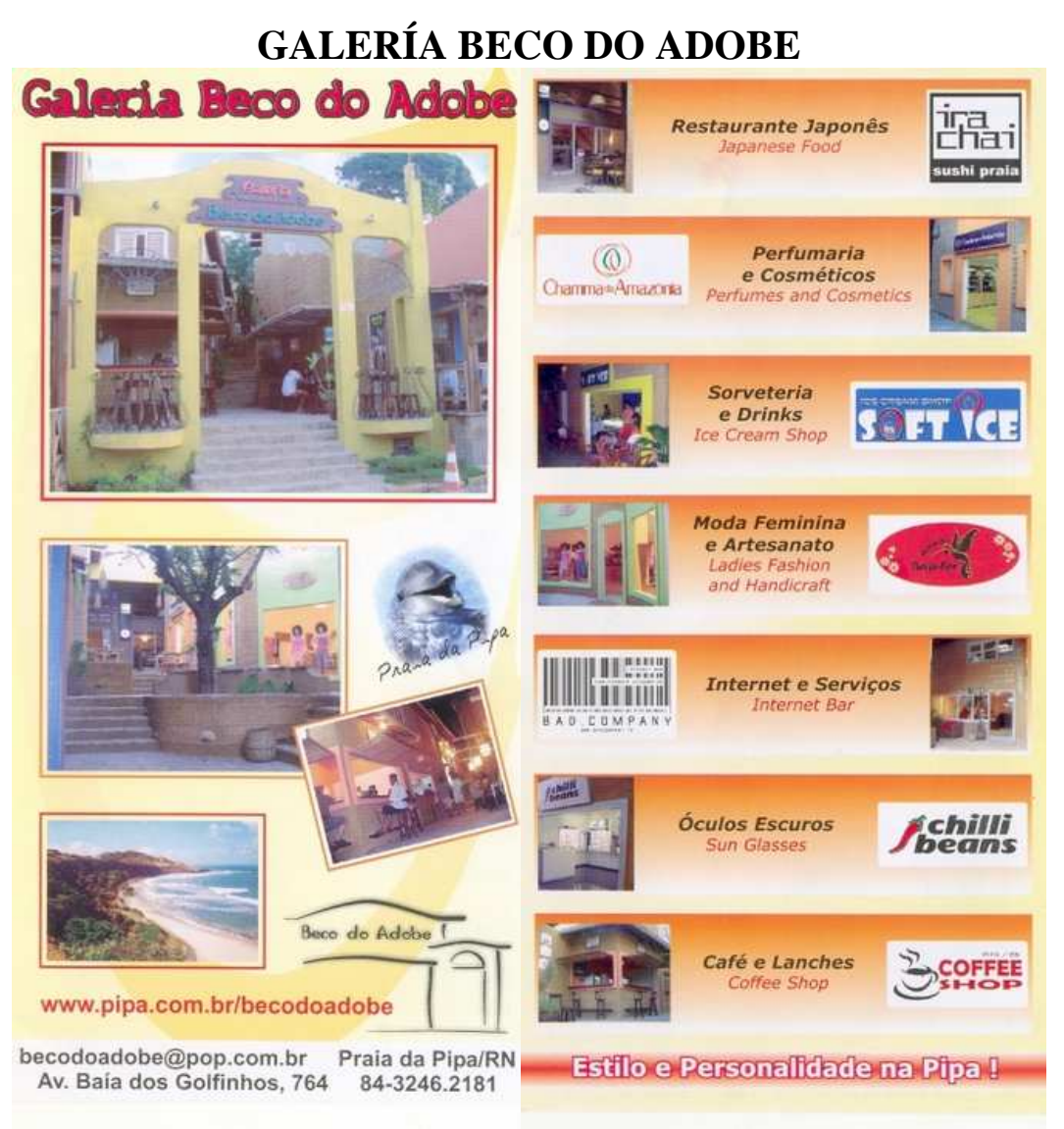

Texto 8

Al adoptar el punto de vista del lector, lo primero que nos llama la atención es el predominio de la imagen frente a lo verbal, una vez que un $90 \%$ de este texto está compuesto por imagen. En la primera página del texto, lo verbal consiste solamente en el nombre del lugar anunciado y su ubicación. En la segunda, lo verbal se limita a enumerar los servicios que se puede encontrar en este local: restaurante japonés, perfumería y cosméticos, heladería y bebidas, moda femenina y artesanía, servicios de informática e internet, tienda de gafas de sol y cafetería.

Adoptamos esta publicidad como un ejemplo de la hegemonía del discurso visual frente a lo escrito en la publicidad contemporánea. Por medio de este anuncio el lector puede ser llevado a inferir el siguiente enunciado: "visita la playa de pipa en Natal, donde está la Galería Beco do Adobe, en este local podrás encontrar restaurante japonés, perfumería y cosméticos, heladería y bebidas, moda femenina y artesanía, servicios de informática e internet, tienda de gafas de sol y cafetería”. 
El producto visual consiste en la propia imagen de la "Galeria Beco do Adobe", sus tiendas y la imagen panorámica de la playa en la que se ubica. El mensaje manifiesto es de un lugar elegante, pequeño y tranquilo. El mensaje latente es de un lugar de estilo y personalidad en la playa de Pipa como está en el eslogan de este anuncio.

Ferraz Martínez en El Lenguaje de la Publicidad (2000) define la publicidad desde un enfoque múltiple, que abarca la publicidad, institución social; la publicidad, técnica comercial; la publicidad, industria cultural; publicidad y propaganda; la publicidad, lenguaje persuasivo y connotativo; y, para finalizar, la comunicación publicitaria: su dimensión pragmática. Intentemos ver a continuación nuestra perspectiva para este enfoque múltiple.

\section{Los enfoques múltiples de la publicidad}

Los seis enfoques presentados arriba particularizan lo que es la publicidad en seis ámbitos distintos. Eso implica que el fenómeno publicitario es bastante complejo y que la clasificación del texto publicitario frente al texto literario y al texto no literario exige un estudio profundizado de los principales aspectos que giran alrededor del discurso publicitario. Empecemos por comprender estos seis enfoques aludidos para adoptarlos como punto de partida.

El primero tiene como aspecto principal la finalidad social de fomentar la adquisición de bienes por parte de la "sociedad de consumo", como afirma el propio Ferraz Martínez (2000:9) cuando dice que "para fomentar el consumo, la publicidad persigue llegar a todos los rincones a través de los medios de comunicación social o "mass media' (prensa, carteles, radio, cine y televisión)". 
BERRO DO JEGUY POUSADA

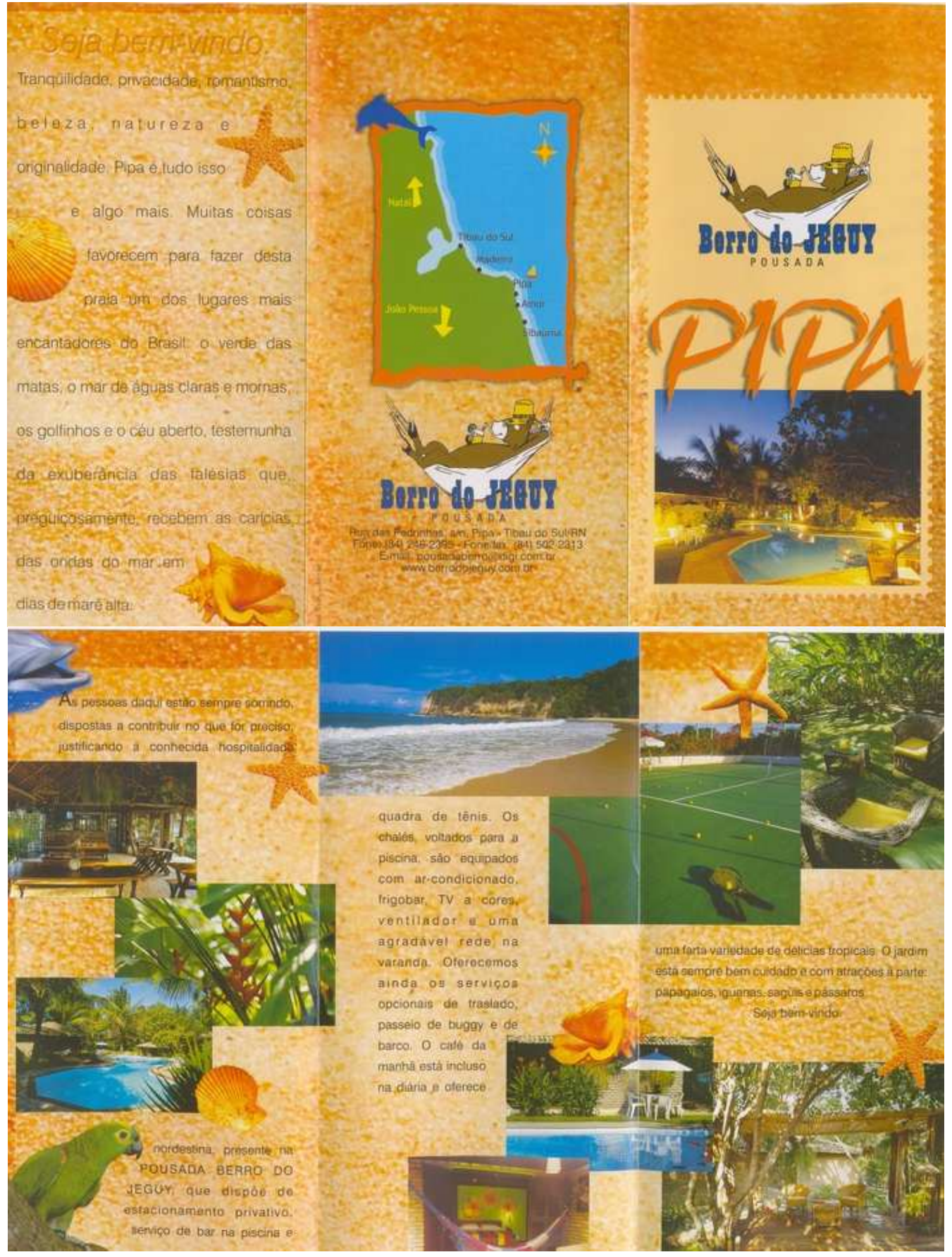

Texto 9

En la macroestructura del texto 9 figura la descripción del "Berro do Jeguy Pousada", la presentación de su localización, y sus servicios. Sirve como una forma de influir en la decisión del interlocutor con el consumo de la playa de pipa y de este hostal como productos turísticos.

El texto está constituido por un 50\% de imagen y un 50\% de texto verbal, en el que se afirma seas bienvenido. Tranquilidad, privacidad, romanticismo, belleza, naturaleza y 
originalidad. Pipa es todo eso y algo más. Muchas cosas favorecen a que esta playa sea uno de los lugares más encantadores de Brasil; el verde de las plantas, el mar de aguas claras y tibias, los delfines y el cielo abierto son testigos de la exuberancia de las falesias que, perezosamente, reciben las caricias de las olas del mar en los días de marea alta.

En esta primera parte del discurso verbal presente en la publicidad estudiada, es importante destacar el uso de la metáfora y, sobre todo, la prosopopeya. Dicho de otro modo, del recurso retórico usado para personificar las falesias y atribuirlas un carácter más bien humano como recibir perezosamente caricias, además de la personificación del mar pues sus olas son quienes acarician las falesias.

Ya en la segunda parte del texto se añade a eso que las personas de aquí están siempre sonriendo, dispuestas a contribuir en lo que sea necesario, justificando la conocida hospitalidad nordestina, presente en la "Berro do Jeguy Pousada", que dispone de aparcamiento privado, servicio de bar en la piscina y cuadra de tenis [...]. El desayuno está incluido en la diaria y ofrece una gran variedad de ricuras tropicales. El jardín está siempre bien cuidado y con atracciones añadidas; papagayos, iguanas, sagüis y pájaros. Seas bienvenido.

En todo el texto, tanto en la primera parte como en la segunda, la persona del discurso presente es la inscripción del "você", en portugués de Brasil, que tiene la fuerza semántica del "tú" en español, lo que acorta las distancias entre el emisor y el destinatario y aporta más confianza.

El producto visual consiste en la propia imagen del "Berro do Jeguy Pousada", sus instalaciones internas, externas, su vista privilegiada del mar, cuyo mensaje manifiesto puede ser de un lugar elegante y tranquilo para la instalación del turista y el mensaje latente es de un lugar acogedor, confortable, relajado, ubicado en medio a la naturaleza exuberante de un "paraíso tropical".

En el segundo enfoque la publicidad consiste en una parte del 'marketing o mercadotecnia' que difunde sus mensajes por medio de los medios de comunicación social. En este sentido, es necesario tener en cuenta la distinción entre publicidad 
comercial y publicidad institucional ya que para Ferraz Martínez (2000:9) la finalidad mercantil "distingue la publicidad comercial de la llamada publicidad institucional (por ejemplo, las campañas realizadas por las autoridades para prevenir accidentes de tráfico o para evitar incendios forestales)". En el caso del texto 9 estamos frente a un ejemplo de publicidad comercial que anuncia un producto turístico: "Berro do Jeguy Pousada".

El tercer enfoque de la publicidad contribuye a la formación de la llamada cultura de masas por medio de la difusión de ideologías y estereotipos, que serán adoptados por el público. En ese sentido Ferraz Martínez (2000:10) dice que la publicidad se apoya en:

\footnotetext{
Valores de carácter simbólico asociados de forma estable a los productos: éstos se convierten así en signos sociales de distinción, éxito, juventud, modernidad, atracción erótica, etc. En este sentido, puede decirse que la publicidad no sólo difunde sino que también conforma los valores sociales de la ideología y 'mitología' de nuestro tiempo.
}

Dichos valores están difundidos en el folleto publicitario presentado anteriormente. Basta echar un vistazo en el uso léxico de la parte verbal del texto, en la que observamos la presencia de tranquilidad, privacidad, romanticismo, belleza, naturaleza, originalidad, más encantadores, el verde, aguas claras y tibias, sonriendo, dispuestas, hospitalidad, gran variedad, ricuras, tropicales, siempre, bien cuidado, atracciones, bienvenido. Es decir, un léxico positivo que presenta el producto turístico por medio de un texto artísticamente elaborado que va dirigido a la emoción y a los instintos humanos. Es un texto informativo, descriptivo, pero predominantemente argumentativo y persuasivo.

El cuarto ámbito usado por este autor para llevar a cabo la definición de publicidad establece la diferencia entre la publicidad y la propaganda que hace uso de los mismos elementos de comunicación masiva, pero se distinguen, dado que la primera tiene fines comerciales mientras la segunda tiene fines ideológicos. 


\section{HOTEL PARQUE DA COSTEIRA}

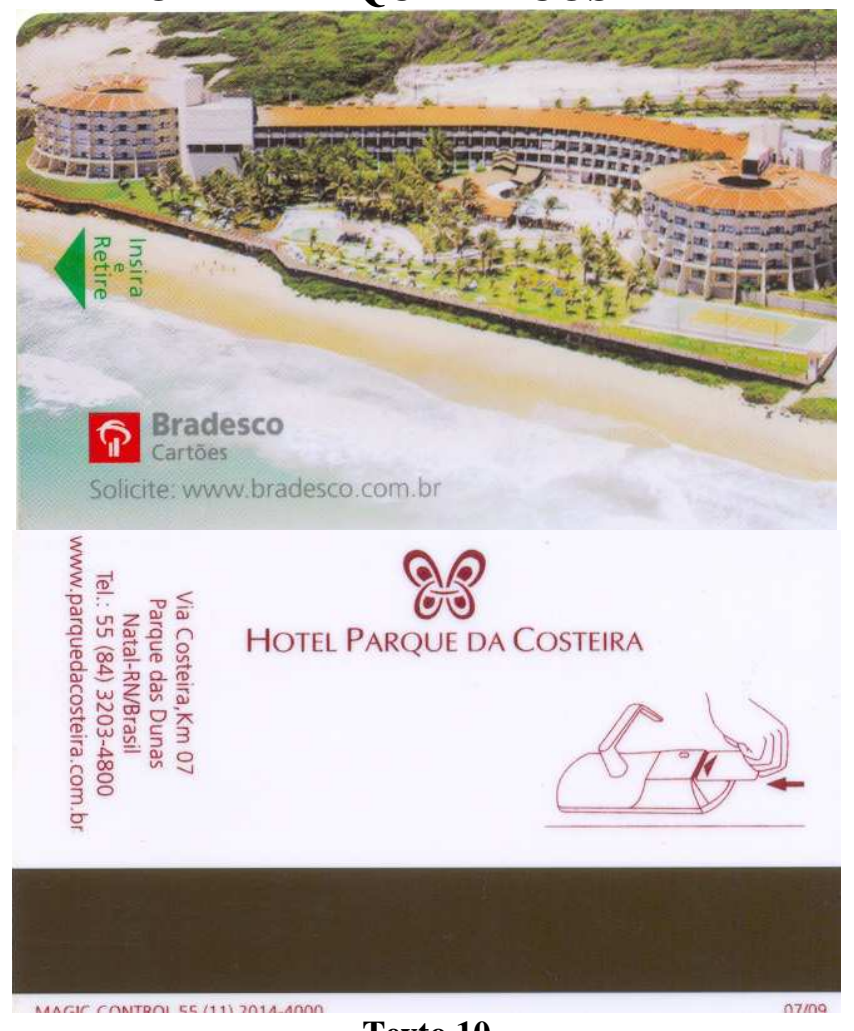

Texto 10

El texto 10 presenta un anuncio publicitario del hotel Parque da Costeira y el formato adoptado fue el de una tarjeta magnética que funciona como llave para los cuartos del hotel. En este mismo anuncio, se hace la publicidad de las tarjetas del banco "Bradesco". En momento alguno el anuncio afirma que se debe visitar este hotel. Simplemente enseña una foto panorámica de sus instalaciones físicas y expone su dirección física, el número de teléfono y su dirección electrónica. Es, por lo tanto, una publicidad porque tiene como objetivo la venta de un producto, como veremos más detalladamente en el punto 4.3 de nuestro trabajo.

En su macroestructura figura una imagen con función descriptiva de las instalaciones externas del "Hotel Parque da Costeira", la presentación de su localización, y el logo de este hotel y del banco financiador de este tipo de tarjeta.

La persona del discurso presente es la inscripción del "você", en portugués de Brasil, que tiene la fuerza semántica del "tú" en español, presentando así un carácter de proximidad entre el emisor y el destinatario. El producto visual consiste en una tarjeta que sirve de llave de acceso al "Hotel Parque da Costeira". El mensaje manifiesto es de 
un lugar muy amplio, moderno y elegante. El mensaje latente es de un hotel sofisticado, moderno y confortable, a empezar por su tarjeta de acceso a las instalaciones.

No obstante, esa distinción entre publicidad y propaganda no puede ser absoluta ya que para Ferraz Martínez (2000:10-11) los mensajes publicitarios "promueven valores sociales y formas de comportamiento. Esto significa que sus efectos van más allá del terreno comercial. En este sentido, la publicidad es también una suerte de propaganda capitalista".

Otro punto que debe ser destacado en el anuncio visto anteriormente es el uso del modo imperativo en verbos como solicita, en el anuncio del banco, pero no dice qué exactamente se debe solicitar y el lector lo comprende por medio de inferencias. Aún así, este es un texto de muy fácil lectura para quien conoce este tipo de tarjeta y su uso, lo que sería una publicidad sin sentido para quienes nunca vieron estas tarjetas ni conocen su utilidad. Este sería un indicador del público objeto del anuncio: personas que están acostumbradas a viajar y que están al día de las novedades del sector turístico.

El formato del anuncio también atribuye al Hotel Parque da Costeira un carácter moderno, actual, contemporáneo ya que "los creadores de anuncios, al exaltar en ellos un mundo perfecto, feliz y optimista, no sólo fomentan la venta de productos y servicios, sino que, además, ejercen una función social e ideológica, amén de contribuir al sostén de los intereses económicos imperantes" (Ferraz Martínez, 2000:10-11), en el caso del texto 10 exaltan la modernidad del producto anunciado.

En el quinto ámbito de la publicidad se hace la distinción entre publicidad informativa o denotativa y la publicidad persuasiva o connotativa. La primera trabaja con argumentos lógicos y va direccionada más a la razón, mientras la segunda actúa de forma persuasiva y va direccionada más a la emoción. Ésta no es una distinción absoluta una vez que para Ferraz Martínez (2000:11) "no hay que olvidar que en último término toda publicidad es connotativa. Digan lo que digan los mensajes publicitarios siempre connotan lo mismo: la excelencia del producto o de los servicios anunciados". 
CARNATAL

Principais Vias de Natal

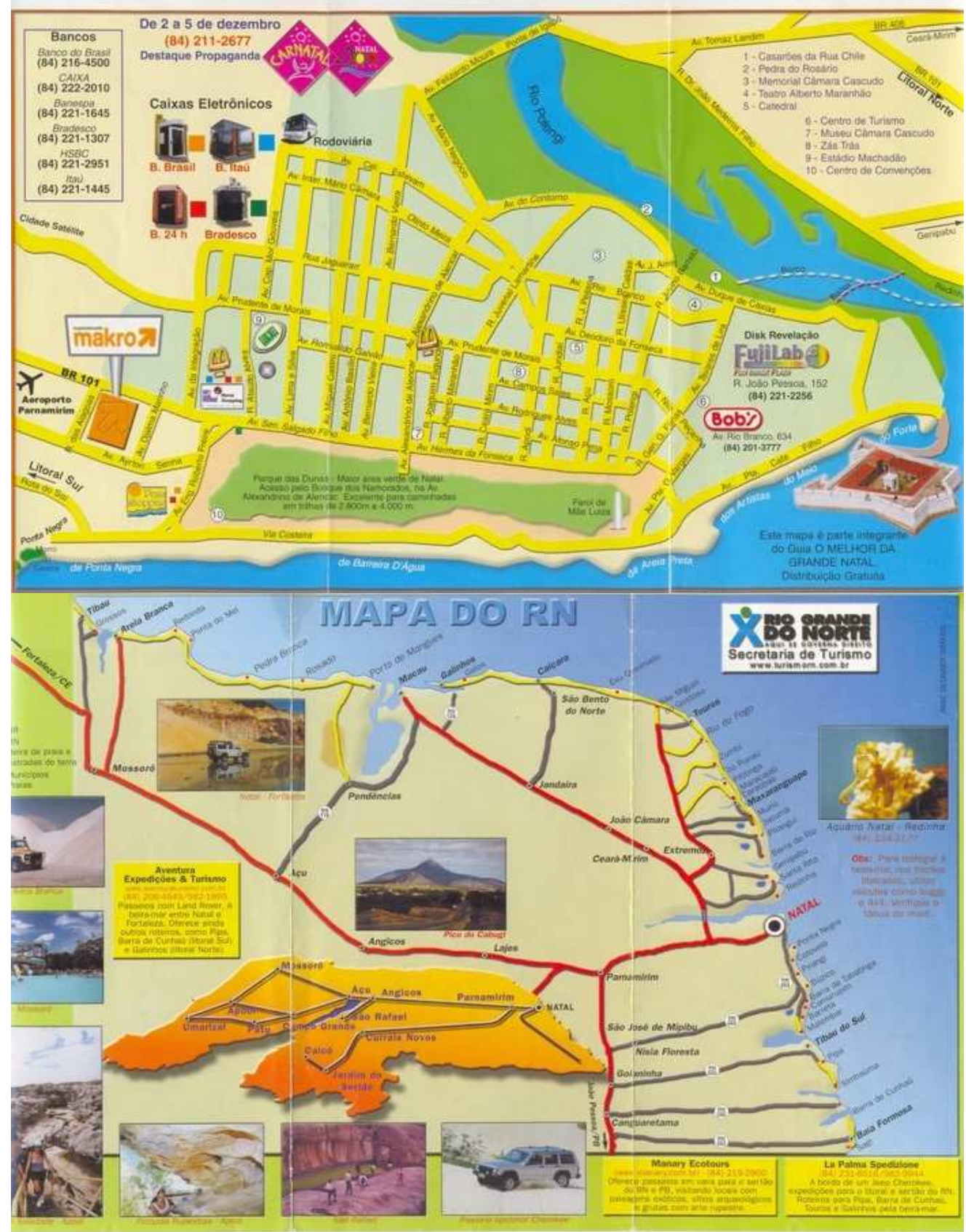

Texto 11

El propio Ferraz Martínez (2000:11) afirma que "toda publicidad es, por fuerza, elogiosa". Este anuncio publicitario del carnatal, carnaval fuera de temporada de Natal, hace uso de elementos denotativos pues utiliza el formato de un mapa de las principales vías de la ciudad. Y toda la información del mapa es denotativa e informativa, además añade al mapa puntos de interés turístico que el visitante del carnatal también puede disfrutar. 
En su macroestructura figura la descripción de Natal y de los principales puntos de interés turístico del estado brasileño de Rio Grande del Norte. La progresión temática es de temas derivados. No hay inscripción de personas en el discurso en virtud de la objetividad de la publicidad en formato de mapa.

Su producto visual consiste en la propia imagen del mapa de la cuidad de Natal y la del mapa del estado brasileño Rio Grande do Norte, con sus principales puntos de interés turístico. El mensaje manifiesto es la descripción de este estado y de Natal. El mensaje latente es de un estado de gran atractivo turístico, además del carnatal.

El sexto y último enfoque consiste en la dimensión pragmática de la comunicación publicitaria, que según Ferraz Martínez (2000:11-12), se establece entre:

- El emisor - la firma anunciante por medio de las agencias publicitarias -
envía el mensaje o anuncio a los receptores, a los que quieren ganar para sus
propósitos comerciales, a través de un canal artificial o técnico - los medios
de comunicación social - que determina un proceso comunicativo unilateral,
es decir, que no busca obtener una respuesta verbal; sí pretende, en cambio,
persuadir a los receptores para que consuman. La función dominante es, por
tanto, la apelativa o conativa. Aunque los receptores no toman parte en el
proceso de comunicación, son su factor determinante.

Por lo tanto, la dimensión pragmática es la persuasión orientada a la conducta de los receptores, como afirma Ferraz Martínez (2000:12) cuando dice que "el acto de comunicación de la publicidad nace movido por el interés económico, o dicho de otra manera, tiene una dimensión pragmática: la persuasión ejercida por el emisor está orientada a influir en la conducta de los receptores". A partir de aquí, podemos llegar a la siguiente estructura de la comunicación publicitaria: 


\section{ACTO DE COMUNICACIÓN PUBLICITARIO}

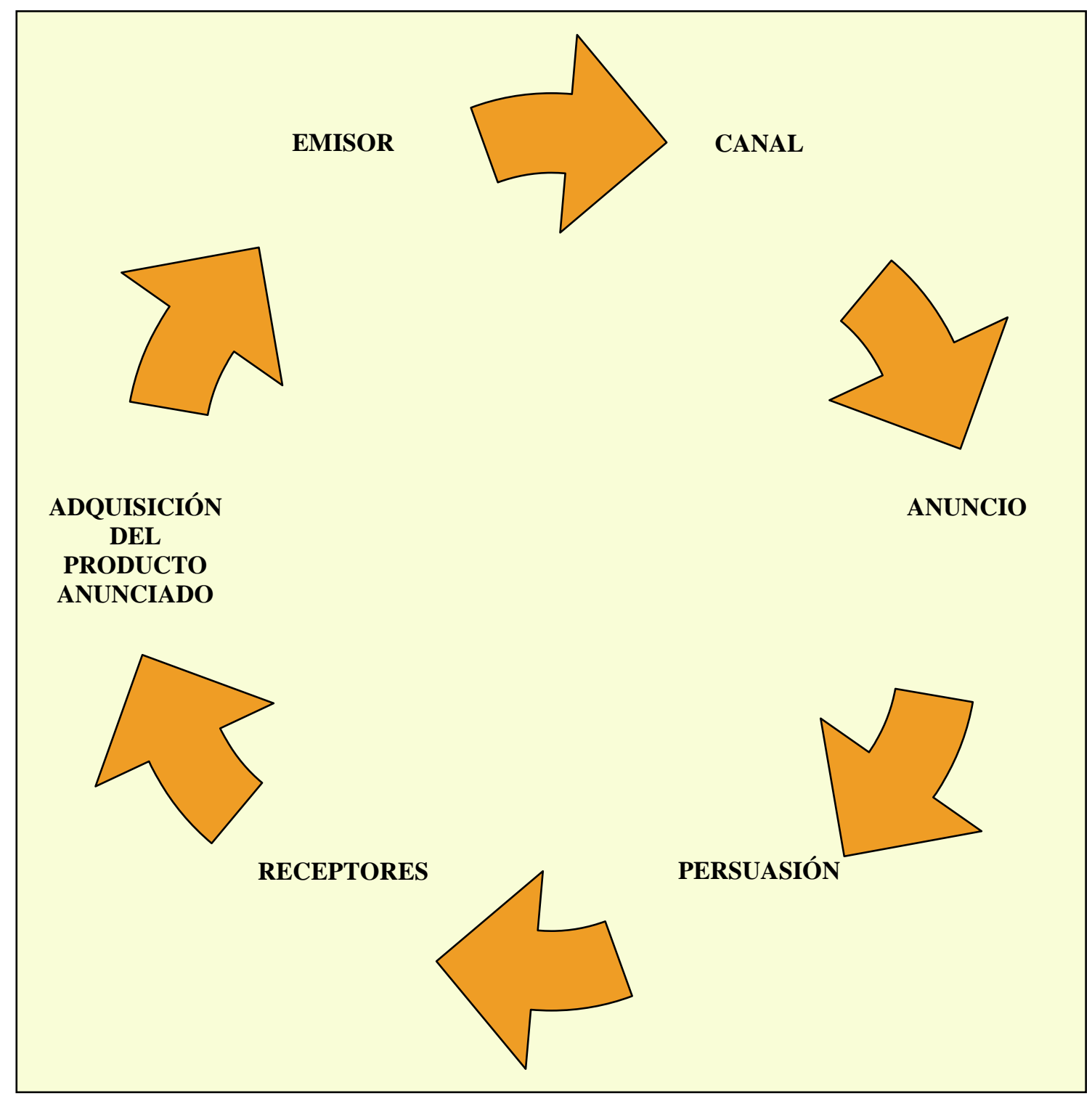

Cuadro elaborado por la autora

Según la línea de razonamiento expuesta en esta imagen, podemos afirmar que el proceso comunicativo en la publicidad es cíclico. El emisor no espera una repuesta verbal concreta del receptor/consumidor, sino la adquisición del producto o servicio anunciado.

Las bases de un diseño de estudio para el fenómeno publicitario

Frente a las cuestiones expuestas hasta este punto sobre lo publicitario, no se puede negar que se trata de un tipo de texto y que puede ser clasificado entre oral y escrito, guardando, pues, todas las características generales presentes en cualquier texto. En este 
trabajo se prioriza el discurso escrito frente al oral para que lleguemos a un resultado común sobre las especificidades del discurso publicitario a partir de esos seis ámbitos presentados anteriormente.

Según Puértolas (2001), para que un enunciado sea un texto tiene que constituir una unidad de carácter lingüístico emitido por un hablante, en una situación comunicativa concreta y con una finalidad determinada. Debe también poseer tres estructuras: la semántica (la organización de ideas), la sintáctica (la relación entre oraciones) y la pragmática (emisor, receptor, canal, código, situación, etc.). El texto publicitario, como cualquier otro tipo textual, cumple esta regla, además, apoyados en las afirmaciones de Ferraz Martínez (2000), presentadas anteriormente, daremos énfasis, más adelante, a la estructura pragmática del discurso publicitario, es decir, a elementos como el emisor, el receptor, el canal, el código y la situación.

Ya en los orígenes de la publicidad se observan característica de la tradición de los libros y de la ilustración estética y artesanal como afirman Adam \& Bonhomme (2000:73):

\begin{abstract}
La publicidad hunde sus orígenes en dos grandes tradiciones: primero la del libro, de escritura densa y calibrada, y luego en la de la ilustración estética y artesanal. El discurso publicitario se presenta así en un principio como una estructura semiológica mixta, un híbrido laxo e inestable, debido a las amplitudes de dosificación que permite entre el texto y la imagen y, sobre todo, de la diversidad de sus componentes.
\end{abstract}

Para esos mismos autores hay cuatro características fundamentales del discurso publicitario, que consistirían en la dimensión débilmente secuencial; la naturaleza aparentemente poco codificada; la polisemia inherente; y las limitaciones metalingüísticas. Para ellos, los constituyentes del discurso publicitario son elementos como la estructura semiótica mixta (significante icónico, significante lingüístico, la marca, constituyente mínimo - marca de la firma y nombre del producto -; el eslogan, constituyente condensado - el gancho y la frase de asiento -; lo redaccional, constituyente expandido y el logotipo: un significante compuesto). 
TAP PORTUGAL

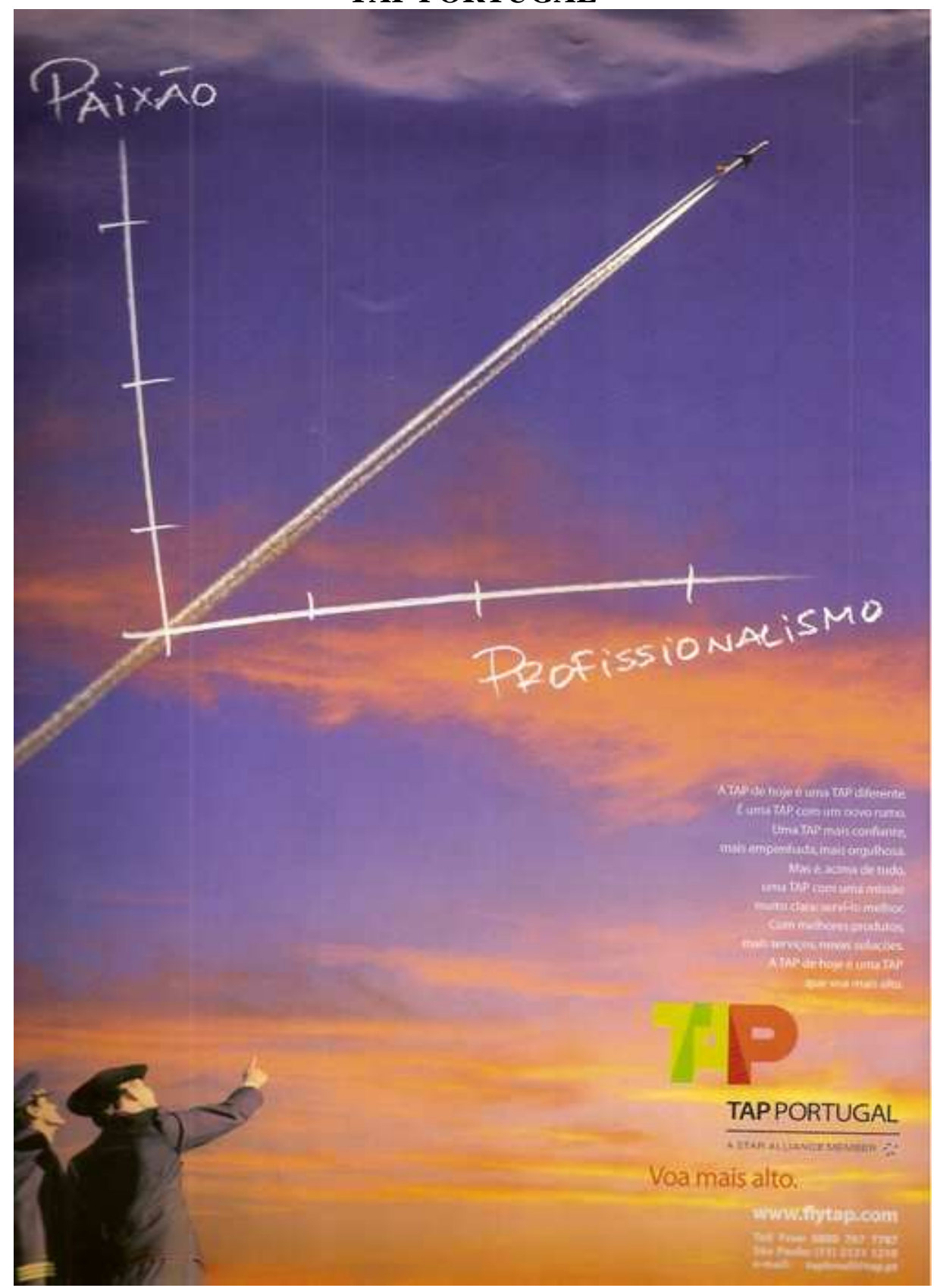

Texto 12

También resaltan puntos como la interferencia intersemiológica de los constituyentes, la verbalización de lo icónico, la iconización de lo verbal, motivación figurativa de la marca, tentación caligráfica del eslogan y, por último, la iconización de lo redaccional.

En el texto 12, podemos encontrar todos los posibles constituyentes del discurso publicitario a la vez, o sea, la estructura semiótica mixta, significante icónico, significante lingüístico, la marca de la firma, el nombre del producto, el eslogan, el gancho, la frase de asiento, lo redaccional, el logotipo y el significante compuesto. 
El propio texto como un todo ejerce la función de un gancho, ya que para decodificarlo hace falta una determinada atención, asociada a un nivel de conocimiento y el saber enciclopédico por parte del lector. En eso se muestra la delimitación del público objeto de esta publicidad y consecuentemente de este producto. El producto turístico anunciado son los vuelos realizados por la línea aérea TAP (Transporte Aéreo Portugués). Este mensaje se infiere a partir del contenido del texto publicitario en cuestión. Con lo cual la marca anunciada consiste en la TAP.

Esta publicidad como un todo es una estructura semiótica mixta y posee lo redaccional distribuido por todo el anuncio, de modo que el texto va siendo construido a partir de la lectura del significante icónico asociado al lingüístico. El constituyente expandido de la parte redaccional consiste en el texto siguiente: la TAP de hoy es una TAP distinta. Es una TAP con un nuevo rumbo. Una TAP más confiante, más empeñada, más orgullosa. Pero es, sobre todo, una TAP con una misión muy clara: servirte mejor. Con productos mejores, más servicios, nuevas soluciones. La TAP de hoy es una TAP que vuela más alto. TAP Portugal, miembro de la star alliance. Vuela más alto.

Observemos la organización estética del texto y su musicalidad. Se adopta el paralelismo en su escritura de modo que la construcción sintáctica de todas las frases del texto coincide y está formada por sintagma nominal sujeto, el verbo copulativo ser o estar y el atributo, con lo cual tenemos las siguientes oraciones:

La TAP de hoy es una TAP distinta.

La TAP de hoy es una TAP con un nuevo rumbo.

La TAP de hoy es una TAP más confiante.

La TAP de hoy es una TAP más empeñada.

La TAP de hoy es una TAP más orgullosa.

La TAP de hoy es una TAP con una misión muy clara.

La TAP de hoy es una TAP con productos mejores.

La TAP de hoy es una TAP con más servicios.

La TAP de hoy es una TAP con nuevas soluciones.

La TAP de hoy es una TAP que vuela más alto. 
Con eso se crea también el sonido martillado por medio de la repetición de la construcción sintáctica la TAP de hoy es una TAP, lo que sirve para crear una sonoridad y un determinado ritmo que contribuyan para fijar el anuncio y la marca anunciada: TAP. El mensaje final del texto consiste en que la TAP de hoy vuela más alto y corresponde, prácticamente, al eslogan del anuncio que consiste en la frase TAP Portugal vuela más alto. Este mensaje puede ser interpretado denotativamente en el sentido de que la empresa realmente vuela más alto y connotativamente, en el sentido de que la empresa aérea creció, está renovada, es más potente, con nuevos objetivos, con muy buenas perspectivas de futuro, etc. Por lo tanto no es un mensaje cuya decodificación sea muy sencilla, como ya hemos dicho anteriormente.

En lo que toca a la parte léxica del texto hay un uso significativo de ideas positivas en palabras como hoy, distinta, nuevo rumbo, más confiante, más empeñada, más orgullosa, clara, mejor, más servicios, nuevas soluciones, vuela más alto, lo que conlleva a una interpretación positiva del producto y su consecuente adquisición.

Además de la parte verbal, el componente de la imagen de este texto llama mucho la atención, sobre todo el uso de un gráfico con un eje llamado de pasión y otro de profesionalismo. El punto de coordinada de estos ejes es un avión de la TAP. Así, el mensaje del gráfico puede ser interpretado como los vuelos TAP son el punto de coordinada más alto entre la pasión y el profesionalismo. Dicho de otro modo, los servicios de TAP están en el punto más alto entre la pasión y el profesionalismo, están coordinados por la pasión y el profesionalismo, por lo tanto tienen muy alta calidad.

Es importante resaltar las similitudes de abordaje de lo publicitario desde la perspectiva de Ferraz Martínez (2000) y Adam \& Bonhomme (2000), sobre todo, cuando ambos enfatizan el carácter pragmático de la publicidad, sin el cual estaría anulada el análisis de lo publicitario bajo una perspectiva estrictamente de sus elementos comunicativos, mejor dicho, de los elementos que forman parte de este tipo de comunicación.

La publicidad ha sido estudiada bajo los paradigmas de la teoría de la comunicación, no obstante, se trata de un campo de estudio de la comunicación lingüística como afirman Adam \& Bonhomme 2000:31) cuando dicen que la publicidad "pone en relación a individuos para transacciones económicas, ha sido estudiada tradicionalmente en 
términos de teoría de la comunicación. Sin embargo, se trata de una situación de comunicación-interacción escrita”.

Tomando como punto de partida el concepto defendido por Kurt Spang (2005) anteriormente, podemos considerar la publicidad como un acto de comunicación cuyo mensaje está cargado de elementos persuasivos que orientan la audiencia a contestar eficazmente el mensaje según la intencionalidad del emisor. Sin embargo aquí no se especifica en qué consistiría la publicidad.

Lo cierto es que en la publicidad se pueden encontrar elementos informativos, sugestivos y persuasivos que le sirven como una base para el acto de comunicación publicitario. Cabe añadir que la publicidad es pragmática, presenta imágenes y su mensaje es sintético. Para Adam \& Bonhomme (2000:31), la publicidad es un tipo de "comunicación solicitante y aleatoria, en tanto que se dirige a un destinatario que no la espera y que no se halla siempre dispuesto a recibirla".

El diseño de estudio del tema en cuestión parte de los modelos de comprensión del fenómeno publicitario concebidos por Martínez (2000) y Adam \& Bonhomme (2000), presentados anteriormente, más específicamente, seguiremos como directriz un fundamento básico por medio del que se comprende lo publicitario como un acto de comunicación complejo cuyo carácter pragmático es bastante peculiar. Más adelante abordaremos el estudio de dicho proceso comunicativo y todos los elementos pragmáticos que lo permean.

Como conclusión de lo que hemos mencionado antes, llegamos a nuestro primer postulado: la publicidad es un tipo textual heterogéneo cuyo proceso de comunicación presenta algunas especificidades en su estructura pragmática, es decir, en todo lo que toca a elementos comunicativos como el emisor, el receptor, el canal, el código y la situación.

\section{Los reclamos y el desarrollo de la publicidad}

Al principio, el reclamo era el texto de carácter informativo o publicitario que formaba parte del cuerpo de un periódico o una revista. Este tipo de publicidad pasó por un 
proceso de resistencia por parte de la población antes de su total aceptación por parte de la sociedad. Referente a eso Gérard Lagneau (1981:13) afirma que:

\begin{abstract}
Los obstáculos políticos desempeñaron un papel accesorio, como el del impuesto cobrado sobre los anuncios en Inglaterra hasta el 1856; pero por detrás de las fuertes discusiones a favor y en contra de la libertad de imprenta, surgen las resistencias culturales a la invasión del reclamo; hasta en Londres, la capital mundial del comercio, se consideró durante mucho tiempo indigno de un 'getleman' sucumbir a la publicidad. En relación a París, el miedo del desprestigio frenó durante mucho tiempo la posibilidad de los periódicos de sacar provecho de los beneficios ofrecidos por los anuncios.
\end{abstract}

Mientras en Europa se discutía la aceptación de la publicidad, en Estados Unidos esta forma de comunicación era germinada, cultivada y desarrollada en función del modelo económico, político e ideológico de este país. Gérard Lagneau (1981:14) afirma al respecto que:

\begin{abstract}
Mutables de un país a otro, las condiciones para la propaganda se mostraron más favorables en Estados Unidos, donde la doble ideología liberal, política y religiosa, encontró menos obstáculos en estructuras sociales pré-industriales y una tradición cultural aristocrática. De modo que fue en América donde surge como pionera de la publicidad, con periódicos diarios repletos de anuncios desde 1832, y con agencias de publicidad a partir de 1840.
\end{abstract}

Hubo una restricción de los usos del "hacer valer" y de los reclamos a los medios de comunicación impresos. Sin embargo, con el advenimiento de los medios electrónicos surge una nueva necesidad de reformulación de la publicidad, dado que había necesidad de la presentación visual de un producto y no solamente la presentación de sus informaciones básicas. En ese sentido el reclamo pasaba a estar compuesto por la asociación entre texto e imagen.

Aristóteles, en la Grecia Antigua, proponía que la comunicación estaba formada básicamente por un emisor, que remitía un mensaje destinado a un interlocutor. Ese modelo de comunicación empezó a cambiar en el ámbito de lo publicitario, cuando los mensajes publicitarios pasaron a ser destinados a grandes públicos heterogéneos, sobre todo, con el advenimiento de los medios electrónicos. Los publicitarios de la época de la radiodifusión deberían elaborar trabajos considerando siempre la heterogeneidad de su público, sus especificidades y las circunstancias bajo las cuales estaban condicionados 
dichos mensajes. Esa realidad se ha conservado hasta la actualidad, época en la que se sabe que la publicidad puede sufrir cambios según su público específico y circunstancias de producción. Gérard Lagneau (1981:18-19) aborda ese tema cuando afirma que:

\begin{abstract}
En lugar de un modelo vertical de sociedad regularmente estratificada, tenemos hoy una articulación de grupos con consumos diferenciados y cuyas claves deberemos encontrar para ejercer una influencia sobre los mismos. La publicidad no puede echar mano a todas oportunidades, como hacía el reclamo, de las dos motivaciones inversas y complementares: imitación de las clases superiores, distinción de las clases inferiores. En ella se necesita olvidar la visión de un público homogéneo y analizar los mercados reales que pretende convencer.
\end{abstract}

\title{
La consolidación de la industria publicitaria: una contextualización
}

Para contextualizar las cuestiones que estudiaremos seguidamente, es decir, todo lo que forma parte del amplio proceso comunicativo llamado de publicidad, empezaremos por algunos conceptos básicos y su desarrollo histórico.

En la época de la revolución industrial, los Estados que poseían una industria consolidada o en desarrollo para la producción de gran cantidad de bienes de consumo asumieron características mercantilistas. Como consecuencia, las relaciones establecidas en este medio adoptaron un carácter consumista. Con la producción de bienes a larga escala la industria pasó a necesitar estrategias que contribuyeran a la venta de sus productos para que no hubiera un desequilibrio entre la oferta y la demanda. Eso se tornó cada vez más común con la competitividad entre las empresas del mismo sector industrial.

Surge, entonces, el concepto del "hacer valer" que, según Gérard Lagneau (1981:8), "consiste en todo y cualquier proceso socialmente utilizado para valorar un bien (producto o servicio) a los ojos de aquellos a quienes está destinado”. En ese concepto están las raíces del campo de la comunicación que se consolidaría, posteriormente, como publicidad. ${ }^{20}$

\footnotetext{
${ }^{20}$ En la fuente original: "Todo e qualquer processo socialmente utilizado para valorizar um bem (produto ou serviço) aos olhos daqueles a quem ele é destinado".
} 
Antes de su configuración, la publicidad, tal como es conocida con toda dinámica y complejidad propias de ese campo de la comunicación social, sufrió varias modificaciones necesarias para acompañar el tiempo, las necesidades y el desarrollo de los medios de difusión de la comunicación. En ese sentido Gérard Lagneau (1981:8-9), en su capítulo introductorio de La Sociología de la Publicidad, habla del desarrollo de la publicidad en la historia y de la importancia que las técnicas usadas para llamar la atención y convencer a los compradores a adquirir determinados productos desde la civilización griega.

El método de "hacer valer" es el método de hacer publicidad más antiguo según Gérard Lagneau (1981). Además de este, en la historia del desarrollo de la publicidad, hubo otros que tuvieron un determinado relieve en su época, como por ejemplo los reclamos, en la época del Antiguo Régimen en Francia. En este período, mientras unos periódicos franceses publicaban solamente las noticias, otros consistían en verdaderos cuadernos de clasificados llenos de reclamos, ya que, cuando Théophraste Renaudot desarrolló la imprenta moderna creó un periódico y una agencia de publicidad, cada una con sus atribuciones específicas sin que fuera posible el hibridismo entre esos vehículos de informaciones. Más tarde, en el año de 1836, surgen en Francia los vehículos de informaciones que mezclaban su contenido entre reclamos y noticias.

\section{El publicista, la elaboración de una campaña publicitaria y sus etapas}

Otro concepto fundamental para la comprensión del fenómeno publicitario es el de publicista, pues contribuye a la formación del concepto de emisor del discurso publicitario. Esta es la persona responsable de la creación de la publicidad y también ha sufrido cambios a lo largo de la historia. 
Los pregoneros ejercieron el papel de publicista oral en su época y los que supervaloraban los productos que anunciaban también pasaron a ser conocidos como charlatanes. Lagneau (1981:10) hace alusión a la constitución de la imagen del publicista en la sociedad contemporánea y a las atribuciones de sus respectivas funciones del uso de la creatividad para persuadir al público objeto cuando dice que:

\begin{abstract}
Ya no se debe buscar la vocación del publicitario en los juegos espectaculares de los charlatanes, sino en la salida regular de los productos normalizados y producidos en serie en la industria, en la distribución en gran escala de las novedades salidas en masas cada vez más grandes de las fábricas que van poco a poco obstruyendo nuestros paisajes. ${ }^{21}$
\end{abstract}

Las partes que constituyen una campaña publicitaria eficaz son básicamente tres: la búsqueda del contenido del mensaje publicitario, el desarrollo de los recursos empleados para difundir el mensaje y, por fin, la definición del medio que será vehículo de emisión del mensaje que será difundido con la finalidad de captar la atención del interlocutor.

Es importante tener en cuenta que en la difusión de la publicidad no existe la posibilidad de que sea más o menos eficiente, porque tiene la función de buscar el máximo retorno financiero para quien anuncia, por eso es fundamental la elección de signos lingüísticos que sean asimilados fácilmente por el consumidor. En relación a esto, Piratininga (1994:87) defiende el uso de imágenes del día a día, cercanas al consumidor y que pueden llevar éste a repensar su propia realidad.

Tomando como base lo que hemos presentado en ese apartado, llegamos a nuestro segundo postulado sobre el fenómeno publicitario dado que ya podemos afirmar que la publicidad es un acto de comunicación que tiene como finalidad seducir a su audiencia y que dicho acto comunicativo posee como sus tres puntos básicos de apoyo el lenguaje, la cultura y el medio social, que por cambiar constantemente aportan a lo publicitario el carácter de efímero y de texto camaleón, es decir, se adapta a los cambios para adecuarse a sus objetivos.

\footnotetext{
${ }^{21}$ En la fuente original: "Já não se deve buscar a vocação do publicitário nos lances espetaculares dos charlatães e sim no escoamento regular dos produtos normalizados e fabricados em séries nas oficinas, na distribuição em grande escala das novidades saídas em massas cada vez maiores das fábricas que vão aos poucos obstruindo nossas paisagens".
} 


\subsection{Publicidad y propaganda}

La publicidad y la propaganda son dos términos que muchas veces generan problemas de delimitación sobre lo que concierne específicamente al primero y en qué consiste el segundo, dado que ambos términos hacen referencia prácticamente a lo mismo y usan los mismos elementos básicos. Sin embargo, aunque no exista una delimitación muy estricta, la publicidad difiere de la propaganda porque tiene el comercio como base de su índole, por eso su aspiración es básicamente la promoción o la venta bien de un producto o de una marca. La propaganda, a su vez, tiene como carácter predominante lo político e institucional de carácter ideológico; como ejemplo de esto, podemos mencionar las propagandas publicitarias de una campaña de prevención de un determinado tipo de enfermedad, de accidentes y hasta las campañas políticas.

La propaganda, por lo tanto, difiere de lo que comprendemos por la publicidad. La primera se distingue de la segunda por presentar la transmisión de ideas, mientras ésta transmite informaciones. Sin embargo, esta distinción no está del todo bien establecida y para autores como Ferraz Matínez (2000) la publicidad también es un tipo de propaganda. La propaganda en su origen está relacionada con el carácter religioso como afirman López Eire y Santiago Guervós (2000:8) cuando dicen que:

La palabra propaganda es de origen religioso, lo que la hace ya de entrada sospechosa. Aparece por vez primera aplicada a la institución del Vaticano denominada Sacra Congregatio de Propaganda Fide, o Sagrada Congregación para la propagación de la fe, fundada el año 1622, y posteriormente se utilizó para designar la difusión de los discutibles valores ideológicos que generaron los procedimientos horrendos y brutales empleados por los nazis y los comunistas. De ahí su connotación justamente peyorativa con respecto a la palabra información. 
Frente a lo dicho anteriormente, podemos afirmar que la publicidad tiene como objetivo recibir una respuesta de consumo, mientras que la respuesta esperada por la propaganda es más ideológica y de conducta. De ese modo, podemos dividir la publicidad y la propaganda en una tabla con las siguientes características distintivas:

\begin{tabular}{|c|c|}
\hline PUBLICIDAD & PROPAGANDA \\
\hline Venta & Difusión de ideas \\
\hline Comercio & Actuación ideológica \\
\hline Acción de compra & Cambio de opinión \\
\hline Consumo & Cambio de actitud \\
\hline
\end{tabular}

No obstante, hay una tendencia a la aproximación de esos dos elementos, toda vez que tratan básicamente de lo mismo y hacen uso de los mismos elementos en la producción de sus mensajes. A este respecto Gérard Lagneau (1981:22) afirma que:

\begin{abstract}
En un pasado bastante reciente, esos dos conceptos se distinguían esencialmente por la observancia o por el rechazo de una especie de regla de no agresión entre anunciantes rivales. Ahora bien, la propaganda se está alejando cada vez más de sus procesos de ataque personal y de argumentación simplista que recuerdan la crudeza de la propaganda antigua, para entregarse a especialistas en marketing que aplican las mismas técnicas a las campañas electorales y comerciales.
\end{abstract}

Aunque parezca simple establecer rasgos distintivos entre la publicidad y la propaganda, esta no es una cuestión tan sencilla, pues no está resuelta y es tema de muchas divergencias entre los investigadores de este campo del conocimiento. Así que empecemos por la génesis del problema, desde el concepto de marketing y su relación con la publicidad y la propaganda, para que sea posible aclarar, primeramente, las distinciones existentes entre conceptos como marketing, propaganda y publicidad.

\title{
Marketing, publicidad y propaganda
}

Con la expansión del campo de estudio y actuación del marketing, han sido desarrolladas incontables actividades relacionadas dentro de esta misma área, lo que posibilitó el surgimiento de varios segmentos dentro de un mismo campo de actuación para atender a las demandas de este campo de trabajo y adaptarse a las situaciones de 
decisiones administrativas en las que se prioriza la importancia del análisis de control de calidad, de contenido, de los medios, del público, etc.

Así, desde la perspectiva del marketing, se debe seguir la regla de las cuatro "Ps", a saber: product (producto), place (en qué sitio será distribuido), price (el precio o el coste) y promotion (bajo qué condiciones promocionales). Más tarde se adopta la teoría de las cuatro Cs: consumidores, coste, conveniencia y comunicación. Además de esta secuencia de actuación del marketing, también es común que sean añadidos el servicio personal, público y embalaje de presentación.

A partir de esta línea de pensamiento, J.B. Pinho (2006) hace la distinción entre elementos como marketing, publicidad y propaganda. Para ello, define el primer término como la delimitación de qué tipo de producto o servicio se desea poner en el mercado y para quien está dirigido. Eso aleja el marketing de la publicidad y la propaganda.

Dicho esto, es importante tener en cuenta que la publicidad es solamente uno de los métodos o fines que los profesionales responsables del marketing de una determinada empresa hacen uso para divulgar sus productos. La propaganda también puede ser adoptada como una estrategia de marketing igualmente a la publicidad, pero como hemos visto anteriormente esta tiene objetivos ideológicos, mientras aquella de venta. En relación a eso Pinho (2006:131) afirma que: 'la publicidad y la propaganda conservan la función de técnicas de persuasión, pero con distintos propósitos y funciones".

\section{La propaganda}

La palabra propaganda deriva del vocablo latino propagare que tiene el concepto general de la propagación de doctrinas, principios y teorías religiosas, políticas, científicas, etc. En Sampaio (1999:24) se habla de las diversas acepciones que se puede 
encontrar de la propaganda, pero "todas más o menos parecidas. Unas más simples y otras menos, con algunas diferencias en lo accesorio, pero semejantes en su esencia". ${ }^{22}$

La palabra propaganda ya era utilizada en el siglo XVII para designar un organismo del Vaticano, la Congregatio de Propaganda Fide (la Congregación para la Propagación de la Fe), 'instituida con el objetivo de organizar las formas de difusión de los principios católicos romanos en oposición a los hechos ideológicos o doctrinales de la Reforma Luterana'. De ese modo, la propaganda consiste en acciones que objetivan la difusión de ideas, sobre todo políticas'. Se distingue, por lo tanto, de la publicidad, o sea, del 'acto de habla que posee como objetivo dominante el incentivo al consumo de productos' (Pinho, 2006:131). ${ }^{23}$

Con el tiempo, por tratarse de una práctica de comunicación secular, la propaganda entró en proceso de modernización apoyado por los avances sociales, económicos y tecnológicos en las estrategias de mercado para la divulgación de una ideología. Hoy en día la propaganda se puede encontrar en prácticamente todos los ámbitos de la vida de un individuo y por consiguiente de una sociedad.

\footnotetext{
${ }^{22}$ En la fuente original: "Existem muitas definições de propaganda. Todas mais ou menos parecidas. Umas mais simples e outras menos, com algumas diferenças no acessório, mas semelhantes na sua essência".

${ }^{23}$ En la fuente original: "De comum, a propaganda e a publicidade conservam o fato de serem técnicas de persuasão, mas com diferentes propósitos e funções. A palavra propaganda já era utilizada no século XVII para designar um organismo do Vaticano, a Congregatio de Propaganda Fide (Congregação para a Propagação da Fé), 'instituída com o objetivo de organizar as formas de difusão de princípios católicos romanos em oposição aos feitos ideológicos e doutrinários da Reforma Luterana'. Dessa forma, a propaganda constitui-se de 'ações que estão voltadas para a difusão de idéias, principalmente políticas'. Diferencia-se, portanto, da publicidade, ou seja, 'atos que possuem como objetivo dominante incentivar o consumo de produtos"”.
} 


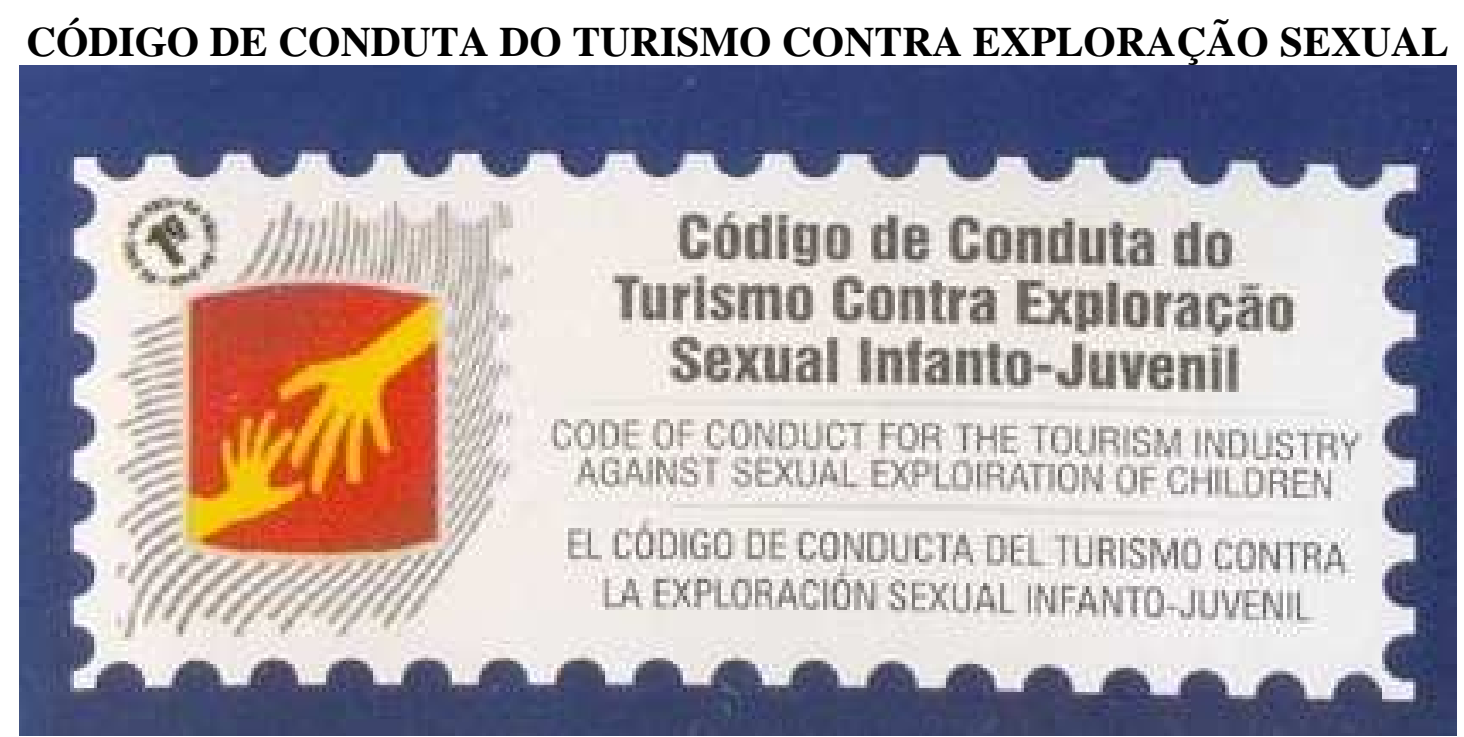

Texto 13

El texto expuesto arriba es la propaganda del gobierno federal brasileño contra el turismo sexual infantil en Brasil, como ya hemos visto anteriormente. En el texto verbal aparece el enunciado código de conducta del turismo contra la explotación sexual infanto-juvenil en lengua portuguesa, lengua inglesa y lengua española. Como se trata de una propaganda, el hibridismo entre la imagen y el texto está presente. Aquí lo que se intenta influir a partir de este texto es un cambio de conducta y no la venta de un producto.

La propaganda es anterior a la publicidad, que está íntimamente relacionada con las teorías y prácticas de la propaganda, como si fueran dos caras de una misma moneda. La palabra publicidad deriva del vocablo publicus perteneciente a la lengua latina, que en su origen etimológico tiene el sentido del acto de divulgar y tornar público. Sin embargo, aunque estén estrechamente relacionados esos dos modos de anunciar se distinguen en sus conceptos y definiciones prácticas particulares de cada uno.

Así que, de acuerdo con lo que ya hemos mencionado con respecto de la divergencia entre esos dos términos, la propaganda consiste en sugerir una propuesta, una idea, una creencia, una forma de comportamiento, etc., mientras la publicidad, además de todo eso, tiene la finalidad única de vender el producto o servicio anunciado. Por lo tanto, mientras la propaganda actúa en un nivel puramente ideológico, la publicidad actúa en un nivel de producción de un acto: la adquisición del producto o servicio anunciados. 
Según Rafael Sampaio, en su libro Propaganda de A a Z (1999), la propaganda sirve para que una empresa o marca pase del estado de desconocida a una posición de elemento presente en la mente de los consumidores. Una vez más se puede afirmar que la propaganda actúa básicamente en un ámbito ideológico. En relación a eso Sampaio (1999:18) afirma que:

\begin{abstract}
Además de modificar comportamientos, la propaganda puede crear, ampliar, consolidar y fortificar imágenes, conceptos y reputaciones. Llegando a hacer que una empresa o marca pase de un total desconocimiento por parte del mercado a una posición viva, fuerte, presente en la cabeza de los consumidores. $^{24}$
\end{abstract}

En ese sentido, este autor llega a mezclar lo que sería la propaganda y en qué consistiría la publicidad, una vez que trata de consumidores, elemento fundamental para la publicidad. No obstante, sigue defendiendo que la propaganda actúa en un campo ideológico.

Además de difundir y propagar ideologías, la propaganda actúa como un verdadero eje propulsor de economías, hecho más común a partir del siglo XX. También sirve como un elemento de desarrollo cultural y social en relación a sus formas de exponer y agregar valores a una sociedad, que llega a repensar sus propios valores a partir de la propaganda, como ejemplo de eso dentro del turismo podemos mencionar la propaganda que hemos visto anteriormente.

\title{
Los comienzos de la propaganda
}

En el inicio de la práctica de la propaganda, no existían reglas que homogeneizaran esa práctica, de modo que cada autor de una propaganda seguía sus leyes propias en la elaboración de sus mensajes. Hopkins (1993:23) afirma que:

La falta de principios básicos fue el principal problema de la propaganda en el pasado. Cada publicitario era su propia ley. Todo el conocimiento anterior, todo progreso en el campo, funcionaba como un libro cerrado para los publicistas. Como si el hombre intentase construir una locomotora moderna

\footnotetext{
${ }^{24}$ En la fuente original: "Além de modificar comportamentos, a propaganda pode criar, ampliar, consolidar e fortificar imagens, conceitos e reputações. Fazendo com que uma empresa ou marca passe de um total desconhecimento por parte do mercado para uma posição viva, forte, presente na cabeça dos consumidores".
} 
sin observar con antelación lo que los demás habían hecho. Como un Colón que partiera en busca de una tierra desconocida. ${ }^{25}$

El origen de las prácticas propagandistas puede ser considerado como un salto en la oscuridad. No había ningún tipo de orientación básica para que se llevara a cabo cualquier teoría sobre lo que sería la propaganda y en qué consistiría. En esa época la creación de una propaganda se apoyaba en los caprichos, las fantasías y las intuiciones como herramienta principal.

Muchas experiencias de propagandas tenían sus resultados frustrados, algunas otras lograban algún tipo de éxito, pero para que llegara a lo que se conoce hoy en día por propaganda fue necesario pasar por un largo camino de desarrollo. Con la configuración de los principios básicos de la propaganda, los métodos de creación dejaron de ser un problema para dejar el lugar a los problemas concernientes a lo qué se anunciaría.

De ese modo la actividad de la propaganda pasó a ser sistematizada y perdió su carácter caótico sin antecedentes a seguir. En esa misma línea de pensamiento, Claude Hopkins (1993:23) afirma que:

\begin{abstract}
Ahora las únicas inseguridades se referían a las personas y a los productos, no a los métodos. Es difícil medir las idiosincrasias, las preferencias y prejuicios, los gustos y aversiones existentes. No podemos decir que un artículo se va a tornar popular, pero sabemos cómo descubrir eso rápidamente. $^{26}$
\end{abstract}

Una vez más se podría confundir el concepto de propaganda empleado por ese autor con el concepto adoptado en este texto, lo que puede corroborar la falta de acuerdo que muchas veces se hace común en la delimitación del campo de la publicidad y de la propaganda.

\footnotetext{
${ }^{25}$ En la fuente original: "A falta de princípios básicos foi o principal problema da propaganda no passado. Cada publicitário era sua própria lei. Todo o conhecimento anterior, todo o progresso no campo, era-lhe um livro fechado. Como se um homem tentasse construir uma locomotiva moderna sem primeiro verificar o que os outros tinham feito. Como um Colombo que partisse em busca de uma terra não descoberta".

${ }^{26}$ En la fuente original: "Agora, as únicas incertezas dizem respeito às pessoas e aos produtos, não aos métodos. É difícil medir as idiossincrasias, as preferências e preconceitos, os gostos e aversões que existem. Não podemos dizer que um artigo vai se tornar popular, mas sabemos como descobrir isso com muita rapidez".
} 
Con el tiempo, la propaganda pasó a ser sinónimo de prestigio y respeto. Sus teorías nacieron y expusieron la intención de hacer posible el reconocimiento de su importancia como una de las principales vertientes de la comunicación social. Con el establecimiento de sus leyes propias la esencia de la propaganda pasó a ser la originalidad.

Con eso es posible llegar a la conclusión de que, aunque con la creación de las leyes que rigen el origen de una propaganda, el arte de la creatividad empleado para generarla no viene en manuales, es decir, esas leyes sirven solamente como una orientación para los profesionales de ese campo.

\section{El funcionamiento de la propaganda}

Aun trabajando con el simple objetivo de informar e inducir a comportamientos y valores ideológicos, el proceso de comunicación que rige una propaganda es complejo y tiene como función principal que la simplicidad y objetividad del mensaje sirvan para alcanzar a su público objeto. En ese sentido, la tecnología, el talento y la experiencia son piezas esenciales para hacer que las propagandas ganen vida e inicien su función en el día a día de las personas.

Para que las propagandas puedan alcanzar a sus respectivos públicos, además de trabajar con diversos campos del conocimiento humano y del sentido común, existe todo un aparato, dividido por sectores, para la generación, realización y funcionamiento de las producciones propagandísticas.

Dichos sectores están divididos en partes como: el anunciante, los correctores y agenciadores, las agencias de propaganda y publicidad, los proveedores y las productoras, los vehículos y el destinatario. Es una especie de lead (quién, qué, dónde, cuándo, cómo y por qué) comúnmente usado por el periodismo.

Ese es el camino seguido por el producto propagandístico desde su idealización hasta su concreción, pero la secuencia de lead presentada no sirve como una regla fija y general. Lo más importante del acto de comunicación de una propaganda es mantener sus tres 
puntos básicos de apoyo, a saber: el anunciante, el vehículo y el destinatario. El objetivo mínimo de dicho acto es que la propaganda sea concretada y llegue a su público objeto.

Hay autores como Rafael Sampaio que no hacen distinción entre la publicidad y la propaganda, pues las clasifican a ambas como propaganda publicitaria y las dividen por campos de la economía y por las características que la propaganda asume en cada ámbito, como se puede vislumbrar en el cuadro ${ }^{27}$ abajo, elaborado a partir de su obra Propaganda de A a Z (1999):

\begin{tabular}{|l|l|}
\hline \multicolumn{1}{|c|}{ LO ANUNCIADO } & CARACTERÍSTICAS DE LA PROPAGANDA \\
\hline BIENES DE CONSUMO & $\begin{array}{l}\text { Destinada al consumidor final; } \\
\text { Difunde e impone marcas; } \\
\text { Fundamental para la comunicación y la venta de } \\
\text { productos; } \\
\text { Sector que invierte más en propagandas. }\end{array}$ \\
\hline BIENES INDUSTRIALES & $\begin{array}{l}\text { Diversidad por la especificidad del público objeto; } \\
\text { Importante para incrementar las ventas de sus } \\
\text { productos; } \\
\text { Informativa, expositiva y comparativa; Productos } \\
\text { comercializados como materias primas, recursos de } \\
\text { producción, equipamientos, herramientas, etc. }\end{array}$ \\
\hline SERVICIOS & $\begin{array}{l}\text { Informa sobre las características del producto; } \\
\text { Divulga ventajas, precios y condiciones de uso; } \\
\text { Bancos, instituciones financieras, empresa de } \\
\text { transporte y turismo son los principales segmentos } \\
\text { que la utiliza; } \\
\text { Informativa y comparativa. }\end{array}$ \\
\hline COMERCIOS & $\begin{array}{l}\text { Herramienta eficaz en la generación y expansión de } \\
\text { negocios; } \\
\text { Empleadas con técnicas menos sofisticadas y utilizan } \\
\text { los medios de comunicación más baratos (listas } \\
\text { telefónicas, clasificados de periódicos, spot's } \\
\text { radiofónicos); Informa, divulga y sugiere productos } \\
\text { para el consumo; }\end{array}$ \\
\hline
\end{tabular}

\footnotetext{
${ }^{27}$ Todos los datos están basados en las páginas 102-107 del libro Propaganda de A a Z (1999) de Rafael Sampaio.
} 


\begin{tabular}{|l|l|}
\hline \multirow{5}{*}{ INTERMEDIARIOS } & $\begin{array}{l}\text { Revendedoras, distribuidoras y comercio al por } \\
\text { mayor utilizan la propaganda buscando el lucro; } \\
\text { Promueve la imagen comercial de las organizaciones } \\
\text { segmentadas de este sector; } \\
\text { Son elaboradas en escalas más pequeñas en } \\
\text { comparación con otros sectores; } \\
\text { Son realizadas de forma coordinada. }\end{array}$ \\
\hline SERVICIOS PÚBLICOS & $\begin{array}{l}\text { Son usuarios constantes; } \\
\text { Incentiva el consumo de estos servicios; Informativo, } \\
\text { educativo. }\end{array}$ \\
\hline INSTITUCIONALES & $\begin{array}{l}\text { Son utilizados para destacar los deberes y los } \\
\text { derechos de las instituciones; } \\
\text { Parte de este tipo de propaganda es elaborada de } \\
\text { forma gratuita; } \\
\text { Están ordenadas bajo una determinada clasificación: } \\
\text { campañas educativas, motivación cívica, legislativa, } \\
\text { proclamación comunitaria; informativa y } \\
\text { motivacional. }\end{array}$ \\
\hline
\end{tabular}

En este sentido se elimina el problema de la distinción entre la publicidad y la propaganda, pero surge otro problema: la palabra propaganda siempre debería estar seguida por el adjetivo publicitario para corresponder al sentido de cualquier tipo de campaña publicitaria, además, ¿a qué correspondería el vocablo publicidad? ¿Cuándo emplear la palabra propaganda sin el acompañamiento del atributo "publicitario"?

Basándonos en esto creemos que es preferible hacer la debida distinción entre la publicidad y la propaganda, que serían dos partes pertenecientes al macro campo del marketing de una empresa o institución, puesto que clasificar estos dos campos como propaganda publicitaria desvirtuaría lo que sería la publicidad propiamente dicha. Dicho esto, defendemos que la publicidad se distingue de la propaganda porque tiene objetivos más bien comerciales, mientras ésta se mueve en función de ideologías y eso no anula la posibilidad de hibridismo en algunos casos que la publicidad también actúe como una especie de propaganda. 


\subsection{La palabra en la publicidad}

La palabra es esencial para la publicidad y funciona como materia prima que es moldeada o pulida para ese oficio llevado a cabo por medio de la palabra asociada a la imagen. El significado de cada palabra en un anuncio publicitario invoca más que las acepciones presentadas como lemas en los diccionarios, pues sugiere sonido, olor, sensación, sabor, apariencia y emociones. Es plurisignificativa, mejor dicho, está llena de sentidos culturales y sociales.

Por eso estamos de acuerdo con Rodríguez Ferrer (1994:65) cuando dice que "la palabra, reina del lenguaje publicitario, refleja no sólo la noción de la cosa - caudal informativo -, sino el sabor de ella - caudal emocional -, entre lo que esa cosa es y lo que parece ser; del significado a la sugestión". Para este mismo autor "desde el texto al contexto, la palabra publicitaria es siempre una palabra viva", lo que implica el dinamismo propio de la palabra en la publicidad (Rodríguez Ferrer, 1994:66).

Al entrar en el universo publicitario, las premisas que inician una discusión sobre este estudio, casi siempre parten del campo ideológico de los mensajes, que intentan persuadir e, incluso, influencian al consumidor a adquirir nuevas costumbres. Sin embargo, en la génesis de este tipo de comunicación las herramientas lingüísticas sirven como base de este campo multidimensional llamado de publicidad. 


\section{PARAÍSOS DO NORDESTE}
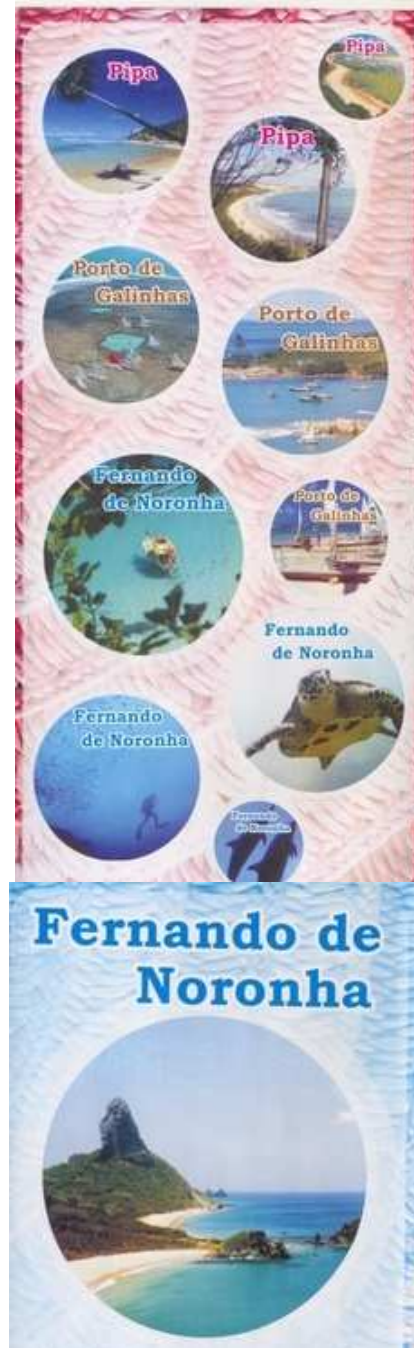

Falar de Fernando de Noronha é năo encontrar deteitos, aperias virtudes. ecallzadr no meio do Oceano Attantico, e peixes de espécies raras, encanta todos com a sua beleza. Originadas de process beza. Flativamente modernos, as seis ithas ques compóe o arquipelago constituem mportantes santuários ecológicos, de iquezas naturais impares, Enfirm, um local ideal para a prática de mergutho, surt, trilhas e passeios ecológicos.

O encontro entre vocé e a natureza.

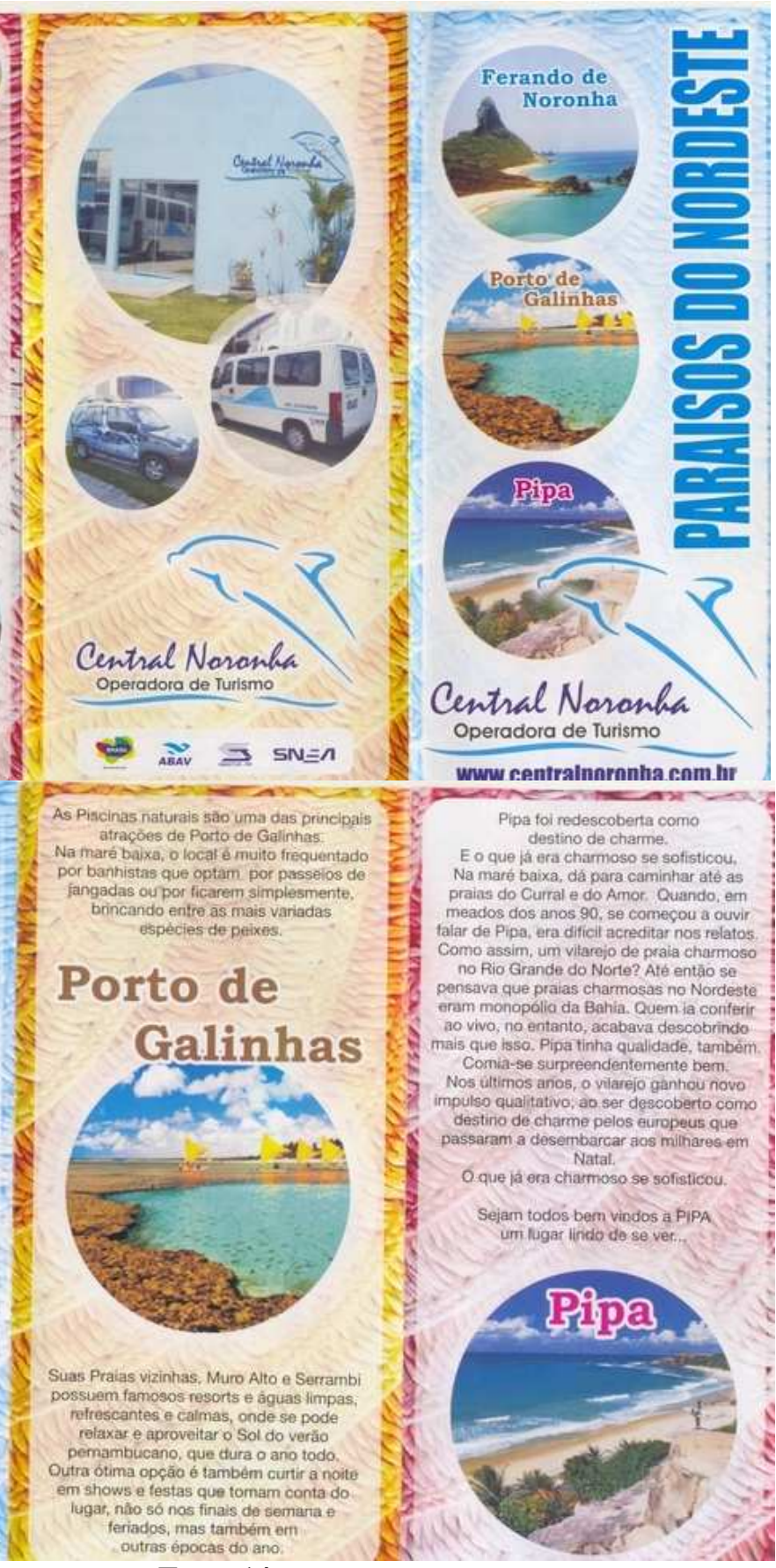

Texto 14

En este contexto, la palabra surge como un abanico lleno de recursos, herramientas y posibilidades para explotar la creatividad en los mensajes. En los sistemas que sirven de soporte para la publicidad, no están presentes solamente los aspectos de la retórica. Los recursos lingüísticos asumen un papel de fundamental importancia en la construcción del texto publicitario y en la eficacia de su mensaje. Al fin y al cabo, la "publicidad es discurso, lenguaje, y, por lo tanto, manipula símbolos para hacer la mediación entre 
objetos y personas, haciendo uso más del lenguaje del mercado que de los objetos" (Carvalho, 12:2000). ${ }^{28}$

El texto publicitario representa el caudal informativo y el caudal emocional, gravitando entre lo que anuncia realmente y lo que parece anunciar. La operadora de turismo Central Noronha anuncia por medio del texto 14, presentado anteriormente, los paraísos del nordeste brasileño, como el propio titular del texto lo anuncia.

El folleto es compuesto por 6 partes, las 3 primeras funcionan como una introducción a los productos turísticos anunciados y las tres últimas consisten en la presentación desarrollada de estos productos. En las tres primeras partes del texto se puede inferir que los paraísos del nordeste brasileño son Fernando de Noronha, Porto de Galinhas y Pipa, que aparecen como escenarios exóticos y de playas paradisíacas.

El constituyente expandido de la parte redaccional muestra esos tres destinos turísticos de forma elogiosa para destacar sus cualidades e influenciar positivamente la adquisición de este producto turístico por parte del lector/consumidor. El texto sobre Fernando de Noronha dice que: hablar de Fernando de Noronha es no encontrar defectos, solo virtudes. Ubicado en medio al océano atlántico, ese paraíso de aguas trasparentes y peces de especies raras, encanta a todos con su belleza. Originadas de procesos volcánicos relativamente modernos, las seis islas que componen el archipiélago constituyen importantes santuarios ecológicos, de riquezas naturales únicas dentro y fuera del mar. En fin, un lugar ideal para bucear, surfear, hacer senderismo y paseos ecológicos. El encuentro entre tú y la naturaleza.

Ya en el texto sobre Porto de Galinhas consta que: las piscinas naturales son una de las principales atracciones de Porto de Galinhas. En la baja marea, el local es muy frecuentado por bañistas que optan por paseos de jangandas o por quedar simplemente jugando entre las más variadas especies de peces. Sus vecinas playas, Muro Alto y Serrambi, poseen resorts famosos y aguas limpias, refrescantes y calmas, donde se puede relajar y aprovechar el sol del verano pernambucano, que dura todo el año. Otra excelente opción es también aprovechar la noche en conciertos y fiestas que se difunden

\footnotetext{
${ }^{28}$ En la fuente original: "Publicidade é discurso, linguagem, e portanto manipula símbolos para fazer a mediação entre objetos e pessoas, utilizando-se mais da linguagem do mercado que a dos objetos".
} 
por el lugar, no solo en los fines de semana y puentes, sino también en otras épocas del aก̃o.

Por último, el constituyente expandido sobre Pipa afirma que: Pipa fue redescubierta como destino elegante. Y lo que ya era bonito quedó más sofisticado. En la baja marea, se puede caminar hasta las playas de Curral y del Amor. Cuando, a mediados de los años 90, se empezó a hablar de Pipa, era difícil cree en los relatos. ¿Cómo podría existir una villa de playa hermosa en Rio Grande del Norte? Hasta entonces se pensaba que playas bonitas en el Nordeste era un monopolio de Bahía. Sin embargo, quien iba a confirmar personalmente descubría más que eso. Pipa tenía calidad también. La comida era sorprendentemente buena. En los últimos años, la villa ganó un nuevo impulso cualitativo, al ser descubierto como destino elegante por los europeos que pasaron a desembarcar en Natal. Lo que era hermoso se sofisticó. Seáis todos bienvenidos a PIPA un lugar lindo para uno venir a ver...

En la macroestructura de este texto publicitario como un todo figura la descripción de tres sitios en la costa del nordeste brasileño: Fernando de Noronha, Porto de Galinhos y Pipa. Así, la progresión temática de este texto puede ser definida como de progresión de temas derivados. La persona del discurso presente es la inscripción del "você", en portugués de Brasil, que tiene la fuerza semántica del "tú" en español, presentando así un carácter de proximidad entre el emisor y el destinatario, lo que aporta más intimidad y confianza al lector/consumidor.

¿Por qué esos textos son persuasivos? Porque son elaborados de forma cuidadosa, por tener el receptor como elemento fundamental en su producción, por no ofrecer dificultades en su decodificación, por ser elogioso, por anunciar un producto y, sobre todo, por su acto perlocutivo consistir en la estrategia de persuasión publicitaria que tiene como finalidad recibir del interlocutor la confirmación en forma de un acto de compra.

El producto visual consiste en la propia imagen de los tres sitios en la costa del nordeste brasileño: Fernando de Noronha, Porto de Galinhos y Pipa. El mensaje manifiesto es la de que esos son sitios apropiados para ir de vacaciones, mientras el mensaje latente consiste en la idea de paraíso y bellas playas desiertas. 
Al entrar en el universo publicitario, las premisas que inician una discusión sobre este estudio, casi siempre parten del campo ideológico de los mensajes, que intentan persuadir e, incluso, influencian al consumidor a adquirir nuevas costumbres. Sin embargo, en la génesis de este tipo de comunicación las herramientas lingüísticas sirven como base de este campo multidimensional llamado de publicidad.

La palabra en el texto realmente forma parte de un abanico lleno de recursos, herramientas y posibilidades adoptados para sacar al máximo los beneficios de un léxico positivo en el discurso publicitario. Por eso merece la pena detener nuestra atención en el marco léxico de los textos presentados anteriormente, sobre todo en el uso de sintagmas como: defectos, virtudes. océano atlántico, paraíso de aguas trasparentes, peces de especies raras, encanta, belleza, modernos, importantes santuarios ecológicos, riquezas naturales únicas, lugar ideal, principales atracciones, muy frecuentado por bañistas, jugando, playas, famosos, aguas limpias, refrescantes, calmas, relajar, aprovechar, sol, verano, excelente, noche, conciertos, fiestas, destino elegante, bonito, más sofisticado, hermosa, calidad, sorprendentemente, buena, nuevo, impulso, cualitativo, descubierto, destino elegante, bienvenidos, lugar lindo.

En lo publicitario, aunque cada palabra tenga un carácter individual, es parte constitutiva del lenguaje que posee un carácter social. La palabra publicitaria sirve para traducir ideas que se transforman en anuncios. Además, sirve de base para la composición del texto publicitario que actúa a favor de un mercado económico. 
En fin, la palabra es para la publicidad el elemento seductor que cautiva al público receptor, objeto de manipulación comunicativa, como podemos constatar en el texto 14 . Resaltando la importancia del léxico en la publicidad, Rodríguez Ferrer (1994:67) dice que:

En ese espacio riguroso, la palabra no solo actúa en función de la compra de algo, sino dentro de un fenómeno colectivo de comportamiento, cuando la apetencia de las cosas se entrelaza, consciente o subconscientemente, con la apetencia de las palabras en un juego de coquetería recíproca, de deslumbres visuales, de colores fonéticos, de embriaguez seductora.

Apoyamos esa idea de Ferrer de que las cosas anunciadas por medio de palabras se transforman en palabras y éstas, a su vez, en las propias cosas. En la publicidad es importante la elección de cada palabra dado que en muchos contextos la misma palabra puede tener connotaciones positivas o negativas. La palabra sol, por ejemplo, para quien siempre ha vivido bajo un sol muy fuerte y para quien vive en un sitio donde casi nunca se ve el sol. Otro ejemplo sería la palabra ocio, que asociada a la industria de entretenimiento tiene sentido positivo, no obstante, relacionada con la pereza aporta connotaciones negativas.

Además, el orden de las palabras en un enunciado dado puede alterar su sentido. Relacionado con eso no es lo mismo decir pobre niño que niño pobre, como no es lo mismo decir ir de tapas que ir a por tapas. También se puede destacar dentro de este contexto los juegos de palabras en los cuales se juega con el sentido y la construcción sintáctica, de manera que puedan generar enunciados creativos, sorprendentes y que son fáciles de comprender y acordarse.

Como ejemplo de un juego original con creatividad en la unión de palabras y la construcción de sonoridad podemos mencionar la construcción "Coca-cola". Merece atención en el lenguaje publicitario las palabras de carácter homónimo, eufemístico, antónimo, palíndromo, parónimo, paronomásico y polisémico. Este anuncio del hotel Miramar dice en su eslogan: Tu lugar en el paraíso. La persona del discurso está destacada en el enunciado por medio del posesivo "tu", que aparece en el inicio de la frase. Eso sirve para destacar la persona más importante en este acto de habla: el receptor. 
HOTEL MIRAMAR

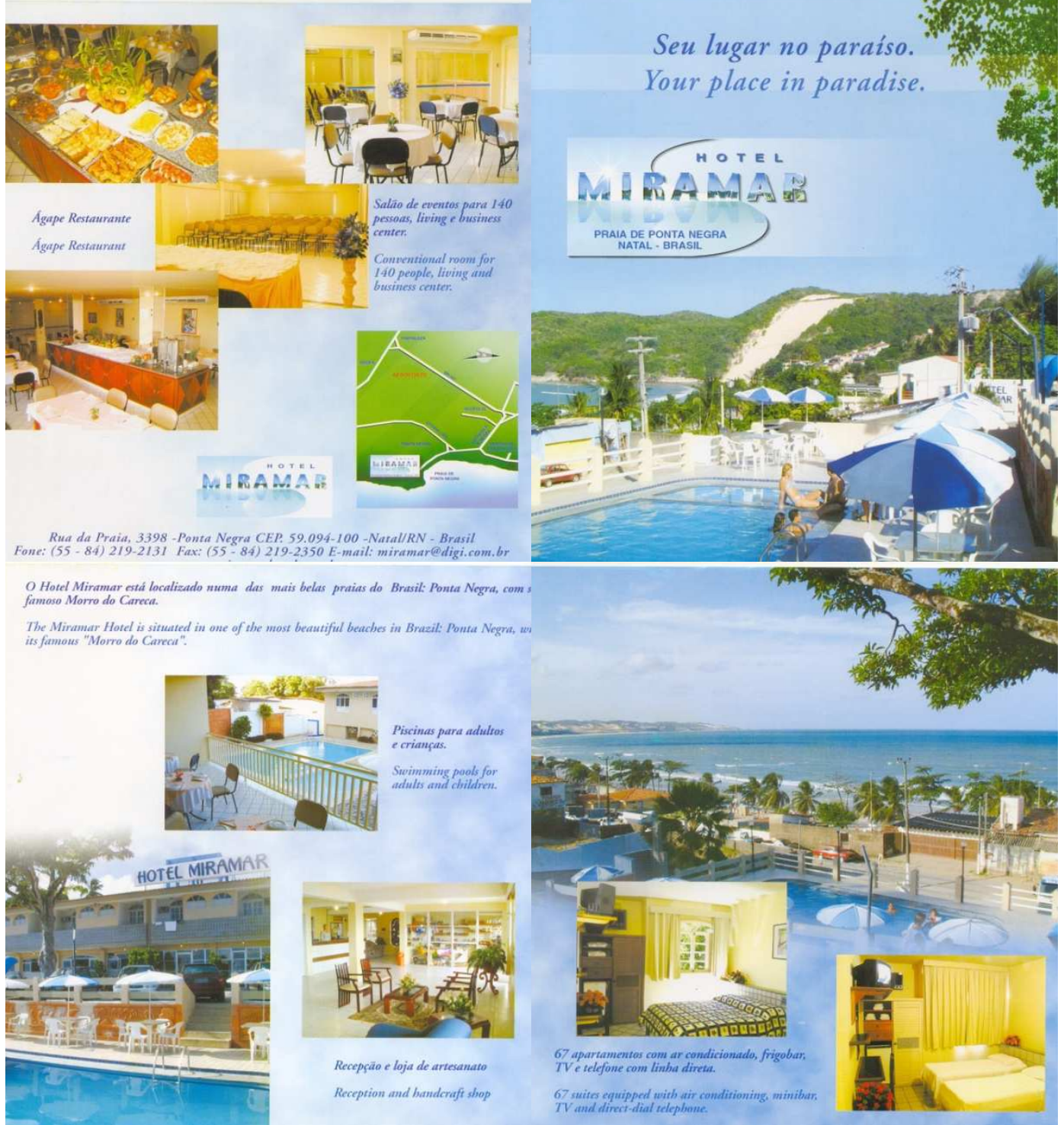

Texto 15

Tu lugar en el paraíso es la frase de efecto que actúa como gancho a la hora de atrapar la atención de un lector para que siga leyendo el anuncio. Luego, más abajo, se descubre qué lugar es este: el hotel Miramar, localizado en Natal. Así se puede comprender Natal como el paraíso y el hotel Miramar como tu lugar en este paraíso.

\section{El soporte del lenguaje}

Ahora bien, ¿por qué este es un texto publicitario? Porque consiste en un tipo de discurso elaborado por medio de un código mixto (imagen y lenguaje verbal), según las leyes de una preocupación estética tanto con lo lingüístico como con la parte de imagen, 
además del cuidado en la elección de un léxico influyente positivamente por medio de sintagmas como: paraíso, restaurante, bellas, playas, más, famoso, tienda y artesanía.

Las letras forman palabras que son soporte del lenguaje. Seguir la secuencia letrapalabra-signo-pensamiento es un camino natural para el lenguaje y la emisión de un enunciado. Esto es lo que afirma Rodríguez Ferrer (1994:146) cuando menciona que "ir de la letra a la palabra, como del signo al pensamiento, es la operación natural de todo lenguaje, de un simbolismo a otro. Si la letra es soporte de la palabra, la palabra lo es del lenguaje".

Las personas del discurso presentes en el texto 15 son la inscripción del "você", en portugués de Brasil, que tiene la fuerza semántica del "tú" en español, presentando así un carácter de proximidad entre el emisor y el destinatario; además de la inscripción de la tercera persona del singular usada para describir el producto turístico ofertado de modo impersonal.

Ya sabemos que este texto pertenece al género del discurso publicitario, pero ¿por qué persuade? Por ser un texto que desde un punto de vista de la tipología textual posee una secuencia dominante de texto argumentativo, por no exigir procesos cognitivos difíciles por parte del interlocutor, por ser seductor, por usar un lenguaje positivo y porque su acto de habla perlocutivo consiste en la estrategia de persuasión publicitaria que tiene como finalidad recibir del interlocutor la confirmación en forma de un acto de compra.

El producto visual consiste en la propia imagen del logotipo del "Hotel Miramar", sus instalaciones internas y externas; sus vistas del mar y del "morro do careca". El mensaje manifiesto es de un hotel elegante y tranquilo para la instalación del turista. El mensaje latente sería la excelencia de los productos y de los servicios ofertados. 


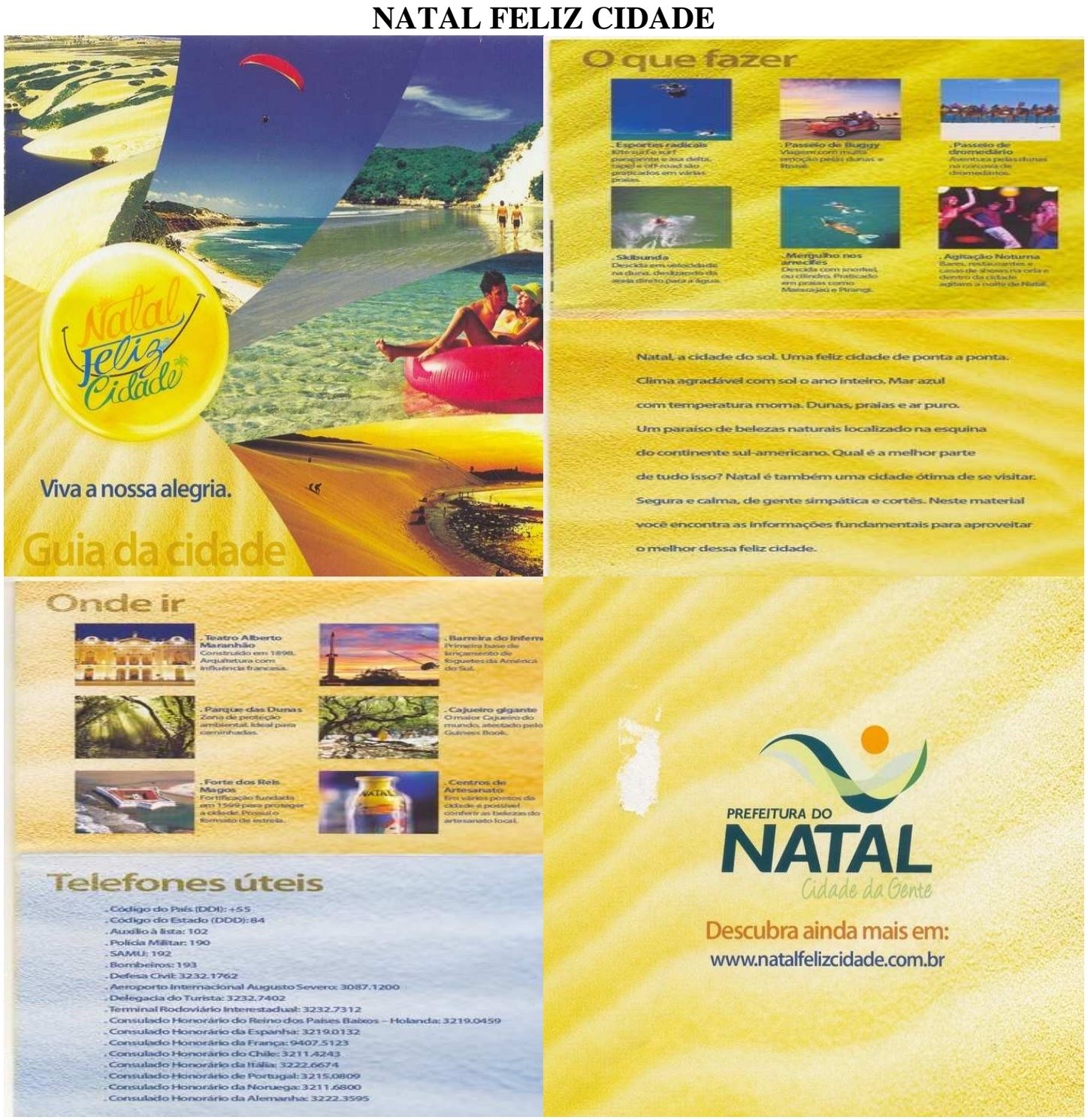

Texto 16

Compartimos la opinión del autor mencionado anteriormente en lo que concierne a la importancia de la palabra para la publicidad. Hay autores que defienden incluso la importancia de unidades como las letras antes de empezar a valorar la propia palabra; muchos asocian determinadas letras a algunas palabras. Como ejemplo, podemos recordar a Watson Duna (apud Rodríguez Ferrer 1994:147) cuando dice que "la letra "I" corresponde a las cinco palabras para el éxito de un mensaje: Idea, Impresión, Interés, Información e Impulsión."

En el texto 16 las personas del discurso presentes son la tercera persona del singular usada para describir Natal como un producto turístico de forma impersonal y la 
inscripción del "você", en portugués de Brasil, que tiene la fuerza semántica del "tú" en español, presentando así un carácter de proximidad entre el emisor y el destinatario.

Este texto pertenece al género del discurso publicitario y desde un punto de vista de la tipología textual posee una secuencia dominante de texto argumentativo, ya que la descripción funciona más bien como un recurso persuasivo. En el marco léxico, figuran sintagmas de reflejos hedonistas como: feliz, viva, alegría, sol, agradable, mar, playa, mejor, excelente, segura, tranquila, simpática y cortés.

El producto visual consiste en imágenes de los principales puntos de interés turísticos de Natal, de las principales ACTs de esta ciudad como producto turístico. En el mensaje manifiesto se puede inferir como el núcleo una ciudad muy bonita y con muchas actividades turísticas relacionadas con el mar. El mensaje latente consiste en lo bien que se pasa en esta ciudad que proporciona mucha felicidad a sus visitantes.

Creemos que en la publicidad cada letra y cada palabra son responsables de la construcción del sentido lingüístico del enunciado. Por eso, es importante la elección tanto de las letras como de las palabras para la publicidad. La palabra publicitaria incluso puede contribuir a la formación de la construcción de sentidos y sensaciones como también afirma Rodríguez Ferrer (1994:152) cuando menciona que "la palabra publicitaria, como la poética, es la que transforma la cosa en imagen; lo sensible en creíble; lo creíble en acción; lo literal en alegórico; la expresión en frase; la frase en aguijón”. Aquí también podríamos añadir que la palabra de la publicidad también recrea la propia palabra y se hace por medio de ella imagen, sonido y olor.

En la publicidad presentada anteriormente se anuncia Natal como un destino turístico, pero no es un destino cualquiera sino una ciudad feliz, alegre, tranquila y la ciudad del sol. Los atributos de Natal son muchos y pueden ser enumerados a partir del léxico empleado para fraguar esta ciudad de forma material por medio de ese folleto turístico.

También es importante destacar el uso de la palabra en construcciones inusuales que les atribuye un sentido polisémico como es el caso de la construcción feliz cidade, dado que en la construcción gramaticalmente correcta sería cidade feliz, siguiendo la secuencia del sujeto y su atributo, pero cuando se dice feliz ciudad también se crea un abanico 
semántico al enunciado, es decir, además de decir que Natal es una ciudad feliz, se compone la palabra felicidad en portugués de forma novedosa "felizcidade", que no corresponde gráficamente a la palabra felicidade, sino fonéticamente. Además, se emplea la construcción del deseo de que uno tenga una feliz navidad en portugués, así una feliz cidade es lo mismo que feliz natal, por cierto, no es una coincidencia que Natal sea el nombre de esta ciudad.

Para Ferraz Martínez (2000:48), el vocabulario elegido por la publicidad es un espejo fiel de las principales características de la sociedad contemporánea, como por ejemplo el hedonismo. En ese sentido, ese autor afirma que:

\begin{abstract}
El vocabulario publicitario es hedonista: palabras como 'placer', 'confort', 'sensación', 'agradable', 'suave', 'aromático', ‘sabroso', 'delicioso', y otras similares así lo atestiguan. Los argumentos del placer, las sensaciones y el erotismo se explotan mucho en anuncios de colonias, bebidas, tabaco o joyas, pero también aparecen en los de productos mecánicos como los coches, cuya posesión se presenta como una comunicación sensual. Ya lo sabemos: los productos se 'viven'.
\end{abstract}

En la publicidad los argumentos son ordenados por la lengua, su discurso tiene como objetivo convencer, despertar interés, la orden de consumo se establece como imperativo de felicidad y las palabras tienen la función de influenciar positivamente o negativamente al receptor. El texto 16 lo muestra cuando intenta vender, además de Natal como destino turístico, la felicidad y la alegría de esta ciudad. Y las palabras empleadas en este anuncio juegan un papel fundamental a la hora de contribuir con sus estrategias de persuasión dirigidas al caudal emocional y al caudal informativo del texto.

El texto publicitario agrega dos modos de lenguaje: verbal y no verbal. Por eso, para que los elementos lingüísticos sean bien aplicados, el conocimiento de la lengua es fundamental. En este sentido Carvalho (2000:13) afirma que "toda argumentación publicitaria sostiene una argumentación icónico lingüística que lleva al consumidor a ser convencido de modo consciente o inconsciente" ${ }^{29}$. El texto 16 posee un $85 \%$ de

\footnotetext{
${ }^{29}$ En la fuente original: "Toda argumentação publicitária sustenta uma argumentação icônico-linguística que leva o consumidor a convencer-se consciente ou inconscientemente".
} 
lenguaje no verbal y un $15 \%$ de lenguaje verbal, o sea, su mensaje tanto está direccionado al consciente como al inconsciente del público objeto.

Las características lingüísticas empleadas en un texto publicitario están relacionadas directamente con el público objeto. Las informaciones presentes en un texto publicitario son inherentes a los aspectos lingüísticos, que engloban el contenido del texto y de la imagen. De ahí la importancia de los recursos lingüísticos. En la opinión de Carvalho (2000:19):

\begin{abstract}
Los recursos lingüísticos tienen el poder de influenciar y orientar las percepciones y pensamientos, es decir, el modo de estar en el mundo y vivirlo, siendo posible permitir o no determinados conocimientos y experiencias. Los términos que dominamos y conocemos constituyen un 'patrimonio intelectual', que se amplia de acuerdo con la intensidad de nuestra vivencia, de modo que permita una comprensión cada vez mejor del mundo (en el papel de receptores) y una cantidad más grande de matices de significado (en el papel de emisores). ${ }^{30}$
\end{abstract}

En fin, como ya hablamos anteriormente, la comunicación publicitaria se establece de forma distinta, intenta la adopción implícita de un sistema de valores. Esa estrategia es llevada a cabo por medio de las palabras que ejercen la función de soporte y, bajo la orientación de Carvalho (2000) se dividen en: fonética (silabancia, onomatopeya, aliteración y asonancia); léxico semántico (vocablos inéditos, expresiones con sentidos diferenciados, palabras de uso común, dichos populares y préstamos lingüísticos); y morfosintaxis (formas de grafías distintas, frases que no siguen una lógica gramatical tradicional).

En suma, no se puede olvidar que "en publicidad se emplean con profusión neologismos y tecnicismos que aportan autoridad, prestigian los productos y dan cuerpo al mensaje" (Santiago Guervós, 2005:80).

\footnotetext{
${ }^{30}$ En la fuente original: "Os recursos lingüísticos têm o poder de influenciar e orientar as percepções e pensamentos, ou seja, o modo de estar no mundo e de vivê-lo, podendo permitir ou vetar determinados conhecimentos e experiências. Os termos que dominamos e conhecemos constituem um "patrimônio intelectual", que se amplia de acordo com a intensidade de nossa vivência, de modo a permitir uma compreensão cada vez maior do mundo (no papel de receptores) e uma quantidade maior de matizes de significado (no papel de emissores)".
} 
Las palabras en la elaboración de un mensaje publicitario

En la elaboración del mensaje de una propaganda o de una publicidad se realiza minuciosamente una selección léxica, tomando como base el público objeto. El mensaje generalmente es corto, con palabras y frases efímeras, términos simples y del día a día, vocabulario común para que el receptor lo digiera inmediatamente. Además, lo más importante es la fusión que ocurre entre los mecanismos lingüísticos que llegan a crear neologismos y elaboran el relieve que se quiere atribuir a la marca o producto.

\section{NATAL CIDADE DO SOL}

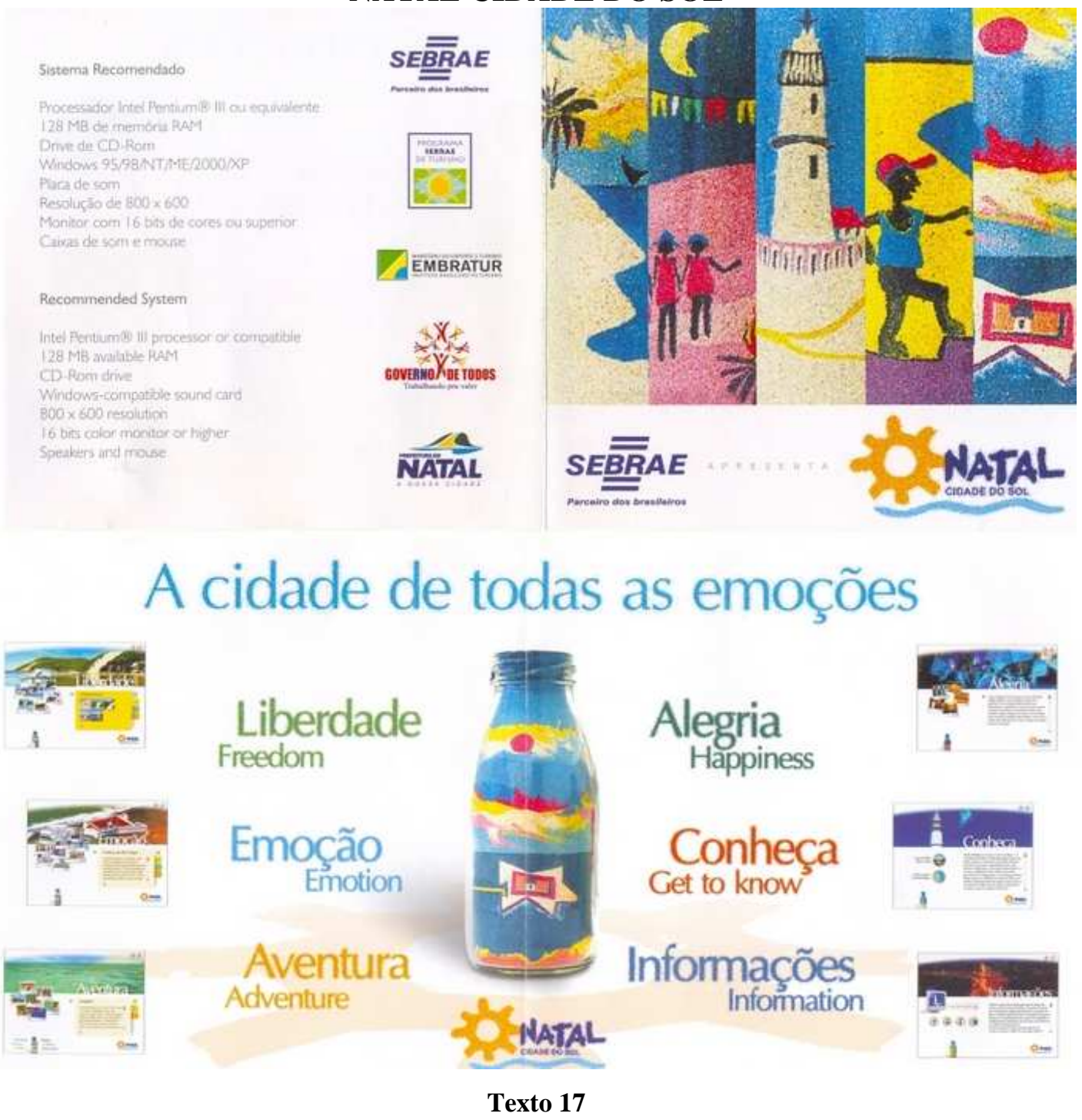

Las investigaciones de las palabras no funcionan como un campo restricto. Sin embargo, cada término aplicado llega a transmitir una gama de ideas implícitas. El mensaje transmitido entre las líneas del texto engloba todo un sistema ideológico, y en 
la mayoría de los casos busca crear una proximidad con el interlocutor haciendo uso de expresiones coloquiales.

Echemos un vistazo al texto 17, que anuncia Natal como producto turístico. En cada ícono correspondiente a un punto de interés turístico o de servicio de información se le atribuye un titular, sumando así una cantidad léxica por medio de la cual uniendo lo verbal y la imagen el locutor actúa como coautor del anuncio. La frase de efecto del anuncio es: la ciudad de todas las emociones. Luego se expone qué emociones son esas: libertad, emoción, aventura, alegría, conocimiento e información. Es decir, un léxico de carácter hedonista muy bien empleado por la publicidad.

En su macroestructura figura el anuncio de Natal como producto turístico. Así, la progresión temática de este texto puede ser definida como de progresión de tema constante. La persona del discurso presente es la inscripción de la tercera persona del singular para tratar de modo impersonal el producto anunciado. El acto de habla locutivo consiste en el discurso constituido por el lenguaje verbal escrito y el lenguaje visual; el ilocutivo en la descripción del producto turístico ofertado y su ubicación; y el perlocutivo en la estrategia de persuasión publicitaria que tiene como finalidad recibir del interlocutor la confirmación en forma de un acto de compra.

El producto visual se presenta con la imagen de los principales puntos de interés turístico de Natal, además de una imagen de un tipo de artesanía típica de esta ciudad, cuyo mensaje manifiesto es el propio anuncio de Natal como destino turístico y el mensaje latente es que la visita a esta ciudad puede proporcionar libertad, emoción, aventura y alegría a su visitante.

Los ejemplos más evidentes de los tipos de publicidad basada en el uso específico de la lengua escrita son: los anuncios de los periódicos, folletos, revistas y outdoors (carteles de grande extensión expuestos generalmente a las afueras de las ciudades y pegados en soportes de madera). Sin embargo, cada uno de esos vehículos de comunicación exige, en particular, un determinado tipo de lenguaje específico para cada caso ya que hay variación en la extensión del texto, el tamaño de su representación gráfica, además del tipo de interlocutor. 
CIDADE DO SOL RENT A CAR

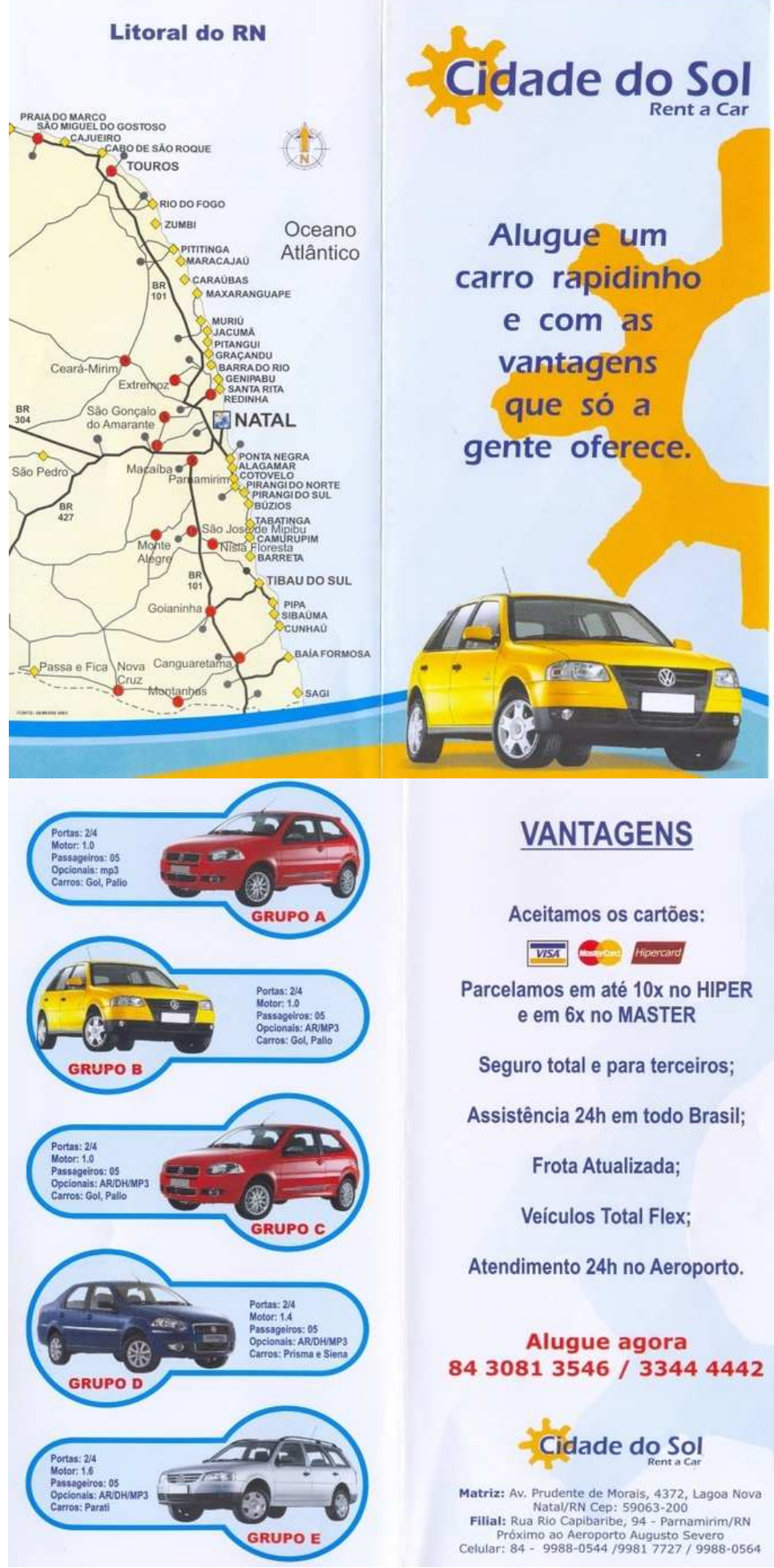

Texto 18

Desde un punto de vista formal, este texto sigue el formato propio del texto publicitario en el que están asociados el código verbal y el no verbal en la creación de un mensaje artísticamente elaborado. Así, no queda duda de que el texto 18 fue creado a partir de recursos textuales heterogéneos, es decir, su contenido verbal y su contenido visual. En 
su macroestructura figura la descripción de los productos y servicios ofertados por "Cidade do Sol Rent a Car". Las personas del discurso presentes son "nosotros y la inscripción del "você", en portugués de Brasil, que tiene la fuerza semántica del "tú" en español, presentando así un carácter de cortesía retórica por medio del "nosotros" y de la proximidad entre el emisor y el destinatario, con el "tú".

El producto visual es la imagen de cinco tipos de coches distintos y el mapa del litoral del rio Grande del Norte, sobre todo de Natal. El mensaje manifiesto del anuncio es de una agencia de alquiler de coches. Y el mensaje latente: "alquila un coche". Si miramos el texto 18 atentamente vemos que solo un $20 \%$ de su texto tiene contenido verbal, con lo cual no puede estar fraguado por medio de un contenido expandido muy extenso.

En la primera página de este anuncio figura el siguiente texto: alquila un coche muy rápido y con las ventajas que solamente nosotros ofrecemos. En seguida se enumeran las ventajas de la siguiente forma: aceptamos tarjetas de crédito, dividimos hasta 10 veces, seguro total y para terceros, asistencia 24 horas en todo el territorio brasileño, frota actualizada, vehículos total flex, atendimiento 24 horas en el aeropuerto. Alquila ahora.

En este mensaje merece destacarse el argumento de cantidad y de escasez. Basta observar el anuncio que dice: "Somos los únicos que ofrecemos estas ventajas". Además del uso del verbo principal en el modo imperativo: alquila. Sin embargo, no se refiere a alquilar un coche en cualquier momento, sino alquila ahora mismo, en el momento presente, inmediatamente para no perder ningún beneficio.

Aunque este tipo de mensaje divida su espacio con imágenes, símbolos, eslóganes, entre otro tipo de elementos visuales, en la mayoría de los casos esos mensajes están anclados en la palabra que sirve para conducir a la percepción de lo que se quiere decir, influenciar en las decisiones del interlocutor y contribuir, consecuentemente, para la eficacia del mensaje. 
En el caso de el texto 18 se intenta claramente convencer al interlocutor de que debe alquilar un coche en Cidade do Sol Rent a Car, y para ello, lanza varios argumentos de las ventajas ofrecidas por medio de los servicios de esta empresa. De ahí que:

La palabra deja de ser meramente informativa, se la elige en función de su fuerza persuasiva, clara o disimulada. Su poder no es simplemente el de realizar la venta de tal marca, sino integrar al receptor a la sociedad de consumo. Se puede, eventualmente, resistir al imperativo (“compra"), pero casi siempre se obedece al indicativo. (Carvalho, 2000:18). ${ }^{3}$

\section{El léxico como elemento persuasivo}

El lenguaje publicitario intenta siempre convencer a su receptor, pero en este caso la palabra forma parte de un contexto más amplio, puesto que a partir de la identificación del interlocutor potencial, de acuerdo con el género (masculino o femenino), grupo social, edad, nivel de estudios, ramos de actividades, etc. se adoptará un determinado tipo de léxico y términos adecuados para la creación de una campaña publicitaria eficaz.

El texto 19 anuncia bucea en Maracajaú. Descubre nuestro Caribe brasileño. APA (Área de Preservación Ambientral). Número limitado por día (para buceo). Siente el placer de bucear con snorkel y cilindro.

Las palabras, en el contexto de la publicidad, pueden cambiar el tipo de actitud de su interlocutor. Llegan incluso a moldear la visión del consumidor con un mensaje que llena expectativas, agrega cualidades y estados de ánimo al producto. Para la corroboración de esa idea Carvalho (2000:19) dice que "la función persuasiva en el lenguaje publicitario consiste en intentar cambiar la actitud del receptor". ${ }^{32}$

\footnotetext{
${ }^{31}$ En la fuente original: "A palavra deixa de ser meramente informativa, e escolhida em função de sua força persuasiva, clara ou dissimulada. Seu poder não é simplesmente o de vender tal marca, mas integrar o receptor à sociedade de consumo. Pode-se, eventualmente, resistir ao imperativo ("compre"), mas quase sempre se atende ao indicativo".

${ }^{32}$ En la fuente original: "A função persuasiva na linguagem publicitária consiste em tentar mudar a atitude do receptor".
} 


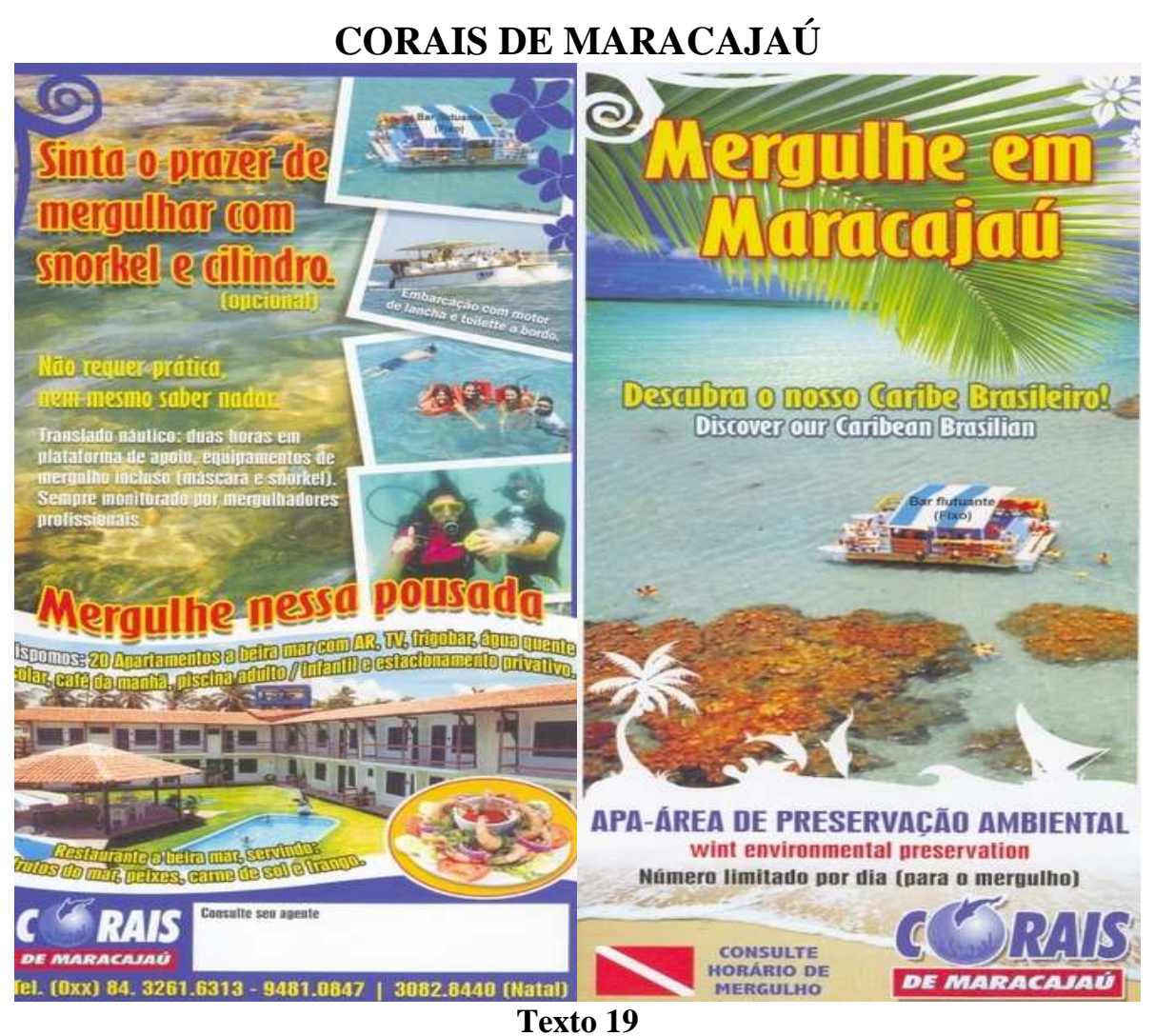

El folleto turístico presentado anteriormente no desvirtúa esa función persuasiva del lenguaje publicitario mencionado por Carvalho (2000) y hace uso de palabras como bucear, descubrir, Caribe, preservación ambiental, sentir y placer. Es decir, un léxico positivo y de carácter hedonista que funciona como un elemento de persuasión en la actual sociedad de consumo.

Desde un punto de vista formal, el texto 19 sigue el formato propio del texto publicitario con el uso de un código híbrido. En su macroestructura figura la descripción del buceo en Maracajaú, lugar descrito como el Caribe brasileño. La progresión temática de este texto puede ser definida como de progresión de tema constante. La persona del discurso presente es la inscripción del "você", en portugués de Brasil, que tiene la fuerza semántica del "tú" en español, presentando así un carácter de proximidad entre el emisor y el destinatario. El producto visual consiste en la propia imagen del agua donde se bucea en Maracajaú, sus instalaciones de hostelería y su vista privilegiada del mar. El mensaje manifiesto es de un lugar exótico y el mensaje latente es de un lugar paradisíaco con aguas trasparentes. 
En ese anuncio se adopta también el argumento de la escasez, es decir, no hay producto disponible para quien lo desea porque hay un número limitado por día (para buceo). Otro elemento usado en este texto persuasivo son los verbos principales de las oraciones en el modo imperativo, con sentido de consejo. Así tenemos bucea y Siente.

El sentido de las expresiones y las palabras se complementan, el significado de cada término está relacionado directamente con su contexto cultural. En este universo de significados, los términos empleados en la publicidad son vistos naturalmente asociados a principios de proximidad o contraste, ya que las palabras evocan automáticamente al campo léxico al que están relacionadas. Por eso, la elección léxica es crucial para el éxito o el fracaso de un anuncio. Sobre la importancia de la selección del léxico en la publicidad, Santiago Guervós (2008:66) afirma que "como se sabe, las palabras predisponen a favor de ciertas líneas de pensamiento. Cada término está impregnado de connotaciones, lleva tras de sí su historia, un contexto comunicativo al que suele adscribirse, una serie de implicaturas y suposiciones que lo enriquecen o lo empobrecen".

\section{VISUAL PRAIA HOTEL}

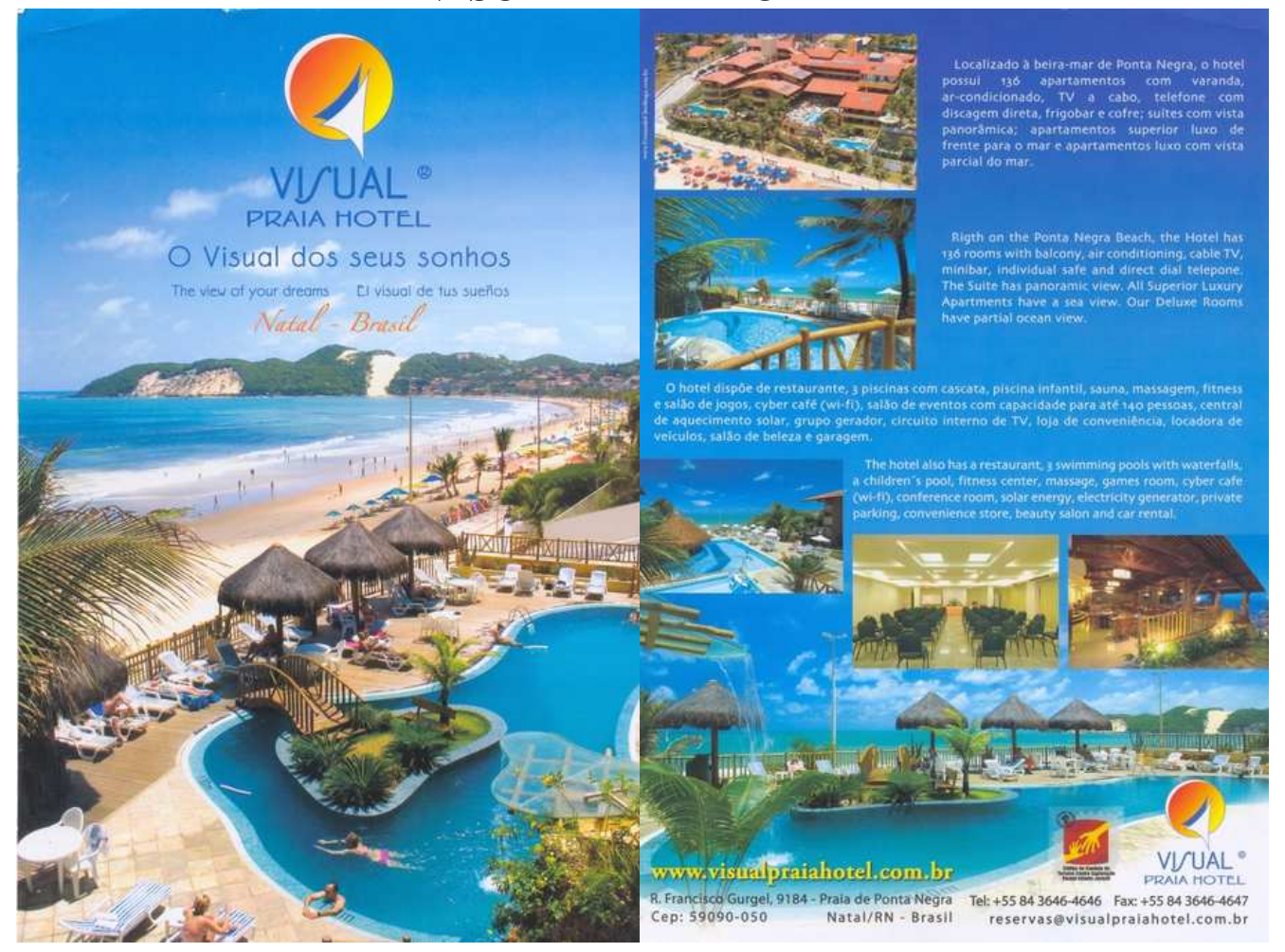

Texto 20 
El visual Praia hotel. El visual de tus sueños. Ubicado en la orla marítima de Ponta Negra, el hotel posee 136 apartamentos con balcón [...], apartamento superior lujo en frente al mar y apartamentos de lujo con vistas parciales del mar.

En el texto 20, un $80 \%$ de su contenido es imagen y un $20 \%$ es texto escrito en el que existe la presencia de un léxico positivo por medio del que se describe el producto turístico anunciado. Aquí es importante destacar el uso de la palabra lujo y el eslogan el visual de tus sueños, dando la idea de que el lujo y el confort forman parte de los sueños del receptor/consumidor.

Las clases de palabras como los sustantivos, los adjetivos y los verbos son aplicadas en la publicidad de acuerdo con las exigencias del contexto y son reconstruidas por sus recursos figurativos (connotación) y literales (denotativos). El discurso publicitario, por su parte, está permeado por los mecanismos estilísticos de un tipo de lenguaje denotativo o connotativo. Ese alargamiento en la estructura semántica de las palabras en su sentido de diccionario consiste en una apertura a nuevos significados, como afirma Carvalho (2000:20) cuando dice que:

\begin{abstract}
En realidad, el campo significativo de las palabras plenas (sustantivos, adjetivos y verbos) es ampliado por el desarrollo del sentido figurado (connotado) al lado del literal (denotado). Mientras la denotación transmite la información, la connotación permite una apertura en un abanico de significados. ${ }^{33}$
\end{abstract}

La palabra en un texto publicitario actúa en esferas humanas como el campo psicológico, por medio de las emociones, deseos y sentimientos, y el campo social, en el que el léxico está cargado de aspectos socioculturales. De ese modo, el sentido de una determinada construcción ordena los vocablos en posición de mayor o menor relieve. También la repetición de palabras es muy utilizada en un mismo espacio para producir un determinado significado, ritmo o sonoridad, sirve para fijar el mensaje, especialmente la marca.

\footnotetext{
${ }^{33}$ En la fuente original: "Na verdade, o campo significativo das palavras plenas (substantivos, adjetivos e verbos) se amplia pelo desenvolvimento do sentido figurado (conotado) ao lado do sentido literal (denotado). Enquanto a denotação transmite a informação, a conotação permite uma abertura em leque do significado".
} 
En la macroestructura del texto 20 figura la descripción del "Visual Praia Hotel", la presentación de su localización, también de sus instalaciones externas e internas. La progresión temática del texto puede ser definida como siendo de progresión de tema constante. Las personas del discurso presentes son la tercera persona del singular referente al producto anunciado de forma objetiva y la inscripción del "tú", presentando así un carácter de proximidad entre el emisor y el destinatario.

Este texto pertenece al género del discurso publicitario y desde un punto de vista de la tipología textual posee una secuencia dominante de texto argumentativo, ya que la descripción funciona más bien como un recurso persuasivo. El producto visual consiste en el logotipo del "Visual Praia Hotel", sus vistas del mar y sus instalaciones externas e internas, además de una imagen de dos manos que remiten a la propaganda de una campaña del gobierno federal contra la prostitución infantil, que ya hemos visto anteriormente. El mensaje manifiesto coincide con el propio anuncio del producto turístico ofertado y el mensaje latente connota la elegancia y el confort del hotel anunciado, cuyo eslogan dice la visión de tus sueños y en eso se resume su mensaje latente: una verdadera visión de un ambiente de ensueño.

\section{PRAIA MAR HOTEL}

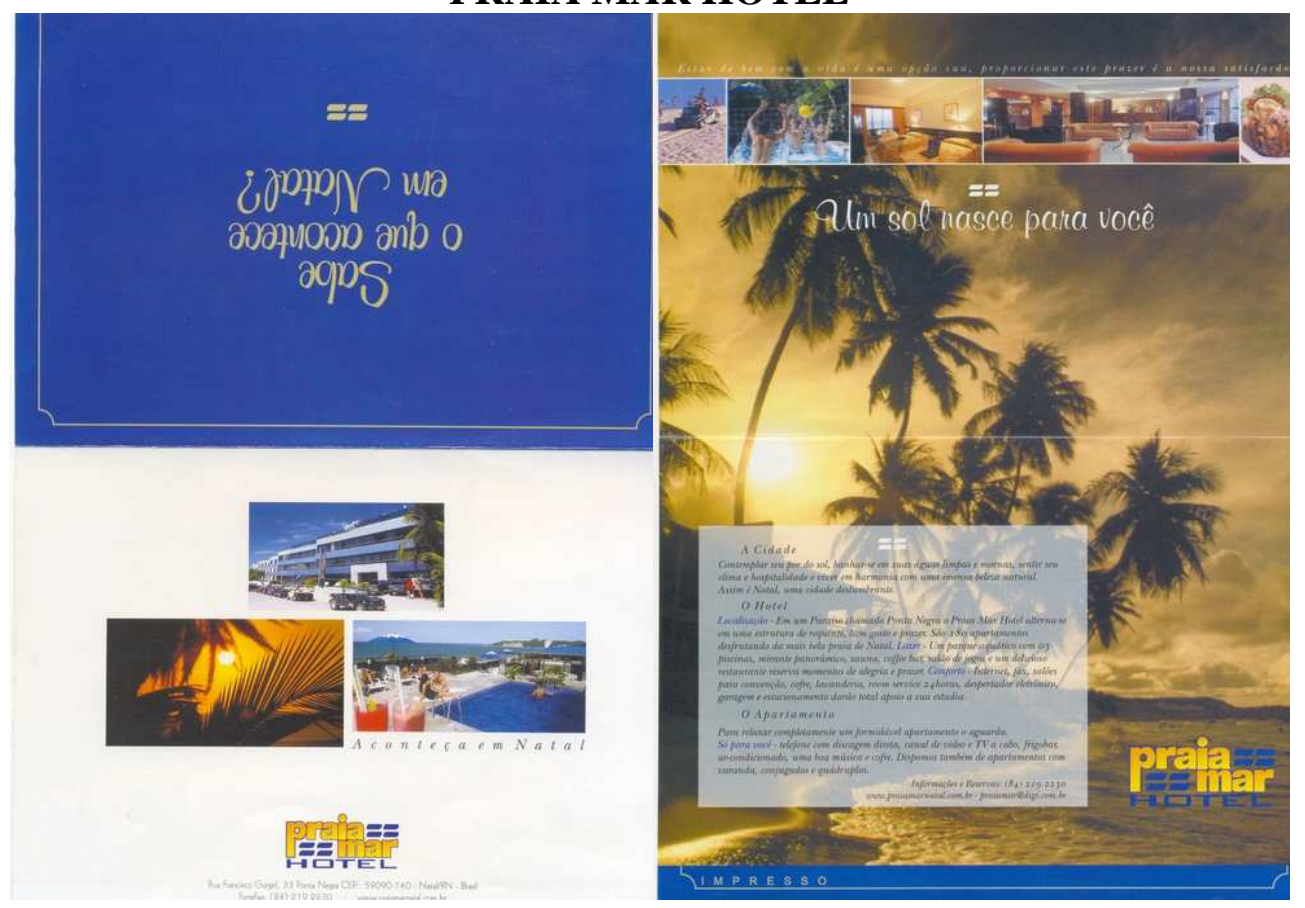

Texto 21 
Desde un punto de vista formal, el texto 21 sigue el formato propio del texto publicitario que se manifiesta por medio del hibridismo de imagen y texto verbal escrito. En su macroestructura figura la descripción del "Praia Mar Hotel", la presentación de su localización y de la ciudad en la que está ubicado. Las personas del discurso presentes son la tercera persona del singular que remite al producto turístico anunciado y la inscripción del "tú" que aproxima los interlocutores de ese tipo discursivo.

El producto visual consiste en la propia imagen del "Praia Mar Hotel", cuyo mensaje manifiesto coincide con el propio anuncio de ese hotel y el mensaje latente connota la belleza, la elegancia, la comodidad y el confort del Praia Mar.

En general, la marca de un producto establece un nombre propio, como es el caso del "Praia Mar Hotel", que por medio de la unión de tres sustantivos comunes se crea una marca, o sea, un nombre propio. Por lo tanto, la marca tiene el objetivo de crear una identidad que impone una especie de polisemia. Transformando, así, un nombre común en propio, estableciendo su asociación con imágenes, resumiendo sus funciones, estableciendo la relación entre la marca y el consumidor, atribuyendo valor de ascensión por medio de la adquisición de lo que se anuncia. En la opinión de Carvalho (2000:37) "todos los ítems son presentados lingüísticamente por la clase de nombres: sustantivos propios (marca), sustantivos comunes (presentación del objeto), sustantivos abstractos (cualidades del objeto) y adjetivos (carácter del objeto)". ${ }^{34}$

El principio de la estrategia publicitaria consiste en llamar la atención del interlocutor, consumidor potencial. Para ello hace uso de vocablos evaluativos de semántica positiva en la creación de una marca, por medio de la que pueden surgir expresiones léxicas, términos inéditos e, incluso, excluir el significado original de una palabra.

\footnotetext{
${ }^{34}$ En la fuente original: "Todos os itens são apresentados lingüisticamente pela classe dos nomes: substantivos próprios (marca), substantivos comuns (apresentação do objeto), substantivos abstratos (qualidades do objeto) e adjetivos (caráter do objeto)".
} 
Otros sentidos pueden ser establecidos a partir de figuras de lenguaje como onomatopeyas y metonimias. Además, la palabra actuará en la formación del sentido de lo que se anuncia:

\begin{abstract}
El vocabulario, sin embargo, no desempeña un papel pasivo, no es solamente un reflejo o la reproducción de nuevas concepciones históricas, sociales, científicas. Las puede definir también, al mismo tiempo que sufre su influencia. Las palabras, en resumen, no expresan las cosas, sino la conciencia que tenemos de ellas (Carvalho, 2000:22). ${ }^{35}$
\end{abstract}

La estrategia publicitaria usada en el texto 21 para llamar la atención del interlocutor es la pregunta retórica ¿Sabes qué pasa en Natal?, y más adelante el consejo: ocurre en Natal. La contestación para la pregunta retórica del inicio del anuncio viene en la segunda página del folleto: un sol nace para ti. A través del léxico se desarrolla la dinámica entre las palabras de un texto que conllevan contrastes, el propio empleo de cada palabra, el uso de las figuras de lenguaje y la simetría rítmica. Las palabras forman una base sobre los términos que representan placer, sentimientos positivos, credibilidad y símbolos de status.

Claro que en la frase un sol nace para ti, el sustantivo sol tiene un sentido connotativo, mejor dicho, metafórico. El sustantivo en cuestión tiene el sentido de acontecimiento, vida, hechos, luz. Eso queda claro en el contenido expandido del anuncio que dice: $L a$ ciudad. Contemplar su puesta del sol, bañarse en sus aguas limpias y tibias, sentir su clima y hospitalidad y vivir en armonía con una inmensa belleza natural. Así es Natal, una ciudad deslumbrante. Hotel. Localización. En un paraíso llamado Ponta Negra el Praia Mar Hotel se alterna con una estructura requintada, buen gusto y placer. Son 180 apartamentos disfrutando de la más bella playa de Natal. Ocio. Un parque acuático con 3 piscinas, mirante panorámico, sauna, coffee bar, sala de juegos y un rico restaurante reservan momentos de alegría y placer. Confort. [...] total apoyo a tu permanencia.

\footnotetext{
${ }^{35}$ En la fuente original: "O vocabulário, contudo, não desempenha um papel passivo, não é apenas o reflexo ou a reprodução de novas concepções históricas, sociais , científicas. Ele pode também defini-las, ao mesmo tempo que sofre sua influência. As palavras, em resumo, não exprimem as coisas, mas a consciência que temos delas".
} 
En ese texto hay algunas palabras clave como puesta del sol, aguas limpias y tibias, sentir, hospitalidad, vivir, harmonía, inmensa belleza natural, ciudad deslumbrante, paraíso, estructura requintada, buen gusto, placer, disfrutando, más bella playa, ocio, bar, sala de juegos, rico restaurante, alegría, placer, confort, lujo, sueños. En el producto final de la publicidad, todos los elementos tienen que estar en consonancia unos con los otros, hecho que será establecido por medio de los sentidos de las palabras, entre sus sinónimos y antónimos, la confirmación de la imagen y el nombre de la marca que se construye.

Por fin, para crear la estética entre el juego de palabras, se adoptan todas las estrategias lingüísticas posibles como el eufemismo, la polisemia, sinónimos, repeticiones y juegos de antónimos. La profesora de lengua portuguesa Nely Carvalho (2000:49) habla del vocabulario en la publicidad y afirma que:

\footnotetext{
El trabajo sobre el vocabulario del mensaje publicitario implica, todavía, sustituciones eufemísticas, o sea, el empleo de palabras y expresiones que amenicen los vocablos considerados desagradables [...]. Por la frecuencia de uso, el eufemismo puede llegar al punto de no serlo, porque pasa a identificarse semánticamente con el nombre que procura disfrazar.
}

Los adjetivos, los adverbios y las locuciones adverbiales también son formas intensificadoras usadas en el lenguaje publicitario, como hemos visto en el texto 21 . Son términos que desempeñan semánticamente un papel muy importante al intentar establecer algún tipo de influencia sobre el interlocutor. "Aunque no sea estudiado de forma sistemática en las gramáticas, consiste en un recurso muy utilizado en la lengua corriente, escrita u oral, en especial en los discursos que pretenden influenciar al receptor, como la publicidad" (Carvalho, 2000:69). ${ }^{36}$

\section{Los juegos de palabras}

El uso común del lenguaje, sea en el lenguaje oral o escrito, siempre remite a las tradiciones populares de lenguaje, que generalmente están permeadas por conceptos simplistas, basados en el sentido común. El uso de dichos populares y juegos de

\footnotetext{
${ }^{36}$ En la fuente original: “Apesar de não ser estudado de forma sistemática nas gramáticas, é um recurso muito utilizado na língua corrente, escrita ou falada, em especial nos discursos que visam influenciar o receptor, com a publicidade".
} 
palabras causa una discusión en el campo de la comunicación, dado que mientras unos defienden la idea de que consisten en pobreza lingüística, otros valoran su papel relevante a la hora de dotar de eficacia el mensaje.

Sin embargo, esta sería una discusión innecesaria ya que no se pueden favorecer los juegos de palabras cuando se pone en juego la producción de un acto de habla eficaz, sobre todo cuando se refiere al lenguaje publicitario que necesita una práctica de la comunicación social basada en la realidad, es decir, reproducir la realidad lingüística de su público objeto como uno de los objetivos únicos de este tipo de discurso. Tognolli (2001:55) se refiere a eso cuando dice que:

\begin{abstract}
El lenguaje actúa como mediación entre el individuo y la realidad, entre él y sus prácticas objetivas, en las que incluso hoy, circula la llamada ideología. Los dichos y las frases hechas se legitiman en los procesos de comunicación social y en los medios de comunicación en general porque, creemos, ya compone significativamente la práctica social, sin la cual el propio código verbal no funciona.
\end{abstract}

Con base en esta idea, no se puede rechazar cualquier tipo de lenguaje o adoptar una postura que denote cualquier prejuicio lingüístico en la elección de una palabra u otra, de un dicho u otro, de una determinada expresión de lenguaje popular porque esa es una forma real de representar el lenguaje adoptado por diversos grupos de hablantes que formarán parte del público interlocutor de determinadas campañas publicitarias.

\title{
4.4. Imagen y publicidad
}

La imagen en la publicidad actúa como lenguaje complejo bajo una cadena de perceptiva simple, aparentemente, que puede tener resultados ilocutivos y perlocutivos. Así, "en el centro del proceso funcional de la publicidad, la imagen atestigua una complejidad real, tras la evidencia engañosa de su percepción" (Adam \& Bonhomme, 2000:221). Así, en la argumentación icónica:

Al contrario del texto, que puede crear estructuras argumentativas autónomas, la imagen publicitaria necesita del apoyo lingüístico, por pequeño que este sea (nombre de la marca, eslogan), para desencadenar un desarrollo argumentativo. Esto explica por qué el caso límite de la publicidad enteramente icónica es imposible, salvo si el ícono incorpora elementos 
lingüísticos, como la foto del producto con su denominación o su etiqueta (Adam \& Bonhomme, 2000:245).

La publicidad crea costumbres, cambia valores, influye en el uso de la lengua, interviene en la vida política, social y cultural. En fin, ocupa un papel preponderante en la sociedad de un modo general y, sobre todo, en el mundo de los negocios, aunque no se pueda afirmar con precisión hasta qué punto influye positivamente en las ventas.

\section{CLASSE A LOCADORA VIAGENS E TURISMO}

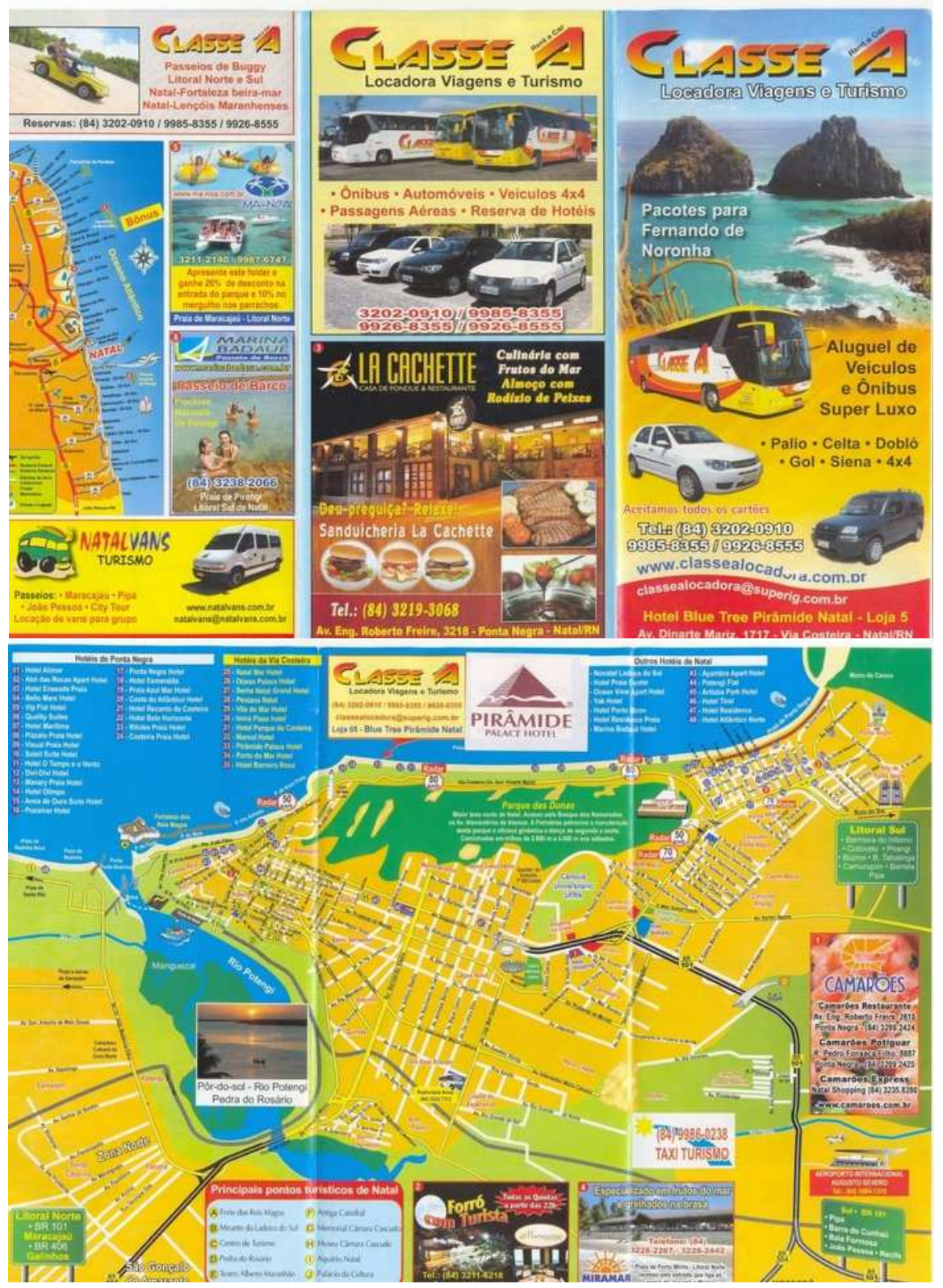

Texto 22 
Muchos abogan por la importancia de la imagen frente al uso del código verbal en el anuncio publicitario. En oposición a ello, otros defienden que el texto verbal tiene más importancia que la imagen en la publicidad. De hecho, lo único que no se puede negar es que la palabra y la imagen se unen para que el lenguaje publicitario sea más eficaz, mejor dicho, desempeñan el mismo papel y tienen la misma importancia.

Desde un punto de vista formal, el texto 22 sigue el formato propio del texto publicitario y presenta un folleto codificado por medio de la imagen y del código verbal escrito. En su macroestructura figura la descripción, básicamente por medio de imágenes, de los productos turísticos vendidos por "Classe A, Locadora, Viagens e Turismo". Así, la progresión temática de este texto puede ser definida como de progresión de temas derivados. En el texto aparece la inscripción del tú, lo que establece una relación de proximidad entre los interlocutores.

El producto visual consiste en la propia imagen de los productos turísticos ofrecidos por "Classe A, Locadora, Viagens e Turismo" y el mapa de la costa de Natal. El mensaje manifiesto es de varios productos turísticos y el mensaje latente es elije tu producto turístico favorito, contacta “Classe A, Locadora, Viagens e Turismo” para comprar uno de nuestros productos.

En el anuncio en cuestión, la imagen predomina frente al lenguaje verbal, pero este no pierde su importancia de anclaje. La imagen, sin ningún tipo de texto verbal, quedaría ambigua y el mensaje publicitario perdería una de sus principales características: la de producir un acto de habla eficaz. También cuenta la presencia léxica de sintagmas como lujo, relajar y pereza, de carácter hedonista, lo cual aporta un carácter positivo al discurso publicitario. 


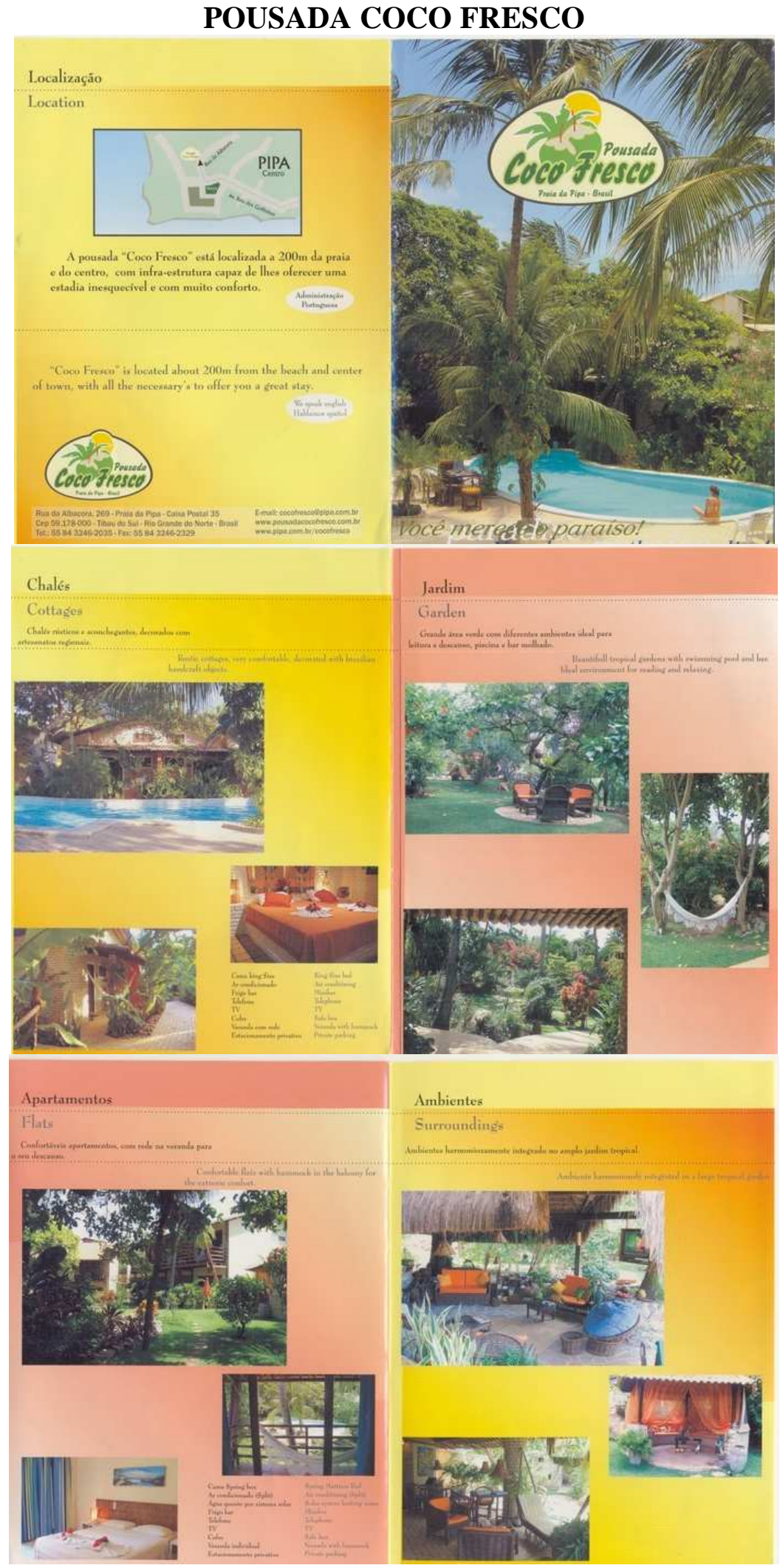

Texto 23

Adam \& Bonhomme (2000:246) también mencionan que "la imagen publicitaria actúa entonces a la manera de una máquina ostentatoria que genera pistas contextuales de 
lectura, unas veces esbozadas y otras fuertemente marcadas". En publicidad todo debe ser mostrado por medio de una descripción fiel de lo que se anuncia porque este tipo de lenguaje exige la demostración y la imagen para captar la atención y seducir al destinatario-consumidor. En los anuncios hay una gran variedad de disposiciones especiales porque la publicidad saca provecho de combinaciones geométricas con valor persuasivo como se observa a continuación:

\begin{abstract}
Más allá de estas disposiciones espaciales, la publicidad saca partido de otras combinaciones geométricas igual de persuasivas. Pueden tomar la forma de un barrido panorámico, circunscrito por la figura aplastada y alargada de un rectángulo. El anuncio se sitúa generalmente en la parte inferior de una página doble, lo cual amplía al máximo el campo ocular, como en algunas publicidades turísticas que representan paisajes (Adam \& Bonhomme, 2000:104).
\end{abstract}

Como vimos anteriormente, tanto la imagen como el código verbal tienen importancia fundamental en el lenguaje publicitario, y por eso opinamos que los elementos visuales se funden con los elementos verbales. Luisa Blanco Rodríguez (2005:171) apunta que "la figura se articula en palabra y la palabra se resume en figura; como consecuencia la visión no sustituye a la lectura, sino que se confunde con ella".

En la macroestructura del texto 23, figura la descripción de la "Pousada Coco Fresco" y sus instalaciones. La progresión temática de este texto puede ser definida como progresión de tema constante. La persona del discurso presente es la inscripción de la segunda persona del singular, que disminuye las distancias entre emisor y el destinatario.

En el eslogan de la publicidad en cuestión se dice: mereces este paraíso, con una foto de la Pousada Coco Verde, ubicada en la playa de Pipa, municipio de Natal. En el marco léxico de este anuncio figuran sintagmas como paraíso, inolvidable, confort, rústico, acogedor, grande, descanso, confortable, hamaca, harmoniosamente, amplio y jardín tropical, es decir, todos los sintagmas forman parte de un léxico positivo que probablemente influirá de forma positiva en sus interlocutores.

Este texto posee una secuencia dominante de texto argumentativo, ya que la descripción funciona más bien como un recurso persuasivo. Su producto visual consiste en la propia 
imagen de la "Pousada Coco Fresco" y sus instalaciones, cuyo mensaje manifiesto anuncia un lugar elegante y tranquilo para la instalación del turista, y el mensaje latente apunta un lugar acogedor, confortable, relajado y paradisíaco. Además se afirma que mereces el paraíso.

¿Por qué este texto es persuasivo? porque llama la atención del lector, es memorable, usa un lenguaje positivo y de fácil decodificación; es conciso, atrapa la atención del receptor y presenta las imágenes de los productos turísticos de forma tan real como el propio producto o servicio.

Además, se puede perfectamente sacar la conclusión de que la mezcla de códigos visuales y verbales en la publicidad es más bien una regla que una excepción, ya que es lo que encontramos normalmente en el texto publicitario. Luisa Blanco Rodríguez (2005:172) defiende esta misma concepción de mezcla de códigos en el mensaje publicitario cuando admite que:

\begin{abstract}
La multiplicidad y complejidad de factores que intervienen en la publicidad hacen que esta se haya convertido en un fenómeno interdisciplinario en el que colaboran varios ramos del saber y de la técnica. Aunque, actualmente, la imagen y el sonido están en su máximo apogeo, el lenguaje sigue siendo un vehículo significativo de información y de sugestión en la publicidad.
\end{abstract}

Lo que se puede ver en ese contexto es que algunos teóricos priorizan como importante el lenguaje verbal, mientras que otros dan más valor a la imagen. Entre los publicistas actuales están los que defienden que "una imagen vale más que mil palabras". Sin embargo, podemos añadir que una imagen sola puede volverse ambigua y sin comprensión, por eso, muchas veces necesita la palabra para anclarla. Ante lo expuesto hay, pues, una necesidad de armonización entre lenguaje escrito y visual, dado que, aunque una imagen valga más que mil palabras, frases como esta no pueden ser dichas sin el uso de la palabra.

Victoria Romero (2005:86) defiende una tipología del uso de la imagen y el texto de forma equilibrada en la publicidad. Para ello, establece las cuatro categorías siguientes de combinaciones de imagen y texto según la función e importancia de cada uno: 


\begin{tabular}{|l|l|}
\hline \multicolumn{1}{|c|}{ CATEGORÍA } & \multicolumn{1}{c|}{ COMBINACIÓN } \\
\hline PRIMERA & Un texto funcional y una imagen racional \\
SEGUNDA & Un texto poético e imagen racional \\
TERCERA & Un texto funcional y una imagen más poética \\
CUARTA & Un texto poético, subjetivo, etc., e imagen simbólica \\
\hline
\end{tabular}

Según Martínez (2000:18), la imagen en la publicidad desempeña la función fática, la función apelativa o conativa, la función referencial y la función poética. En lo que concierne a la asociación entre la imagen y el mensaje publicitario, está claro que la cooperación mutua de estos dos códigos suma características lingüísticas positivas en la construcción de un texto publicitario equilibrado y eficaz. Victoria Romero (2005:84) también defiende esa misma idea de equilibrio entre imagen y texto y afirma que "no se debe considerar el texto como una brida que siempre sujeta la imagen, hay que desechar el prejuicio de la naturaleza vicaria o subordinada de la imagen respecto del texto”.

\section{La imagen social}

En la sociedad del bienestar, muchas veces, la apariencia y la posesión de bienes que encuadran a la gente en un determinado grupo social pueden ser más importantes que cualquier otra cosa. Antonio Vilarnovo (2005:46) defiende la idea del hombre como un ser social, por eso en "la compra de un producto el consumidor puede buscar reconocimiento social. Así, el grupo se transformaría en el marco de referencia de los miembros. [...]. Comprar un producto supondría acceder a un grupo".

Desde esta perspectiva, la publicidad ayuda al consumidor a elegir el grupo al cual quiere pertenecer socialmente y cómo debe parecer para sentirse parte de dicho grupo. Ello implica la adquisición de bienes de consumo que supuestamente los miembros de determinado grupo social necesitan poseer. En la opinión de Antonio Vilarnovo (2005:61), "la publicidad se manifiesta como un medio poderoso de interacción social y cultural. De ahí la necesidad de una ética del discurso publicitario". 


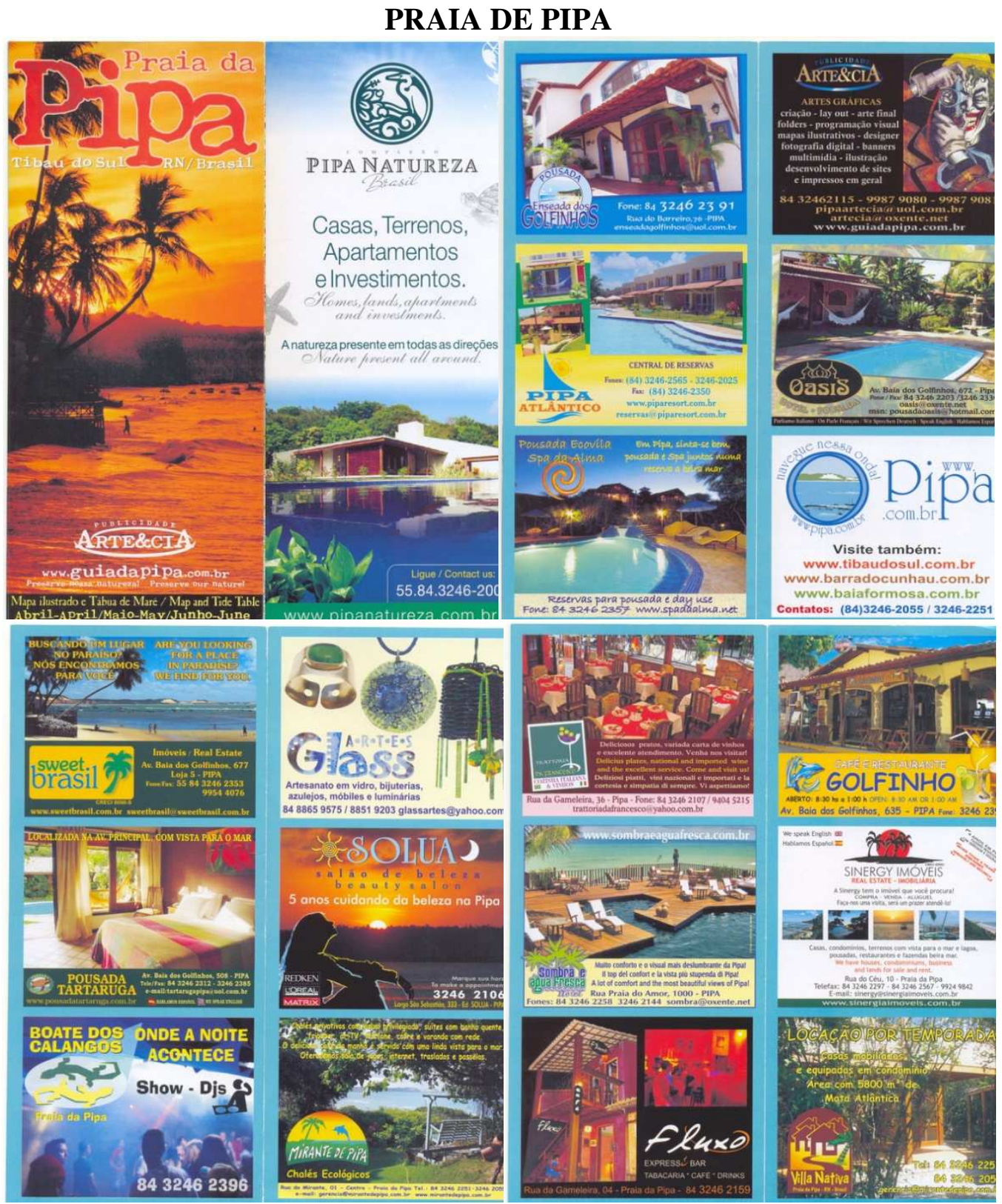

Texto 24

En complemento a la idea del establecimiento de una ética en la publicidad, es importante resaltar que en cada país hay una legislación específica que rige y controla la producción publicitaria, pero eso no implica que existan mecanismos de defensa del consumidor frente al dominio ideológico de la publicidad en los medios de comunicación en masa.

Pese a temas como la ética en la publicidad, lo que queremos resaltar en este punto de nuestro trabajo es que la imagen es tan importante para el lenguaje publicitario como las palabras. La asociación creativa e inteligente de ambas crean la imagen positiva o 
negativa de determinado producto, objeto o persona e influye en la decisión del interlocutor.

En la macroestructura del texto 24, figura la descripción de todos los productos turísticos que se puede encontrar en la playa de Pipa. Su progresión temática puede ser definida como de progresión de temas derivados.

El texto es impersonal y su acto de habla locutivo está constituido por el lenguaje verbal escrito y el lenguaje visual; el ilocutivo, en la descripción del producto turístico ofertado y su ubicación; y el perlocutivo, en la estrategia de persuasión publicitaria que tiene como finalidad recibir del interlocutor la confirmación en forma de un acto de compra.

El producto visual consiste en la propia imagen de todos los productos de interés turístico que se puede encontrar en Pipa. Su mensaje manifiesto es de un lugar ecléctico y con los más diversos productos turísticos y el mensaje latente invita al interlocutor a visitar Pipa.

Este folleto publicitario es un ejemplo del uso del medio y del código para anunciar varios productos a la vez en un único anuncio. El mensaje lingüístico tiene la función de anclaje y el mensaje visual sirve como gancho. Sin embargo, en la unión de esos dos códigos reside la creatividad y la particularidad de un anuncio publicitario. En el marco léxico del texto en cuestión, figuran palabras como bello, paraíso, belleza, descanso y confort, es decir, un léxico positivo, típico de la publicidad. 
Para concluir este apartado sobre la imagen publicitaria, es importante observar que Martínez (2000:12-28), cuando remite al estudio e interpretación de la imagen publicitaria, subdivide ese tema en cinco apartados, como exponemos a continuación.

\begin{tabular}{|l|l|}
\hline \multicolumn{1}{|c|}{ APARTADO } & \multicolumn{1}{c|}{ SUBDIVISIÓN } \\
\hline PRIMERO & Mensajes en la publicidad impresa; \\
SEGUNDO & Regímenes de figuración; \\
TERCERO & Funciones de la imagen publicitaria; \\
CUARTO & Funciones del mensaje lingüístico en relación con la imagen; \\
QUINTO & Funciones del mensaje lingüístico en relación con la imagen. \\
\hline
\end{tabular}

\subsection{Lenguaje en la publicidad}

El lenguaje de la publicidad está anclado en un material auténtico y original, a partir de un código internacional que combina el lenguaje iconográfico con el verbal y difunde mensajes de comprensión fácil en las que el componente pragmático es importante a la hora de decodificarlas. Este tipo de lenguaje puede servir como muestra de los diversos registros y variedades linguí́sticas de una comunidad dada de hablantes, pero eso no compromete sus tres reglas de oro que son: la concisión, la claridad y la brevedad.

La fuerza ilocutiva en el discurso publicitario proviene de la intención de su locutor: conquistar clientes. Para López Eire (1998:65), la fuerza ilocutiva del acto de habla publicitario es resultado de la intencionalidad (voluntas) de su emisor, a saber: ganarse la voluntad de grupos de individuos de la sociedad de consumo para abrirles el apetito de adquirir productos. 


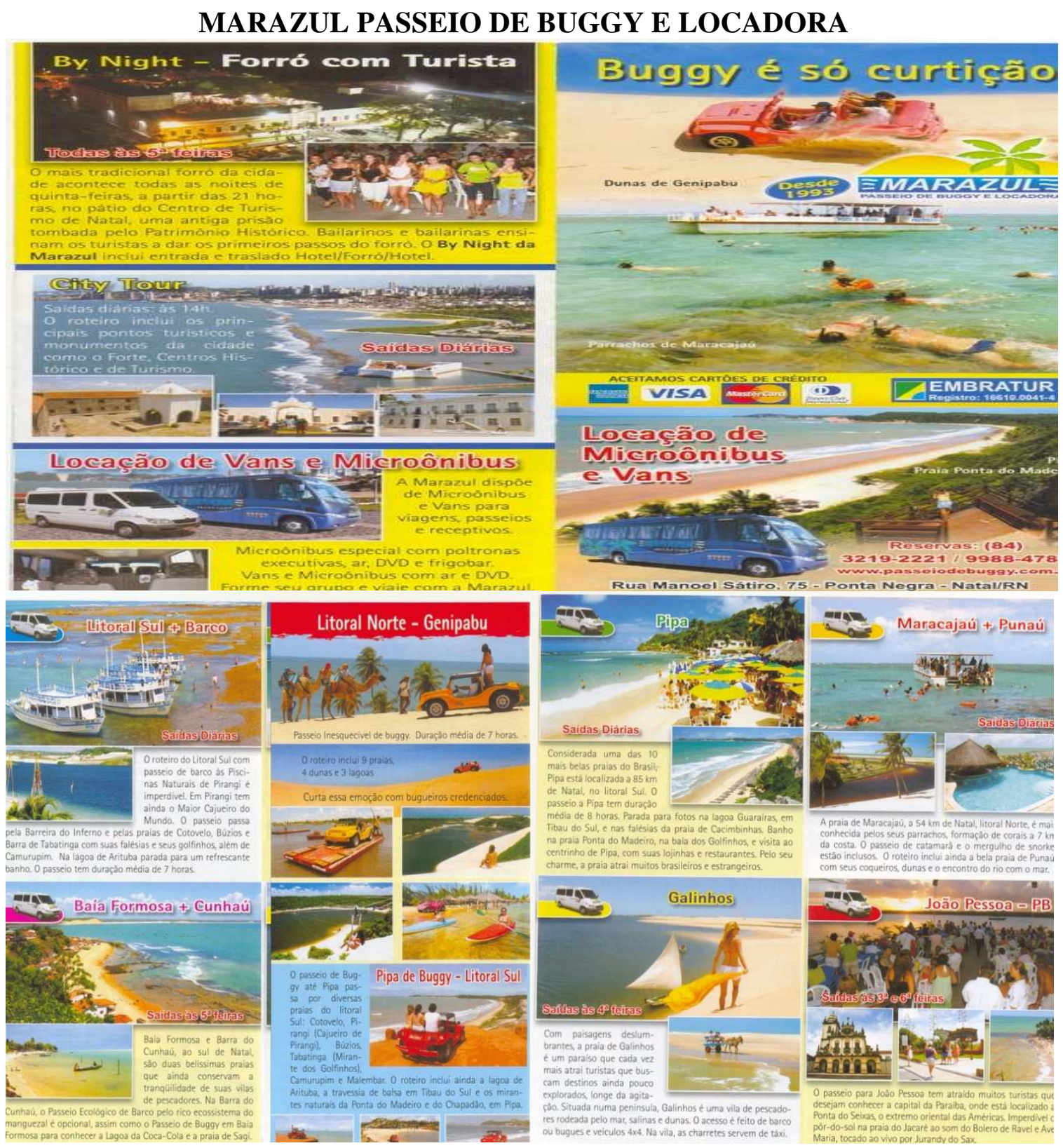

Texto 25

El lenguaje publicitario tiene un carácter seductor que actúa en la persuasión del consumidor y en la seducción para la compra, o sea, para el consumo del producto o servicio anunciados. No obstante, es efímero porque se fundamenta en valores sociales y culturales cambiantes. La publicidad, a su vez, es un mecanismo inseparable de la economía en la sociedad contemporánea, sobre todo en los países económicamente desarrollados donde se vive el estado de bienestar social.

En su macroestructura figura la descripción de la agencia "Marazul Passeio de Buggy e Locadora" y la forma de entrar en contacto con esta agencia. Además, presenta todos los 
productos turísticos comercializados por esta empresa. La progresión temática de ese texto puede ser definida como de progresión de temas derivados.

La persona del discurso presente es la inscripción del "nosostros", como una forma retórica de cortesía. El texto está contextualizado en la ciudad de Natal y otros puntos de interés turístico cercanos. El acto de habla locutivo consiste en el discurso constituido por el lenguaje verbal escrito y el lenguaje visual; la fuerza ilocutiva en la descripción del producto turístico ofertado y su ubicación; y el efecto perlocutivo en la estrategia de persuasión publicitaria que tiene como finalidad recibir del interlocutor la confirmación en forma de un acto de compra.

El producto visual consiste en la propia imagen de todos los productos turísticos comercializados por "Marazul Passeio de Buggy e Locadora”. El mensaje manifiesto es la calidad y exuberancia de estos productos. El mensaje latente es una invitación al consumo de dichos productos turísticos.

Al describir los productos turísticos por imagen y por el lenguaje verbal, se adopta un léxico positivo en el que figura un vocabulario como: fiesta, tradicional, antigua, patrimonio histórico, principales, especial, inolvidable, emoción, imperdible, refrescante, bellísima, tranquilidad, bellas, paisajes, deslumbrante y paraíso.

En lo visto hasta ahora, parece claro que el lenguaje de la publicidad emplea códigos distintos (verbal y visual) además de ser un fenómeno contemporáneo y social, de carácter pragmático, que culmina en acción: la adquisición de un producto o servicio. 
CONHEÇAM NATAL TURISMO

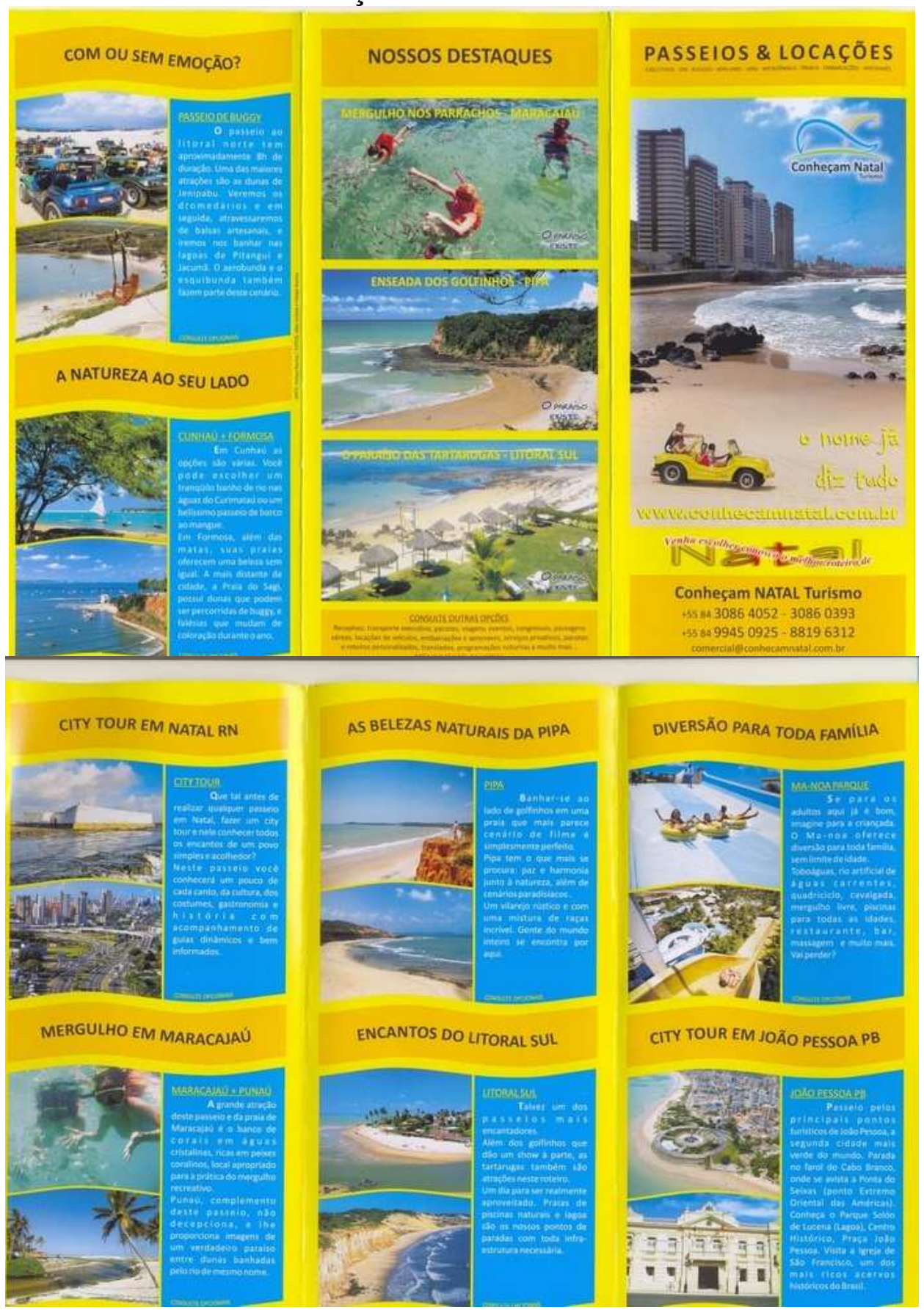

Texto 26 
Ya en el siglo $\mathrm{V}$ a. C. se enunciaban el carácter activo del discurso en el ámbito social. Siglos más tarde, Gracián, por ejemplo, entendía las palabras como sombra de los hechos, idea reafirmada cuando recientemente se concibe el lenguaje como un fenómeno activo, pragmático y social, es decir, palabras en acción. López Eire (1998:11) destaca esta aportación:

\begin{abstract}
El lenguaje es fundamentalmente interactivo, pragmático y está necesariamente encuadrado en el entorno social en el que actúa, y que por consiguiente la retórica, que es arte de la palabra en acción, puede entrar con todo derecho a tomar parte en el amplio debate en el que participan varias y variadas disciplinas que se mueven en torno a esa función social y pragmática por excelencia que es el objeto de estudio del arte de comunicar.
\end{abstract}

Múltiples disciplinas como la hermenéutica, la lógica, la psicología, la sociología, la pedagogía, la poética y la lingüística contribuyen para los estudios de la comunicación social, en la que la retórica figura como ciencia subdividida en ámbitos como el de la argumentación, el de técnicas de expresión, el de las estrategias comunicativas, el de la publicidad y el de la comunicación audiovisual, etc.

En la macroestructura del texto 26 figura la descripción todos los productos turísticos comercializados por la empresa "Conheçam Natal Turismo". Además, esta publicidad también expone los medios y formas de ponerse en contacto con esta empresa. La progresión temática de este texto puede ser definida como de progresión de temas variados y la persona del discurso presente es la inscripción del "vosotros", presentando así un carácter de proximidad entre el emisor y el destinatario.

Ese texto pertenece al género del discurso publicitario y desde un punto de vista de la tipología textual posee una secuencia dominante de texto argumentativo, ya que la descripción funciona más bien como un recurso persuasivo. El producto visual consiste en la propia imagen de todos los productos turísticos ofertados por la empresa “Conheçam Natal Turismo". El mensaje manifiesto es la calidad e importancia de los productos turísticos anunciados y el mensaje latente es la excelencia de dichos productos y la invitación a consumirlos.

Con el eslogan "el nombre ya lo dice todo", la empresa anunciada formula una invitación a sus interlocutores: "ven a elegir con nosotros la mejor ruta de Natal". A 
partir de ello presenta sus productos (Citytour, Pipa, Ma-noa Parque, Maracajaú y Punaú, Litoral Sul, João Pessoa, paseo de buggy, Cunhaú y Formosa). Para presentar esos productos usa tanto lenguaje visual como el verbal, por medio del que adopta un léxico positivo con sintagmas como; realizar, conocer, encanto, simple, acogedor, costumbres, gastronomía, dinámicos, bien informados, perfecto, paz, harmonía, naturaleza e increíble.

Según Ferrer (1994:290), “tres elementos gramaticales comandan fundamentalmente el lenguaje publicitario. Son los colores más usuales en el gran telón de su pintura. Nos referimos al sustantivo, al adjetivo y al verbo." Como podemos ver en el marco léxico destacado del texto 26 , los elementos gramaticales predominantes en este anuncio son realmente sustantivos, adjetivos y verbos, con lo cual, sirve para corroborar lo que dijo Ferrer (1994).

Con eso podemos inferir que esas tres clases de palabras son predominantes en un texto publicitario que muchas veces explicita algunas identificaciones nacionalistas y apelaciones sexuales tanto a través de imágenes como por el léxico adoptado.

\begin{abstract}
Una de las inclinaciones del lenguaje publicitario que merece atención es el giro sexualista [...]. Creemos que las imágenes cinematográficas y las televisivas han impulsado decisivamente esta tendencia. Lo que revalida nuestra tesis de que son los contenidos de los medios de comunicación, el libro y la pintura incluidos, los que más influyen en los hábitos o conductas del público. Como tema social no es nuevo (Ferrer, 1994:334).
\end{abstract}

El lenguaje publicitario puede ser denotativo o connotativo, y la opción por uno u otro está determinada por el texto, el producto al cual se refiere, la situación, etc. Así, un texto publicitario puede tener tanto la característica de un texto utilitario que se difunde por medio de un lenguaje denotativo, como la característica de un texto artístico o literario, que es connotativo por excelencia.

Además, el lenguaje de la publicidad está desautomatizado, en el sentido de que construye significados múltiples y distintos sin limitarse a las acepciones del diccionario; también es plurisignificativo y posee la función poética como una de sus funciones de lenguaje predominantes. 
En el marco léxico del texto 27, que expondremos a continuación, figura también el predominio del sustantivo, del adjetivo y del verbo como los tres elementos gramaticales predominantes en el lenguaje de la publicidad. La selección léxica adoptada tiene un carácter positivo y por eso contribuye a la persuasión del interlocutor. No obstante, el lenguaje visual adoptado en este texto no es tan neutro y utilitario como el lenguaje verbal, ya que, desde nuestro punto de vista, trabaja con apelaciones o giros sexuales, pues en casi todas las imágenes hay un curioso protagonismo de la imagen femenina. Eso corrobora que el giro sexual es una de las más variadas estrategias de seducción de la publicidad y fue adoptado en la elaboración de este folleto publicitario.

\section{PIZZATO PRAIA HOTEL}

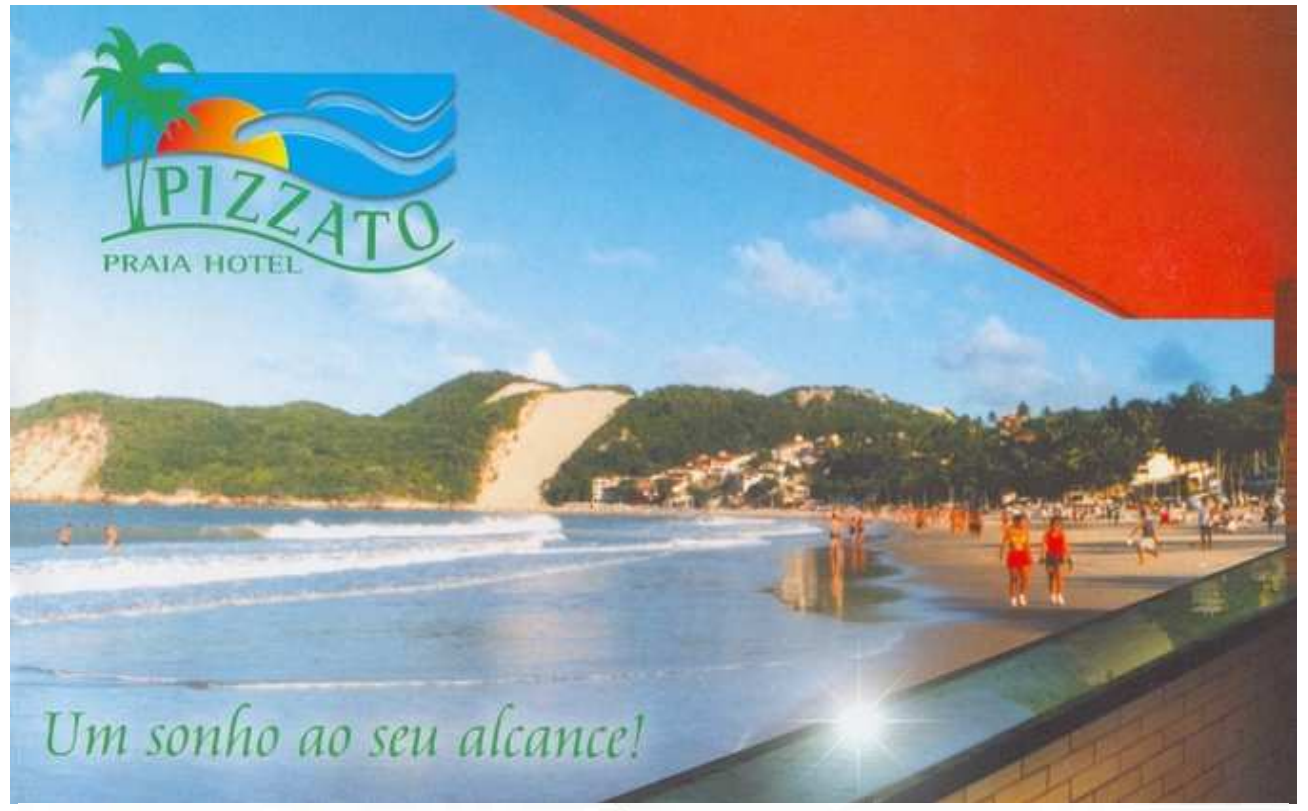

Entregue-se ao prazer de uma maravilbosa bospedagem! Surrender to the pleasure of a wonderful lodging!

O Pizzato Praia Hotel possui todos os requisitos para a estadia dos seus sonbos. Além de estar localizado na bela e famosa Praia de Ponta Negra, encontra-se proximo a sbopping centers, feira de artesanato, bares, ao Centro de Contençóes e esta a apenas 15 minutos do aeroporto.

o Pizzato dispóe de 63 excelentes apariamentos, uma agradátel área de lazer que inclui piscina com cascata, coffee sbop, american bar, loja de souvenirs e restaurante com delicioso café da manbã e cardapio regional e internacional. O Hotel conta com salào de eventos e de jogos com teläo, internet e fax e serviços de lavanderia.

Pizzato Praia Hotel bas eteryibing you need for your dream fodging. It is located at the famons and beautifuf Ponta Negra beacb near sbopping centers, bandcraft shops, bars, the Contemtion Center and it is only 15 minutes away from lbe airport

Pizzato offers 63 excellent rooms, a pleasant amusement area, wbicb includes a pool witb cascade, a coffee sbop, american bar, somenir store and a restaurant witb a delicious breakfast witb local and international menus. Tbe botel also has a room for events and games witb a big screen TV, internet, fax and laundry services
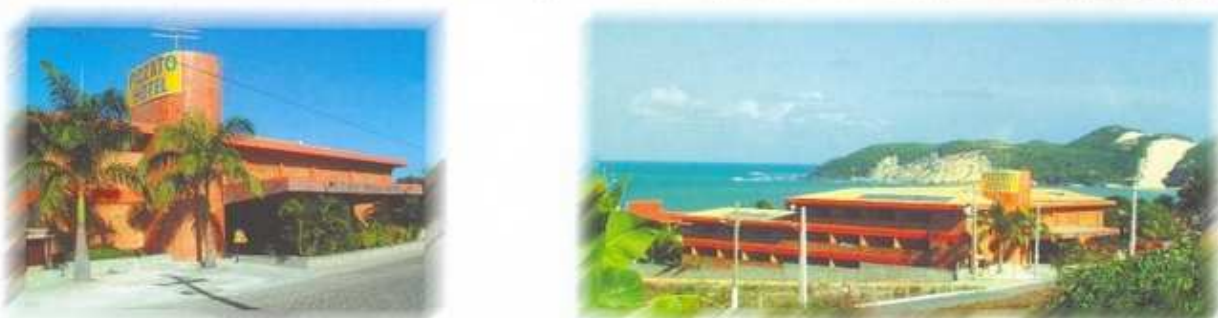


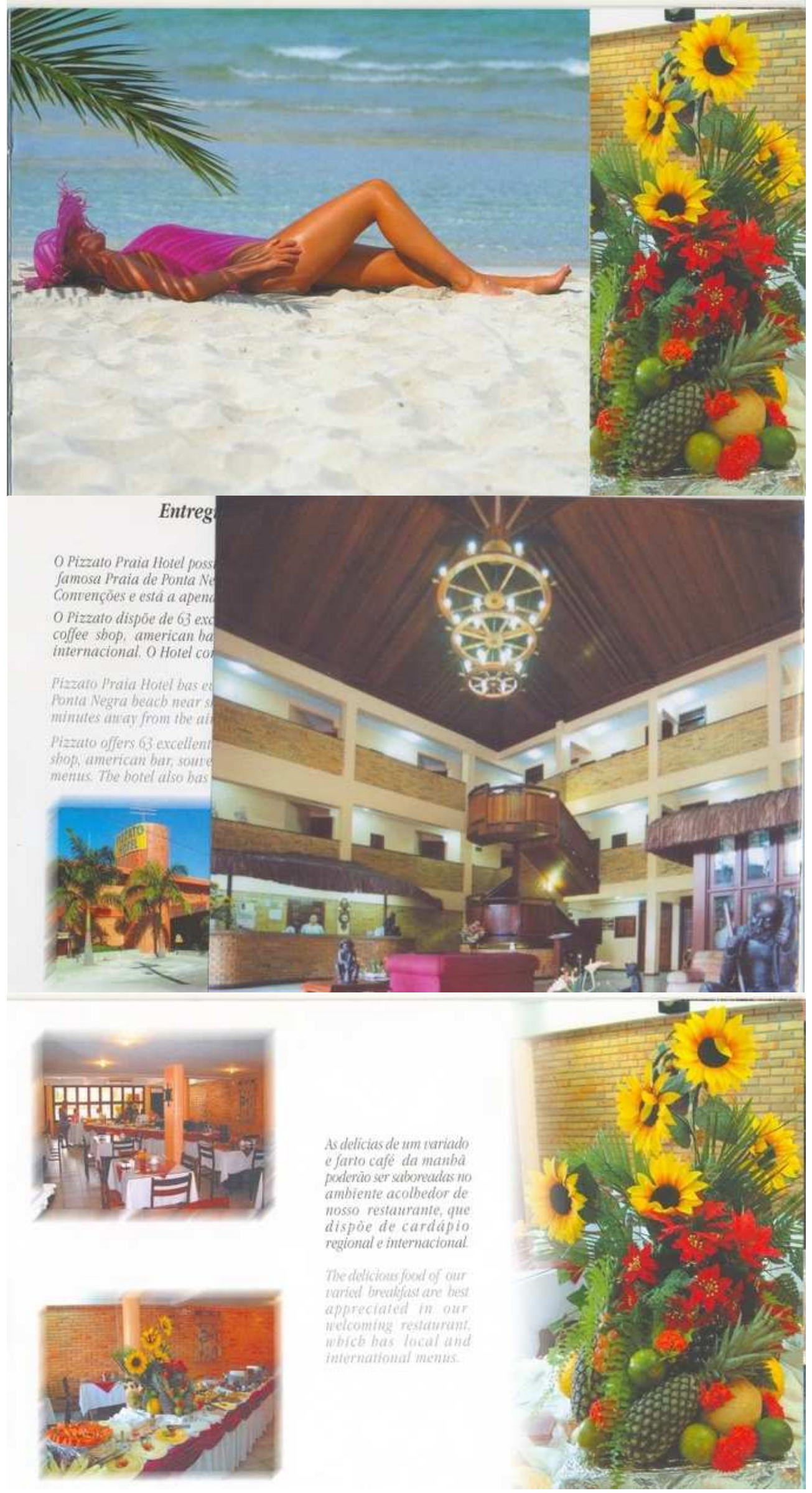




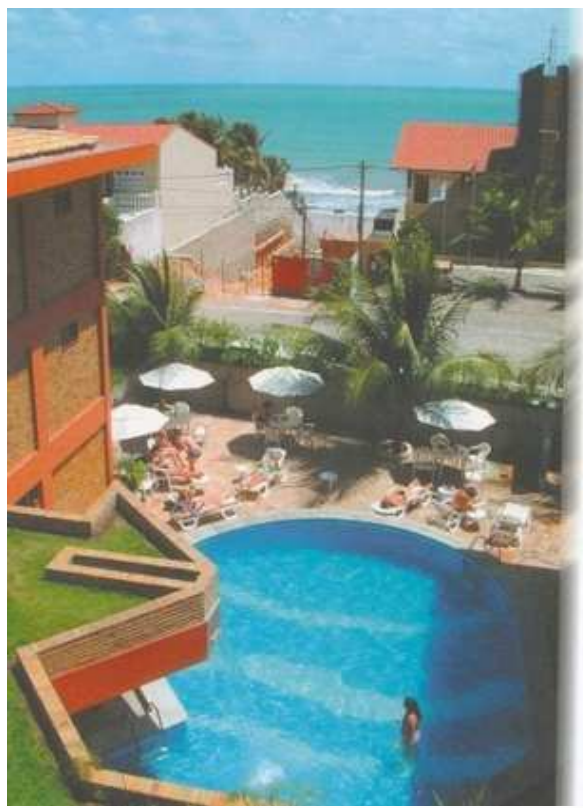

Nada como um belo dia de sol e um deliciaso e relaxante banbo em nossa piscina com cascata.

There is notbing as relaxing as a suim in our pool weith cascade.
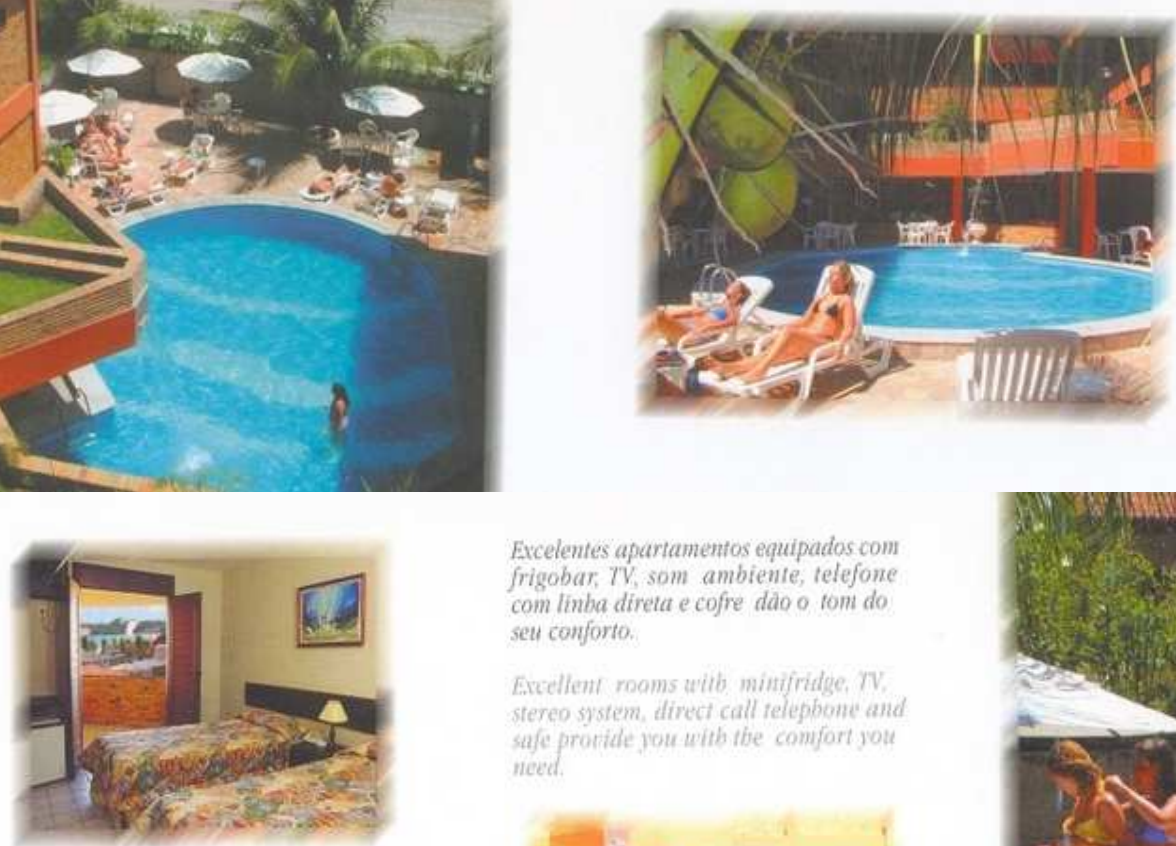

Excelentes apartamentos equipados com frigobar TV som ambiente, telefone com linha direta e cofre dao o tom do seu conforto.

Excellent rooms witb minifridge, $7 V$, stereo system, direct call telepbone and safo proride you with the complort yot need.
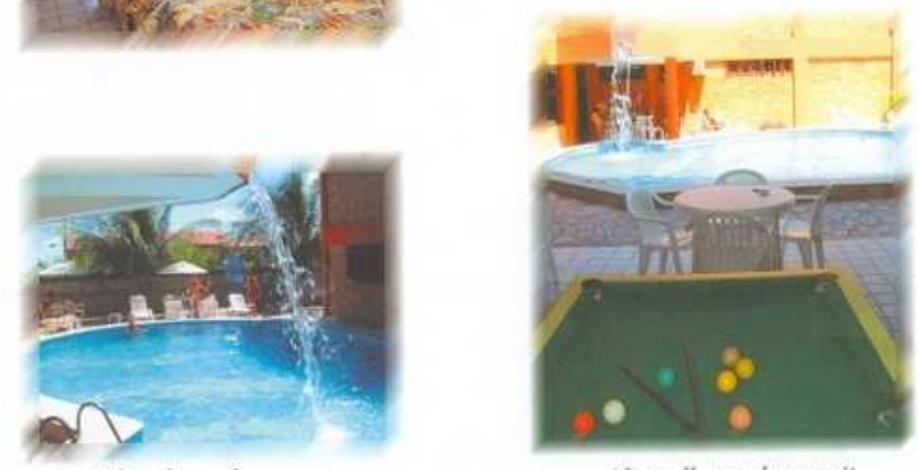

Aftercell, you deserve it.
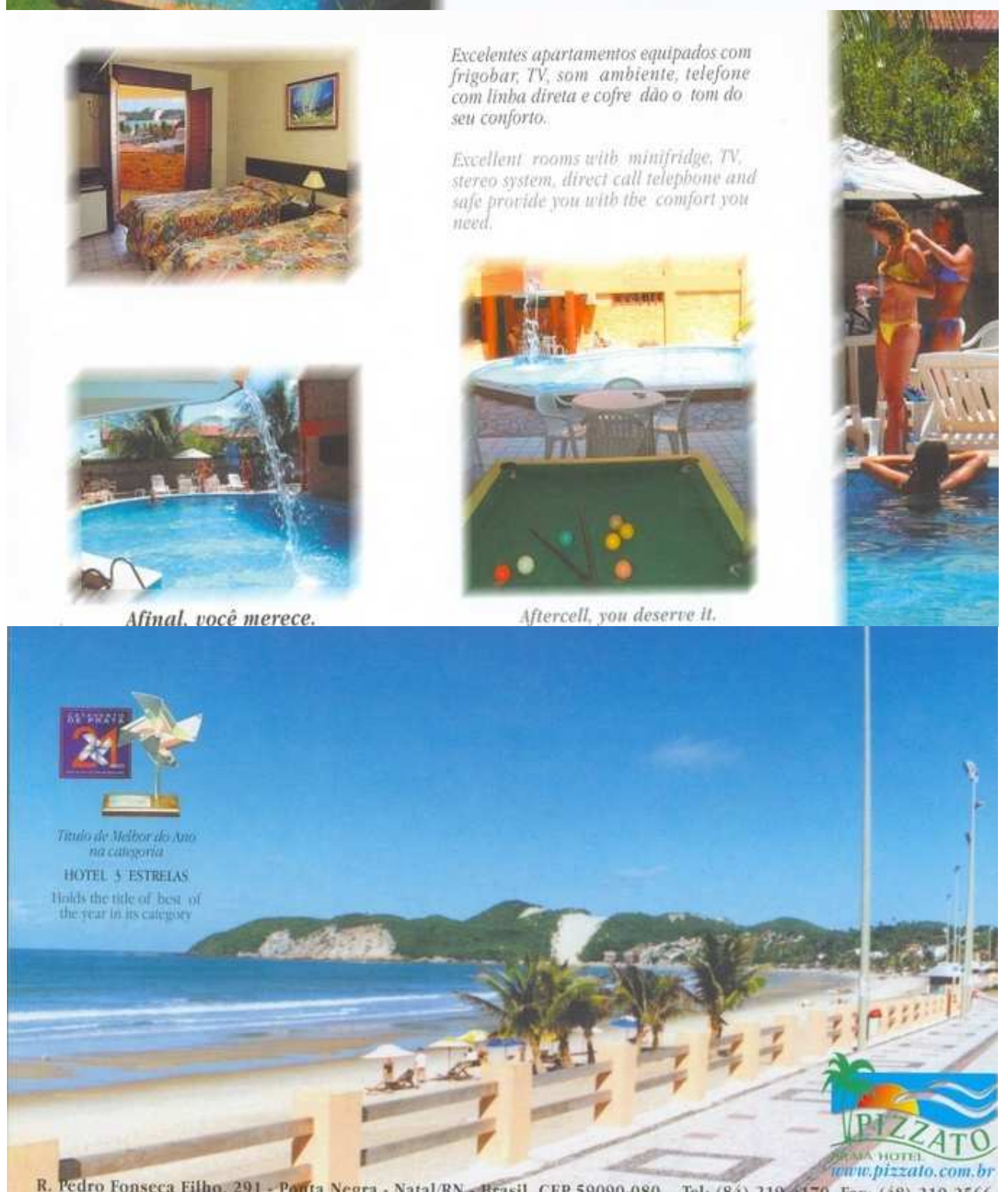

Texto 27 
Desde un punto de vista formal, ese texto sigue el formato propio del texto publicitario. Fue elaborado a partir de una mezcla de códigos, más específicamente del código visual y el código verbal. En su macroestructura figura la descripción del "Pizzato Praia Hotel”, la presentación de su localización, sus servicios y sus instalaciones (internas y externas).

La progresión temática de este texto puede ser definida como una progresión de tema constante. Las personas del discurso presentes son la tercera persona del singular que designa al objeto anunciado de forma impersonal y la inscripción del "você", en portugués de Brasil, que tiene la fuerza semántica del "tú" en español, presentando así un carácter de proximidad entre el emisor y el destinatario, lo que acorta las distancias y aporta más confianza entre los interlocutores.

El acto de habla locutivo consiste en el discurso constituido por el lenguaje verbal escrito y el lenguaje visual; el ilocutivo en la descripción del producto turístico ofertado y su ubicación; y el perlocutivo en la estrategia de persuasión publicitaria que tiene como finalidad recibir del interlocutor la confirmación en forma de un acto de compra.

El producto visual consiste en la propia imagen interna y externa de "Pizzato", cuyo mensaje manifiesto consiste en el propio anuncio de este hotel y el mensaje latente connota un ambiente relajado, elegante y confortable. El contenido expandido del texto dice ya en la primera página del folleto: Pizzato Praia hotel, un sueño a tu alcance, es decir, se anuncia la realización de un sueño.

Bajo este eslogan se presenta el siguiente texto: Entrégate al placer de un maravilloso hospedaje. El Pizzato Praia Hotel posee todos los criterios para una estancia de tus sueños. Además de ubicarse en la bella y famosa playa de Ponta Negra, está localizado cerca de los centros comerciales, feria de artesanía, bares, centro de convenciones y está solo a 15 minutos del aeropuerto. El Pizzato dispone de 63 excelentes [...]. Las ricuras de un sabroso y variado desayuno pueden ser degustadas en un ambiente acogedor de nuestro restaurante, que dispone de un menú regional e internacional. Nada como un bello día de sol y un buen y relajante baño en nuestra piscina con cascada. Excelente apartamento equipado con [...] matizan tu confort. 
Una vez más, es importante destacar el marco léxico de este anuncio que presenta términos básicamente positivos y hedonistas: agradable, ocio, sabroso, placer, maravilloso, hospedaje, todos los criterios, estancia de tus sueños, bella, famosa, cerca, centros comerciales, feria de artesanía, bares, centro de convenciones, excelentes, ricuras, rico, variado, desayuno, degustadas, ambiente acogedor, restaurante, internacional, bello, sol, buen, relajante y confort.

En el texto 27 se trata del producto anunciado de modo muy objetivo y se sigue una secuencia descriptiva verbal. La parte visual, por su parte, sigue una línea más poética y subjetiva que sirve como gancho del texto, que es más funcional. Otro punto que merece ser destacado en este folleto es el intento de despertar sentidos como la visión y el gusto. También se puede encontrar un lenguaje elegido cuidadosamente que puede adquirir un sentido desautomatizado y plurisignificativo.

En fin, todo tiene que ver con que el mensaje publicitario manipule un lenguaje centrado sobre sí mismo, una vez que se vuelve sobre su propio significante y significado. Según Ferrer (1994:344) “enemigo de la ambigüedad, el lenguaje publicitario es un sistema comunicativo con finalidad. Trata de ser un sistema de estímulos apto para provocar una respuesta prevista o planeada". También es importante mencionar en este contexto que el lenguaje publicitario es familiar, próximo, humanista y popular.

Refiriéndose al poder de las palabras, López Eire (1998:23) plantea la idea de su finalidad de producir una acción social. Según este autor, "el lenguaje más bien está destinado a la acción, a la interacción social, mediante esa tremenda fuerza que en él reside y que es capaz de arrasar y hacer añicos el usual significado de las palabras".

Actualmente el lenguaje publicitario ocupa un papel de protagonismo en la sociedad, además de ser un lenguaje interesado que crea necesidad de consumo y muestra la resolución de todos los problemas de la audiencia o, mejor dicho, la propia felicidad del interlocutor por medio de la adquisición de un determinado producto o servicio. 


\section{ZÁS-TRAS SHOPPING SHOW}
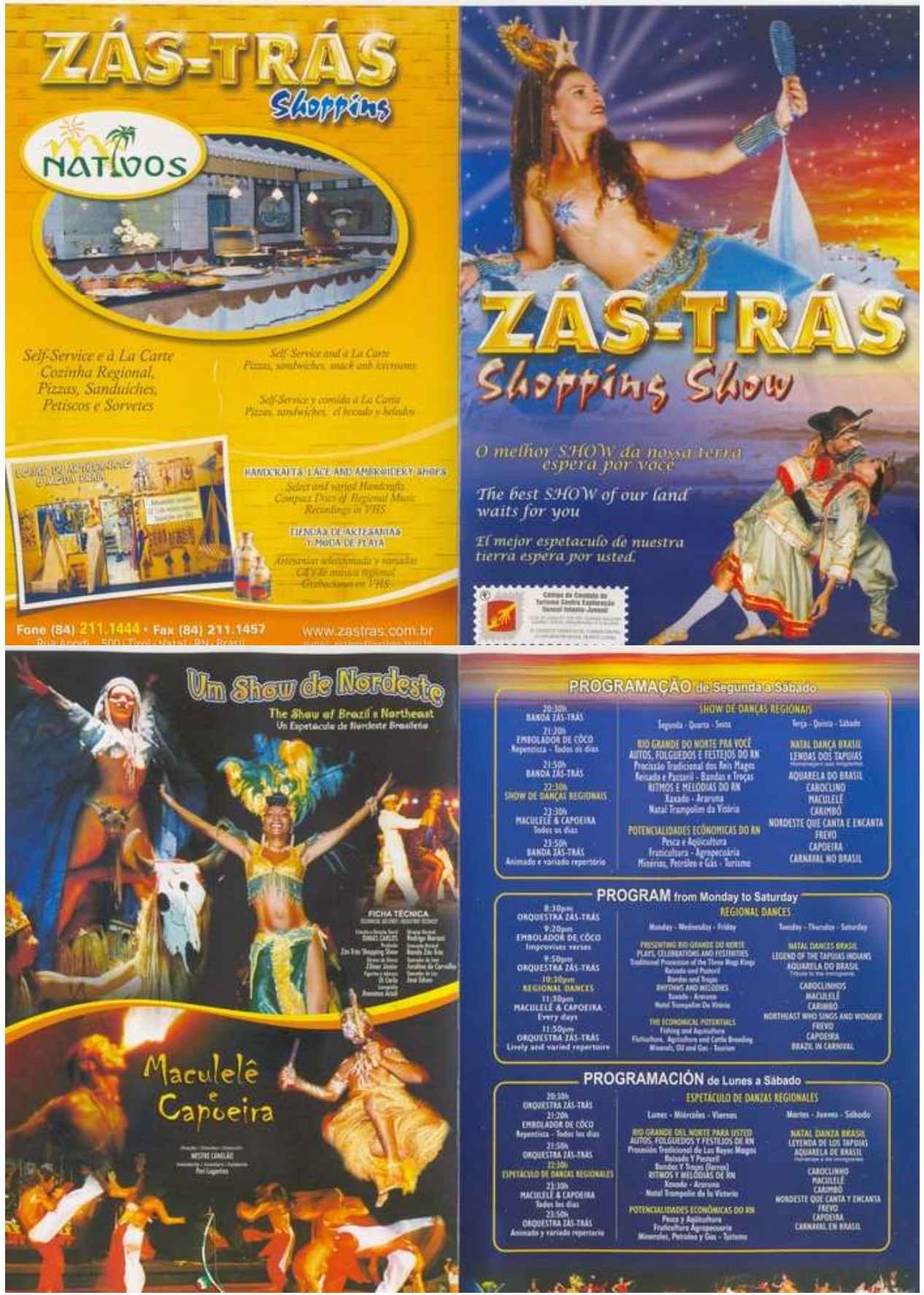

Texto 28

El zás-tras shopping show, el mejor espectáculo de nuestra tierra espera por ti. A partir de este eslogan, el texto 28 define el producto que será anunciado y, como no podría ser distinto, se trata del mejor. Sin duda alguna, estamos delante de un texto publicitario y, por lo tanto, persuasivo.

En su macroestructura figura la descripción del "Zás-Tras Shopping Show", la presentación de su localización, sus espectáculos y su forma de contacto. La progresión 
temática de este texto puede ser definida como de una progresión de tema constante. Las personas del discurso presentes son la tercera persona del singular, que remite al producto anunciado, y la inscripción del "você", en portugués de Brasil, que tiene la fuerza semántica del "tú” en español, presentando así un carácter de proximidad entre el emisor y el destinatario.

Como todo texto publicitario, el acto de habla perlocutivo consiste en la estrategia de persuasión publicitaria que tiene como finalidad recibir del interlocutor la confirmación en forma de un acto de compra. Mientras el acto de habla locutivo muestra el discurso constituido por el lenguaje verbal escrito y el lenguaje visual; y el ilocutivo, la descripción del producto turístico ofertado y su ubicación.

El producto visual consiste en la propia imagen del ambiente externo e interno del "ZásTrás", además de la imagen de los artistas caracterizados de ropas folklóricas típicas para los espectáculos de esa casa. El mensaje manifiesto corresponde al anuncio publicitario del "Zás-Tras Shopping Show" y el mensaje latente connota la alegría, la belleza, la sensualidad y la cultura local presente en este sitio. Refleja la conquista de la palabra y del lenguaje sobre la ideología dominante para un determinado grupo social. Según Ferrer (1994:27), "la conquista por la palabra ha remplazado a la conquista por las armas. Las palabras que no sólo hablan al mundo, sino que lo seducen, lo cual nos obliga a conocer el lenguaje con mayor precisión". Todo ello suma valores a nuestra opinión respecto del dominio que el lenguaje tiene sobre la sociedad contemporánea, sobre todo el lenguaje publicitario.

Tanto el lenguaje visual como el verbal tienen un carácter utilitarista e informativo de modo que el producto anunciado es tratado denotativamente. Sin embargo, el giro sexual como estrategia persuasiva en los textos publicitarios, también puede ser identificado en ese texto, de la misma forma que lo identificamos en el texto 28 , por la presencia de mujeres vestidas sensualmente como protagonistas de las imágenes.

Para López Eire (1998:57) "la características esenciales del lenguaje publicitario: la concisión y la redundancia”. Martínez (2000:31), por su parte, con respecto a la lengua de la publicidad, afirma que es un lenguaje interesado y está regido por las leyes de eficacia, libertad y economía informativa. Este mismo autor subdivide el apartado 
dedicado a este tipo de lengua de la siguiente forma: características generales; características gráficas; nivel morfosintáctico; nivel léxico-semántico; publicidad y retórica.

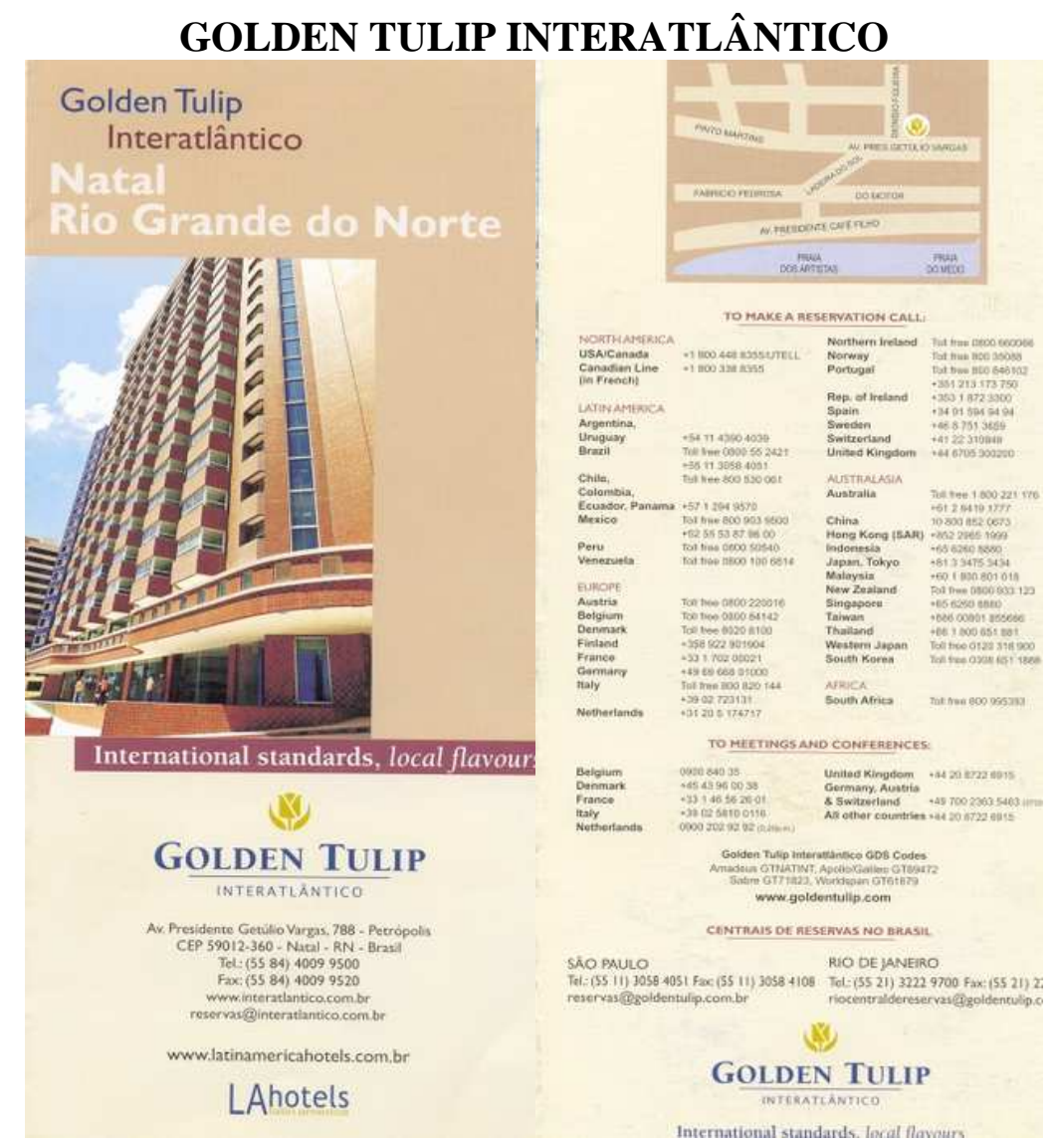

Texto 29

En el texto 29 el lenguaje es extremamente conciso, eficaz y está permeado por una economía informativa. Para quien conoce el Goden Tulip, sabe que se trata de una cadena de hoteles internacionales de alta calidad. Así, el anuncio se limita a informar su ubicación en Natal. En este sentido se infiere esa información como conocimiento compartido entre el emisor y su interlocutor, dicho de otro modo, su audiencia.

Desde un punto de vista formal, ese texto sigue el formato propio del texto publicitario y por eso se trata de un texto persuasivo. Pero ¿por qué persuade? Es un texto objetivo, informa sobre un producto, su decodificación no exige un gran esfuerzo cognitivo y su aspecto visual es atractivo. 
En su macroestructura figuran la descripción del "Tulip Golden Interatlântico" y la presentación de su localización. La progresión temática de ese texto puede ser definida como de progresión de tema constante. Por la objetividad del texto no es posible encontrar alguna persona del discurso presente en la inscripción de este anuncio.

El producto visual consiste en la propia imagen de las instalaciones externas del “Golden Tulip Interatlântico", además de un mapa orientativo con la dirección del hotel anunciado. El mensaje manifiesto consiste en la excelencia y seriedad del producto ofertado y el mensaje latente culmina en la imagen de un gran hotel de lujo con un patrón internacional. Es justo este enunciado, patrón internacional, lo que atribuye la alta calidad al producto. Aparece destacada en el folleto publicitario en cuestión para argumentar por qué uno debe consumirlo.

La publicidad ejerce su papel social a favor de un determinado mercado económico y para ello actúa como formadora y manipuladora de opiniones. Por medio de esa manipulación y difusión ideológica, su objetivo mayor es seducir al interlocutor para la adquisición de los productos o servicios anunciados que sirven para aumentar los beneficios de la empresa anunciada. Por eso estamos de acuerdo con Kurt Spang (2005:27):

\footnotetext{
El mercado es inmisericorde y su hija, la publicidad, lo es también. Los ademanes publicitarios que a primera vista percibimos como gestos de amable y sonriente servicial en realidad - no nos hagamos ilusiones - son frío cálculo y a veces sutil manipulación con el único fin de incrementar los beneficios de la empresa que anuncia el producto o el servicio.
}

En el ámbito publicitario existe la preocupación por su objetivo fundamental que es la persuasión de la que se ocupa la retórica, como el arte que trata de persuadir. Para convencer a su público lector, la publicidad echa mano de los más distintos códigos como el verbal, el icónico, el sonoro y el quinésico, muy evidente en los estudios contemporáneos. Por eso, en el mensaje publicitario hay una heterogeneidad de códigos que vemos como esencial, de acuerdo con lo que afirma María Victoria Romero Gualda (2005:83), que trata de la "pluralidad de sistemas, códigos y signos como característica esencial del mensaje publicitario", como se puede ver arriba en el texto 29. 


\section{Funciones del lenguaje}

Las funciones del lenguaje dominantes en un texto publicitario son la función expresiva (yo); función conativa (tú); función fática (contacto); función referente (metalingüística); y, por último, función poética. Para Martínez (2000), la función dominante en la publicidad es la apelativa o conativa. Eso está de acuerdo con la opinión López Eire (1998) cuando, por su parte, destaca, dentro de esas cinco funciones, la función conativa como la de mayor relieve para el lenguaje de la publicidad. En palabras de este autor:

De entre todas estas funciones del lenguaje destaca en el mensaje publicitario la función conativa con su variante de aplicación al proceso comunicativo que es la función fática. Llamar la atención del público, implicar al oyente en el anuncio, es la misión primordial del mensaje publicitario (López Eire, 1998:59).

Es importante destacar que, entre las funciones del lenguaje publicitario presentadas anteriormente, las funciones lingüísticas predominantes en el acto de habla publicitario son la conativa y la poética por ser un tipo de discurso predominantemente que implica al interlocutor, conciso, novedoso y recurrente.

\section{Un fenómeno de nuestro tiempo}

El lenguaje publicitario, como afirma Martínez (2000:7), es "un fenómeno muy de nuestro tiempo: el lenguaje de la publicidad es resultado de una conjunción de signos diversos, en especial icónicos y verbales".

En el texto 30, que se puede ver abajo, la función conativa del lenguaje fue empleada como una estrategia de persuasión propia de la publicidad, comprendida como un fenómeno contemporáneo. El texto está configurado en códigos heterogéneos, más específicamente, en lenguaje visual y escrito. Los personajes protagonistas del anuncio son personas jóvenes, guapos, felices y con un buen nivel socioeconómico. 


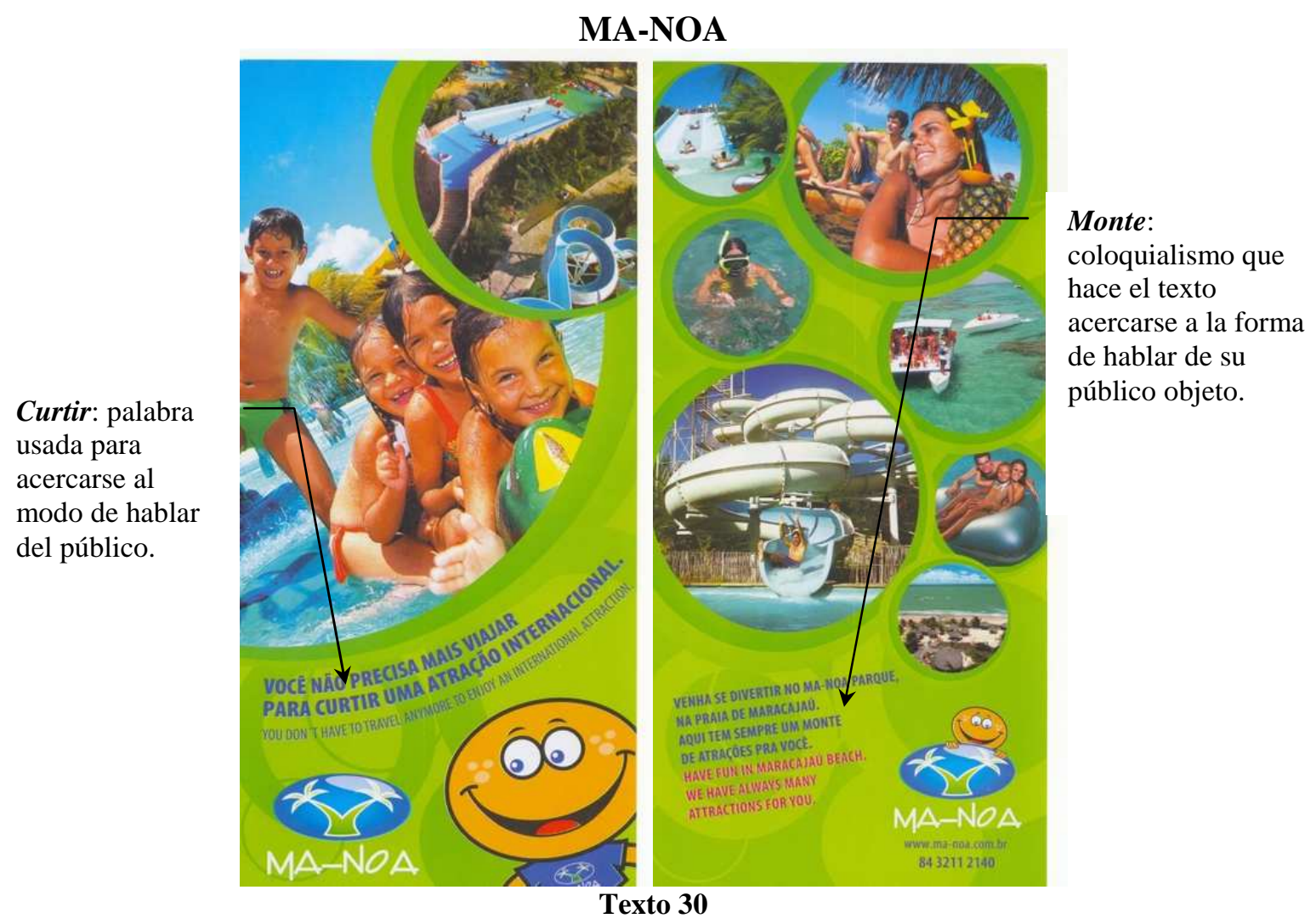

En la primera página del folleto se anuncia que no necesitas viajar más para pasarlo bien en una atracción internacional. Luego, el interlocutor se pregunta qué atracción internacional es esta. Lo que descubrirá con un poco de atención y al seguir la secuencia natural de lectura occidental, o sea, de la izquierda a la derecha y de arriba abajo. Un poco más abajo está el logo y el nombre MA-NOA.

Por las imágenes presentes en esta parte del folleto y lo que está escrito, el lector puede fácilmente inferir que se trata de un parque de atracciones acuáticas de nivel internacional que se llama Ma-Noa. Como ya hemos destacado anteriormente, este texto va dirigido a un público familiar y joven, por eso habla el lenguaje de este público, por ejemplo, con el empleo de la palabra curtir, que es un coloquialismo del lenguaje juvenil que significa pasarlo bien, aprovechar.

Jorge David Fernández Gómez (2005:89) también se refiere a la adecuación y aproximación lingüística que el lenguaje publicitario debe mantener constantemente con su público objetivo cuando afirma que "el lenguaje publicitario se caracteriza por su brevedad, sencillez, concisión y cercanía. Esto es, textos que aparte de gozar de 
economía expresiva también se adecuen a los públicos a los que se dirigen”, como es el caso del texto 30 .

Ya en la segunda página del folleto en cuestión, hay una continuación de lo que fue presentado en la primera página: imágenes de un ambiente familiar con atracciones acuáticas cuyos protagonistas son personas guapas, jóvenes, alegres y con un buen poder adquisitivo. Además, presenta el siguiente texto; ven a pasártelo bien en el MaNoa Parque, en la playa de Maracajaú. Aquí siempre hay muchas atracciones para ti.

Como hemos visto anteriormente, el tuteo aporta confianza entre los interlocutores del acto de habla, que también hablan el mismo lenguaje. En esta segunda parte se usa la palabra monte, propia de la jerga juvenil y moderna para designar mucho/a. El mensaje publicitario atrae la atención del público para provocarlo y seducirlo para que los receptores del mensaje pasen a ser compradores del producto anunciado. Eso queda muy claro cuando se comprueba la sustentación de este tipo de mensaje en la información, la sugerencia y la persuasión.

Aquí es posible enaltecer la publicidad y su dinamismo, ya que sobre la variedad de estrategias linguiísticas de la publicidad en la elaboración de sus mensajes podemos mencionar la memorable opinión de Ferrer (1994:40) sobre los tipos de lenguaje de los que la publicidad hace uso:

\footnotetext{
Dentro de esta suma de lenguajes que forman parte de la comunicación y le dan vida - desde el político y el religioso hasta el de la propaganda; desde el económico y comercial hasta el periodístico - , el lenguaje de la publicidad es, seguramente, el de más diversos tonos y alcances: ocupa el territorio más ancho, dinámico y sensible de la comunicación. Es un territorio cada día más agrandado en los dominios generales del idioma. Lenguaje en acción, tanto como una modalidad, es un lenguaje de características propias y distintivas, capaz de comunicar cuanto hay que decir y cómo decirlo, cubriendo las zonas vitales del comportamiento humano.
}

En eso encontramos una vez más la idea de lenguaje en acción, también empleada por López Eire (1998), y sobre la que opinamos que es sinónimo de lenguaje dinámico, vivo, dicho de otro modo, camaleónico. La publicidad, por excelencia, tiene la necesidad de hablar la lengua de su público objetivo, tiene que familiarizarse con ese 
público como forma de entrar a formar parte de él, convivir y comprender la mejor manera de llamar la atención y convencer a ese público.

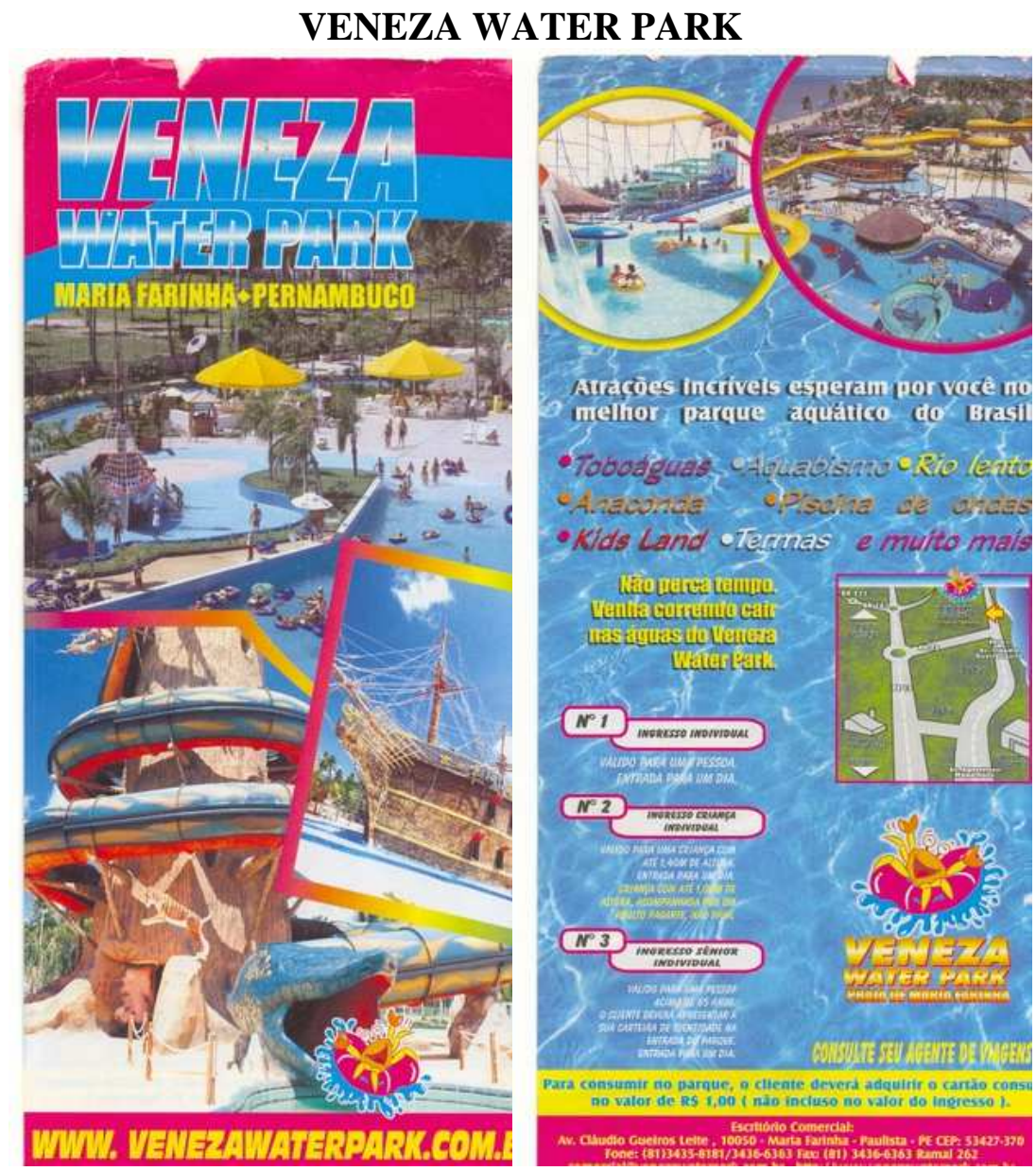

Texto 31

El texto 31 sigue el mismo ejemplo de concisión linguiística del texto anterior. Sin embargo, adopta un argumento que sigue más bien la función del lenguaje referencial que trata de exaltar las cualidades del producto anunciado, el Veneza Water Park. Y ¿por qué ese anuncio afirma que esta atracción debe ser visitada? la contestación a esa pregunta está en la segunda página del anuncio que dice: atracciones increíbles esperan por ti en el mejor parque acuático de Brasil. Luego el interlocutor infiere que debe visitar este parque acuático porque es el mejor de Brasil y porque allí le esperan atracciones increíbles. Además, el mismo anuncio afirma: no pierdas tiempo, ven corriendo a saltar en las aguas del Veneza Water Park. Es decir, no visitar esta atracción turística es una pérdida de tiempo. Y como es sabido que el tiempo es una moneda muy importante en la sociedad contemporánea, perder el tiempo es lo mismo que perder dinero, por eso todos tienen que visitar el Veneza Water Park ya. 
En el anuncio en cuestión podemos encontrar los ejes de la publicidad: Emisor (Veneza Water Park); Producto (Atracciones ofrecidas por este parque acuático); Medio (Publicidad escrita, más específicamente, folleto turístico); Receptor (Personas interesadas, en general, y familias completas).

El lenguaje publicitario hace uso de la economía lingüística y su papel de formación de opinión, además de las ideologías a favor de las cuales trabaja. Una vez más, podemos reafirmar el carácter dinámico del lenguaje publicitario y nos apoyamos teóricamente en lo que Ferrer (1994:10-11) afirma a continuación:

\footnotetext{
El lenguaje de la publicidad ha acompañado a ésta en su evolución de instrumento de la economía, sin dejar de serlo, a mecanismo social como fenómeno integrador: de la sociedad de consumo, como activadora y reguladora de la oferta y la demanda, a la cultura, como suma de maneras de ser y de pensar; de la tradición de las costumbres al requerimiento de los cambios, incluidos los del saber.
}

El lenguaje publicitario se apoya, sobre todo, en dos columnas: el lenguaje connotativo y el lenguaje denotativo, de modo que se cumplan los requisitos básicos del hecho comunicativo y represente la esencia de la finalidad del lenguaje que es convertir una realidad lingüística, ideológica o material en palabras con sentido completo.

También estamos de acuerdo con Ferrer (1994) cuando enaltece la publicidad como uno de los campos de la comunicación fértiles para los estudios linguiísticos. En eso puede residir la originalidad de la publicidad como un lenguaje estético, fugaz y a la vez dinámico, vivo. Lingüistas como Roland Barthes (apud. Ferrer 1994:41) han calificado el lenguaje de la publicidad como original en sus "tres planos: el literal, con su sentido inmediato; el asociado, con su sentido representativo, y el declarado, con su sentido último".

No obstante, podríamos cuestionar si esos tres planos del lenguaje publicitario actúan a la vez con la misma intensidad y ejerciendo el mismo papel de protagonismo en los mensajes publicitaros. Ferrer (1994:41) defiende que "en el lenguaje publicitario lo funcional es preferible a lo estructural”. Así, podríamos comprender que los tres planos 
señalados por Barthes pueden sufrir variaciones jerárquicas de importancia en el mensaje publicitario en virtud de lo que sea más funcional y pragmático.

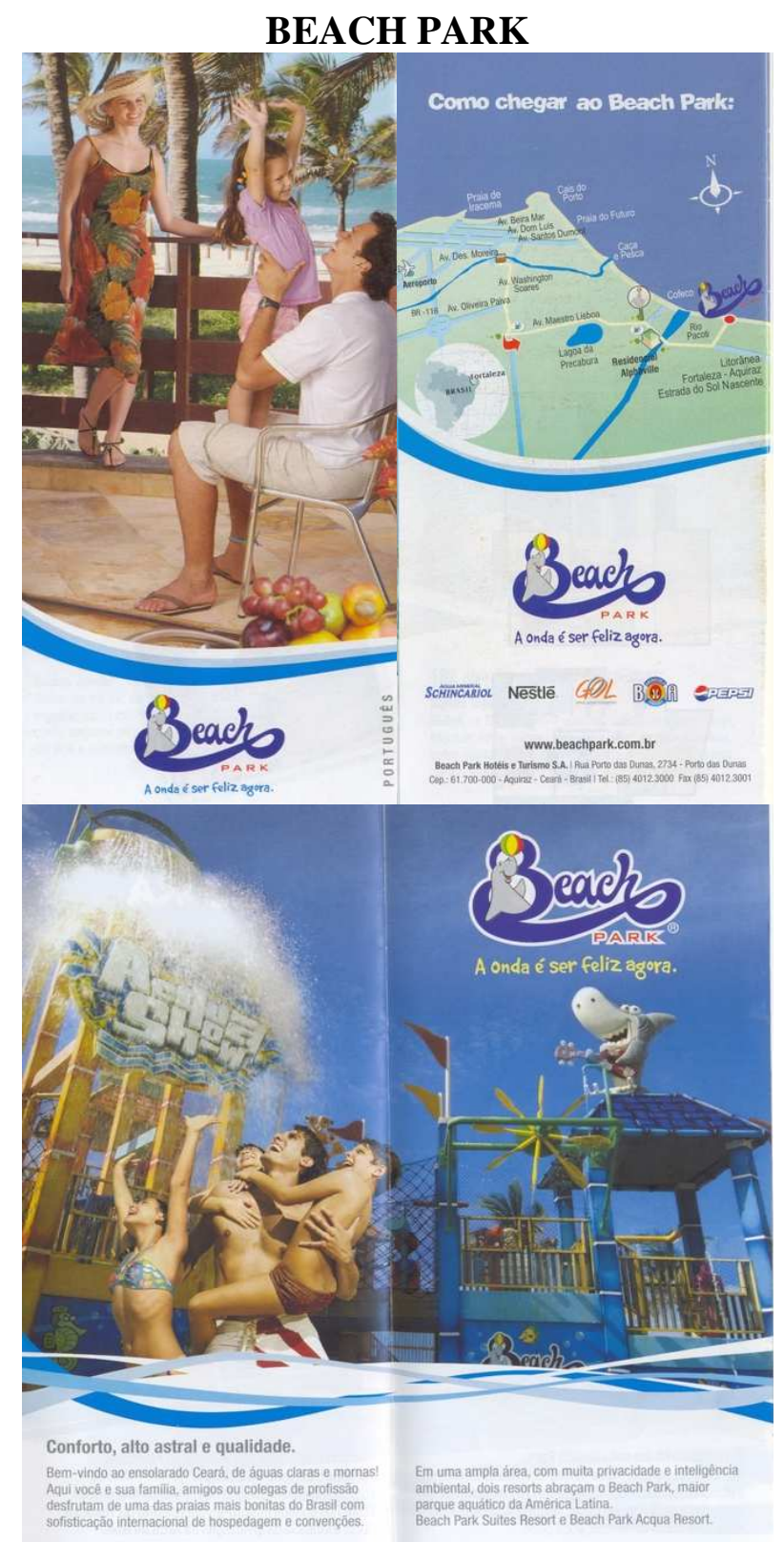

Texto 32

Bajo el eslogan la onda es ser feliz ahora el texto 32 anuncia el Beach Park como atracción turística. Es un texto estéticamente elaborado a partir del código verbal escrito y del código visual. Además no exige mucho trabajo cognitivo en su decodificación y atrapa la atención del lector por su estética organizacional y su heterogeneidad de códigos, de ahí su capacidad de persuasión. 
Los ejes de la publicidad también pueden ser encontrados en el texto 32. Así, el producto anunciado consiste en el Beach Park; la función de este producto es servir de ocio para toda familia; y conviene porque, entre muchas otras características positivas, este parque va a hacer feliz a toda la familia, y como el propio eslogan afirma, hay que serfeliz ahora.

Desde un punto de vista del entendimiento práctico del lenguaje publicitario, Ferrer (1994:41) parte de tres factores básicos: "lo que se ofrece, para lo que sirve y por qué conviene". Creemos que esta estructura es básica en la publicidad si partimos desde el punto de vista que defiende el lenguaje publicitario como seductor y persuasivo, además, trabaja en favor de un mercado que defiende la adquisición de un determinado servicio o producto.

Es importante añadir en ese contexto lo que dice Ferrer (1994:42) cuando afirma que la publicidad "gira a partir de tres ejes: el emisor y su producto; el medio con sus vehículos; el público como el todo receptor". Nos apoyamos en esa idea para defender que la publicidad se apoya sobre todo en un proceso comunicativo cuyo lenguaje exige comprobación visual de lo que dice.

En la segunda página del folleto en cuestión hay un texto que tiene como titular confort, alegría y cualidad. Luego presenta el siguiente texto: ¡Bienvenido al soleado Ceará, de aguas trasparentes y tibias! Aquí tú y tu familia, amigos o colegas de profesión disfrutan de una de las playas más bonitas de Brasil, con sofisticación internacional de hospedaje y convenciones.

Ya en la tercera parte del anuncio se afirma que en una amplia área, con mucha privacidad e inteligencia ambiental, dos resorts abrazan el Beach Park, el park acuático más grande de América Latina. Beach Park suites resort y Beach Park acqua resort. Por último, se presentan en la última página de este folleto turístico las formas de entrar en contacto y llegar al Beach Park.

Observemos una vez más que los personajes que protagonizan las imágenes de este texto publicitario son miembros de familias felices, jóvenes y con un buen poder adquisitivo. Ya en el marco léxico podemos destacar el uso de sintagmas como onda, 
feliz, ahora, confort, alegría, cualidad, bienvenido, soleado, aguas trasparentes y tibias, disfrutan, bonitas, sofisticación, internacional, convenciones, amplia, privacidad, inteligencia, más grande de América Latina. Es decir, un léxico positivo que connota solamente ideas positivas sobre el producto turístico anunciado.

El lenguaje publicitario está vinculado a su propio carácter informativo, sugestivo y persuasivo a través de sus funciones del lenguaje predominantes, como expone Ferrer (1994:42) cuando afirma que las características del lenguaje publicitario son asociadas a sus funciones de lenguaje: descriptiva, expresiva y persuasiva. Aquí, podemos explicar el fenómeno publicitario a partir del lenguaje de un acto comunicativo cuya tarea social consiste en tornar una idea común, de forma creativa y desarrollada.

También merece destacarse en el texto anunciado el uso del recurso retórico de la prosopopeya o personificación cuando afirma que el Beach Park es abrazado por dos resorts en la siguiente oración: dos resorts abrazan el Beach Park, el parque acuático más grande de América Latina. Beach Park suites resort y Beach Park acqua resort. Como podemos ver, los dos resorts, que son seres inanimados, pasan a actuar con características humanas y abrazan al Beach Park.

Otro punto que merece ser destacado es el uso de la palabra "onda" (ola), que forma parte del portugués coloquial y de la jerga juvenil y moderna, es decir, es una forma de actuar de modo parecido o igual al interlocutor, ya que su propia forma de hablar es adoptada por el emisor del mensaje. Además, para acercar aun más esos dos ejes de la publicidad - emisor y receptor - se adopta el uso de la segunda persona del singular "tú", lo que aporta proximidad entre los interlocutores del acto de habla publicitario.

En el lenguaje publicitario, la brevedad está estrictamente relacionada con la eficacia del trabajo. Así, Ferrer (1994:44) afirma que "una máxima gramatical encuadra las esencias del lenguaje publicitario: lo más claramente explicado es más fácilmente comprendido". Aquí hacemos uso de esa cita de Ferrer para defender la idea de que el lenguaje publicitario debe ser sencillo, de fácil comprensión y pragmático, como hemos visto en el ejemplo del texto 32. 
Se puede afirmar también que el lenguaje publicitario mantiene relación con el lenguaje poético, es más, guarda herencias de la poesía, en el caso del texto expuesto arriba el uso de la prosopopeya lo comprueba. El lenguaje publicitario comunica a su audiencia los sentimientos de sus propios receptores. Ferrer (1994:49) conjetura que "si el lenguaje publicitario es el del sentido común es porque está enclavado en la comunidad, es el del pueblo, de ahí que parezca a menudo que el pueblo habla el lenguaje de la publicidad".

Aquí podríamos concebir el carácter poético de la publicidad a partir de la poesía popular, común en la literatura oral. Una vez más, nos remitimos al texto 32 para mostrar un ejemplo práctico de la forma de hablar del receptor del mensaje publicitario expuesta en el propio texto elaborado por el emisor, el caso del uso léxico de onda, como hemos visto anteriormente.

\section{Reflejo de una sociedad}

El lenguaje publicitario sería así reflejo de una determinada sociedad y su época, como las tradiciones de la poesía oral y popular, creada a partir del lenguaje de uso común en una determinada comunidad lingüística, sin olvidar la economía lingüística como norma de la sociedad contemporánea y necesaria para el establecimiento de la comunicación instantánea y simultánea comunes en nuestro tiempo. Es importante resaltar que aunque el lenguaje de la publicidad posea esa característica de particularidades lingüísticas, ha adquirido un relieve a nivel universal. Esto es compatible con la afirmación de Ferrer (1994:53):

\footnotetext{
No es extraño que, al margen de las particularidades de su uso social, conforme lo requiere cada comunidad o país, el lenguaje publicitario haya adquirido rango universal. Lo ha adquirido por impulso de las leyes económicas que han borrado o fijado las fronteras nacionales, influyendo decisivamente en los cambios políticos y sociales del conocimiento científico y por el fenómeno más asombroso de todos: la comunicación instantánea y simultánea.
}

Añade Ferrer (1994:30) que "el lenguaje es el punto de partida de la comunicación, en tanto que la comunicación contribuye a ensanchar los territorios del lenguaje". Esto sirve para poner énfasis a la relación de intercambio existente entre la comunicación y el 
lenguaje. Desde este punto de vista comunicativo, podemos afirmar que el lenguaje publicitario es un lenguaje simple y común usado por la gente. También es un instrumento típico de la actualidad que presenta a través de un lenguaje creativo las características de la claridad, agilidad, comunicabilidad, autoridad y veracidad.

\title{
El lenguaje publicitario y los medios de comunicación masivos
}

El lenguaje de los mensajes publicitarios está relacionado directamente con el medio de comunicación que le sirve de vehículo comunicativo. Los mass media poseen su lenguaje propio y la publicidad necesita adaptarse a las peculiaridades de cada vehículo. Este tipo de lenguaje depende de la elección de su vehículo, de las características del producto anunciado y la selección del tipo de consumidor que se desea alcanzar. En relación a la práctica que antecede a la elaboración del lenguaje que deberá ser utilizado en una campaña publicitaria, Pinho (2001:184) señala:

\begin{abstract}
El profesional de la comunicación se enfrenta, entonces, con un cuadro de opciones - la radio, la televisión abierta, la TV por contrato, cine, revista, periódico, outdoor, y los medios de comunicación dirigida - teniendo que hacer la elección de la mejor combinación de ellas para alcanzar impacto y eficacia a su público objeto, presentándose al cliente anunciante en la forma de recomendaciones. ${ }^{37}$
\end{abstract}

Ese proceso anterior a la elaboración del mensaje publicitario en concreto (anuncios, reclamos, propaganda, entre otros.) tiene una importancia fundamental en la decisión de qué tipo de lenguaje se deberá hacer uso para llevar a cabo dicha elaboración.

\section{Los medios de comunicación electrónicos}

El lenguaje publicitario acompaña todos los cambios de los medios de comunicación, se ha adaptado también a las innovaciones técnicas $\mathrm{y}$, principalmente, a las transformaciones de la sociedad. Por lo que se refiere a los medios de comunicación electrónicos, que de acuerdo con la clasificación de Pinho (2001) son la radio, la televisión y el cine, reúnen apelaciones sensoriales y perceptivas que influyen en el trabajo final de la obra publicitaria.

\footnotetext{
${ }^{37}$ En la fuente original: "O profissional de mídia defronta, então, com um quadro de opções - rádio, televisão aberta, TV por assinatura, cinema, revista, jornal, outdoor e meios de comunicação dirigida - , devendo se decidir pela melhor combinação delas para atingir com impacto e eficácia seu público-alvo, apresentando-se ao cliente anunciante na forma de recomendações".
} 
El cine tiene presente en su lenguaje elementos como las imágenes, los sonidos, el color, las dimensiones de la pantalla y el movimiento; la radio ejecuta la palabra en forma de discurso oral, en mensajes rápidos, con recursos de la sonoplastia y de la música, que sirven para ilustrar y llamar la atención del interlocutor; el periódico, las revistas y los folletos manipulan el discurso escrito (verbal y no verbal) como herramientas en la elaboración de su publicidad; por último, internet es uno de los medios de comunicación que más se han desarrollado en los últimos tiempos, sobre todo, a finales del siglo XX y principios de XXI. Dispone de una capacidad muy alta de hibridación, una vez que puede mezclar el texto escrito; la imagen; el audio, el video, etc.

Los primeros mensajes publicitarios eran muy objetivos, transmitían solamente las informaciones elementales, como el nombre del producto y donde podría ser encontrado. Con el tiempo la forma de abordaje de la publicidad cambió, su lenguaje pasó a adoptar estrategias persuasivas, que además de informar empezaron a insertar argumentos retóricos para seducir a los compradores. Con ese desarrollo del mensaje publicitario "la producción de las piezas publicitarias envuelven entonces diversos aspectos técnicos y estéticos para que esos mensajes combinen creatividad y pertinencia y, de ese modo, provoquen fuerte impacto en el público objeto" (Pinho, 2001:217). ${ }^{38}$

\section{Los soportes del lenguaje publicitario}

El lenguaje elegido para elaborar un texto publicitario sobre un determinado producto o servicio necesita tener como base datos consistentes. El discurso escrito en la publicidad se sostiene sobre dos pilares: lo verbal y lo no verbal, es decir, lo escrito y la imagen. Para la ordenación de este tipo de mensaje es necesario el conocimiento de datos como los objetivos de la empresa, las informaciones características del producto (cualidades y ventajas), los lugares de ventas, las informaciones sobre sus garantías, los eventos promovidos, la imagen de la marca, el rescate de campañas anteriores, el privilegio de los datos relativos al perfil del consumidor en potencia y, por último, el ajuste del mensaje al medio de comunicación que servirá como soporte de presentación del mensaje publicitario.

\footnotetext{
${ }^{38}$ En la fuente original: "A produção das peças publicitárias envolve então diversos aspectos técnicos e estéticos para que as mensagens combinem criatividade e pertinência e, assim, provoquem forte impacto no público-alvo".
} 


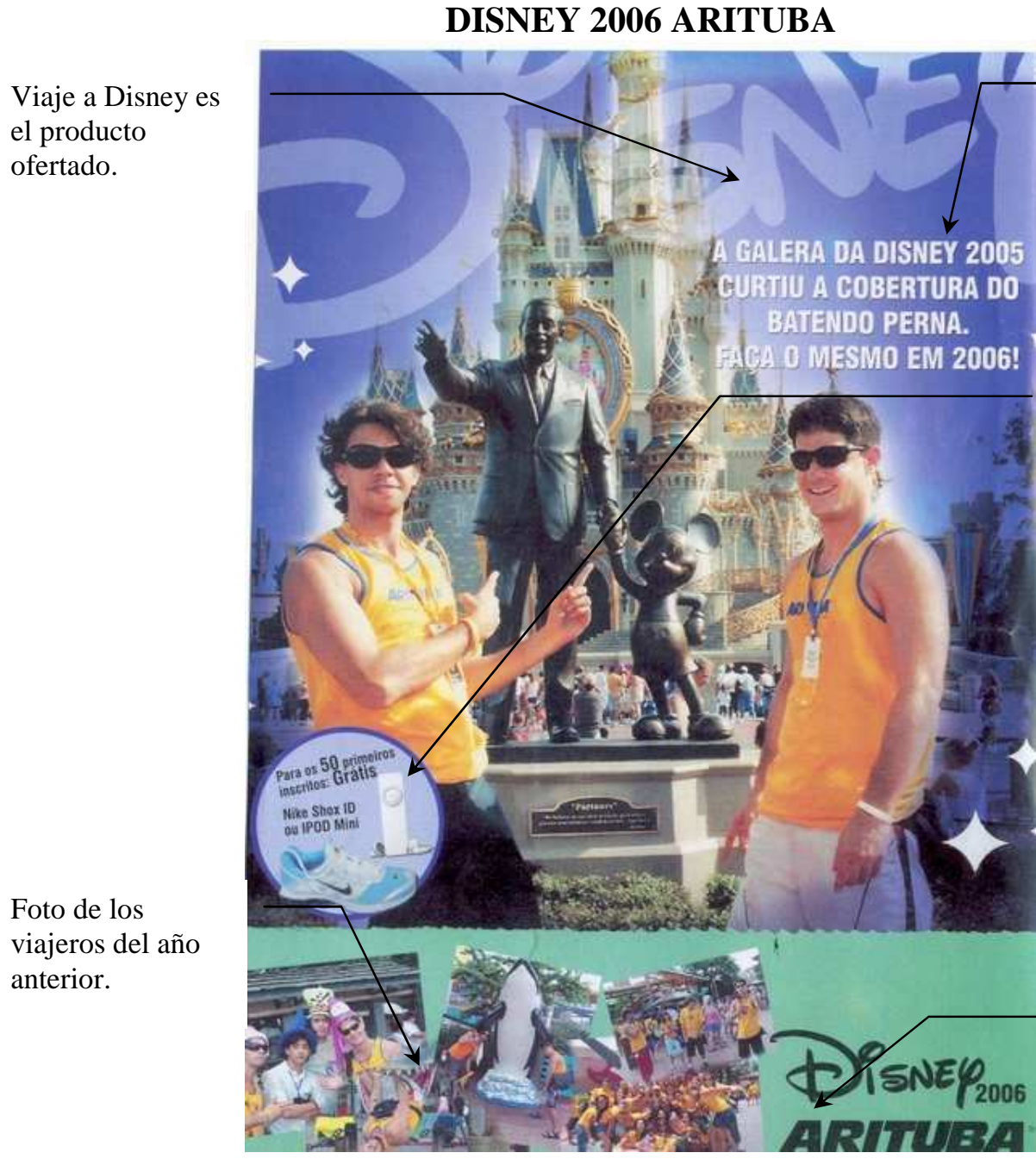

Texto 33
Texto que habla del éxito del mismo producto turístico en el año anterior.

Regalo para las primeras personas que hagan su inscripción para este viaje.

Agencia de viaje que vende el producto.

En el texto 33 encontramos un ejemplo de economía lingüística propia de la publicidad ya que menos es siempre más. El texto anuncia un viaje a Disney vendido por la agencia de viajes Arituba. El contenido expandido del texto dice que los viajeros de Disney 2005 lo pasaron muy bien en el paseo. ¡Haz lo mismo en 2006! En realidad, no se vende un viaje a Disney y en ninguna parte del texto hay la palabra viaje, con lo cual esta información debe ser inferida por el interlocutor a través de la lectura del código verbal asociado al código visual.

Es más, el interlocutor de este anuncio debe poseer en su patrimonio intelectual lo que significa Disney, Arituba, la expresión bater perna que significa caminar, pasear, además de conocer el significado de la palabra galera, que se refiere a panda o grupo de amigos. En este anuncio se presentan imágenes de personas jóvenes y felices, 
pertenecientes a una capa de la sociedad que disfruta de un buen nivel de poder adquisitivo.

Para hablar a este público joven se adopta en el leguaje del anuncio una jerga juvenil como es el caso de la expresión bater perna y la palabra galera. Además, los propios protagonistas del anuncio representan el público objeto del anuncio, su forma de vestir, de hablar y su propia apariencia.

Por fin, para corroborar la calidad del producto anunciado, se presentan las fotos de lo bien que se lo pasaron los viajeros del año anterior. Además, se regala deportivas y Ipods para los que primero se inscriban para este viaje.

El título, texto e ilustración son inseparables y se complementan para formar un todo: el mensaje publicitario. No obstante, son ordenados jerárquicamente, es decir, esos elementos pueden ocupar un lugar de mayor o menor relieve dentro del anuncio. El título, por ejemplo, puede ser presentado de forma directa o indirecta. En el primer caso, proporciona una idea sobre el producto o una promesa, mientras en el segundo aparece de modo más sutil, con la intención de provocar un impulso de curiosidad.

En el cuerpo de este tipo de mensaje entran todas las informaciones, signos y símbolos del anuncio; tiene como función exponer y aclarar el mensaje de promoción de lo que se quiere vender, como muy bien lo ilustra el texto expuesto arriba. Para ello, se basa en elementos razonables y emocionales como afirma Pinho (2001:224) cuando dice que "el texto presenta dos formas básicas: lo razonable y lo emotivo. El texto razonable se dirige a la inteligencia, actúa por medio de la lógica de los hechos, [...] justifica las razones por las cuales debe ser comprado". El lado emotivo está explotado para establecer una asociación entre el producto anunciado y los sentimientos y valores simbólicos como la belleza, el status, la satisfacción, la familiaridad, etc.

En el texto 33 se alterna lo razonable y lo emotivo como elementos que contribuyen a la persuasión publicitaria. Así, se puede llegar a la siguiente conclusión: uno debe viajar a Disney con la agencia de viajes Arituba porque la gente que lo hace se lo pasa super bien, es guapa, alegre, joven y divertida. Además puede ganar ipods y deportivas si se 
apunta ya a este viaje. En la parte emocional del anuncio está la realización del sueño de un viaje a Disney y el prestigio socioeconómico de quien lo hace.

\section{La cultura y los modelos de lenguaje publicitario}

La publicidad explota las diversas especificidades del lenguaje para conseguir alcanzar sus propósitos comerciales. Eso se ha fosilizado a lo largo del tiempo en la comunicación que hace uso de peculiaridades lingüísticas y textuales para seducir e invitar al consumo por medio de la estética de los medios de comunicación masivos y que ha creado un lenguaje propio, un código y un estilo.

Gracias a una forma de expresión particular, original y distinta, el lenguaje publicitario se estableció, principalmente, porque amplió la posibilidad del público de absorber el mensaje para pasar de la posición de espectador a consumidor. El lenguaje publicitario no depende solamente de aspectos técnicos de los varios medios de comunicación que le sirven como vehículo, también necesita del aparato cultural.

Nely Carvalho (2000:106) afirma que el lenguaje es la unión de aspectos lingüísticos y culturales de la sociedad y observa que "si el público es indio o musulmán, por ejemplo, la forma de presentar la vaca o un cerdo deberá ser cuidadosamente estudiada. Entre los occidentales, la muerte no tiene buena aceptación, eso aglomera dificultades en el abordaje que se debe tener para anunciar un seguro de vida". 39

El estudio del lenguaje de la publicidad, que se presenta como un campo de conocimiento de la comunicación social para el que el dominio de la expresión cultural tiene un papel sustancial, puede también servir como principio del conocimiento de las prácticas sociales. La producción publicitaria, sea cual sea el tipo de lenguaje elegido, tendrá que transmitir la similitud con la cultura en la que está inserta. Así, tanto los mensajes explícitos como los implícitos tienen que generar una identificación inmediata con el consumidor. Carvalho (2000:107) observa que "la publicidad usa connotaciones

\footnotetext{
${ }^{39}$ En la fuente original: "Se o público for indiano ou mulçumano, por exemplo, o modo de apresentar uma vaca ou um porco deverá ser cercado de cuidados. Entre os ocidentais, a morte não é bem aceita, o que acarreta dificuldades de abordagem quando se trata de mensagem sobre seguro de vida".
} 
culturales, icónicas y lingüísticas, sobre todo aquellas que están relacionadas con estereotipos, cuya codificación y comprensión no ofrezcan dificultades". 40

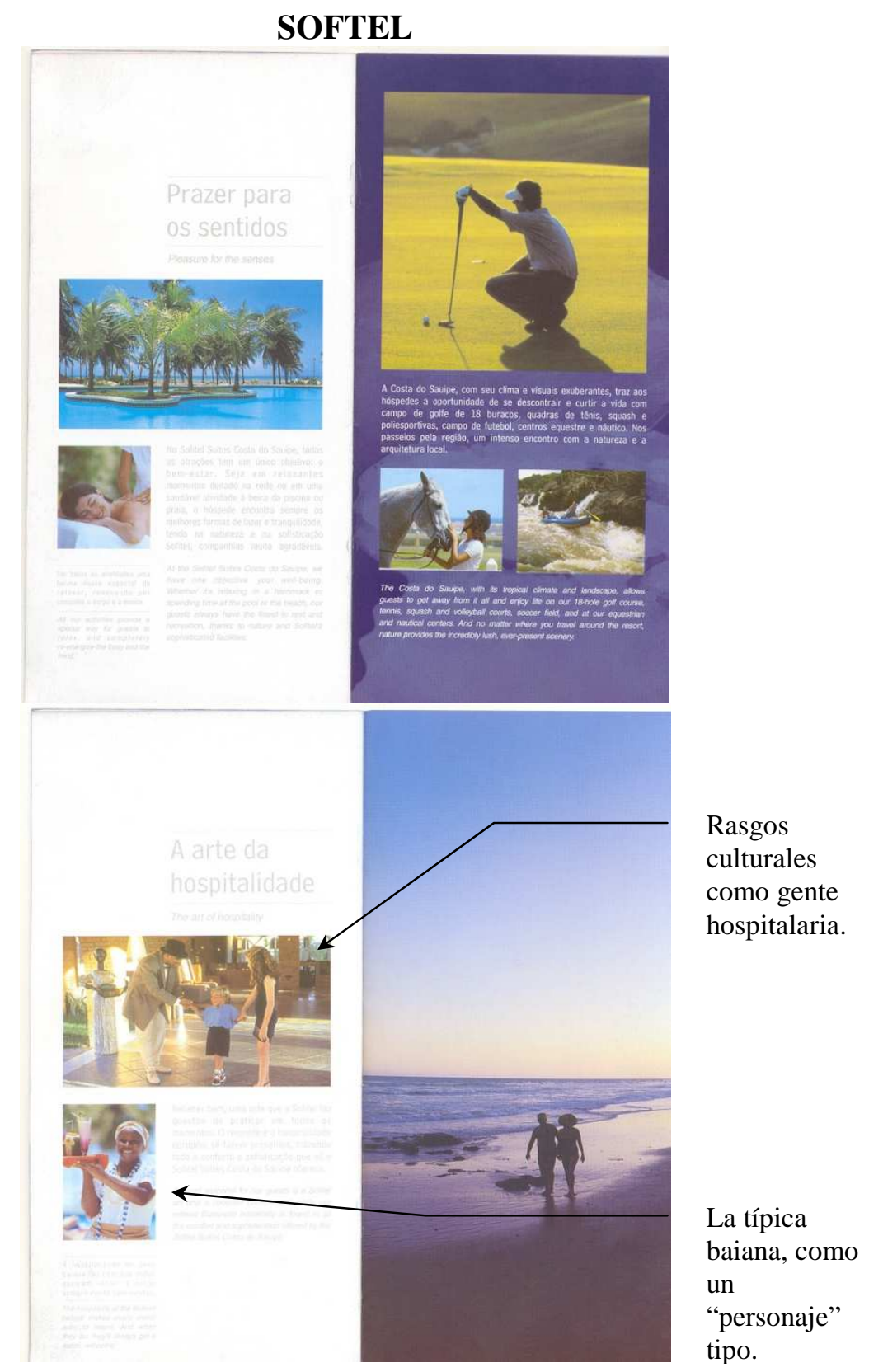

Texto 34

El texto 34 forma parte del anuncio del Softel de Salvador de Bahia. En la primera parte de este anuncio se presenta de forma panorámica las instalaciones del hotel anunciado; en la segunda se afirma que es un encuentro con la naturaleza; en la tercera que es elegancia y bienestar; en la cuarta aborda los sabores y sensaciones y en la quinta se

\footnotetext{
${ }^{40}$ En la fuente original: "A publicidade usa conotações culturais, icônicas e lingüísticas, sobretudo aquelas que veiculam estereótipos, mais facilmente codificáveis e compreensíveis".
} 
destaca el placer de los sentidos. Por último, en la sexta, se destaca el arte de la hospitalidad. Si observamos la quinta y la sexta parte de este anuncio vemos que está plagado de personajes tipos, o sea, el típico jugador de golf, la típica gente hospitalaria y la camarera representa la típica baiana como un prototipo de los personajes locales.

Claro que para comprender los rasgos culturales de este anuncio hace falta el uso del saber enciclopédico del interlocutor. También es importante destacar la selección léxica que emplea un vocabulario positivo compuesto por sustantivos hedonistas como: encuentro, naturaleza, elegancia, bienestar, sabores, sensaciones, placer, sentidos, arte y hospitalidad.

El principio que estructura los aspectos culturales en los anuncios publicitarios adopta los estereotipos socioculturales, sobre todo en la representación de determinados grupos sociales. Al comunicar para un público colectivo, se adoptan esos modelos de "personajes-tipo" de una sociedad asociados a su estilo de expresión, lingüística, quinésica y a su imagen propia, como en los casos de la presentación del ama de casa, la deportista, la ejecutiva, la madre, el padre, etc.

En ese caso se adopta el estereotipo de los consumidores, pero también se podría adoptar el de la sociedad de consumo, pues ambas están cargadas de valores culturales que pueden ser expresados por medio de las palabras y las imágenes, adaptados al segmento de mercado al que se dirige. En relación a ello, Carvalho (2000:108) apunta:

Otra posibilidad es que la elección esté fundamentada en un estereotipo impuesto por la sociedad de consumo, reflejando una visión modificada de la realidad, que podrá ser confirmada o rechazada y que, desde un punto de vista lingüístico, es traducida en neologismos formales, conceptuales, o en una nueva lexía compleja. ${ }^{41}$

\footnotetext{
${ }^{41}$ En la fuente original: "Outra possibilidade é a escolha recair sobre um estereótipo imposto pela sociedade de consumo, refletindo uma visão modificada da realidade, que poderá ser confirmada ou recusada e que, do ponto de vista linguístico, é traduzida em neologismos formais, conceptuais, ou numa nova lexia complexa".
} 
HOTEL RESIDENCE

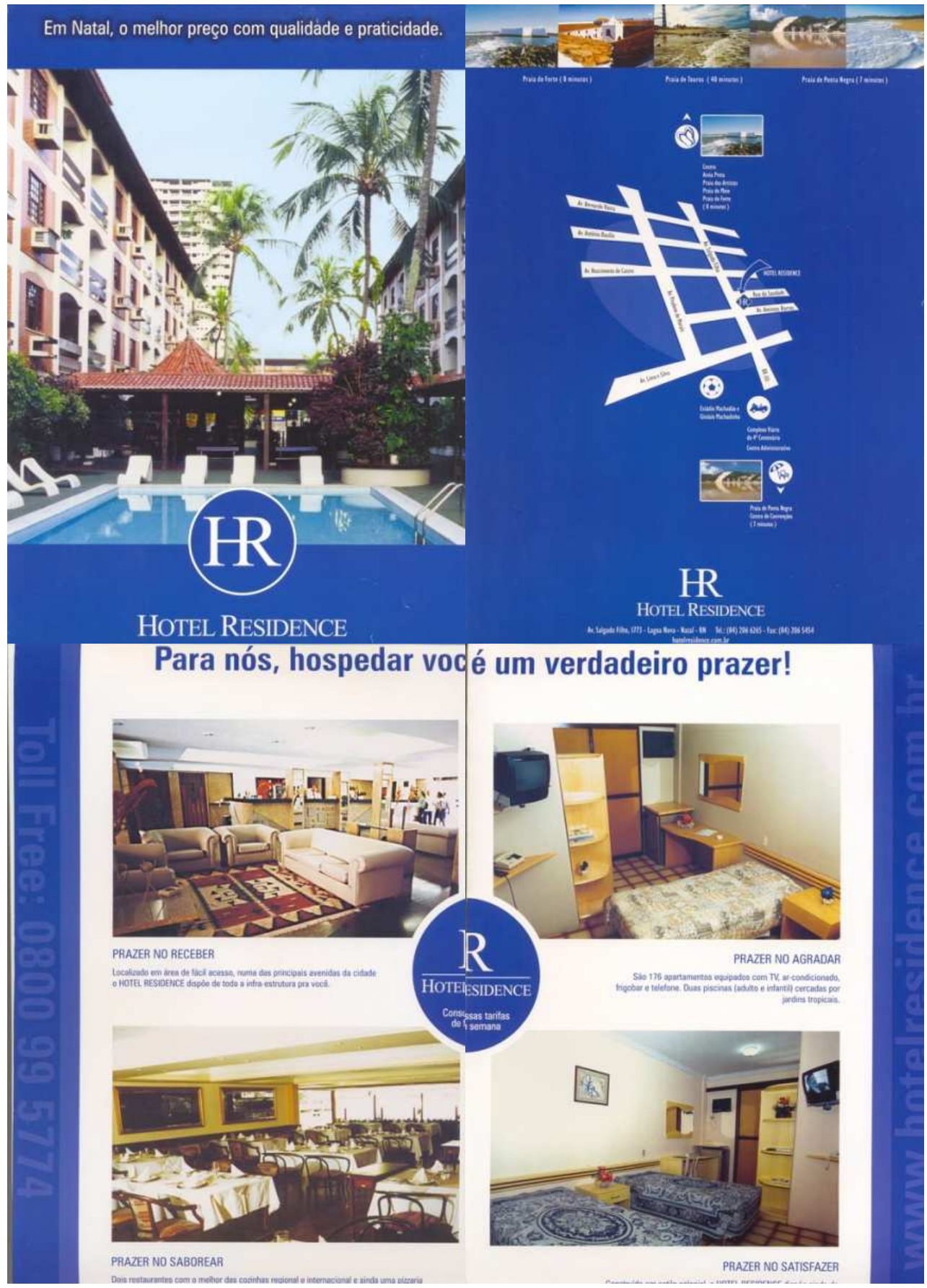

Texto 35

Es fundamental para el análisis semántico del lenguaje publicitario la adopción de un punto de vista fundamentado en los aspectos culturales, ya que, en muchos casos, los elementos que constituyen los mensajes tienen un sentido referencial, que puede ser vulnerable a modificaciones dependiendo del lugar, del punto geográfico, de los hábitos socioculturales, económicos, etc. 
Desde un punto de vista formal, el texto 35 sigue el formato propio del texto publicitario. En su macroestructura figura la descripción del "Hotel Residence", la presentación de su localización, y los puntos de interés turísticos que están próximos a este hotel. Por lo tanto, la progresión temática de este texto puede ser definida como de progresión de tema constante.

Las personas del discurso presentes son la primera persona del plural (nosotros), que funciona como un recurso retórico de cortesía y la inscripción del "você", en portugués de Brasil, que tiene la fuerza semántica del "tú" en español, presentando así un carácter de proximidad entre el emisor y el destinatario.

Ya en la portada del folleto se anuncia: en Natal, el mejor precio con cualidad y practicidad. Luego, en la secuencia aparece el nombre del Hotel Residence y su logomarca. A continuación, se afirma que ¡para nosotros hospedarte es un placer! luego se enumera qué tipo de placer: placer en recibir, placer en degustar, placer en agradar y placer en satisfacer. Así, es difícil que el interlocutor no se sienta importante y se fie hospedándose en un sitio que le valora tanto y tiene el placer de tratarlo bien.

En el marco léxico de ese folleto, es importante también observar el empleo de sintagmas típicos de la publicidad, como por ejemplo: mejor, practicidad, calidad y placer, sobre todo esta última palabra, por ser repetida muchas veces en el mismo anuncio publicitario.

El producto visual consiste en la propia imagen del "Hotel Residence", sus instalaciones internas, sus instalaciones externas y su ubicación privilegiada. El mensaje manifiesto de este anuncio es la calidad del hotel anunciado como producto. En lo que concierne al mensaje latente, podemos concebirlo como la elegancia, el confort y la atmósfera seria del Hotel Residence.

Todo el texto, tanto su contenido visual como su contenido verbal, contribuye para la formación de una imagen y un concepto positivo del hotel anunciado. El interlocutor no necesita de mucho esfuerzo cognitivo para decodificar todo el texto y ser convencido para hospedarse en un hotel que, además de cualidad, posee el mejor precio de la ciudad. 
Dentro de los aspectos culturales, se puede aludir a las cuestiones de género, ya que se adoptan distintos artificios para llamar la atención de los consumidores de distintos sexos. En ese sentido, el lenguaje publicitario puede incorporar en el discurso elementos típicos del acto de habla propio del mundo femenino o masculino. En el caso del anuncio en cuestión se adopta un lenguaje neutro que presenta valores de carácter universal.

Para finalizar, es importante decir que, desde un punto de vista comunicativo, el lenguaje puede formar un sistema comunicativo propio y específico sujeto a cambios constantes en función del dinamismo de la propia vida y la constitución social. Aquí se hace necesario insertar lo que Ferrer (1994:49-50) señala a ese respecto cuando dice que "los nombres y las ideas pueden ser los mismos, como ya está dicho anteriormente. Lo que cambia es el hombre y su tiempo, en una escala de valores a la que se incorporan, con el suyo, los medios de comunicación”. Además, para ese mismo autor, comprender el lenguaje de la publicidad "desde sus fuertes cargas comparativas y competitivas es entender mejor nuestro tiempo, con los anclajes del pasado, los cambios del presente y las tendencias del futuro" Ferrer (1994:38). Es decir, la comprensión de la publicidad en nuestro tiempo ejerce la misma función que la comprensión del arte.

\subsection{El sistema comunicativo en la publicidad}

La historia mundial pudo registrar muchos cambios políticos, científicos, tecnológicos, económicos y sociales, a lo largo de todo el siglo XX. En ese siglo, ocurrieron las dos grandes guerras mundiales y la ciencia médica y tecnológica realizaron sus grandes descubrimientos. En medio a tantos cambios, ubicados históricamente entre el siglo XX y principios del XXI, podemos destacar los avances de los medios de transporte y comunicación, gracias a los cuales existe la posibilidad de desplazarse a cualquier parte del mundo y de comunicarse sin el establecimiento de fronteras temporales, geográficas, lingüísticas o culturales.

Con esta evolución de los medios de transporte y comunicación, sumada al desarrollo de la cartografía, se ha proporcionado la proximidad de sitios y personas ubicados geográficamente en lugares muy lejanos. Dicho de otra manera, hombres y mujeres de cualquier continente, país, estado, ciudad, etc. pasaron a poder comunicarse o 
desplazarse sin los impedimentos geográficos de antaño. Eso quiere decir que los más diversos países y personas de formaciones culturales distintas pueden interrelacionarse, hecho impensable en tiempos anteriores, sobre todo, a los siglos XX y XXI.

La apertura comunicativa entre diversas naciones y continentes para la constitución de la actual aldea global establece estrategias de comunicación que están conciliadas con los probables problemas de identidad y culturales de cada nación, por eso estamos de acuerdo con Ferrer (1994:38) cuando afirma que "los proyectos de globalización económica y comercial están asentados en estrategias comunicativas que habrán de conciliarse con los problemas de identidad y cultura de cada pueblo".

Ferrer (1994:32) también afirma que la comunicación puede ser vista como "una inmensa red que abarca las dimensiones vertebrales del espacio-tiempo, creando la sociedad de la comunicación". Junto a eso, hay un fuerte intercambio de culturas en los tiempos modernos, las lenguas nos lo muestran, a su modo, por medio de las expresiones y palabras que intercambian a través de los llamados préstamos lingüísticos.

Sin embargo, no se sabe a ciencia cierta cuáles son los resultados de dichos cambios y avances para la sociedad contemporánea, ni cuáles son sus puntos positivos y negativos para la humanidad, ni tampoco cómo influye eso en el comportamiento y en los sentimientos humanos. Lo único que se puede ver es que a lo largo de todo ese tiempo, la comunicación ha tenido un papel decisivo para el avance de la tecnología, la ciencia y la economía. Junto a eso, se ha desarrollado la linguiística, ciencia del lenguaje, que ha surgido y evolucionado a lo largo de todo el siglo XX. Ferrer (1994:32) dice que "nunca, como hoy, el lenguaje fue tan importante como medio de comunicación". La propia aparición de la lingüística y su desarrollo, insertos en su contexto histórico, sirven para corroborar la innegable importancia del lenguaje y de la comunicación en el mundo contemporáneo.

Además del desarrollo de medios y sistemas de comunicación, surgen las modernas telecomunicaciones, indispensables para la agilidad de los trámites comerciales y de flujo de capitales, constituyendo una de las columnas de sustentación de la economía globalizada. Frente a ello, y para entender el complejo fenómeno de la comunicación, de forma general, Ferrer (1994:33) afirma que se puede ver el acto de la comunicación 
como "un tejido construido por el lenguaje a través del que la experiencia convive realmente con los significados del hacer y del vivir desde la ley permanente de la reciprocidad".

\section{La comunicación publicitaria y sus teorías}

De los tres elementos del modelo aristotélico de comunicación (la persona que habla fuente o emisor; el discurso - el mensaje; y el auditorio - el receptor) se derivan varias teorías sobre la comunicación publicitaria de las cuales destacaremos solamente las principales.

La primera es la teoría y modelo de Lasswell (1948) que trata del mensaje producido a partir de la contestación de preguntas como ¿quién?, ¿qué dice?, ¿en qué canal?, ¿a quién?, ¿con qué efectos? En segundo lugar, destacamos la teoría matemática de Shannon y Weaver (1949) que concibe elementos como fuente (locutor); código; mensaje; canal; decodificador; receptor (audiencia).

En tercer lugar, merece la pena destacar las teorías de McLuhan, con su concepto de medios calientes y medios fríos. En cuarto lugar, viene el modelo lingüístico de Jakobson, en el que cada entidad del proceso comunicativo corresponde a una función del lenguaje, a saber: emisor (función emotiva), destinatario (función conativa), contexto (función referencial), mensaje (función poética), contacto (función fáctica) y el código (función metalingüística).

La quinta teoría básica para la comunicación publicitaria es la teoría funcionalista estructural y la sexta el modelo de Gerbner, por medio de la cual se concibe que en un proceso de comunicación, la fuente percibe un enunciado, genera una respuesta en una situación por determinados medios, en determinada forma y en determinado contexto, considerando un contenido y sus efectos.

La séptima teoría básica para la comunicación publicitaria es la teoría y modelo de Maletzke (1963), bajo la que se crea el establecimiento de los binomios emisor mensaje; emisor - medio; emisor - receptor; mensaje - medio; receptor - mensaje; receptor - medio. Por último, la octava teoría básica es el modelo de difusión e 
innovación (1973) basada en elementos como el conocimiento, la persuasión, la decisión y la confirmación.

En los primeros postulados sobre publicidad hubo una defensa de esas varias teorías que eran adoptadas por los profesionales de la comunicación en la elaboración de sus trabajos publicitarios. Durante el período entre las guerras mundiales surgieron en Estados Unidos una serie de investigaciones académicas que desarrollaban teóricamente la comunicación social. Entre tales teorías se puede mencionar la hipodérmica, también conocida como Bullet Theory, sobre la cual Wolf (2003:5) afirma que:

El principal componente de la teoría hipodérmica es, de hecho, la presencia explícita de una 'teoría' de la sociedad de masas, ya que la vertiente de la 'comunicación' actúa completamente una teoría psicológica de la acción. Se puede también describir el modelo hipodérmico como una teoría de la propaganda y sobre ella: con efecto, ese es el tema central relativo al universo de los mass media. ${ }^{42}$

Además de esta teoría también se puede mencionar la conductista, que tiene como estrategia principal la repetición y el mecanicismo. Basada en ella, surge la sigla AIDA formada a partir de las iniciales de Atención, Interés, Deseo y Acción. En relación con ello, Neusa Demartini (2003:88) dice que "un anuncio debe sucesivamente llamar la ‘atención', suscitar el 'interés', provocar un 'deseo’ y desencadenar una ‘acción'. Del que se infiere que la imagen publicitaria debe constituir solamente 'ilustración' cuya función principal es la de conducir a la lectura del texto". ${ }^{43}$

\footnotetext{
${ }^{42}$ En la fuente original: "O principal componente da teoria hipodérmica é, de fato, a presença explícita de uma 'teoria' da sociedade de massa, enquanto na vertente de 'comunicação' age completamente uma teoria psicológica da ação. Pode-se também descrever o modelo hipodérmico como uma teoria da propaganda e sobre ela: com efeito, este é o tema central relativo ao universo da mídia".

${ }^{43}$ En la fuente original: "Um anúncio deve sucessivamente chamar a 'atenção', suscitar o 'interesse', provocar um 'desejo' e desencadear uma 'ação'. Disso se infere que a imagem publicitária deve constituir somente 'ilustração' cuja função principal é a de conduzir à leitura do texto".
} 
Sin embargo, esta teoría ya ha perdido su fuerza dado que está basada en corrientes de estudios psicológicos como la del reflejo condicionado y del behaviorismo. A este respecto, Neusa Demartini (2003:88) afirma que:

Este esquema está inspirado en los estudios de la psicología de Pavlov (reflejo condicionado) y en el conductivismo estadounidense de Watson (behaviorismo), Skinner, Jan y otros. El enfoque de esta teoría impone algunas limitaciones porque impide cualquier tipo de reflexión que tenga una base empírica de comprobación inmediata. ${ }^{44}$

Otra teoría es la Interpretación Motivacional. Esta corriente pasó a ser adoptada en la década de 1950 y trae una fuerte influencia de los estudios de Freud con respecto al poder que el inconsciente puede ejercer en las acciones humanas. En ese sentido, la publicidad debería sensibilizar a la audiencia con anuncios capaces de llegar a su inconsciente. En relación con esa teoría, Neusa Demartini (2003:90) afirma:

El destino de la imagen sería la región del inconsciente de forma que, mientras el texto se dirige, preferiblemente, a los deseos manifestados, la imagen, a los deseos reprimidos. Esta teoría no fue muy adelante porque era mucho más afirmativa que explicativa, y se trataba de una interpretación centrada en el valor simbólico de las imágenes, hecho que condujo a un estudio de los sistemas de significación y simbolización icónicas. ${ }^{45}$

\footnotetext{
${ }^{44}$ En la fuente original: "Este esquema está inspirado nos estudos da psicologia de Pavlov (reflexo condicionado) e no condutivismo norte-americano de Watson (behaviorismo), Skinner, Jan e outros. O enfoque desta teoria impõe algumas limitações porque impede qualquer tipo de reflexão que tenha uma base empírica de comprovação imediata".

${ }^{45}$ En la fuente original: "O destino da imagem seria a região do inconsciente de forma que, enquanto o texto se dirige, preferencialmente, aos desejos manifestados, a imagem, aos desejos reprimidos. Esta teoria não foi muito adiante porque era muito mais afirmativa que explicativa, e trata-se de uma interpretação centrada no valor simbólico das imagens, o que conduz a um estudo dos sistemas de significação e simbolização icônicas".
} 
Por último, se puede mencionar otra teoría que sirve de apoyo a la publicidad llamada de Interpretación Semiótica. A partir de esa corriente teórica, se puede hacer uso del simbolismo que la publicidad es capaz de transmitir. Neusa Demartini (2003:88) señala:

Esta interpretación parte de la preocupación con aspectos significativos, propios del análisis motivacional e intenta agotar las posibilidades de análisis científica de la imagen, considerándola como un soporte para la producción de un sentido, abandonando toda consideración ajena al campo epistemológico por ejemplo, el rechazo del uso de elementos propios de la psicología y de la sociología. ${ }^{46}$

Las teorías clásicas de la comunicación postulan modelos comunicativos como los unilaterales (polo anunciador - polo público); los modelos lineales (estímulo respuesta). Aquí es importante resaltar que para Martínez (2000) la publicidad figura como un tipo de comunicación unilateral, puesto que no busca obtener una respuesta verbal. A continuación, hemos elaborado una tabla con el modelo lineal de Lasswell (1948) para una mejor visualización:

\begin{tabular}{|c|c|c|c|c|}
\hline EMISOR & REFERENTE & RECEPTOR & CANAL & RESPUESTA \\
\hline ¿Quién? & ¿Qué dice? & ¿A quién? & ¿Por qué canal? & ¿Con qué efectos? \\
\hline
\end{tabular}

Además, también podemos mencionar el modelo de Lavidge \& Steiner basado en la información (notoriedad y conocimiento); los efectos (atracción, preferencia y convicción) y el comportamiento (compra). Hay también el modelo triádico basado en el aprendizaje, el gusto y la acción (learn, like y do).

En la contemporaneidad, teorías como la marxista de los medios de comunicación; la teoría crítica o de la escuela de Frankfurt; la teoría de la hegemonía; y, por último, la teoría de la economía política de la comunicación permean los estudios actuales sobre la comunicación publicitaria, en los que esta última teoría es el modelo ya adoptado en países desarrollados y en determinados países en desarrollo.

\footnotetext{
${ }^{46}$ En la fuente original: "Esta interpretação parte da preocupação com aspectos significativos, próprios da análise motivacional e pretende esgotar as possibilidades de análise científica da imagem, considerando-a como o suporte para a produção de um sentido, abandonado toda a consideração alheia a seu campo epistemológico por exemplo, a recusa da utilização de elementos próprios da psicologia e da sociologia".
} 
La psicología de la comunicación y la psicología de la publicidad son directrices propias de nuestro siglo que consideran elementos psico-sociales para la elaboración de un discurso. Con respecto a esto, López Eire (1998:51) afirma:

\begin{abstract}
En publicística, esta directriz psico-social se introdujo a principios de siglo, en paralelo estricto a tres procesos importantísimos que tuvieron lugar en los comienzos de nuestra centuria, a saber: el desarrollo de la psicología empresarial e industrial, el nacimiento de la sociedad de la comunicación y el brote de la ciencia de la conducta, interesadísima en conocer con detalle el comportamiento del consumidor. Pasó luego la psicología de la publicidad, una vez constituida, por varias etapas antes de llegar a ser lo que actualmente es, o sea, psico-social, neoconductista, cognitiva y antimecanicista.
\end{abstract}

Como muy bien apunta López Eire (1998), el sistema publicitario actual elabora su modo de acción con base en conocimientos psicológicos, sociales, neoconductistas, cognitivos y antimecaniscistas, que son apoyados en teorías como:

\title{
1- La concepción clásica (conductivismo);
}

2- La concepción motivacional (psicología profunda);

3- La concepción semiológica (semiología y lingüística estructural).

En la primera, la comunicación publicitaria debe llamar la atención, despertar interés, despertar un deseo y producir una acción. De eso surge la fórmula AIDA, que hemos mencionado anteriormente. La interpretación motivacional tiene el psicoanálisis como base de su marco teórico. Por último, la interpretación semiótica se preocupa de los aspectos del significado propios del análisis motivacional. En esta corriente se cree que hay tres características que tornan un mensaje publicitario efectivo, a saber: ser redundante, ser implicativo y ser evaluable. Con base en estas características, el mensaje publicitario adquiere un carácter más bien connotativo que denotativo, de ahí se explica la perpetuación del uso de procedimientos retóricos en la publicidad que es un signo característico de la cultura moderna.

\section{La tercera revolución industrial}

Hay un consenso de que los medios de telecomunicación forman un nuevo paradigma tecnológico, llamado de Tercera Revolución Industrial, que permite un mayor alcance a la globalización, principalmente, en la esfera de las transacciones financieras. En este 
contexto, la comunicación, que, según Ferrer (1994:35), "es el lenguaje más el habla", se mueve en un gran mercado económico. Junto a esto, se invierte cada vez más en el desarrollo del sector comunicativo, de forma general, y en el ámbito de los estudios y medios de comunicación para el sector de la publicidad tienen especial relevancia.

La comprensión de la publicidad como un proceso comunicativo es algo básico, ya que implica la existencia de una respuesta. Para que sean establecidas directrices de estudio de ese complejo campo de la comunicación que presenta la ambivalencia como una de sus características, Adam \& Bonhomme (2000:32) afirman:

\begin{abstract}
La comunicación publicitaria es ambivalente. A la retórica bífida (verbal e icónica) del texto/imagen se añade la ambivalencia de una producción simbólica determinada por el mercado económico: el emisor financia sus propias palabras con el propósito de suscitar una compra del destinatarioconsumidor potencial que compense así a su gasto comunicativo y asegure su dominación sobre la competencia. En otras palabras, comunicación simbólica y comunicación comercial son inseparables, lo cual es fuente de ambigüedades potenciales: se pondrá el énfasis ora sobre el intercambio económico, ora sobre el intercambio simbólico.
\end{abstract}

Según Ferrer (1994:260), "la teoría del lenguaje publicitario tiene como punto de partida una trilogía elemental: anunciante, publicista y público. Equivalente a la de emisor, medio y receptor en tres direcciones fundamentales: objetivo, entendimiento y conocimiento". A partir de esta idea comprenderemos la publicidad como un acto de comunicación que depende de sus elementos fundamentales en la construcción de su eficacia. Sobre ese tema, Casamiglia y Tusón (2002:16) señalan:

Comunicación que se entiende, no tanto como un simple y mecánico proceso de transmisión de información entre dos polos, sino como un proceso interactivo mucho más complejo que incluye la continua interpretación de intenciones expresadas verbal y no verbalmente, de forma directa o velada. 
En este sentido, el proceso de comunicación es dinámico, está ordenado a partir de unidades como el enunciado, la enunciación, el enunciador y el enunciatario, anclados en un determinado contexto lingüístico, local, cognitivo o sociocultural; para eso, el enunciado necesita estar configurado en un determinado código. Casamiglia y Tusón (2002:17) mencionan la importancia de la ordenación del estudio discursivo a partir de unidades establecidas para ese fin y afirman que:

\footnotetext{
En lo que se refiere a los aspectos más concretos del estudio discursivo, es evidente que para abordarlo es necesario establecer unas unidades que permitan ordenar el análisis. La unidad básica es el enunciado entendido como el producto concreto y tangible de un proceso de enunciación realizado por un Enunciador y destinado a un Enunciatario.
}

A partir de ello, serán establecidos siete elementos que serán adoptados como unidades básicas del discurso publicitario, a saber: el enunciado (como es comprendido por Casamiglia y Tusón); la enunciación; el enunciador; el enunciatario; el contexto; el código; y, para finalizar, el vehículo de comunicación.

En los elementos de la comunicación publicitaria, el emisor es el anunciante, la agencia de publicidad es el codificador, el mensaje viene en las campañas publicitarias, los canales con los vehículos y el receptor es el público objeto. Así, llegamos al siguiente sistema de comunicación publicitaria: 


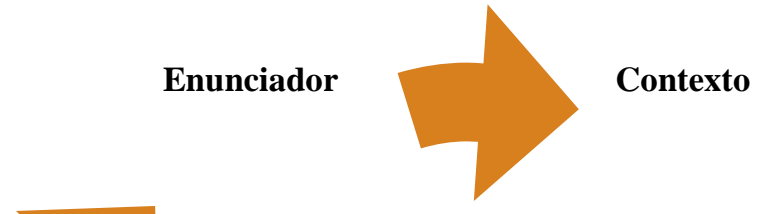

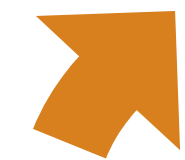

Enunciatario

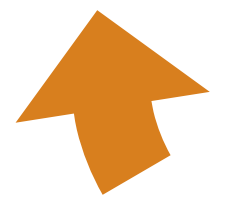

Enunciación

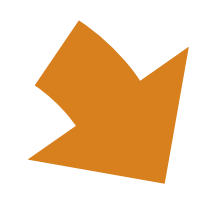

Código

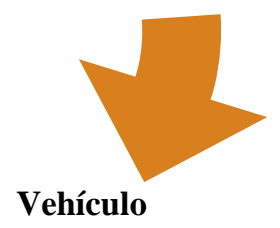

Enunciado

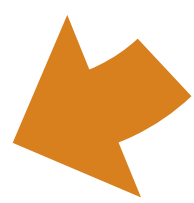

Estos elementos especifican la comunicación publicitaria porque se comportan de forma distinta a los demás tipos de comunicación, ya que el enunciado posee un objetivo estrictamente económico (la venta), el enunciador está formado por una empresa que contrata los servicios de un publicista y/o de una agencia de publicidad, el contexto puede ser el más variado posible, el código tiene un alto grado de hibridismo y hay mucha diversidad en el vehículo de comunicación. Por eso, nuestro trabajo se limita al estudio de la publicidad escrita. A continuación, detallaremos esos elementos básicos de la comunicación y cómo ellos se manifiestan, específicamente, en el discurso publicitario.

Con las teorías de comunicación publicitaria presentadas anteriormente concluimos la exposición general del tema propuesto y los fundamentos de nuestra Teoría del Acto de Comunicación Publicitario. Sin embargo, todo eso no es suficiente para aclarar la cuestión perseguida: ¿es la publicidad un texto literario o no literario? Para descubrirlo, necesitamos profundizar más nuestro conocimiento respecto del fenómeno publicitario, 
sobre todo en lo que concierne a cómo se da el proceso comunicativo desde el punto de vista de la publicidad.

\subsection{El acto de habla en la publicidad}

El establecimiento de un proceso comunicativo con un fin publicitario implica en la interacción del enunciado, la enunciación, enunciador, el enunciatario, el contexto, el código y el vehículo de comunicación, con un relieve especial de la audiencia y del código.

En el proceso comunicativo de la publicidad es fundamental la noción de la importancia del público objeto, del vehículo y del código de comunicación en la elección de las estrategias del abordaje comunicativo, como herramientas que favorecen la imagen del anunciante en una determinada sociedad. Por eso, la agencia publicitaria es una figura importante en este proceso. La propia agencia y sus profesionales establecerán un puente intermediario entre el anunciante, el vehículo y el público. El publicista es responsable de administrar o, incluso, crear las ideas que se tornarán públicas.

A partir de ese punto es posible formular el esquema de que el anunciante y la agencia de publicidad pueden producir un resultado positivo para garantizar o satisfacer al consumidor. Dicho resultado debe ser medido en lo que concierne al modo de cómo la audiencia recibió la información divulgada por la publicidad, o sea, su eficacia. Sant'Anna (2002:202) expone que uno de los mejores métodos para evaluar dicha eficacia fue desarrollado por la Advertising Research Foudation y añade:

Hay seis etapas de propagación y efecto de la publicidad. Las tres primeras, relacionadas con una medida según la cual las personas quedan expuestas a la publicidad son: distribución del vehículo, exposición del vehículo y exposición a la publicidad. Las tres últimas, relacionadas con la respuesta a la publicidad son: percepción de la publicidad, comunicación de la publicidad y respuesta de ventas. ${ }^{47}$

47 En la fuente original: "Há seis etapas da propagação e efeito da publicidade. As três primeiras, relacionadas com a medida segundo a qual as pessoas ficam expostas à publicidade são: distribuição do veículo, exposição do veículo e exposição à publicidade. As três restantes, relacionadas com a resposta à publicidade são: percepção da publicidade, comunicação da publicidade e resposta de vendas". 
Medir la percepción de una campaña publicitaria ofrece muchas dificultades porque sería lo mismo que saber a ciencia cierta qué elementos de la publicidad quedaron registrados en la mente del target. La comunicación en la publicidad es un proceso muy complejo. Para establecer un estudio de sus efectos en un determinado público se hace uso de entrevistas para recoger informaciones sobre la capacidad del público de recordar determinada publicidad.

Por último, es importante añadir que la publicidad depende en gran medida del modo que es considerado el principal motor del consumo, principalmente del consumo de lujo. Por eso es natural que la industria del turismo ejerza "una cierta influencia sobre la moda turística. Nos referimos al vasto campo de la publicidad turística, que impulsa a las masas a proponerse objetivos y a alcanzarlos por la elección del itinerario y el lugar de estancia" (Krapf, 1953:44).

\section{El enunciador}

El enunciador o anunciante es una entidad bastante compleja dentro del proceso de comunicación de la publicidad. Es una de las grandes particularidades del discurso publicitario, ya que, en la mayoría de los casos, es un publicista o una agencia de publicidad contratados por una empresa para anunciar sus productos o servicios.

Además, el discurso publicitario del ámbito turístico se configura por medio de mensajes que son pagados por su emisor. Por lo tanto, los anuncios publicitarios del turismo conllevan un precio y son limitados por factores económicos, de tiempo y de espacio.

El emisor de un anuncio publicitario inicia todo el proceso de comunicación persuasiva y no espera del interlocutor una respuesta verbal, sino un acto de compra. Para incrementar sus negocios y generar beneficios, entre otras motivaciones, es el propio anunciante que paga por la elaboración y la difusión de sus mensajes que intentan actuar sobre el comportamiento del consumidor o público objeto. En ese sentido, es un enunciador colectivo - empresa y publicista - sin que haya un emisor único o sin la más mínima orientación técnica para producir su mensaje. 
WHEL TOUR

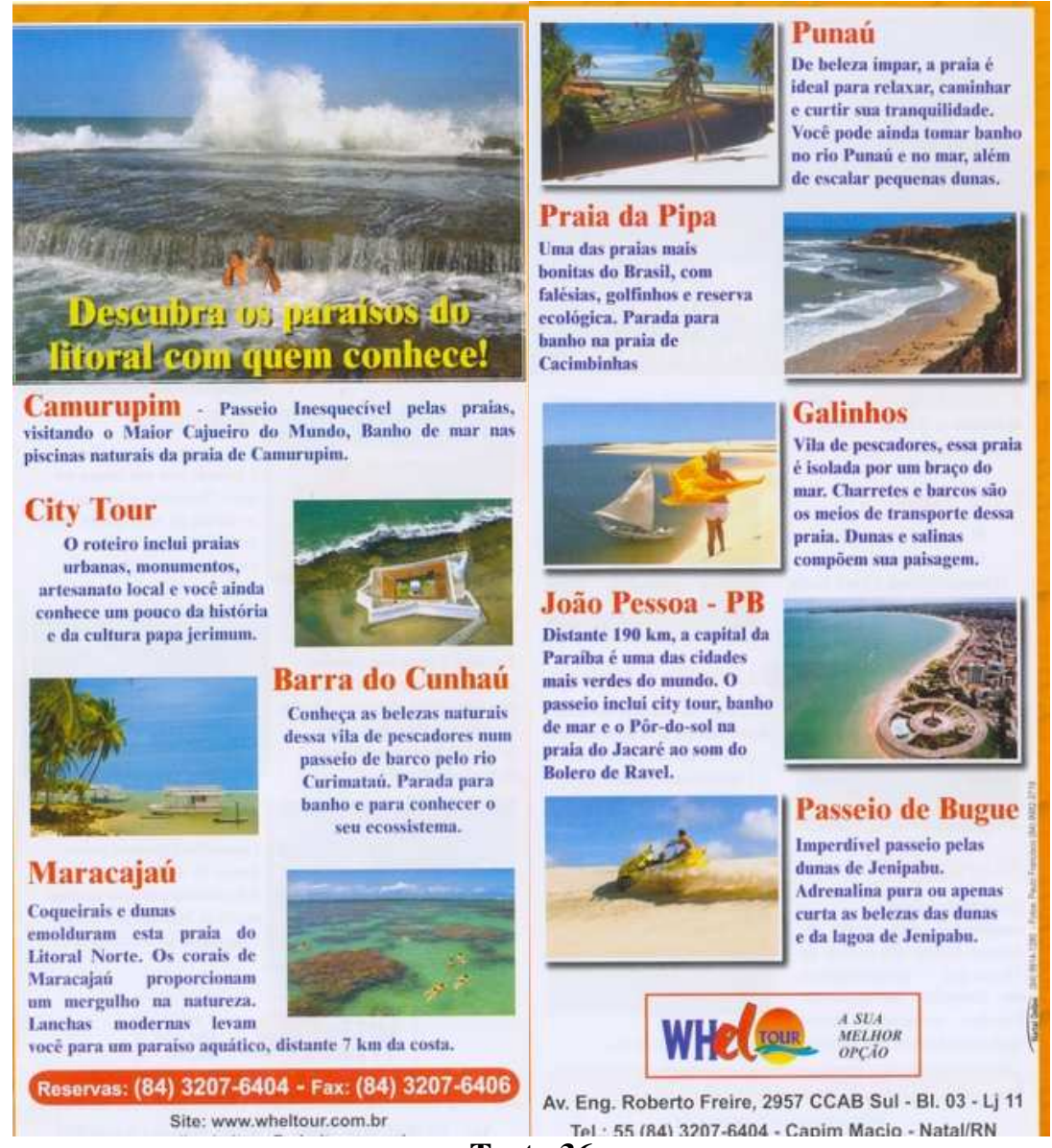

Texto 36

Sin embargo, las agencias publicitarias no son consideradas los emisores de los mensajes publicitarios, cuya elaboración está vinculada a un proceso complejo. Es lo que Asunción Escribano (2006:141) afirma cuando escribe que "el emisor en la publicidad es una instancia compleja que está formada por los fabricantes, quienes a través de una agencia de publicidad elaboran un mensaje dirigido a posibles receptorescompradores".

En la publicidad turística tenemos el anunciante - institución pública o privada que anuncia un producto tangible o intangible; la operadora de turismo - que oferta y promueve la venta del producto turístico - y la agencia de viaje que vende este producto turístico. A partir de ello, definiremos como emisores de los mensajes publicitarios turísticos esta entidad tríade formada casi siempre por estos tres elementos.

Por lo tanto, en la elaboración de una pieza publicitaria como el texto 36, existe la actuación de un emisor colectivo: una agencia de viajes - Whel Tour; una agencia de 
publicidad y los publicistas que trabajan en esta agencia. $\mathrm{O}$ sea, una formación de una entidad colectiva que tiene como interés último generar beneficios y que se relaciona por medio de una actividad profesional remunerada.

En la macroestructura del texto 36 figura la descripción del "Whel Tuor" y sus productos turísticos. La progresión temática de este texto puede ser definida como de progresión de temas derivados. Las personas del discurso presentes son la tercera persona del singular, usada para referirse al producto ofertado de forma impersonal y la inscripción del "você", en portugués de Brasil, que tiene la fuerza semántica del "tú" en español, presentando así un carácter de proximidad entre el emisor y el destinatario.

Este texto pertenece al género del discurso publicitario y desde un punto de vista de la tipología textual posee una secuencia dominante de texto argumentativo, ya que la descripción funciona más bien como un recurso persuasivo. En la textura discursiva están presentes los elementos léxicos con connotaciones positivas como por ejemplo los sintagmas: paraíso, inolvidable, más grande, naturales, monumentos, artesanía, cultura, bellezas, relajar, tranquilidad, bonitas, indispensable, adrenalina pura, y pasarlo bien.

El producto visual consiste en la propia imagen del "Whel Tuor" y sus productos turísticos. El mensaje manifiesto corresponde a la publicidad de las principales playas del litoral natalense como producto turístico, y el mensaje latente corresponde a la belleza de esas playas y su ambiente idílico y paradisíaco, como ya en el inicio del anuncio en cuestión está expuesto: descubra los paraísos del litoral con quien los conoce. Y ¿quién conoce esos paraísos?, por supuesto la Whel Tuor como al final del anuncio se expone: Whel Tuor, tu mejor opción.

No hay dudas de que este texto es persuasivo, pero ¿por qué persuade? Es un texto que no exige procesos cognitivos muy complejos en su decodificación, usa un lenguaje sencillo y positivo, además está ordenado por medio de una disposición gráfica estéticamente elaborada. 
Contexto

La noción de contexto es fundamental para el análisis y la comprensión de un texto publicitario. Este tema es objeto de estudios como El Contexto en la Teoría de la Relevancia de Arturo Varón López y Context and Cognition: Knowledge Frames and Speech Act de Teun A. Van Dijk. Ambos artículos, publicados en la red y accedidos en el año de 2011, muestran que el concepto de contexto es complejo y, en un principio, fue dividido en verbal y no verbal, con los siguientes subtipos:

1- Físico;

2- Empírico;

3- Natural;

4- Práctico;

5- Histórico;

6- Cultural.

No obstante, distinguir todos estos tipos de contextos es poco práctico, así que en la pragmática actual se suele distinguir los contextos lingüísticos, situacionales y socioculturales. Sin embargo, entre tantas distinciones de este término, los autores mencionados anteriormente están de acuerdo cuando tratan al contexto como un concepto bastante dinámico.

En virtud de esto, el contexto del discurso publicitario no puede ser clasificado de forma homogénea, dado que puede sufrir las más diversas variaciones posibles, siempre teniendo como lo más importante la producción de un mensaje eficaz, según su objetivo único. Sobre la importancia del concepto de contexto para la producción y comprensión del discurso publicitario, Adam \& Bonhomme (2000:41) afirman que "la comunicación publicitaria depende en gran medida de condiciones contextuales".

Por lo tanto, la contextualización es fundamental para la compresión y, por consiguiente, el análisis del discurso. Además, "el concepto de contexto es esencial para todos los estudios lingüísticos que se plantean desde una perspectiva pragmática o discursivo-textual" (Calsamiglia \& Tusón, 2002:101). 
El contexto puede ser abordado desde varios puntos de vista distintos como el de la antropología, el de la lingüística, el de la pragmática y el análisis del discurso (contexto espacio-temporal, contexto situacional o interactivo, contexto sociocultural, contexto cognitivo). Sin embargo, esta división tiene una función más bien conceptual, puesto que el concepto de contexto conlleva una gran complejidad como hemos dicho anteriormente.

Es importante considerar la definición del contexto bajo el paradigma de la teoría de la relevancia (o pertinencia), que según Calsamiglia \& Tusón (2002:112), desde una perspectiva psicológica, "se define el contexto dentro del marco de la teoría de la relevancia (o pertinencia), como ese conjunto de factores que permiten la producción y la interpretación de los enunciados con un mínimo coste de procesamiento".

En una situación típica de enunciados escritos, o sea, la publicidad turística objeto de este estudio, los productores y receptores del mensaje usan el texto para comunicarse de modo que no necesitan compartir el mismo espacio y el mismo tiempo, es decir, el ambiente de emisión y recepción pueden no coincidir. Se dice que en la escritura está la información durable, sea por medio de textos largos o cortos. Los anuncios y los carteles son ejemplos típicos de textos breves, que usan un canal mecánico.

En fin, asociada a la práctica discursiva está la noción de contexto, sea lingüístico, local, cognitivo o sociocultural, ya que desde un punto de vista discursivo ese elemento es fundamental en la constitución de textos. La configuración del contexto y sus dimensiones actúan en la localización o marco socioespacial; en el comportamiento no verbal; en la lengua como contexto; y en el contexto extrasituacional. Por último, "el contexto se define como el conjunto de supuestos, de tamaño y contenido arbitrario que interviene en la interpretación un enunciado" (Varón López, s/d: 32).

La publicidad turística, en consonancia con la coyuntura de la industria turística que está orientada hacia las exigencias de un consumidor sofisticado, intenta elaborar sus mensajes bajo un concepto de contexto neutro, en el sentido de que intenta elaborar mensajes sin particularizar cuestiones contextuales. Así, pueden elaborar mensajes lo más universales e internacionales posibles. 


\title{
Código
}

El código es uno de los elementos fundamentales en el discurso publicitario, dado que su elección será definitiva en la hora de la producción del mensaje publicitario. A partir de un determinado código, se logran objetivos distintos en la publicidad de manera que el éxito de un anuncio está vinculado también al código en el que se difunde dicho anuncio. Confirmando esta línea de pensamiento Kety Betés Rodríguez (2005:125) afirma que:

\begin{abstract}
Algunos códigos son más idóneos para alcanzar un objetivo publicitario u otro: crear notoriedad, recordar la publicidad de otros medios, incentivar una promoción, informar sobre cuestiones concretas, conservar la fidelidad del cliente, crear o mantener una determinada imagen de marca o de empresa, transmitir acciones de prestigio o de relaciones públicas, modificar actitudes y apoyar al equipo de ventas. El objetivo publicitario irá ligado al uso de un código u otro.
\end{abstract}

En publicidad, hasta el formato al cual está vehiculado un código para la transmisión de un mensaje puede tener objetivos publicitarios. En este apartado es importante que se deje registrada la importancia del código y del formato publicitario para la delimitación de los objetivos del anuncio según su público objetivo. En virtud de la importancia de la atracción visual de un anuncio, David Roca Correa (2005:141) señala:

\footnotetext{
En cierta manera, el visual actúa como nexo entre el titular y el cuerpo del texto. Es decir, estos tres elementos deberían estar totalmente integrados dentro del anuncio. Hay que destacar, sin embargo, que el visual está robando protagonismo a los elementos textuales, en una publicidad que persuade cada vez más con imágenes y menos con palabras, hasta el punto que ya se habla del no copy advertising, es decir, la publicidad que no utiliza texto.
}

Eso implica que el uso y el dominio de la imagen en el texto publicitario es una tendencia actual. Además estamos de acuerdo con este autor con respecto al protagonismo y el imperio del código visual en la publicidad, aunque, como ya hemos dicho anteriormente, una imagen vale más que mil palabras, pero una frase como esta no puede ser expresada por una imagen. 


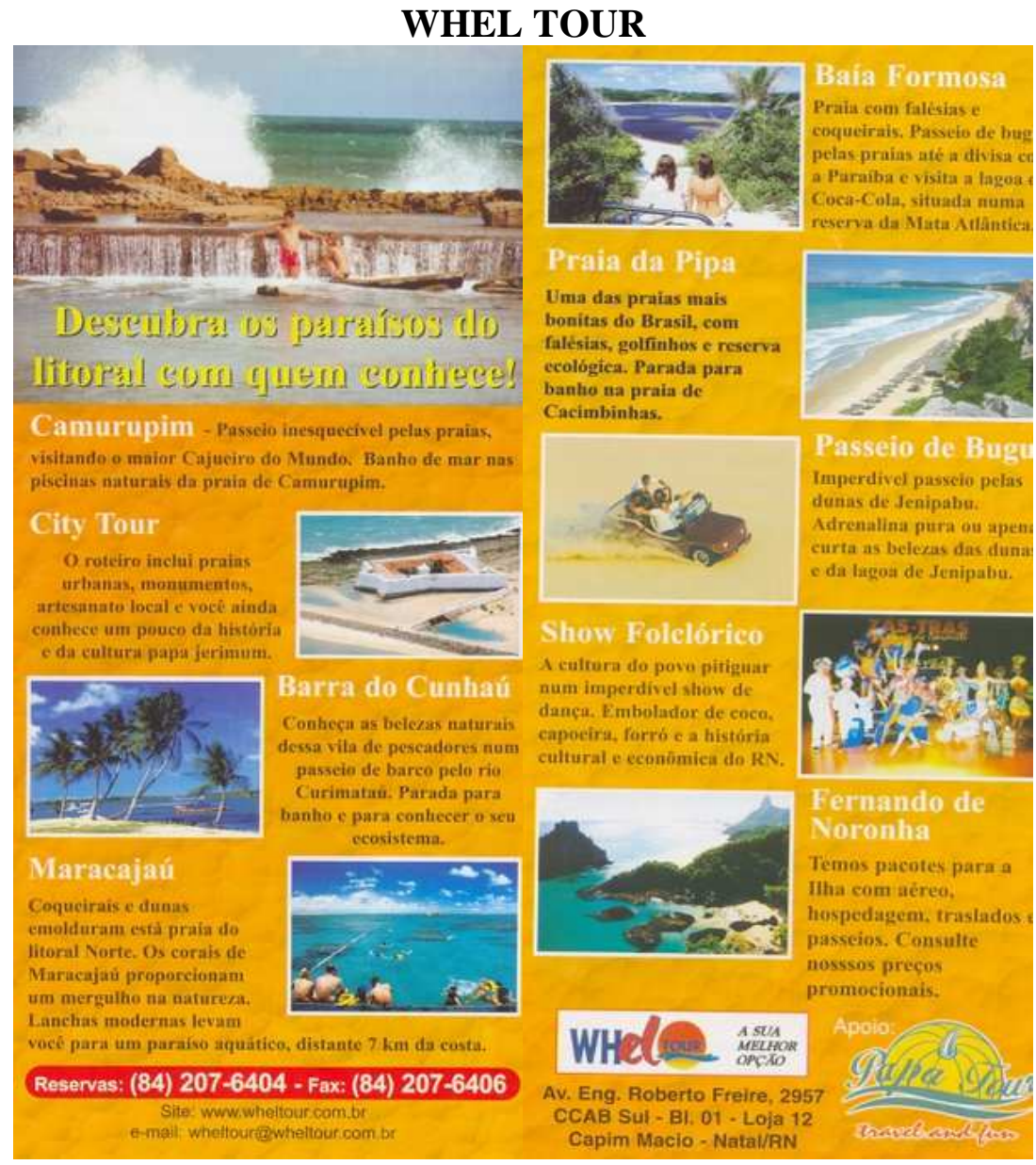

Texto 37

Extremamente relacionada con la elección de un determinado código y su disposición en los anuncios, está toda la parte de tipografía de la publicidad. Por eso, debemos mencionar que la tipografía moderna está históricamente relacionada con los movimientos de vanguardia del modernismo de principios del siglo $\mathrm{XX}$, sobre todo en los llamados ismos que valoraban la imagen. Según Luisa Blanco Rodríguez (2005:161), en esencia, el diseño gráfico de buena calidad consiste en comunicar a través "de la palabra escrita, combinada a menudo con dibujos y fotografías. A lo largo de los siglos, el arte de exhibir la palabra escrita ha evolucionado mucho hasta convertirse en un campo muy complejo del diseño gráfico".

En el texto 37, la disposición gráfica, la fotografía, los colores, los tamaños de la fuente, el color del papel y el contenido expandido del lenguaje verbal constituyen la originalidad del anuncio publicitario de Natal como destino turístico. En el texto en cuestión se puede encontrar la harmonía de la imagen asociada al lenguaje verbal para 
formar un texto persuasivo de modo que un $50 \%$ del texto es lenguaje visual y los otros $50 \%$ es lenguaje verbal.

A partir de lo que afirma Luisa Blanco Rodríguez se puede entender el diseño gráfico como una forma del arte de exhibir la palabra, y como el texto publicitario hace uso del diseño gráfico lo podemos clasificar como una forma evolucionada de lenguaje, como podemos observar en el ejemplo arriba.

La disposición gráfica del anuncio también está relacionada con el lenguaje de este anuncio que, en el caso del impreso, está constituido por los signos lingüísticos anclados en un sistema verbal como las lenguas, unidos a los signos no lingüísticos como las señales, los símbolos y los íconos. En los anuncios, según Luisa Blanco Rodríguez (2005:160):

\footnotetext{
La palabra se convierte en figura; el significado se hace transparente en el significante y se manifiesta a través de la materia gráfica. La escritura se despoja de la lectura normal de izquierda a derecha y se desarrolla ahora en varios sentidos, circular, ondulado, horizontal, vertical, en zigzag... lo que obliga a una lectura plurisintáctica, multidireccional, más reposada y, por supuesto, a una renovación de la disposición tipográfica.
}

Desde un punto de vista formal, este texto 37 sigue el formato propio de un texto publicitario. En su macroestructura figura la descripción del "Whel Tuor", sus productos y la forma de acceder a ellos. La progresión temática de este texto puede ser definida como de progresión de temas derivados.

Las personas del discurso presentes son la tercera persona del singular para indicar al producto anunciado de forma impersonal y la inscripción del "você", en portugués de Brasil, que tiene la fuerza semántica del "tú" en español, presentando así un carácter de proximidad entre el emisor y el destinatario.

El producto visual consiste en las imágenes de los productos turísticos ofertados por la "Whel Tuor". El mensaje manifiesto corresponde a la publicidad del producto ofertado y el mensaje latente connota el carácter idílico y paradisíaco de los paisajes presentados como productos turísticos. 
En el marco léxico de este folleto publicitario se puede encontrar palabas como paraíso, inolvidable, más grande, naturales, monumentos, artesanía, cultura, bellezas, relajar, tranquilidad, bonitas, indispensable, adrenalina pura, baile, promocionales y pasarlo bien. Es decir, un léxico positivo asociado a imágenes positivas para presentar un producto turístico tan perfecto como el propio paraíso. Por eso, hace la invitación: ¡descubre los paraísos del litoral con quien los conoce!

\section{El vehículo de comunicación}

La publicidad hace uso de los distintos medios de comunicación como canales vehículos de difusión del texto publicitario, así que la elección del canal condiciona qué código se elegirá. También el tipo de producto, el destinatario y el emisor determinan el mensaje publicitario y cómo será presentado. De ahí que, para Asunción Escribano (2006:142), "en cualquier caso, lo que es cierto es que el producto anunciado determina el tipo de publicidad que se emplea para darlo a conocer".

El vehículo de comunicación publicitaria puede ser de los más diversos tipos como la radio, la televisión, los periódicos, las revistas, el cine, los carteles, los outdoors, etc. Cada uno limita el tipo y la forma del mensaje. En este trabajo nos limitamos al estudio de la publicidad escrita, así que el vehículo de comunicación de este tipo de publicidad consiste básicamente en libros, folletos, revistas y periódicos, como hemos visto en nuestro tercer capítulo.

Para la realización de una campaña exitosa, es importante conocer al público y estructurar el mensaje de la mejor forma posible para conquistarlo. Pero para ello, el público necesita poder acceder al mensaje publicitario que necesita ser difundido por medio de un código y un vehículo de comunicación accesibles. Por eso, la elección del código y del medio de comunicación vehicular es fundamental en la conquista del público objeto. A este respecto Sant'Anna (2002:193) expone:

El problema de la selección de vehículos debe ser decidido en el momento exacto de planear, pues de un lado, el grupo consumidor a ser alcanzado dicta la elección del género de los vehículos, por otro lado, la naturaleza del mensaje, la forma más apta de expresarla, el presupuesto disponible para la campaña, etc. influyen igualmente en la selección, siendo de este modo 
indispensable coordinar todos esos factores antes de empezar la preparación de la piezas publicitarias. ${ }^{48}$

Por lo tanto, el vehículo de comunicación usado para difundir un mensaje publicitario está íntimamente relacionado con el código que será adoptado. En nuestro caso, los vehículos estudiados son los folletos y casi siempre adoptan como códigos el lenguaje verbal y el lenguaje visual como hemos visto anteriormente.

\section{El enunciado}

En el discurso publicitario escrito el enunciado suele presentarse en forma de una verdadera obra de arte que muchos críticos clasifican como obra de arte literaria en nuestro tiempo. La verdad es que los publicistas hacen uso de toda creatividad y artificios posibles para la elaboración de un mensaje original, que llame atención de su audiencia, que sea comprendido fácilmente, que sea leve y fácil de recordar.

La novedad y la redundancia forman los dos polos por los que se mueve la publicidad porque el contexto se lo permite al interlocutor la descodificación de este tipo de mensaje. En palabras de López Eire (1998:67), a la publicidad le interesa que "sus mensajes sean a la vez novedosos y redundantes, además de concisos, porque en el acto de habla publicitario la situación y el contexto permiten en todo momento al receptor del mensaje desentrañarlo o descodificarlo debidamente".

El acto de habla producido por la publicística se ubica entre la brevedad y la redundancia y por eso es un acto de habla que se distingue del retórico y del poético. Según López Eire (1998:71), “tiene como propósito, en concordancia perfecta con la intención o voluntad (voluntas) del anunciante, ser fácil de recordar y memorable o digno de ser recordado, y por ello breve, chocante y a la vez redundante".

\footnotetext{
${ }^{48}$ En la fuente original: "O problema da seleção de veículos deve ser decidido no momento exato de planejar, pois se de um lado, o grupo consumidor a visar é que dita o gênero dos veículos a escolher, por outro lado, a natureza da mensagem, a forma mais apta a expressá-la, a verba disponível para a campanha, etc. influem igualmente na seleção, sendo assim indispensável coordenar todos esses fatores antes de começar o preparo das peças publicitárias".
} 


\section{La enunciación}

La enunciación de los mensajes publicitarios camina para una finalidad única, esto es, el objetivo del mensaje publicitario por excelencia es la venta de un producto o de un determinado tipo de servicio. Dicho de otro modo, todo mensaje publicitario enuncia que el interlocutor debe adquirir lo que se anuncia.

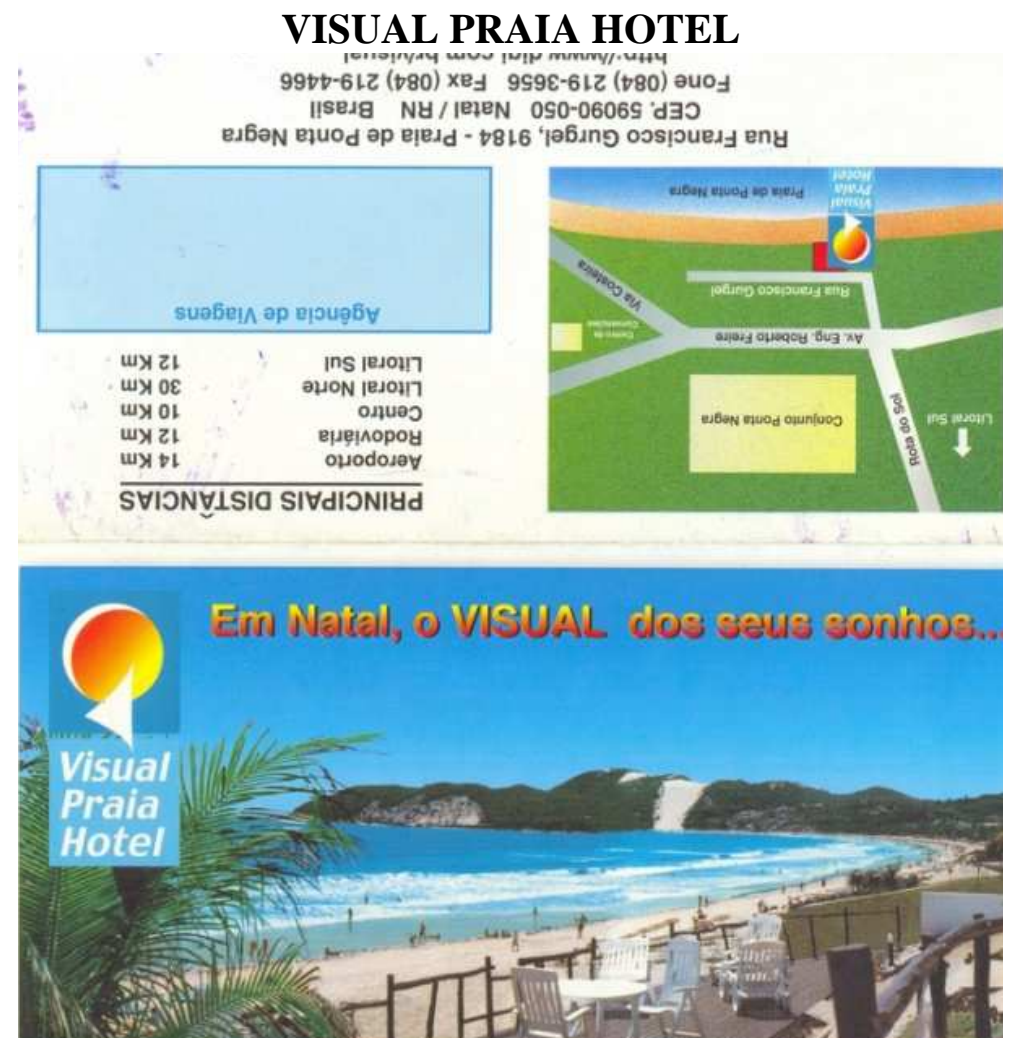



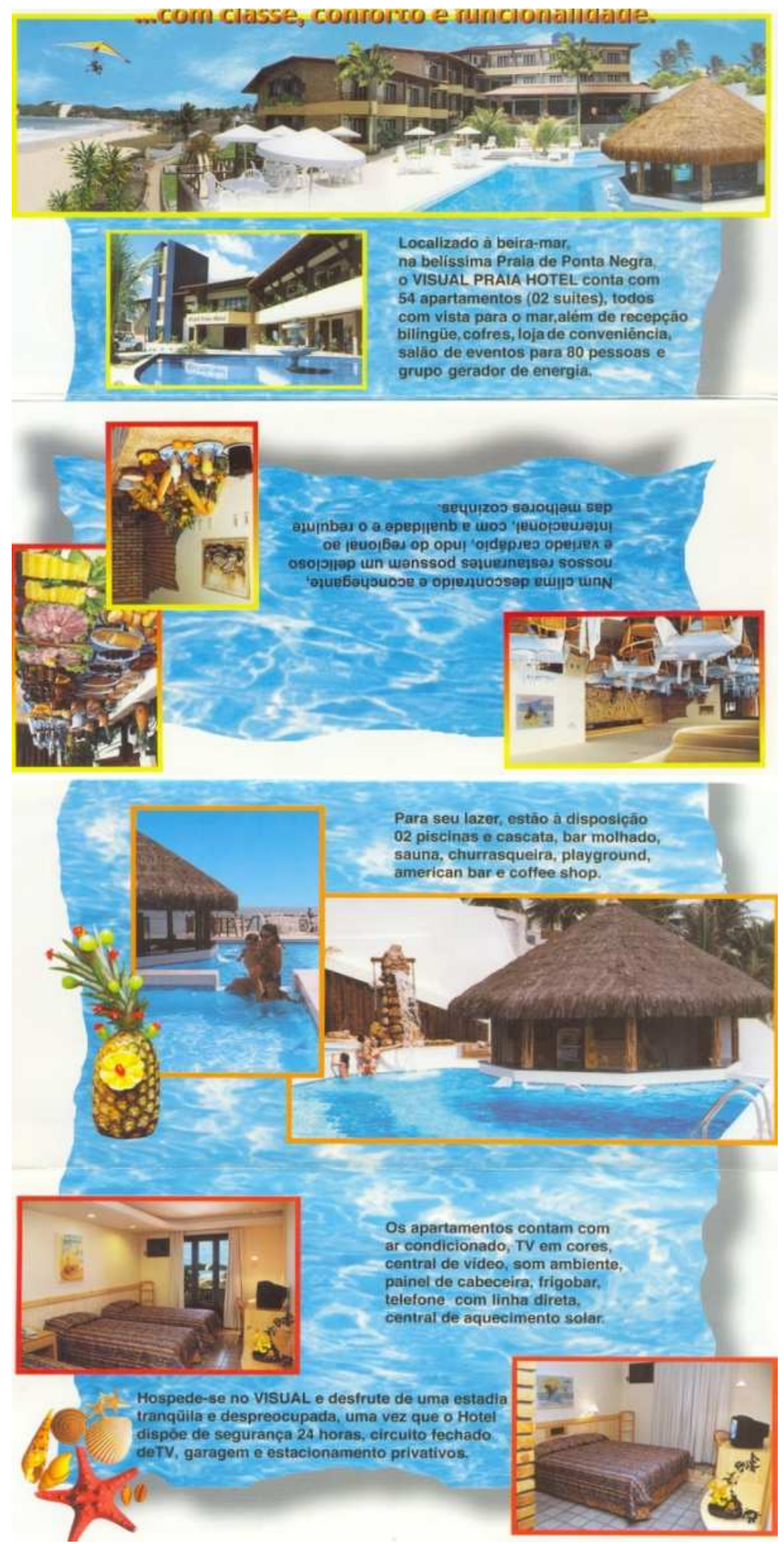

Texto 38

Desde un punto de vista formal, el texto 38 sigue el formato propio del texto publicitario. En su macroestructura, figura la descripción del "Visual Praia Hotel", sus instalaciones internas y externas, además de su localización. La progresión temática de este texto puede ser definida como de progresión de tema constante. 
Las personas del discurso presentes son la tercera persona del singular que remite al producto ofertado y la inscripción del "você", en portugués de Brasil, que tiene la fuerza semántica del "tú" en español, presentando así un carácter de proximidad entre el emisor y el destinatario, eso acorta las distancias entre los interlocutores y aporta más confianza.

El acto de habla locutivo consiste en el discurso constituido por el lenguaje verbal escrito y el lenguaje visual; el ilocutivo en la descripción del producto turístico ofertado y su ubicación; y el perlocutivo en la estrategia de persuasión publicitaria que tiene como finalidad recibir del interlocutor la confirmación en forma de un acto de compra, o sea, la enunciación consiste en el acto de la adquisición del producto turístico anunciado.

En la textura discursiva están presentes los elementos léxicos positivos como: sueños, vista, bellísima, relajado, acogedor, sabroso, internacional, mejores, cualidad, ocio, disfrute, tranquila, despreocupada y privado. Lo que significa toda una estructura léxica en la predomina el uso de verbos, sustantivos y adjetivos.

El producto visual consiste en la propia imagen del "Visual Praia Hotel" y sus instalaciones, tanto externas como internas, además de la presentación de sus servicios. El mensaje manifiesto corresponde a la propia publicidad del producto ofertado y el mensaje latente connota la belleza, el confort y la comodidad del "Visual Praia Hotel". En suma, toda una estructura persuasiva que intenta vender un sueño, una estancia en una ciudad sobre la que el propio anuncio afirma: en Natal, el visual de tus sueños.

\section{El enunciatario}

El interlocutor desempeña un papel fundamental en la construcción del discurso publicitario como observan Adam \& Bonhomme (2000:105) cuando dicen que los anuncios exigen una "participación activa de sus destinatarios, que se ven obligados a interrogarse sobre el acto de la recepción publicitaria”.

La noción de audiencia en la publicidad es muy importante porque se trata de un tipo textual dedicado y creado a partir de un receptor, de un público objetivo, sin el cual la 
estructura de la publicidad no podría ser llevada a cabo, ya que está siempre destinada a un tipo específico de consumidores en potencia, es decir, está elaborada a partir de un público y direccionada a él. Daniel Vela Valldecabres (2005:67) dice que "por definición, toda la publicidad está dirigida al consumidor de una época determinada, al que es necesario comprender para obtener la eficacia del mensaje", eso nos muestra cómo la publicidad depende de su audiencia.

El origen de esta preocupación por la audiencia remonta al desarrollo capitalista estadounidense de finales del siglo XIX, cuando hubo un aumento sustancial de la población en EUA y el consecuente aumento de producción y ventas en todos los sectores industriales. En esta época, el modelo publicitario seguía una línea guiada por la argumentación racional.

Sin embargo, con el surgimiento de la primera sociedad de consumo en el inicio del siglo XX, el texto publicitario pasó por algunos cambios para atender al mercado emergente y la nueva configuración social. Por lo tanto, a partir de la segunda mitad del siglo XX, la publicidad pasa a adoptar una postura menos racional frente a su público. A este respecto Daniel Vela Valldecabres (2005:69) señala que:

Conforme se asienta la economía de libre competencia, se van especializando los productos, por lo que la publicidad se dirige a un segmento de mercado. Ya en la segunda mitad del siglo XX, la publicidad ha ido perdiendo el punto de vista racional y se centra en resaltar la imagen de la marca. Es decir, el posicionamiento de la marca en el mercado ha pasado a ser el objetivo prioritario del mensaje publicitario, que se asocia directamente al modus vivendi del consumidor. De hecho, a partir de los años sesenta, se experimenta un cambio en la estrategia de marketing segmentado, puesto que el consumidor pasa a valorar mucho más el producto según su estilo de vida, por encima incluso de su nivel socioeconómico.

Así, la publicidad sufrió profundas modificaciones durante el siglo XX y se configuró en el estilo que valora el destinatario, producto de la sociedad de consumo, de la ideología capitalista y moldeado según los valores de la ideología de bienestar social y económico presentes en toda sociedad desarrollada. 
Además, el destinatario, mientras lector de un texto publicitario, pasó a actuar como un coautor del texto, ya que el acto de lectura no es un acto pasivo, sino activo en el que entra en juego su conocimiento enciclopédico y su disponibilidad para la lectura. No obstante, el interlocutor es un sujeto pasivo en este acto de comunicación por no tener que generar una respuesta verbal, sino un acto de compra. Según Ana María Rodríguez Fernández (2005:216):

El destinatario es el elemento más importante del mensaje publicitario, pero no es un elemento activo en este proceso de comunicación. La publicidad se constituye en un mensaje unidireccional e interesado que, sin embargo, intenta incumbir su intención comercial y activar en el destinatario un tipo de recepción del mensaje no consciente de los fines pretendidos.

Como podemos ver, tanto Daniel Vela Valldecabres como Ana María Rodríguez Fernández reconocen la importancia fundamental del destinatario para la publicidad, que consiste en un mensaje interesado y cuyas intenciones se intentan ocultar al interlocutor, que muchas veces produce la respuesta esperada por los publicistas o la empresa que anuncia sin la consciencia de que fueron convencidos por un anuncio.

El modelo capitalista adoptado en las sociedades de bienestar, tiene en la publicidad una aliada en la defensa y propagación de su ideología para difundir valores. Por eso, la publicidad crea y modifica costumbres, otorga y quita importancia a hechos y productos según el interés del mercado, formando e, incluso, creando la propia sociedad como señala Daniel Vela Valldecabres (2005:76) cuando dice que "en las sociedades consumistas los objetos y su universo simbólico generan la sociedad y no al contrario".

Eso sirve para enfatizar el papel hegemónico que la publicidad ocupa en la sociedad actual y, sobre todo, en las sociedades desarrolladas que gozan del llamado bienestar social, anclado muchas veces en el consumo de servicios, bienes y productos convertidos en el propio sueño de felicidad para los consumidores, como hemos visto en el texto 38 presentado anteriormente.

Además, la sociedad moderna pasó por muchos cambios durante el siglo XX y en los primeros años del siglo XXI muestra señales de los resultados de una sociedad formada para el consumo, en la que, muchas veces, el hecho de poseer bienes materiales, tener 
una apariencia exitosa y parecer perfecto adquieren más valor que los sentimientos humanos o, incluso, la propia existencia.

Aquí, una vez más, la publicidad ejerce su protagonismo dado que nos encontramos en medio de valores cultivados por una sociedad producto de su publicidad, en la que no hay límites fijados en relación a muchos valores humanos, dado que el hedonismo y el consumismo imperan.

La masa de la sociedad, que a veces no es consciente ni por qué valora determinadas cosas y modos de vida, cultiva diversos valores difundidos por la publicidad, sobre todo el valor de vivir el presente, disfrutar de la juventud, de la belleza y de la vida. El lema "disfrutar" en ese contexto significa, más bien, ser hedonista, participar de un determinado estilo de vida y consumir, claro, los productos anunciados. Frente a eso, Daniel Vela Valldecabres (2005:78) apunta:

\begin{abstract}
Al impulsar una sociedad de clases, la publicidad actual alienta también el carpe diem. Frente a los discursos mítico, ideológico o religioso que aludían al pasado o al provenir, el discurso publicitario exige el presente absoluto y actúa como el crisol donde se funden los afanes y deseos de las personas, las formas de entender el mundo o los estilos de vida. Ahí cuaja la actual mitología e ideología del objeto cotidiano.
\end{abstract}

En general, la publicidad diagnostica el perfil de la audiencia y, al compartir el imaginario social y cultural del público meta al que dirige su mensaje, defiende la temática de la seguridad, de la adquisición de personalidad, del éxito, del prestigio, de la tecnología, de la novedad y del placer. A través de eso y de los recursos lingüísticos y no lingüísticos empleados en los anuncios, intentan persuadir al potencial comprador, como observa Sara Robles (2005:225):

La publicidad es un género semiológico que utiliza cualquier lenguaje y tiende normalmente a la imbricación de distintos procedimientos comunicativos (imagen, palabras, sonidos, etc.). La característica principal de la publicidad comercial es lograr la atención del receptor y persuadirlo para que adquiera el bien que anuncia.

Por lo tanto, no queda duda de que la publicidad hace uso de los más variados procedimientos comunicativos como las imágenes, las palabras y los sonidos para 
conquistar la atención de la audiencia y, sobre todo, persuadirla para que obtenga el producto o servicio anunciado.

\subsection{Conclusión}

En nuestro cuarto capítulo defendemos la idea de que la publicidad es un fenómeno contemporáneo que está fundamentado en cuestiones como el concepto de la publicidad, el origen del fenómeno publicitario, la distinción entre la publicidad y la propaganda, el uso de la palabra en la publicidad, el uso de la imagen en el discurso publicitario, el lenguaje publicitario y, por último, el proceso comunicativo en la publicidad.

También defendemos, a partir de este capítulo, que la publicidad es un proceso específico de comunicación y que esa especificidad reside en el hecho de que el enunciador, el contexto, el código, el vehículo, el enunciado, la enunciación y el enunciatario se comportan de modo particular en el acto de habla publicitario y, por lo tanto, eso distingue este tipo discursivo del discurso literario y del no literario.

Para ello usamos nuestra revisión bibliográfica, además de la muestra de folletos publicitarios adoptada en la parte empírica de esta investigación. En suma, a partir de todo lo que hemos visto en este capítulo defendemos nuestra Teoría del Acto de Comunicación Publicitario, que concibe la publicidad como un acto de habla específico y por eso el discurso publicitario se distingue del discurso literario y del no literario, ya que el discurso publicitario está fraguado por medio del comportamiento particular de esos siete elementos fundamentales que componen el acto de comunicación publicitario. 


\section{Capítulo V}

\section{PUBLICIDAD TURÍSTICA: ASPECTOS RETÓRICOS}

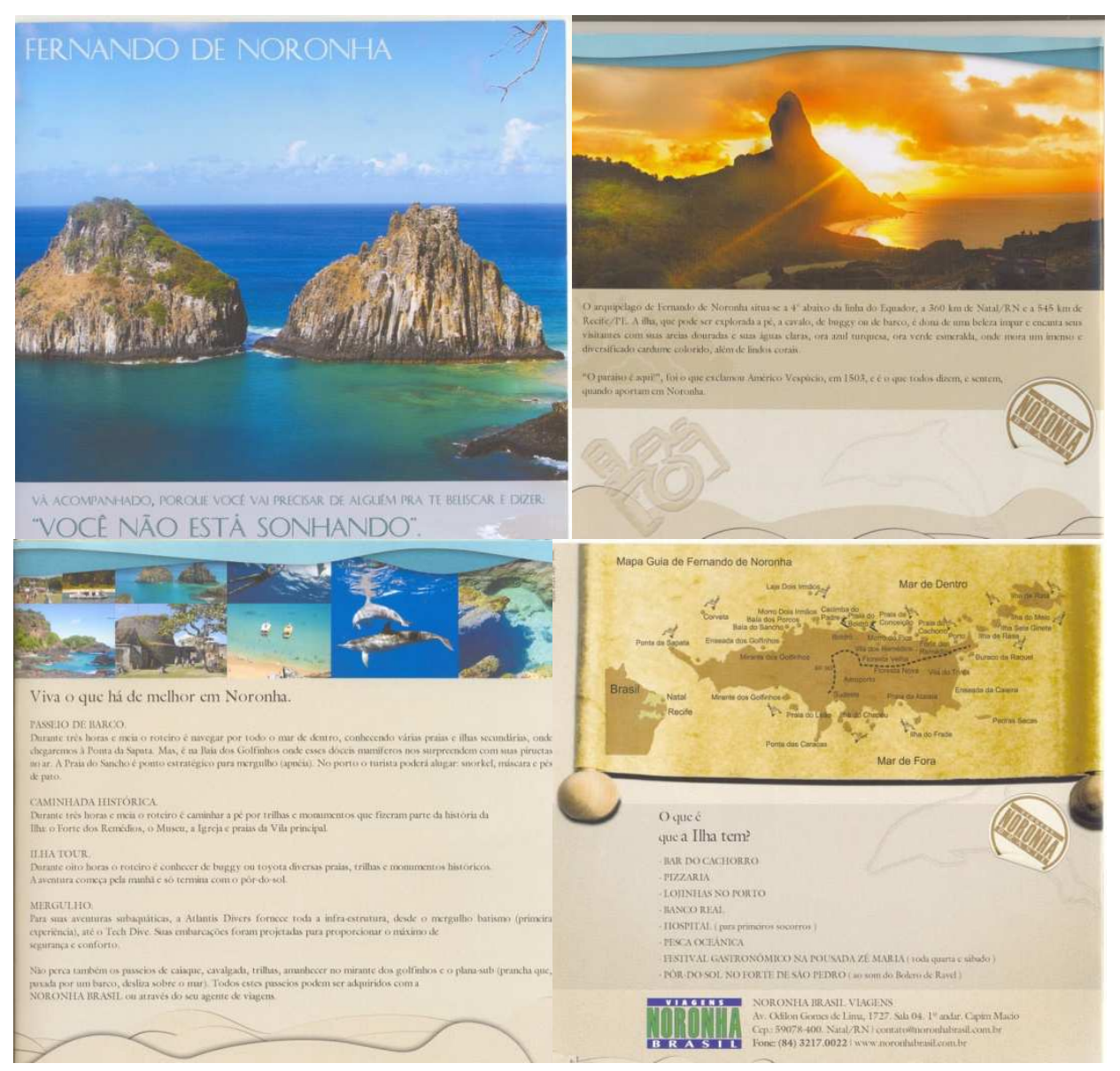

"La publicidad es retórica, pero no retórica clásica, sino pura y auténtica retórica moderna".

(Eduardo Fernández) 


\section{CAPÍTULO V - PUBLICIDAD TURÍSTICA: ASPECTOS RETÓRICOS}

Hemos definido la publicidad turística como un discurso que materializa un producto o servicio y que constituye un acto de comunicación específico, como hemos visto en el capítulo anterior. Un texto puede ser considerado publicitario cuando se dan algunas condiciones determinadas. Entre estas condiciones están los aspectos retóricos del texto publicitario. Por ello, el quinto capítulo de nuestro trabajo presenta los aspectos retóricos como elementos básicos para la comprensión de la publicidad escrita. Intentamos así encontrar lo que llamamos aquí las especificidades del discurso publicitario, comprendido como un tipo de discurso elaborado artísticamente.

\subsection{La retórica y su definición}

Primero, para iniciar nuestra discusión sobre la retórica empecemos por intentar definirla. Para ello, tomaremos en consideración la etimología de la palabra retórica, proveniente del griego rhetor, que significa orador. El diccionario Aurélio presenta cuatro acepciones para ese lema, a saber: a) Elocuencia, oratoria; b) Estudio del uso persuasivo del lenguaje, en especial para entrenar oradores; c) Adornos pomposos de un discurso; d) Discurso de forma primorosa, pero sin contenido. ${ }^{49}$

\footnotetext{
${ }^{49}$ En la fuente original: "1. Eloqüência; oratória./ 2. Estudo do uso persuasivo da linguagem, em especial para o treinamento de oradores./ 3. Adornos empolados ou pomposos de um discurso./ 4. "Discurso de forma primorosa, porém vazio de conteúdo".
} 
Sin embargo, la autora Tereza Lucia Halliday (1999:7) está en contra las dos últimas acepciones presentadas en el diccionario de lengua portuguesa Aurélio y da su definición de retórica cuando dice que la retórica "pasa como sinónimo de charla cotidiana, discurso que no corresponde ni a los actos ni a los hechos. Hasta los diccionarios ayudan a hacer mal juicio sobre la retórica, cuando la defienden como lenguaje pomposo y rebuscado". ${ }^{50}$ Esta misma autora define la retórica como una subárea de la comunicación que trata de actos comunicativos como una campaña publicitaria cuando señala:

\begin{abstract}
El uso de la comunicación para definir las cosas de la manera como deseamos que los demás las vean. Cuando hacemos eso estamos actuando retóricamente [...]. 'Retórica' también es el nombre dado a una disciplina o subárea dentro de los estudios de la comunicación humana. Se ocupa de examinar, describir, prescribir y evaluar actos y eventos que tengan como objetivo influenciar percepciones, sentimientos, actitudes y acciones, con palabras y otros símbolos. Por ejemplo, las campañas para elegir un candidato, [...] anuncios publicitarios, notas oficiales, manifiestos y movimientos a favor de una causa o en contra una idea (Halliday, 1999:08-09). ${ }^{51}$
\end{abstract}

Antonio López Eire se ha dedicado al estudio de este tema con el propósito de destacar el carácter retórico en el mensaje publicitario, además de abordarlo como un fenómeno del lenguaje que va más allá de una materia que se asocia a la literatura y a la lingüística, de modo que se asocia la retoricidad de la publicidad a las más variadas ciencias, todas muy pragmáticas, con una aplicabilidad social. Al destacar la operatividad social y política de la retórica, López Eire (1998:9) señala:

\begin{abstract}
Muy al contrario, la primera retórica que conocemos, la retórica griega de época clásica, era una retórica oral y política que se realizaba en los espacios públicos de la pólis o ciudad-estado y estaba presente en casi todas o prácticamente todas las manifestaciones oficiales ciudadanas. La retórica era una estrategia social de múltiple uso. Y eso - nos guste o no - es lo que la retórica en mayor o menor medida ha sido y hoy está volviendo a ser.
\end{abstract}

\footnotetext{
${ }^{50}$ En la fuente original: "Passa como sinônimo de "conversa fiada", discurso que não corresponde nem aos atos nem aos fatos. Até os dicionários ajudam a fazer mau juízo dela, quando a definem como linguagem pomposa e rebuscada".

${ }^{51}$ En la fuente original: "O uso da comunicação para definir as coisas da maneira como desejamos que os outros vejam. Quando fazemos isto, estamos agindo retoricamente [...]. "Retórica" também é o nome dado a uma disciplina, ou subárea dentro dos estudos da comunicação humana. Ocupa-se de examinar, descrever, prescrever e avaliar atos e eventos que visem influenciar percepções, sentimentos, atitudes e ações, com palavras e outros símbolos. Por exemplo, campanhas para eleger um candidato [...], anúncios publicitários, notas oficiais, manifestos e movimentos em prol de uma causa ou contra uma idéia (Halliday, 1999:08-09)".
} 
Aunque la imagen del orador es hoy día anacrónica, está surgiendo una nueva figura, la del comunicador adaptado a todos los modernos medios de comunicación, que la reemplaza.

Al presentar la retórica desde una perspectiva diacrónica, López Eire (1998:10) define la retórica como una modalidad artística o científica de acción social. Para ello afirma que "la retórica era ya en aquellos tiempos lo que nunca ha dejado totalmente de ser y por tanto todavía es hoy, a saber: una modalidad específica del arte o la ciencia de la acción o praxis social". Eduardo Fernández, (2006:15), demuestra que "la publicidad es retórica, pero no retórica clásica, sino pura y auténtica retórica moderna”. Así, los dos autores mencionados anteriormente igualan a esos dos campos del conocimiento, pues los tratan como un tipo de arte de la acción social por medio de palabras.

Desde nuestro punto de vista, defendemos la idea de que la retórica es un campo de la lógica que trata de los argumentos en un discurso. Por eso, los retóricos validan sus discursos por medio del arte de la argumentación que acompaña a la historia de la formación social y política de las más variadas sociedades. Para Adam \& Bonhomme (2000:28), la manera de pensar la retórica debe ser:

\begin{abstract}
Más en términos de persuasión y de acción (compra-consumo), que en términos de convicción e inteligencia. Muy lejos de dar razones a favor o en contra de una tesis, el discurso publicitario se aparenta al género epidíctico (<<demostrativo >> de los Latinos). Esta forma de discurso espectáculo, que corresponde a los sermones, elogios fúnebres y discursos de ceremonias conmemorativas, se distingue, desde Aristóteles y de manera muy útil, de los géneros judicial y deliberativo.
\end{abstract}

La retórica tiene como objeto el tratamiento de las formas de expresar y proferir enunciados atractivos para la audiencia. Según Calsamiglia \& Tusón (2002:337), "los enunciados producidos con el ánimo de atraer la atención de la audiencia acentúan su fuerza ilocutiva y su efecto perlocutivo, ya que en ellos se manifiesta la intención de mover hacia la acción, conmover o crear la adhesión de los destinatarios". La retórica es considerada una dimensión básica para el análisis de cualquier texto y está fundamentada en las virtudes o máximas del ars bene dicendi, a saber:

1- Máxima de puritas (purismo lingüístico); 
2- Máxima de perspicuitas (claridad y precisión);

3- Máxima de ornatos (la creatividad discursiva);

4- Máxima de aptum (apropiación situacional).

Al hablar de la retórica, López Eire (1998:23) la define como un arte comunicativo que influye sobre las decisiones del prójimo por medio del lenguaje, eso es lo que podemos ver a partir de la cita presentada a continuación: "La retórica es arte de la comunicación a través del lenguaje cuya principal función es influir sobre el prójimo que con nosotros lo comparte".

Por tanto, la retórica se entiende como un tipo de arte comunicativo que conduce a una acción social por medio de palabras. Este concepto de retórica está presente en la muestra de textos publicitarios adoptada, en la que se acentúan fuerza ilocutiva y el efecto perlocutivo de los textos que forman parte del material empírico de nuestro trabajo.

En el texto presentado abajo se acentúan su fuerza ilocutiva y su efecto perlocutivo una vez que se trata de un texto persuasivo. Desde un punto de vista formal, ese texto sigue el formato propio del texto publicitario, género discursivo que adopta, como la retórica, las llamadas virtudes o máximas del ars bene dicendi, más específicamente el cuidado lingüístico con el texto verbal, la claridad y precisión textuales, la creatividad discursiva y la apropiación situacional, además del uso de un código híbrido, o sea, verbal y visual.

En la macroestructura del texto 39 figura la descripción del "Villa do Sol Hotel", la presentación de su localización y sus servicios. La progresión temática de este texto puede ser definida como de progresión de tema constante. Las personas del discurso presentes son la tercera persona del singular que remite al producto anunciado y la inscripción del "tú", que aporta un carácter de proximidad entre los interlocutores del acto de habla publicitario.

La fuerza ilocutiva y su efecto perlocutivo son acentuados para atraer la atención de la audiencia, ya que la publicidad es una información persuasiva y, por lo tanto, su finalidad última es que el público objeto produzca una acción: la adquisición del producto anunciado. En el caso del texto 39, que veremos a continuación, se intenta 
vender la visita a Natal como un destino turístico y la estancia en el "Villa do Sol Hotel", como producto perteneciente a la industria del turismo.

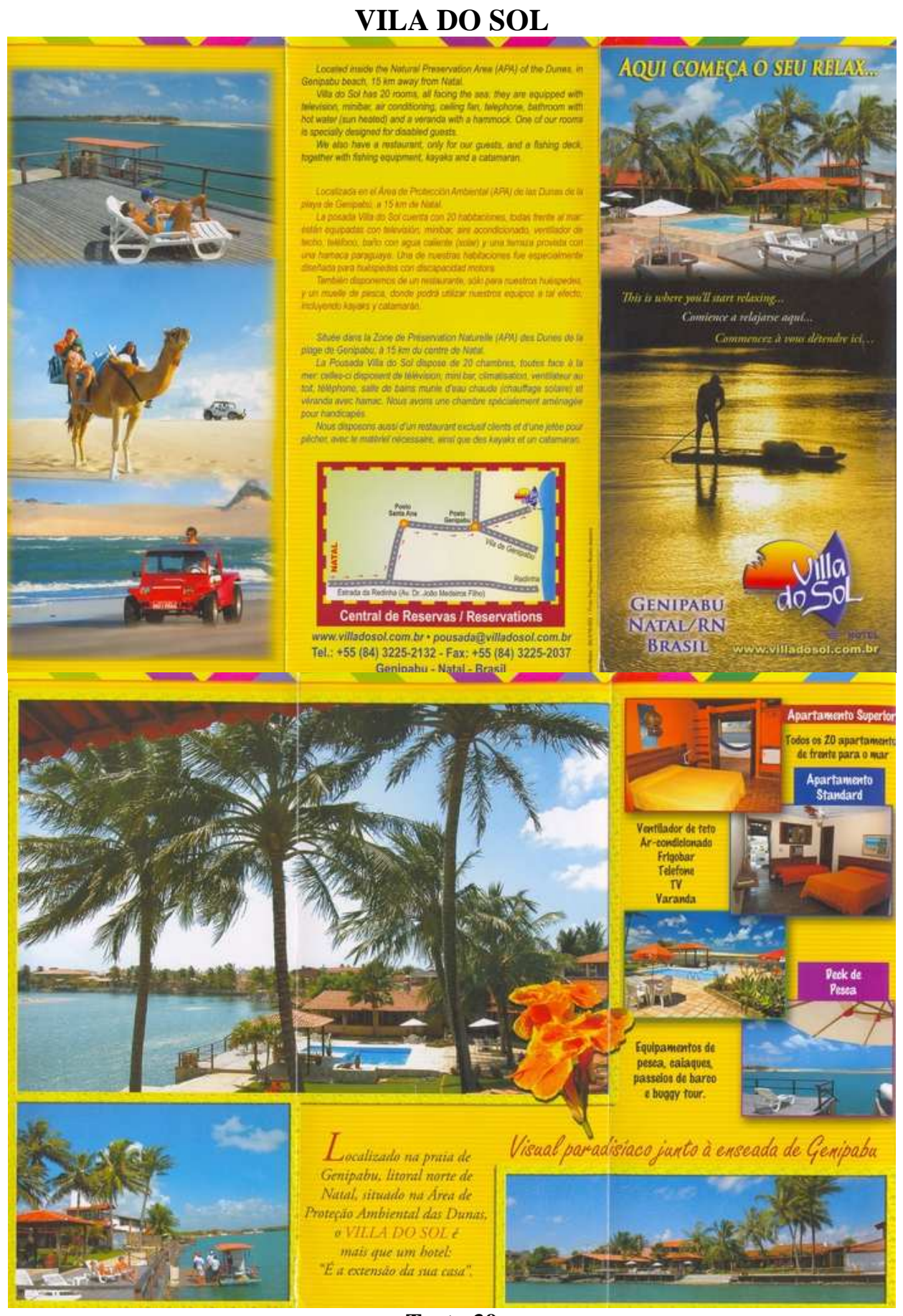

Texto 39 
El texto 39 es un texto estéticamente elaborado y de fácil decodificación. También es atractivo a los ojos del lector y adopta un léxico positivo como: descanso, sol, protección, playa, mar, equipada, especialmente, muelle, empieza.

La comunicación mercadológica puede ser comprendida como una variante de la comunicación de masa. La publicidad forma parte de este tipo de comunicación y tiene como objetivo persuadir a su audiencia a adquirir un determinado producto o servicio. El afán de persuadir de este texto publicitario hace que emplee enunciados como el de su eslogan que dice: aquí empieza tu descanso; además de la frase de efecto: Villa do Sol es más que un hotel: es la extensión de tu casa. Así, se transmite claramente la preocupación que el locutor tiene por el bienestar de su interlocutor y demuestra un ambiente familiar, ya que el hotel es una extensión de la casa de su audiencia.

En el acto de comunicación publicitario hay dos componentes teóricos que, según Pèninou (1976), son los elementos icónicos y los elementos textuales. El producto visual del texto 39 consiste en la propia imagen de las instalaciones internas y externas del "Villa do Sol Hotel", que sirve como una descripción fiel del producto turístico anunciado. Su mensaje manifiesto corresponde a la publicidad del producto turístico y los servicios ofertados y su mensaje latente connota un lugar idílico, romántico, acogedor y confortable.

Así, queda claro que el objetivo principal del texto publicitario en cuestión es influir sobre el comportamiento del prójimo por medio de un leguaje cuidadosamente elaborado que profiere mensajes atractivos a su audiencia. Por lo tanto, no queda duda de que el anuncio publicitario es una forma de perpetuación de la retórica en la contemporaneidad.

\subsection{La retórica y sus orígenes históricos}

La retórica tiene aproximadamente 4.500 años. Según Zoppi-Fontana (2006:80), “de acuerdo con la opinión de la mayor parte de los autores que se dedican al estudio de la retórica, las operaciones argumentativas destinadas al convencimiento/persuasión del interlocutor, tiene su origen en Grecia entre los siglos V y IV a. C." Sin embargo, en Egipto, Ptahhotpe ya veía la utilidad y el poder de las palabras como herramienta de 
relación interpersonal. Aristóteles, por su parte, en la Grecia antigua, escribió el Arte Retórico y defendía la persuasión como una obligación retórica. En relación al poder de este arte presentado por Aristóteles, Halliday (1999:63) afirma que:

\begin{abstract}
El uso irresponsable de la retórica es capaz de causar daños graves. No obstante, no es solamente con la retórica que pasa eso. Aristóteles recuerda otros casos: 'la fuerza, la salud, la riqueza, el arte militar', cuyo uso puede traer gran provecho y cuyo uso injusto 'puede originar daños muy siniestros'. 52
\end{abstract}

Las sociedades clásicas cultivaban la oratoria y el arte del buen discurso como forma de interacción entre el poder público y la sociedad. La práctica política era muy importante en esas sociedades y era concretada por medio de mítines y asambleas populares. Para ello, era fundamental el buen dominio de la retórica, como la scientia bene dicendi de Quintiliano.

En la actualidad, la retórica todavía es utilizada como una herramienta que sirve como introducción a los discursos, las conferencias, los mítines, debates, etc. Grandes usuarios de este arte están en el medio político, pero los comentaristas, los periodistas, los juristas, los publicistas y profesores de diversas áreas también hacen uso de este arte. La relevancia de la retórica en las relaciones interpersonales y en la comunicación le asegura el protagonismo en las más diversas sociedades desde los clásicos hasta la contemporaneidad. El ejemplo máximo de la retórica de nuestro tiempo es la publicidad, como ya hemos dicho anteriormente.

La retórica clásica está dividida en tres géneros: el judicial, el deliberativo y el demostrativo. La adopción de un género u otro está condicionada a los objetivos y a la audiencia del orador. El género judicial (Iudicialem) era usado, en su origen, para crear acusaciones o defensas, realizando juicios a favor o en contra de determinados asuntos o personas. Es, pues, el género de la argumentación, como afirma Lausberg (1990:108) "en la inventio de este genus el centro de gravedad gira en torno a los argumentos". El género deliberativo (Deliberativum), como está implícito en el propio término, sirve

\footnotetext{
${ }^{52}$ En la fuente original: "O uso irresponsável da retórica é capaz de causar graves danos. Mas não é só com a retórica que isso acontece. Aristóteles lembra outros casos: 'a força, a saúde, a riqueza, a arte militar', cujo uso justo pode trazer grande proveito e cujo uso injusto 'pode originar danos muito funestos'".
} 
para deliberar, es decir, actúa en la toma de decisiones por medio de la presentación de historias que sirven como ejemplos ilustrativos. La política es su elemento. Por último, el género demostrativo (Demonstrativum o Epiditicum) tiene como objetivo la alabanza y la crítica, de ese modo sirve para elogiar la virtud y lo honesto, pero también para criticar el vicio y la falta de virtud.

La publicidad contemporánea se vale de los más diversos recursos retóricos a la hora de persuadir a sus receptores. En la publicidad turística, como se puede ver en el texto 40, tanto la parte escrita como la imagen son usadas en el discurso publicitario como procedimientos retóricos próximos al género Demonstrativum o Epiditicum. En este anuncio se alaba el producto ofrecido por "Via Natal Rent a Car" de modo que los elogios que van dirigidos a esa empresa de alquiler de coches afirman que alquilar un coche allí es más fácil y más barato.

En la macroestructura del texto 40 figura la descripción del "Via Natal Ren Car", sus formas de contacto, su localización y sus productos. La progresión temática de este texto puede ser definida como progresión de tema constante. Las personas del discurso presentes son la tercera persona del singular (él/ella), que remite al producto ofertado, y la inscripción del "tú", que otorga la proximidad entre el emisor y su auditorio.

La fuerza ilocutiva del texto 40 corresponde a la descripción del producto turístico ofertado, es decir, el alquiler de coches en "Via Natal Ren Car". En el anuncio en cuestión, esta empresa y sus productos son presentados por medio de la descripción textual, sea por medio del código verbal como del código no verbal.

El efecto perlocutivo de este texto publicitario consiste en la estrategia de persuasión publicitaria que tiene como finalidad recibir del interlocutor la confirmación en forma de un acto de compra, ya que la publicidad produce mensajes interesados y connota siempre la adquisición de un producto en su efecto perlocutivo. 


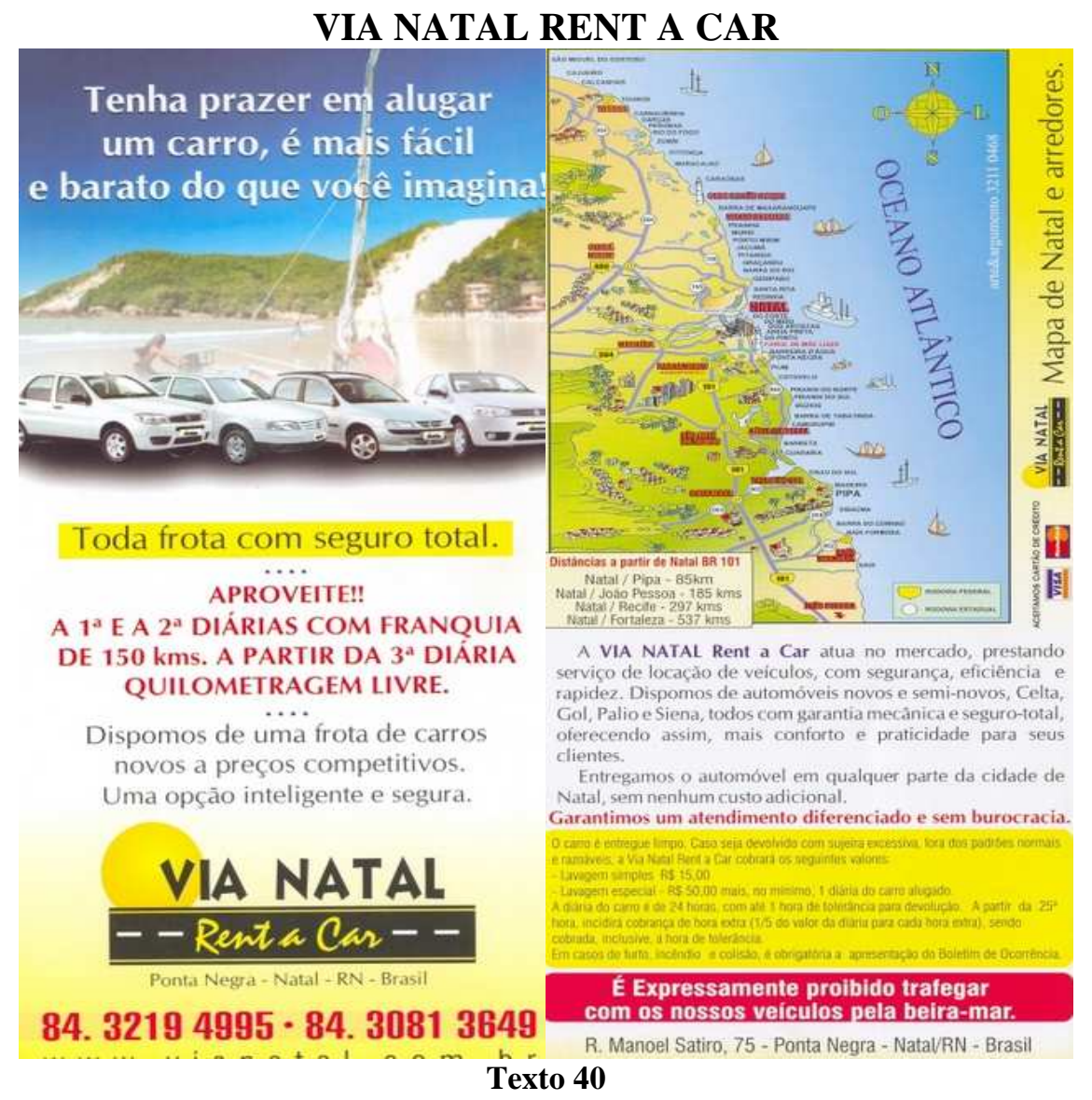

Este texto pertenece al género del discurso publicitario y desde un punto de vista de la tipología textual posee una secuencia dominante argumentativa, ya que la descripción funciona más bien como un recurso persuasivo. En la textura discursiva está presente una selección léxica cuyos elementos son semánticamente positivos.

Ese léxico positivo adoptado, generalmente, en los anuncios publicitarios actúa como vector en la calificación de los productos o servicios que se anuncian. De ese modo, la publicidad vende no solamente un producto o servicio en concreto, sino su excelencia y sus efectos positivos en la vida de quienes adquieren lo anunciado.

El contenido expandido del anuncio en cuestión afirma en la primera página que: ¡Tengas el placer de alquilar un coche, es más fácil y barato de lo que imaginas! Toda frota con seguro total. iiiAprovecha!!! [...]. Disponemos de una frota de coches nuevos a precios competitivos. Una opción inteligente y segura.

A continuación también se expone en este mismo texto publicitario que: Via Natal Rent a Car actúa en el mercado, prestando servicio de alquiler de coches, con seguridad, 
eficiencia y rapidez. Disponemos de coches nuevos [...] ofreciendo así, más confort y practicidad a sus clientes. Entregamos el coche en cualquier parte de la ciudad de Natal, sin ningún coste añadido. Garantizamos un atendimiento diferenciado y sin burocracia.

El producto visual del texto en cuestión consiste en la propia imagen del producto turístico ofrecido por el "Via Natal Ren Car" y un mapa con la ubicación de esta empresa en la cuidad de Natal. El mensaje manifiesto corresponde a la publicidad del producto anunciado y el mensaje latente connota la buena calidad de los productos anunciados y la seriedad de la empresa.

Los procedimientos retóricos son usados en la publicidad con el objetivo de persuadir a los interlocutores. "A este respecto, no se debe olvidar que la retórica nació entre los griegos en el siglo V a. de C. con una finalidad pragmática: la persuasión en los juicios" (Martínez, 2000:52). También, al relacionar la retórica y la publicidad, Eduardo Fernández (2006:87) establece un pensamiento común al de Martínez cuando afirma que:

\begin{abstract}
En retórica clásica se habla de tres tipos de discursos según cada una de estas finalidades específicas: el deliberativo si se espera lograr la adhesión de la asamblea, el judicial para convencer a un juez y el demostrativo, únicamente para deleitar a los oyentes. La publicidad podría situarse en un paso intermedio entre el deliberativo y el demostrativo puesto que busca lo bueno y lo conveniente, a la vez que elogia las virtudes del producto, pero parece que para nada entra en juego la consideración de lo justo o injusto, propio del género judicial.
\end{abstract}

Al volver al texto publicitario expuesto anteriormente no es difícil reconocer los recursos retóricos empleados para presentar lo bueno y lo conveniente del producto anunciado, además de los elogios que van dirigidos a las virtudes del producto, sin considerar de ninguna forma su lado negativo. Así, no es extraño que para ello el locutor emplee un léxico positivo como: placer, coche, más fácil, seguro total, aprovecha, disponemos, nuevos, precios competitivos, opción inteligente, segura, seguridad, eficiencia, rapidez, confort, entregamos, sin ningún coste añadido, garantizamos, un atendimiento diferenciado, sin burocracia. 
Para finalizar, se nos hace importante destacar que en la retórica clásica la argumentación forma parte de su vertiente más filosófica, mientras la elocutio, las figuras y los tropos se ubican dentro de la retórica clásica en una vertiente más bien semiótica y literaria. Es más, de acuerdo con Zoppi-Fontana (2006:183) "el arte de argumentar y persuadir se vuelve un campo del conocimiento teórico y práctico delimitado disciplinalmente por la retórica, que junto con la lógica y la gramática, integra el núcleo de las prácticas educativas de la Antigüedad”.

\subsection{Retórica, discurso y persuasión}

La retórica clásica origina la nueva retórica que se divide en una vertiente filosófica dedicada a la argumentación y otra de carácter semiótico y literario, que trata de la elocutio, las figuras y los tropos. Con la revalorización de la retórica fue posible insertarla en el campo del análisis del discurso como una contribución significativa para cuestiones como géneros, argumentación y retórica de la elocución, como muy bien apuntan Calsamiglia \& Tusón (2002:25):

\footnotetext{
En ella se inspiran las propuestas actuales sobre los géneros como pautas y convenciones de las prácticas discursivas orales y escritas; sobre las fases de la composición textual y su posible combinatoria; sobre la argumentación en sus aspectos dialógicos y estratégicos y sobre la retórica de la elocución aplicada no solamente al ámbito público de discurso parlamentario, periodístico, publicitario, político o judicial sino también a las relaciones interpersonales en el ámbito privado.
}

Adam \& Bonhomme (2000:128) siguen la misma línea de razonamiento de Calsamiglia \& Tusón (2002:25) y afirman que las divisiones retóricas del discurso son: la Inventio; la Dispositio; y la Elocutio. El discurso puede establecer la relación entre la retórica antigua y la clásica. La primera consistía en presentar un mensaje a un determinado público por medio de la capacidad del orador o comunicador. La segunda, a su vez, está inserta en el ámbito de las nuevas tecnologías de la comunicación. Se trata de la práctica de exponer mensajes a través de los mass media, es decir, el periódico, la revista, la radio, la televisión y la red internet. A ese respecto, Halliday (1999:68-69) señala que: 
El enlace entre la retórica de ayer y la de hoy está en la concepción aristotélica de discurso convincente como siendo aquél que consigue hacer el público sentirse identificado con el comunicador y su propuesta. El nexo entre retórica antigua y la retórica contemporánea también se establece por medio de la clasificación de Aristóteles para los tipos de mensajes o discursos, según el objetivo y el contexto, considerando las necesidades de cada situación. ${ }^{53}$

El carácter persuasivo de un texto publicitario es fácilmente detectado en el texto 41 por presentar un discurso convincente por medio del que el lector/comprador vive una especie de catarsis, ya que consigue la adhesión del público a tal punto que este se siente identificado con el locutor y su propuesta.

Desde un punto de vista formal, el texto 41 sigue el formato propio del texto publicitario y en su macroestructura figura la descripción del "Venezia Flat Service", su ambiente externo e interno, además de su desayuno y su localización. La progresión temática del texto en cuestión puede ser definida como de progresión de tema constante y las personas del discurso presentes son la tercera persona del singular, que remite al producto turístico anunciado y la segunda persona del singular, como forma de tratamiento que aporta cercanía entre el locutor y el interlocutor.

Consideramos un anuncio publicitario un tipo de texto por medio del que se establece un acto de habla. En el caso del anuncio en cuestión el acto de habla locutivo consiste en el discurso constituido por el lenguaje verbal escrito y el lenguaje visual; su fuerza ilocutiva es la descripción del producto turístico ofertado; y su efecto perlocutivo consiste en la estrategia persuasiva empleada para adquirir la adhesión de la audiencia y la consecuente compra del producto y/o servicio anunciados.

\footnotetext{
${ }^{53}$ En la fuente original: "O elo entre a retórica de ontem e a de hoje está na concepção aristotélica de discurso convincente como sendo aquele que consegue fazer o público sentir-se identificado com o comunicador e sua proposta. A ponte entre retórica antiga e a retórica contemporânea também se faz através da classificação de Aristóteles para os tipos de mensagens, ou discursos, segundo o objetivo e o contexto, levando em conta as necessidades de cada situação".
} 
VENEZIA FLAT SERVICE

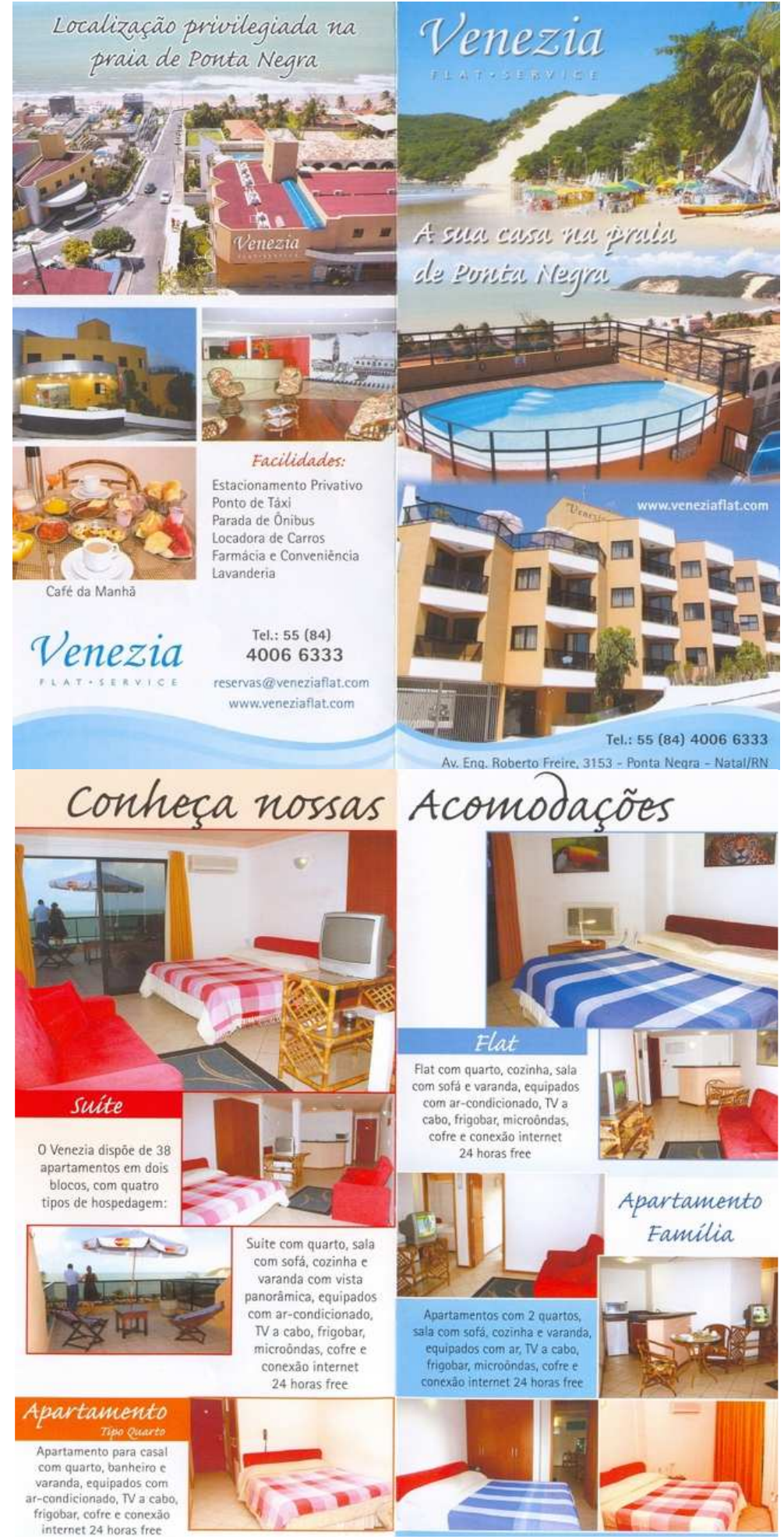

Texto 41 
En lo que concierne al poder de persuasión del discurso retórico, la lingüística textual y la publicidad aparecen como campos nuevos de estudio en la sociedad contemporánea. A este respecto, Eduardo Fernández (2006:48) menciona la aptitud de persuasión del discurso retórico y añade que éste, desde el ámbito lingüístico, “contribuye al estudio y a la reflexión científica de un nuevo campo, el de la publicidad, en el que se ponen en práctica y se desarrollan ampliamente los componentes de la cultura actual y de la nueva sociedad del futuro".

Como ejemplo de la perpetuación de la retórica en la publicística, el leguaje elogioso del texto 41 ilustra su carácter persuasivo. Así, el componente expandido del anuncio publicitario expuesto arriba dice que: Venezia flat service, tu casa de playa en Ponta Negra. Conoce nuestras acomodaciones [...]. Ubicación privilegiada en la playa de Ponta Negra. Y bajo este eslogan realmente se presenta las acomodaciones de este flat por medio de un léxico objetivo y positivo que usa sintagmas como casa, playa, acomodaciones y ubicación privilegiada.

El componente visual de este anuncio sirve para ilustrar y reforzar los argumentos de excelencia del producto defendidos en su componente expandido, por eso el producto visual del texto publicitario en cuestión consiste en la imagen de las instalaciones externas e internas del "Venezia Flat Service" y sus servicios. El mensaje corresponde a la promoción publicitaria de este producto turístico y su mensaje latente connota la sencillez, lo elegante, lo acogedor y lo confortable que caracterizan ese Flat. Es decir, tanto el código verbal como el visual son usados para destacar las cualidades del producto anunciado, un recurso propio de la retórica, como ya lo hemos visto. 
Como hemos visto anteriormente, la publicidad turística se vale de los más diversos recursos retóricos con el objetivo de persuadir a su audiencia. Por eso es importante tener en cuenta que las figuras de lenguaje consisten en estrategias retóricas y que, al hablar de retórica, es fundamental abrir un apartado sobre esos procedimientos retóricos.

Robrieux (1993) [apud Calsamiglia \& Tusón (2002:341)] hace la distinción entre los siguientes tipos de figuras: las figuras de palabras; las figuras de construcción; las figuras de pensamiento; y las figuras de sentido. Siguiendo esta división, veremos la clasificación de los procedimientos retóricos para Calsamiglia \& Tusón (2002), Sara Robles (2004), Kurt Spang (2005) y Antonio Ferraz Martínez (2000).

\section{Figuras de palabras}

Para Calsamiglia \& Tusón (2002:341) "son figuras que se elaboran a partir de operaciones que se aplican al nivel fónico/gráfico, morfológico o léxico de palabras relacionadas entre sí en su disposición lineal”, a saber: la rima; la aliteración; la paronomasia; los juegos ortográficos; la reduplicación; la anáfora; las anadiplosis; las epanadiplosis; las antanaclasis; la dialogía; la ermutación; el poliptoton; y la supresión.

Además de las figuras de palabras, los arcaísmos, tecnicismos, neologismos, palabras saco, etc. también son usados para llamar la atención del interlocutor en lo que concierne al carácter léxico del mensaje. El anuncio que se puede ver a continuación ilustra los diversos recursos retóricos que la publicidad turística emplea en la elaboración de sus mensajes. El texto 42 está formado por cuatro páginas y describe Guarujá como destino turístico. Y como no podría ser de otra manera, alaba esta ciudad como un producto turístico y presenta elogios de las virtudes de este sitio. 
PREFEITURA MUNICIPAL DE GUARUJÁ

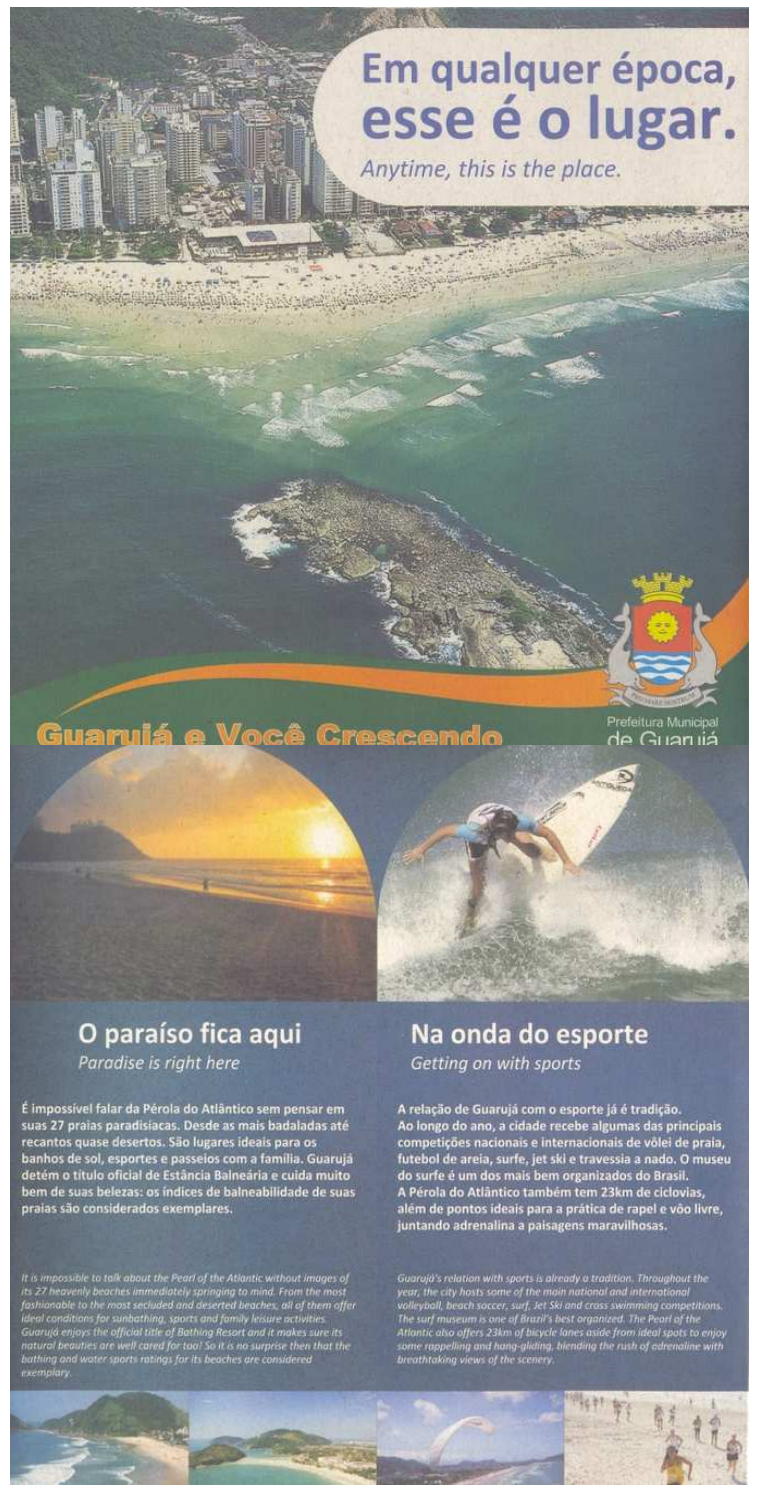




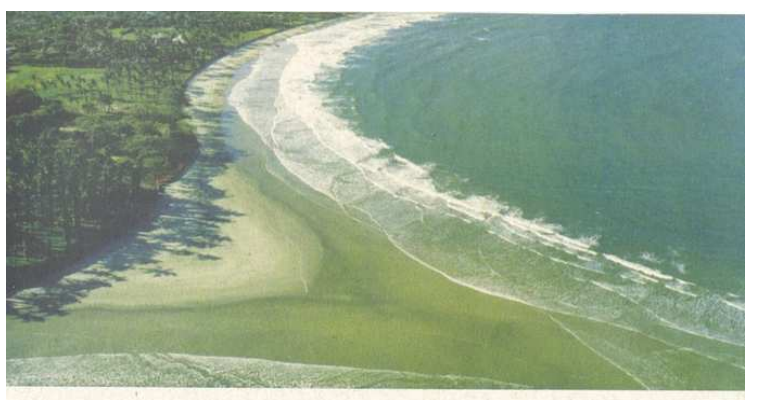

Em qualquer época, esse é o lugar.

In anytime, this is the place.

Localizada na llha de Santo Amaro, Guarujá é conhecida como a Pérola do Atlântico.

E não é à toa. A cidade tem atrações turisticas o ano todo. Além disso, é o lugar perfeito para a realizaçấo de diversos tipos de eventos.

Saiba mais sobre os encantos deste paraiso natural. Comece a se apaixonar agora.

Located on the island of Santo Amaro, Guaruja is known as the Pearl of the Atlantic. And fo a good reason too. The city offers tourist attractions the year around. Aside from that, the place is perfect to stage a variety of events. Learn ma
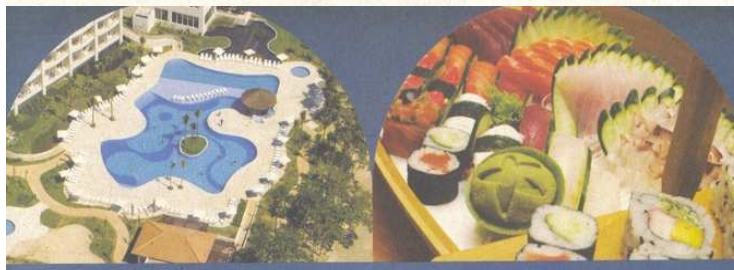

Fácil de chegar, gostosa de ficar

Easy to get there, a delight to stay

Uma cidade de muitos sabores

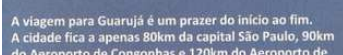
A city of many flavors

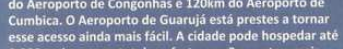

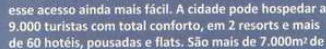

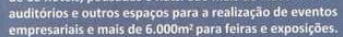

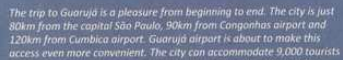

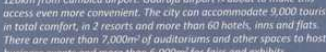

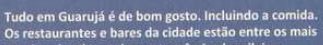

equintados do roteiro gastronômico brasileiro.

Săo opşées de pratos e drinques para todos os gos

A grande atraçio é o Festival Gastronómico de Guarujé,

que aco
gostosi.

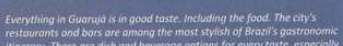

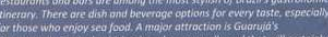

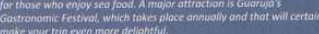

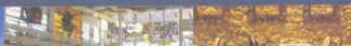

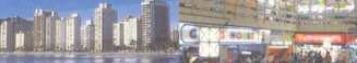




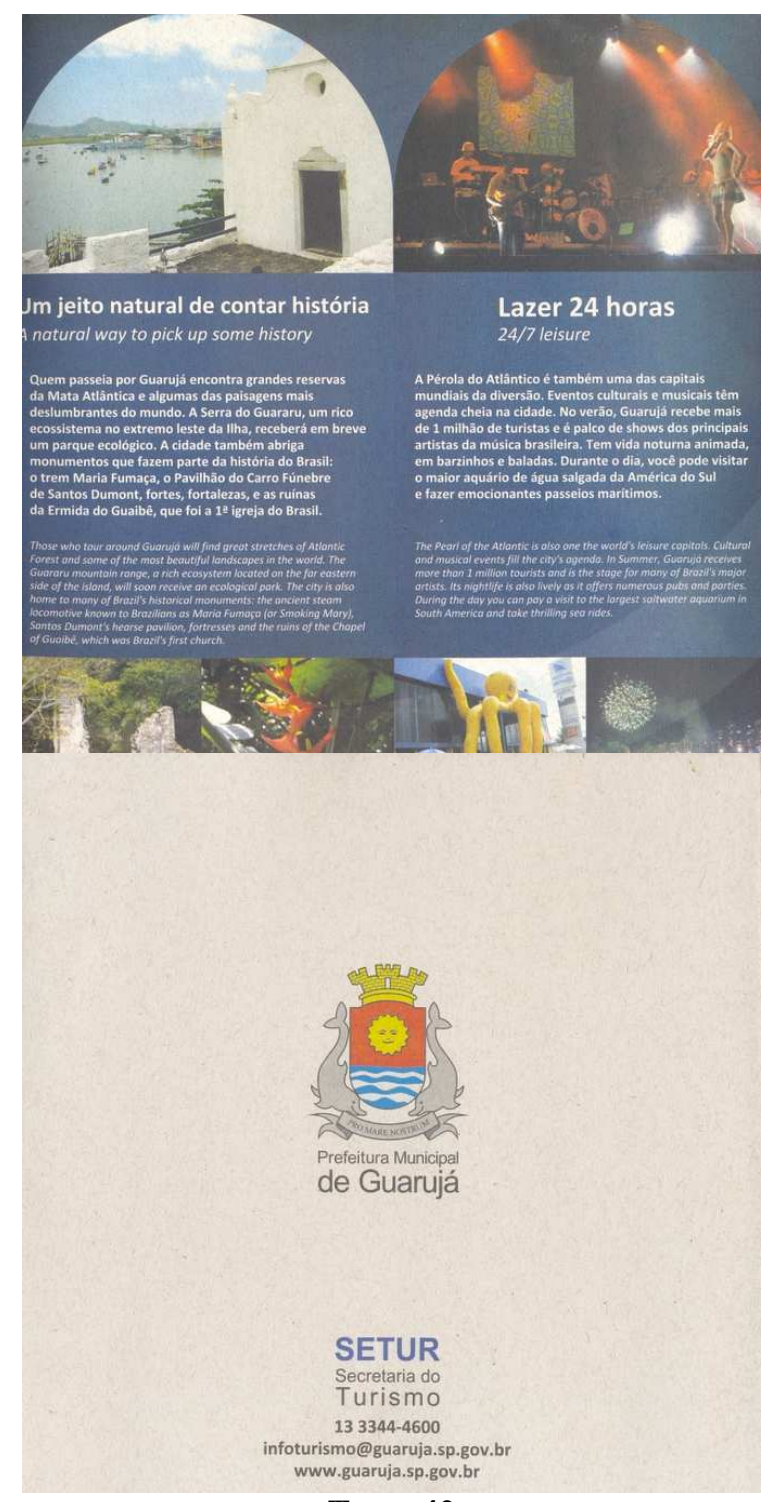

Texto 42

De inicio, merece ya destacarse el eslogan que dice: En cualquier época, ese es el lugar. Guarujá creciendo contigo. Es decir, en cualquier momento, el lugar que uno debe visitar es Guarujá porque crece junto a ti. Si echamos otro vistazo en este eslogan, vemos la presencia de figuras de palabras a partir del nivel gráfico del mensaje con la diferencia de tamaño y del color que destacan lugar como sintagma más importante del enunciado, ya que el tamaño de la fuente en un texto publicitario le aporta más importancia. Y, entonces, el interlocutor se pregunta: ¿qué lugar es ese? La respuesta aparece en seguida: Guarujá.

No es coincidencia que en ese eslogan haya la presencia de la rima asonante del sintagma lugar con guarujá. El receptor, perteneciente a nuestra llamada cultura de masas, percibe en este anuncio el ambiente, los personajes en traje de baño surfeando y 
la gastronomía de una ciudad moderna. Como titulares del contenido expandido del código verbal de esta publicidad se presenta respectivamente: el paraíso está aquí; en la onda del deporte; en cualquier época ese es el lugar; fácil de llegar, sabrosa para quedar; una ciudad de muchos sabores; una forma natural de contar historias; ocio 24 horas.

El mensaje icónico puede resultar en la interpretación de una serie de connotaciones que forman parte del mensaje iconográfico de esta imagen. El receptor de nuestra actual cultura asociaría la escena presentada al verano, a las vacaciones, al ocio, a la modernidad, a la cultura, a la gastronomía, a la libertad, a la aventura y a la tranquilidad.

Además, se adoptan los recursos retóricos como estrategia persuasiva. Por ejemplo, observemos que en la onda del deporte, se usa la palabra onda, sinónimo de ola, pero a la vez, consiste en un neologismo típico de la jerga juvenil, aportando un carácter de juventud y modernidad al léxico empleado en el anuncio. Por otra parte, se hace uso del paralelismo entre fácil de chegar, gostosa para ficar, que también presenta rima entre chegar y ficar.

En fácil de llegar, gostosa de ficar hay la supresión del sujeto y con eso el interlocutor puede preguntarse a dónde es fácil llegar y agradable quedar. La respuesta viene en seguida sin exigir mucho esfuerzo cognitivo: Guarujá, claro. Y para completar, observemos que chegar, ficar y Guarujá también riman.

Otra forma usada en este texto para llamar la atención del interlocutor en lo que concierne al carácter léxico del anuncio es el empleo de un vocabulario positivo constituido por palabras como: creciendo, paraíso, paradisiacas, famosas, ideales, sol, deporte, paseo, familia, cuida, bellezas, ejemplares, tradición, principales, nacionales, internacionales, más bien ordenados, adrenalina, paisajes, maravillosos, conocida, atracciones turísticas, perfecto, varios, encantos, natural, empiece, enamorarse, ahora, fácil, sabrosa, viaje, placer, buen gusto, comida, especialmente, deslumbrantes, rico, ocio, diversión, verano, conciertos, música, artistas, vida, divertida, fiestas, visitas, más grande y emocionantes. 
Así que la oferta presentada por este anuncio se vuelve irresistible para las personas que buscan diversión y tranquilidad a la vez, a quienes les encantan los deportes acuáticos y que les gustan el turismo de sol y playa, pues el Guarujá es presentado como el lugar ideal para sus vacaciones. Para la creación de este mensaje de la publicidad turística sus elaboradores hicieron uso de los más diversos recursos retóricos, entre los que podemos destacar las creaciones fraseológicas y léxicas como es el neologismo y la innovación léxica pues, desde un punto de vista semántico, el lexema “onda" es un neologismo.

\section{Figuras de construcción}

El anuncio expuesto a continuación refleja el uso de una imagen con un mensaje ligüístico en el que se puede encontrar uno de los recursos retóricos que se encajan en el grupo de las figuras de construcción. Para Calsamiglia \& Tusón (2002:343), "estas figuras se basan en procedimientos que afectan a la sintaxis" y pueden ser clasificadas en elipsis; asíndeton; parataxis; anacoluto; hipérbaton; paralelismo; antítesis; enumeración; gradación; polisíndeton; redundancia; reformulación; y pleonasmo.

En el caso de la publicidad turística que podemos ver abajo, se usó el paralelismo: Viajando con la CVC cruceros. Te quedas deslumbrado con el servicio de bordo. Te quedas deslumbrado con las instalaciones. Te quedas deslumbrado con el lujo. Ah, y con los paisajes también. En esta última oración el "Te quedas deslumbrado" está elidido. De modo que se utiliza el recurso retórico que afecta a la sintaxis del texto y se forma el paralelismo con la siguiente estructura:

Te quedas deslumbrado con el servicio de bordo.

Te quedas deslumbrado con las instalaciones.

Te quedas deslumbrado con el lujo.

(Te quedas deslumbrado) con los paisajes también. 


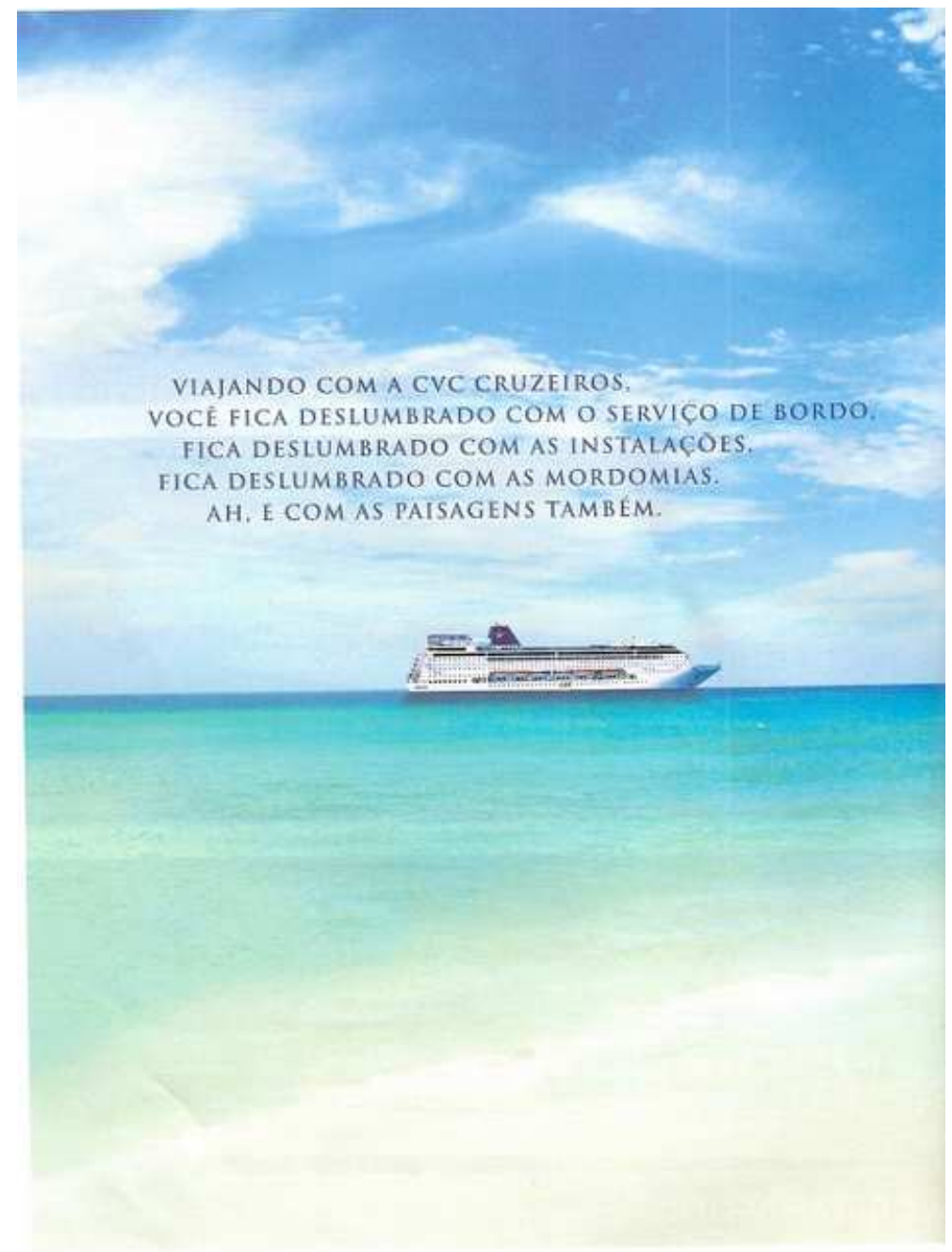

Texto 43

Figuras de pensamiento

Las figuras de pensamientos están relacionadas con operaciones mentales y procesos cognitivos más complejos relacionados con las ideas. En las palabras de Calsamiglia \& Tusón (2002:344), bajo esta nomenclatura están las figuras "que juegan con los conceptos representados por palabras pero también operaciones más complejas y macroestructurales basadas en relaciones entre ideas y en otras operaciones cognitivas". A partir de aquí, establece una estructura que clasifica nueve figuras de pensamiento, a saber: la paradoja; el oxímoron; la antilogía; la hipérbole; las lítotes; las antífrasis; el eufemismo; los procedimientos de decir y no decir; y, por último, la preterición.

En el componente verbal expandido del texto 44 se anuncia: Ramazont Trans Tur paseos náuticos. Imagine un mar de diversión. Tu paseo ya empieza con agua en la 
cintura y mucha emoción. Paseos panorámicos, piscinas naturales, playas paradisíacas por la orla marítima de Natal, y mucho más. Capacidad para hasta 16 pasajeros, con mucho confort y seguridad total. Conoce Natal y sus playas desde un punto de vista único e inigualable. Ramazont espera por ti.

En este texto se registra el uso de la hipérbole, cuando se usa la expresión un mar de diversión para decir mucha diversión. También, en el nivel gráfico y fónico del anuncio hay juegos gráficos con el tipo de la fuente empleada como un procedimiento de significación de la escritura, además de agrupamiento de palabras.

\section{RAMAZONT TRANS TUR}

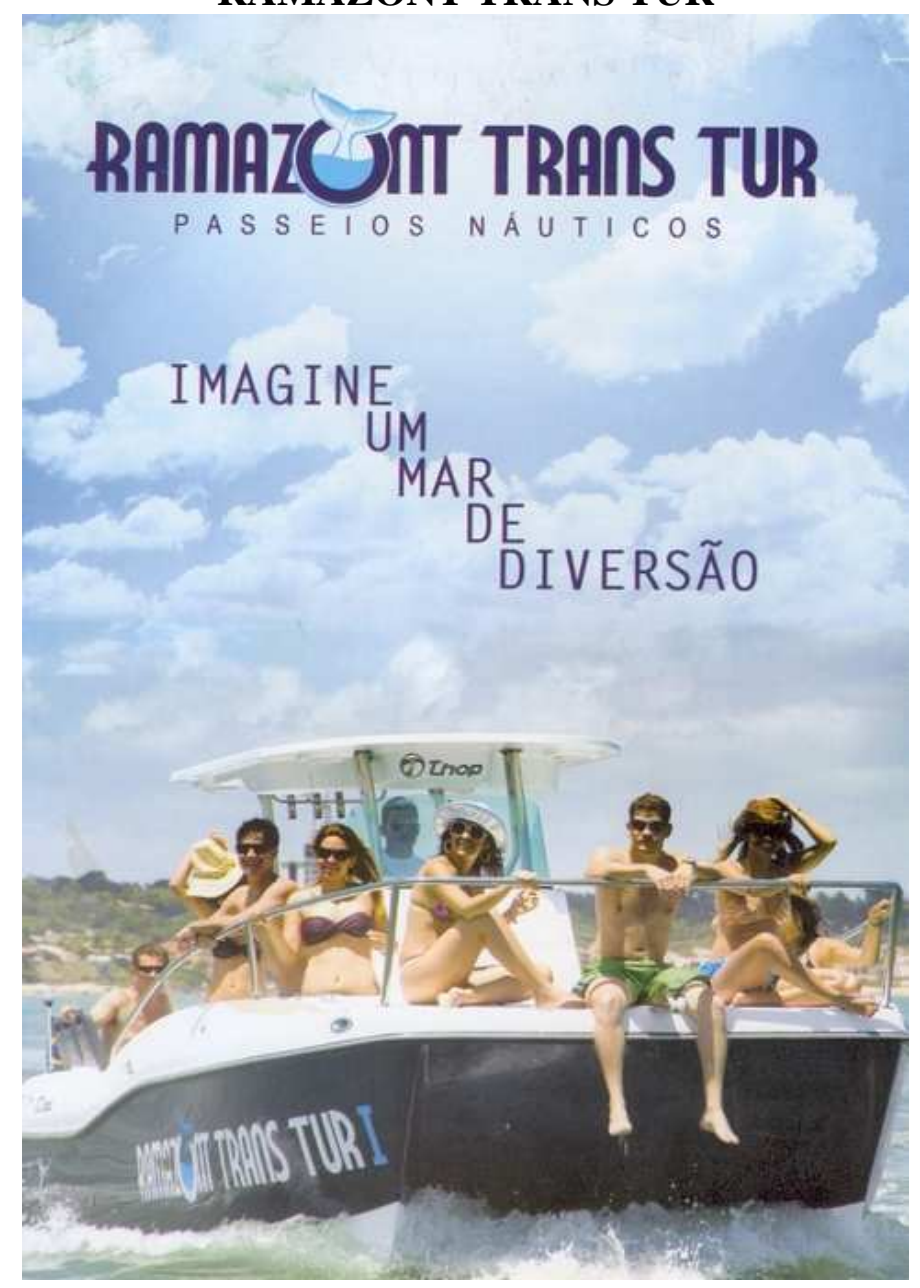




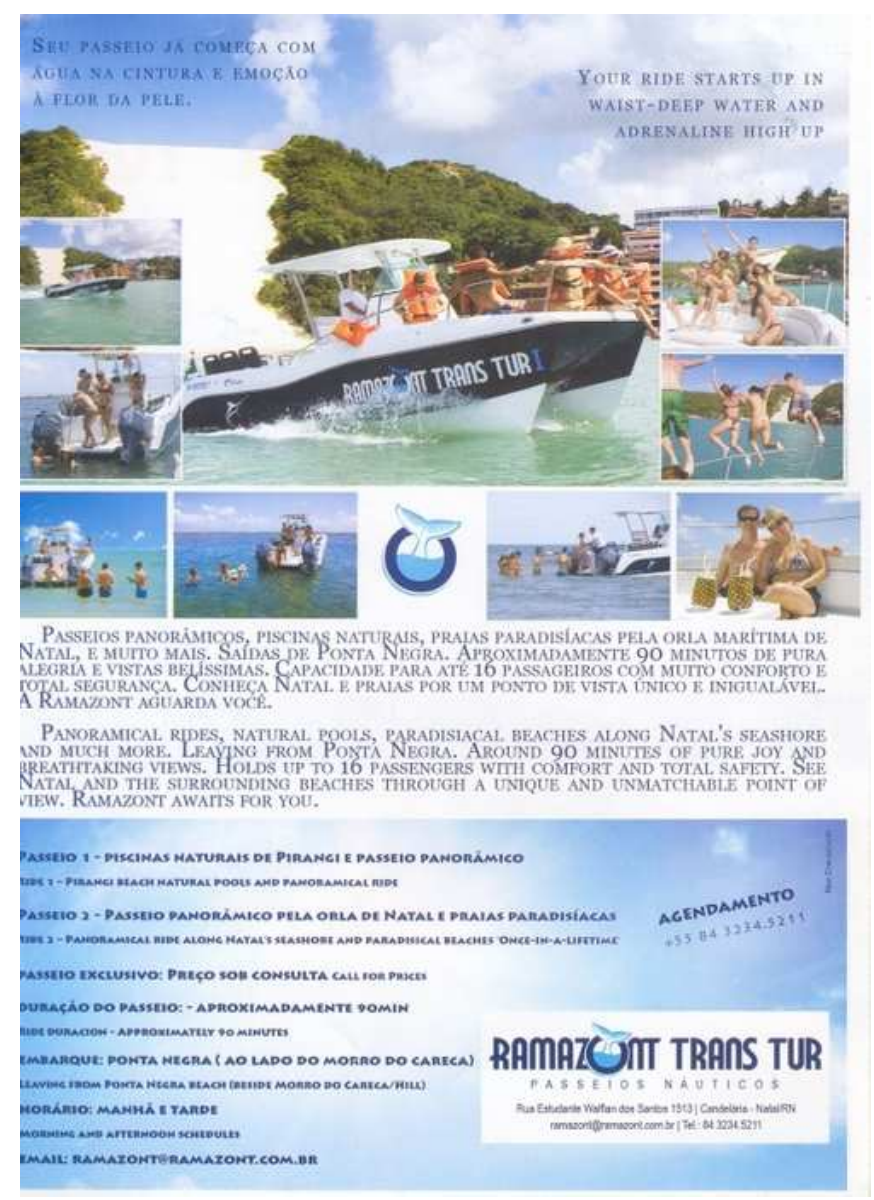

Texto 44

El texto en cuestión está formado por el lenguaje verbal y el lenguaje visual. Además, en ese texto se puede ver ese hibridismo de códigos en la construcción de un mensaje de alabanza a un producto turístico. La asociación entre imágenes y texto escrito connota vacaciones, verano, alegría, juventud, salud, ocio, fiesta y un ambiente paradisíaco. Para eso, la selección léxica presentada tiene connotaciones positivas y está formada por sintagmas como: diversión, paseo, empieza, mucha, emoción, panorámicos, piscinas, naturales, playas, paradisíacas, mucho, capacidad, confort, seguridad, total, único e inigualable.

Al detenernos en este texto publicitario del turismo, también nos encontramos con la oración imperativa "imagine un mar de diversión", en la que están presentes dos funciones del lenguaje: la fática y la apelativa. Así, podemos llegar a la conclusión de que se quiere implicar al receptor con este texto y que, por eso, el lector es un factor determinante en la publicidad turística y en el proceso de comunicación establecido por este tipo de texto. 
A partir de este anuncio, el receptor infiere connotaciones y asocia el escenario presentado a la gente joven de vacaciones, al verano, al descanso, a la aventura de embarcar en los paseos náuticos del Ramanzont Trans Tur, que ofrece una cantidad de diversión equiparadas al tamaño del mar, al atlántico, o sea, se ofrece un mar de diversión al receptor/consumidor. Así, el lector que se siente identificado con este perfil y le apetezca este tipo de turismo será persuadido por medio de todos los recursos retóricos empleados en este texto.

\section{Figuras de sentido (tropos)}

Las figuras de sentido "están relacionadas estrechamente con los procesos de significación por analogía o por otros tipos de relación entre los rasgos de un objeto. De hecho, son los ejemplos máximos del lenguaje comúnmente llamado <<figurado>>" (Calsamiglia \& Tusón, 2002:345). Tales figuras serían la metáfora; la metonimia; la sinécdoque; la ironía; y la antífrasis.

Sara Robles, a su vez, dedica especial atención a la retórica en la cuarta y última parte de su obra. En este capítulo, la autora presenta los conceptos de los recursos retóricos más usados en publicidad bajo el título de Retórica para la Ponderación. Así, Sara Robles (2004:69) señala que:

\footnotetext{
La retórica, o ars bene dicendi, es el arte que nos permite utilizar de forma óptima todas las posibilidades expresivas que nos ofrece la lengua, con el fin de persuadir a nuestro interlocutor. Por este motivo, no es de extrañar que el publicitario, como género semiológico de fuerte carga intencional, recurra al empleo de artificios retóricos y los convierta en su seño de identidad.
}

Esta autora categoriza los tropos de la siguiente forma: tropos por desplazamiento de límites (la perífrasis, la sinécdoque, la antonomasia, la metonimia, la hipérbole, la personificación); tropos por salto (la metáfora y la ironía); tropos combinados (la combinación de esas dos clases de tropos anteriores). A su vez, las figuras retóricas, en Sara Robles, están divididas en:

1- Figuras de omisión (la elipsis y el asíndeton); 
2- Figuras de amplificación (la enumeración, la definición, la corrección, la dubitación, la antítesis, el oxímoron, la paradoja, la comparación, el epíteto);

3- Figuras de repetición (la geminación, la anadiplosis, la epanadiplosis, la anáfora, la epífora, el polisíndeton, la aliteración, la diseminación, la gradación, el pleonasmo);

4- Figuras de posición (el hipérbaton y el paralelismo);

5- Figuras de apelación (la interrogación retórica y la exclamación).

\section{TROPICAL TUR}

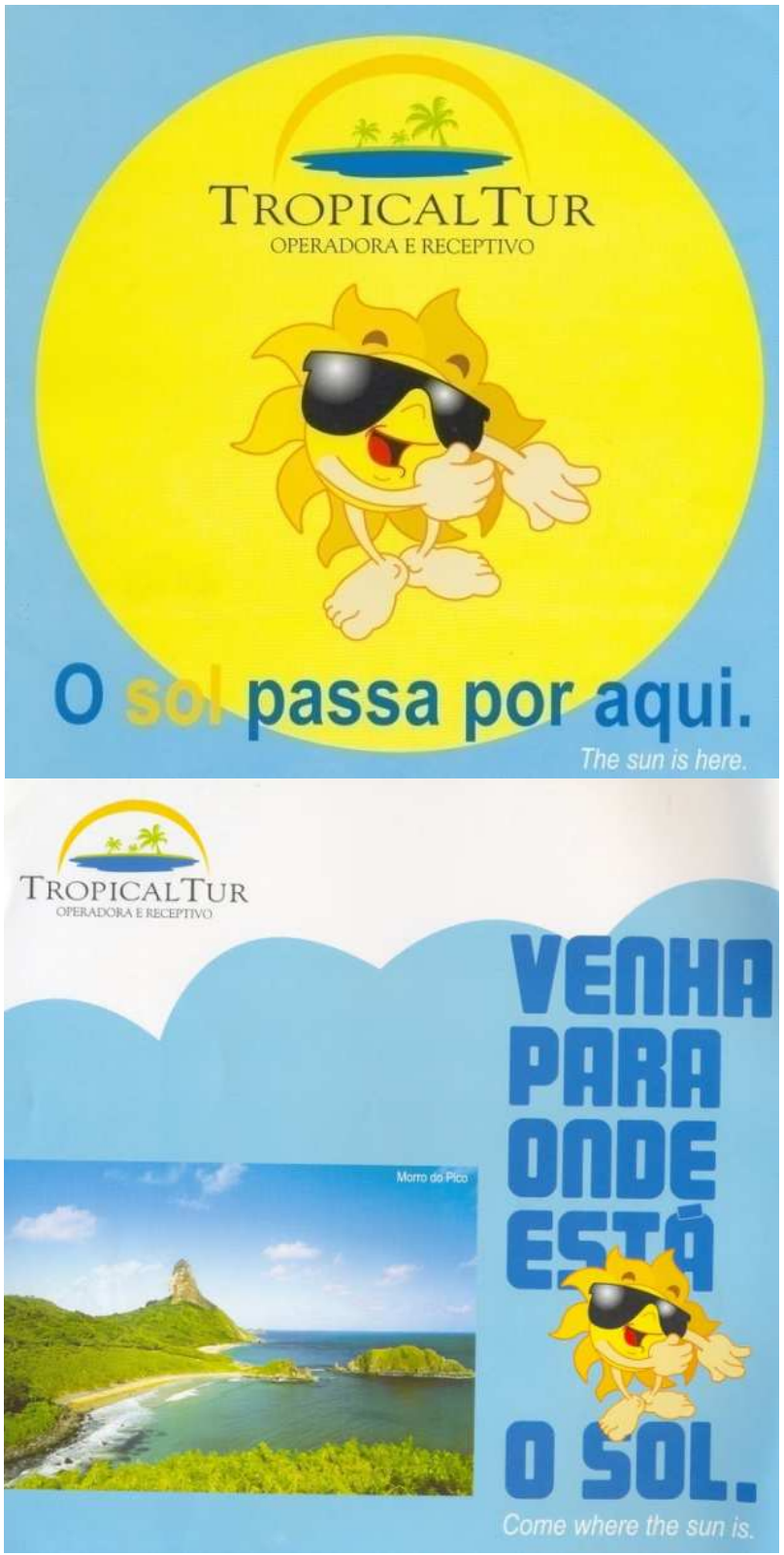




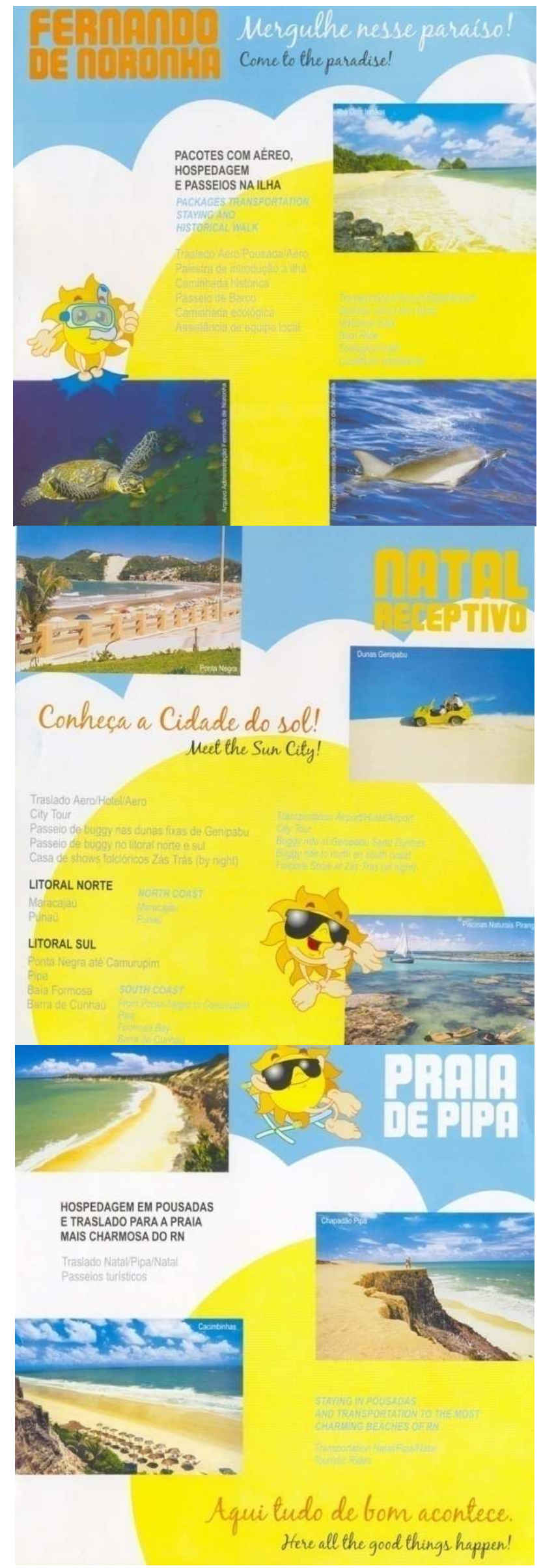




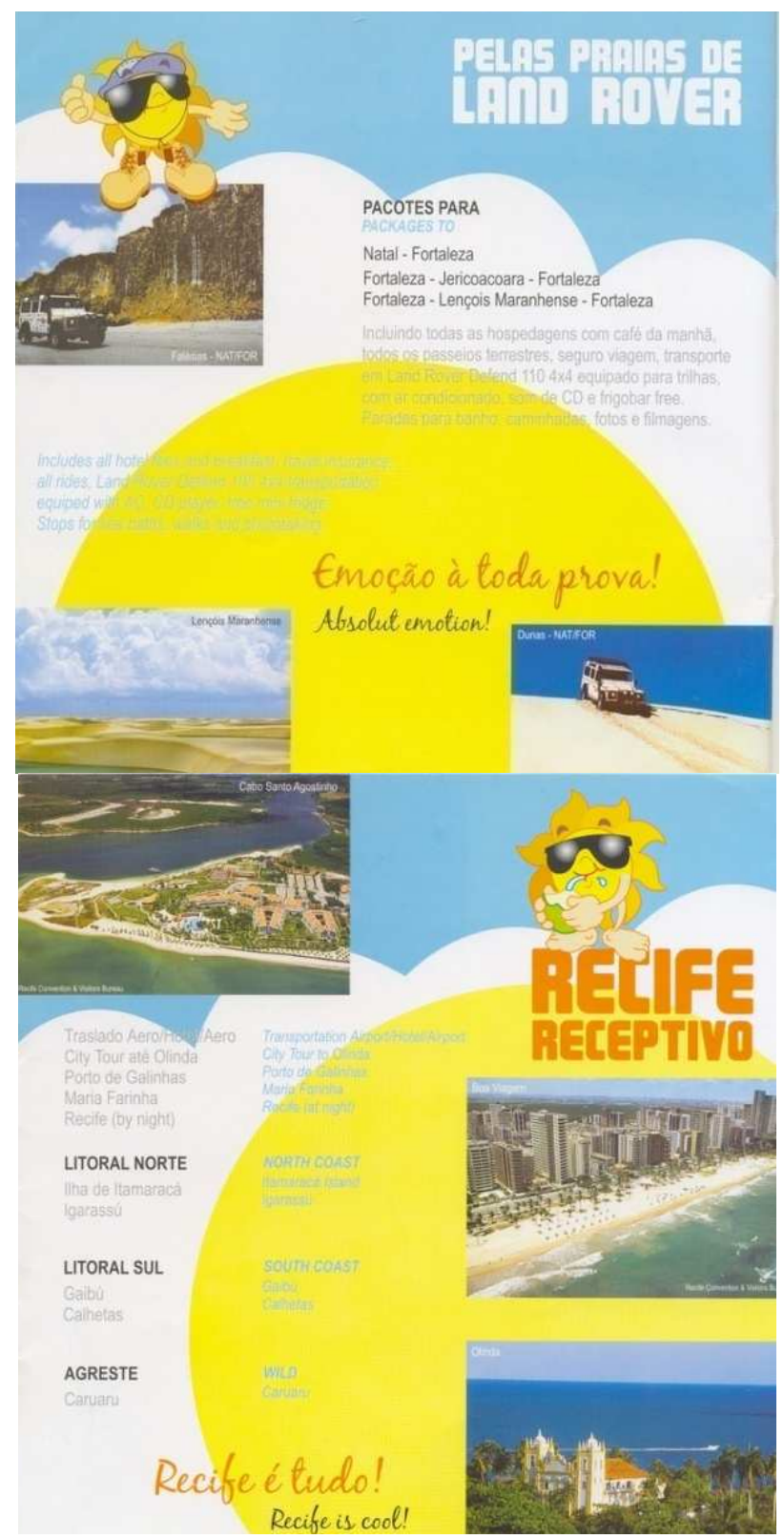




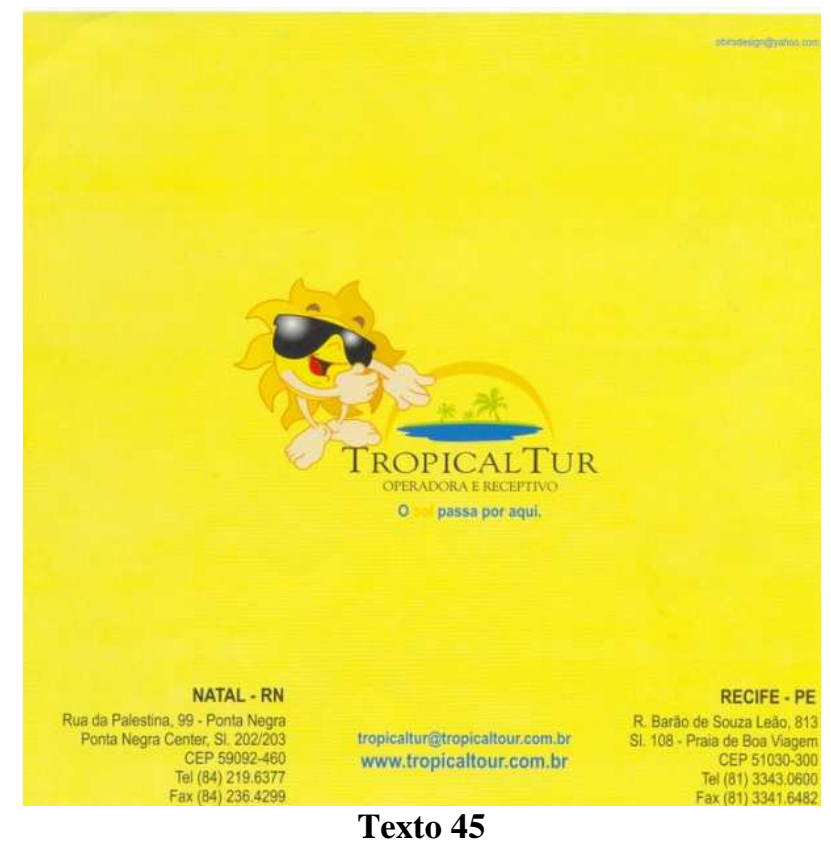

Desde un punto de vista formal, el texto 45 sigue el formato propio del texto publicitario con un hibridismo de códigos (visual y verbal). En su macroestructura figura la descripción de la "Tropical Tur" y sus productos turísticos. La progresión temática de este texto puede ser definida como de progresión de temas derivados, ya que anuncia diversos productos turísticos a la vez.

Las personas del discurso presentes son la tercera persona del singular que remite al producto turístico anunciado y la inscripción del "você", en portugués de Brasil, que tiene la fuerza semántica del "tú" en español, presentando así un carácter de proximidad entre los interlocutores del acto de habla publicitario.

El producto visual consiste en el logotipo del "Tropical Tur", un sol y las imágenes de todos los puntos de interés turístico comercializados por esta agencia de viajes. Es importante observar que la imagen del sol comprende la figura retórica de la prosopopeya o personificación, puesto que el sol no es un ser animado tal como presenta esta imagen. El mensaje manifiesto corresponde al propio anuncio de estos productos turísticos de la "Tropical Tur". Ya el mensaje latente connota la exuberancia del producto turístico ofertado, su variedad y la excelencia de su calidad.

El texto 45 presenta un 50\% de imagen y 50\% de contenido expandido. En este figura el siguiente enunciado: Tropical Tur operadora y receptivo. O sol pasa por aquí. Ven a 
donde está el sol (morro do pico). Fernando de Noronha (bucea en ese paraíso). Natal receptivo, conoce la cuidad del sol. Playa de Pipa, estancia en hostales y traslado para la playa más hermosa de RN. Aquí lo bueno abunda. Por las playas de Land Rover. Emoción al máximo. Recife receptivo, Recife lo es todo.

En el eslogan de la Tropical Tur, el sol pasa por aquí, también hay una prosopopeya o personificación, ya que el atributo pasar es característico de seres animados. En la tercera página de nuestro anuncio la oración bucea en ese paraíso compara el archipiélago de Fernando de Noronha al paraíso, es más, afirma que este lugar es el propio paraíso, lo que remite a la memorable metáfora cuya creación fue atribuida a Américo Vespucio que, en 1503, al ver el archipiélago de Fernando de Noronha dijo: El paraíso es aquí.

Este texto hace uso de una heterogeneidad del lenguaje y usa signos múltiples (palabra e imagen). Además, posee un estilo condensado que refleja la economía lingüística presente en el texto publicitario. En la cuarta página del texto 45 se presenta el enunciado Conoce la cuidad del sol donde el sustantivo propio "Natal" es sustituido por la metáfora cuidad del sol, ya que el sol brilla durante todo el año en esta ciudad.

El marco léxico del contenido expandido del anuncio publicitario en cuestión está formado por un vocabulario positivo en el que figuran lexemas como: tropical, sol, aquí, paraíso, conoce, estancia, hostales, traslado, playa, más, hermosa, bueno, abunda, emoción, máximo y todo. Lo que contribuye en el proceso persuasivo del texto en cuestión.

Kurt Spang presenta un estudio sobre retórica y publicidad en la obra Lenguaje Publicitario (2005). Como complemento de este estudio dedica un apéndice de la misma obra a un repertorio de recursos retóricos. Este autor hace la distinción de cinco divisiones de figuras de acuerdo con su funcionamiento dentro del texto, a saber:

1- Figuras de posición;

2- Figuras de repetición;

3- Figuras de amplificación;

4- Figuras de omisión; 
5- Figuras de apelación.

Al presentar esa división de las figuras retóricas, Kurt Spang clasifica todos los demás recursos retóricos como tropos. Luego presenta su "repertorio" ordenado según su orden alfabético con los siguientes elementos: alusión; anadiplosis; anáfora; anástrofe; antítesis; antonomasia; ceugma; clímax; comparación; concatenación; derivación; dialogismo; dilogía; diseminación; elipsis; enumeración; epífora; eufemismo; exclamación; germinación; hipérbole; ironía; lítotes; metáfora; metonimia; neologismo; oxímoron; paralelismo; paréntesis; paronomasia; perífrasis; personificación; pleonasmo; poliptoton; pregunta retórica; quiasmo; redición; reticencia; simulación y sinécdoque.

Antonio Ferraz Martínez (2000) también dedica un apartado al tema de la publicidad y la retórica, lo que reafirma la importancia de ese campo de conocimiento para lo concerniente al mensaje publicitario. Martínez (2000) presenta, asistemáticamente, algunos procedimientos retóricos como la aliteración; la paronomasia; la anáfora; la epífora; la anadiplosis; la epanadiplosis; el paralelismo; la derivación; el poliptoton; la dilogía; la antanaclasis; la antítesis; la paradoja; la hipérbole; las lítotes; el símil; la metáfora; la metonimia; la sinécdoque; la sinestesia y la personificación sin entrar en muchos detalles ni clasificaciones específicas.

De esos cuatro autores, desde nuestro punto de vista, la mejor explicación de los recursos retóricos se encuentra en Calsamiglia \& Tusón; en segundo lugar, está la de Spang y en tercer la de Sara Robles, que, como Calsamiglia \& Tusón, se detiene con más atención en explicar y ejemplificar cada uno de los recursos retóricos que presentan. Por último, en cuarto lugar está la de Antonio Ferraz, como hemos visto anteriormente, es el que plantea un estudio más superficial sobre los recursos retóricos.

Todo lo que hemos visto sobre la retórica y el abordaje de esos cuatro autores mencionados anteriormente nos sirve para ver la importancia de la retórica en el discurso de la publicidad, más específicamente la publicidad turística, que consiste en nuestro objeto de estudio. Además, queda claro que los más diversos recursos retóricos son empleados en el discurso publicitario con el objetivo de persuadir a su auditorio. 


\subsection{La retórica en la publicidad}

Como hemos visto anteriormente, la publicidad, como un proceso comunicativo, se acerca a la retórica, dado que este arte y la publicística pueden influir en la conducta de la audiencia por medio de un lenguaje estéticamente elaborado. Según López Eire (1998:32), "la retórica y la publicística pretenden persuadir mediante procesos de comunicación, se proponen influir sobre la conducta de los receptores a través de sus respectivos discursos". La retórica y la publicística coinciden nuevamente cuando ambas producen discursos en los que hay características afectivas, laudatorias y ornamentales. En palabras de López Eire (1998:33):

\footnotetext{
La retórica y la publicística coinciden en promover discursos más afectivos, laudatorios y ornamentales que referenciales, discursos que ensalcen verosímilmente y con el apoyo del eficaz ornato la peculiar excelencia de una tesis (retórica) o de un producto (publicística) de acuerdo con el sistema de valores vigentes en la sociedad en la que se mueven y sobre la que actúan.
}

Como hemos visto anteriormente, la retórica clásica divide los géneros del discurso en distintos tipos, de los que el deliberativo, el judicial y el demostrativo o epidíctico, se presentan como principales. El arte publicitario puede ser clasificado de dos formas distintas. La primera sería la publicidad de venta y promoción, cuya finalidad, como el propio nombre indica, es la promoción o venta de un determinado producto o servicio. Por otro lado, está la publicidad de prestigio que no se ocupa de vender o promocionar productos y servicios, sino que sirve para evidenciar la existencia de una marca o institución empresarial. 
TAM

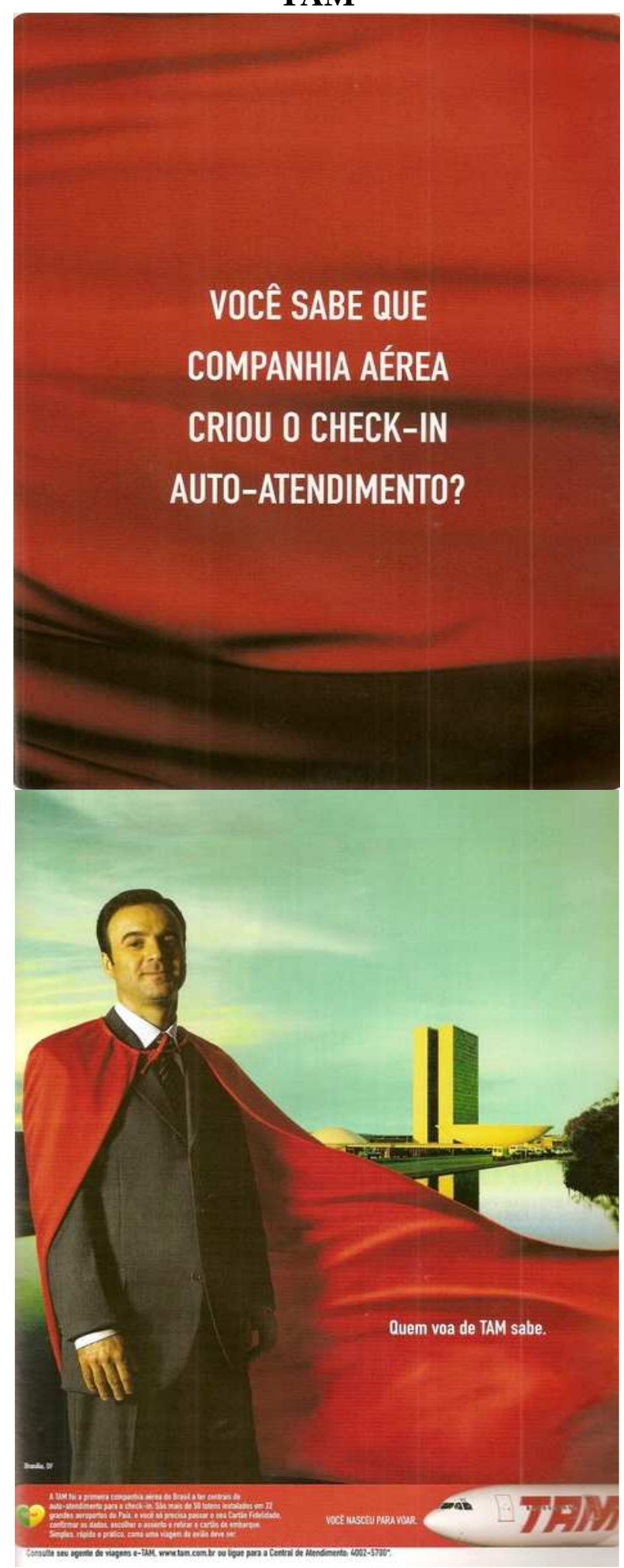

Texto 46

En la elaboración del texto 46 se usan diversos recursos retóricos para persuadir a su receptor, de modo que ya en la primera página se formula la siguiente cuestión: “¿Sabes qué compañía aérea creó la facturación por autoservicio?”. Consideramos esta pregunta retórica como lo más relevante del texto en cuestión, ya que tiene la función de 
gancho, es decir, de estrategia comunicativa para atrapar la atención del lector/consumidor e inducirle a concluir la lectura del anuncio.

La respuesta a esta pregunta retórica está presente en todo el anuncio y, para que no quede duda, el propio remitente del mensaje la contesta en la segunda página del texto: "Quien vuela con TAM lo sabe". El anuncio que exponemos arriba puede ser considerado una publicidad de prestigio porque sirve para promocionar la marca de la aerolínea brasileña TAM. Sin embargo, también es una publicidad de venta, ya que al final de texto hay la frase "consulte tu agente de viajes e-TAM. www.tam.com.br o llame a la central de atendimiento: 4002-5790".

En ese texto todos los recursos de imagen y léxico tienen un significado específico. El receptor puede encontrar el color corporativo de la marca (rojo) por todo el texto. El personaje presente en el anuncio representa el prototipo del hombre de negocio adornado con una capa roja. Claro que un empresario no suele andar con una capa como un súper héroe, por eso mismo este anuncio llama la atención de su público objetivo: es que no es un ejecutivo cualquiera, es uno que vuela TAM y por ello tiene características superiores a los demás como un super man.

Dicho de otro modo, es el que sabe la respuesta para la pregunta del anuncio y además el que nació para volar como está puesto en el propio texto "naciste para volar". Y para que no quede duda de que la compañía aérea TAM es una aerolínea brasileña, la imagen de fondo es un ícono representativo de Brasília, la capital de Brasil construida en la década de 1960. Consiste en la imagen del Palacio do Planalto, edificio emblemático en la arquitectura moderna brasileña y mundial, además figura entre los edificios considerados como patrimonio de la humanidad por la UNESCO.

Al observar el anuncio en cuestión, se puede ver que está dispuesto en dos páginas, lo que le atribuye mucha importancia, además la fuente más grande del texto es la que presenta la palabra TAM, lo que atribuye la máxima importancia a ese elemento léxico. Por último, es importante destacar que en el contenido expandido de ese texto publicitario figura que TAM fue la primera compañía aérea de Brasil en tener tarjetas de autoservicio para la facturación. Son más de 50 [...] instalados en 22 grandes aeropuertos del país, solo necesitas pasar tu tarjeta fidelidad, confirmar los datos, 
elegir el asiento y retirar la tarjeta de embarque. Simple, rápido y práctico, como un viaje $[\ldots]$.

El marco léxico de este anuncio está fraguado por medio de un vocabulario positivo constituido por lexemas como: primera, compañía aérea, tener, tarjetas, autoservicio, facturación, más, instalados, grandes, fidelidad, confirma, datos, elegir, simple, rápido, práctico y viaje. Además de recursos como el argumento de pionero (TAM fue la primera compañía aérea de Brasil en tener tarjetas de autoservicio para la facturación), el argumento de cantidad (Son más de 50 [...] instalados en 22 grandes aeropuertos del país) y la comparación (Simple, rápido y práctico, como un viaje).

Los anuncios publicitarios que forman parte de nuestro corpus de estudio están formados por diferentes categorías textuales: folletos turísticos, folletos turísticos mixtos, libros, libros mixtos, publicidad electrónica, periódicos y revistas, como podemos ver en el gráfico abajo:

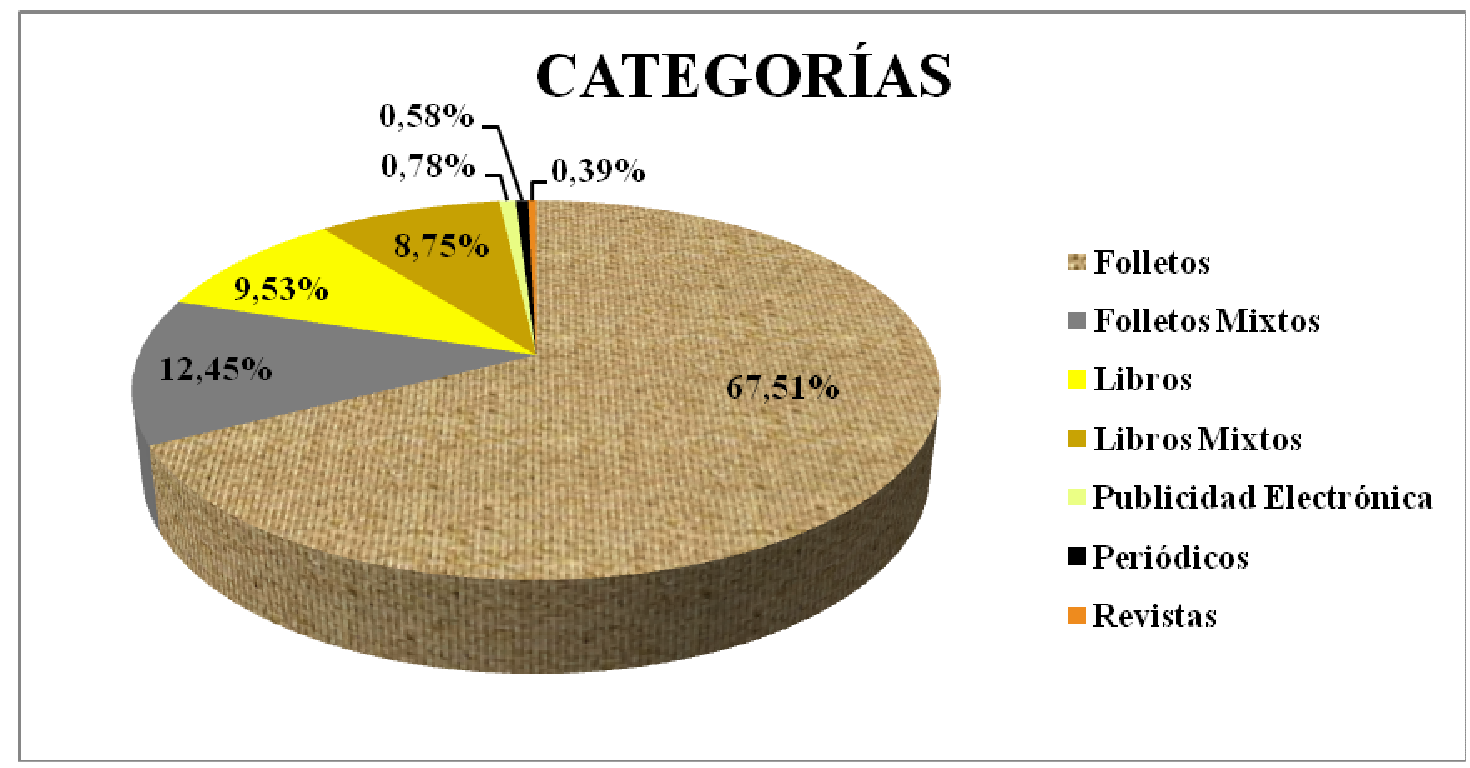

Gráfico 16

En el caso de la publicidad turística, es muy común que haya un género mixto, es decir, los folletos de venta se mezclan a los folletos informativos y dan lugar al folleto mixto. Ya los libros informativos se mezclan con los libros de venta y dan lugar al libro mixto, etc. Otro aspecto muy importante que debemos destacar sobre los anuncios que forman parte de nuestro corpus de estudio es que una misma publicidad, generalmente, 
promueve a la vez una marca, un producto turístico y un lugar para visitar donde, por supuesto, se encuentra el producto turístico anunciado.

En realidad, según lo que hemos constatado a través de nuestro corpus de estudio, lo más común es que en una misma publicidad anuncie varios productos a la vez. Por eso, hemos adoptado el término soporte publicitario para designar el vehículo de información publicitaria del producto turístico, dicho de otro modo, tanto los folletos de venta, los folletos informativos, los folletos mixtos, los libros de venta, los libros informativos, los libros mixtos, la publicidad electrónica, los periódicos y las revistas fueron encuadrados en un grupo más grande que llamamos de soporte publicitario. En el gráfico abajo se puede vislumbrar ese dato de nuestra investigación:

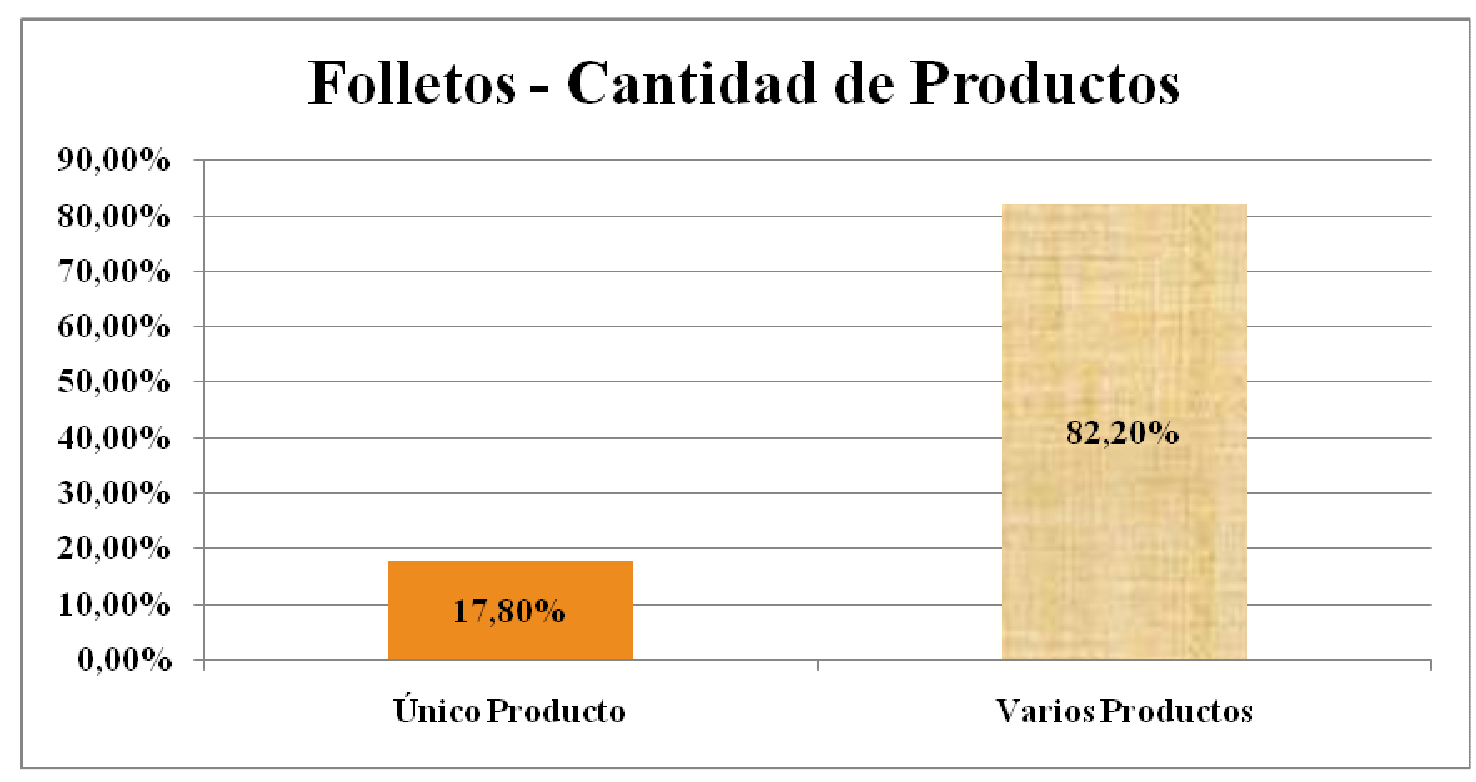

\section{Gráfico 17}

Así, en el corpus de los textos publicitarios estudiados, la cantidad de productos anunciados en cada folleto se configura de la siguiente forma: 60 folletos anuncian solamente un único producto; mientras 277 folletos anuncian varios productos a la vez. Lo que nos lleva a afirmar que la publicidad turística funciona más bien como un soporte publicitario que anuncia varios productos al mismo tiempo. 


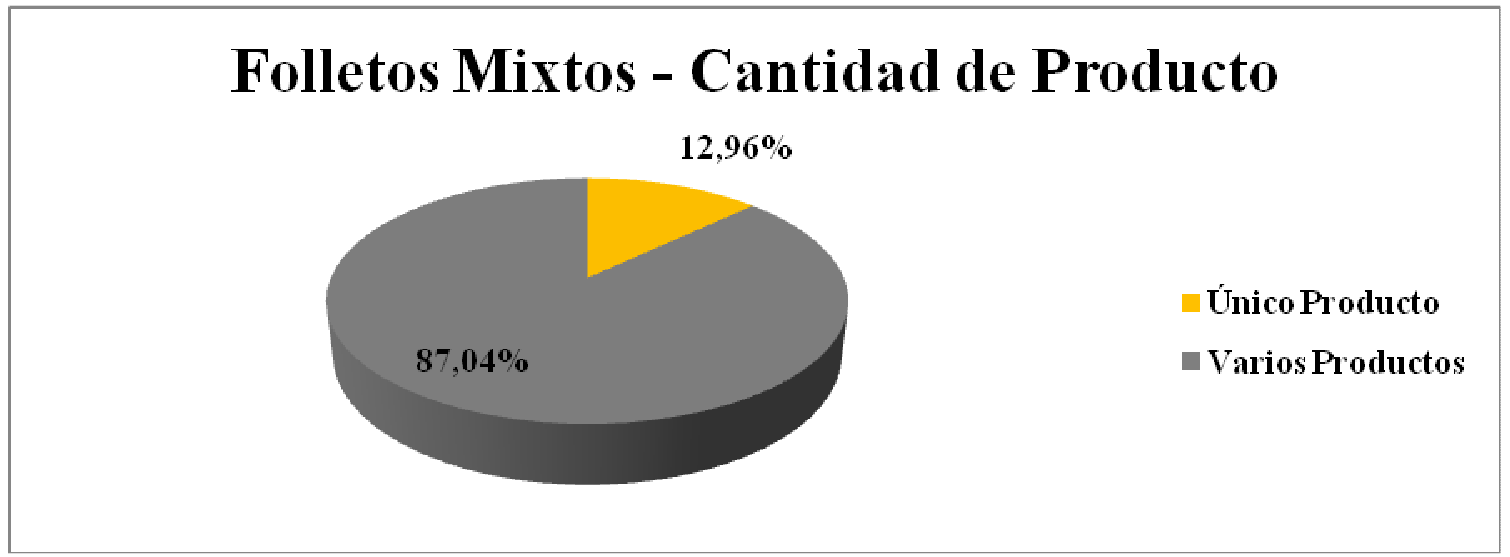

Gráfico 18

Lo mismo ocurre con los folletos mixtos. En esa categoría, la publicidad que anuncia varios productos a la vez quedó con la mayoría, dado que 7 de los folletos mixtos estudiados anunciaban solamente 1 producto, mientras 47 anuncian varios productos a la vez. Ya para la categoría libros todos anuncian diversos productos a la vez, puesto que del valor total de los libros que hemos encontrado 39 se refieren a anuncios de varios productos. Por último, en la categoría libros mixtos, no hemos encontrado ninguno que se refiriera a publicidad de un único producto, con lo cual los 35 libros analizados anunciaban varios productos a la vez.

Es decir, un mismo anuncio suele promover la marca, la agencia de viaje, la operadora de viaje, el lugar y el producto que anuncia, etc. Como ejemplo de lo que hemos mencionamos anteriormente, el texto 47, presentado a continuación, promueve la marca Noronha como operadora de turismo, la playa de Pipa como destino turístico y los hostales como productos. Lo que queremos destacar en este punto de nuestro estudio es que la publicidad en el turismo funciona como un conjunto de anuncios en el mismo soporte publicitario, como es el caso del folleto presentado a continuación, por ejemplo. 


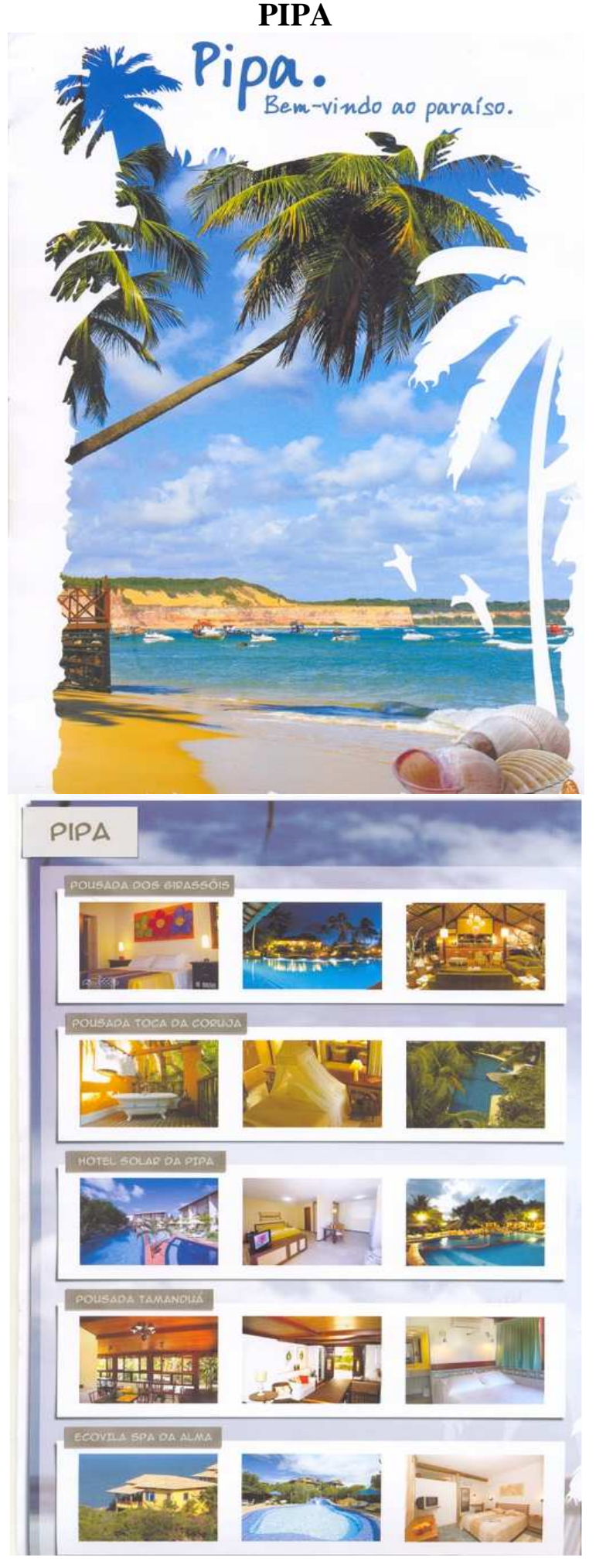




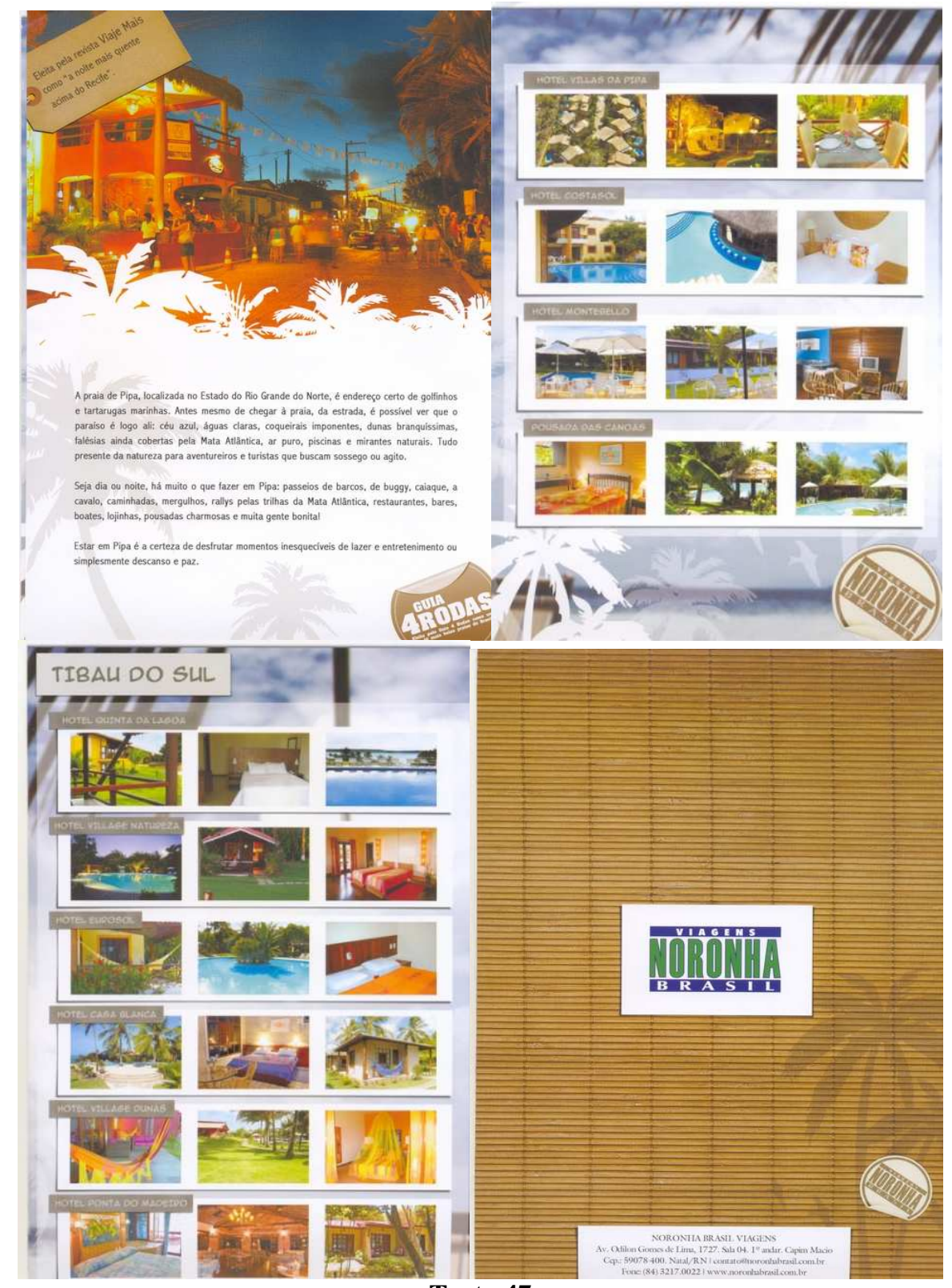

Texto 47

Desde un punto de vista formal, el texto 47 sigue el formato propio del texto publicitario. En su macroestructura figura la descripción de Pipa como un producto turístico vendido por la agencia de viajes Noronha. Además de la presentación de la localización de esta empresa, los puntos de interés turísticos con los cuales trabaja y las formas de ponerse en contacto con esta agencia.

En el componente expandido del contenido verbal de este texto publicitario figura el siguiente enunciado: Pipa, bienvenido al paraíso. Elegida por la revista Viaje Mais como "la noche más caliente por encima de Recife". La playa de Pipa, localizada en el estado de Rio Grande do Norte, es la dirección cierta de los delfines y de las tortugas 
marinas. Antes de llegar a la playa es posible que el paraíso esté allí: cielo azul, aguas transparentes, cocoteros, dunas blanquísimas, falesias todavía recubiertas por la Mata Atlántica, aire puro, piscinas y miradores naturales. Todo como un regalo de la naturaleza para aventureros y turistas que procuran tranquilidad o fiesta. Durante el día o la noche, hay mucho que hacer en Pipa: paseos de barco, de buggy [...]. Estar en Pipa es seguramente disfrutar de momentos inolvidables de ocio y entretenimiento o simplemente descanso y paz.

La persona del discurso presente es, como se puede ver, la inscripción de la tercera persona del singular como forma de presentar al objeto anunciado de forma impersonal. El acto de habla locutivo consiste en el discurso constituido por el lenguaje verbal escrito y el lenguaje visual; la fuerza ilocutiva en la descripción del producto turístico ofertado y su ubicación, como estrategias de persuasión; y su efecto perlocutivo consiste en el objetivo de recibir del interlocutor la confirmación en forma de un acto de compra.

La selección léxica del anuncio en cuestión está formada por sintagmas como: bienvenido, paraíso, elegida, más, playa, cierta, delfines, tortugas marinas, llegar, posible, cielo azul, aguas transparentes, cocoteros, dunas blanquísimas, aire puro, piscinas, naturales, regalo, naturaleza, aventureros, turistas, tranquilidad, fiesta, paseos, seguridad, disfrutar, momentos inolvidables, ocio, entretenimiento, simplemente, descanso y paz. Es decir, un léxico positivo que actúa como un elemento persuasivo en el proceso de convencimiento del auditorio.

El producto visual consiste en imágenes de Pipa, las instalaciones internas de su hostelería y de la playa vecina, Tibau do Sul. El mensaje manifiesto es el propio anuncio del producto turístico del texto publicitario analizado, mientras que el mensaje latente es la alta calidad del producto turístico anunciado y el ambiente paradisíaco de Pipa.

A partir del elemento retórico del lenguaje, la publicidad presenta los elementos de persuasión a su audiencia, a saber: la implicación del destinatario, la concisión, la novedad y la recurrencia, como afirman Calsamiglia \& Tusón (2002). Esta forma de comunicar se instaura como una institución moderna. López Eire (1998) dedica un apartado del segundo capítulo de La Retórica en la Publicidad a los puntos de contacto 
de la retórica y la publicística, y para ello resalta el papel político y social tanto de la retórica como de la publicidad. Además, ambas hacen uso de la persuasión por medio del lenguaje argumentativo de forma lógica, psicológica y estética.

\begin{abstract}
La publicidad es objeto de un arte o una moderna ciencia denominada publicística, cuyo objetivo es dar con un lenguaje específicamente publicitario que produzca en los conciudadanos un impacto especial que les impulse a solicitar y consumir unos determinados productos, por cuyo consumo aboga el publicista. Es, por consiguiente, asimismo, política y social, ya que presupone - como hemos dicho - una sociedad política determinada, la sociedad de consumo. La retórica es el arte o ciencia que enseña al orador a defender eficazmente su causa utilizando el lenguaje en el ámbito de lo social y político, es decir, en el área de la ciudad-estado, la pólis - como sobreentendían los griegos - o en la vida ciudadana.
\end{abstract}

Las transformaciones y los avances de los medios de comunicación masivos proporcionaron a la retórica nuevos campos de actuación. La publicidad, como ya hemos visto anteriormente, es una de las habilitaciones de la comunicación social que sirve como un ejemplo muy de nuestro tiempo del arte de seducir o persuadir por medio de un texto, por eso es reconocida como una hija de la retórica clásica.

Con el fin de la Segunda Guerra Mundial, el surgimiento de la mercadotecnia, la industrialización y la globalización, hay un aumento en la oferta con relación a la demanda. A partir de ello, la persuasión comercial se configura como un acto pensado y calculado, dando origen a teorías como:

1- La publicidad mecanicista;

2- La publicidad sugestiva;

3- La publicidad proyectiva;

4- La publicidad lúdica. 
Para Adam \& Bonhomme (2000:26) "la filiación entre estos cuatro tipos de publicidad y las dos grandes categorías retóricas" (deliberativo y epidíctico) sería la siguiente:

\begin{tabular}{|l|c|c|}
\hline \multirow{2}{*}{ TIPO DE PUBLICIDAD } & \multicolumn{2}{|c|}{ GÉNEROS RETÓRICOS } \\
\cline { 2 - 3 } & DELIBERATIVO & EPIDÍCTICO \\
\hline MECANICISTA & + & - \\
\hline SUGESTIVA & + & + \\
\hline PROYECTIVA & + & + \\
\hline LÚDICA & - & + \\
\hline
\end{tabular}

Todavía para Adam \& Bonhomme (2000:118), "la finalidad esencial del discurso epidíctico consiste en consolidar la adhesión a valores compartidos", de ese modo, la publicidad estaría en íntima relación con la retórica clásica. Además, la retórica forma parte tanto del sistema persuasivo como del argumentativo de este tipo de mensaje. Para Adam \& Bonhomme (2000:119) "lo epidíctico se relaciona principalmente con la parte descriptiva de la lengua y lo deliberativo con su parte argumentativa. Estas dos grandes funciones del lenguaje [...] son hasta tal punto inseparables".

Desde un punto de vista formal, el texto 48, expuesto a continuación, sigue el formato propio del texto publicitario en el que hay una unión de códigos visuales y verbales. En su macroestructura figura la descripción del "Praiamar Hotel", la presentación de sus productos y su localización en el mapa del mundo. Las personas del discurso presentes son la tercera persona del singular (usada para remitir al producto anunciado) y la inscripción del "você", en portugués de Brasil, que tiene la fuerza semántica del "tú" en español, presentando así un carácter de proximidad entre el emisor y el destinatario.

El producto visual consiste en la imagen de las instalaciones del "Praiamar Hotel", sus clientes y su ubicación en el mapa del mundo y en Natal. El mensaje manifiesto consiste en el propio anuncio del producto turístico ofertado y el mensaje latente connota la elegancia, el confort, la alegría y la comodidad que se puede disfrutar en el "Praiamar Hotel". 
PRAIAMAR HOTEL

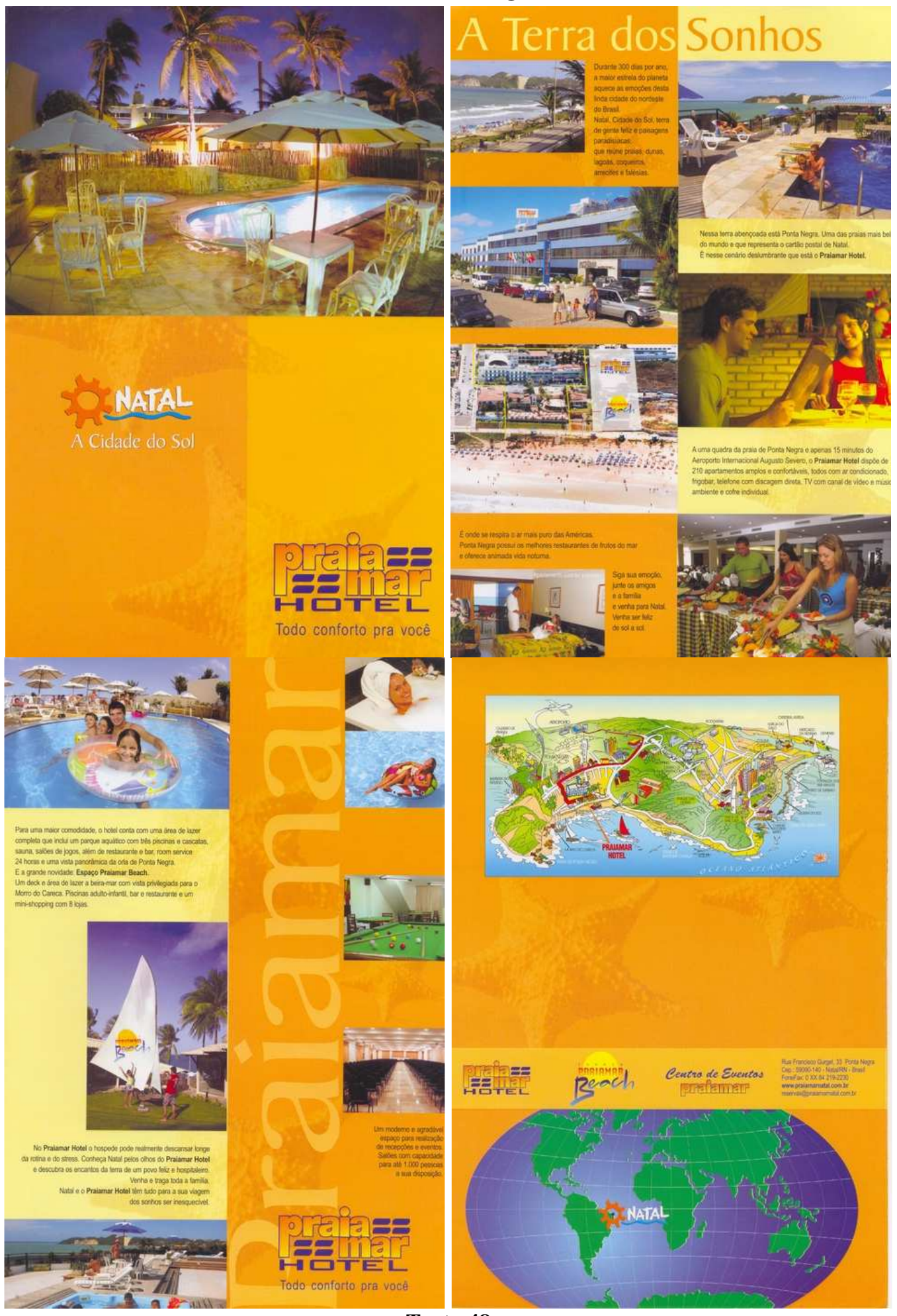


En la primera página del texto 48 se presenta un ambiente de piscina muy acogedor y el enunciado: Natal, ciudad del sol. Praiamar Hotel, todo confort para ti. Luego, el lector infiere que el ambiente acogedor que se puede contemplar en la imagen está en Natal, la ciudad del sol, y forma parte de un hotel llamado Praiamar, que le ofrece todo confort. Una vez más, podemos encontrar el uso de un recurso retórico como la metáfora que compara Natal como la ciudad del sol, como ya hemos visto también en el texto 45 .

No cabe duda, pues, de que este texto posee características del discurso epidíctico, ya que intenta consolidar la adhesión a valores compartidos. Además, describe el producto anunciado tanto por medio de imágenes como por el componente expandido que presentamos abajo, lo que configura el texto publicitario con lo epidíctico y, por consiguiente, con la parte persuasiva del texto, lo que más una vez nos muestran elementos retóricos en la publicidad.

Bajo el titular de tierra de los sueños, la segunda página del texto 48 afirma que: durante 300 días por año, la estrella más grande del planeta calienta las emociones de esta bella ciudad del nordeste de Brasil. Natal, ciudad del sol, tierra de gente feliz y paisajes paradisíacas, que reúne playas, dunas, lagos, cocoteros, arrecifes y falesias. En esta tierra bendecida está Ponta Negra, una de las playas más bellas del mundo y que representa la postal de Natal. En este escenario deslumbrante está el Praiamar Hotel. A una cuadra de la playa de Ponta Negra y solamente a 15 minutos del aeropuerto internacional Augusto Severo, el Praiamar Hotel dispone de 210 apartamentos amplios y confortables [...].

Al volver al texto publicitario expuesto anteriormente no es difícil identificar los recursos retóricos presentes en el discurso elogioso, como es el caso de la publicidad turística, empleados para presentar lo bueno y lo conveniente del producto anunciado, es decir, el Praiamar Hotel, además de elogiar las virtudes del producto, sin considerar de ninguna forma su lado negativo.

Luego el mismo texto continúa en la misma línea de razonamiento persuasiva y afirma que Natal es donde se respira el aire más puro de las Américas. Ponta Negra posee los mejores restaurantes de mariscos y ofrece una vida nocturna animada. Sigue tu 
emoción, llama los amigos y la familia y ven a Natal. Ven a ser feliz de sol a sol. Para una mayor comodidad el hotel cuenta con un área de ocio completa [...].

Todo el contenido expandido del anuncio publicitario en cuestión está ilustrado por bellas imágenes que presentan un escenario paradisiaco, con personajes prototípicos muy felices, en muy buena forma física, gente joven y guapa, en una playa de aguas trasparentes y en un ambiente muy confortable. Lo que está concluido verbalmente con el texto a continuación: en el Praiamar Hotel el huésped puede realmente descansar lejos de la rutina y del estrés. Conoce Natal por los ojos del Praiamar Hotel y descubre los encantos de una tierra de gente feliz y hospitalaria. Ven y trae toda la familia. Natal y el Praiamar Hotel tienen todo para que tu viaje de ensueño sea inolvidable. Un moderno y agradable espacio para la realización de recepciones y eventos. Salones con capacidad para hasta 1.000 personas a tu disposición.

Desde ese texto heterogéneo, compuesto por imagen y palabra, fraguado por medio de un léxico positivo, se puede inferir que se anuncian viajes para Natal con hospedaje en el Praiamar Hotel. El público objetivo de este texto sería, por lo tanto, familias que se sintieran reflejadas en el anuncio con la imagen de una familia perfecta y feliz, que corresponde a la idea de perfección, confort y alegría trabajada por el texto publicitario en cuestión.

Ese anuncio va dirigido más bien a las emociones. Quizás diga que cualquier familia que vaya de viaje a Natal y se hospede en el Praiamar Hotel se iguala a las de las fotos, que representan un modelo de familia muy de nuestro de tiempo y que probablemente tiene un poder adquisitivo alto. La tendencia de la publicidad contemporánea de trabajar argumentos más emocionales es más común de lo que se puede pensar y ese anuncio que presentamos como ejemplo lo ilustra muy bien.

De ese modo, el texto 48 presenta una publicidad sugestiva y proyectiva que engloba tanto el género retórico deliberativo como epidíctico. Dicho de otro modo, este anuncio sugiere un estilo de vida y promueve la proyección de ese estilo de vida en la mente del interlocutor para persuadirlo a consumir el bien o servicio anunciado. 
Como hemos visto en el anuncio en cuestión, tanto la retórica como la publicidad hacen uso de argumentos estrictamente racionales, emocionales y estéticos, de modo que provoquen reacciones emocionales forzadas por cuestiones sociales, porque según López Eire (1998:32), “ambas disciplinas buscan, en efecto, construir mensajes en los que predominen argumentos que provoquen reacciones emocionales". Ya para Adam \& Bonhomme (2000:171):

\footnotetext{
La argumentación publicitaria, en tanto que discurso de influencia dedicado a la acción, abarca dos de los tres grandes géneros de la retórica: el epidíctico y el deliberativo. Retoma mayoritariamente sus grandes articulaciones (inventio, disposito, elocutio), así como los principales esquemas argumentativos. Simplemente, adapta las formas y las prácticas de la retórica a sus objetivos económicos, a sus fines comerciales en el marco de una sociedad de consumo moderna.
}

Surgen algunas nuevas categorías de la retórica a través del establecimiento de ese arte con la comunicación social. Dichas categorías consisten en: comunicabilidad, atracción, cantidad de información, connotación, estilo, definición, sofisticación, dualidades discursivas, etc. La publicidad, por lo tanto, forma parte de la categoría designada como comunicabilidad, está relacionada con la retórica de la influencia y enfatiza las marcas, los eslóganes y los textos publicitarios. Adam \& Bonhomme (2000:274) afirman que "la publicidad constituye una de las pruebas más evidentes de la perpetuación de la retórica". La muestra de textos publicitarios adoptada para este estudio es buena prueba de ello. El texto 48 en el que figura el eslogan: Praiamar Hotel, todo confort para ti, lo demuestra también.

En el marco léxico del texto mencionado anteriormente figura la presencia de sintagmas como: sol, confort, estrella, más, grande, calienta, emociones, bella, ciudad, feliz, paisajes paradisíacas, playas, dunas, lagos, cocoteros, arrecifes, falesias, postal, escenario deslumbrante, amplios, confortables, aire más puro de las Américas, mejores restaurantes de mariscos, animada, emoción, amigos, familia, comodidad, ocio y completa. Todo eso sirve para justificar que este texto es persuasivo porque no exige un gran proceso cognitivo en su decodificación, es agradable a la vista del interlocutor y atrapa su atención con el gancho de la presentación de un producto de forma estéticamente elaborada por medio de un léxico positivo, sencillo y de fácil comprensión. 
BARRA DO PUNAÚ
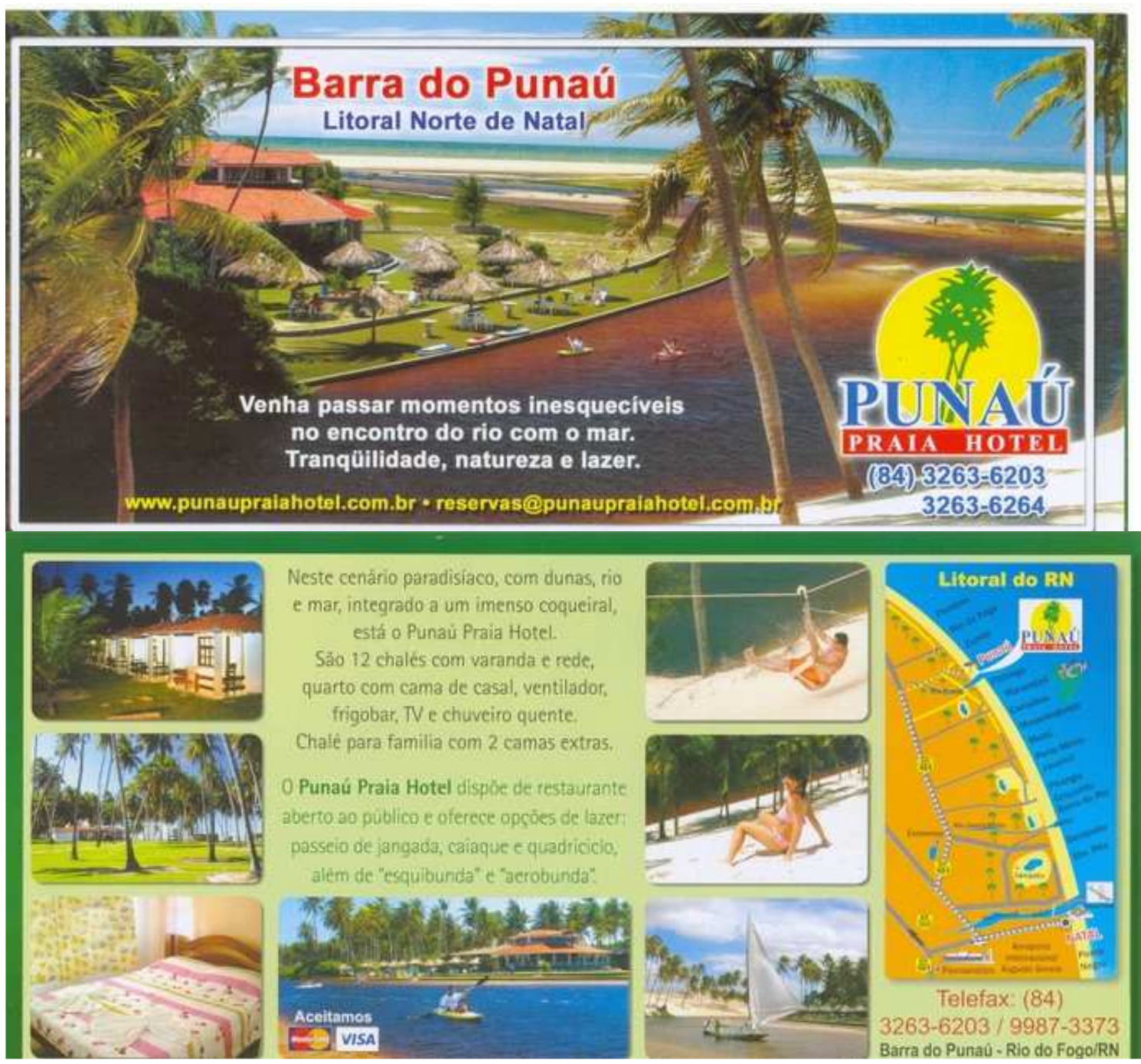

Texto 49

El hombre es un animal social, político y retórico y se mueve desde esos principios en la actual sociedad de consumo. Al plasmar el carácter moderno de la publicidad, López Eire (1998) la relaciona con el proceso de revolución burguesa, la industrialización y el desarrollo de la sociedad contemporánea. Para ello afirma que no se puede concebir la publicidad sin "los procesos previos de la revolución burguesa, de la industrialización, de la producción de bienes en serie, [...] de la libertad de consumo, y del empeño inversionista en las más increíbles actividades empresariales, del que no escapa ni la mismísima publicidad".

Desde el punto de vista de la retórica, la publicidad es considerada, pues, como un subgénero epidíctico por ser un discurso que se ocupa de alabar. Para corroborar esa clasificación del discurso publicitario a partir de la retórica, Kurt Spang (2005:31) 
afirma que el texto publicitario tiene "como la actitud predominante si no exclusiva del discurso la alabanza".

El texto 49 presenta un producto muy de nuestro tiempo: el turismo. Y como la publicidad tiene la actitud de alabar, este texto funciona como una especie de alabaza capitalista del producto turístico anunciado. Desde un punto de vista formal, este texto sigue el formato propio del texto publicitario en el que hay una heterogeneidad de códigos.

En su macroestructura figura la descripción del "Punaú Praia Hotel”, la presentación de su localización, sus vistas del mar y sus actividades turísticas. Por lo tanto, la progresión temática de este texto puede ser definida como de una progresión de tema constante. Este folleto turístico está compuesto por dos páginas, en la primera dice: Barra do Punaú, litoral norte de Natal. Ven a pasar momentos inolvidables en el encuentro del río con el mar. Tranquilidad, naturaleza y ocio.

En este ejemplo, el discurso publicitario no se presenta simplemente como un discurso de la alabanza y del elogio, sino como el discurso en el que el interlocutor está reflejado, es decir, en el que hay una proximidad entre el emisor y el receptor del texto. Dicha proximidad está establecida por medio del uso del vocabulario y de las personas del discurso. En este texto, como se puede observar, se usa la tercera persona del singular para designar el producto anunciado de forma impersonal, además de la segunda persona del singular "tú", lo que aproxima los interlocutores del acto de habla publicitario.

Una de las grandes diferencias entre el discurso publicitario y el discurso retórico es que este hace uso solamente del lenguaje verbal, mientras aquel hace uso del mayor número de códigos de forma sincrética. Eso es lo que afirma López Eire (1998:40) cuando dice que el discurso retórico "está configurado única y exclusivamente por lenguaje verbal y que, por consiguiente, ni capta tanto la atención de los oyentes ni se descodifica con tanta facilidad ni es fácil hacerlo presente por doquier o casi ubicuo, como llega a ser el mensaje publicitario". La publicidad tiene objetivos fundamentalmente económicos y eso delimita la elaboración del mensaje publicitario, cada vez más presente en a la actual sociedad de consumo. 
El texto 49 presenta esta diversidad de códigos de modo que un $30 \%$ del texto es presentado por medio del código verbal escrito, mientras un $70 \%$ está codificado por medio de un lenguaje visual. Eso corrobora el predominio de la imagen frente a lo verbal en la publicidad contemporánea. En la segunda página de ese texto se afirma que en este escenario paradisiaco con dunas, río y mar, integrado a una grande plantación de cocoteros, está el Punaú Praia Hotel. Son 12 chalets con [...].

Este contenido expandido del anuncio viene ilustrado por varias imágenes en las que aparecen el personaje prototipo del anuncio, o sea, personas contentas, relajadas, jóvenes, en muy buena forma física, guapas y que aparentan tener muy buenas condiciones financieras. El producto visual consiste en el logotipo, las vistas y las actividades turísticas del "Punaú Praia Hotel", además de un mapa del litoral del Rio Grande do Norte y la ubicación de este hotel en este mapa. El mensaje manifiesto corresponde al anuncio publicitario completo del "Punaú Praia Hotel" y el mensaje latente connota el confort, la vida, la alegría y el ocio que los clientes encuentran en este hotel.

Se cree que la publicidad, vista como el arte de persuadir a través de la alabanza y un lenguaje artísticamente elaborado, como podemos ver en el texto 49, está relacionada con la retórica por medio del género epidíctico, como ya hemos visto más arriba. López Eire (1998:55) llega a ver la publicidad como una continuación de la retórica cuando dice que:

\begin{abstract}
No cabe la menor duda de que el mensaje publicitario es, mutatis mutandis, un moderno discurso retórico muy concentrado, redundante, cerrado, perceptible, conciso y breve, pero pese a ello, generado con todo escrúpulo y todos los requisitos de la afectividad propios de este tipo de discurso persuasivo, es decir, un discurso pensado para beneficiar y ayudar al emisor mediante la aportación de un esfuerzo notorio para vencer ciertas dificultades que le impiden o le dificultan obtener una victoria en el mercado.
\end{abstract}

Con eso, no cabe duda de que estamos delante de un ejemplo de la continuación de la retórica en la modernidad. Es un texto corto, pero a la vez eficaz, en el que el acto de habla locutivo consiste en el discurso constituido por el lenguaje verbal escrito y el lenguaje visual; su fuerza ilocutiva en la descripción del producto turístico ofertado y su ubicación, que favorece a la persuasión del mensaje; y su efecto perlocutivo en el 
objetivo final de toda publicidad: recibir del interlocutor la confirmación en forma de un acto de compra que beneficia la industria del turismo.

El discurso publicitario alaba lo que anuncia tomando como punto de partida el vocabulario, los deseos y sentimientos de su audiencia. En el texto en cuestión el uso de un léxico positivo por medio de sintagmas como: litoral, momentos inolvidables, encuentro, río, mar, tranquilidad, naturaleza, ocio, escenario paradisiaco, dunas, integrado, grande, plantación y cocoteros. Lo que contribuye a la persuasión del interlocutor. Con eso también refleja los sentimientos y deseos de una sociedad en la que el ocio y el descanso ganan cada vez más importancia frente a una rutina ajetreada.

También, es importante resaltar que la publicidad es la retórica actual, aunque, pese a tantas similitudes, poseen divergencias, dado que se distinguen en lo que concierne al hecho de que la primera no insta al consumo como la segunda. Para López Eire (1998:36):

\footnotetext{
Pese a tal coincidencia, sin embargo, la gran diferencia entre retórica y publicidad estriba en los fines y, por tanto, en los medios y en la estructura misma de los respectivos mensajes, el retórico y el publicitario. La retórica tiene por meta fabricar el discurso retórico, que trata de convencer a un auditorio en cuestiones civiles, políticas o de ciudadanía. En cambio, la publicística, por su parte, aspira a generar buenos mensajes de comunicación publicitaria, que es aquella destinada a persuadir a la sociedad, o a un determinado sector de ella, de la demanda y del consumo de determinados productos para beneficio de sus productores, que son precisamente quienes pagan la publicidad.
}

Por lo tanto, no cabe duda de que la publicidad y la retórica mantienen una relación de mucha proximidad. Además, aunque la retórica y la publicidad posean algunos puntos divergentes y por ello no coincidan en absoluto, les une un parentesco genérico que consiste en el hecho de que ambas forman parte de la Teoría General de la Comunicación. Respecto a eso, López Eire (1998:53) afirma que "ambas son partes de la Teoría General de la Acción Social. Es decir, en virtud de ese su común ancestro que es la Teoría General de la Acción Social, la retórica, la publicística, la ciencia de la educación y la ciencia política están emparentadas". 


\subsection{La publicidad y la literatura}

Al comprender la publicidad como un segmento de la retórica clásica y del género epidíctico, visto por los retóricos de la antigüedad como un género de menos peso, caracterizado por su aspecto carnavalesco como el espectáculo y el entretenimiento, que culminó en la literatura, se puede establecer un nexo entre publicidad y literatura, como bien afirma Eduardo Fernández (2006:60) cuando dice que "la retórica como arte de lo verosímil se asemeja bastante al de la mímesis poética; de hecho, son muchos los que tratan de definir la poesía precisamente por este aspecto".

Es común encontrar algunas afirmaciones al respecto de que la publicidad es un tipo de poesía contemporánea y, por lo tanto, igualan la publicidad a la literatura. De hecho, las especificidades de la literatura, o sea, la complejidad textual, la multisignificación textual, el predominio de la connotación, la libertad en la creación, el énfasis en el significante y la variabilidad discursiva están presentes en el discurso publicitario. Por eso, no resulta difícil llegar a la conclusión de que la publicidad es una especie de literatura contemporánea y, por lo tanto, consiste en un arte.

Como hemos visto anteriormente, muchos recursos retóricos empleados por la literatura son utilizados en los textos publicitarios, como por ejemplo, la rima, la metáfora, el paralelismo, la comparación, los neologismos, la supresión, la personificación, etc. A continuación, presentamos un ejemplo de un folleto publicitario extenso en el que hay la presencia de todas las especificidades de la literatura, incluso una intertextualidad de un texto clásico de la literatura mundial moderna.

Y no es difícil encontrar parte de textos literarios populares y muy conocidos figurando intertextualmente en los anuncios de cualquier tipo de publicidad. Por el contrario, esa es una práctica extendida y muy a menudo empleada por los publicistas. Es un recurso más para atrapar la atención de la audiencia y formar parte de su consciencia cultural. Por ejemplo, el texto 50 presenta Belo Horizonte como un producto turístico. Para ello presenta esta ciudad por medio de un código mixto de imagen y lenguaje verbal. El texto está distribuido en 9 páginas y desde la primera página ya se puede observar su complejidad textual. 
BELO HORIZONTE

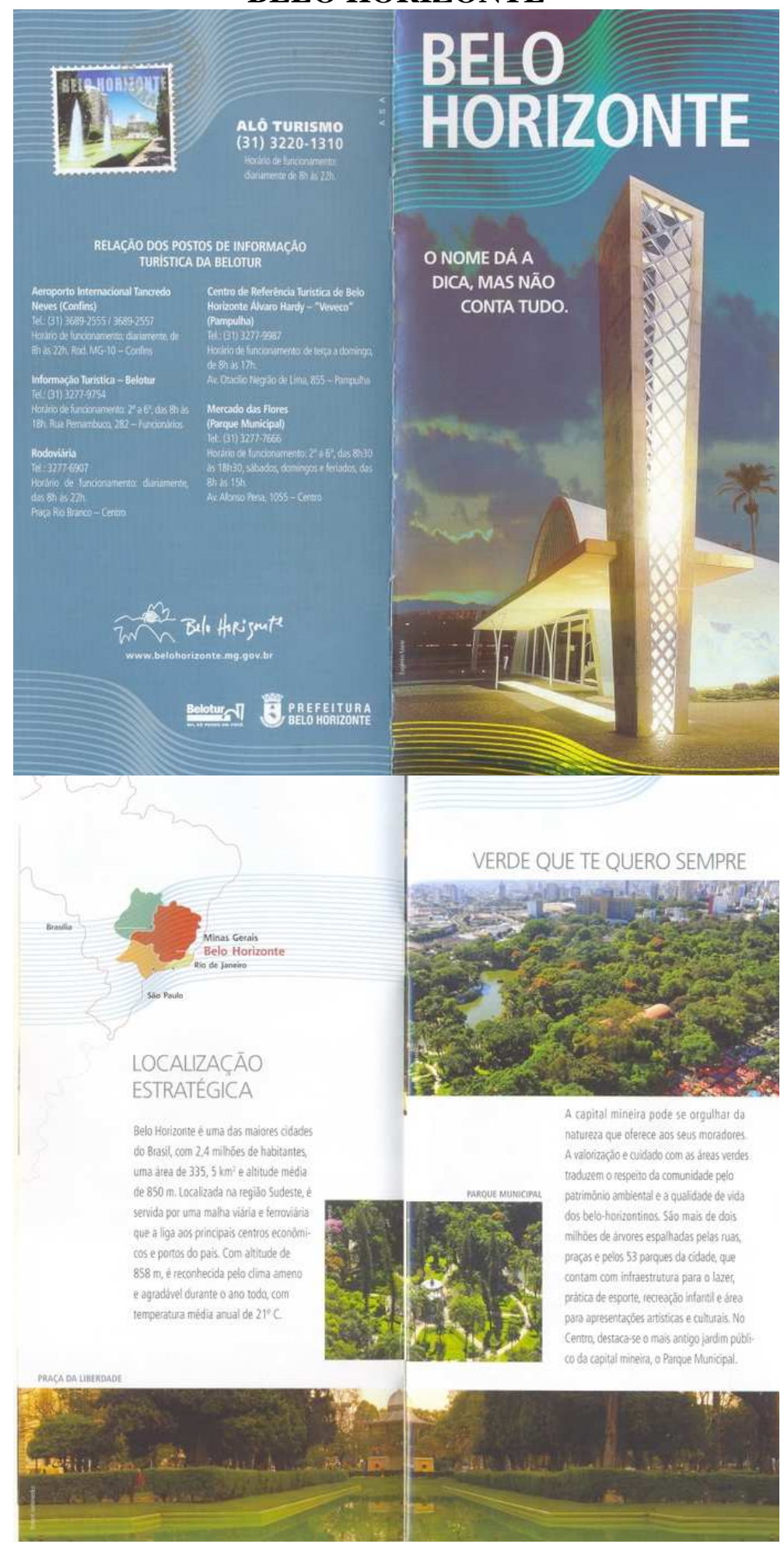




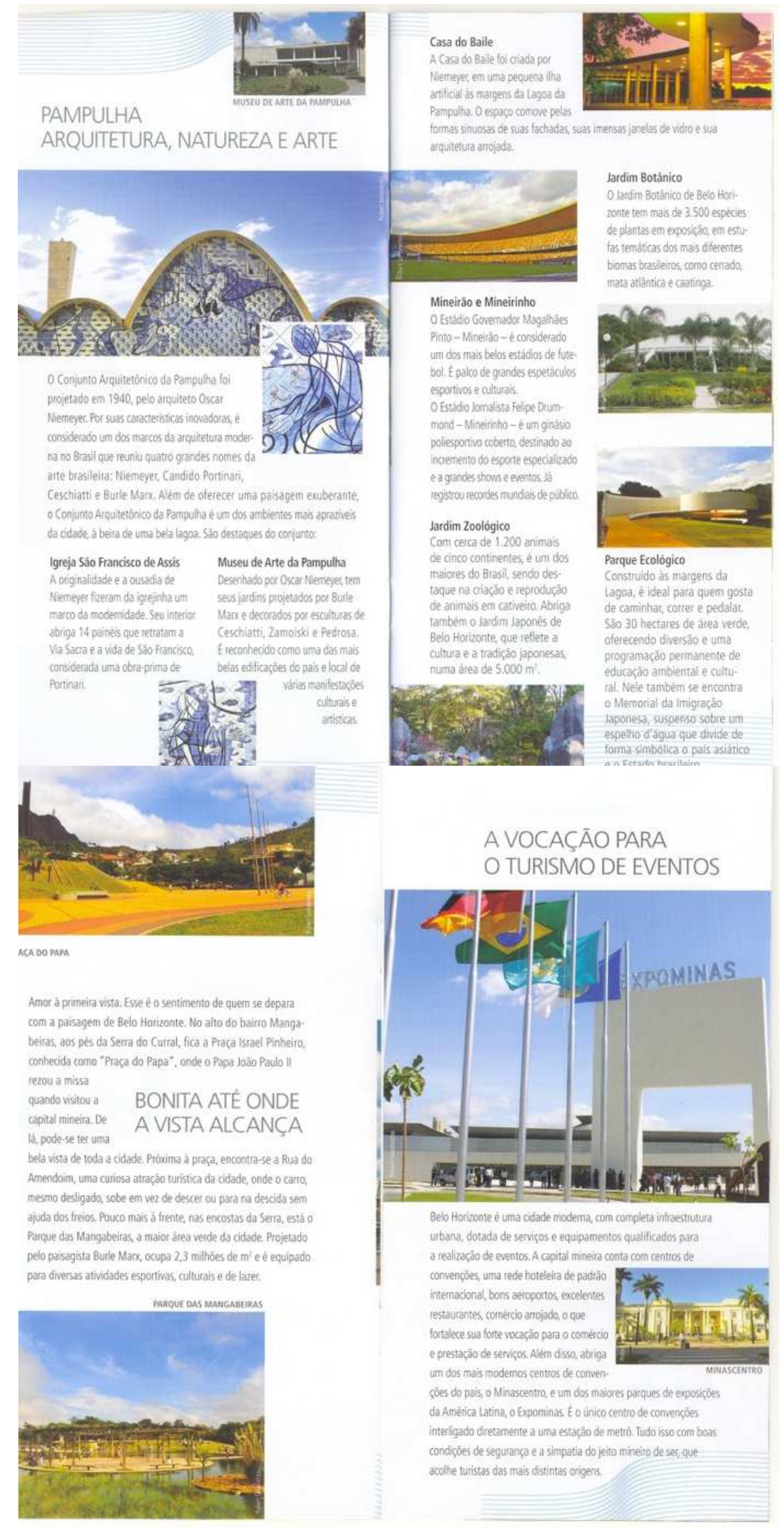




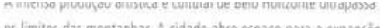

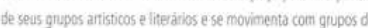
grande talento como o t" Ata, Giramundo e o Grupo Corpo, reco. nhecidos internacionalmente. No teatro, a forca e a personalidade do

TALENTO Grupo Galpåo impressiona e cativa PARA PRODUZIR Malatis pelo mundo. A capital de

TALENTOS a Belo Horizonte lanca na Brasl eno exterior artistas formadores da cultura nacional, como Milion Nasciments o revere Clute do Fsainae as bur de umanutitiond exbiçä antistica locale para rectber grandes espettóculos nacionà's e intermacionais, como o Palàcio das Artes, um dos mais completos

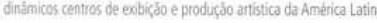
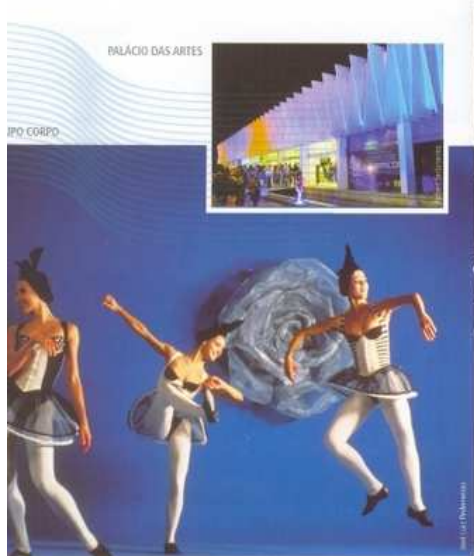

na capital. Para quen busca attenticidade, beleza e diversidade, 0

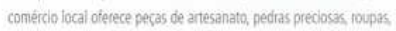

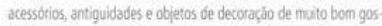

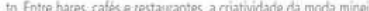
pote sernconirac Cos shopningrda oddde № Barro Pieto, concentrase o comercio atacodista de moda, com mais de 800 lojas de pronts entrega. As ferias tipicas de Belo Horizonte tambem atraem mithres de pessous. A mis concorrida e a feira de Arte $e$ Artesanato da Avenida PASSEIO, LAZER, Atonso pena, a maios técica COMPRASE $\begin{array}{ll}\text { en respaco aberto da Amenica } \\ \text { Latina, realizada } & \text { MUITA DIVERSÃO }\end{array}$

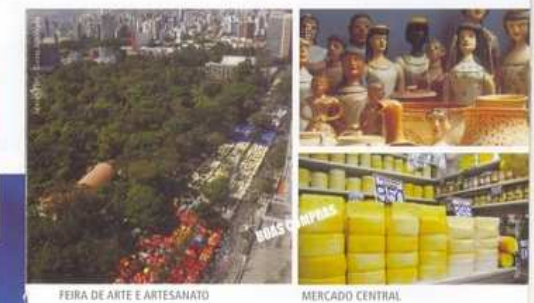

nas manhass de domingo na principal vả do centro da cidade. Atér

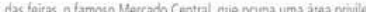
giada no centro da cicta de to

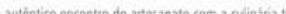
produtos almenticios

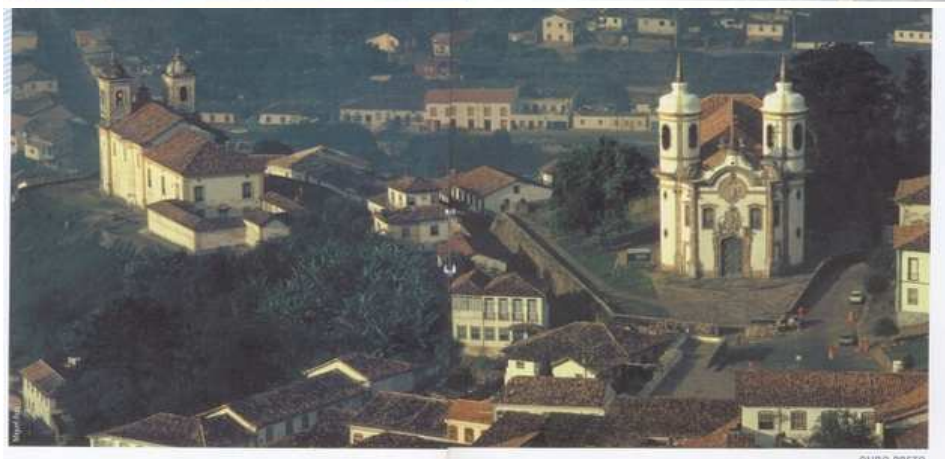

PORTA DE ENTRADA PARA A HISTÓRIA DO BRASIL

Stuada no crorăâa de Minas Gerais, Belo Horizonte é a porta de

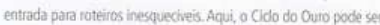

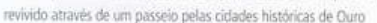
Preto, Mariana, Diamantina, Congonhas do Campo e Sabarc. Alèm da histónia, a natureza no entorno da cidade e pivivegiada. As grutas de Maquine, Lapinha e Rei do Mato exibem slöes de estalocitites e estalagnites milenares e inscriç̄os nupestres em sias paredes. Os parquer flovestals da Setr do Cipó e do Caraca presenem àreas

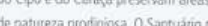
iho da Serta da Piedzde permite una visấo privilegiada de vernos municioios da Regäo Nettopolitana de Beip Horizante. strura do cipo

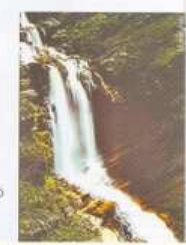

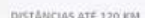
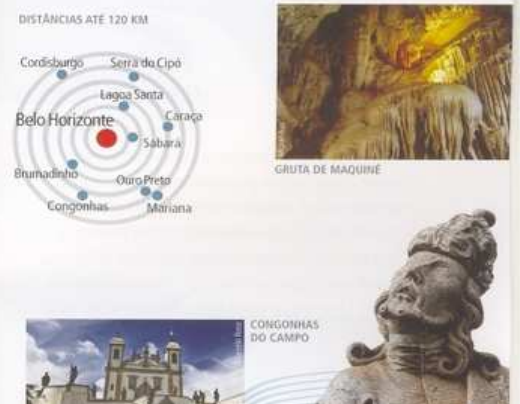

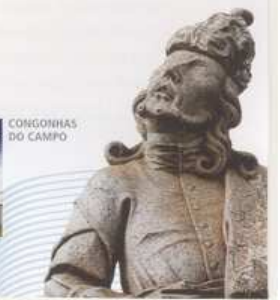




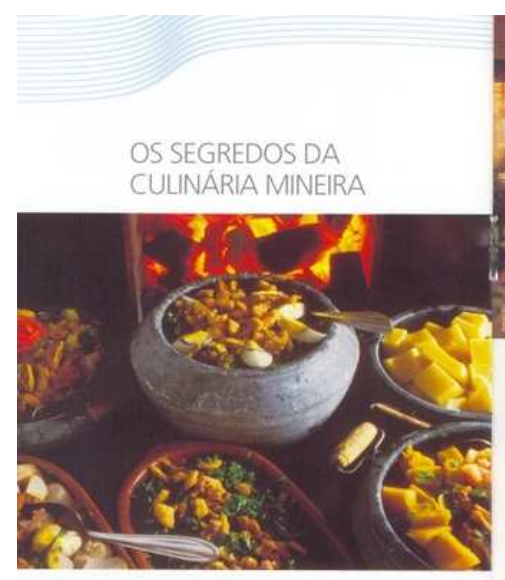

Un ouno tipo de cultura tamberin se tar presente em Betb Horizonte a da boa mesa. Espathadoss por diverss bairus da odade, os 1estausantes e botecos caprician quandoo assunto e a sabocoss e farta culinäna minetera, marca do in-

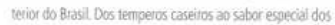
pratos preparados no fogẫo a lentha, como o trango cam quiabo ou a molho parda, otutu com toresmo, o tejajo

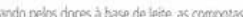

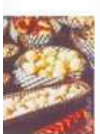

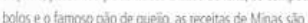

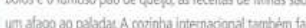

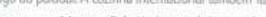

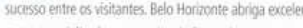
fancess ente ourtat

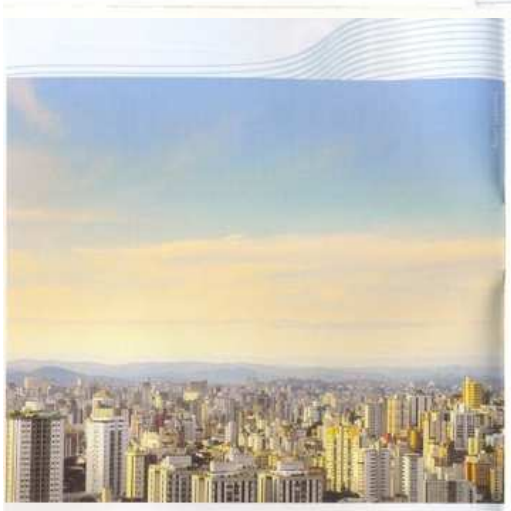

SOB O SIGNO DA MODERNIDADE

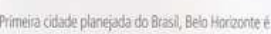
hoje uma metróple dinarmicre esupreendente Traçada pelas linhas geometicicas de Aarió fieis distinque-se. de outras cidaddes da mesta e epoca pela divessidade dos estios arquitedonicos que soube ncomporar ro sey plano orighali: ruas largex, grandes aveni. dase quateirges simetricos. Em meio a tanta moderiodede, a historia tambèm tem tanta modernidode, a historia também tem

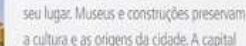
a cultura e as origens drocode A captat

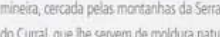
cate e referencia histricica, éun dos mellowes (ugares do Brasi para wive e passeac.

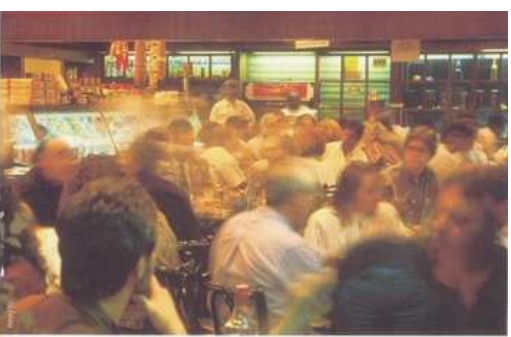

Belo Horizonte é conhecida conno a capital nacional dos bares. A tradiciço boémia da cidade é antiga A A not te belo-karizonting toi cúmplice de varias geraróes de anistas intelectuaise boèmlos que A NOITE marcaram época eliygares Stoo cafes. pubs, bates com pista de dança,

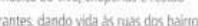

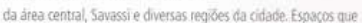

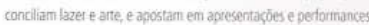

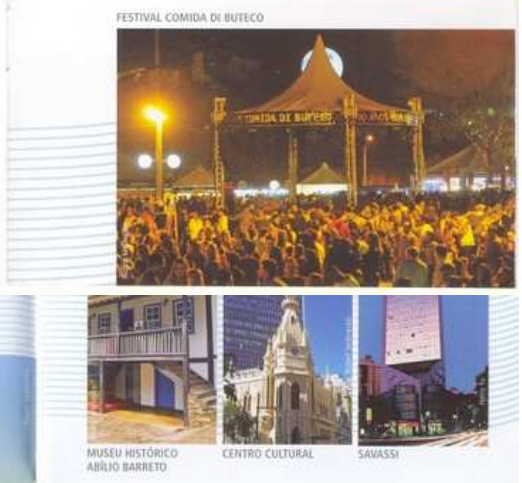

LIBERDADE DE ESTILOS

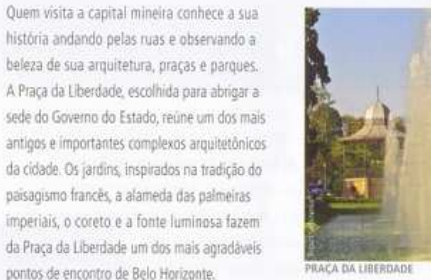

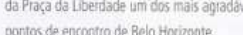

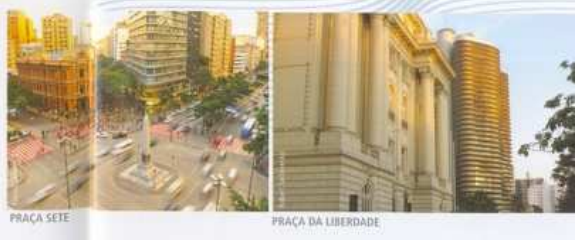




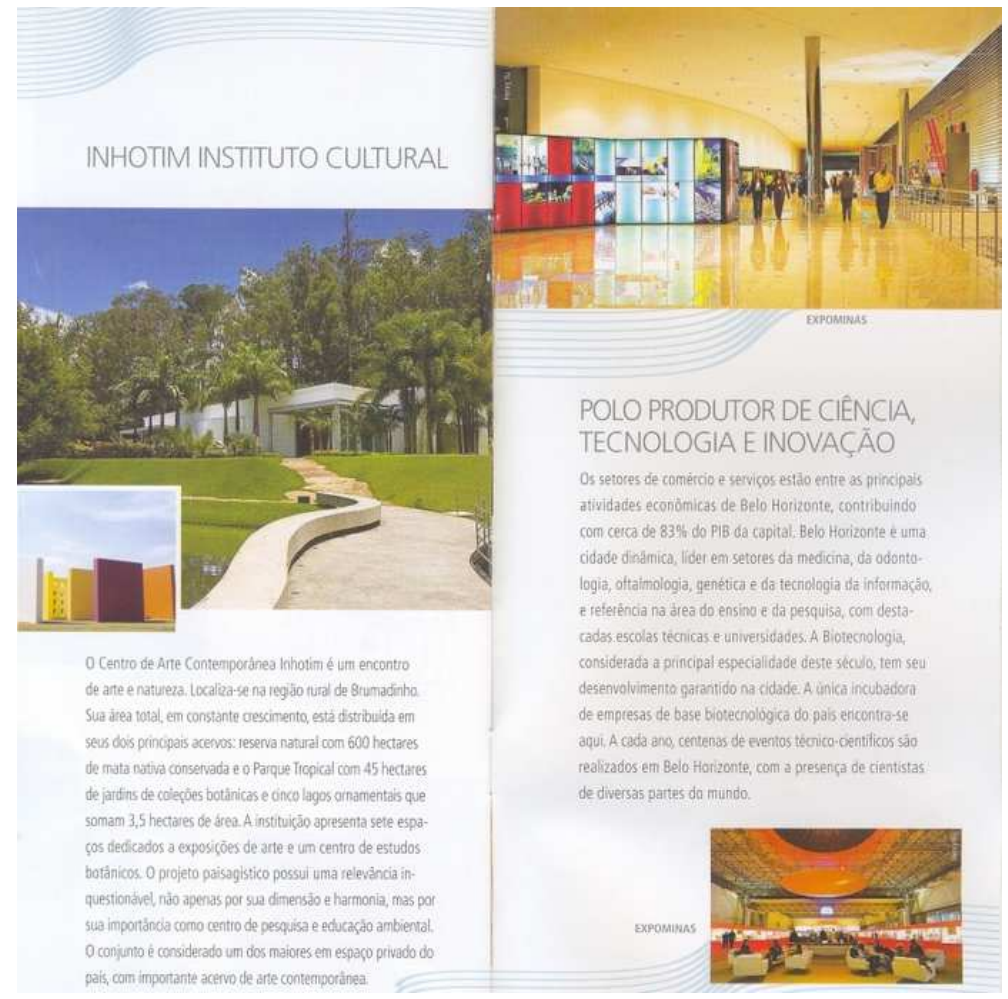

Texto 50

La primera página del anuncio en cuestión dice Belo Horizonte. El nombre da una pista, pero no nos cuenta todo. Observemos que el nombre de la ciudad gana más importancia gracias a la organización gráfica del anuncio que lo presenta en una fuente de tamaño superior a la frase de efecto.

La frase de efecto, por cierto, intenta despertar la curiosidad del interlocutor para intentar descubrir qué es que no cuenta el nombre y para ello tiene que seguir leyendo el anuncio. Si echamos un vistazo a esa frase vamos a ver que es atribuido al sujeto nombre las acciones de dar y contar. No obstante, eso no sería posible en un texto en el que no hubiera el predominio de la connotación, ya que nombre no es un ser animado y por lo tanto no puede producir acciones como dar y contar. Aquí se puede afirmar que se hizo uso de la personificación o prosopopeya, uno de los recursos retóricos también utilizados comúnmente por la literatura.

En la segunda página del texto publicitario en cuestión, vemos la descripción de esta ciudad brasileña bajo dos titulares: bajo el singo de la modernidad y libertad de estilos, que sirven para destacar el estilo arquitectónico de la ciudad. Esos titulares están 
cargados por una multisignificación textual, ya que los lexemas modernidad y libertad pueden estar cargados de significados distintos del que viene en el diccionario.

La libertad en la creación de este anuncio publicitario puede ser claramente encontrada en la tercera página del texto que presenta dos titulares más, a saber: ubicación estratégica y verde que te quiero siempre. Este último fue creado bajo una libertad creativa en la que se emplea la intertextualidad literaria, pues para describir un parque municipal y la exuberante naturaleza de Belo Horizonte, como una atracción de interés turístico, se usó como estrategia la remisión a un verso muy popular en el occidente: "Verde que te quiero verde", que consiste en el primer verso del Romance Sonámbulo del escritor moderno español Federico García Lorca.

En la cuarta, quinta, sexta, séptima, octava y novena página del texto 50 aparecen respectivamente los titulares: Pampulha, arquitectura, naturaleza y arte; bonita hasta donde la vista alcanza; vocación para el turismo de eventos; talento para producir talentos; paseo, ocio, compras y mucha diversión; puerta de entrada para la historia de Brasil; los secretos de la culinaria minera; la noche de los mil y un bares; Nhotim Instituto Cultural; y polo productor de ciencia, tecnología e innovación.

En el titular talento para producir talentos hay el uso retórico de la repetición y con ello se crea una sonoridad y un ritmo específico en la oración. Y en la noche de mil y un bares hay una clara alusión al clásico de la literatura universal Las Mil y Una Noches.

Todos esos titulares llaman la atención del lector/comprador para las cualidades de Belo Horizonte como producto turístico, de modo que lo intenta persuadir de que esta ciudad es bonita, produce talentos, promueve paseo, ocio, compras y mucha diversión, además es la puerta de entrada para la historia de Brasil, etc.

En ese sentido la publicidad y la literatura se relacionan por medio de aspectos retóricos como el género epidíctico compartido por ambas. Con respecto a eso, Adam \& Bonhomme (2000:121) establecen ese nexo cuando dicen que "estamos aquí en pleno epidíctico. Los aspectos literarios y gratuitos característicos del género, la enfatización de la facilidad verbal corresponden a lo que podemos decir del discurso publicitario". Además, Adam \& Bonhomme (2000:62) defienden la noción del universo diegético 
para el análisis del texto publicitario, lo que consiste en otro de los recursos del análisis del discurso literario adoptado por el análisis del discurso publicitario, como se puede ver en la siguiente cita:

Utilicemos la noción de universo diegético para designar los mundos singulares construidos por el discurso publicitario. Sometido a sus propias leyes, un universo diegético está poblado de individuos (personajes, animales y objetos) que poseen propiedades que se hallan más o menos próximas de las de los individuos similares de nuestro universo de referencia.

La publicidad turística escrita en cuestión es un tipo de texto que presenta el énfasis en el significante, es de fácil decodificación, el lector puede elegir cuándo lo va a leer, presenta una variabilidad discursiva, de modo que el lector tiene una libertad subjetiva en su descodificación. Además, está ordenado de modo que si el lector lo desea, puede leer solamente los titulares para saber cuáles son las mayores cualidades de Belo Horizonte. Por eso persuade.

Desde un punto de vista de la poética de la percepción, en la que se trabaja el despertar de todos los sentidos del lector por medio del texto, la publicidad también comparte este aspecto propio del campo literario. Además, es común encontrar textos literarios o parodias de textos literarios en anuncios publicitarios, como hemos visto anteriormente. A partir de esos préstamos, la publicidad tiene mucho de literario. Al relacionar la literatura y la publicidad por medio de la retórica, Eduardo Fernández (2006:17) afirma que:

\footnotetext{
La retórica puede resumirse en este periodo a un conjunto de repeticiones y extrañamientos que pasan a la poética: son de hecho los recursos que utiliza la literatura y muchas veces la publicidad (coupling) los que ayudan a mantener la atención del discurso literario y que por los mismo motivos, han pasado al servicio de la composición de los mensajes persuasivos empleados en publicidad.
}

Otra característica típica de la literatura que está presente en la publicidad es la connotación, puesto que, como afirma Martínez (2000:16) “de todos los mensajes, el connotativo es el predominante en la publicidad, a diferencia de las imágenes periodísticas, que son fundamentalmente informativas o documentales". Volviendo al anuncio publicitario presentado anteriormente, en el titular Puerta de entrada para la 
historia de Brasil no denota que Belo Horizonte es una puerta por medio de la cual uno puede entrar en la historia de Brasil, sino connota la importancia de esta ciudad como monumento importante en la historia brasileña.

\section{La metáfora en la publicidad}

Con el establecimiento del nexo entre el discurso literario y el discurso publicitario a través de la retórica, se hace necesario destacar que estos dos tipos discursivos también comparten elementos generales propios de la literatura como los procedimientos retóricos.

Todos los procedimientos retóricos pueden estar presentes en el texto literario y en el texto publicitario, igualando esos dos tipos de texto en este aspecto. En ese contexto, destacaremos la metáfora como la figura del lenguaje de mayor relieve para el discurso publicitario. Para Lázaro, F. \& Tusón, V. (1988:10) la metáfora es:

\footnotetext{
El más importante de los tropos y el de mayor presencia en el lenguaje literario. En la metáfora, la imagen se identifica con el término real, mediante un acto mental que los iguala (las perlas de su boca). Tal igualación o identificación es posible porque $\mathrm{R}$ e I poseen propiedades que permiten compararlos. Toda metáfora se basa en una comparación (sus dientes, por brillo y color, son como perlas; por tanto, dientes = perlas).
}

El uso de metáforas en la publicidad llega a aproximarla, por lo tanto, de la literatura, sobre todo, de la poesía como el lenguaje que traduce y despierta los sentidos del hombre. Para corroborar eso Ferrer (1994:157) admite que "pudiera decirse que el lenguaje poético de la metáfora se transmite, en gran parte, al de la publicidad, que quiere ser, como el de la poesía, el lenguaje del placer". Además de la metáfora, otros préstamos de la poesía usados por la publicidad son la rima, la métrica y los versos pareados. 
DANDARA

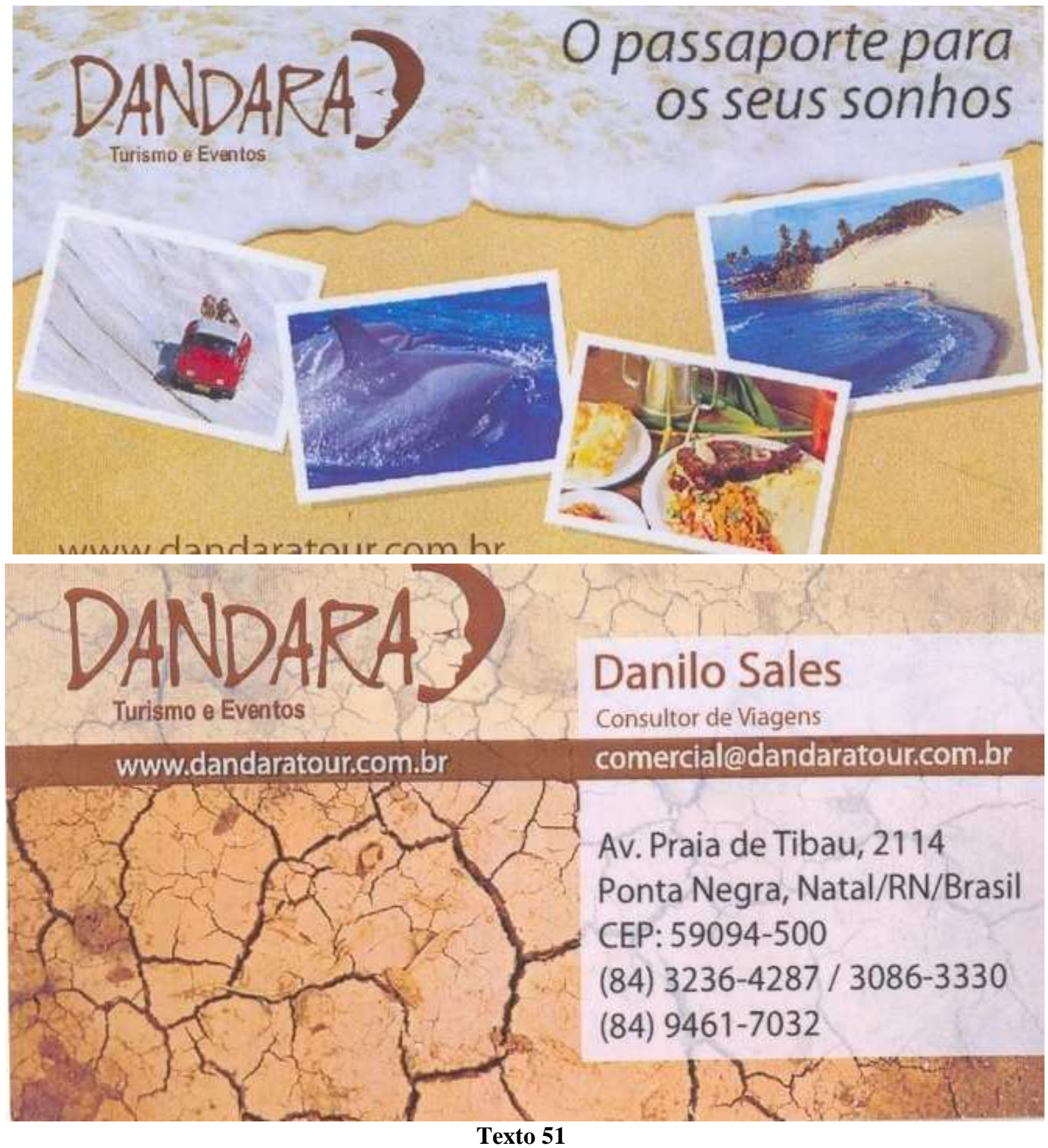

En el texto 51 aparece el siguiente enunciado: Dandara. El pasaporte para tus sueños. El anuncio en cuestión está ilustrado por imágenes como una playa de aguas claras y de arena blanca, comida, una pareja de paseo por las dunas y un delfín. Si vamos al diccionario y consultamos el significado de pasaporte, vamos a ver que es el nombre de un documento usado como identidad oficial en los viajes internacionales, de modo que el interlocutor necesita entender las connotaciones que hay bajo esta palabra. Así, sin muchos esfuerzos cognitivos, formulará por inferencias que, si tu sueño es conocer un ambiente con este aspecto para ir de vacaciones, Dandara Tuor es más que una agencia de viaje, es el propio pasaporte para tus sueños pues te permitirá realizarlos. Así, en ese 
contexto, solo se puede comprender la palabra pasaporte desde un punto de vista metafórico.

También, se dan otros factores que aproximan el texto publicitario del texto literario, sobre todo de la poesía, como por ejemplo el lirismo, los dichos populares, la asonancia, la consonancia, los pregones, la jingle, la brevedad, la sencillez y la preocupación con la estética textual. Henri Lefebvre (apud Ferrer 1994:164) reconoce que "la publicidad se convierte en la poesía de la modernidad, en el motivo y pretexto de los espectáculos más logrados. Se apodera del arte, de la literatura, del conjunto de los significados disponibles y de los significados vacantes. Se vuelve una manera artística de comunicación".

\section{LUCK NATAL}

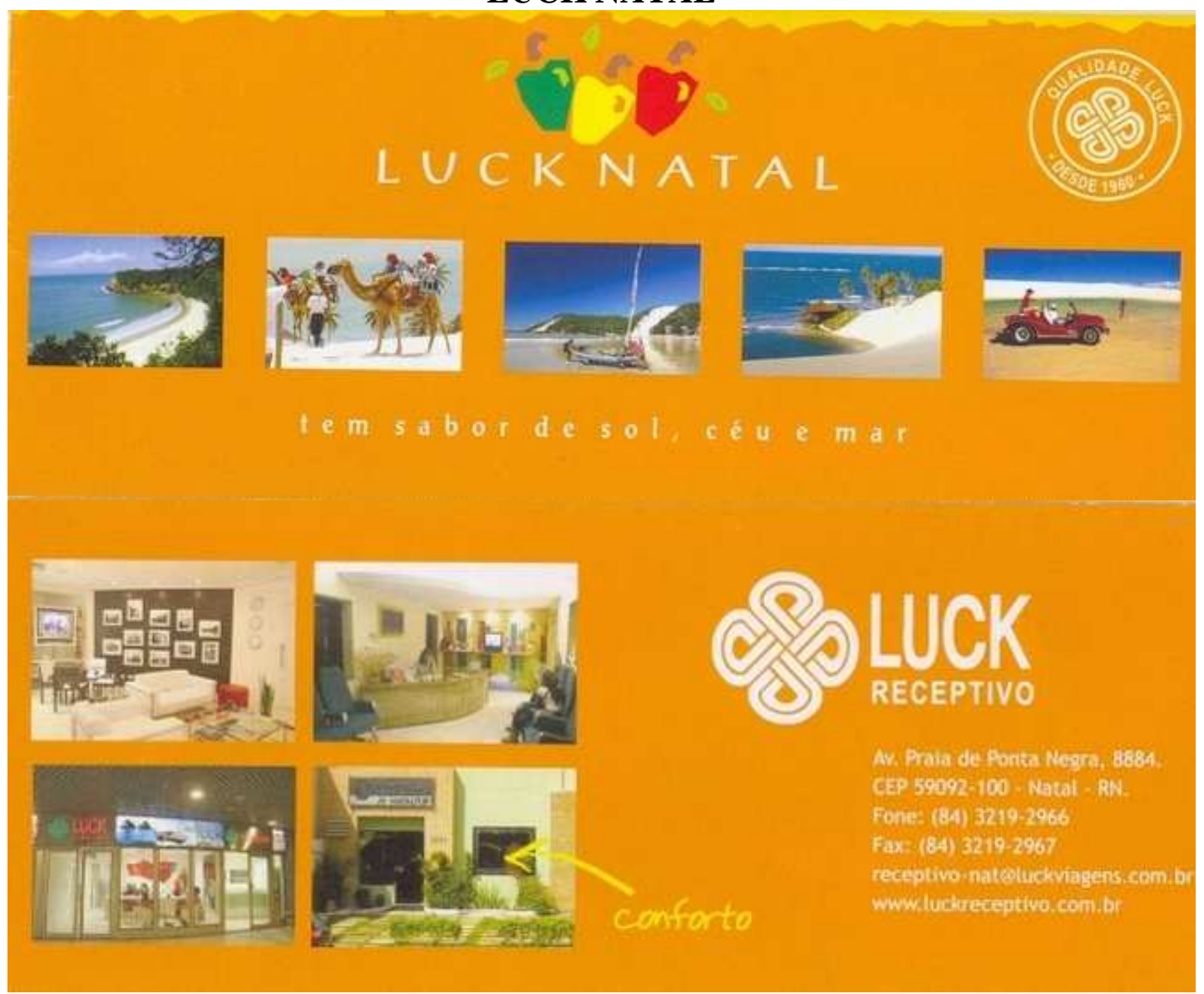

Texto 52

Como ejemplo de esos factores el texto 52 es muy breve y sencillo, además, presenta una preocupación por su parte estética. La primera página del anuncio dice que LUCK NATAL tiene sabor de sol, cielo y mar. La primera cosa que nos llama la atención en ese 
enunciado es la repetición de fonemas sibilantes que dan inicio a palabras como sabor, sol y cielo. Esa selección léxica no fue hecha adrede porque es muy común en Brasil, casi como un pregón, el uso de estas tres palabras encadenadas y de construcciones como sol y agua fesca; sol, céu e mar para referirse al descanso y a las vacaciones en la playa.

Desde un punto de vista formal, este texto sigue el formato propio del texto publicitario. En su macroestructura figura la descripción del "Luck Natal", una empresa de turismo receptivo, y la forma de entrar en contacto con esa empresa. La progresión temática de este texto puede ser definida como progresión de tema constante.

La persona del discurso presente es la inscripción del "él", como forma impersonal de tratar del objeto anunciado. El acto de habla locutivo consiste en el discurso constituido por el lenguaje verbal escrito y el lenguaje visual; la fuerza ilocutiva en la descripción del producto turístico ofertado y su ubicación; y el efecto perlocutivo en la estrategia de persuasión publicitaria que tiene como finalidad recibir del interlocutor la confirmación en forma de un acto de compra.

El producto visual consiste en la propia imagen del "Luck Natal", sus instalaciones externas e internas, además de cinco fotos de playas natalenses. El mensaje manifiesto de este anuncio es la calidad de los servicios ofertados por esta empresa de turismo receptivo, el confort de sus instalaciones físicas y la exuberancia del producto turístico ofertado. Ya el mensaje latente es la buena calidad de los servicios ofertados por "Luck Natal", cuyo sabor del producto turístico anunciado sería de "sol, cielo y mar", como figura en el eslogan, pero ¿qué sabor tiene sol, cielo y mar? Sabor de vacaciones, descanso y confort.

En la selección léxica de este anuncio figuran sintagmas como: sabor, sol, cielo, mar y confort. Un léxico positivo que coopera con el carácter persuasivo de este tipo de texto que persuade porque es de fácil descodificación, llama la atención del receptor/comprador y está dirigido más a la emoción que a la razón.

Lo que ocurre muchas veces es que las nuevas tecnologías, los nuevos medios de comunicación de masas y el desarrollo de las sociedades vehiculan la elaboración de un 
texto publicitario que está creado a partir de su audiencia y en función de ella. Eso puede haber modificado muchos de los aspectos clásicos de la poesía adoptados por la publicidad que conserva elementos básicos de la poesía clásica y de la popular, como hemos visto anteriormente. En función de esa concepción, Ferrer (1994:169) afirma que "los medios han cambiado espectacularmente en la gran metamorfosis tecnológica de la segunda mitad del siglo, pero el anuncio lírico conserva la forma del pregón original, desarrollado y acelerado con todos los deslumbramientos audiovisuales de nuestros días".

\section{Los elementos poéticos y persuasivos en la publicidad}

Guy Cook, en su obra Applied Linguistics (2003), dedica un capítulo a la persuasión y la poética; también a la retórica y resistencia. En esta parte de su libro destaca algunos aspectos del lenguaje artísticamente elaborado, como la estilística literaria, y sobre este aspecto menciona que:

Such features of language use, frequently remarked upon in stylistics, are by no jeans exclusive to literature. They characterize other highly valued uses of language such as prayer, song, and rhetoric which, like literature, can comfort and strengthen, inspire and identify. More generally, if less nobly, they and other similar devises occur in persuasive and emotive uses of language in society at large, whether in commercial, political, or interpersonal communication (Cook, 2003:63). ${ }^{54}$

Este mismo autor también aborda en su obra la importancia del lenguaje elaborado estéticamente para la persuasión. En este sentido establece la importancia de la estilística literaria en la elaboración de anuncios y para el lenguaje comercial. Además, destaca el papel de la comprensión de las técnicas de persuasión en la sociedad contemporánea. Desde este punto de vista, Cook (2003:63) señala:

Language can be used to tell the truth, whether it be literal truth or the more general truths of poetry or (for believers) prayer. Yet it can also be used to distort facts, or to persuade people to take a particular stance towards them. Literary language partakes of this persuasive power, but is perceived as

\footnotetext{
54 Traducción de la autora: "Este uso del lenguaje, frecuentemente observado en la estilística, no es exclusivo de la literatura. Caracteriza otro uso del lenguaje como en el discurso religioso, en canciones, y la retórica, como literatura, puede confortar y fortalecer, inspirar e identificar. Generalmente, es muy frecuente en el uso del lenguaje persuasivo y emotivo en la sociedad de masa, además del lenguaje comercial, político o en la comunicación interpersonal".
} 
inspiring and uplifting. It manipulates our feelings and thoughts though in ways which we are willing, even eager, to accept. Other uses of language are less benign, seeking to control and influence our ideas in the service of some vested political or commercial interest. ${ }^{55}$

Respecto al lenguaje persuasivo, este mismo autor menciona la oleada de informaciones con carácter persuasivo que presiona a la sociedad de la información contemporánea, la gran cantidad de mensajes que intentan atrapar nuestra atención hasta cambiar nuestro comportamiento, como por ejemplo los anuncios publicitarios. Cook (2003:63) apunta:

\begin{abstract}
In our contemporary 'information society', the need both to understand and to combat such language uses has become particularly pressing. We are assailed at every turn by carefully crafted words seeking to attract our attention, win our support, change our behavior. Corporations, advertisers, politicians, journalists, pressure groups, scientists, celebrities - even shop assistants and telephone operators speaking from learned scripts - are busy telling us, not only what they and their organizations do, but also why it is good for us and for the world in general. ${ }^{56}$
\end{abstract}

El autor de Applied Linguistics todavía menciona el efecto dañino del lenguaje persuasivo, en el sentido de que el poder de la palabra puede provocar consecuencias para la salud, el bienestar y la prosperidad. En relación con eso Cook (2003:64) dice que "understanding linguistic techniques of persuasion can enhance our ability to make the rational informed judgments on which decision making depends" ${ }^{57}$

\footnotetext{
${ }^{55}$ Traducción de la autora: "El lenguaje puede ser usado para decir la verdad, puede ser una verdad literal o verdades más generales de la poesía o (para los creyentes) oraciones. También puede ser usado para distorsionar hechos, o persuadir personas a adoptar un comportamiento particular. El lenguaje literario es partícipe de este poder persuasivo, pero es percibido como inspiración y ánimo. Manipula nuestros sentimientos y pensamientos por medios que estamos predispuestos a aceptar. Otros usos del lenguaje son menos benévolos, buscando controlar e influenciar nuestras ideas a favor de algunos intereses políticos o comerciales".

${ }^{56}$ Traducción de la autora: "En nuestra sociedad contemporánea de la información, la necesidad de comprender y combatir este tipo de lenguaje se ha vuelto una presión particular. Somos atacados estratégicamente con palabras trabajadas para atrapar nuestra atención, ganar nuestro apoyo y cambiar nuestro comportamiento. Empresas, publicistas, políticos, periodistas, grupos, científicos, celebridades incluso asistentes de ventas y operadores de teléfono que hablan por un guión fijo - están ocupados en decirnos, no solamente lo que sus compañías hacen, sino también por qué son buenas para nosotros y para el mundo en general".

${ }^{57}$ Traducción de la autora: "La comprensión de las técnicas lingüísticas de persuasión puede aumentar nuestra habilidad crítica de la que dependen nuestras decisiones".
} 


\subsection{La persuasión publicitaria}

Perelman CH. y Olbrechts-Tyteca, L. (1989:67) afirman que "nuestro lenguaje utiliza dos nociones, convencer y persuadir". Así, se distingue el acto de convencer del de persuadir. Estas finalidades de la argumentación son diferentes porque la primera induce a una acción por medio de la razón y la segunda promueve la adhesión de la audiencia por medio de los sentimientos.

En consonancia con la cita de Perelman CH. y Olbrechts-Tyteca, L. (1989), Barreto (s.d.:17) también distingue el acto de convencer del de persuadir, dado que el primero actúa con objetividad y está ligado al razonamiento lógico y, por otro lado, el segundo actúa de modo subjetivo y está relacionado más bien con la emoción. El autor hace una paráfrasis de la mitología y afirma que "convencer es, pues, un esfuerzo dirigido a la mente, a la Psique; persuadir es el dominio de lo emotivo, propio de Venus, diosa del amor, de ahí su proximidad con el arte de la seducción”.

Al intentar comprender la persuasión desde el punto de vista de la retórica, se pude confirmar que este no es únicamente el arte de hablar bien, sino un arte de la persuasión y a partir de ello forma parte de un sistema de comunicativo complejo. Al relacionar la retórica, la literatura y la persuasión a la publicidad, Eduardo Fernández (2006:19) dice que:

En este sentido la publicidad actual encuentra un camino abierto para la utilización de los recursos facilitados por los avances poético-retóricos. Es una comunicación persuasiva, regida por las normas de la lingüística pragmática, en la que los medios para embellecer el discurso son equivalentes a los empleados tradicionalmente en la literatura.

La persuasión puede ser vista como algo intrínseco al acto de comunicación y hace uso de aspectos emotivos y lógicos, con elogios y razonamientos. En este sentido, el acto de comunicación es para Ferrer (1994:341) un acto dirigido a alguien y requiere un "cierto sentido de persuasión o mucho, según el tema de que se trate, del acuerdo que se busque y las peculiaridades del receptor. Es, sin duda, una mezcla sutil de pregunta y respuesta; de emoción y lógica; de alabanza y entendimiento". 
El lenguaje de la publicidad, ya relacionado anteriormente con el de la literatura, hace uso y saca provecho de la persuasión como una de las características principales de este tipo de lenguaje. Según Ferrer (1994:342), "si hay un lenguaje que dependa fundamentalmente de la persuasión, este es el de la publicidad. Es una de las figuras más relevantes de la gramática y uno de los ejes fundamentales en el lenguaje humano de la comprensión."

En el texto 53 el lenguaje publicitario se muestra cargado de elementos persuasivos como la emoción, los elogios y el razonamiento lógico. Y no hay duda de que no podría ser de forma distinta, ya que la publicidad depende de la persuasión, como hemos visto anteriormente. Desde un punto de vista formal, el texto sigue el formato propio del texto publicitario y hace uso de un código mixto, es decir, del lenguaje verbal y del visual, en la elaboración de su mensaje. En su macroestructura figura la descripción interna, externa y de los servicios ofertados por el "Divi-Divi", además de su vista al mar. Por lo tanto, su progresión temática puede ser definida como de una progresión de tema constante.

El anuncio está fraguado en un $80 \%$ de lenguaje visual y un $20 \%$ a través del lenguaje verbal, por medio del que se puede leer los enunciados a continuación: DIVI-DIVI Playa Hotel. Simplemente encantador. Ponta Negra, Natal. Disfruta de las ricuras de Ponta Negra con confort y seguridad. Descansa en un ambiente relajado y acogedor. Confort y localización. Apartamentos amplios y lujosos con TV y cable. Suite máster con sala de hidromasaje. Infraestructura para portadores de necesidades especiales. Suite ejecutiva con sala y amplio cuarto. Mirante con vista panorámica. Gastronomía y ocio. Excelente desayuno regional. Sabrosas copas y pinchos. Piscina adulto e infantil con bar mojado y cascada. Generador de electricidad, ascensor, servicio de fax. Sala de internet. 


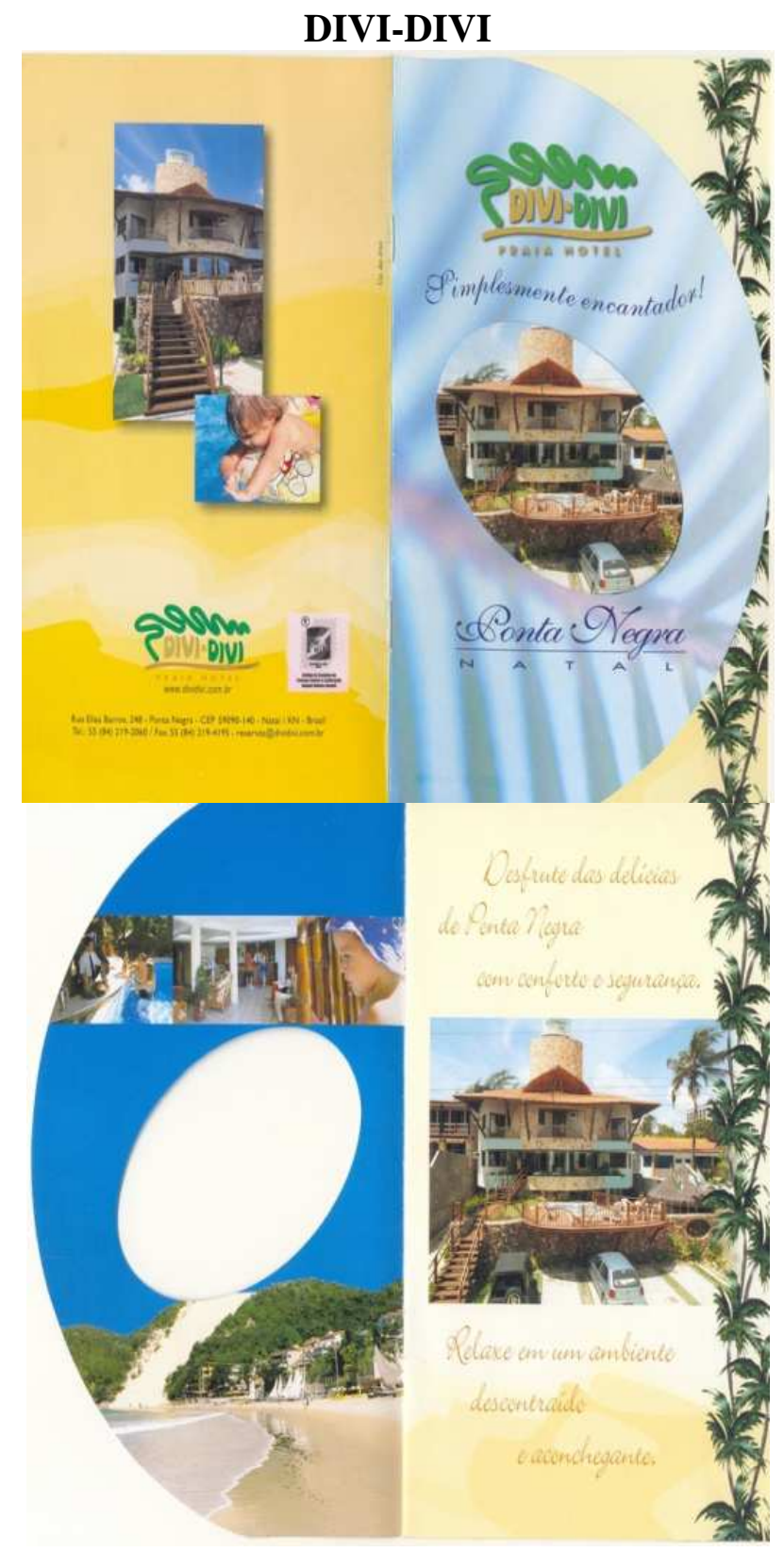




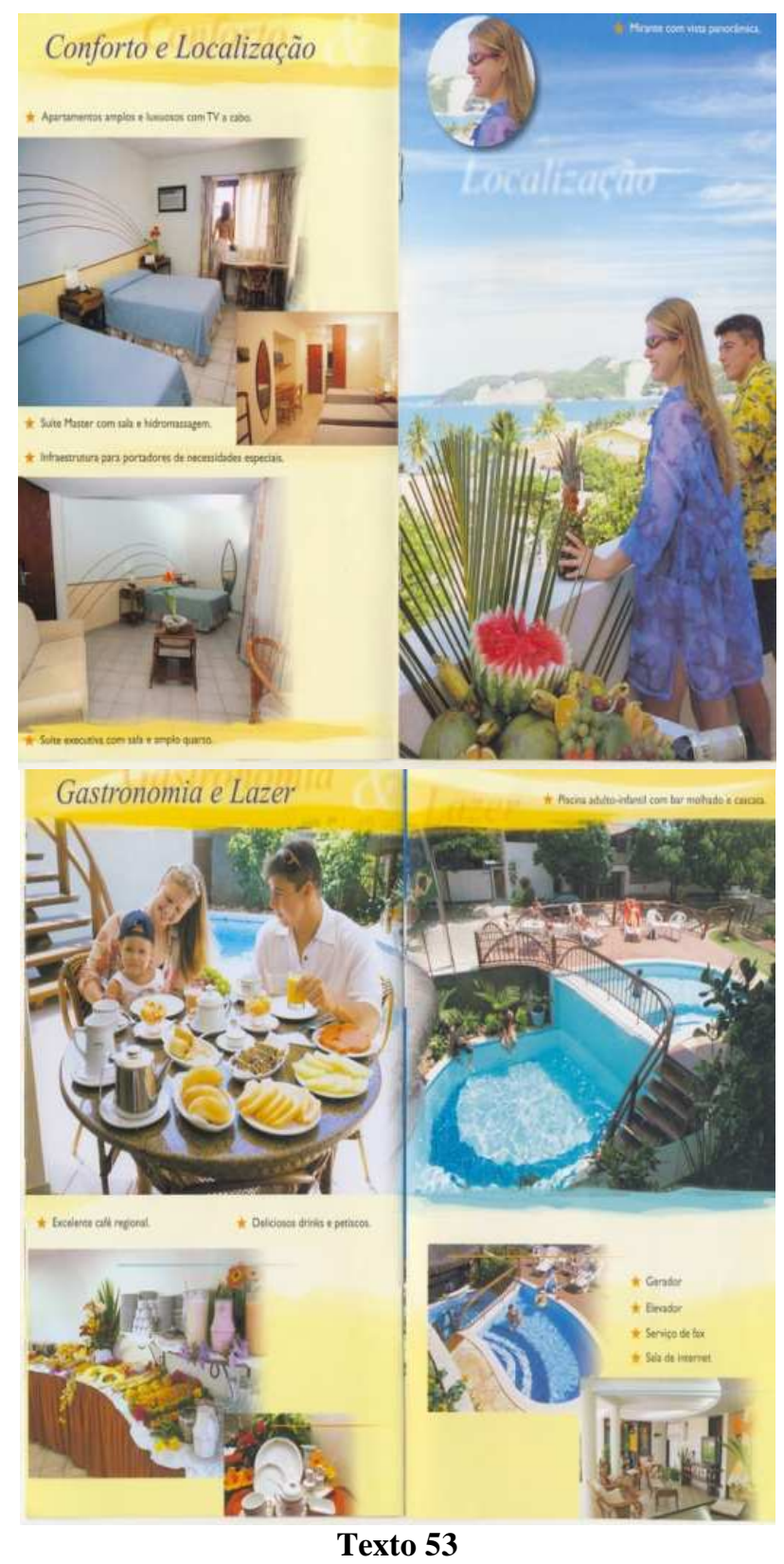

Todo el texto está elaborado de forma elogiosa e intenta persuadir a los interlocutores por cuestiones emocionales y racionales. Sin embargo, lo emocional viene siempre en primer lugar. Las propias imágenes que ilustran este texto ya intentan atrapar al lector/comprador por cuestiones emocionales.

En el mensaje hay el uso de verbos en el modo imperativo de forma que transmite un mensaje más bien como una orden o un consejo. Las personas del discurso presentes son la segunda y tercera personas del singular. Lo que contribuye para que el texto presente el producto ofertado de forma impersonal y objetiva y a la vez trata al 
interlocutor con proximidad ya que el tuteo aporta más cercanía entre los elementos del acto de habla publicitario.

El acto de habla locutivo consiste en el discurso constituido por el lenguaje verbal escrito y el lenguaje visual; la fueza ilocutiva en la descripción del producto turístico ofertado y su ubicación; y el efecto perlocutivo en la estrategia de persuasión publicitaria que tiene como finalidad recibir del interlocutor la confirmación en forma de un acto de compra.

En la textura discursiva están presentes los elementos léxicos como: hotel, simplemente, encantador, disfruta, ricuras, confort, seguridad, descansa, ambiente relajado, acogedor, amplios, lujosos, hidromasaje, especiales, ejecutiva, vista panorámica, gastronomía, ocio, excelente, desayuno, regional, sabrosas. O sea, un léxico hedonista y elogioso que, en conjunto con el anuncio y su mensaje, contribuye a la persuasión del interlocutor.

El producto visual consiste en la propia imagen de las instalaciones internas y externas del hotel anunciado, sus vistas, huéspedes y una imagen de una campaña del gobierno federal contra el turismo sexual. El mensaje manifiesto consiste en el propio anuncio y descripción del producto turístico anunciado. El mensaje latente connota un lugar serio, familiar, comprometido socialmente, elegante, confortable, relajado y acogedor.

La persuasión en la publicidad surge paulatinamente hasta el punto de convertirse en una característica natural del discurso publicitario. En esa línea de pensamiento, Adam \& Bonhomme (2000:27) afirman que "las diferentes técnicas de persuasión han aparecido sucesivamente, desde luego, pero todas ellas parecen estar co-presentes en la publicidad actual”. Para Kurt Krapf (1953:46):

\footnotetext{
La publicidad no limita sus funciones a la simple información desinteresada y al papel de aconsejar. En manos del empresario se convierte en un instrumento que asegura la renta y que es indispensable debido a la necesaria reducción de gastos fijos por medio de la producción masiva. La publicidad aparece entonces como un medio de sugestión, de 'persuasión'.
}

Para estos mismos autores, el acto de persuadir está tan relacionado con el acto de comunicar que el segundo depende del primero para existir. Además, el lenguaje está en 
el lado razonable y no razonable de las cosas y de las personas. Como afirma Ferrer (1994:343), "sin persuasión, no hay comunicación. Que pueda distorsionarse o exagerarse es un riesgo propio de todo uso o ejercicio. Más aún en el lenguaje persuasivo que está en la razón y en la sinrazón de las cosas y de las gentes”.

En el texto 54, el elogio propio del lenguaje publicitario es inducido por medio de la imagen de la primera página del anuncio, que sugiere al interlocutor un hotel deslumbrante e impecable, con una estructura física muy moderna y elegante.

\section{CORAL PLAZA}
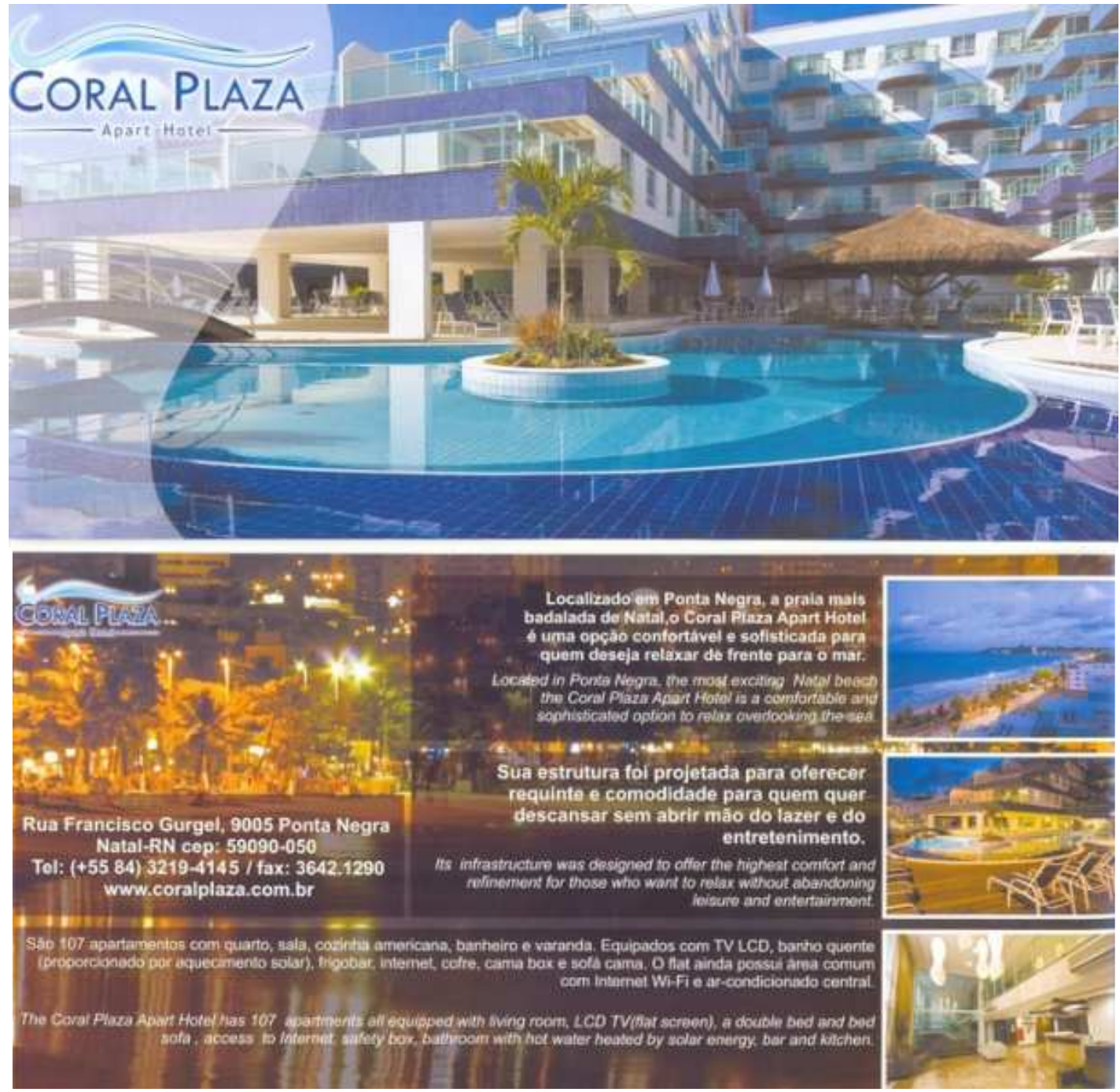


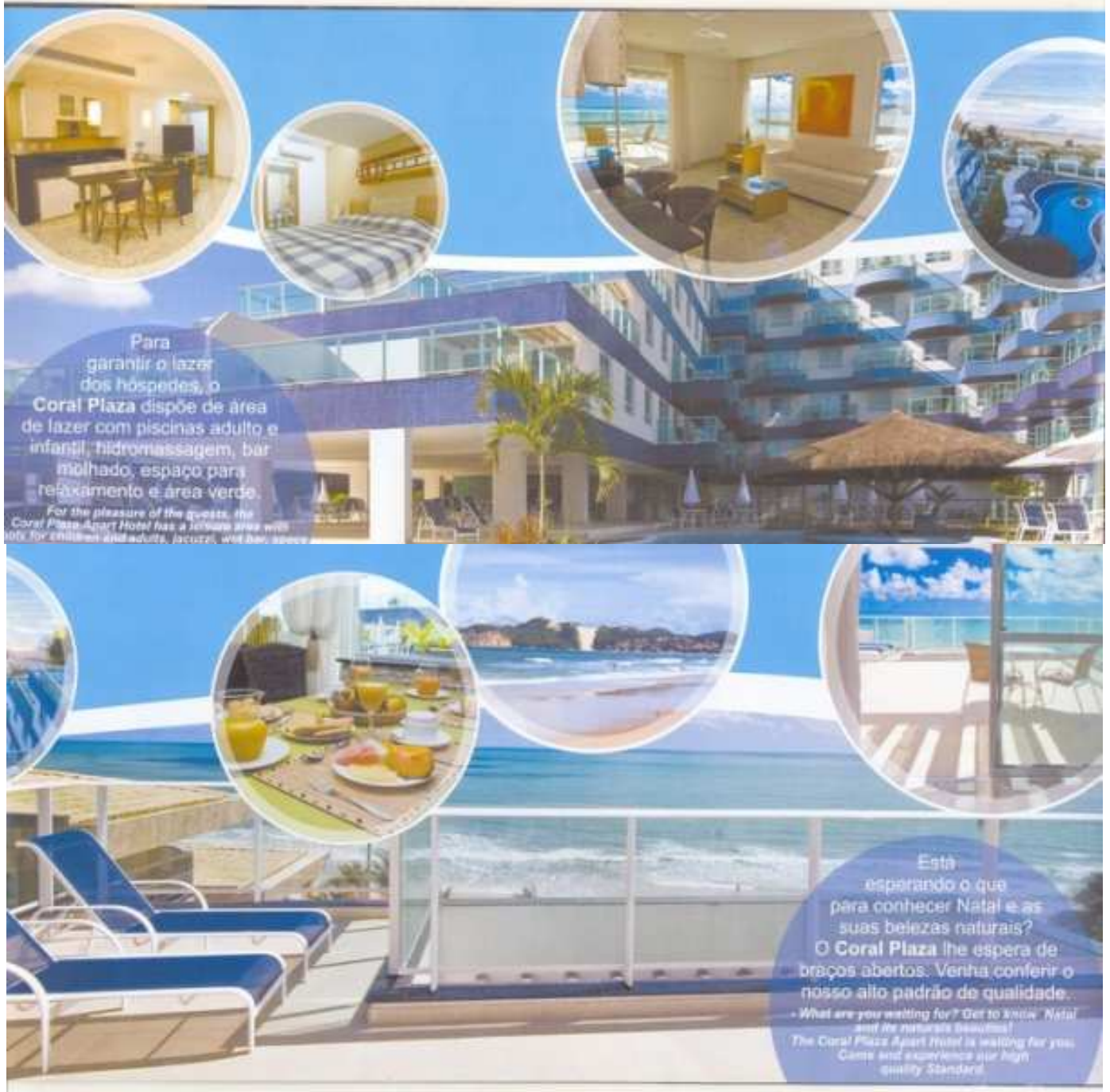

Texto 54

Desde un punto de vista formal, este texto sigue el formato propio del texto publicitario. En su macroestructura figura la descripción del "Coral Plaza Apart Hotel", la presentación de su localización, y sus instalaciones. La progresión temática de este texto puede ser definida como una progresión de tema constante.

Su componente expandido consiste en: localizado en Ponta Negra, la playa más famosa de Natal, el Coral Plaza Apart Hotel es una opción confortable y sofisticada para quien desea relajar en frente al mar. Su estructura fue proyectada para ofrecer sofisticación y comodidad para quien quiere descansar sin dejar de tener ocio y entretenimiento. Son 107 apartamentos con cuarto, sala, cocina americana, baño y balcón [...]. Para garantizar el ocio de los huéspedes, el coral plaza dispone de área de ocio con piscinas adulto e infantil, hidromasaje, bar mojado, espacio para descanso y área verde. ¿Qué 
estás esperando para conocer Natal y sus bellezas naturales? El coral plaza te espera de brazos abiertos. Ven a comprobar nuestro alto patrón de calidad.

El mensaje lingüístico de este anuncio presenta un vocabulario y estereotipos propios de la publicidad, que aborda lo moderno, lo internacional, lo singular y lo feliz del producto turístico anunciado. Las personas del discurso presentes son "nosotros" como un recurso retórico de cortesía y la inscripción del "você", en portugués de Brasil, que tiene la fuerza semántica del "tú" en español, presentando así un carácter de proximidad entre el emisor y el destinatario.

La pregunta retórica ¿Qué estás esperando para conocer Natal y sus bellezas naturales? implica al interlocutor en este acto de comunicación persuasivo que es la publicidad, cuyo acto de habla locutivo consiste en el discurso constituido por el lenguaje verbal escrito y el lenguaje visual; la fuerza ilocutiva en la descripción del producto turístico ofertado y su ubicación; y el efecto perlocutivo en la estrategia de persuasión publicitaria que tiene como finalidad recibir del interlocutor la confirmación en forma de un acto de compra.

El producto visual del texto en cuestión consiste en la propia imagen del "Coral Plaza Apart Hotel", la presentación de su localización, sus instalaciones internas y su vista privilegiada del mar, cuyo mensaje manifiesto consiste en la presentación de un lugar elegante y tranquilo para la instalación del turista y el mensaje latente es de un lugar acogedor, confortable, relajado y de paraíso tropical.

\section{Aspectos psicológicos de la persuasión}

En Principios de la Comunicación Persuasiva, Santiago Guervós (2005:9) intenta presentar "una aproximación a la comprensión de la comunicación persuasiva". A partir de esa obra, se puede llegar al postulado de que la comunicación persuasiva puede ser abordada desde varios puntos de vista como el retórico, el psicológico, el etnográfico, el sociológico, el etológico, el del análisis del discurso, el pragmático, etc.

Para una comprensión más amplia del fenómeno de la persuasión, no se debe ignorar el mestizaje de los diversos terrenos científicos que buscan hallar una explicación al 
funcionamiento de la comunicación, sobre todo la persuasiva, que favorezca a la aclaración del binomio estímulo/respuesta. Santiago Guervós (2005:9) dice que no se debe "cerrarle las puertas a ninguna ciencia que haya pretendido alcanzar su explicación, y hacerlo desde una perspectiva humanística para evitar ver el estudio de la comunicación de forma atomizada”.

TOA TOA
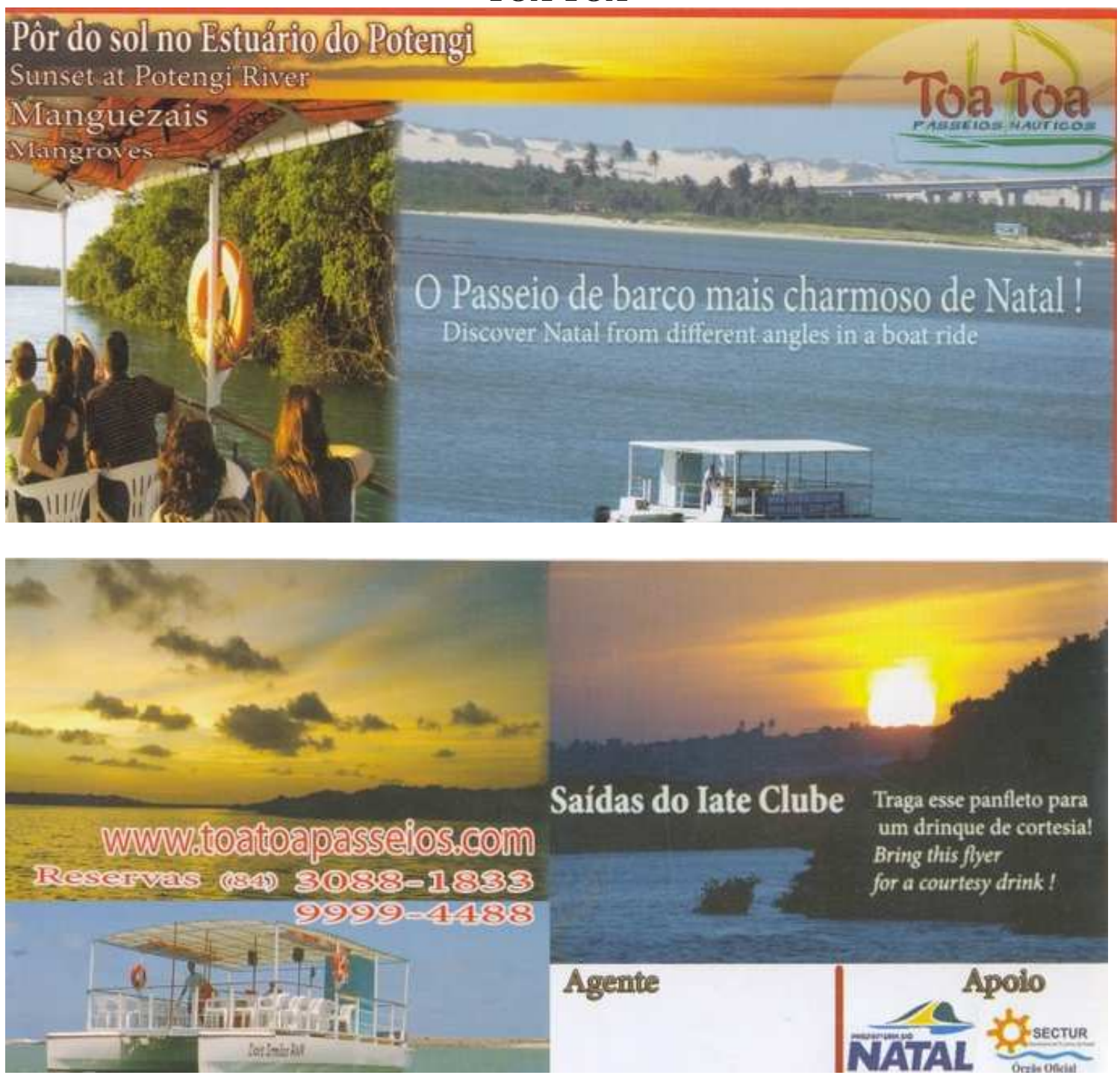

Texto 55

El estímulo visual en el texto 55 es definitivo a la hora de llamar la atención del interlocutor y a la vez persuadirlo para consumir el producto turístico anunciado. Ya el contenido verbal del anuncio en cuestión se limita a anclar el mensaje visual afirmando: La puesta del sol en el estuario del Pontengi. El paseo de barco más hermoso de Natal. Salidas del Iate Club. Trae este folleto para una bebida gratis. En otras palabras, el 
propio interlocutor formulará el mensaje publicitario a partir de la unión del lenguaje visual y del lenguaje verbal.

Por medio de los universales de la comunicación, se puede decir que en el cerebro humano hay herencias genéticas de reptiles, mamíferos primitivos y mamíferos evolucionados, es decir, podemos dividir el cerebro en tres partes: reptiliano, límbico y neocórtex. El cerebro reptiliano tiene que ver con conductas rutinarias y repetitivas. Dicho tipo de conducta, según Santiago Guervós (2005:17), "las compartimos con los reptiles y están directamente relacionas con la idea de previsibilidad [...], y que resulta fundamental en la comunicación persuasiva”. El límbico se relaciona con las emociones y es anterior al neocórtex, que permite el razonamiento:

\begin{abstract}
Podemos deducir, entonces, que la emoción se pone en marcha antes que el pensamiento, y de un modo completamente independiente a él. El sistema límbico puede reaccionar con un arrebato de rabia o de miedo antes de que el neocórtex se dé cuenta de lo que está ocurriendo. El hecho de que el cerebro emocional sea muy anterior al racional y que éste sea una derivación de aquél revela con claridad las auténticas relaciones existentes entre el sentimiento y el pensamiento: el sentimiento es primero por su propia esencia, por la propia estructura cerebral. El pensamiento le sigue. Primero sentimos, luego racionalizamos el sentimiento (Santiago Guervós, 2005:18-19).
\end{abstract}

El emisor del texto 55, por medio de la previsibilidad, espera que el interlocutor del texto lo formule mentalmente y actúe favorablemente a la intención previa del locutor. Para ello, la audiencia tiene que actuar movida por el sentimiento, ya que en el texto es presentada una imagen bastante sugestiva y más bien poética.

Desde un punto de vista formal, el anuncio en cuestión sigue el formato propio del texto publicitario. En su macroestructura figura la descripción del "Toa Toa Passeios Náuticos", la presentación de la ruta realizada por este barco y su localización. La progresión temática de este texto puede ser definida como progresión de tema constante. Las personas del discurso presentes son la inscripción de la tercera persona del singular, que remite al producto anunciado, y la inscripción del "você", en portugués de Brasil, que tiene la fuerza semántica del "tú" en español, presentando así un carácter de proximidad entre el emisor y el destinatario. 
En el acto de habla publicitario establecido por este anuncio, la fuerza ilocutiva está en la descripción del producto turístico ofertado y su ubicación; y su efecto perlocutivo corresponde a la estrategia de persuasión publicitaria que tiene como finalidad recibir del interlocutor la confirmación en forma de un acto de compra.

El producto visual consiste, principalmente, en el barco y el ambiente de la puesta del sol del río Potengi, paseo vendido por el "Toa Toa Passeios Náuticos". El mensaje manifiesto corresponde a la publicidad del producto turístico anunciado y el mensaje latente connota lo elegante, lo tranquilo, lo romántico y lo bello de paseos como estos.

En el texto 55 todo significa de modo que eso corresponde a lo que afirma Santiago Guervós (2005:26) cuando dice que "todo comunica y, como se ve, de forma universal. Aquellos que pretenden conseguir persuadirnos y llevarnos hacia la respuesta prevista emplean todos los elementos que puedan jugar en su favor".

Así, el texto persuasivo actúa directa o indirectamente sobre las conductas humanas, teniendo como aliados la respuesta del miedo de individuo o la esclavitud de la imagen frente a la sociedad. Los que llevan el folleto publicitario en cuestión ya pasan a formar un grupo de individuos y por lo tanto no estarán solos. Formarán el grupo de los que ganarán una copa gratis mientras disfrutan del encantador paseo de barco anunciado con sus vistas espectaculares de la naturaleza potiguar. 
HOTEL PARQUE DA COSTEIRA

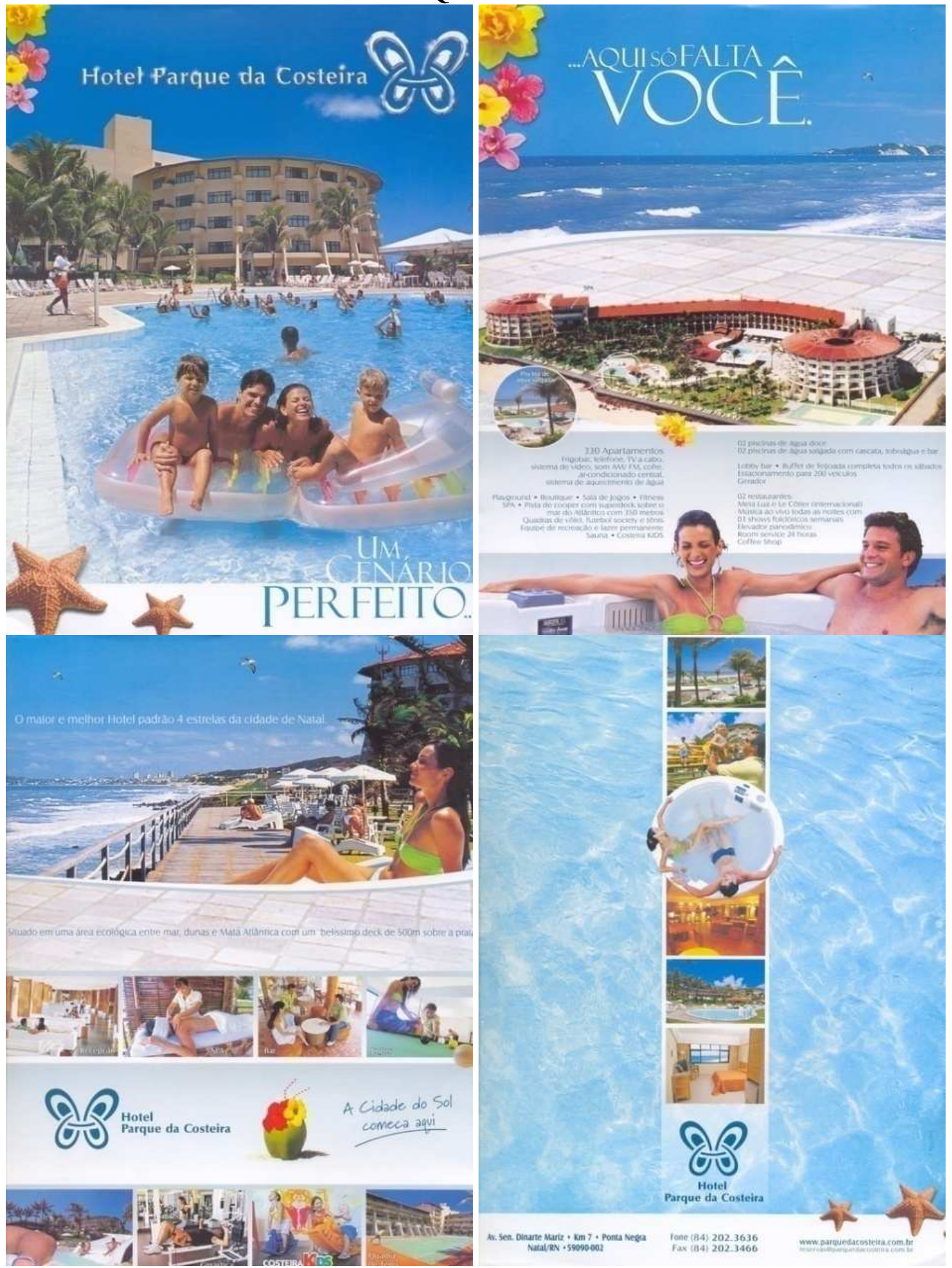

Texto 56

El texto 56 presenta un escenario de playa con la descripción de un gran hotel que está al lado del mar. Se supone que en la piscina de hidromasaje de este hotel hay una pareja relajada y feliz. La propia imagen del anuncio invita al descanso, a las vacaciones y a la playa. Para completar el mensaje y fortalecer su aspecto persuasivo se puede leer: "Aquí 
solo faltas tû". Así, se puede inferir que en este lugar hay de todo y, además, se supone que todos los demás lo están pasando bien en este escenario, pero tú no. Estamos, pues, delante de un ejemplo de gregarismo como elemento de persuasión publicitaria.

Desde un punto de vista formal, este texto sigue el formato propio del texto publicitario. En su macroestructura figura la descripción del "Hotel Parque da Costeira", la presentación de su localización, sus instalaciones externas, sus instalaciones internas y los productos ofertados por este hotel, por lo tanto su progresión temática puede ser definida como de progresión de tema constante.

El anuncio dice: Hotel Parque da Costeira un escenario perfecto. Aquí solo faltas tú. 330 apartamentos [...]. El más grande y mejor hotel patrón 4 estrellas de la ciudad de Natal. Ubicado en un área ecológica entre mar, dunas y flora atlántica con un bellísimo deck de 500 metros sobre la playa. Hotel Parque da Costeira, la ciudad del sol empieza aquí.

Como se puede ver las personas del discurso presentes son la tercera persona del singular para indicar la impersonalidad del texto y la inscripción del "você", en portugués de Brasil, que tiene la fuerza semántica del "tú" en español, presentando así un carácter de proximidad entre el emisor y el destinatario.

El mensaje elogioso de esta publicidad intenta convencer a su audiencia a consumir el producto turístico anunciado, de modo que su acto de habla locutivo consiste en el discurso constituido por el lenguaje verbal escrito y el lenguaje visual; su fuerza ilocutiva consiste en la descripción del productor turístico ofertado y su ubicación; y el efecto perlocutivo en la estrategia de persuasión publicitaria que tiene como finalidad recibir del interlocutor la confirmación en forma de un acto de compra.

El producto visual consiste en la propia imagen del "Hotel Parque da Costeira", sus instalaciones internas, externas y su vista privilegiada del mar. El mensaje manifiesto de este anuncio es la excelencia del producto anunciado y el mensaje latente es la de un "escenario perfecto" para el ocio y la diversión de toda la familia. 
En la textura discursiva del texto en cuestión están presentes los elementos deícticos y el mantenimiento del referente se da por procedimiento léxicos y gramaticales. El vocabulario positivo adoptado en el anuncio en cuestión está formado por sintagmas como: hotel, parque, escenario perfecto, más grande, mejor, ciudad de Natal, ecológica, mar, dunas, flora atlántica, bellísimo, playa, sol y empieza.

Como muy bien apunta Santiago Guervós (2005:27) cuando habla de la apelación de la comunicación persuasiva a la autoimagen, basta simplemente "ojear la publicidad televisiva para ser consciente de que en la mayor parte de los casos no se venden las excelencias de un producto sino que se juega con asociaciones de valores que aportan al posible comprador la imagen que desea tener de sí mismo" y los elementos léxicos contribuyen para ello porque generan esas asociaciones a través de una selección léxica positiva, como hemos visto anteriormente.

Del mismo modo, Gutiérrez Ordóñez (2000) propone que la publicidad actúa sobre los instintos del hombre, en cuestiones como las que abordan temas como sexo, carácter, triunfo, conquistas, bienestar social y económico, etc. Desde esta línea de pensamiento este autor afirma que:

En publicidad, por ejemplo, la mejor efectividad no se consigue a través del bombardeo o de la estimulación del nivel consciente. Desde los descubrimientos de Freud y Pavlov, la publicidad acude predominantemente a la estimulación de los apetitos más o menos reprimidos (sexualidad, violencia, éxito, deseo de triunfo, nivel de vida) o a la asociación del producto anunciado a una manifestación positiva del nimbo de valores (Gutiérrez Ordóñez, 2000:9).

Para lograr el convencimiento, el texto persuasivo hace uso de teorías como la de la disonancia cognitiva (cuando uno piensa una cosa y hace otra), la reciprocidad y el gregarismo (la tendencia a formar parte del grupo aporta seguridad). Un ejemplo del efecto gregario en las campañas publicitarias es el argumento de la cantidad. 
PIRÂMIDE
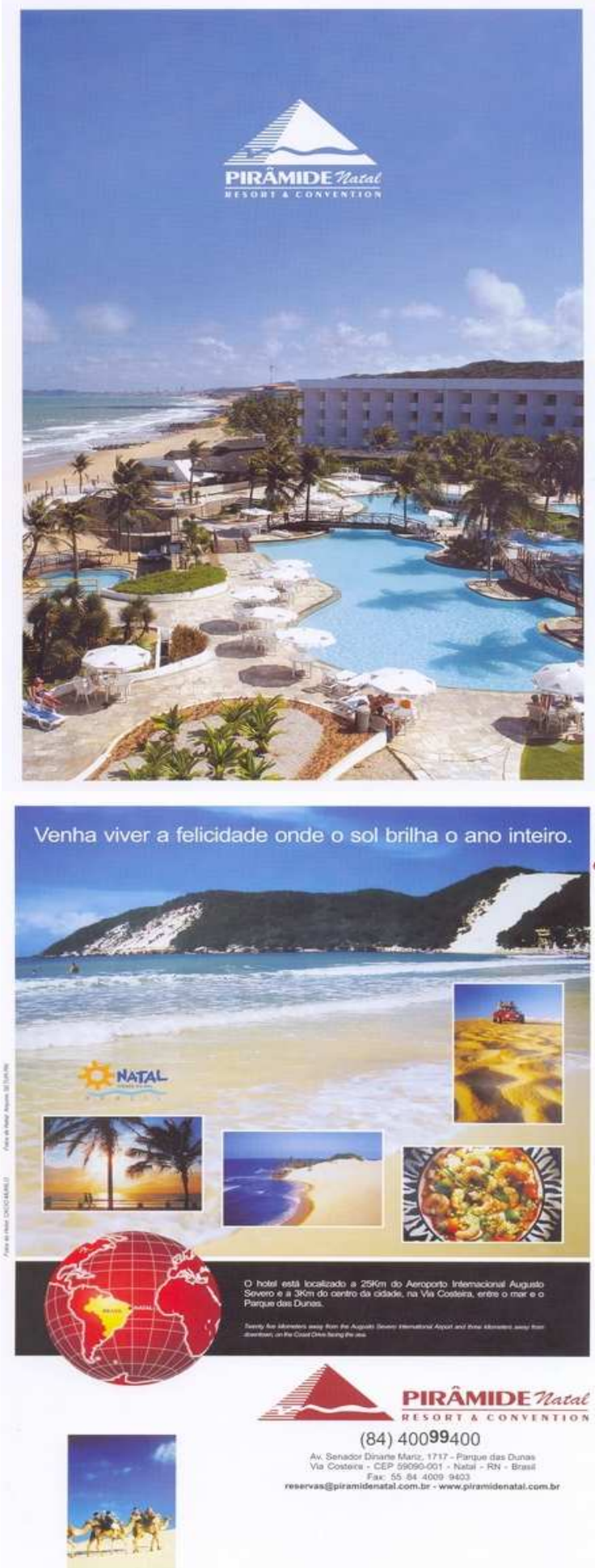

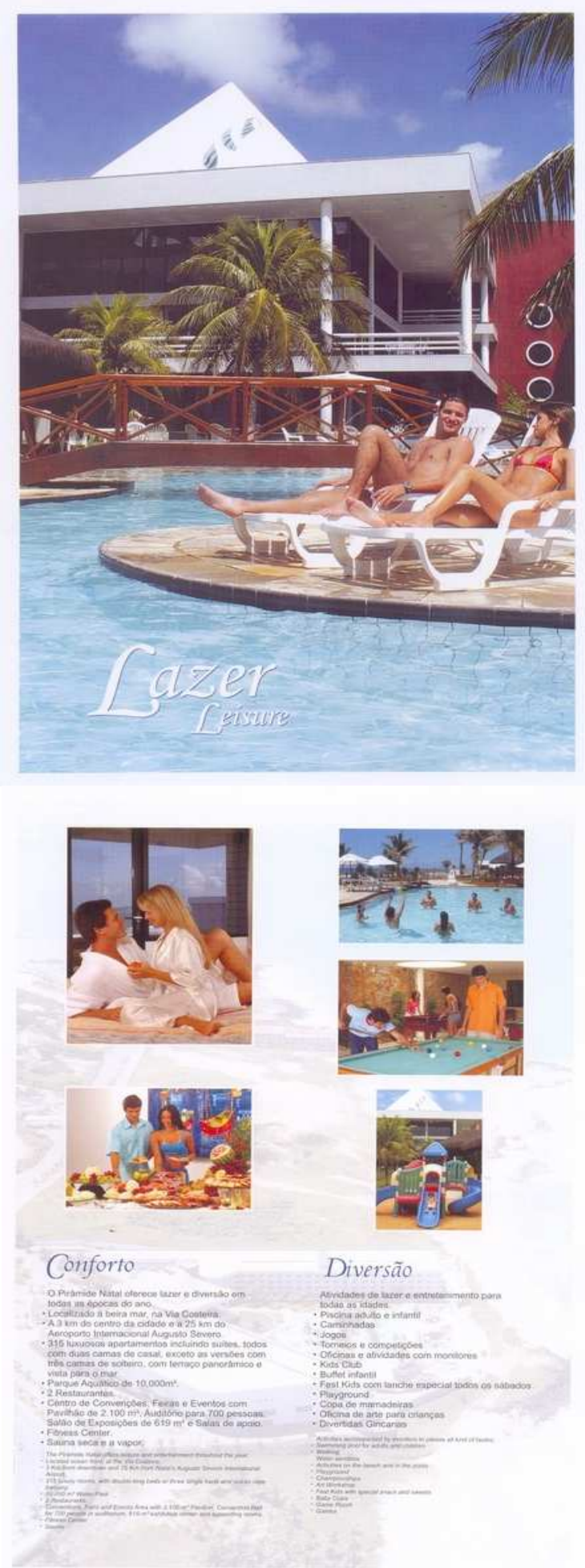

Texto 57

Otro punto importante para el éxito de un texto persuasivo es la previsibilidad. Como afirma el propio Santiago Guervós (2005:38) "lo previsible es familiar y a lo familiar se le otorga confianza, por tanto, vende. [...] lo conocido es fiable. Ante lo desconocido, cuando menos, hay que ser precavido. De ahí que las empresas se gasten ingentes cantidades de dinero en dar a conocer su producto". 
El texto 57 está formado por un $80 \%$ de imagen frente a un $20 \%$ de lenguaje verbal, con lo cual, el estímulo visual y, por lo tanto, sentimental, predomina frente a lo verbal y lo razonable. En este anuncio el Hotel Pirâmide se beneficia por ser una marca de hotel muy conocida en Natal, eso aporta confianza en la marca, como hemos visto anteriormente.

Desde un punto de vista formal, el texto en cuestión sigue el formato propio del texto publicitario. En su macroestructura figura la descripción de las instalaciones internas y externas del "Pirámide", sus contactos, su localización y los puntos de interés turísticos más cercanos de ese hotel. La progresión temática del texto puede ser definida como una progresión de tema constante.

El componente verbal expandido de ese anuncio publicitario afirma: Pirámide Natal. Resort y Convention. Ven a vivir la felicidad donde el sol brilla todo el año. Ocio. Confort y diversión. De modo que las personas del discurso presentes son la tercera persona del singular, que corresponde al objeto anunciado, tratado de un modo impersonal. Además se usa la segunda persona del singular "tú" para dirigirse al interlocutor de forma cercana, es decir, se adopta una estrategia de comunicación que aporta proximidad entre el emisor y el destinatario.

A partir del texto publicitario presentado anteriormente se produce un acto de habla propio de la comunicación publicitaria, cuyo acto locutivo consiste en el discurso constituido por el lenguaje verbal escrito y el lenguaje visual; la fuerza ilocutiva en la descripción del producto turístico ofertado y su ubicación; y el efecto perlocutivo en la estrategia de persuasión publicitaria que tiene como finalidad recibir del interlocutor la confirmación en forma de un acto de compra. En la textura discursiva están presentes los elementos deícticos y el mantenimiento del referente se da por procedimiento léxicos y gramaticales. Es importante resaltar en este anuncio el uso de una selección léxica positiva formada por sintagmas como: felicidad, ocio, confort y diversión, que sirve para reforzar el carácter persuasivo del texto.

El producto visual del texto 57 consiste en la propia imagen de las instalaciones internas y externas del hotel anunciado, su logomarca y la imagen de las personas que supuestamente se hospedan en este resort. El mensaje manifiesto de estas imágenes 
consiste en el propio anuncio descriptivo del producto anunciado y sus cualidades. El mensaje latente connota un lugar de personas de éxito, felices, disfrutando del ocio de forma confortable y divertida, en un ambiente muy elegante que también recibe esas mismas características.

\section{El poder persuasivo de la publicidad}

Con respecto a la publicidad, sus objetivos de persuasión transforman rasgos lingüísticos no convencionales en elementos naturales, como afirma Lomas (1996) [apud Calsamiglia \& Tusón (2002:209)] cuando dice que en publicidad la hipérbole con la que se tratan a los productos anunciados se vuelve en algo común mediante los objetivos persuasivos de los anuncios "y también en este caso, existen - desde no hace mucho y no en todas partes - legislaciones (diferentes según el país) que regulan hasta dónde se puede llegar en la publicidad".

La marca Tulip Inn es una marca consagrada internacionalmente, lo que ya atribuye prestigio y confianza al contenido del texto 58, expuesto a continuación, que desde un punto de vista formal, sigue el formato propio del texto publicitario. En su macroestructura figura la descripción del “Tulip Inn Potengi Flat”, su estructura externa e interna, además de sus servicios. La progresión temática de este texto puede ser definida como de progresión de tema constante.

El componente expandido del anuncio en cuestión dice que Tulip Inn Potengi Flat. Natal Rio Grande do Norte. Facilidades. El emprendimiento ofrece 3 salas de reuniones con toda infraestructura necesaria para la realización de eventos y capacidad para acomodar hasta 60 personas en el auditorio. Servicios. El Tulip Inn Potengi Flat pone a disposición de sus huéspedes: piscinas, sauna a vapor, terraza, bar americano y restaurante. Localización. El Tulip Inn Potengi Flat está localizado en una región privilegiada, próxima a la plaza cívica, al centro y a la orla marítima. Además de la proximidad con algunos puntos turísticos, como el Forte dos Reis Magos, dispone de un acceso fácil y rápido a las dunas y al famoso encuentro de las aguas del mar con el río Potengi. 
TULIP INN

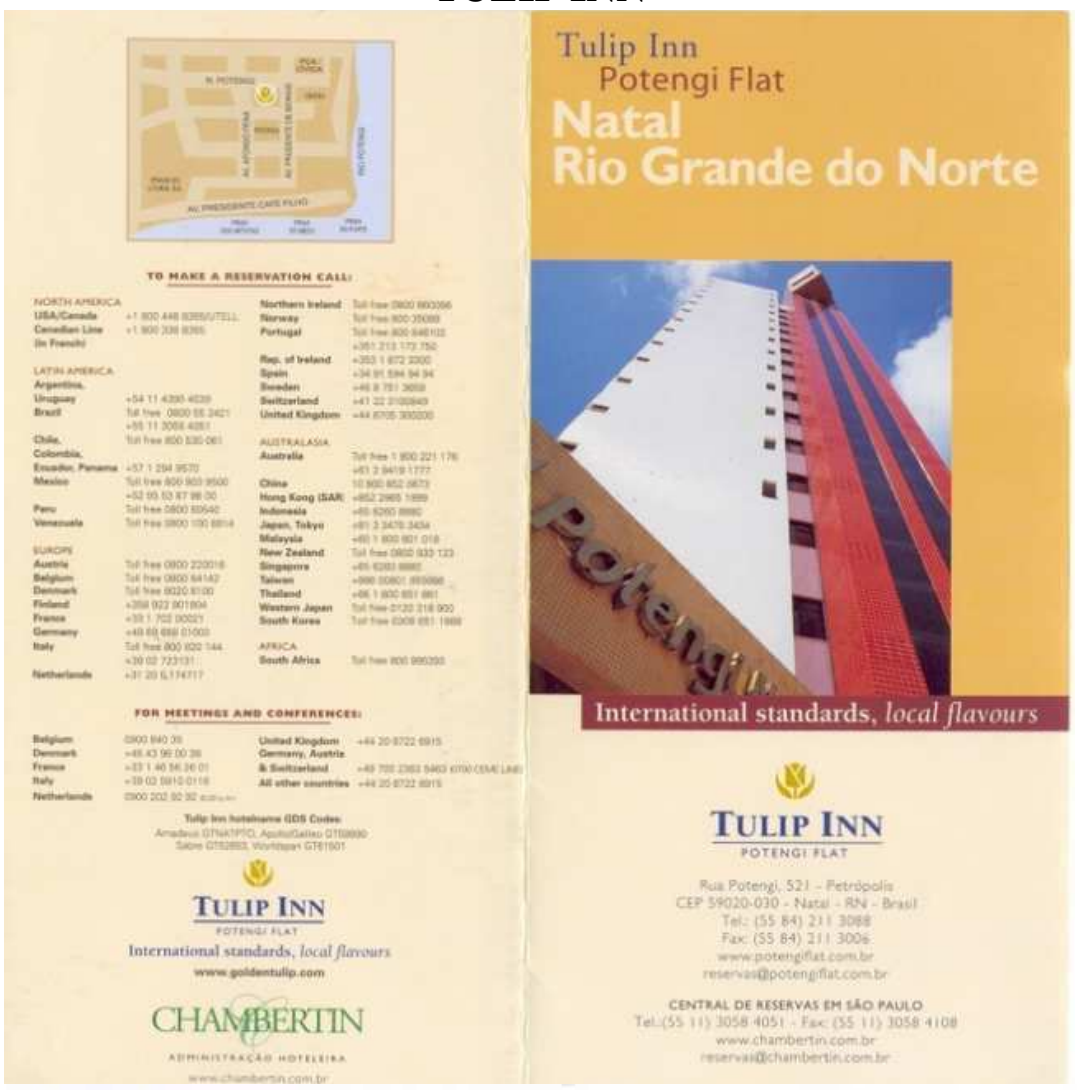

Tulip Inn

Potengi Flat

Natal

Rio Grande do Norte

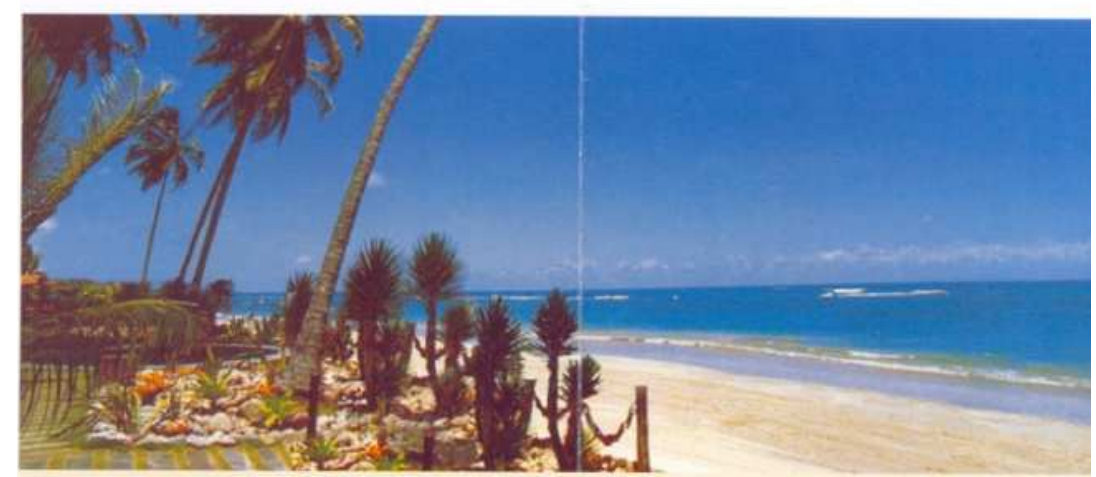

LOCALIZACÃO

O TULIP INN POTENGI FLAT està localizado em uma regiäo privilegiada, proximo a Praça

Civica, ao centro e a orla maritima. Alem da proximidade de alguns pontos turisticos.

como Forte dos Reis Magos, tem fácil e rapido acesso as dunas e ao famoso encontro das águas do mar com o Rio Potengi. 

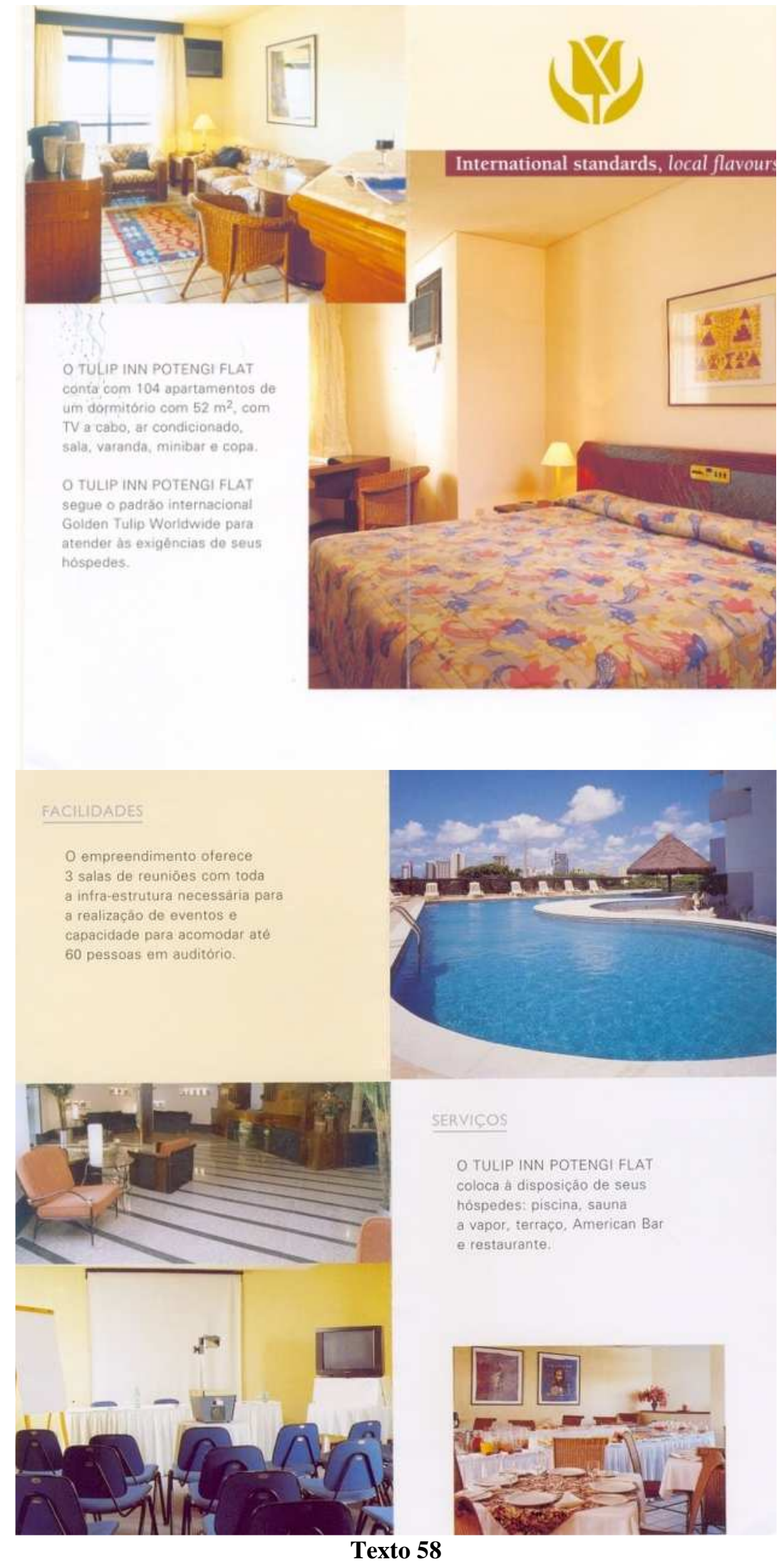

Como se puede observar, la persona del discurso presente en este texto es la inscripción de la tercera persona del singular, que remite al producto anunciado de forma 
impersonal. El acto de habla locutivo consiste en el discurso constituido por el lenguaje verbal escrito y el lenguaje visual; su fuerza ilocutiva en la descripción del producto turístico ofertado y su ubicación; y su efecto perlocutivo en la estrategia de persuasión publicitaria que tiene como finalidad recibir del interlocutor la confirmación en forma de un acto de compra.

El texto 58 pertenece al género del discurso publicitario y desde un punto de vista de la tipología textual posee una secuencia dominante de texto argumentativo, ya que la descripción funciona más bien como un recurso persuasivo. En la textura discursiva están presentes los elementos deícticos y el mantenimiento del referente se da por procedimiento léxicos y gramaticales.

El producto visual consiste en la imagen descriptiva de los ambientes externos e internos del "Tulip Inn Potengi Flat", además de sus vistas del mar. El mensaje manifiesto corresponde al propio anuncio de los servicios ofertados por ese hotel y el mensaje latente connota la modernidad, la elegancia, la tranquilidad, el confort y lo relajado de su ambiente.

Esta idea de excelencia del hotel anunciado está reflejada en la selección léxica de este anuncio, que contribuye positivamente en la composición de un texto persuasivo, por eso está fraguada por medio de sintagmas como: facilidades, emprendimiento, toda infraestructura necesaria, eventos, capacidad, acomodar, servicios, disposición, huéspedes, piscinas, sauna a vapor, terraza, bar americano, restaurante, localización, región privilegiada, próxima, centro, orla marítima, proximidad, puntos turísticos, dispone, acceso fácil y rápido, famoso, encuentro, aguas, mar y río.

¿Por qué el texto presentado anteriormente persuade? Es un texto de fácil decodificación, está elaborado por medio de una mezcla entre imagen y texto, posee una selección léxica positiva, se preocupa por su interlocutor, acota las distancias entre emisor y receptor, además actúa directamente en los sentimientos de su audiencia. 


\section{TAVERNA PUB}

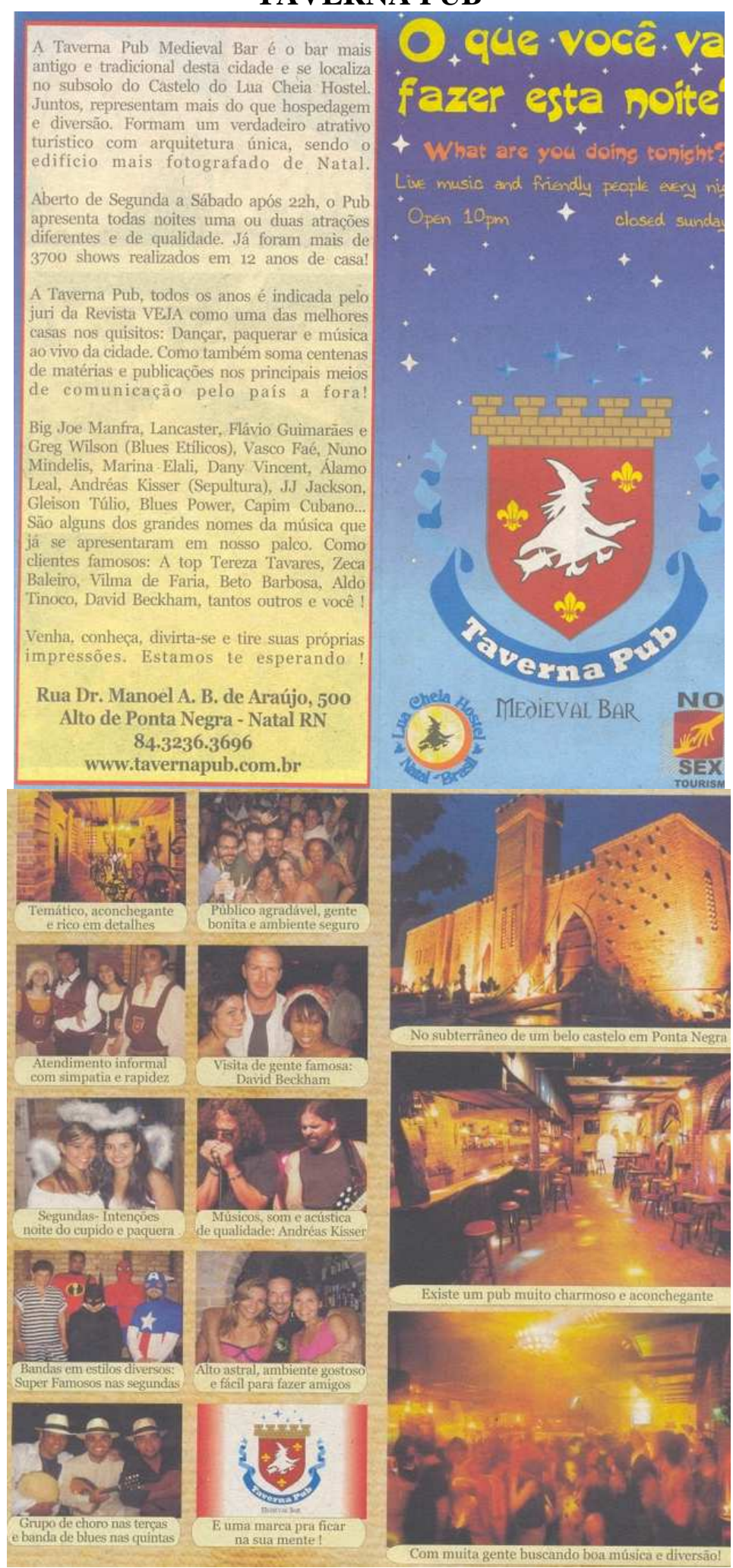

Texto 59

El texto publicitario que vemos arriba se titula Taverna Pub. Presenta este bar de copas como producto turístico. El anuncio en cuestión está fraguado por medio de una estrategia persuasiva de autoridad de los personajes prototípicos del anuncio, por eso 
cuenta con la presencia de mucha gente famosa como personajes prototípicos, entre los que se destaca la imagen de David Beckham, como una de las personas que frecuenta a este bar, lo que otorga familiaridad y confianza al local, luego persuade.

En su macroestructura figura la descripción del "Taverna Pub Medieval Bar", sus atracciones y servicios. Su progresión temática puede ser definida como de progresión de tema constante. Las personas del discurso presentes son la tercera persona del singular y la inscripción del "você", en portugués de Brasil, que tiene la fuerza semántica del "tú" en español, aproximando los interlocutores del acto de habla publicitario.

Su componente expandido empieza con una pregunta retórica ¿Qué vas a hacer hoy por la noche? Y en seguida viene una contestación en forma de sugerencia: Taverna Pub Medieval Bar. Para convencer al interlocutor de que hoy por la noche vaya al Taverna Pub, el texto sigue de forma elogiosa y afirma: temático, acogedor y rico en detalles; público agradable, gente guapa y ambiente seguro; servicio informal con simpatía y rapidez; visita de gente famosa: David Beckham; segundas intenciones: noche del Cupido y de ligue; músicos y acústica de calidad; grupos musicales de estilo diversos; alegría, buen ambiente y fácil de conocer amigos; concierto de choro en los martes y Blues en los jueves; ;Taverna Pub Medieval Bar es una marca para quedar en tu mente!

Como se puede inferir, el acto de habla locutivo producido por el texto publicitario en cuestión consiste en el discurso constituido por el lenguaje verbal escrito y el lenguaje visual; su fuerza ilocutiva en la descripción del producto turístico ofertado y su ubicación; y su efecto perlocutivo en la estrategia de persuasión publicitaria que tiene como finalidad recibir del interlocutor la confirmación en forma de un acto de compra.

Ese anuncio publicitario también hace uso de una estructura textual de narrativa literaria como elemento persuasivo cuando presenta en la tercera página del folleto publicitario en cuestión parte de su componente expandido que dice: en el subterráneo de un bello castillo en Ponta Negra, hay un pub muy bonito y acogedor, con mucha gente en búsqueda de buena música y diversión. 
El anuncio en cuestión pertenece al género del discurso publicitario y, desde un punto de vista de la tipología textual, posee una secuencia dominante argumentativa, ya que la descripción funciona más bien como un recurso persuasivo. En la textura discursiva están presentes los elementos deícticos y el mantenimiento del referente se da por procedimiento léxicos y gramaticales. El producto visual consiste en la propia imagen del "Taverna Pub Medieval Bar" en su ambiente de fiesta externo e interno. Usa la autoridad de la imagen, como el caso de David Beckham, para aumentar el prestigio del bar frente a sus clientes. El mensaje manifiesto es el propio anuncio de este producto turístico, ya el mensaje latente connota un lugar muy animado, con muy buen ambiente con mucho nivel, con gente guapa, feliz y famosa.

Por último, en la última página de este anuncio se afirma que el Taverna Pub Medieval Bar es el bar más antiguo y tradicional de esta ciudad y está ubicado en el subsuelo del Castelo do Lua Cheia Hostel. [...]. Ven, conoce, pásatelo bien y saca tus propias impresiones. Te estamos esperando. Con lo cual, no queda duda de que estamos frente a un texto persuasivo que fue artísticamente elaborado y que está dirigido más a la emoción que a la razón de su público objeto.

También merece destacarse la selección léxica del texto en cuestión que hace uso de un léxico positivo en el que figuran sintagmas como: noche, temático, acogedor, rico, detalles, público agradable, gente guapa, ambiente seguro, servicio informal, simpatía, rapidez, visita, gente famosa, segundas intenciones, noche, Cupido, ligue, músicos, acústica, calidad, estilos diversos, alegría, buen ambiente, fácil, conocer, amigos, concierto, marca, quedar, mente, bello, castillo, hay, pub, muy bonito, acogedor, mucha gente, búsqueda, buena música, diversión, bar, más antiguo, tradicional, ciudad, conoce, pásatelo bien, saca, propias y esperando. 
La persuasión también tiene como cómplices al principio de la economía cognitiva, al argumento de la escasez, a la sumisión, al concepto de autoridad, a la autoridad del orador y a la autoridad del canal, con eso logra sus objetivos de difundir principios que, luego, serán adoptados por la sociedad. Por algunas razones lógicas, los medios de comunicación social difunden ideologías y comportamientos a la sociedad, que los asimila con su carga de valores, como muy bien apunta Santiago Guervós (2005:49):

\begin{abstract}
En la actualidad, los acuerdos sociales nos llegan no ya desde la comunicación directa y personal sino a través de los medios de comunicación. Los medios de comunicación transmiten unos clichés ideológicos que asumimos sin pestañear; la personalidad deseada, la imagen que deseamos transmitir, el comportamiento socialmente correcto, lo admirable, lo respetable. Hay una razón por la cual los modelos de los medios de comunicación resultan persuasivos: sirven de pista para determinar que una determinada conducta es legítima y apropiada.
\end{abstract}

El dominio que la comunicación ejerce sobre las personas está tan fosilizado en la sociedad contemporánea que muchas veces, como afirma este mismo autor, "los medios de comunicación de masas puede que no consigan decir a la gente qué pensar, pero como decíamos, tienen un éxito extraordinario a la hora de decir a sus oyentes y espectadores sobre qué tienen que pensar" (Santiago Guervós, 2005:50).

Otras cuestiones que están a favor de un texto persuasivo son la autoridad del contexto y la autoridad del código:

El hombre se somete a la autoridad: por una parte, esta sumisión forma parte de sus genes, es una tendencia natural ante lo que desconoce o ante lo que supone en un estrato jerárquico mayor. Y está (sic) sumisión genética, natural, esta idea innata, se ve acompañada por aquellas ideas que introduce la socialización del ser humano, aquello que culturalmente entiende como jerárquicamente superior $\mathrm{y}$, por ende, autorizado. Lo más importante, sin embargo, es comprobar como (sic) la respuesta ante esos estímulos genéticos y culturales es siempre emocional. En la comunicación persuasiva se apela, fundamentalmente, a las emociones. [...] los persuasores conocen la respuesta a esos estímulos, luego tienen el poder de persuadir (Santiago Guervós, 2005:52). 
Volviendo al ejemplo del texto 59, como hemos destacado anteriormente, se usa la sumisión a la autoridad cuando se expone que entre los que van a la Taberna Pub por la noche está David Beckham, eso otorga prestigio al ambiente anunciado, ya que uno de los grandes futbolistas de los últimos años frecuenta el lugar anunciado. De ese modo, el interlocutor puede pensar que el nivel del sitio es muy alto por la presencia de este jugador de fútbol de fama internacional en las fotos del bar anunciado. Además, el interlocutor se sentirá semejante a David Beckham por el hecho de frecuentar el mismo bar de copas.

\section{Aspectos sociales de la comunicación persuasiva}

También es importante destacar las ideas sociales y la socialización como interferencia. De hecho, muchas actitudes del hombre están condicionadas por cuestiones puramente sociales o son adoptadas bajo una presión de la sociedad. Y "sólo la conjugación correcta de ideas innatas y sociales permite la comunicación fluida y la previsibilidad de las respuestas" (Santiago Guervós, 2005:58).

A continuación presentamos el texto 60 por medio del que se muestra un prototipo socialmente difundido de una surfista, es decir, una chica guapa, joven, en muy buena forma física, rubia y con algunos tatuajes, además de tener la piel dorada por el sol. Este prototipo está condicionado a cuestiones sociales, como hemos visto anteriormente.

El contenido expandido del anuncio en cuestión está compuesto por el enunciado que afirma: School Surf. Clases individuales o en grupo de surf. Las clases incluyen la tabla y la ropa. Profesor de educación física. Presenta este folleto y gana completamente gratis un refresco. En ningún punto del texto se afirma: apúntate a clases de surf, sino lo sugiere y el interlocutor por medio de sus conocimientos enciclopédicos e inferencias compone el mensaje persuasivo del anuncio en cuestión. 
SCHOOL SURF

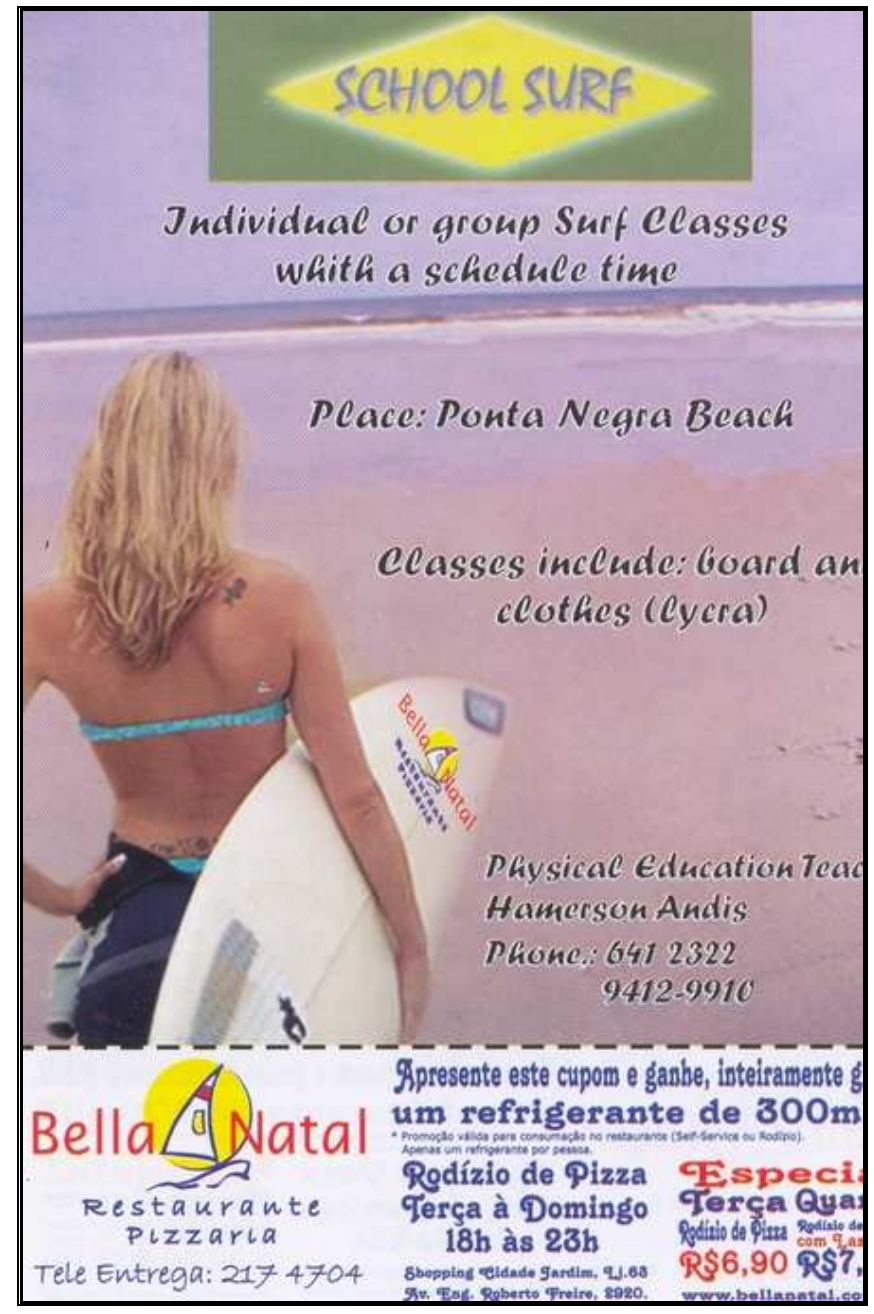

Texto 60

Desde un punto de vista formal, el texto 60 sigue el formato propio de un folleto publicitario para el turismo. En su macroestructura figura la descripción de la "School Surf”, la presentación de su localización y las formas de contactos. La progresión temática de este texto puede ser definida como una progresión de tema constante.

La persona del discurso presente es la inscripción del "você", en portugués de Brasil, que tiene la fuerza semántica del "tú" en español, presentando así un carácter de proximidad entre el emisor y el destinatario. El acto de habla locutivo consiste en el discurso constituido por el lenguaje verbal escrito y el lenguaje visual; su fuerza ilocutiva en la descripción del producto turístico ofertado y su ubicación; y su efecto perlocutivo en la estrategia de persuasión publicitaria que tiene como finalidad recibir del interlocutor la confirmación en forma de un acto de compra. 
En la selección léxica de nuestro anuncio 60 figuran sintagmas positivos como: escuela de surf, surf, clases, individuales, grupo, incluyen, tabla, ropa, profesor de educación física, presenta, folleto, gana, completamente gratis y refresco. El producto visual consiste en la propia imagen del logotipo de la "School Surf" y de una chica en frente al mar con una tabla para surfear. El mensaje manifiesto es el propio anuncio del producto turístico y el mensaje latente la idea de lo relajado, lo joven y el estilo de vida alternativo de este tipo de deporte.

Los estereotipos sociales, como hemos visto en este anuncio, tienen un papel preponderante en el contexto de la publicidad. Para Santiago Guervós, (2005:60) "en la comunicación persuasiva hemos de estimular las ideas innatas partiendo del conocimiento del entorno social en el que nos movemos, lo cual implica conocer, por una parte, las costumbres y, por otra, aquellos argumentos que la sociedad acepta como propios".

Así, sabemos que el modelo de familia feliz en la sociedad contemporánea refleja una familia formada por un máximo de 4 personas, sanas, en muy buena forma física, guapas, sonrientes y que pueden disfrutar de momentos de ocio como un momento familiar. Esta idea puede ser encontrada en muchos anuncios de la publicidad turística. Claro que en un anuncio como este se reflejan personas que forman parte de un determinado grupo social y se vende la idea de que para que una familia sea feliz tiene que corresponder a ese modelo familiar patrón, lo que muchas veces no se corresponde con la realidad, pero funciona como un argumento publicitario en la venta de un determinado producto o servicio, sobre todo, en la industria del turismo.

$\mathrm{Al}$ observar el texto 61, el receptor puede sentir las ganas de embarcar en un crucero con su familia, pues este es el mensaje que va dirigido a lo emocional. Además, el texto se completa con el argumento de la excelencia y singularidad de la marca de crucero CVC cuando dice: "Líder del mercado en Brasil, la CVC cruceros ofrece una gran variedad de rutas, estilos y tarifas. Y la oportunidad de conocer cosas que nunca imaginaste". A partir del contenido expandido de ese anuncio, se lleva a cabo el argumento de la cantidad, por ejemplo, cuando dice: La CVC cruceros ofrece una gran variedad de rutas, estilos y tarifas, lo que aumenta su patrón de calidad. 


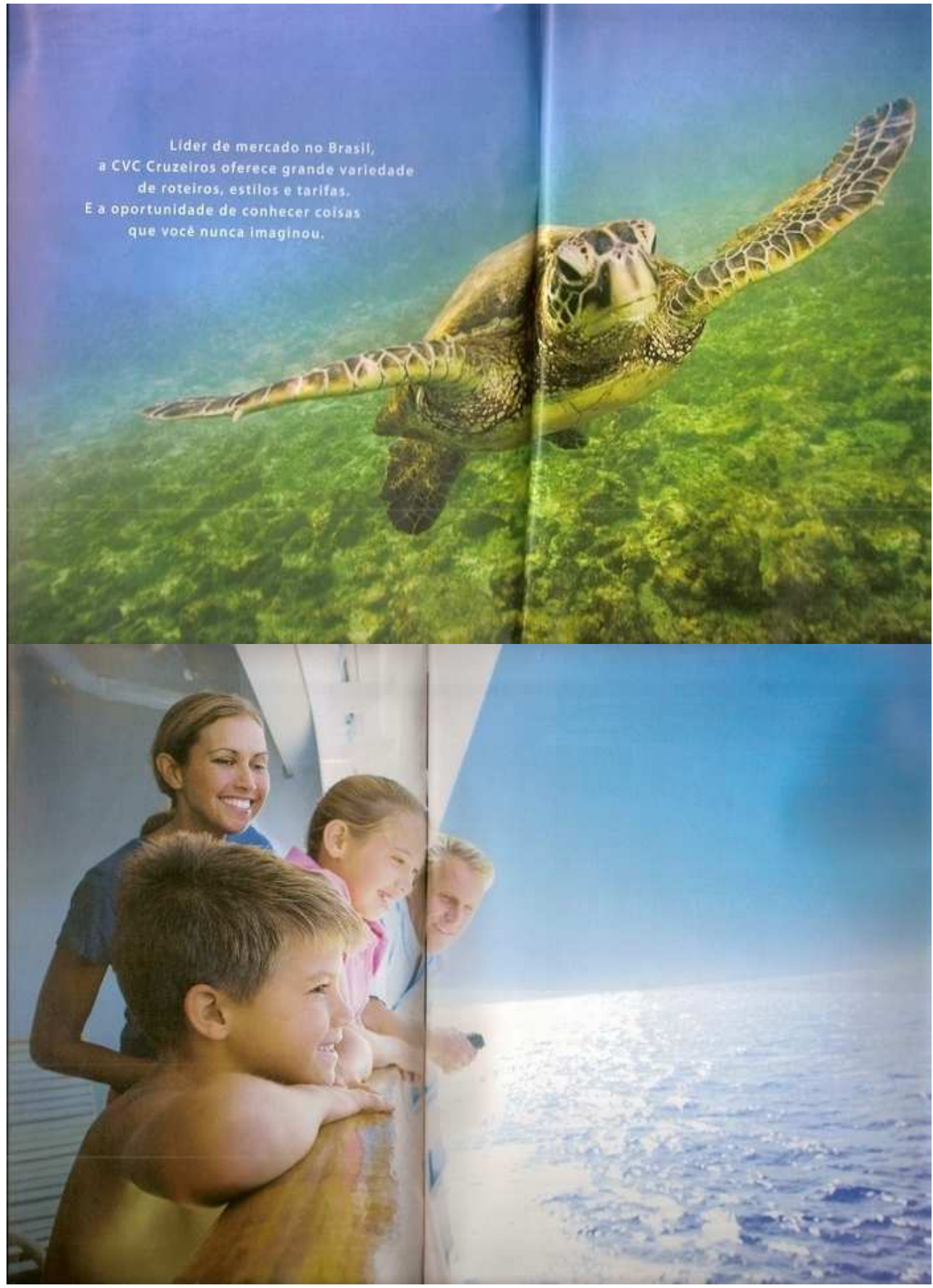

Texto 61

Para Santiago Guervós (2005:75) "en la publicidad contemporánea tiene más peso lo persuasivo que lo informativo, la sugestión emocional que el raciocinio". Por eso no es difícil encontrar argumentos publicitarios en los cuales figuren temas de carácter social o lingüístico y que requieran una respuesta emotiva. También es "muy empleada [...] la interrogación retórica con una intención polémica", como ya hemos visto en anuncios comentados anteriormente. En el anuncio presentado arriba se sugiere más de lo que se 
afirma, dado que hay un predominio de la imagen por medio de la cual el interlocutor interpreta el mensaje que es simplemente sugerido.

\section{El texto persuasivo}

La creación de una imagen positiva a partir de un texto que sigue una estructura simple o de fácil comprensión, acompañada por un leguaje con esas mismas características, además de positivo también otorga un carácter persuasivo al texto publicitario. Eso es lo que dice Santiago Guervós (2008:23) cuando menciona que "el texto añade fiabilidad, innovación, educación, comunicación, rapidez, evolucionar: todos ellos términos positivos en cualquier contexto de comunicación, para anunciar cualquier cosa".

El texto 62 anuncia las clases de baile y, para eso, afirma que iquién baila es más feliz! cambia de vida. ¡Aprende a bailar en tres días! Forró, samba, salsa y otros ritmos. Es súper fácil. Profesor de baile Luiz. Esto implica que no se vende solamente las clases de baile, sino también felicidad y un cambio de vida.

La selección léxica en un anuncio suele ser fundamental para su éxito, ya que como hemos visto, el léxico de la publicidad es hedonista y palabras como: modernidad, libertad, estilo y bello corresponden a la idea de perfección transmitida por la publicidad. En el caso del texto 62 se usan sintagmas como: baile, más feliz, vida, aprende, bailar, fácil, es decir, un léxico positivo que refuerza lo elogioso del discurso publicitario.

Es difícil trazar un perfil único y exacto de un texto persuasivo, pero lo cierto es que "el texto persuasivo consiste en un tipo textual que se dirige a la emoción más que a la razón" (Santiago Guervós, 2008:24). Y no cabe duda de que la persona que elabora un texto persuasivo conoce y domina el uso del lenguaje al máximo grado y por medio del lenguaje (verbal y no verbal) logra estimular al hombre y, además, convencerlo para producir la respuesta esperada: la adquisición del producto anunciado. Eso es lo que podemos vislumbrar en el texto 62 a continuación. 
LUIZ FORRÓ

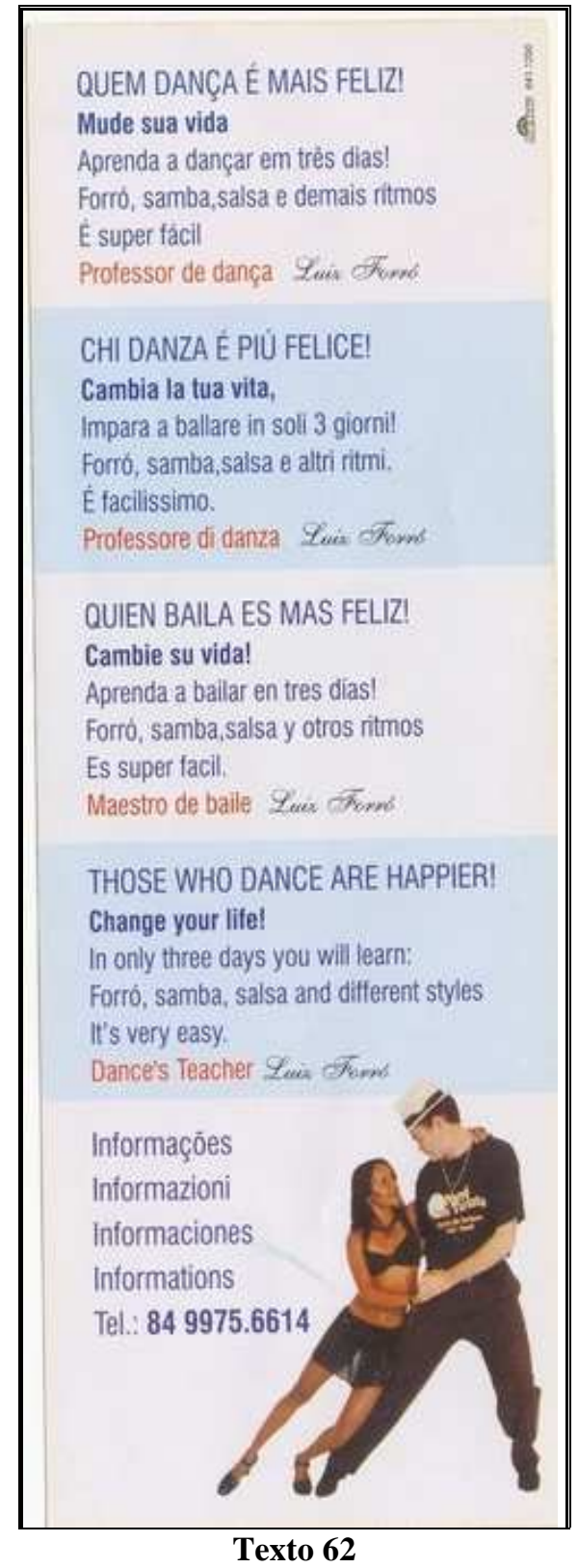

Desde un punto de vista formal, este texto sigue el formato propio del texto publicitario. En su macroestructura figura la oferta del producto anunciado, es decir, clases de baile. Además de los motivos por los que uno debe hacer este tipo de clase. La progresión temática de este texto puede ser definida como de progresión de tema constante. La persona del discurso presente es la inscripción del "você", en portugués de Brasil, que tiene la fuerza semántica del "tú” en español, presentando así un carácter de proximidad entre el emisor y el destinatario. 
Todo eso contextualizado en el ambiente de una ciudad turística en el nordeste de Brasil, donde el "forró" es un baile típico. El acto de habla locutivo consiste en el discurso constituido por el lenguaje verbal escrito y el lenguaje visual; su fuerza ilocutiva en la descripción del producto turístico ofertado y su ubicación; y el efecto perlocutivo en la estrategia de persuasión publicitaria que tiene como finalidad recibir del interlocutor la confirmación en forma de un acto de consumo del servicio anunciado, o sea, apuntarse a tomar esas clases de baile.

El producto visual consiste en la imagen de una pareja bailando, cuyo aspecto de las vestimentas corresponden al estilo de vestirse artísticamente en sitios para este tipo de baile. El mensaje manifiesto de este anuncio consiste en la oferta de las clases de baile y de las ventajas de frecuentar esas clases. Ya el mensaje latente consiste en la forma física, la jovialidad, sensualidad y el buen humor de los que bailan.

\section{Elementos de persuasión}

Martina Eva Fischer (2007) hace una explicación crítica sobre la persuasión en la acepción clásica y analiza la idea de persuasión que está asociada a la subordinación latente, como una vertiente que sale de lo razonable. No obstante, independientemente de la persuasión que se emplea de forma inconveniente o no, ese proceso tiene que ser llevado a cabo en una comunicación compartida o comprendida. "La persuasión es inherente a la actividad comunicativa humana, se configura como proceso de influencia deflagrado por personas u organizaciones a partir de una intencionalidad relacionada muchas veces al cambio (Fischer, 2007:7). ${ }^{58}$

\footnotetext{
${ }^{58}$ En la fuente origianal: "A persuasão é inerente à atividade comunicativa humana, configurando-se como processo de influência deflagrado por pessoas ou organizações a partir de uma intencionalidade relacionada muitas vezes à modificação".
} 
SHERATON BARRA HOTEL Y SUITES

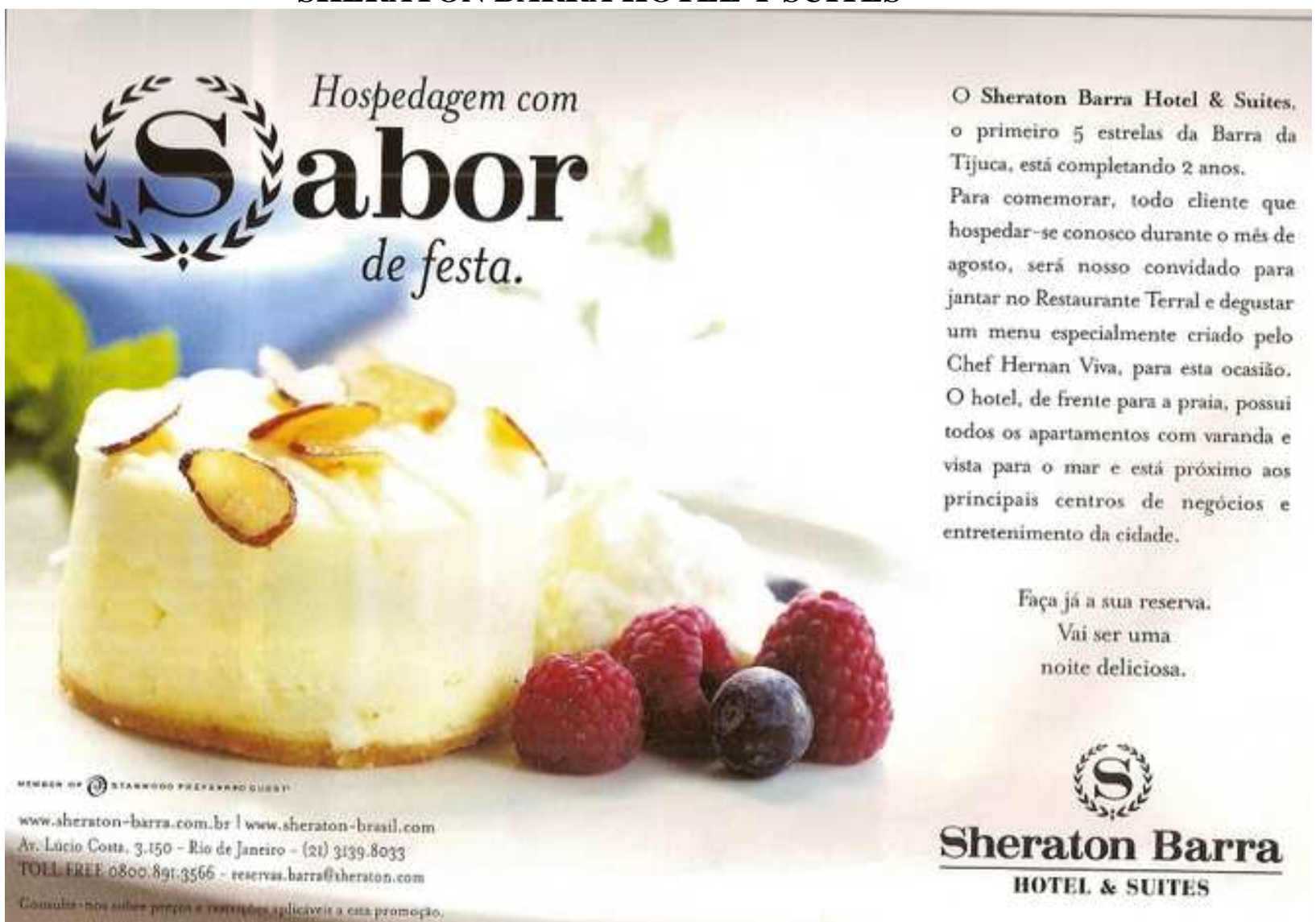

Texto 63

Parece ser una paradoja y un modo inusitado de anunciar un hotel por medio de la imagen de un postre, pero justo por el motivo de la sorpresa, lo inusitado y para despertar el sentido de la degustación, el texto 63 llama la atención, intriga y sorprende a su receptor. La "s" que forma parte del logotipo del Sheraton Barra Hotel \& Suites forma parte de la palabra "sabor" por medio de un juego gráfico.

El poder de persuasión del mensaje reside en el argumento de excelencia y singularidad de este hotel de cinco estrellas localizado en la Barra da Tijuca, una de las zonas más prestigiosas del Río de Janeiro, en Brasil. El anuncio está pensado para quien conoce este dato y la cadena de hoteles Sheraton. Además de eso, también se trabaja en el texto 63 el argumento del regalo y el hecho de disfrutar algunos beneficios como recompensa por la elección del producto anunciado.

La persuasión es una técnica que se propagó paralelamente a la actividad de la comunicación social. Especialmente en el medio publicitario, donde pasó a ser 
comprendida como una forma autoritaria, pero siempre presentándose de manera implícita, influyendo el cambio de actitud del consumidor. Específicamente, en la publicidad televisiva, Eva Martina Fischer (2007) afirma que la persuasión no es un imperativo definitivo, por causa de la rapidez con la que los telespectadores cambian de canal.

En el anuncio en cuestión, el interlocutor no necesita hacer un gran esfuerzo cognitivo para decodificar el mensaje publicitario, ya que la unión del texto con la imagen facilita el proceso de lectura. Un lector común mira este texto por vez primera y lo asocia a comida, que por cierto, parecer ser un postre muy rico, y por eso llama la atención del interlocutor.

Así, la curiosidad por saber más sobre ese postre induce al interlocutor a la curiosidad por saber más sobre lo que ve. De ese modo, empieza a leer: hospedaje con sabor de fiesta. El Sheraton Barra Hotel y Suites, el primer 5 estrellas de la Barra da Tijuca, está cumpliendo 2 años. Para celebrarlo, todos los clientes que se hospeden con nosotros durante el mes de agosto serán nuestros invitados para cenar en el Restaurante Terral y degustar un menú especialmente creado por el chef Hernan Viva, para esta ocasión. El hotel, enfrente de la playa, posee todos los apartamentos con balcón y vista al mar y está cerca de los principales centros de negocios y ocio de la ciudad. Haz tu reserva. Va a ser una noche sabrosa.

Si el interlocutor está predispuesto a hospedarse en un hotel en Río de Janeiro, el anuncio le hace tener la seguridad de cuál es el mejor hotel para hospedarse, porque además de seguro, confortable, nuevo y moderno, también le hace sentirse importante por poder participar del segundo cumpleaños de ese hotel, además de estar invitado a una cena con un menú especialmente elaborado para la ocasión. 
GAMELEIRA REGIONAL
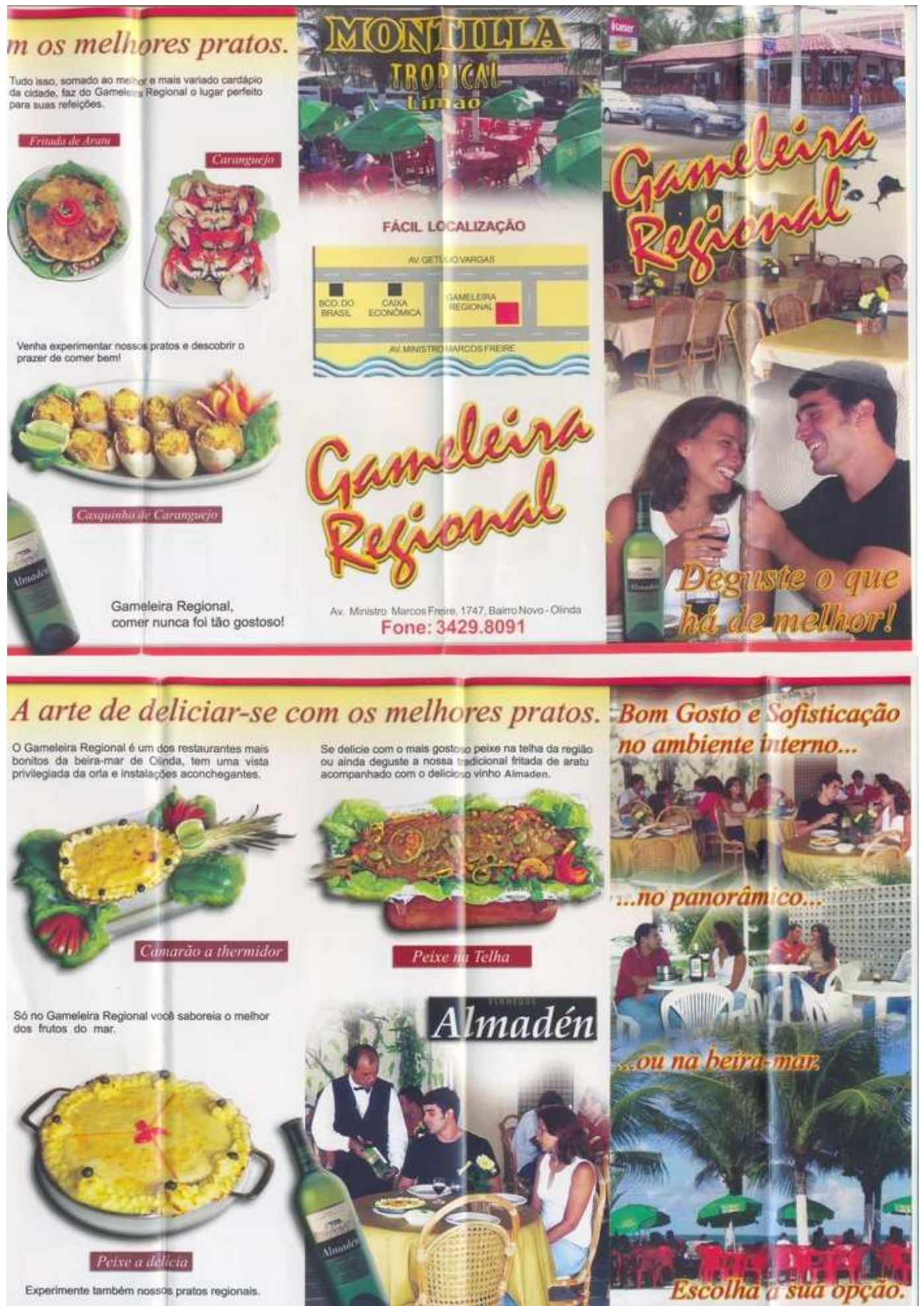

Texto 64

A partir de aquí, surge la idea de que para efectuar la persuasión se establece una relación directa con el campo de las emociones. No obstante, ese puede ser solamente uno de los artificios de esa técnica, pero no el único. De modo bastante sutil y de forma enmascarada, la persuasión, además de convencer, intenta hacer que el público adquiera 
determinadas actitudes, no solamente explotando los aspectos de las apelaciones emotivas. Así, al contrario que la argumentación, la persuasión no puede ser trabajada como una secuencia razonable, sino como una secuencia dirigida hacia las emociones del interlocutor.

Por eso, en un texto persuasivo por excelencia, como es el caso del texto publicitario, la sugerencia elogiosa se hace fundamental, sobre todo, de la parte visual del texto. El texto 64 consiste en el anuncio de Gameleira Regional y se usa el argumento de la excelencia del producto anunciado. Añadido a este argumento, se difunde la idea inconsciente de que las personas que frecuentan ese restaurante son felices. Basta mirar la foto de la pareja que protagoniza el anuncio para percibir esa idea connotada en su imagen.

Desde un punto de vista formal, este texto sigue el formato propio del texto publicitario. En su macroestructura figura la descripción del restaurante "Gameleira Regional", la presentación de sus platos típicos y bebidas. Su progresión temática puede ser definida como de tema constante, como podemos ver en su componente expandido: Gameleira Regional. El arte de encantarse con los mejores platos. Buen gusto y sofisticación en el ambiente interno, en el panorámico o frente al mar. Elige tu opción. Los mejores platos.

Como se puede ver, la persona del discurso presente es la inscripción de la segunda persona del singular, lo que otorga una proximidad entre el emisor y el destinatario. El acto de habla locutivo consiste en el discurso constituido por el lenguaje verbal escrito y el lenguaje visual; la fuerza ilocutiva en la descripción del producto turístico ofertado y su ubicación; y el efecto perlocutivo en la estrategia de persuasión publicitaria que tiene como finalidad recibir del interlocutor la confirmación en forma de un acto de compra.

Desde un punto de vista de la tipología textual, este anuncio posee una secuencia dominante de texto argumentativo, ya que la descripción funciona más bien como un recurso persuasivo. En la textura discursiva están presentes los elementos deícticos y el mantenimiento del referente se da por procedimientos léxicos y gramaticales. Además de un léxico positivo fraguado por medio de sintagmas como: mejores, variado, 
perfecto, probar, descubrir, comer bien, sabroso, sofisticación, bonitos, privilegiada, acogedora, prueba y sabroso.

El producto visual consiste en la imagen de los productos, servicios e instalaciones del restaurante "Gameleira Regional". El mensaje manifiesto es la excelencia de los productos y servicios ofertados en este restaurante, que también es corroborado al mirar el eslogan "degusta lo que hay de mejor". Ya el mensaje latente es de lo bien que se pasa yendo a ese restaurante.

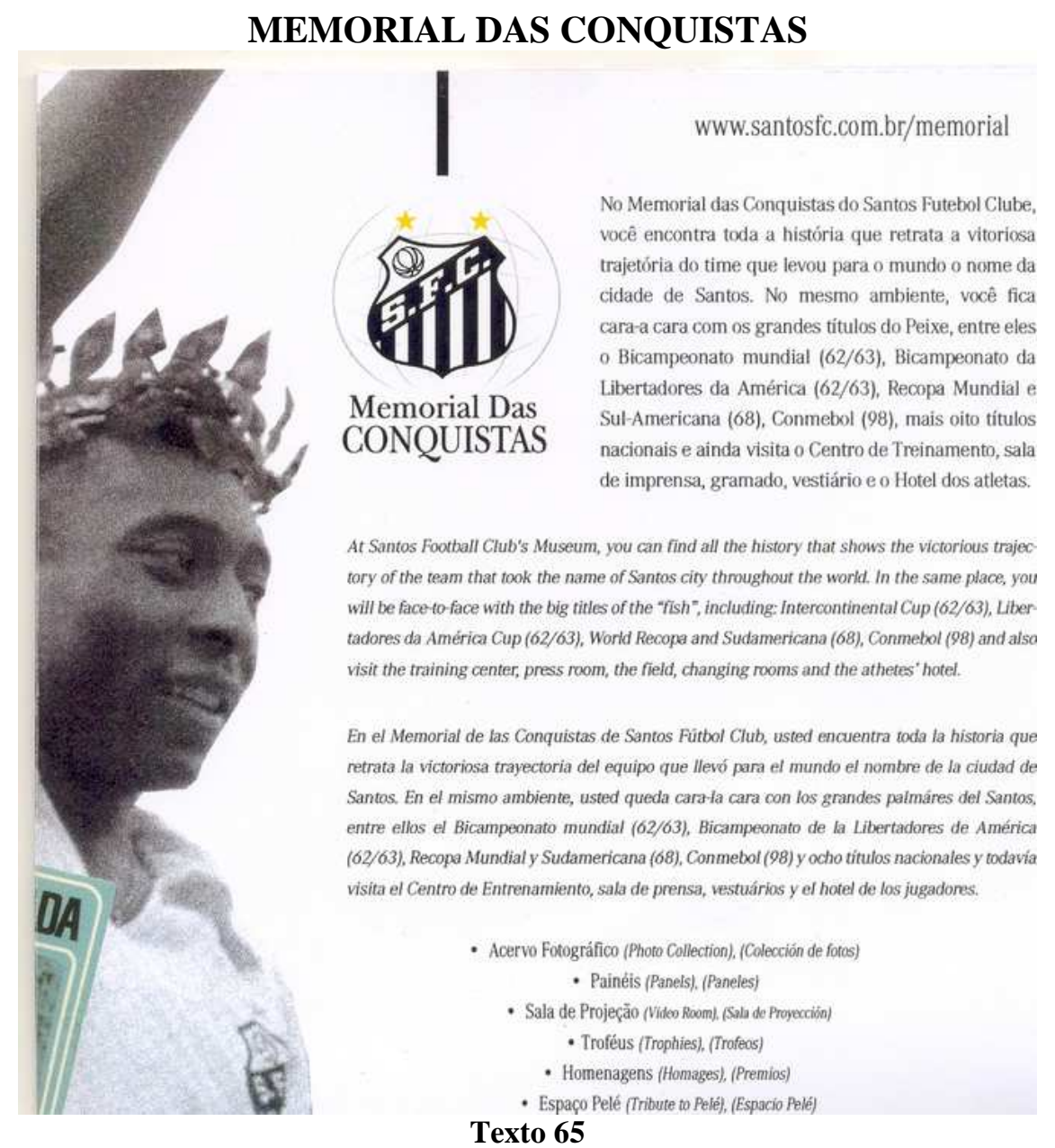

En el texto 65, que presenta el Memorial das Conquistas del Santos Futbol Club, se ha usado la imagen de Pelé, un gran ícono de fútbol internacional que fue jugador de este club deportivo. Eso realmente funciona como una estrategia persuasiva para el discurso publicitario del turismo, ya que para convencer, generalmente, la publicidad utiliza como elementos persuasivos, las figuras de especialistas, celebridades o autoridades. Una imagen ideal para dar celebridad a la publicidad o propaganda y crear una 
atmósfera de familiaridad con el receptor. "La cuestión de la autoimagen es importante en la persuasión operada por la publicidad y propaganda" (Fischer, 2007:11).

Así que, por medio de la imagen de autoridad de Pelé, se anuncia que: En el Memorial de las Conquistas Santos Fútbol Club encuentras toda la historia que retrata la victoriosa trayectoria del equipo que llevó al mundo el nombre de la ciudad de Santos. En el mismo ambiente, te quedas en frente a los grandes títulos del Pez [...], más de ocho títulos nacionales y encima visitas el Centro de Entrenamiento, sala de prensa, césped, vestuario y el hotel de los atletas.

Una vez más, la idea de catarsis se hace importante en los anuncios publicitarios porque implica al interlocutor, o sea, cuando el propio receptor del mensaje se ve representado en una publicidad o ve a un determinado héroe suyo como protagonista de un anuncio publicitario, se siente implicado y eso persuade, porque induce al interlocutor a vivir una especie de catarsis por medio del anuncio publicitario.

El uso de un vocabulario positivo contribuye a ello. Por eso, en el texto en cuestión figura una selección léxica que presenta sintagmas como: conquistas, encuentras, toda, historia, victoriosa, mundo, ambiente, quedas, en frente, grandes, títulos, más, nacionales y atletas. Es decir, un léxico favorable a la persuasión del receptor/comprador de lo que se anuncia. 
Los mensajes publicitarios pasan por procesos comunicativos que van más allá de una simple exposición textual y de hechos. Los recursos técnicos generalmente están asociados a las informaciones y mensajes que influyen exaltando las cualidades del producto. La información presenta el producto, mientras que en el ámbito de la persuasión se establece la exposición de los detalles del objeto, agregando a este un valor simbólico, puesto que el universo persuasivo de la comunicación es un tipo distinto de comunicación, como ya hemos expuesto en nuestra Teoría del Acto de Comunicación Publicitario. La diferencia más saliente en dicho acto comunicativo es que se intenta que el receptor adquiera algún producto/servicio o pase a tener otras actitudes. En este contexto:

\begin{abstract}
Es necesario destacar que todo el proceso de búsqueda de efectos casuales actúa dentro del amplio campo de la comunicación en sus distintos niveles: interpersonal, en grupos y organizaciones, de masas: que por eso puede o no ser descontextualizada de otros procesos generales de la naturaleza psicológica como intención, influencia, recepción, y retroalimentación (Demartine Gomes, 2003:108).
\end{abstract}

Los vehículos de comunicación crean estrategias para alcanzar a los receptores, con la función de provocar algún tipo de estímulo. Surge entonces una especie de pacto implícito en el que el público y el medio establecen una relación, aunque no haya consonancias de opiniones entre los dos agentes. Dicho de otro modo, es una especie de pacto entre el locutor que quiere persuadir y un interlocutor predispuesto a ser persuadido.

El texto 66 anuncia Natal como destino turístico y el Hotel Pousada América do Sol como producto turístico para ser consumido. El componente expandido de ese anuncio consiste, básicamente, en la enumeración de los servicios anunciados y de la frase de efecto si te encantan el sol y la aventura, Natal es tu destino. Claro que, para que ese texto persuada a un interlocutor, éste tiene que estar predispuesto a ser convencido como en una especie de pacto. 
HOTEL POUSADA AMÉRICA DO SOL

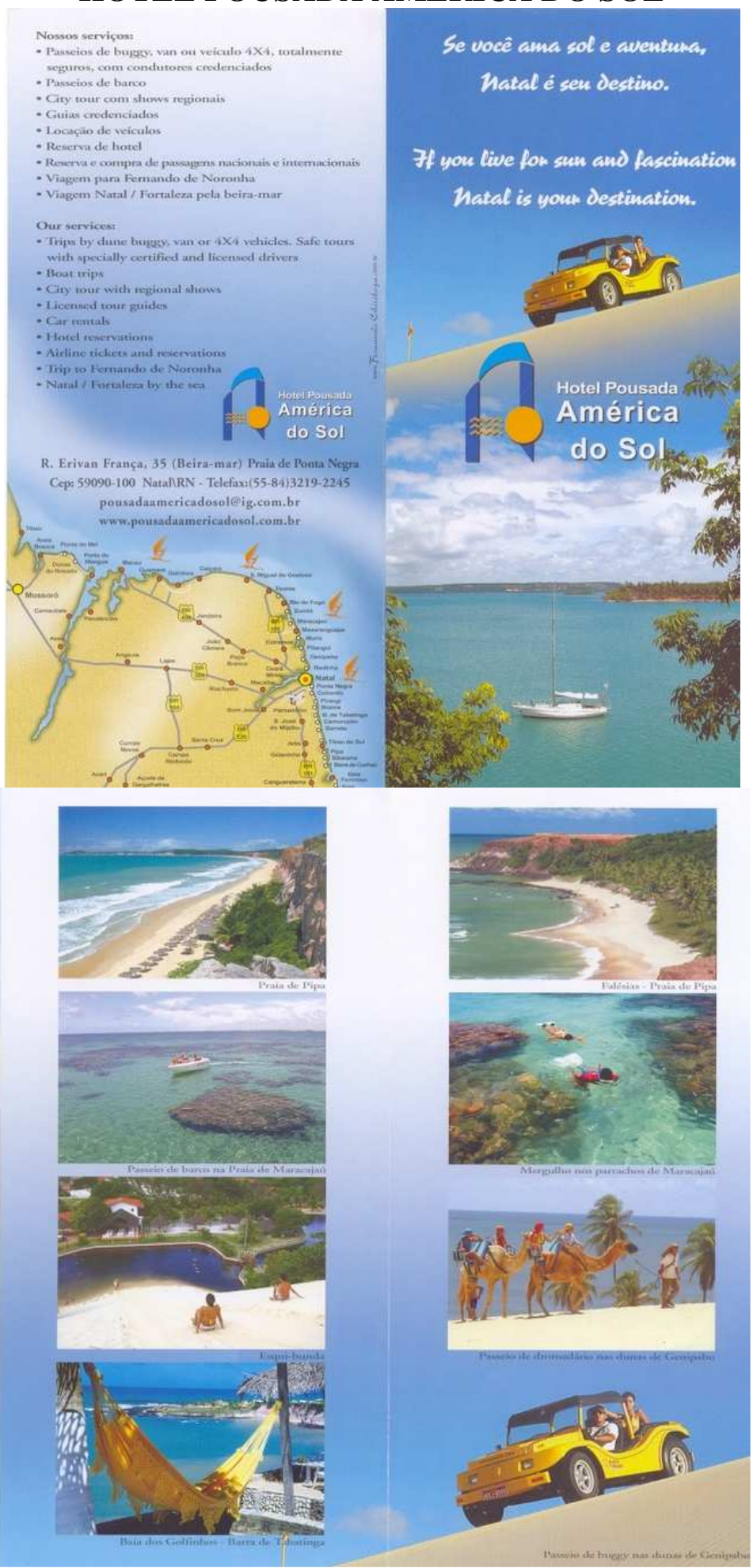

Texto 66

El componente expandido del texto 66 dice: Si te encantan el sol y la aventura, Natal es tu destino. Hotel Pousada América do Sol. En ningún momento el texto habla de precios o dice que uno debe hospedarse en ese hotel, simplemente lo sugiere. Además, 
usa imágenes de Natal que atestiguan por qué esta ciudad es el destino para los que desean estar en alguna aventura bajo el sol.

Desde un punto de vista formal, este texto sigue el formato propio del texto publicitario. En su macroestructura figura la descripción del "Hotel Pousada América do Sol", la presentación de su localización y los puntos de interés turísticos que pertenecen a Natal. La progresión temática de este texto puede ser definida como progresión de tema constante y las personas del discurso presentes son la primera persona del plural (nosotros), usada como un recurso retórico de cortesía, y la segunda persona del singular (tú), una forma de acercamiento entre los dos polos de la comunicación (emisor $\mathrm{y}$ receptor).

El acto de habla locutivo consiste en el discurso constituido por el lenguaje verbal escrito y el lenguaje visual; la fuerza ilocutiva en la descripción del productor turístico ofertado y su ubicación; y el efecto perlocutivo en la estrategia de persuasión publicitaria que tiene como finalidad recibir del interlocutor la confirmación en forma de un acto de compra.

El producto visual consiste en la marca del "Hotel Pousada América do Sol" y algunos de los principales puntos de interés turístico de Natal, como la playa de Pipa, la Barra de Tabatinga, las dunas de Genipabu y Maracajaú. El mensaje manifiesto de este anuncio consiste en la promoción publicitaria del hotel anunciado y el mensaje latente corresponde a la idea de paz y de tranquilidad de las playas de arena blanca y agua transparente del lugar donde está ubicado el hotel anunciado.

En otras palabras, todo el texto, aquí concebimos el anuncio como un todo, o sea, imagen, colores componente textual expandido y significación, forma el mensaje final del anuncio publicitario cuyo efecto perlocutivo es siempre la adquisición de un producto o servicio. Sobre todo cuando hablamos de producto turístico que en general pasa a existir por medio de la publicidad.

Como señala Demartine Gomes, (2003:08) "la comunicación persuasiva se caracteriza por la intención de la fuente decidida claramente a producir algo en el receptor, en los destinatarios, y modificar, en algún sentido, su conducta". Como hemos visto hasta este 
punto de nuestra investigación, el acto de habla perlocutivo siempre connota eso. Dicho de otro modo, la intención persuasiva, en la práctica, quiere influir al comprador a adquirir el producto, a aumentar el consumo, a presentar promociones y a establecer un vínculo con el consumidor y la marca.

Demartine Gomes (2003), de forma sucinta y clara, analiza el trayecto del mensaje al llegar al público, ya que en la comunicación persuasiva el receptor puede darse cuenta de la intencionalidad del texto y, aún así, reaccionar de forma positiva o negativa en lo que toca a la adquisición o el rechazo del bien o servicio anunciado, como si se estableciera un pacto entre los elementos del acto comunicativo.

\section{MARSANS OPERADORA DE VIAGENS}

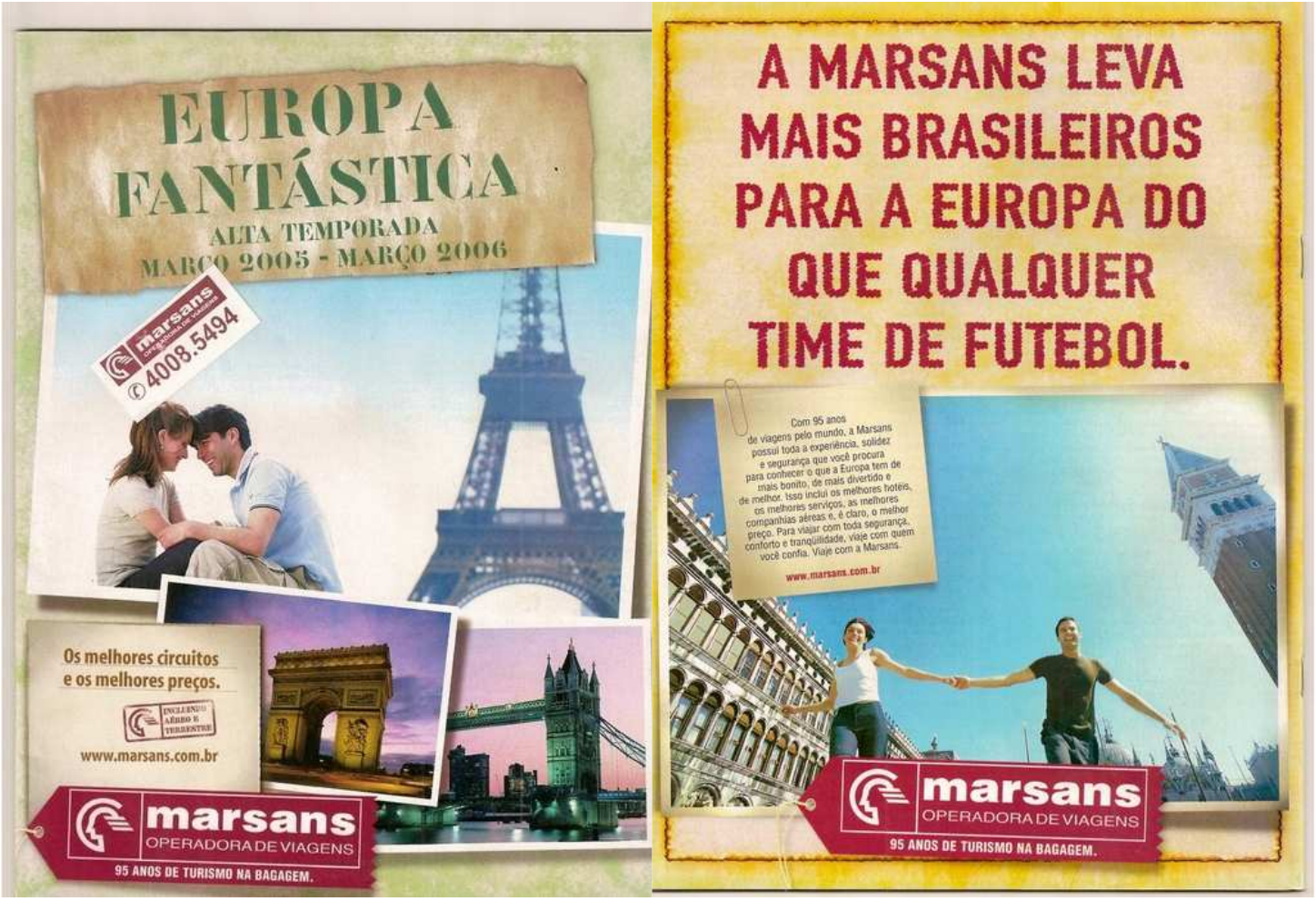

Texto 67

La base del proceso de comunicación en el campo de la publicidad son las acciones informativas y persuasivas. Al presentar conocimientos, los anuncios desempeñan las prácticas de mostrar al consumidor los principales puntos para inducirlos a la compra. "Persuadir supone convencer y, por lo tanto, es necesario motivar. En publicidad se utiliza la información que motiva, que induce al público a adquirir el producto para satisfacer sus necesidades fisiológicas o psicológicas" (Demartine Gomes, 2003:35). 
En el texto 67, el lector común vislumbra un texto publicitario elaborado por medio de la heterogeneidad de signos, sobre todo, de la unión entre contenido icónico y contenido verbal. De modo que todo en este anuncio significa: los colores, las imágenes, el contenido expandido y el sentido. En el texto en cuestión, la imagen y la palabra actúan juntos como ganchos, como información y persuasión a la vez.

Al despertar la curiosidad del interlocutor, el texto 67 afirma: Marsans lleva más brasileños a Europa que cualquier equipo de fútbol. Así, nuestro lector no necesita grandes esfuerzos cognitivos para comprender que se trata del anuncio de una operadora de turismo que se llama Marsans. Luego, al mirar a las imágenes de este anuncio, el interlocutor puede vislumbrar fotos de los más variados puntos de interés turístico del mundo y de dos parejas de enamorados muy felices, lo que puede despertar muchas inferencias en la mente de nuestro lector.

Al hacer uso de su conocimiento enciclopédico, la audiencia de este anuncio puede llegar a formular un enunciado que diga: La operadora de turismo Marsans lleva muchos brasileños de paseo turístico por Europa, ya que los equipos de fútbol europeos suelen contratar a muchos brasileños como jugadores. Este anuncio, por lo tanto, está basado en el argumento de cantidad, que además de los argumentos de mejores viajes, mejores precios, asociados a la fiabilidad de la empresa operadora de viajes Marsans y a la felicidad reflejada en la cara de las dos parejas protagonistas del anuncio, son motivadores y actúan como estrategia persuasiva a la hora de la venta del producto turístico ofertado.

La comunicación persuasiva comprende principalmente la publicidad, la propaganda y, sobre todo, la comunicación política y el campo de las relaciones públicas. Los elementos relacionados con el proceso de emisión y recepción, como el canal, el mensaje, la fuente y el destino acaban agregando técnicas del campo de la psicología, envolviendo también los aspectos sociales del público objetivo o target. 
BARILOCHE COM A CVC

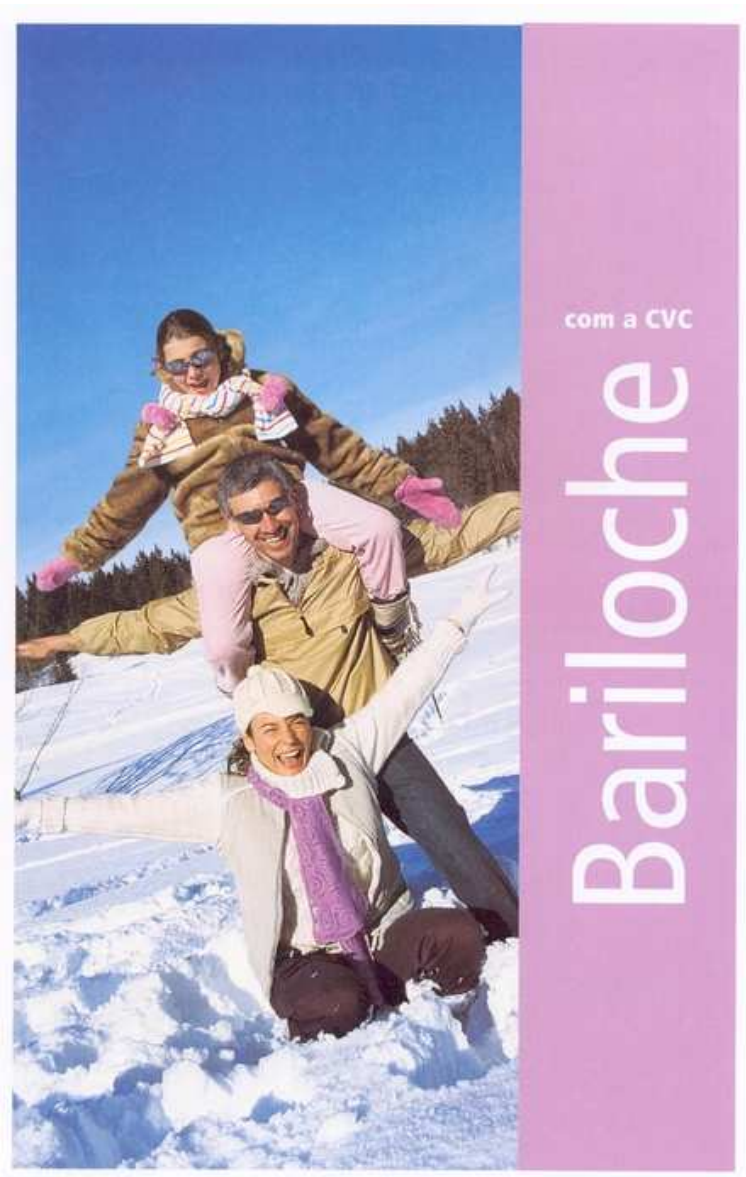




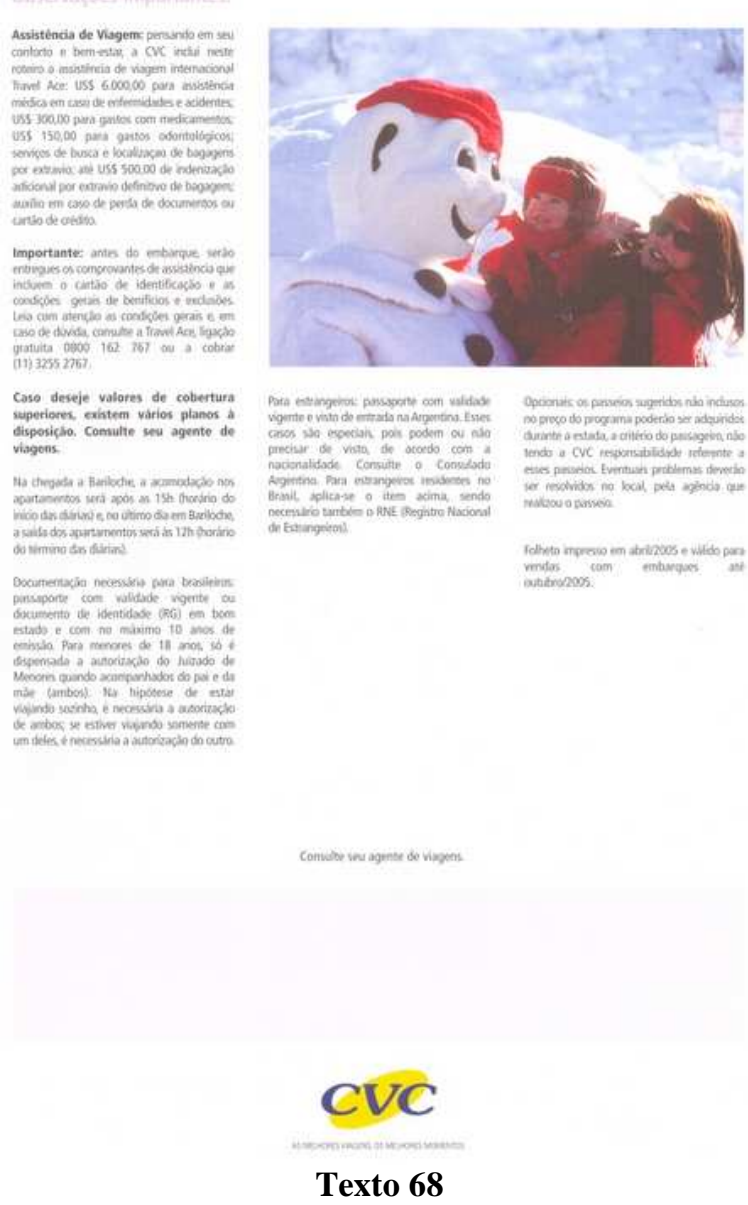

Las acciones con carácter persuasivo trabajan, sobre todo, con el inconsciente del público, siempre con el objetivo de atraer su atención y hacerle producir la respuesta esperada en dicho acto de comunicación. En este sentido, son diversas las técnicas empleadas para persuadir al público con textos persuasivos, desde las de naturaleza psicológica a las de naturaleza lingüística y semántica. Como ejemplo de las técnicas de persuasión utilizadas en el discurso de la publicidad turística, este anuncio transmite, de modo inconsciente, la idea de una familia bien avenida y feliz, jugando en la nieve y vestida a la última moda del deporte de invierno.

Dicho de otro modo, no se vende solamente Bariloche como un destino turístico, ni la operadora de turismo CVC, sino que se vende un estilo de vida, un modelo social de familia a partir de la cual el interlocutor se autoproyecta y se inspira en el modelo porque quiere ser como los personajes prototípicos presentados por la publicidad. Quiere formar parte de ese grupo social al que se elogia tanto y que tiene tanto prestigio. Además, quiere ese modelo de felicidad porque quiere ser feliz como ellos y para ser como ellos hay que imitar a su modelo de triunfo social, ir a Bariloche con la CVC y 
hacer fotos parecidas, aunque si observamos mejor, en la foto de la izquierda el padre y la madre van poco abrigados para quienes están jugando en la nieve, pero ese detalle no importa porque la publicidad es persuasiva y vende el producto anunciado, y eso sí es lo más importante.

Entre los diversos tipos de comunicación de masas, la mercadológica se distingue por centrarse en el medio empresarial. Por eso, las empresas crean una imagen corporativa por medio de la cual se establece su identificación visual. Ese proceso antecede a la conquista del mercado empresarial y la consecuente venta de sus productos, servicios y bienes. Con base en eso, la publicitaria Neusa Demartine Gomes (2003:37) define que "el concepto de comunicación está integrado con el mercado: debe partir de una filosofía que establezca el papel y la profundidad de cada instrumento de comunicación, buscando la ordenación coordinada de cada uno". En nuestro texto 68, la CVC es una marca representada por la identificación visual que está al final de la segunda página del anuncio.

En relación con la comunicación de los productos, cuando es eficaz, se presenta como un resultado del reflejo de la interacción de las empresas con las áreas de actividades del mercado. La relación de la comunicación con los objetivos de una empresa se concentra a través de las prácticas publicitarias, de propagandas, merchandising, promociones y relaciones públicas. A pesar de ser autónomas, cada una de esas actividades debe estar integrada en un programa de marketing.

Los mensajes persuasivos, a su vez, estarán como eje central entre las comunicaciones mercadológicas que asumen el papel de expresar objetivamente la propuesta de la empresa (estrategia de marketing) para el mercado. Una estrategia muy común adoptada por el equipo de marketing de una empresa es la adopción de su imagen corporativa en todos los materiales de oficina que utilizan porque eso ya forma parte de su publicidad, ya sirve para hacer que la empresa sea conocida y eso le aporta más fiabilidad, porque lo familiar es más fiable. La marca de hoteles Dorisol lo hace cuando adopta una carpeta con el logo de la empresa, como se puede ver a continuación: 
DORISOL GRAND HOTELS

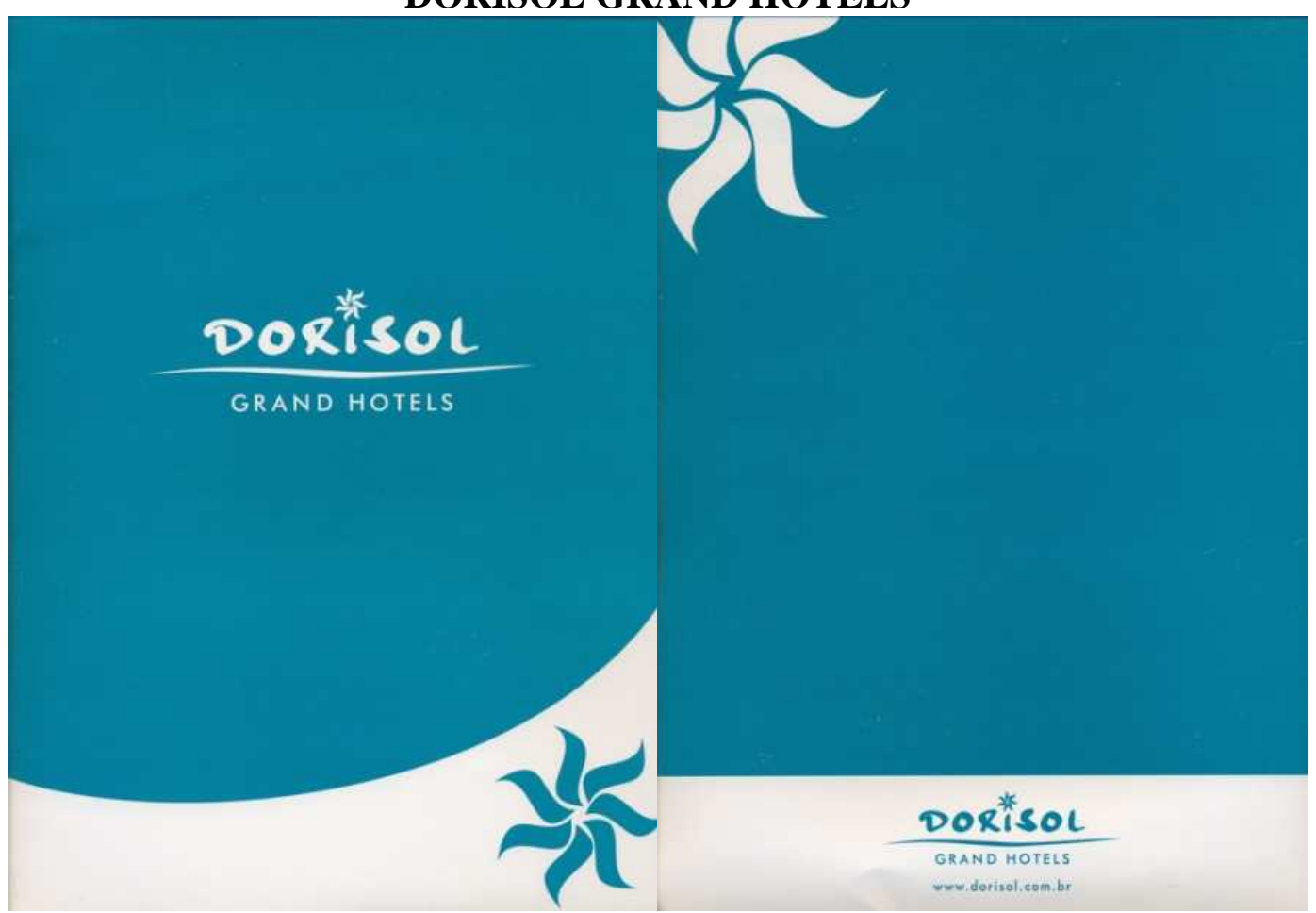

Texto 69

Ese tipo de anuncio no sirve para vender el producto porque forma parte de lo que se conoce por publicidad de prestigio. Su función es más bien popularizar una marca, ya que lo conocido es más fiable y por eso vende. A partir de ello, es fácil comprender cómo las empresas buscan obtener visibilidad en el mercado en el que actúan y qué importancia tienen anuncios como estos para una empresa.

El proceso no es tan simple como parece, consiste en difundir la imagen, el producto y la calidad del producto de una empresa, de modo que sea posible eliminar barreras psicológicas, culturales, comunicativas, etc. Mejor dicho, "la publicidad elimina la barrera psicológica, dando a conocer, por los medios de comunicación masivos, el producto o servicio y sus atributos mercadológicos" (Demartine Gomes, 2003:42).

En el ejemplo de comunicación mercadológica comercial del turismo que hemos visto anteriormente, hay una carpeta que forma parte de la imagen corporativa de la marca "Dorisol", como ya hemos dicho, de modo que lo único que se puede ver en esta carpeta es su logotipo y su color corporativo. Sin embargo, también puede servir como una forma de publicidad turística y anunciar tanto la marca como exponer la forma de contacto como la página electrónica. 
Técnicas de persuasión publicitaria

Roberto Menna Barreto, a través de su obra Criatividade em Propaganda (1978), afirma que para que el anuncio publicitario sea persuasivo es fundamental que presente creatividad editorial, elaborada por medio de palabras (frases, títulos y textos) intrínsecamente relacionadas al campo argumentativo. A todo ello debe ser sumada una buena técnica de composición, de modo que el texto sea preciso, rítmico y espontáneo.

MARAZUL PASEOS DE BUGUY Y VAN

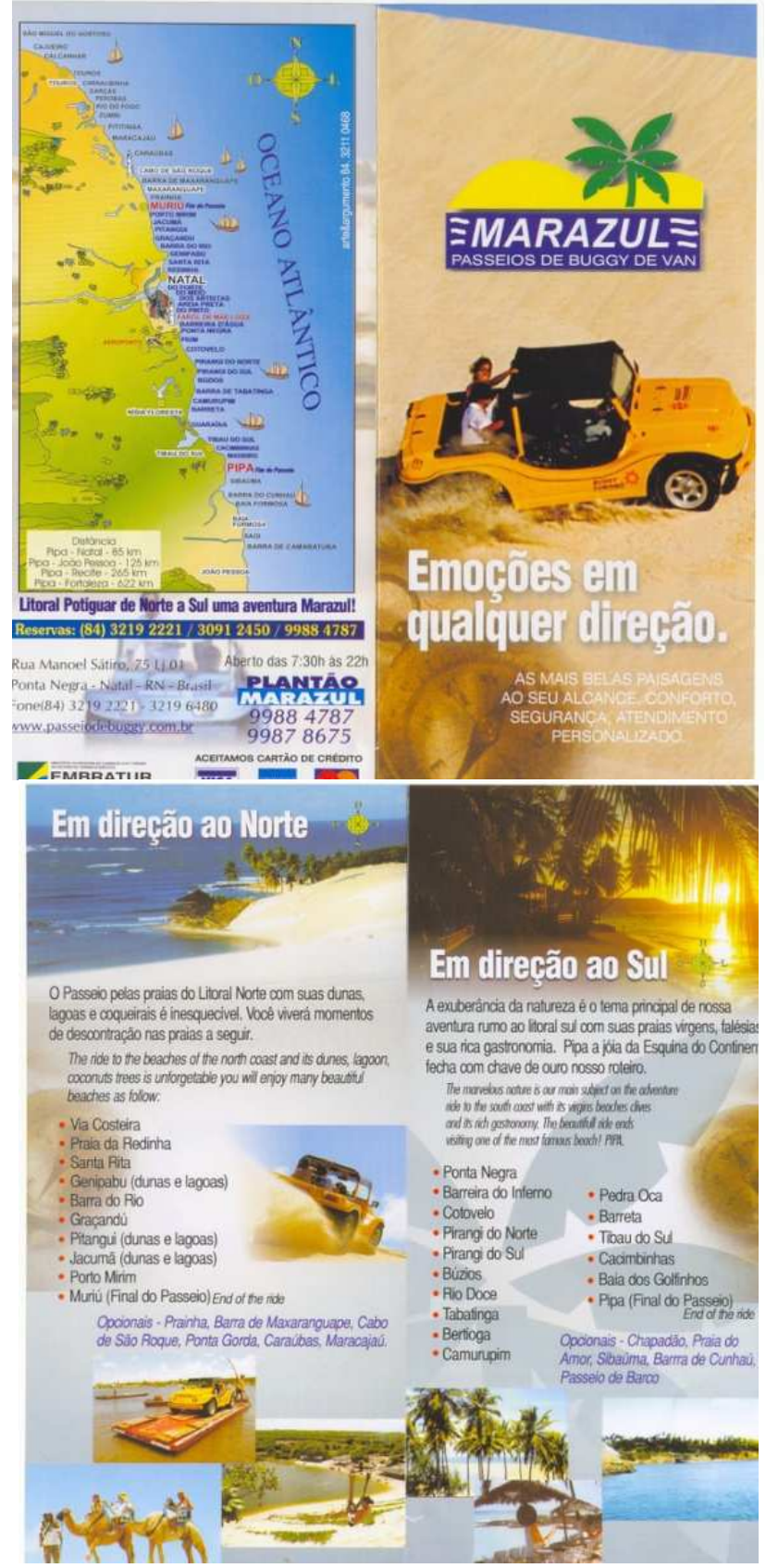

Texto 70 
El texto 70 presenta la creatividad editorial y una frase de efecto intrínsecamente relacionada con el campo argumentativo cuando dice: Marazul Paseos de Buggy y de Van. Emociones a cualquier dirección, porque si observamos la imagen que ilustra esa frase es de un tipo de paseo en el que se pregunta al turista antes de empezarlo: ¿Con emoción o sin emoción? La buena técnica de producción textual adoptada torna el texto muy agradable a los ojos del interlocutor de una forma natural y espontánea. También merece destacarse el uso del color amarillo y azul en todas las páginas del anuncio, propio de un tipo de turismo de sol y playa. El nombre de la agencia de viajes es un neologismo creado a partir de la unión del lexema mar, con el lexema azul. Con lo cual, el color amarillo representa el sol y el azul el cielo y el mar.

En el texto en cuestión se puede leer en su primera página: Marazul Paseos de Buggy y Van. Emociones en cualquier dirección. Los más bellos paisajes a tu alcance. Confort, seguridad, atención personalizada. En dirección al norte. El paseo por las playas del litoral norte, con sus dunas, lagos y cocoteros es inolvidable. Vivirás momentos divertidos [...]. En dirección al sur. La exuberancia de la naturaleza es el tema principal de nuestra aventura rumbo al litoral sur con sus playas vírgenes [...].

Desde un punto de vista formal, este texto sigue el formato propio del texto publicitario. En su macroestructura figura la descripción del producto turístico vendido por la "Marazul", su dirección y las formas de contacto (correo electrónico y teléfonos). La progresión temática de este texto puede ser definida como progresión de temas derivados.

Las personas del discurso presentes son la inscripción del "tú", presentando así un carácter de proximidad entre el emisor y el destinatario, y la inscripción de la tercera persona del singular usada para describir los productos turísticos de forma impersonal. En el marco léxico de este texto se destaca el uso de un vocabulario positivo formado por palabras como: paseos, emociones, más, bellos, paisajes, alcance, confort, seguridad, atención, personalizada, inolvidable, vivirás, momentos, divertidos, exuberancia, naturaleza, principal, aventura, playas.

El acto de habla locutivo establecido por este texto consiste en el discurso constituido por el lenguaje verbal escrito y el lenguaje visual; su fuerza ilocutiva en la descripción 
del producto turístico ofertado y su ubicación como estrategia persuasiva; y el efecto perlocutivo en la finalidad de recibir del interlocutor la confirmación en forma de un acto de compra.

El producto visual consiste en la propia imagen del logotipo de la "Marazul", un mapa orientativo de las playas natalenses y la foto de los productos turísticos vendidos por esta empresa. El mensaje manifiesto consiste en la descripción del propio producto turístico anunciado. El mensaje latente es la calidad del producto ofertado y de paseos muy emocionantes y divertidos.

Uno de los principales puntos para que un mensaje publicitario triunfe es el entusiasmo por parte de sus creadores, si las personas que dan vida al anuncio no están fuertemente implicadas, no hay manera de que el trabajo tenga éxito. El anuncio debe ser creado en base, fundamentalmente, al título o al texto, eso le hará argumentar con el interlocutor y convencerlo.

La cualidad del anuncio no está ligada a la cualidad del producto. Para conquistar el grado de excelencia publicitaria, el camino es conocer el producto, saber lo que se puede decir al respecto y esforzarse para encontrar el argumento más eficaz en el intento de convencer al consumidor. A continuación presentamos un cuadro con las técnicas de persuasión publicitaria presentadas por el autor mencionado anteriormente. 
Luego presentaremos ejemplos para cada uno de los puntos de eventuales opciones estratégicas que harán un texto más persuasivo. Sin embargo, esto no consiste en reglas absolutas e irrefutables para la elaboración de un texto persuasivo porque "no constituyen listas de soluciones, sino solamente un levantamiento de posibilidades" (Roberto Menna Barreto, 1978:203).

\begin{tabular}{|l|l|}
\hline \multicolumn{1}{|c|}{ TÉCNICA } & \multicolumn{1}{|c|}{ EXPLICACIÓN } \\
\hline $\begin{array}{l}\text { 1- Defensa de una tesis inteligente y } \\
\text { apoyada en un razonamiento lógico }\end{array}$ & $\begin{array}{l}\text { El poder de persuasión de una tesis bien } \\
\text { formulada y bien presentada. }\end{array}$ \\
\hline 2- Humanización & $\begin{array}{l}\text { Técnica apoyada en la apelación dirigida a los } \\
\text { sentimientos humanos. }\end{array}$ \\
\hline 3- Particularización & Favorecer la imagen general de lo anunciado. \\
\hline 4- La presentación del producto & El producto debe ser explicado al consumidor. \\
\hline 5- Explicación del antiproducto & $\begin{array}{l}\text { La exposición de acciones negativas por la no } \\
\text { adquisición del producto. }\end{array}$ \\
\hline 6- Uso de dramaticidad & $\begin{array}{l}\text { El consumidor, individuo único, para quien es } \\
\text { destinado el producto. }\end{array}$ \\
\hline $\begin{array}{l}\text { 7- Demostración de la variedad de } \\
\text { ventajas del producto }\end{array}$ & $\begin{array}{l}\text { La propuesta de otras probables ventajas que el } \\
\text { producto presenta. }\end{array}$ \\
\hline 8- Información & $\begin{array}{l}\text { La información debe ser el fundamento del } \\
\text { anuncio. }\end{array}$ \\
\hline 9- Apelación sexual & $\begin{array}{l}\text { Argumento fuerte en la publicidad } \\
\text { contemporánea. }\end{array}$ \\
\hline 10- Uso de testimonios & $\begin{array}{l}\text { Relatos de personas comunes con quienes el } \\
\text { público objeto se identifique. } \\
\text { Recurso que sirve para aumentar el interés del } \\
\text { público. }\end{array}$ \\
\hline 11- Estimular la curiosidad \\
comparada
\end{tabular}

Cuadro elaborado a partir de Roberto Menna Barreto (1978:203-228). 
Técnicas

El razonamiento en un texto creado de forma inteligente es fundamental a la hora de elaborar un texto de carácter persuasivo. La fiabilidad de una tesis y su forma de presentación darán credibilidad a lo anunciado. Si sigue una secuencia que parte de algo general a lo más específico, la razón del enunciado principal comprobará, "por decir así, la 'razón' secundaria del producto. Imposible 'desmentir' ni uno ni otro. Otra gran ventaja: el producto surge valorado por un grado alto de inteligencia. Tales anuncios [...] sirven para dar un tirón en la cabeza del lector, y hacer que le guste eso" (Menna Barreto, 1978:203).

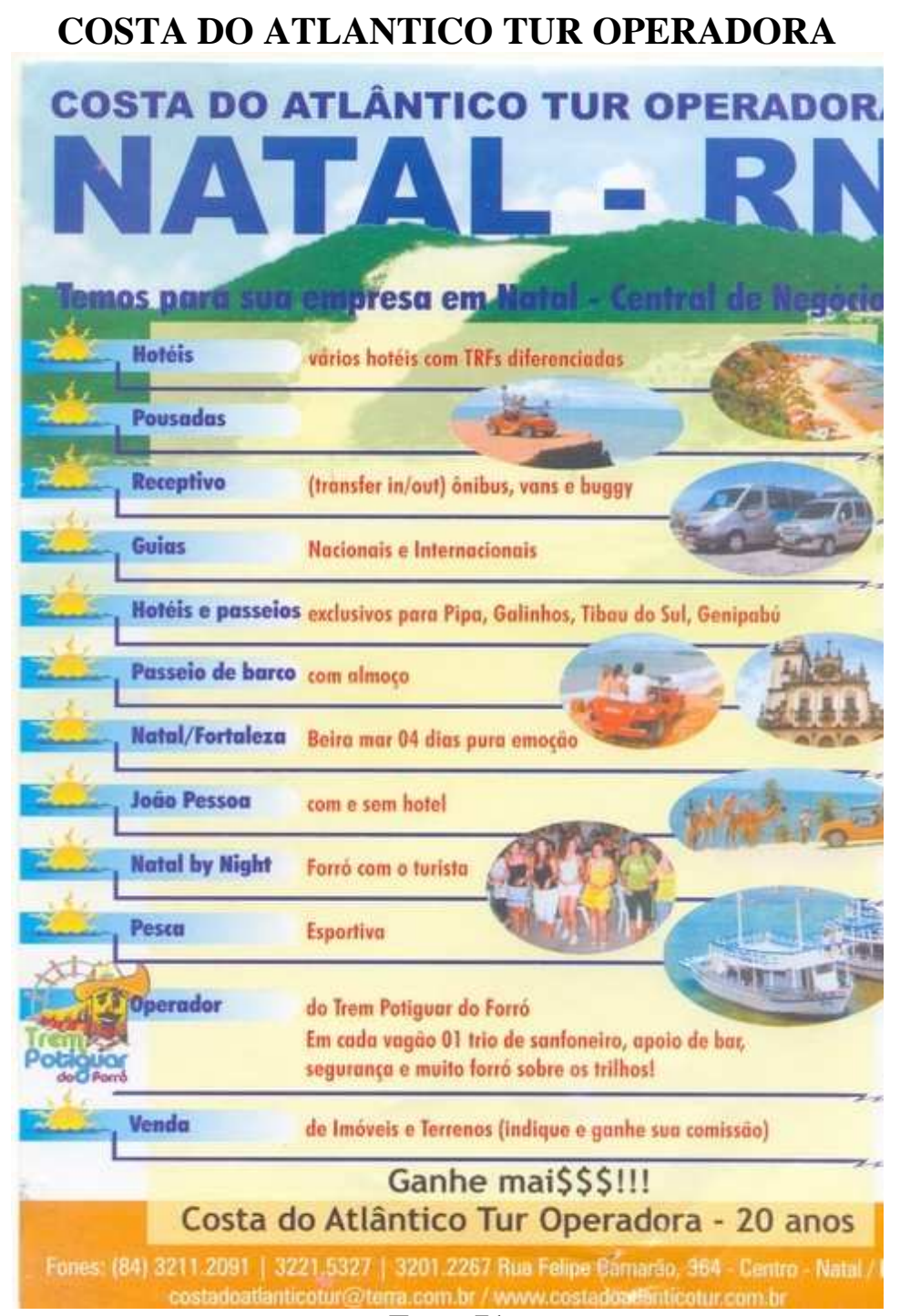

Texto 71

En el anuncio presentado anteriormente se puede contemplar el uso de la defensa de una tesis inteligente y apoyada en un razonamiento lógico. Esta técnica de persuasión está 
apoyada en el poder de persuasión de una tesis bien formulada y bien presentada. En el caso específico del texto 71, tenemos la presentación de los servicios ofertados por la Costa do Atlántico Tur Operadora y los motivos por qué una persona o una agencia de viajes debe optar por sus servicios.

Así, a partir del texto publicitario en cuestión, el lector puede inferir que la Costa do Atlántico Tur Operadora debe ser contactada porque ofrece hoteles con tarifas diferenciadas; hostales; receptivo; guías nacionales e internacionales; hoteles y paseos; paseo de barco con comida; cuatro días en Natal y Fortaleza de pura emoción; João Pessoa; Natal by night; pesca deportiva; operador; ventas inmobiliarias; además de ser una operadora con 20 años de experiencia en el mercado y por medio de la cual uno puede ganar más. Estos dos últimos argumentos, por lo tanto, predominan delante del argumento de la excelencia del servicio anunciado. De ese modo, se intenta sensibilizar al público objeto con una gran diversidad de argumentos lógicos y elaborados de modo estratégico.

Desde un punto de vista formal, este texto sigue el formato propio del texto publicitario. En su macroestructura figura la descripción de los productos turísticos ofertados por la “Costa Atlántico Tur Operadora”. La progresión temática de este texto puede ser definida como una progresión de temas variados. Las personas del discurso presentes son "nosotros", como un recurso retórico de cortesía y la inscripción del "você", en portugués de Brasil, que tiene la fuerza semántica del "tú" en español, presentando así un carácter de proximidad entre el emisor y el destinatario. El acto de habla locutivo consiste en el discurso constituido por el lenguaje verbal escrito y el lenguaje visual; la fuerza ilocutiva en la descripción del producto turístico ofertado y su ubicación; y el efecto perlocutivo en la estrategia de persuasión publicitaria que tiene como finalidad recibir del interlocutor la confirmación en forma de un acto de compra.

En un texto publicitario, como ya hemos visto, todo tiene significado: los colores, las imágenes, el componente expandido y el sentido. En lo que concierne al producto visual del texto en cuestión, podemos ver que corresponde a la propia imagen de los productos turísticos ofertados por la "Costa Atlántico Tur Operadora”. El mensaje manifiesto es el buen precio y la calidad de los productos vendidos por la Costa Atlántico y el mensaje 
364

latente es "si tu empresa trabaja con nosotros vas a tener más beneficios", idea corroborada por el eslogan del anuncio publicitario: ¡Factura má $\$ \$$ !.

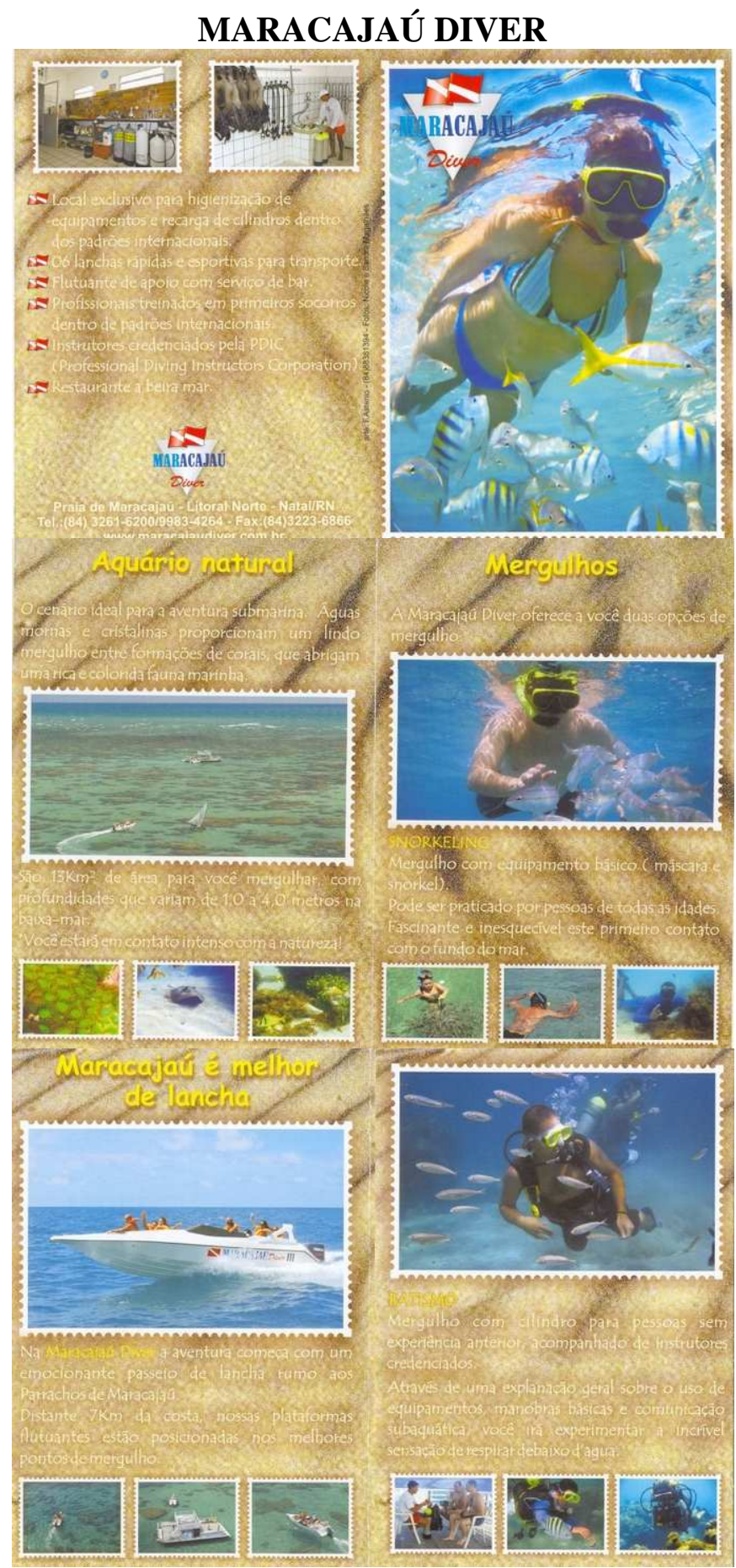

Texto 72

En el anuncio turístico presentado arriba se adopta la humanización, cuyo principal objetivo es encontrar el camino del corazón de las personas para poder conquistarlas. Para Barreto, "humanizar es alcanzar lo más profundamente [...] el sentimiento de las 
personas, conmoverlas hasta que se identifiquen con el producto, con el servicio" (Barreto, 1978:206). En el texto 72 se anuncia el deporte acuático de buceo. Así, los partidarios de ese deporte o los que se interesan por este tipo de deporte se sentirán identificados con los buceadores de las imágenes.

Desde un punto de vista formal, este texto sigue el formato propio del texto publicitario. En su macroestructura figura la descripción del "Maracajaú Diver", sus servicios, su dirección y formas de contacto. La progresión temática de este texto puede ser definida como progresión de tema constante. Las personas del discurso presentes son "él”, usado para describir el producto anunciado de forma impersonal y la inscripción del "tú", que sirve para aproximar los interlocutores del acto de habla publicitario.

El componente expandido del texto dice: Maracajaú Diver. Acuario natural. Escenario ideal para la aventura submarina. Aguas tibias y transparentes proporcionan un bello buceo entre formaciones de corales que abrigan una rica y coloreada fauna marina [...]. Maracajaú es mejor en barco. En la Maracajaú Diver la aventura empieza con un emocionante paseo de barco [...]. El acto de habla locutivo consiste en el discurso constituido por el lenguaje verbal escrito y el lenguaje visual; la fuerza ilocutiva en la descripción del producto turístico ofertado y su ubicación, que sirven como recursos retóricos; y el efecto perlocutivo consiste en recibir del interlocutor la confirmación en forma de un acto de compra.

En la selección léxica de este texto publicitario figura el uso de sintagmas como: acuario, natural, escenario, ideal, aventura, submarina, aguas, tibias, transparentes, proporcionan, lindo, buceo, rica, coloreada, fauna, mejor, barco, empieza, emocionante y paseo. Es decir, todo un léxico positivo que influye en el acto de persuadir. El producto visual consiste en imágenes del producto ofertado por la "Maracajaú Diver" y la logomarca de esta empresa de buceo. El mensaje manifiesto sería el propio anuncio y la descripción del producto turístico ofertado, mientras el mensaje latente destaca la buena calidad del producto ofertado. 
TAM VIAGENS

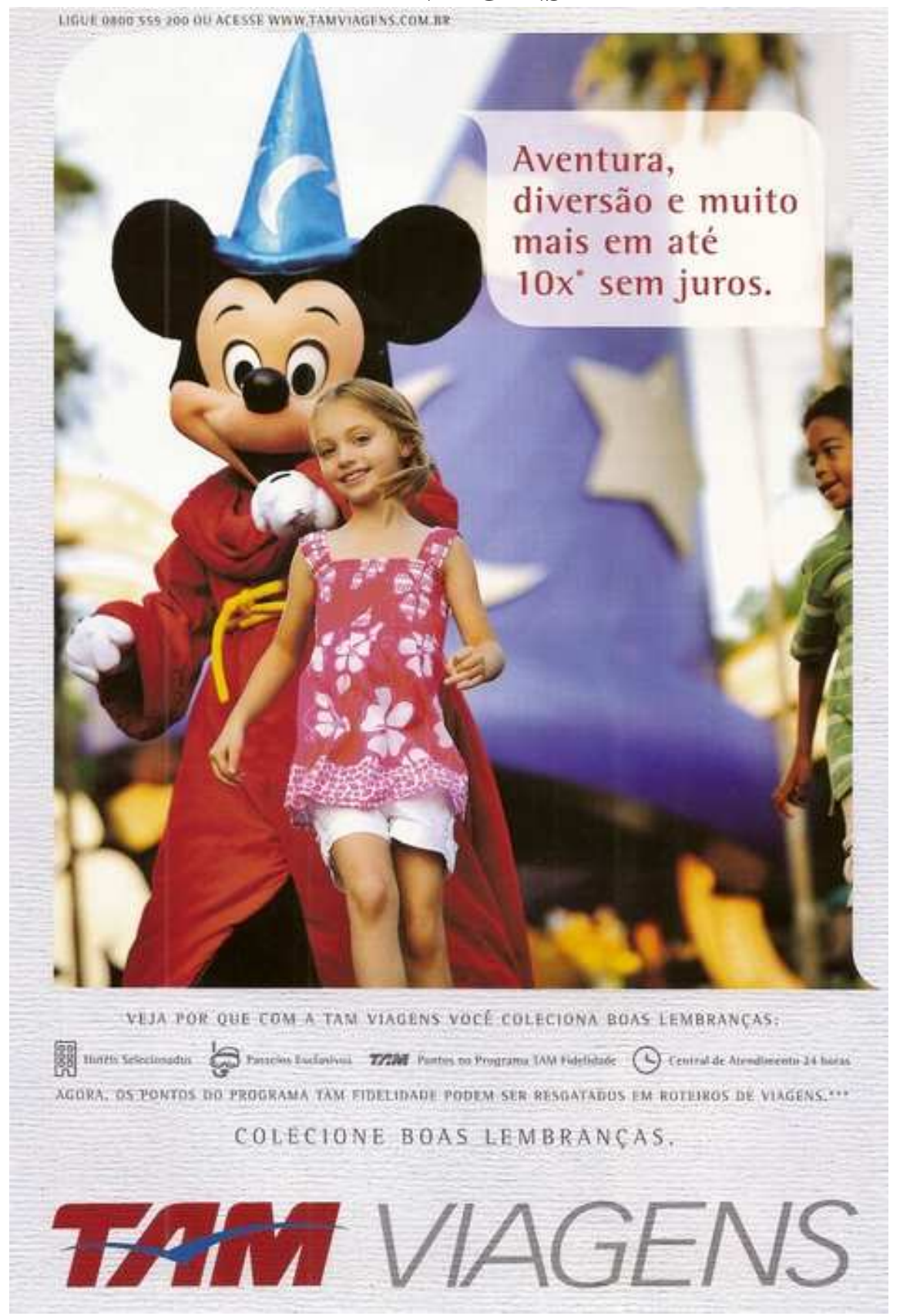

Texto 73

Arriba presentamos otro ejemplo del uso de la técnica de la humanización usada para persuadir al interlocutor. Es muy probable que cualquier niña de edad entre 7 y 11 años se sienta identificada con la del anuncio. Claro está que este anuncio no va dirigido directamente a la niña, sino a sus padres o responsables que le podrán proporcionar el capricho de un viaje a Disney. De todos modos, el anuncio está pensado para afectar directamente al sentimiento de las personas, sea el niño que lo vea o los padres que quieren el bien y la felicidad de sus hijos. 
El texto 73 dice: aventura, diversión y mucho más en 10 veces sin interés. Ve por qué con Tam viajes coleccionas buenos recuerdos. Ahora los puntos del programa Tam fidelidad pueden ser rescatados en destinos de viajes. Colecciona buenos recuerdos. Tam viajes. Aquí la forma de pago, la excelencia de los servicios anunciados y el privilegio de la marca actúan junto a la técnica de humanización para persuadir al público, es decir, a los padres cuyos hijos quieren ir a Disney.

El anuncio publicitario expuesto abajo hace uso de la difícil tarea de la particularización, que es otro paso muy importante en la elaboración de un texto de carácter persuasivo. Su mayor apoyo se encuentra en la imaginación, pues para esa particularización es necesario que se tenga una concentración total en los detalles y en las especificidades del producto que fue elegido para ser trabajado, y eso no ocurre de forma mecánica.

En este caso han definido el Pontalmar Praia Hotel como un lugar de lujo, primor, encanto y hospitalario, además de ser el hotel más nuevo de la playa de Ponta Negra. Muestra el nordeste brasileño como un lugar sensacional gracias a sus especificidades y su cultura particular en comparación con las demás regiones de Brasil. Desde un punto de vista formal, ese texto sigue el formato propio del texto publicitario. En su macroestructura figura la descripción de las instalaciones internas y externas, los servicios y las formas de contacto del "Potalmar Praia Hotel". Su progresión temática puede ser definida como de progresión de tema constante. Las personas del discurso presentes son la tercera persona del singular que remite al producto anunciado de forma impersonal y la inscripción del "você", en portugués de Brasil, que tiene la fuerza semántica del “tú” en español, presentando así un carácter de proximidad entre el emisor y el destinatario.

El acto de habla locutivo consiste en el discurso constituido por el lenguaje verbal escrito y el lenguaje visual; la fuerza ilocutiva en la descripción del producto turístico ofertado y su ubicación, que sirven como estrategias persuasivas; y el efecto perlocutivo tiene como finalidad recibir del interlocutor la confirmación en forma de un acto de compra. El producto visual consiste en la descripción, por medio de imágenes, de la ubicación, la vista, el ambiente, las instalaciones externas e internas, además de los servicios ofrecidos por el "Potalmar Praia Hotel". El mensaje manifiesto consiste en la 
descripción y presentación del producto turísticos anunciado. Ya el mensaje latente es de un lugar acogedor, confortable, relajado, elegante, con mucho lujo y muy moderno.

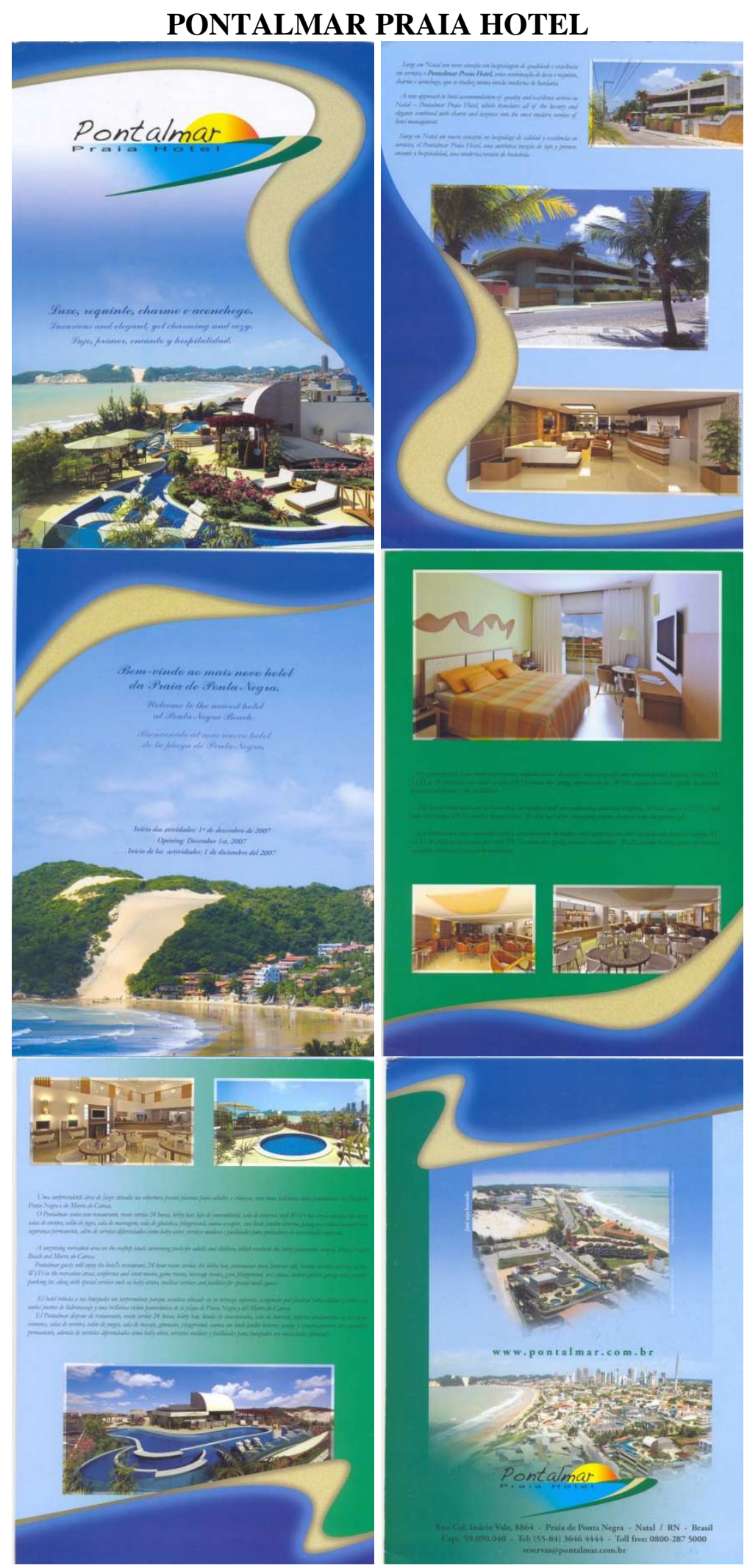

Texto 74 
Para la presentación de un producto, es fundamental hacer que el consumidor conozca bien el producto antes de usarlo, ya que debe sentir la seguridad en relación al producto que está consumiendo. Barreto orienta que "nunca anuncie nada a nadie, sin estar seguro de que ese alguien conoce bien su producto. Y aún así, no deje de explicarlo" (Barreto, 1978:210).

Una buena presentación en el anuncio publicitario es sinónimo de éxito, pues cuanto más conocen las personas el producto más desearán adquirirlo. El anuncio presentado a continuación está elaborado bajo esa técnica y a partir de la mezcla entre los signos verbales y no verbales presenta y explica al máximo grado el hotel Pirâmide: lo presenta, lo describe, lo ubica. En fin, agota todas las posibilidades descriptivas de este producto turístico para promover una buena presentación.

Desde un punto de vista formal, este texto sigue el formato propio del texto publicitario. En su macroestructura figura la descripción pormenorizada del "Pirâmide" y la presentación de su localización. La progresión temática de este texto puede ser definida como progresión de tema constante. La persona del discurso presente es la inscripción de la tercera persona del singular que designa el objeto anunciado de forma impersonal.

El acto de habla locutivo consiste en el discurso constituido por el lenguaje verbal escrito y el lenguaje visual; la fuerza ilocutiva en la descripción del producto turístico ofertado y su ubicación; y el efecto perlocutivo en la estrategia de persuasión publicitaria que tiene como finalidad recibir del interlocutor la confirmación en forma de un acto de compra.

Este texto pertenece al género del discurso publicitario y desde un punto de vista de la tipología textual, posee una secuencia dominante de texto argumentativo, ya que la descripción funciona más bien como un recurso persuasivo. En la textura discursiva están presentes los elementos deícticos y el mantenimiento del referente se da por procedimiento léxicos y gramaticales.

El producto visual consiste en el logomarca del "Pirâmide", fotos descriptivas de las instalaciones internas y externas de ese hotel, además del diseño de su planta y un mapa orientativo de su localización. El mensaje manifiesto es el propio anuncio del hotel y 
sus instalaciones de un modo general. El mensaje latente consiste en transmitir una imagen de un hotel muy grande, elegante y lujoso.

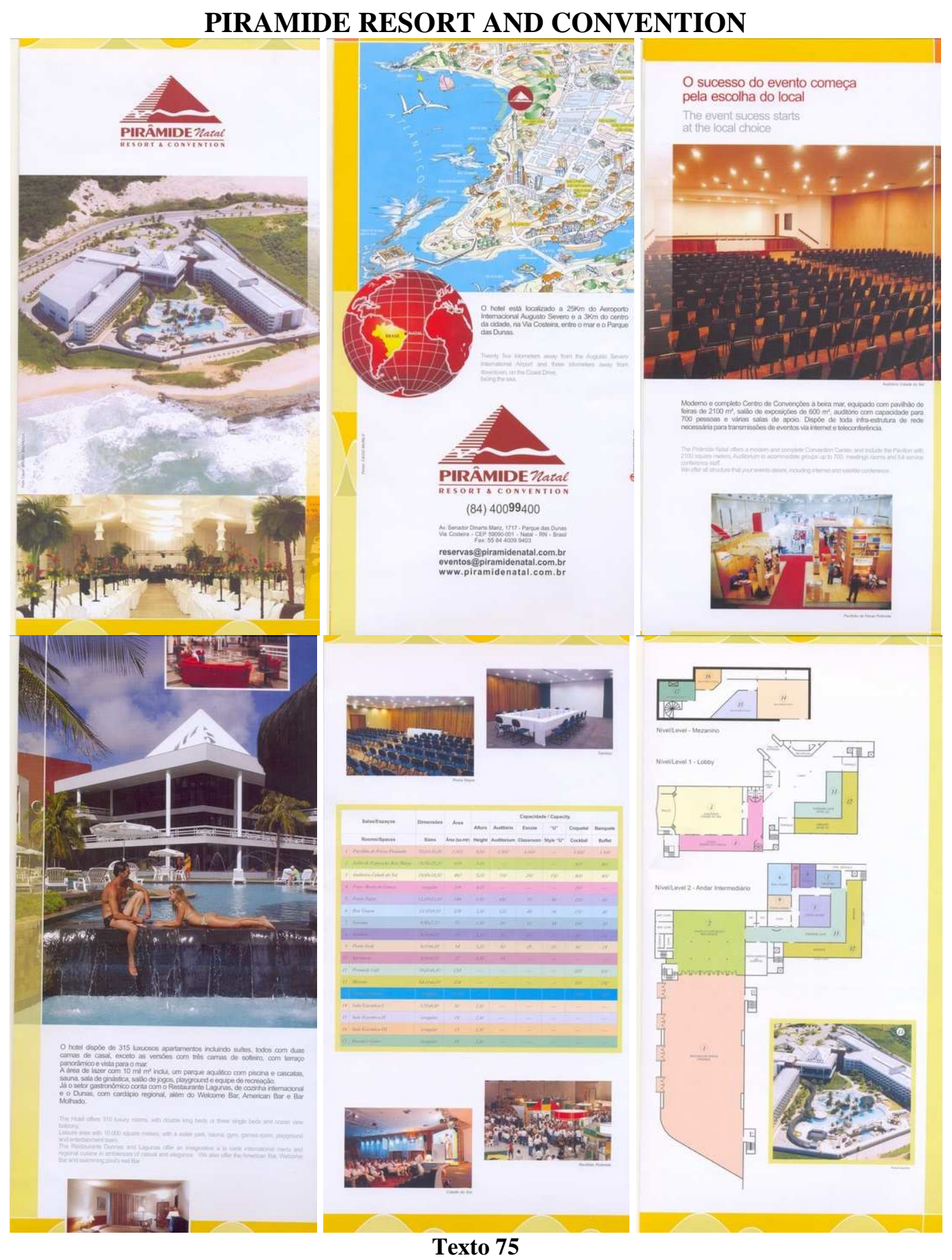

La explicación del antiproducto actúa con la misma importancia que la presentación del producto, sirve para despertar el interés del consumidor, además, es muy ventajosa para el resultado final del anuncio, de modo que el público objetivo sea consciente de los beneficios del producto anunciado y de los maleficios de su no adquisición. Por eso no 
se debe tener "vergüienza de enseñar al consumidor, todas las infelicidades y vicisitudes que no se abatirán sobre él, en caso de que no use el producto anunciado" (Barreto, 1978:211).

El uso de la dramaticidad sirve para crear situaciones dramáticas que llevarán al público a decidirse por el consumo del producto anunciado porque "hay oportunidades en las que uno puede encajar adecuadamente este hombre prototípico en una posición tan crítica que se convencerá por sí mismo" (Barreto, 1978:211).

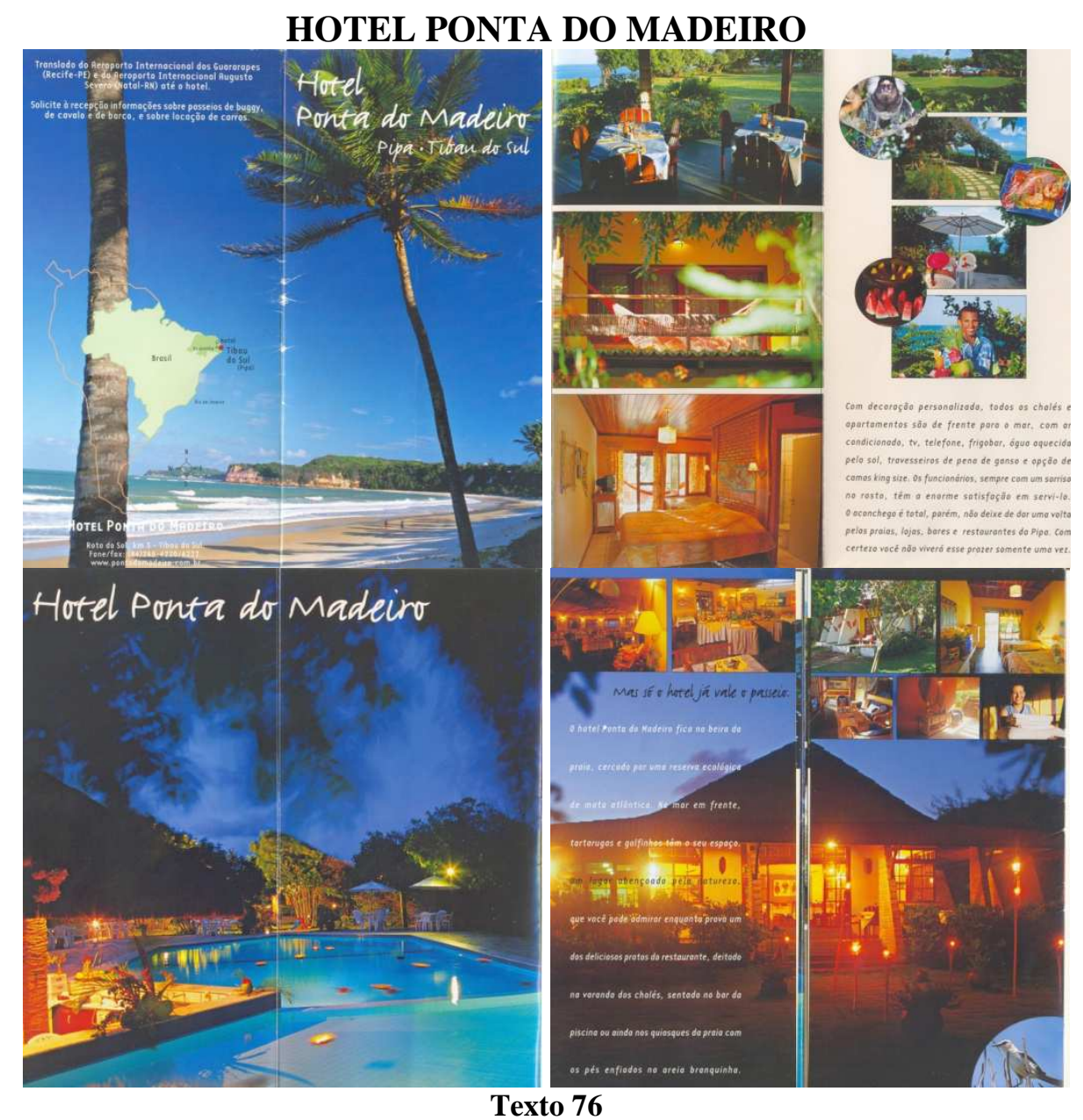

El anuncio expuesto anteriormente usa la técnica de la demostración de la variedad de ventajas del producto, que consiste en la elaboración del anuncio publicitario con la presentación de otras probables ventajas que el producto tiene, ya que en todas las situaciones hay incontables aplicaciones para el producto y no se debe vender el producto desnudo, "véndelo embalado en sugerencias, en ideas [...]. Explote invariablemente todos los usos posibles del producto que será anunciado" (Barreto, 
1978:212). En el caso de esta publicidad turística se presenta "el mundo del tamaño de tus sueños" y sugiere todas las formas de atracciones de interés turístico que uno puede encontrar en el lugar anunciado.

Desde un punto de vista formal, este texto sigue el formato propio del texto publicitario. En su macroestructura figura la descripción del "Hotel Ponta do Madeiro", sus instalaciones internas, externas y sus servicios. La progresión temática de este texto publicitario puede ser definida como de progresión de tema constante. Las personas del discurso presentes son la tercera persona del singular, usada para remitir al producto anunciado de forma impersonal, y la inscripción de la segunda persona del singular, usada para tratar al interlocutor con menos distancia.

En la textura discursiva están presentes los elementos deícticos y el mantenimiento del referente se da por procedimiento léxicos y gramaticales. El contenido expandido del texto consiste en: Hotel Ponta do Madeira. Pipa/Tibau do Sul. Solo por el hotel ya merece la pena el paseo. El Hotel Ponta do Madeiro está en frente a la playa, rodeado por una reserva ecológica de la mata atlántica. En el mar delante del hotel las tortugas y delfines tienen su espacio. Un lugar dichoso por la naturaleza [...]. Aquí podemos destacar el uso de sintagmas positivos como: merece, en frente, playa, rodeado, reserva ecológica, mar, delante, espacio, dichoso y naturaleza. El producto visual consiste en la propia imagen del ambiente donde está ubicado el "Hotel Ponta do Madeiro", sus instalaciones internas y externas. El mensaje manifiesto es el propio anuncio del hotel y de los servicios allí ofertados. Ya el mensaje latente connota un lugar tranquilo, relajado, acogedor, rústico y elegante.

Muy próxima a esta técnica está la idea de que la información es "el alma de la propaganda. Nada, nada convence más al consumidor que los hechos" (Barreto, 1978:213). Esto atribuye fiabilidad y credibilidad al producto y por eso aumenta el poder de persuasión del anuncio, como hemos visto anteriormente, así que es importante añadir hechos que informen más sobre lo que se anuncia en el texto publicitario. El ejemplo que presentamos abajo anuncia la "Pousada Tamanduá" y añade informaciones más particulares sobre el producto turístico anunciado. 


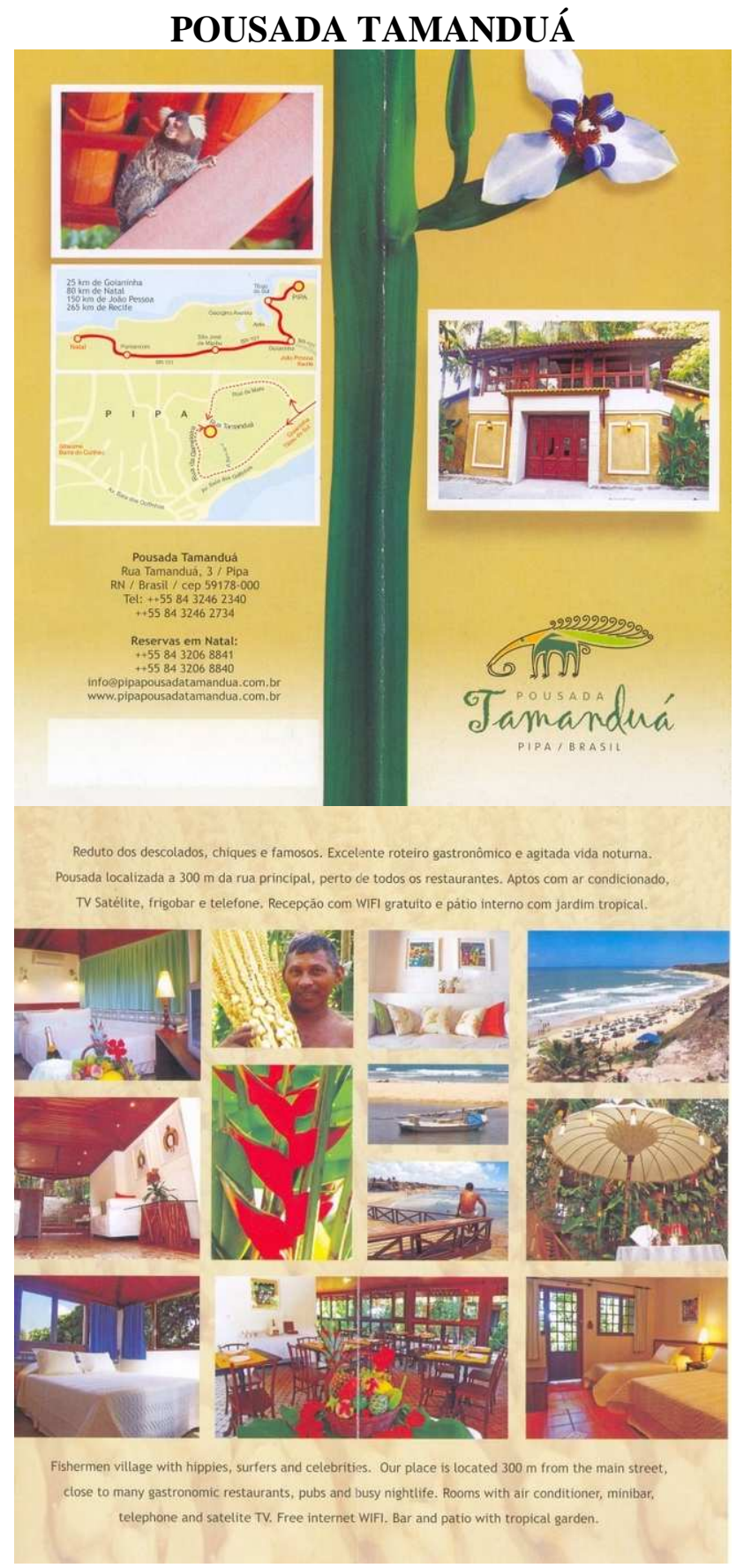

Texto 77

Desde un punto de vista formal, este texto pertenece al género del discurso publicitario y posee una secuencia dominante de texto argumentativo, ya que la descripción funciona más bien como un recurso persuasivo. En su macroestructura figura la descripción de la "Pousada Tamanduá", la presentación de su localización y sus instalaciones externas e internas. La progresión temática de este texto puede ser definida como progresión de tema constante. 
En su componente expandido figura el texto que presentamos a continuación: Pousada Tamanduá. Pipa/Brasil. Reducto de los modernos y famosos. Excelente ruta gastronómica y agitada vida nocturna. Hostal ubicado a 300 metros de la calle principal, cerca de todos los restaurantes. Apartamentos con aire acondicionado, TV satélite, frigobar y teléfono. Recepción con wifi y patio interno con jardín tropical.

El texto fue producido de una forma descriptiva y completamente impersonal. Su acto de habla locutivo consiste en el discurso constituido por el lenguaje verbal escrito y el lenguaje visual; la fuerza ilocutiva en la estrategia de persuasión publicitaria a través de la descripción del producto turístico ofertado y su ubicación; y el efecto perlocutivo tiene como finalidad recibir del interlocutor la confirmación en forma de un acto de compra.

El producto visual consiste en la imagen del logotipo, de las instalaciones internas y externas de la "Pousada Tamanduá", sus vistas, un mapa orientativo y un animal típico de la fauna del Río Grande do Norte. El mensaje manifiesto consiste en el propio anuncio del producto turístico promovido y el mensaje latente connota la idea de un lugar sencillo, en medio a la naturaleza, acogedor y confortable.

Para Barreto la apelación sexual está fuertemente presente en la publicidad, principalmente cuando se desea alcanzar la venta de productos como lencería, productos de cama y baño, ropa femenina y masculina, perfumes, etc. Este autor afirma que "para crear anuncios, buenos anuncios, eficaces, tarde o temprano, o en cualquier momento, se tiene que hacer apelaciones. Ora en una sugerencia, ora en un doble sentido, ora en una invitación explícita” (Barreto, 1978:216). 
PIZZATO PRAIA HOTEL

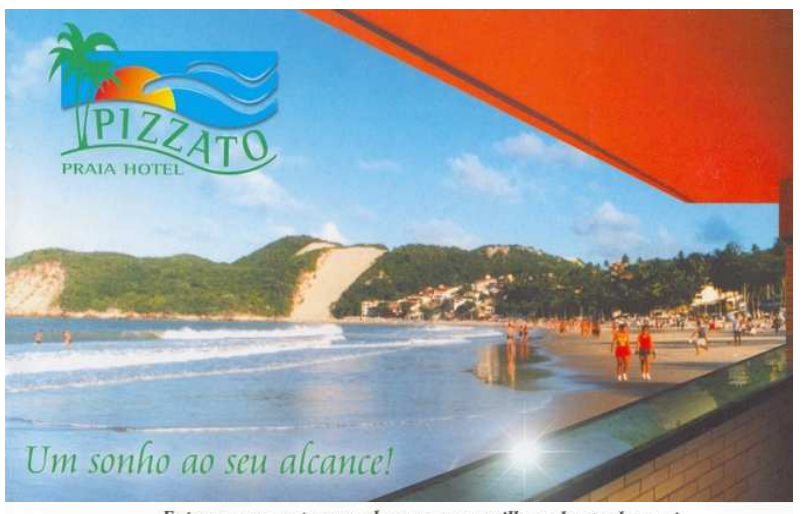

Entregue-se ao prazer de uma maravilbosa bospedagem!

OPizzato Praia Hotel possuit rodos os requisitos para a estadia dos seus sonbos Além de estar localizado na bela e
famosa Praia de Ponta Negra, encontra-se proximo a sbopping centers, feira de artesanalo, bares, ao Centro de OPizzato dispoie de 63 excelentes aros do aeroporto.

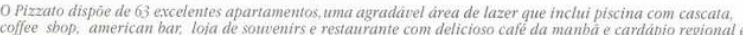

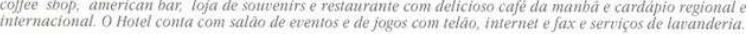

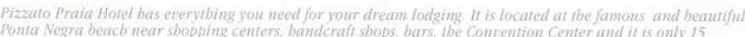
minutes awa) from the airport

Pizzato offers 63 excellemt rooms, a pleasamt amusement area, wbich includes a pooi with cascade, a coffec
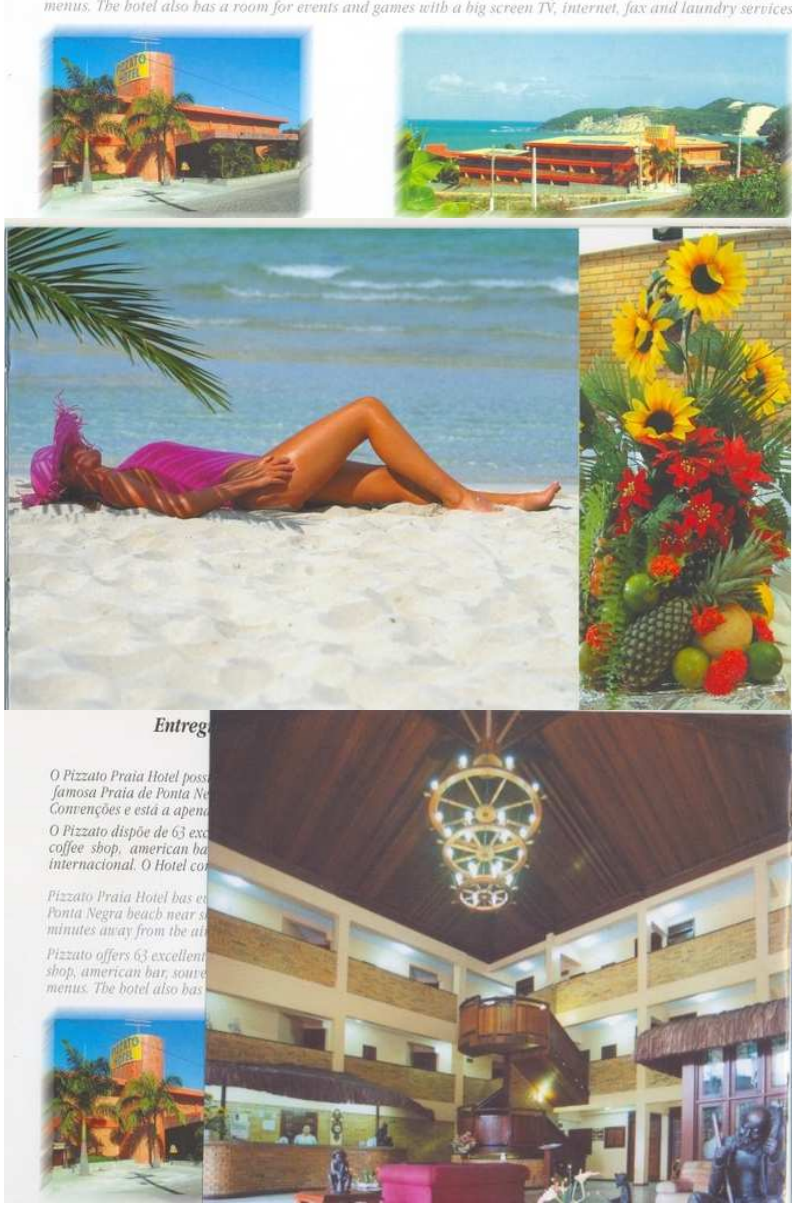


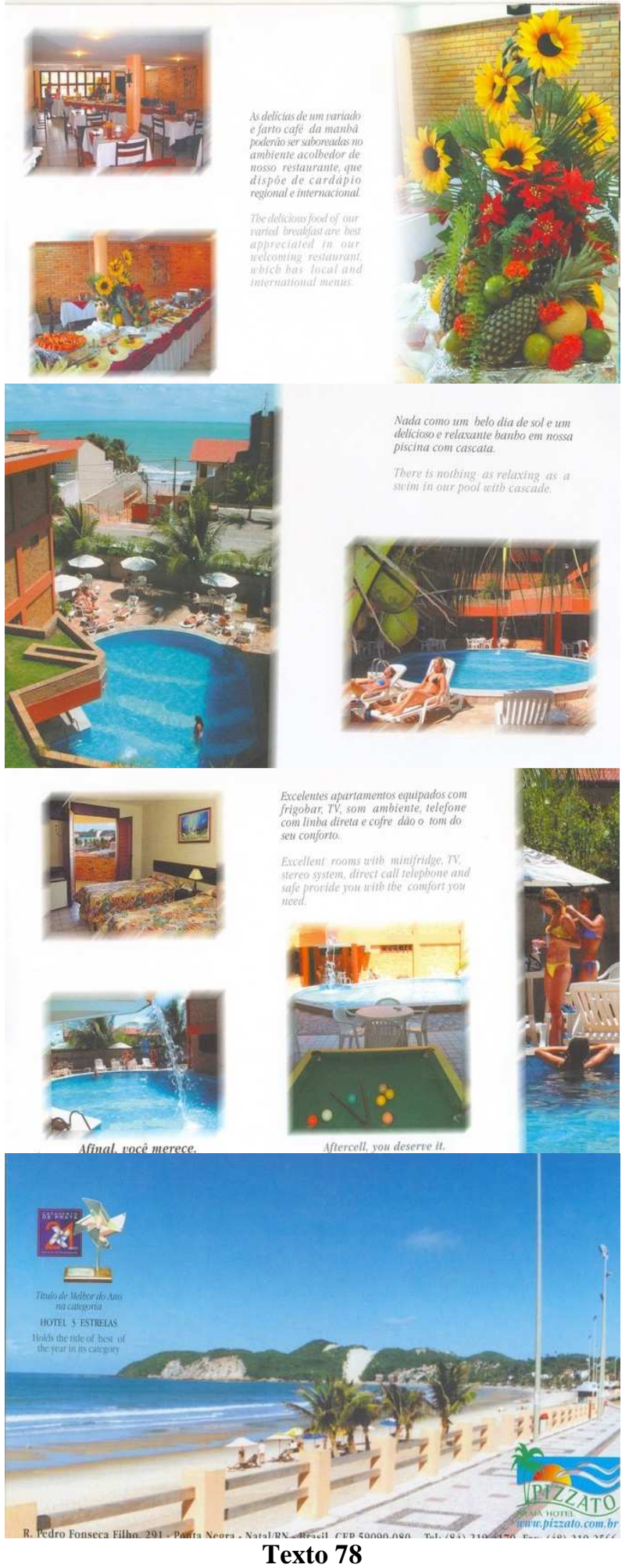

En el caso de la publicidad turística, en general esa apelación es muy sutil, ya que países que eran vendidos como "países exóticos y sensuales", como es el caso de Brasil, están trabajando en contra a este tipo de publicidad. Si observamos el anuncio expuesto anteriormente, aparece la imagen de mujeres en bañador. Consideramos eso como una apelación sexual ya que estas mujeres están solas y en el mismo anuncio no figuran 
fotos de hombres tomando al sol o acompañando a los personajes prototípicos del anuncio.

En la primera página de ese anuncio hay: Pizzato Praia Hotel. Un sueño a tu alcance. Entrégate al placer de un maravilloso hospedaje. El Pizzato Praia Hotel posee todos los requisitos para la estancia de tus sueños. Además de estar ubicado en la bella y famosa playa de Ponta Negra, se encuentra cerca de los centros comerciales, feria de artesanía, bares, centros de convenciones y está a solo 15 minutos del aeropuerto. El Pizzato dispone de 63 excelentes apartamentos, una agradable área de ocio [...].

Desde un punto de vista formal, este texto sigue el formato propio del texto publicitario. En su macroestructura figura la descripción del "Pizzato Praia Hotel", la presentación de su localización, sus servicios y sus instalaciones (internas y externas). La progresión temática de este texto puede ser definida como progresión de tema constante. Las personas del discurso presentes son la tercera persona del singular, que designa al objeto anunciado de forma impersonal, y la segunda persona del singular, que sirve para acotar las distancias entre los interlocutores del acto de habla publicitario.

El contexto de producción de este discurso publicitario sería la ciudad de Natal, que está en la costa de nordeste brasileño donde durante todo el año la temperatura gira en torno de $20^{\circ}$ y $35^{\circ}$ grados. El acto de habla locutivo consiste en el discurso constituido por el lenguaje verbal escrito y el lenguaje visual; la fuerza ilocutiva en la descripción del producto turístico ofertado y su ubicación; y el efecto perlocutivo en la estrategia de persuasión publicitaria que tiene como finalidad recibir del interlocutor la confirmación en forma de un acto de compra.

Ese texto pertenece al género del discurso publicitario y desde un punto de vista de la tipología textual posee una secuencia dominante de texto argumentativo, ya que la descripción funciona más bien como un recurso persuasivo. En la textura discursiva están presentes los elementos deícticos y el mantenimiento del referente se da por procedimiento léxicos y gramaticales. Resaltamos, en ese anuncio, la selección léxica formada por sintagmas positivos como: sueño, mejor, placer, maravilloso, bello, ricuras, sabroso, excelente y relajante. El producto visual del texto 78 consiste en la propia imagen interna y externa de "Pizzato", cuyo mensaje manifiesto consiste en el 
propio anuncio de ese hotel y el mensaje latente connota un ambiente relajado, elegante y confortable.

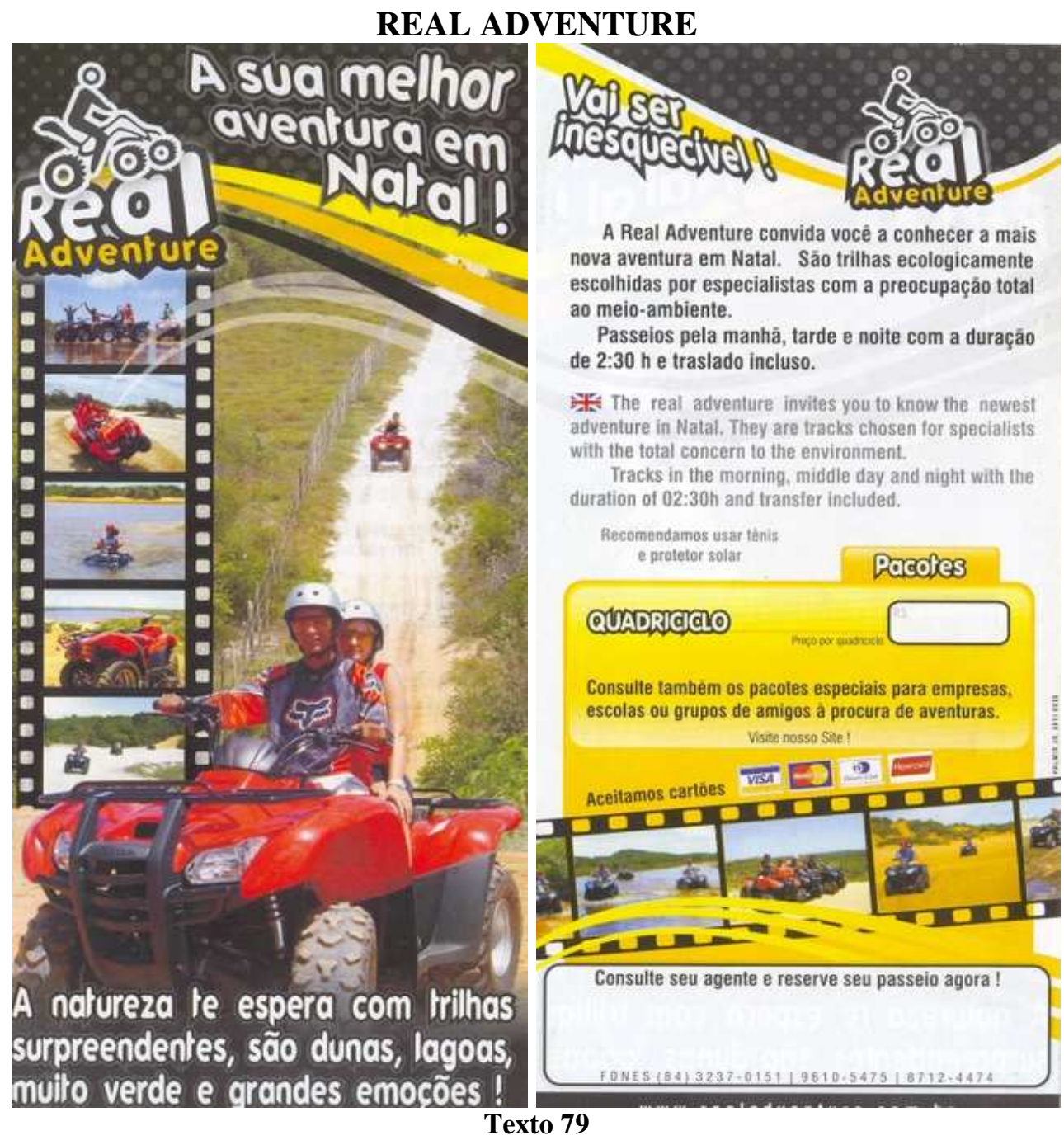

Los testimonios sirven para aumentar la fiabilidad en el producto. Este es un recurso que vende, pues los consumidores se identifican con el discurso simple de una persona que tiene su mismo tipo de vida, y las mismas necesidades. Para esto se debe convocar a "alguien - un consumidor típico del producto - para hablar bien de él". (Barreto, 1978:216). En el caso del anuncio de la publicidad que presentamos arriba, este testimonio está elaborado de forma indirecta cuando presenta la imagen de lo bien que se lo pasan los consumidores del producto turístico anunciado.

El texto 79 dice: Real Adventure. ¡Tu mejor aventura en Natal! La naturaleza te espera con rutas sorprendentes, son dunas, lagos, mucho verde y grandes emociones. Será 
inolvidable. Real Adventure te invita a conocer la más nueva aventura en Natal [...]. Como se puede ver, en la macroestructura de ese texto figura la descripción de la "Real Adventure", la presentación de ese producto turístico y las formas de contactos con esa empresa.

Por lo tanto, su progresión temática puede ser definida como de tema constante. Las personas del discurso presentes son la tercera persona del singular que remite al producto turístico de modo impersonal y la inscripción del "tú", que sirve para acotar las distancias entre los interlocutores del acto de habla publicitario, cuyo acto locutivo consiste en el discurso constituido por el lenguaje verbal escrito y el lenguaje visual; la fuerza ilocutiva en la estrategia de persuasión publicitaria trabajada por medio de la descripción del producto turístico ofertado y su ubicación; y el efecto perlocutivo tiene como objetivo recibir del interlocutor la confirmación en forma de adquisición del producto turístico ofertado.

Así, no queda duda de que ese texto pertenece al género del discurso publicitario y desde un punto de vista de la tipología textual posee una secuencia dominante de texto argumentativo, ya que la descripción funciona más bien como un recurso persuasivo. En la textura discursiva están presentes los elementos léxicos positivos como los sintagmas: mejor, aventura, naturaleza, espera, rutas sorprendentes, mucho verde, grandes emociones, inolvidable, invita, conocer, más у nueva.

$\mathrm{Su}$ producto visual consiste en el logotipo de la "Real Adventure", las fotos del transporte usado para los paseos y fotos de los turistas en todos los ambientes del paseo. El mensaje manifiesto es el propio anuncio del producto turístico que se intenta vender, ya el mensaje latente connota la aventura, la alegría, el ocio y la vida que se puede disfrutar en el turismo de aventura. 


\section{PIAUÍ E RIO GRANDE DO NORTE}

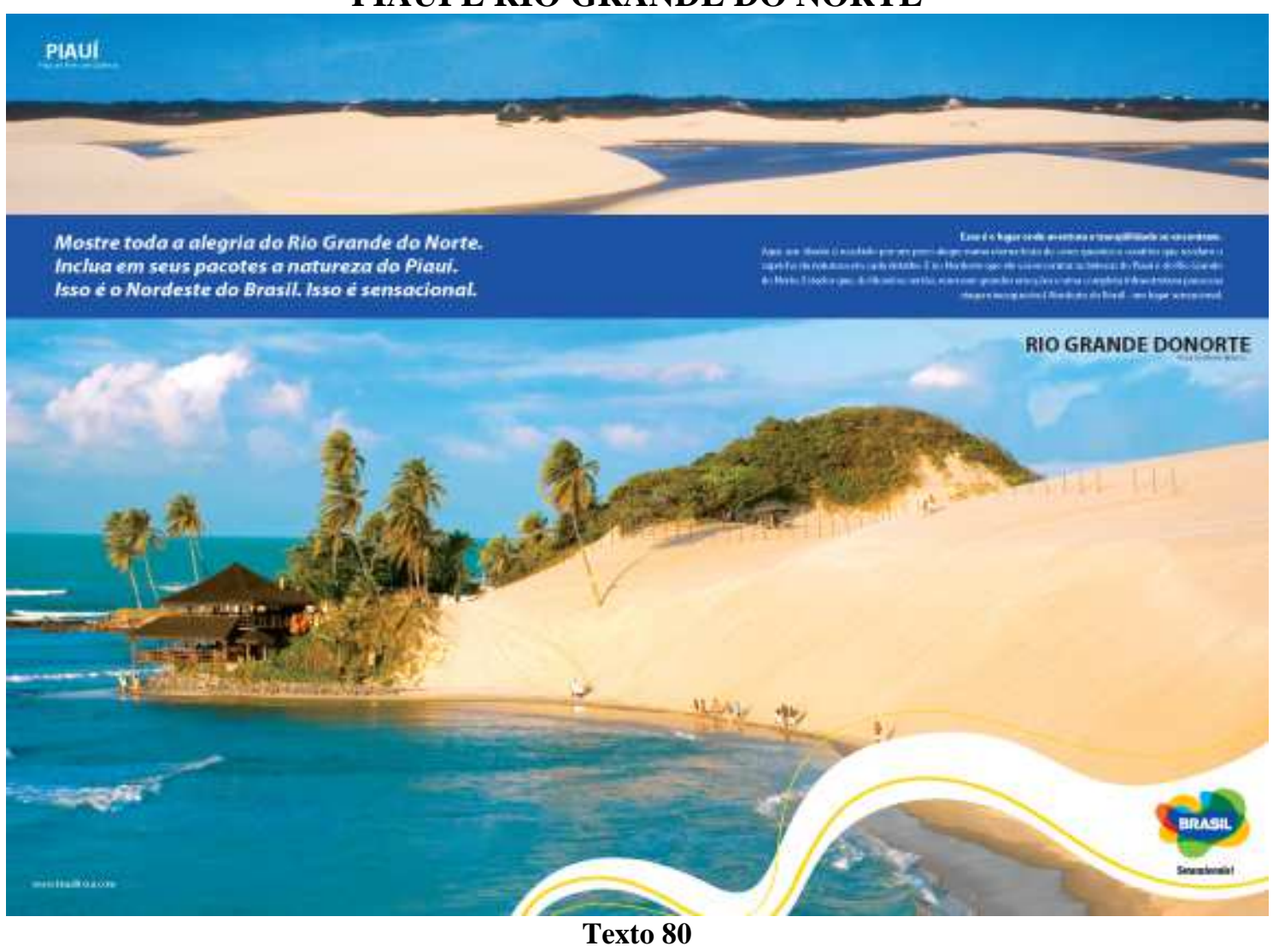

El estímulo de la curiosidad es otro truco de la propaganda porque "todo buen anuncio debe atraer la atención, atrapar el lector" (Barreto, 1978:217). Para ello, este autor recuerda que el título es una buena forma de empezar a despertar el interés del interlocutor por la lectura del texto y la consecuente búsqueda de explicación para el título enigmático.

Debe ser agregado un rótulo al producto, una simple frase de efecto que contribuya en el proceso persuasivo, y también le sirva de identidad, de modo que se aproveche y se explote el producto al máximo y se pueda definir de forma "espectacular, persuasiva, 'un rótulo' que le hará ser leído, que las personas se interesen por comprarlo” (Barreto, 1978:221). El folleto turístico presentado arriba forma parte de una campaña publicitaria del nordeste brasileño nombrada de "Brasil Sensacional", en todos los anuncios de los estados nordestinos era usado como cierre: "Eso es nordeste de Brasil. Eso es Sensacional" como rótulo o frase de efecto. Así, el texto 80 dice: Muestra toda la alegría del Río Grande do Norte. Incluye en tus paquetes turísticos la naturaleza de Piauí. Eso es el Nordeste de Brasil. Eso es sensacional. Brasil Sensacional. Como se 
puede ver, en el texto 80 figura una selección léxica positiva constituida por lexemas como: muestra, alegría, incluye, naturaleza y sensacional.

En ningún momento se dice que uno debe comprar el nordeste brasileño como destino turístico, pero el texto intenta seducir al interlocutor por medio de un texto formado por colores, imágenes, contenido verbal expandido y sentido. La imagen de la playa de Genipabu usada para anunciar Natal es deslumbrante, y asociada al texto escrito despierta muchas connotaciones en la mente del interlocutor al que se tutea como una forma de acotar las distancias entre los polos del acto de comunicación publicitario.

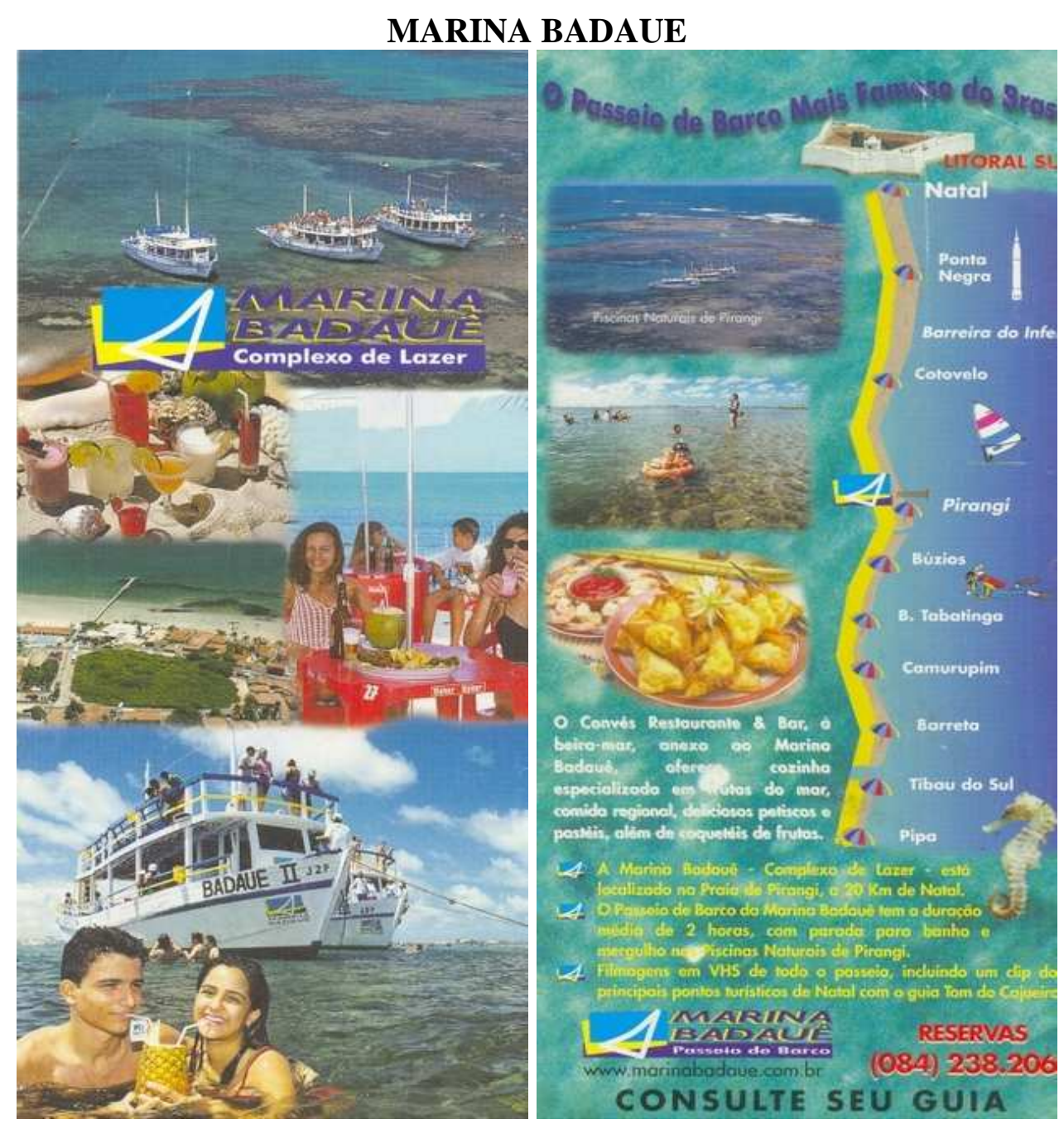

Texto 81

Por último, existe el uso de la propaganda comparada, técnica conocida como hardselling, que utiliza la comparación con la competencia de modo que quede clara la 
superioridad del producto anunciado. Sin embargo, hay que tener cuidado con esta comparación para que no se configure como un procedimiento antiético e inadecuado.

En la macroestructura del texto 81 figura la descripción del "Marina Badauê Complexo de Lazer" y la presentación de su localización. La progresión temática de este texto puede ser definida como una progresión de tema constante. La persona del discurso presente es la inscripción de la tercera persona del singular que representa el objeto del anuncio y atribuye un carácter de impersonalidad al texto.

El contenido expandido dice: Marina Badauê Complexo de Lazer. El paseo de Barco más famoso de Brasil. Lo que implica la comparación de ese paseo de barco con otros ofrecidos en Brasil y la elevación al nivel de máxima cualidad porque es el mejor. El acto de habla locutivo consiste en el discurso constituido por el lenguaje verbal escrito y el lenguaje visual; la fuerza ilocutiva en la estrategia de persuasión publicitaria presente en la descripción del producto turístico ofertado y su ubicación; y el efecto perlocutivo consiste en el objetivo último de toda publicidad: recibir del interlocutor la confirmación en forma de un acto de compra.

El producto visual consiste en la propia logomarca del "Marina Badauê", el punto de interés turístico visitado, las comidas y bebidas de la degustación en el paseo y un mapa orientativo del litoral de Natal. El mensaje manifiesto es el propio anuncio del producto turístico ofertado y el mensaje latente es la felicidad y la relajación de las personas que participan de este paseo. Además de la exuberancia natural del lugar visitado que forma todo un escenario perfecto y de ensueño.

Así que, con base en el marketing de la empresa y con los cuidados necesarios se puede elegir el hard-selling como técnica persuasiva, siempre que sea "un recurso del anunciante pequeño de luchar por igualarse al grande. Es recurso de producto que está todavía en la fase de guerrilla comercial contra la famosa competencia, que domina el mercado" (Barreto, 1978:228). 


\subsection{La argumentación publicitaria}

Los mitos fundacionales de la argumentación como una ciencia humana se remontan al siglo V a. C. cuando Córax y Tisias compusieron el primer método razonado. No obstante, Heródoto atribuye la creación de la argumentación a los egipcios y las primeras reflexiones sobre este tema son atribuidas a Aristóteles. Además, las aportaciones sofistas como la antifonía, la paradoja, lo probable y la dialéctica también son importantes a esta ciencia.

Las bases de la teoría de la argumentación empiezan a asentarse a finales de siglo XIX en consonancia con las circunstancias políticas y sociales y el consecuente interés por la argumentación y el lenguaje persuasivo. Con la rehabilitación de la retórica en la década de 1950, surge la nueva retórica (o teoría de la argumentación) de la que forma parte la retórica de la publicidad. Por lo tanto, la argumentación puede ser relacionada con la retórica del mismo modo que la persuasión tiene su carácter retórico. Además, "tradicionalmente se considera la teoría de la argumentación como la parte fundamental del sistema retórico" (Plantin, 2002:13).

Partiendo de estos conocimientos previos sobre la argumentación, creemos que es posible establecer un nexo entre la publicidad, la retórica, la persuasión y la argumentación, ya que esta "funciona en situación, en la vida corriente. En la esfera social, está en contacto con la economía (permite hacer publicidad, ayuda a vender), con lo judicial (procesos), con la política y con el poder" (Plantin, 2002:25).

CH. Perelman y L. Olbrechts-Tyteca (1989) conciben que la persuasión va más allá que el convencimiento y afirman que "para aquél que se preocupa por el resultado, persuadir es más que convencer, al ser la convicción solo la primera fase que induce a la acción" (Perelman y Olbrechts-Tyteca, 1989:65-66). Por eso comprendemos la persuasión posterior a la argumentación. Estos mismo autores proponen una distinción entre estos dos actos y afirman que "la distinción que proponemos entre persuasión y convicción da cuenta, de modo indirecto, del vínculo que a menudo se establece, aunque de forma confusa, entre persuasión y acción, por una parte, y entre convicción e inteligencia, por otra" (Perelman y Olbrechts-Tyteca, 1989:69). 
En La Argumentación en la Lengua de Jean-Claude Anscombre y Oswald Ducrot se presenta el marco lingüístico en el que se inscribe la Teoría de la Argumentación o Teoría de los Topoi. En esta obra esos autores explican la evolución de dicha teoría. La hipótesis de L'argurmentation dans la Langue "defiende que la argumentación está inscrita en la lengua, en las frases mismas" (Jean-Claude Anscombre y Oswald Ducrot, 1994:18).

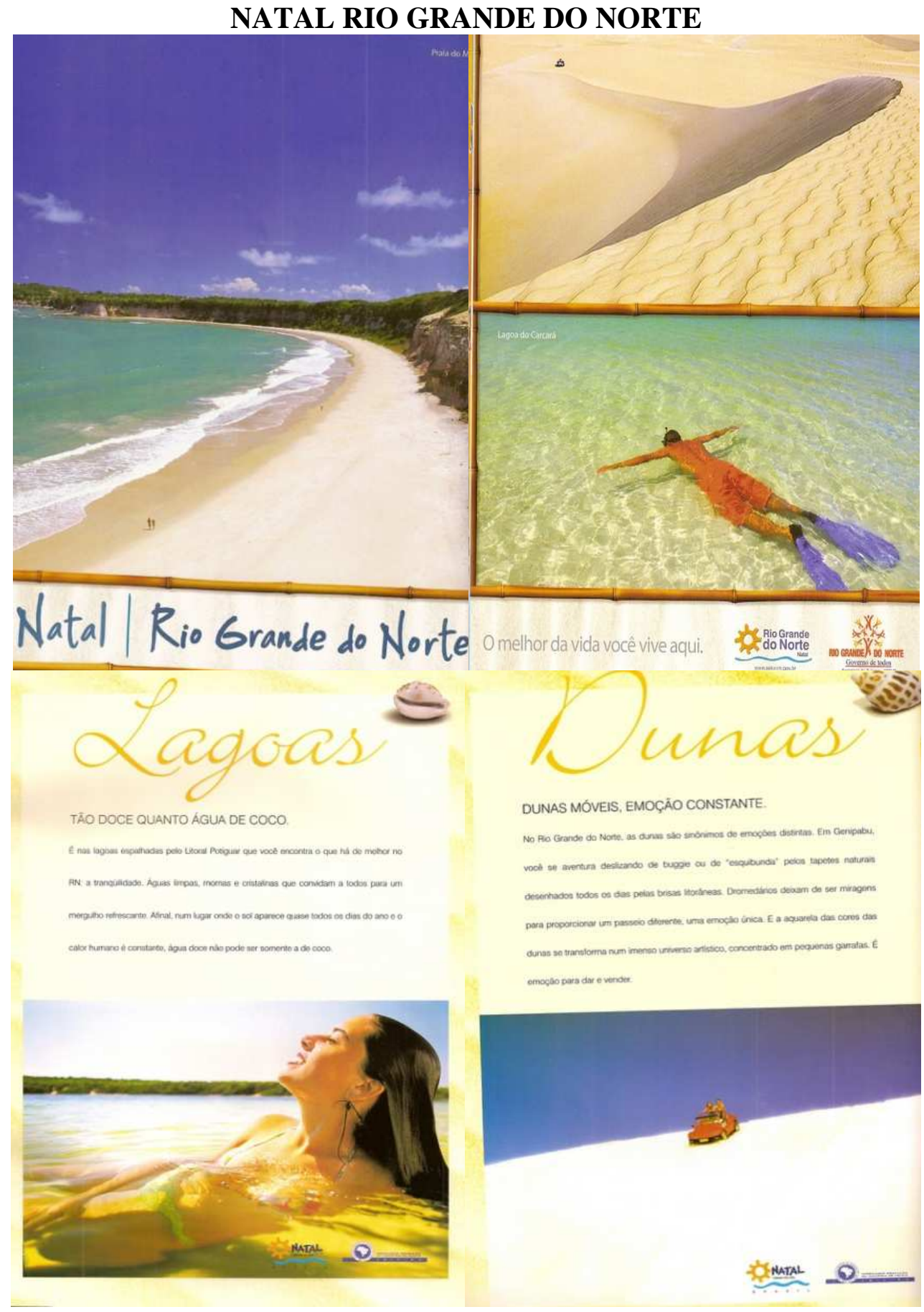




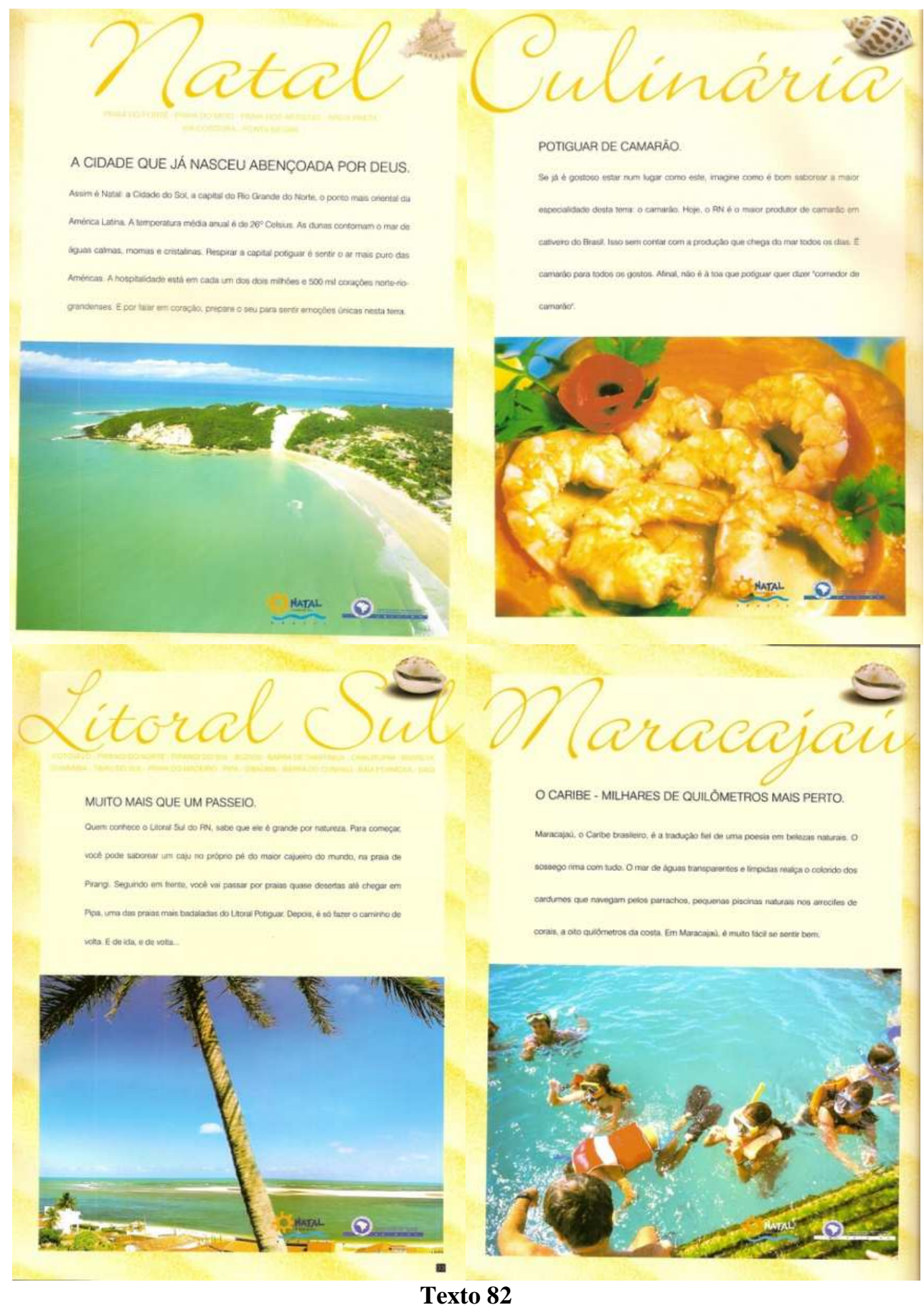

El texto 82, expuesto arriba, anuncia Natal como destino turístico y para ello formula la proposición: Natal, lo mejor de la vida se vive aquí. Observemos que en este texto publicitario, tanto la imagen como el componente verbal expandido tienen un papel argumentativo, en el sentido que se unen para crear pruebas irrefutables y racionales para corroborar el enunciado que se ha demostrado. A partir de la proposición presentada por nuestro anuncio en cuestión, se puede llegar al siguiente silogismo: 
Lo mejor de la vida se vive en Natal.

Voy a visitar Natal.

Luego voy a vivir lo mejor de la vida.

Las dos primeras imágenes componen el enunciado, que podemos considerar como un argumento que no tiene una sola conclusión, sino varias, a saber: debe usted visitar Natal, debe usted comprar este destino turístico, debe usted conocer esta ciudad, etc. Lo mismo ocurre con los demás textos que forman parte del mismo folleto que anuncia Natal como un destino turístico y va mostrando y describiendo por qué uno debe visitar esta ciudad brasileña: los atributos de esta ciudad, su culinaria, su litoral y lo atractivo de sus playas.

Según Perelman y Olbrechts-Tyteca (1989:46), al argumentar o influir a través del discurso "ya no es posible ignorar por completo, al creerlas irrelevantes, las condiciones psíquicas y sociales sin las cuales la argumentación no tendría objeto ni efecto. Así pues, toda argumentación pretende la adhesión de los individuos y, por tanto, supone la existencia de un contacto intelectual". Merece la pena observar, por lo tanto, el ejemplo de publicidad expuesto arriba que anuncia Natal como destino turístico, sobre todo lo que sirve de complemento para el enunciado Natal, lo mejor de la vida se vive aquí, es decir, todo lo que sirve para validar la proposición inicial como una verdad. Dicho de otro modo, las seis páginas del texto que intentan corroborar por qué lo mejor de la vida se vive en Natal.

Las primeras páginas del anuncio muestran dos imágenes de Natal en las que figuran fotos de la playa, dunas y aguas transparentes. A continuación, se expone la foto de una chica en un lago de aguas transparentes en el que figura el titular Lagos y el componente expandido que dice: Tan dulce como agua de coco. Es en los lagos ubicados por el litoral potiguar que encuentras lo que hay de mejor en el RN: tranquilidad, aguas limpias, tibias y transparentes que invitan a todos a un baño refrescante. Porque en un lugar donde el sol aparece casi todos los días del año y el calor humano es constante, agua dulce no puede ser solamente la del coco.

A continuación se expone la imagen de una duna bajo el titular Dunas. En el componente expandido de esta parte del anuncio en cuestión figura: Dunas móviles, 
emoción constante. En Río Grande do Norte, las dunas son sinónimos de emociones distintas. En Genipabu puedes aventurarte deslizando [...]. La acuarela de los colores de las dunas se transforma en un inmenso universo artístico, concentrado en pequeñas botellas. Es emoción para dar y vender.

En las cuatro últimas páginas de este anuncio se presenta, respectivamente, Natal, culinaria, litoral sur, Maracajaú. Para ello sigue el mismo estilo del componente expandido presentado anteriormente y se afirma: Natal. La ciudad ya nació bendecida por Dios. Así es Natal: ciudad del sol, capital del Rio Grande do Norte, el punto más oriental de América Latina. Su temperatura media anual es de $26^{\circ}$. Las dunas contornan el mar de aguas tranquilas, tibias y transparentes. Respirar en la capital potiguar es sentir el aire más puro de las Américas [...]. En las últimas páginas del texto 82 se afirma: culinaria. Potiguar de gambas; Litoral sur. Mucho más que un paseo; Maracajaú. El Caribe millares de kilómetros más cerca.

Así, estamos delante de un texto publicitario que persuade por medio de argumentos diversos y de un lenguaje artísticamente elaborado, además de imágenes fabulosas que deslumbran la vista del interlocutor, que no se puede quedar impasible frente a un texto cuyo efecto perlocutivo es la acción de compra del producto turístico anunciado, o sea, Natal, como destino turístico.

Los recursos retóricos como la comparación tan dulce como agua de coco; y la metáfora ciudad del sol figuran en todo el texto que está fraguado por medio de un léxico positivo compuesto por sintagmas como: mejor, vida, lagos, dulce, agua, coco, litoral, encuentras, hay, tranquilidad, aguas limpias, tibias, transparentes, invitan, baño refrescante, sol, aparece, calor humano, dunas móviles, emoción, constante, puedes, aventurarte, deslizando, acuarela, dar, vender, bendecida, mar, respirar, aire, puro, paseo, más y cerca.

En todo el texto se usa un lenguaje muy sencillo y se tutea al interlocutor, lo que sirve para disminuir las distancias entre los polos del acto de habla publicitario. También figura la presencia de frases hechas como para dar y vender. ¿Por qué se trata de un texto persuasivo? Pues porque es un texto de fácil comprensión, que presenta varios ganchos, está elaborado por una mezcla de códigos y un lenguaje elogioso. 
NORDESTE DO BRASIL

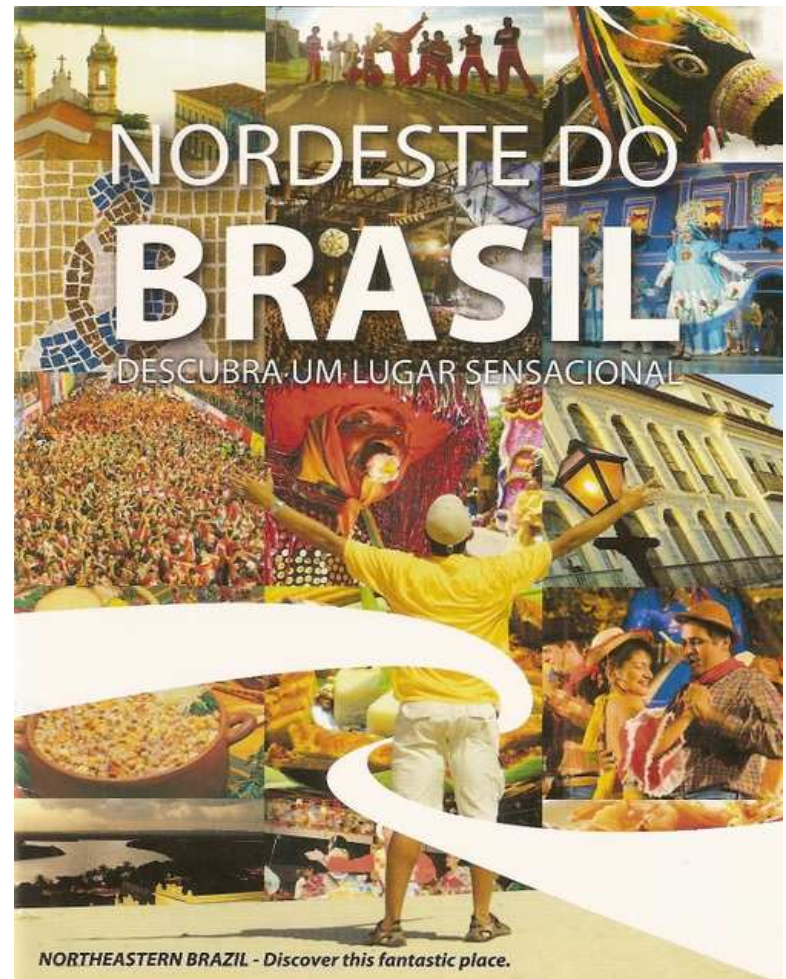

NORTHEASTERN BRAZIL - Discover this fantastic place.

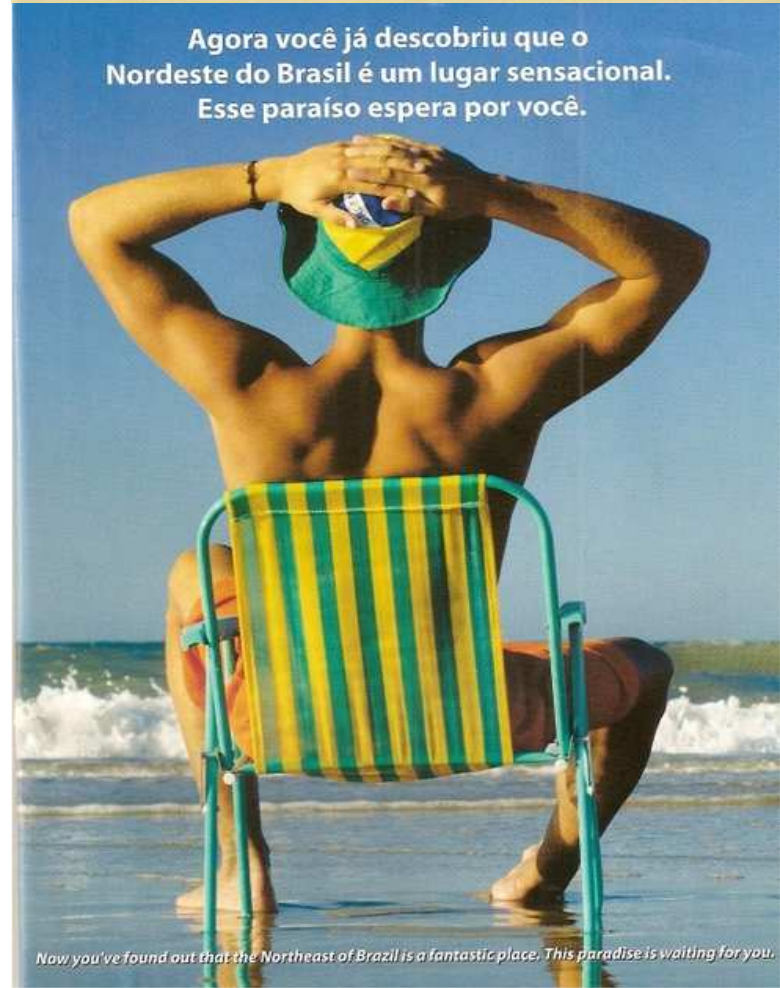

Texto 83

Como ya hemos visto anteriormente, la argumentación puede ser trabajada en "una secuencia razonable, por lo tanto, podemos asociarla a los modos de la retórica clásica en el sentido aristotélico. En la persuasión por la vía periférica, el destinatario dedica poca atención al mensaje, y se considera que no se envuelve" (Fischer, 2007:07), por lo 
tanto, esas dos ciencias se distinguen, pero no se anulan, con lo cual, la publicidad se beneficia de ambas para conquistar su público. Y como afirman Perelman $\mathrm{CH}$. y Olbrechts-Tyteca, L. (1989:69) "es comprensible que el matiz entre los términos convencer y persuadir sea siempre impreciso y que, en la práctica, se suprima”.

El texto 83 anuncia el nordeste brasileño como un producto turístico. Luego, en la portada del anuncio, está el enunciado Nordeste do Brasil. Descubre un lugar sensacional, en el que se comprende que nordeste do Brasil es un lugar sensacional consiste en la proposición. Esta idea es desarrollada en la presentación de este anuncio cuyo cierre consiste en la frase: ahora que ya descubriste que el Nordeste de Brasil es un lugar sensacional. Ese paraíso espera por ti. Con lo cual el interlocutor puede formular el silogismo:

El nordeste de Brasil es un lugar sensacional;

Voy a visitar el nordeste de Brasil;

Luego voy a un lugar sensacional.

Además, el interlocutor puede inferir los enunciados: el nordeste de Brasil es sensacional; el nordeste de Brasil es un paraíso; el nordeste de Brasil espera por ti. Todos esos enunciados pueden ser considerados como un argumento que no tiene una sola conclusión, sino varias, tales como: debe usted visitar el nordeste de Brasil, debe usted comprar este destino turístico, debe usted conocer esta región, etc. 
TAM VIAGENS RECEPTIVO

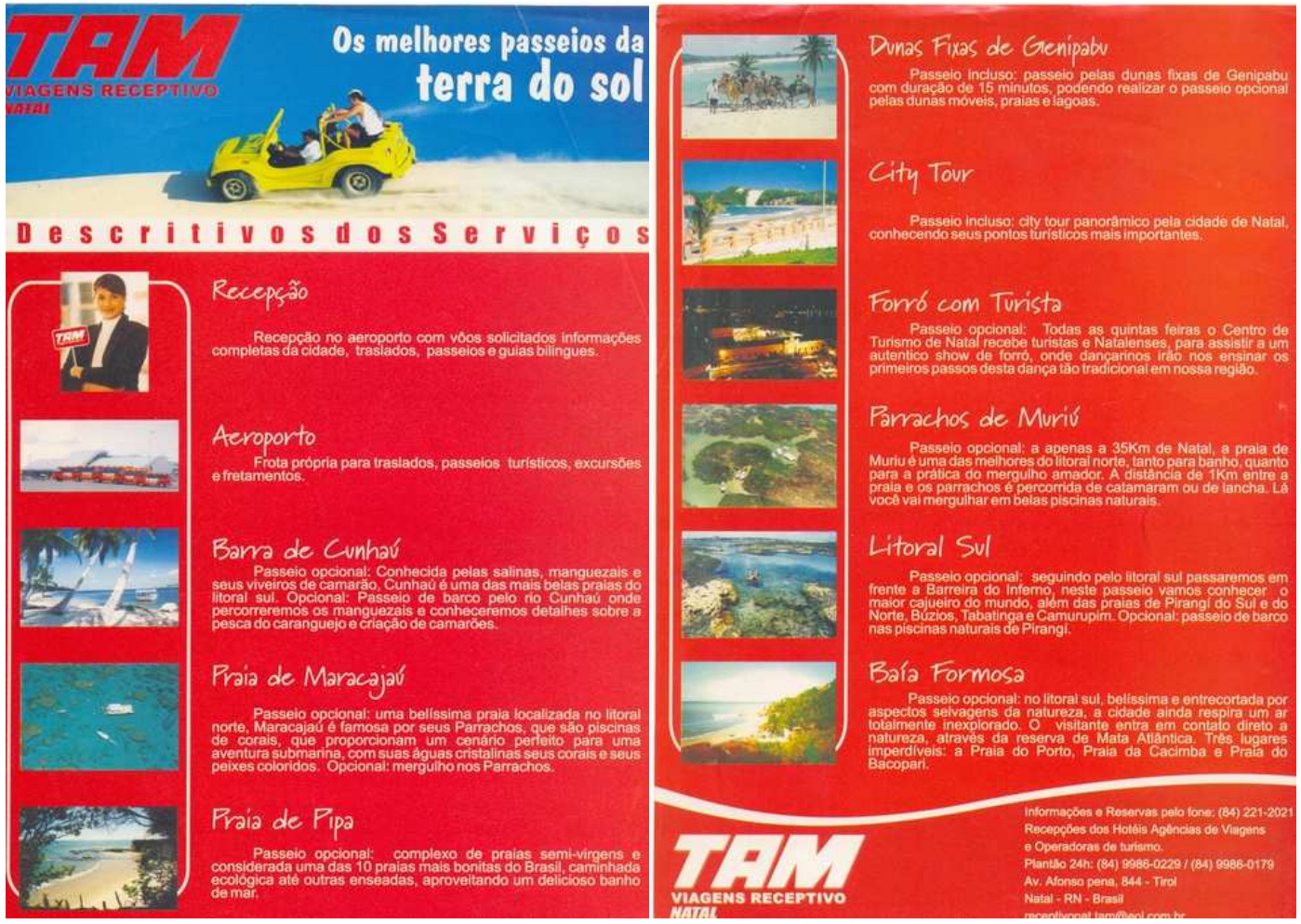

Texto 84

Como hemos visto en Castillo (S/d), la real intencionalidad de la publicidad es direccionar su auditorio a la compra de un determinado producto, por eso se dice que todo anuncio publicitario trae consigo una superestructura argumentativa latente para convencer o, por lo menos, persuadir. Así que sería incongruente dividir la retórica de la persuasión y de la argumentación, tampoco sería congruente alejar esas dos formas de convencimiento de la publicidad, vista como la retórica contemporánea.

La teoría de la argumentación está ubicada dentro de la tradición francesa. Las bases de este enfoque se fundamentan en los estudios de J. C. Anscombre y O. Ducrot, cuya concepción de la argumentación "es un rasgo constitutivo de numerosos enunciados, el que no se los pueda emplear sin pretender orientar al interlocutor hacia un tipo de conclusión (por el hecho de que se excluye otro tipo de conclusión)" (Anscombre y Ducrot, 1994:48).

Argumentar es secuenciar razonamientos a favor o en contra de un determinado objetivo. Para Escandell (2008:94), se han comprendido por lo menos dos cosas distintas como argumentación, en función del ámbito en el que se relaciona este término porque "desde una perspectiva retórica, la argumentación comprende el conjunto de 
estrategias que organizan el discurso persuasivo; desde una perspectiva lógica, una argumentación es un tipo de razonamiento".

En el texto 84, el conjunto de estrategias que organizan el discurso persuasivo defienden la proposición de que la empresa de viajes Tam es el lugar ideal para comprar Natal como producto turístico. Para eso parte del argumento de excelencia del producto: TAM viajes receptivos ofrece los mejores paseos de la tierra del sol. Luego, en el propio anuncio, se aclaran cuáles son esos paseos y por qué uno debe comprar su viaje a Natal por la agencia Tam, a saber: recepción, aeropuerto, barra de cunhaú, Praia de maracajaú, Praia de pipa, dunas fijas de Genipabu, city tuor, forró con turista, parrachos de muriú, litoral sul y baía Formosa.

Desde un punto de vista formal, este texto sigue el formato propio del texto publicitario. En su macroestructura figura la descripción de la "Tam Viagens e Receptivo", sus productos turísticos, su dirección y forma de contacto. La progresión temática de este texto puede ser definida como progresión de temas derivados. La persona del discurso presente es la inscripción de la tercera persona del singular, usada para referirse al producto anunciado de forma impersonal.

El acto de habla locutivo consiste en el discurso constituido por el lenguaje verbal escrito y el lenguaje visual; la fuerza ilocutiva en la estrategia de persuasión publicitaria elaborada por medio de la descripción del producto turístico ofertado y su ubicación; y el efecto perlocutivo persigue el objetivo de cualquier anuncio publicitario: recibir del interlocutor la confirmación en forma de un acto de compra. En la textura discursiva están presentes los elementos léxicos positivos por medio de sintagmas como: viajes, receptivo, ofrece, mejores, paseos, sol, dunas y litoral.

El producto visual consiste en la propia imagen del logotipo de la Tam y diez fotos de cada uno de los productos anunciados. El mensaje manifiesto es el anuncio de los productos turísticos ofertados y el mensaje latente es la variedad y la buena calidad de esos productos. De modo que todo el anuncio se preocupa por el público objetivo, ya que como muy bien apunta Perelman CH. y Olbrechts-Tyteca, L. (1989:53) "para que se desarrolle una argumentación, es preciso, en efecto, que le presten alguna atención 
aquellos a quienes les está destinada. La mayor parte de los medios de publicidad y de propaganda se esfuerzan, ante todo, por atraer el interés de un público".

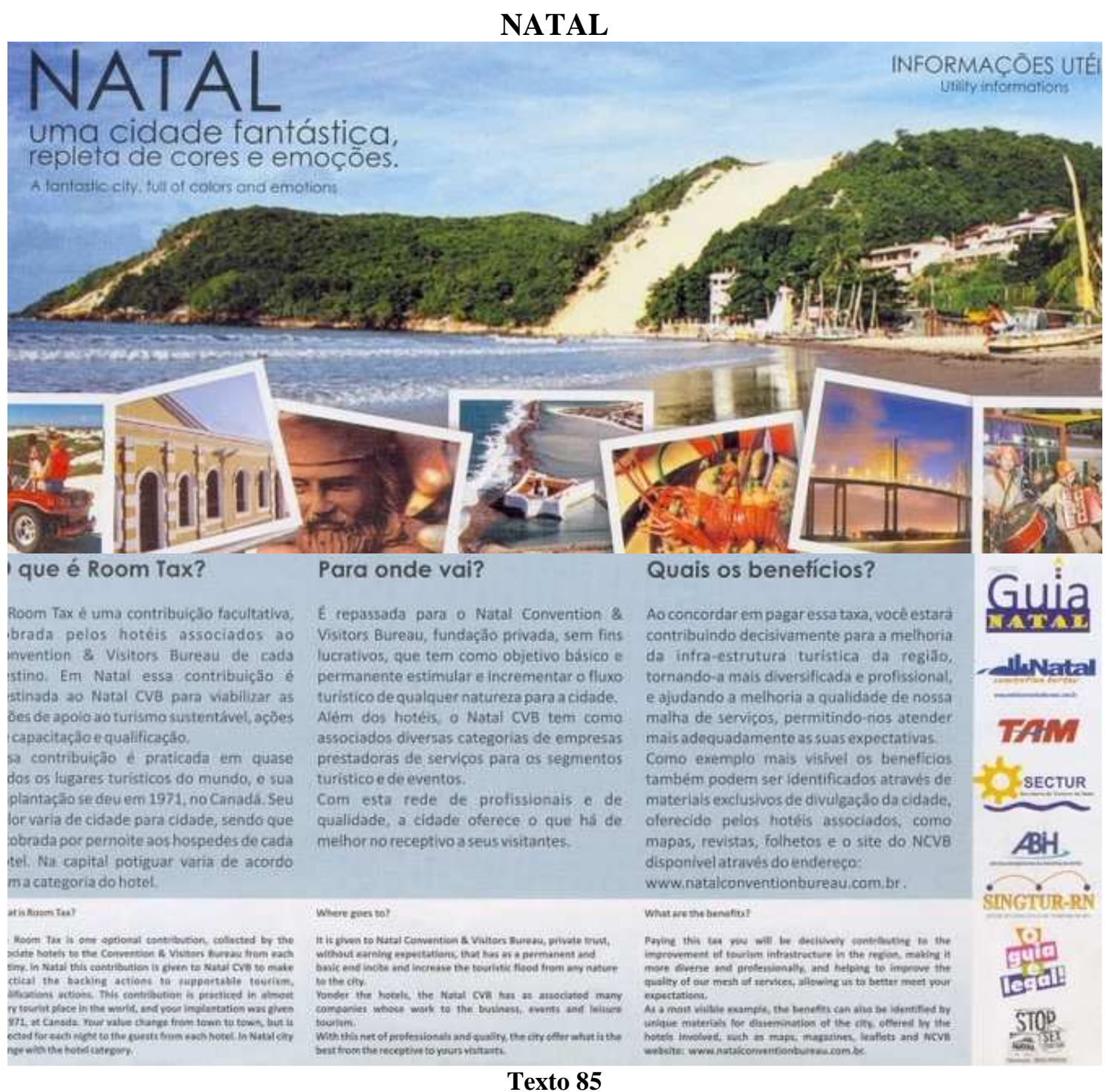

Las concepciones antiguas y clásicas de la argumentación son convergentes en el sentido de que todas la conciben como "una técnica consciente de programación de los dispositivos discursivos" (Plantin, 2002:109). El acto de argumentar consiste en un acto ilocutivo como afirma Escandell (2008:96) cuando dice que la argumentación "es, en el fondo, un tipo de acto ilocutivo realizado por un emisor cuando quiere hacer admitir una determinada conclusión a su interlocutor".

De ese modo, está claro que el gran objetivo de toda argumentación es lograr la adhesión de un auditorio para que produzca una acción positiva, o sea, que el efecto 
perlocutivo de la argumentación sea la producción de un acto, en el caso de la publicidad, el acto de compra del producto o servicio anunciados. Por eso, no se puede olvidar que "todo discurso va dirigido a un auditorio" Perelman CH. y OlbrechtsTyteca, L. (1989:38).

A la teoría de la argumentación le importa la adhesión del auditorio y Perelman CH. y Olbrechts-Tyteca, L. (1989:55) señalan que les parece preferible "definir el auditorio, desde un punto de vista retórico, como el conjunto de aquellos a quienes el orador quiere influir con su argumentación". Por eso el concepto de auditorio es fundamental para el discurso publicitario, como ya hemos visto anteriormente, sobre todo en el momento contemporáneo, ya que estamos frente al siglo de la publicidad y de la propaganda.

En la argumentación el orador que quiera persuadir a un determinado auditorio necesita adaptarse a él. Por eso, frente al siglo de la publicidad, se hace uso de los más diversos recursos del lenguaje para convencer a un determinado auditorio, que puede muy bien ser dividido en función de sus grupos sociales. El tuteo y la adaptación del registro lingüístico al público objetivo es una de las estrategias más comunes, como hemos visto anteriormente, además del uso de un léxico positivo.

En el texto 85 el acto de habla locutivo consiste en el discurso constituido por el lenguaje verbal escrito y el lenguaje visual; la fuerza ilocutiva en la en la estrategia de persuasión publicitaria presente en la descripción del producto turístico ofertado y su ubicación; y el efecto perlocutivo consiste en la producción de un acto de compra por medio del interlocutor/comprador.

Se parte de la premisa de que Natal es una ciudad fantástica, llena de colores y emociones, por lo tanto debe usted visitar Natal. Desde un punto de vista formal, ese texto sigue el formato propio del texto publicitario. En su macroestructura figuran las informaciones útiles para los visitantes de Natal como producto turístico. La progresión temática de este texto puede ser definida como progresión de temas derivados.

Tanto el componente verbal como el de imagen constituyen un mensaje elogioso que destacan la excelencia de Natal como producto turístico. El componente textual 
expandido está fraguado por medio de un lenguaje sencillo en el que figuran lexemas como: fantástica, llena, colores y emociones, es decir, una selección léxica positiva usada para convencer al interlocutor que es tratado por medio del tuteo, lo que crea una determinada familiaridad y confianza entre los interlocutores del acto de habla publicitario.

El producto visual presenta una diversidad de imágenes deslumbrantes de diversos colores y consiste, principalmente, en las imágenes de los principales puntos de interés turístico de Natal, frente a las que el interlocutor no puede quedar imparcial. Su mensaje manifiesto es la propia instrucción de informaciones útiles al visitante y el mensaje latente es de una ciudad bonita y acogedora.

Partiendo de esta constatación empírica, la teoría de la argumentación enfoca el estudio de los elementos lingüísticos explícitos, de los cuales pueden hacerse uso los hablantes para organizar su enunciado de forma argumentativa. Escandell (2008:98), por su parte, muestra que "la teoría de la argumentación se ocupa de los medios lingüísticos (explícitos) de que puede valerse un hablante para orientar argumentativamente sus enunciados".

Desde esa óptica, se puede afirmar que la argumentación está presente a cada momento en el habla, como manifiestan Anscombre y Ducrot (1994:196) cuando afirman que la argumentación, "lejos de ser un fenómeno accidental y limitado a una forma particular de actividad intelectual, está presente a cada momento en el habla, lo que, ciertamente, no prueba que esa argumentación esté señalada en el interior de las frases, pero invita a considerar esa hipótesis". 
NATAL VANS LOCAÇÕES E TURISMO
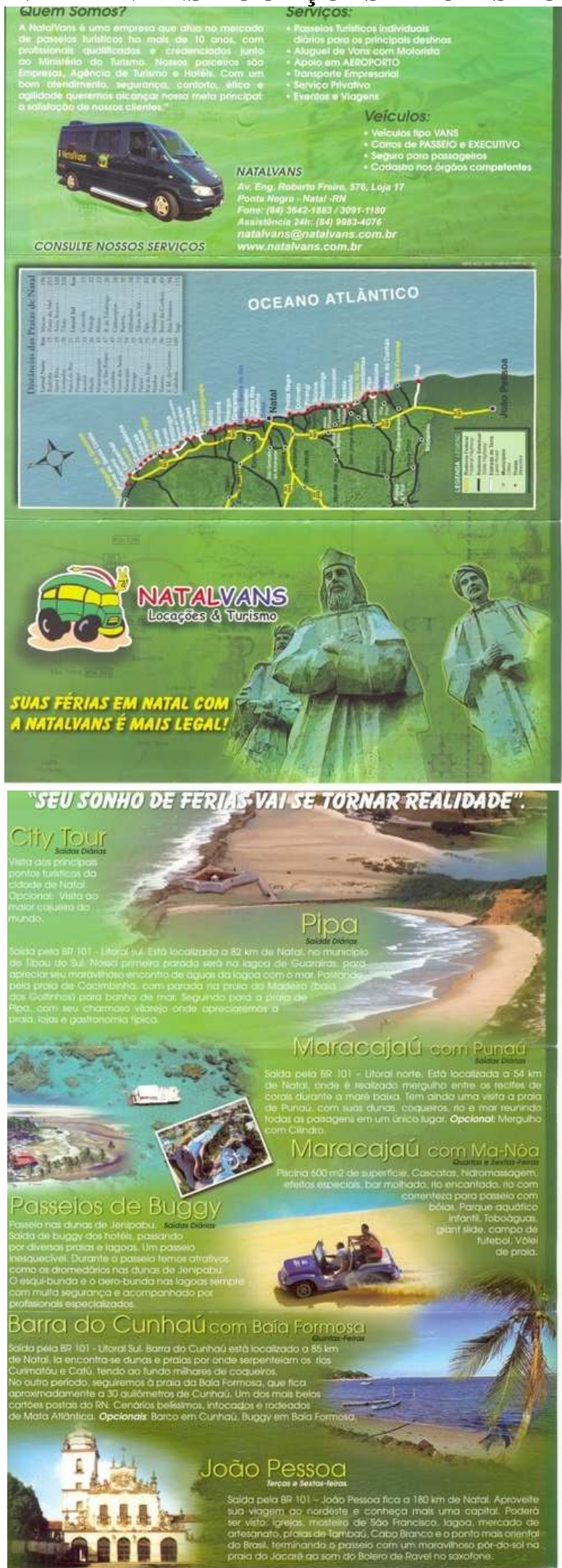

Texto 86 
Para Plantin (2002:118), "la teoría de la argumentación en la lengua muestra con una fuerza particular que el lenguaje no es transparente, y que la argumentación, definida como la lógica de encadenamientos de enunciados, no puede reducirse a una lógica de pensamiento o de los objetos".

Perelman CH. y Olbrechts-Tyteca, L. (1989) abordan el tema de la neorretórica, también conocida como teoría de la argumentación. Con respecto a este tema, conciben una variedad de técnicas argumentativas entre las cuales figuran técnicas como el ridículo y su papel en la argumentación; los argumentos de comparación; la argumentación por el sacrificio; el argumento del despilfarro; el argumento de la autoridad; el grupo y sus miembros; la argumentación por el ejemplo; la ilustración; el modelo y el antimodelo y el ser perfecto como modelo.

El texto 86 hace uso de enunciados como tus vacaciones en iNatal con Natalvans es más guay! Y Tu sueño de vacaciones se volverá realidad para describir los servicios prestados por la empresa de transportes turísticos Natalvans. Desde un punto de vista formal, este texto sigue el formato propio del texto publicitario, en el que se unen imágenes, colores, componente expandido verbal y significado para crear un discurso elogioso y artísticamente elaborado.

En su macroestructura figura la descripción de la "Natalvans Locações \& Turismo", la descripción de sus productos, sus servicios, sus coches y su dirección. La progresión temática de este texto puede ser definida como progresión de tema constante. Las personas del discurso presente son la segunda y la tercera persona del singular, de modo que se presenta el producto de modo impersonal y se dirige a los interlocutores con una cercanía por medio del tuteo que aporta más confianza entre los polos del acto de comunicación publicitaria.

El acto de habla locutivo consiste en el discurso constituido por el lenguaje verbal escrito y el lenguaje visual; la fuerza ilocutiva se configura como la descripción del producto turístico ofertado y su ubicación, lo que corresponde a la estrategia de persuasión publicitaria; por último, el efecto perlocutivo tiene como finalidad recibir del interlocutor la confirmación en forma de un acto de compra. 
En los procedimientos léxicos se puede encontrar el predominio del uso de verbos, sustantivos y adjetivo, de modo que se adopta una selección léxica positiva que presenta sintagmas como: más, guay, sueño, vacaciones, volverá y realidad. El producto visual, por su parte, consiste en la propia imagen del logotipo de la "Natalvans Locações \& Turismo", la imagen de los tres reyes magos que están en la entrada de la ciudad de Natal, la imagen de los principales puntos de interés turístico de esta ciudad, la imagen de un mapa orientativo del litoral natalense y la imagen de una furgoneta usada para los traslados por esta empresa.

A partir de ello se puede afirmar que su mensaje manifiesto consiste en el propio anuncio de los productos ofrecidos por esta empresa natalense de locaciones y transportes para el turismo. Mientras su mensaje latente es de la excelencia de la empresa y de los productos turísticos ofertados, sobre todo, Natal como un destino turístico. Dentro del marco argumentativo se llega a decir que:

\footnotetext{
Nunca hay valores informativos en el nivel de la frase. No sólo no hay frases puramente informativas, sino que ni siquiera hay, en la significación de las frases, componente informativo, lo que queremos decir, es que tales usos (pseudo) informativos son derivados de un componente más profundo <<puramente>> argumentativo (Anscombre \& Ducrot, 1994:214).
}

Por último, cabe señalar que para Plantin (2002:119) el concepto de argumentación consiste en "la confrontación, de una manera polémica o cooperativa, de un discurso y de un contra-discurso orientados por una misma cuestión”. Aplicar ese concepto a la publicidad es leer las entrelineas de los anuncios para ver lo dicho y lo no dicho en este tipo de texto, sobre todo su fuerza ilocutiva y su efecto perlocutivo. 


\section{Capítulo VI}

\section{EL TEXTO PUBLICITARIO: ASPECTOS SEMIÓTICOS Y PRAGMÁTICOS}

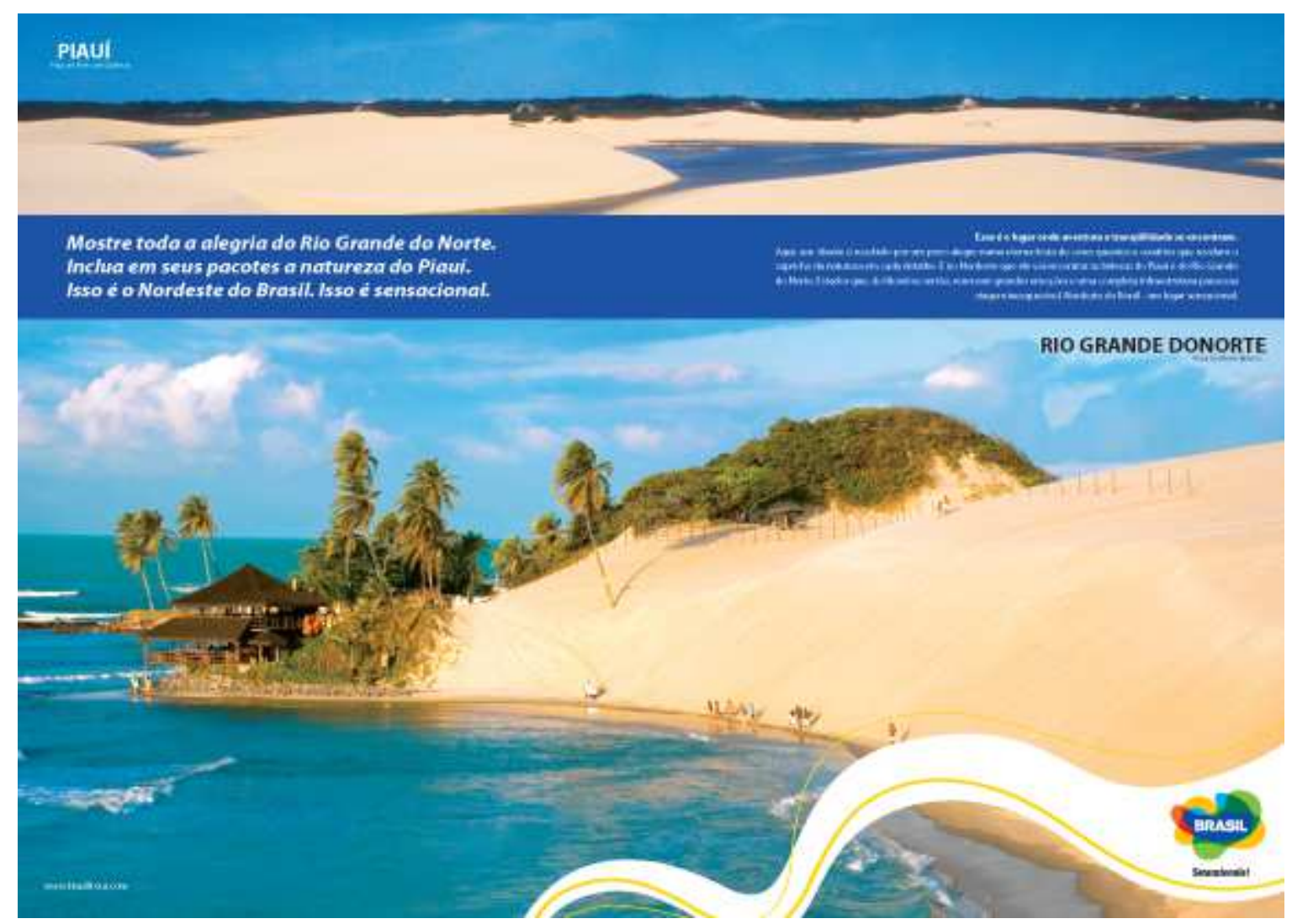

"Los folletos turísticos actúan como sustitutos del producto turístico, dado que se caracteriza por su intangibilidad y por la imposibilidad de separar su producción de su consumo. Este material se convierte en una pieza fundamental a la hora de hacer tangible el producto".

(Manuel Rey) 


\section{CAPÍTULO VI - EL TEXTO PUBLICITARIO: ASPECTOS SEMIÓTICOS Y PRAGMÁTICOS}

La tesis fundamental de nuestra Teoría del Acto de Comunicación Publicitario consiste en afirmar que las características inherentes al discurso publicitario son: el carácter expresivo; el carácter comunicativo; el carácter retórico; el carácter persuasivo; y el carácter pragmático. Por eso, el sexto capítulo de nuestra tesis está consagrado, sobre todo, al carácter pragmático de la publicitad turística. En el presente capítulo hablaremos de la publicidad como un tipo de texto específico. Tomando eso como base, empezaremos con una caracterización del texto publicitario, de modo que todos los aspectos fundamentales para la interpretación de un anuncio sean contemplados. Por último, abordaremos los aspectos semióticos y pragmáticos en el discurso publicitario.

\subsection{Texto publicitario}

En Adam \& Bonhomme (2000:138) vemos que el texto en la publicidad "es, por definición, un objeto transdisciplinario. No pertenece en mayor medida a la hermenéutica que a la filología, a la crítica genética que a la poética. El marco histórico de nuestro enfoque de la argumentación publicitaria es el de una lingüística pragmática y textual”. Las principales contribuciones de la pragmática para la lingüística textual son el lenguajelacción; la Lengua: recursos fónicos, sintácticos y semántica; y el acto de habla, eso es lo que afirma (Corrêa, 2002:44) cuando dice:

\footnotetext{
El lenguaje concebido como acción, la lengua concebida como fuente de recursos fónicos y sintáctico-semánticos y acto de habla comprendido como interface verbal de un ritual no solamente lingüístico son las principales contribuciones de la pragmática. Migrando del enunciado para el texto, la noción de acto de habla gana en complejidad y puede ser aplicada a textos completos o a fragmentos de texto, de tal forma que en una secuencia textual, que puede contener innumerosos actos, puede ser resumida por un único. Se ve, por lo tanto que la lingüística textual (y más una vez el análisis del discurso), puede ser beneficiado con las nociones pragmáticas.
}

La publicística no está muy alejada del ámbito del lenguaje y de la lingüística, aunque se acerque más de la semiótica, como afirma López Eire (1998:54) "el lenguaje de la publicidad, por tanto, cae más bien en el ámbito de la semiótica que en el de la lingüística, pero no está tan alejado, como pudiera creerse, del lenguaje, y, 
especialmente, de su esencial retoricidad”. A partir de ahí, el texto publicitario parece gravitar entre lo textual, pragmático y semiótico. De ahí la importancia de abordar el carácter textual, pragmático y semiótico de la publicidad turística.

\section{HOTEL SOLAR ATLÂNTICO SUL}

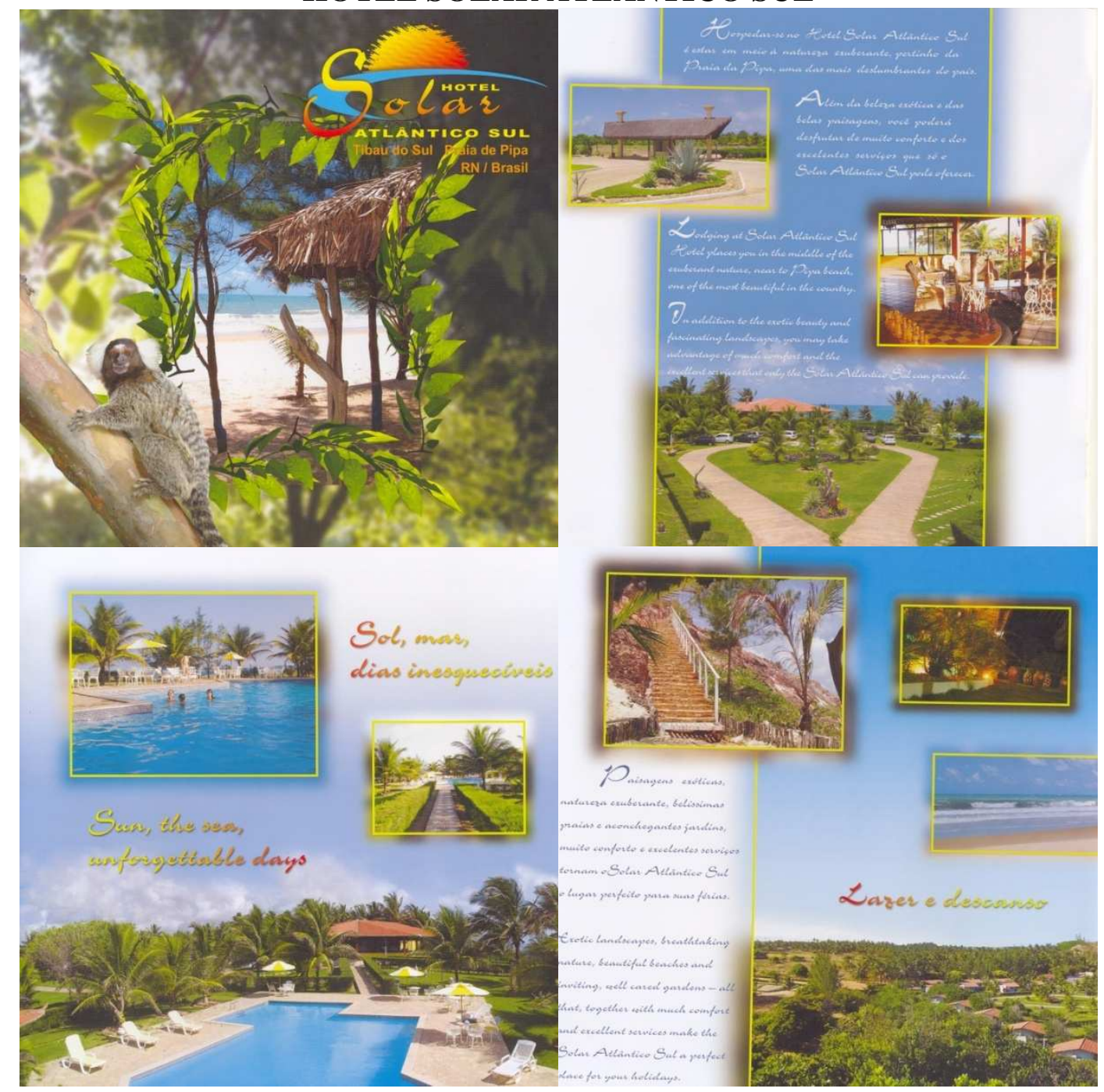




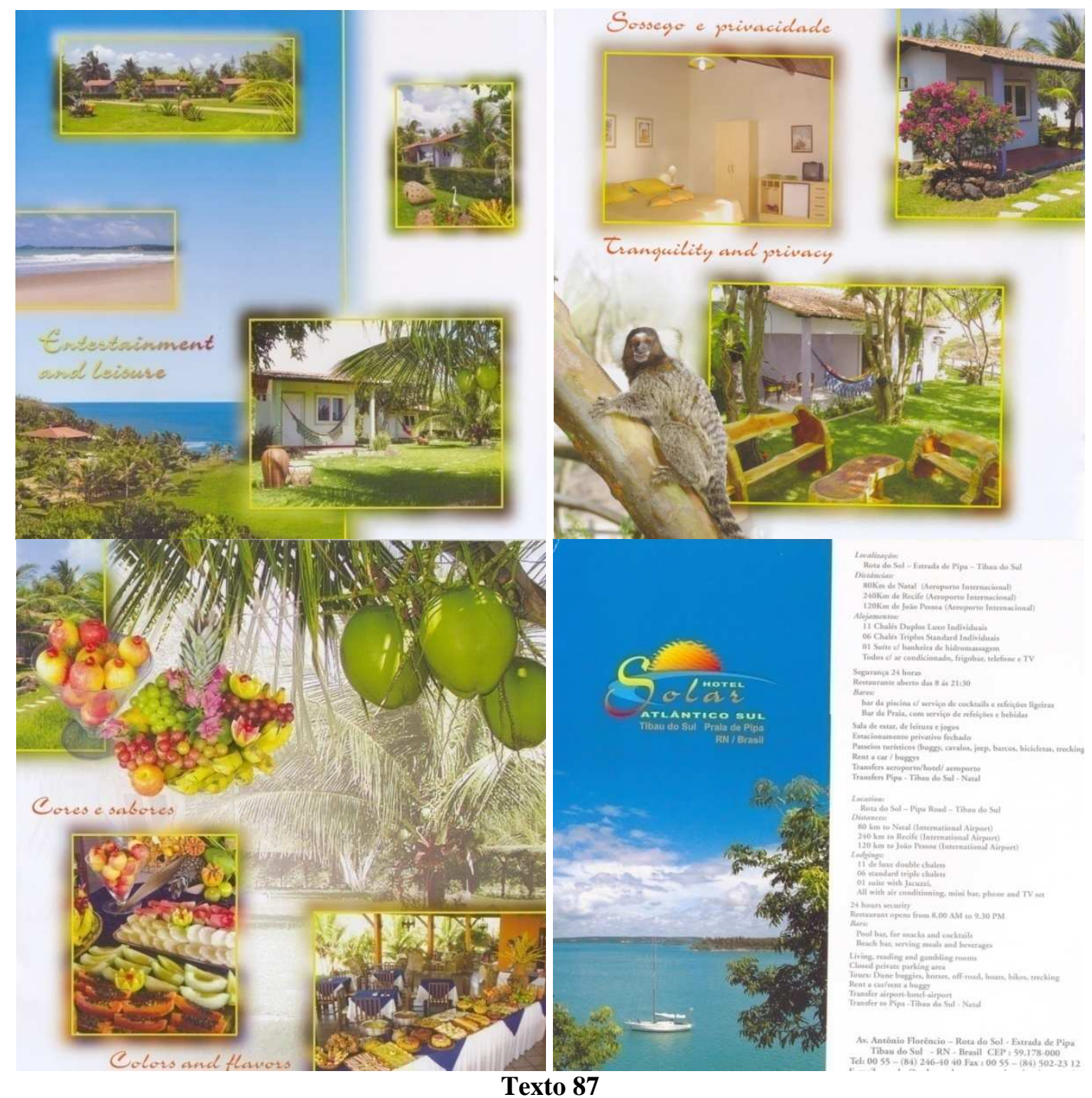

El texto 87 está en consonancia con el género de los elogios, cumplidos y alabanzas. Además presenta todos los principios comunicativos de informar lo pertinente, respetar las conveniencias del género publicitario, ofrecer la evolución de la información y prever qué marcas de conocimiento posee el lector. A partir de este anuncio el destinatario saca una serie de inferencias para descubrir el verdadero significado de lo anunciado. El texto comunica las informaciones sobre el "Hotel Solar Atlántico Sul", localizado en Pipa.

Esa información puede ser inferida en la primera página del anuncio que es seguido por el componente textual expandido de la segunda página, que afirma: Hospedarse en el “Hotel Solar Atlántico Sul” es estar en medio a la naturaleza exuberante, muy cerca de la Praia de Pipa, una de las más deslumbrantes del país. Además de belleza exótica y de los lindos paisajes, podrás disfrutar de mucho confort y de los excelentes servicios 
que solamente el Solar Atlántico puede ofrecer. El uso de adjetivos muy vehementes como confort, excelentes, bellos y lindo agrega el carácter de excelencia del producto turístico anunciado.

En la disposición visual del texto expuesto anteriormente, se evocan ciertos conocimientos enciclopédicos del auditorio que refuerzan la idea de alta calidad del producto anunciado. Ya en la tercera página de nuestro anuncio en cuestión se encuentra la frase sol, mar, día e inolvidables. Que va seguida por la frase ocio y descanso, en la cuarta página de nuestro anuncio. En esta misma página figura el texto: Paisajes exóticos, naturaleza exuberante, bellísimas playas y jardines acogedores, mucho confort y excelentes servicios tornan Solar Atlántico Sul el lugar perfecto para tus vacaciones.

En la sexta página del anuncio se destaca la tranquilidad y la privacidad encontradas en el Hotel Solar Atlántico Sul y en la séptima página se destacan los colores y los sabores de la comida natural y típica servida en ese hotel. Mediante textos publicitarios como estos se presenta una unión del código visual con el código verbal, de modo que el producto visual consiste en la propia imagen del "Hotel Solar Atlántico Sul", sus instalaciones externas e internas, además del logotipo de este hotel. Su mensaje manifiesto corresponde al propio anuncio del producto publicitario y la buena calidad de este hotel. Mientras el mensaje latente connota un ambiente confortable, elegante, relajado, con una fauna y una flora exuberantes.

En el acto comunicativo establecido por la publicidad tiene siempre como efecto perlocutivo la adquisición de un producto o servicio. El género publicitario exige un cierto tipo de elecciones léxicas. En el caso del anuncio en cuestión, hay un predominio de verbos, sustantivos y adjetivos en su selección léxica que poseen un carácter extremamente positivo.

La publicidad es un género mimético y el texto publicitario debe ser persuasivo y para ello puede emplear muchos artificios lingüísticos como las figuras poéticas, el vocabulario positivo y familiar, además del uso pronominal del "tú", segunda persona del singular que aporta cercanía entre los interlocutores del acto de comunicación publicitario. 
El buen éxito de la comunicación publicitaria depende en gran parte de la unión de todos esos elementos. Por su parte, Gutiérrez Ordoñez (1997) matiza que frente a la lingüística, que se ocupa de describir el sentido literal, a la pragmática le corresponde explicar la significación intencional. La lingüística estudia los mensajes exclusivamente desde el código, y la pragmática interpreta los enunciados tomando en consideración todos los elementos que intervienen en la comunicación: emisor, receptor, canal, etc.

Los textos resultan de la combinación de enunciados y son considerados unidades comunicativas completas. Todo texto sería también producto de una intencionalidad, sin ser definido por su extensión, sino por lo que expresa y cómo lo da a conocer. Desde esta noción textual, se puede comprender como texto cualquier unidad comunicativa de sentido completo. Así, tanto imágenes, artículos, tratados científicos como una simple conversación, entre otros ejemplos, pueden ser considerados textos. En este sentido, Casamiglia \& Tusón (2002:17-18) dicen que:

\begin{abstract}
Los enunciados se combinan entre sí para formar textos, orales o escritos. El texto, así, está constituido por elementos verbales combinados, que forman una unidad comunicativa, intencional y completa. La particularidad del análisis discursivo reside en un principio general que asigna sentido al texto teniendo en cuenta los factores del contexto cognitivo y social que, sin que estén necesariamente verbalizados, orientan, sitúan y determinan su situación. Los textos pueden ser muy breves o muy extensos: consideramos texto tanto 'Se vende piso', como una carta personal, una conversación amistosa, un artículo de periódico, una sentencia judicial o un tratado de geología.
\end{abstract}

El texto es, pues, un hecho comunicativo con espacio y tiempo propios que puede ser analizado a través de sus elementos propios, es decir, sus partes constitutivas y los elementos del acto comunicativo que están implicados en la elaboración y organización textual. En la constitución de un texto se puede encontrar la interacción de códigos como verbal y no verbal, asociados a una situacionalidad. Además, se puede hacer una lectura global o parcial de cualquier texto, para ello la noción de géneros, marcadores e indicadores textuales ayudan en la construcción de sentido por parte del interlocutor.

En los anuncios publicitarios, que concebimos como textos, pasan dos cosas a la vez, bien reflejadas por los sistemas lingüísticos: por una parte se anuncia por medio del código visual, por otra parte se anuncia por medio del código verbal. Por medio de esta mezcla de códigos el texto publicitario es constituido. Los textos publicitarios 
demandan una acción o comportamiento específico de su audiencia. Cualquier tipo de texto tiene la finalidad de establecer un proceso de comunicación, por ello tiene carácter social. Desde este punto de vista, Bernárdez (1982:85) define texto como:

\begin{abstract}
La unidad lingüística comunicativa fundamental, producto de la actividad verbal humana, que posee siempre carácter social; está caracterizado por su cierre semántico y comunicativo, así como por su coherencia profunda y superficial, debida a la intención (comunicativa) del hablante de crear un texto íntegro, y a su estructuración mediante dos conjuntos de reglas: las propias del nivel textual y las del sistema de la lengua.
\end{abstract}

Debido al carácter pragmático del texto publicitario, es común la presencia de verbos de acción en los anuncios publicitarios, como hemos visto en el texto anterior. Dentro de un acto de comunicación, pueden existir cuestiones como las incomprensiones, los malentendidos, la difusión comunicativa, el humor y los fracasos de la comunicación. Todo eso puede estar presente alrededor de cualquier texto, que es una unidad discursiva compuesta por elementos verbales ordenados entre sí, formando una unidad de sentido y pragmática. Según Calsamiglia \& Tusón (2002:217):

\begin{abstract}
Cualquier unidad de discurso se compone de elementos verbales que están organizados y relacionados entre sí de manera explícita o implícita. Esta organización e interrelación constituye lo que es la textura del discurso, que da nombre a su concreción: el texto. [...] Todos los estudiosos de este entramado coinciden en afirmar que un texto no es solamente una secuencia de oraciones, sino que, a partir de un conjunto de operaciones de diverso orden - trama y urdimbre -, se constituye como una unidad semánticopragmática.
\end{abstract}

\title{
Características del texto publicitario
}

La publicidad es uno de los tipos de textos escritos marcados por sus elementos gráficos y su disposición. Está lleno de artificios y hace uso de los más variados recursos de puntuación, ya que "la puntuación enfática es característica de la publicidad" (Calsamiglia \& Tusón, 2002:97). El registro del texto publicitario es sencillo, a veces coloquial y con clave informal. 
SOLEIL SUITE HOTEL

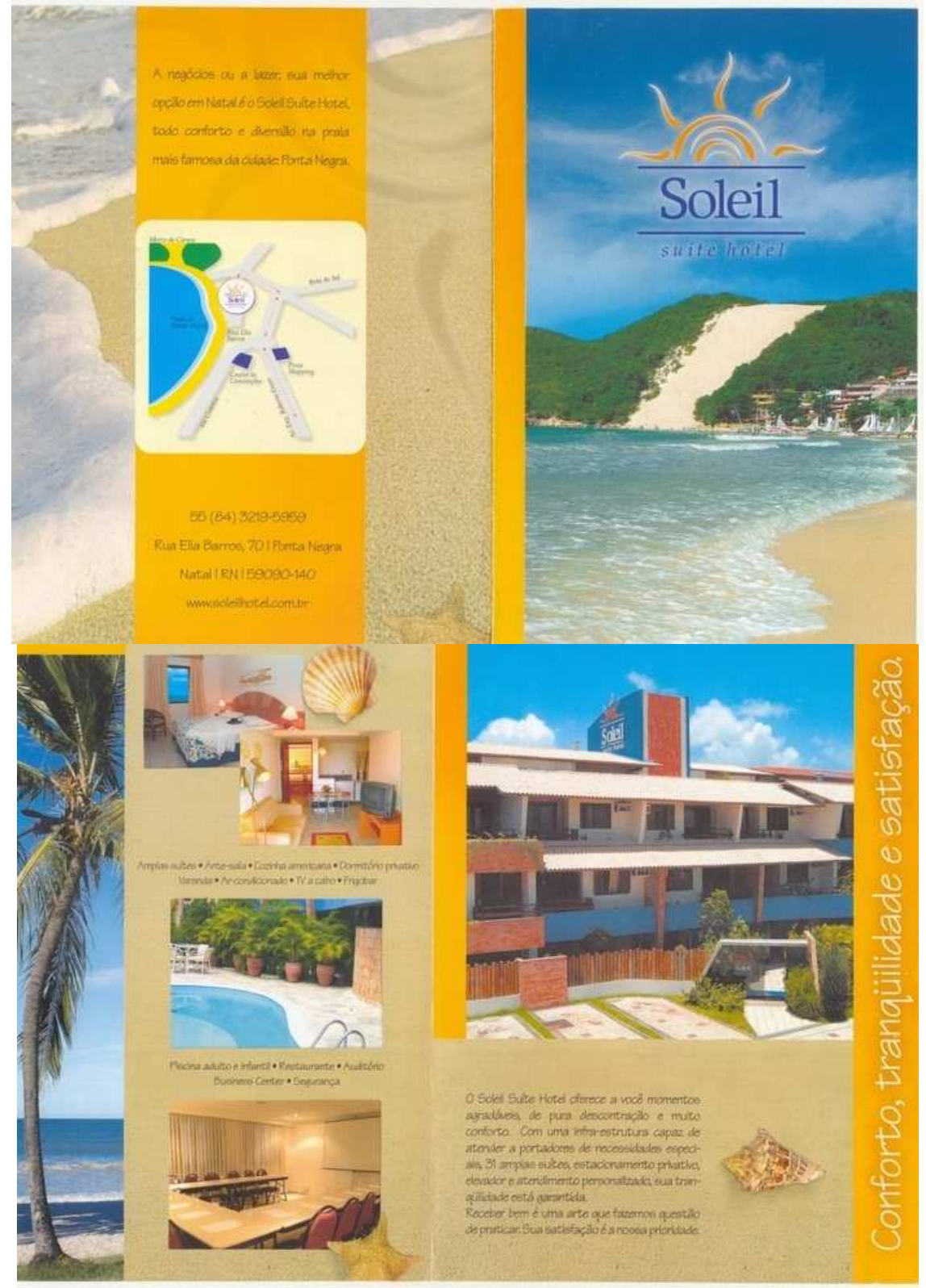

Texto 88

Un aspecto sobresaliente en este género textual es el hibridismo de códigos, como podemos ver en el texto 88. Además de eso, los textos publicitarios juegan con los registros lingüísticos en beneficio propio, como afirman Calsamiglia \& Tusón (2002:94) cuando dicen que "finalmente, en la publicidad se encuentran textos escritos con estilo coloquial, por los efectos persuasivos y de proximidad que se consiguen a través de su uso".

En nuestro anuncio en cuestión, en la primera página se dice: Solei Suíte Hotel. Esto va seguido de lo anunciado en la segunda y tercera páginas que dice: Confort, tranquilidad 
y satisfacción. El Solei Suíte Hotel te ofrece momentos agradables, de pura descontracción y confort. Con una infraestructura capaz de atender a portadores de necesidades especiales [...]. Recibir bien es un arte cuya práctica es nuestra prioridad. Tu satisfacción es nuestra prioridad.

El registro de este texto revela un texto sencillo y de fácil comprensión. Este fragmento pertenece al género llamado discurso publicitario. En este texto hay referencias directas al interlocutor por medio del uso del pronombre "tú". Su tenor es informal, y el modo se refleja en la selección léxica positiva compuesta por adjetivos como agradables, especiales; y sustantivos como confort, tranquilidad, satisfacción, descontracción y prioridad. El registro adoptado en el anuncio publicitario es parte de una decisión estilística del autor que sirve de estrategia de persuasión.

Desde un punto de vista formal, este texto sigue el formato propio del texto publicitario. En su macroestructura figura la descripción del "Soleil Suite Hotel" y sus instalaciones externas e internas. El producto visual consiste en el logotipo del "Soleil Suite Hotel", fotos de sus instalaciones externas e internas y un mapa orientativo del lugar de ubicación del hotel anunciado. El mensaje manifiesto corresponde al anuncio del producto turístico ofrecido. Ya el mensaje latente connota la idea de una ambiente playero, rústico, acogedor y confortable.

En la última página del texto 88, figura un componente expandido que dice: Para negocios u ocio, tu mejor opción en Natal es "Soleil Suite Hotel", todo confort y diversión en la playa más famosa de la cuidad: Ponta Negra. Si observamos el texto publicitario que usamos como ejemplo en su totalidad, veremos que está elaborado con un entramado de signos distintos, como el lenguaje visual y el lenguaje escrito. Lo mismo puede ser observado en el texto 89 , presentado a continuación, que anuncia el parque acuático Ma-noa. 


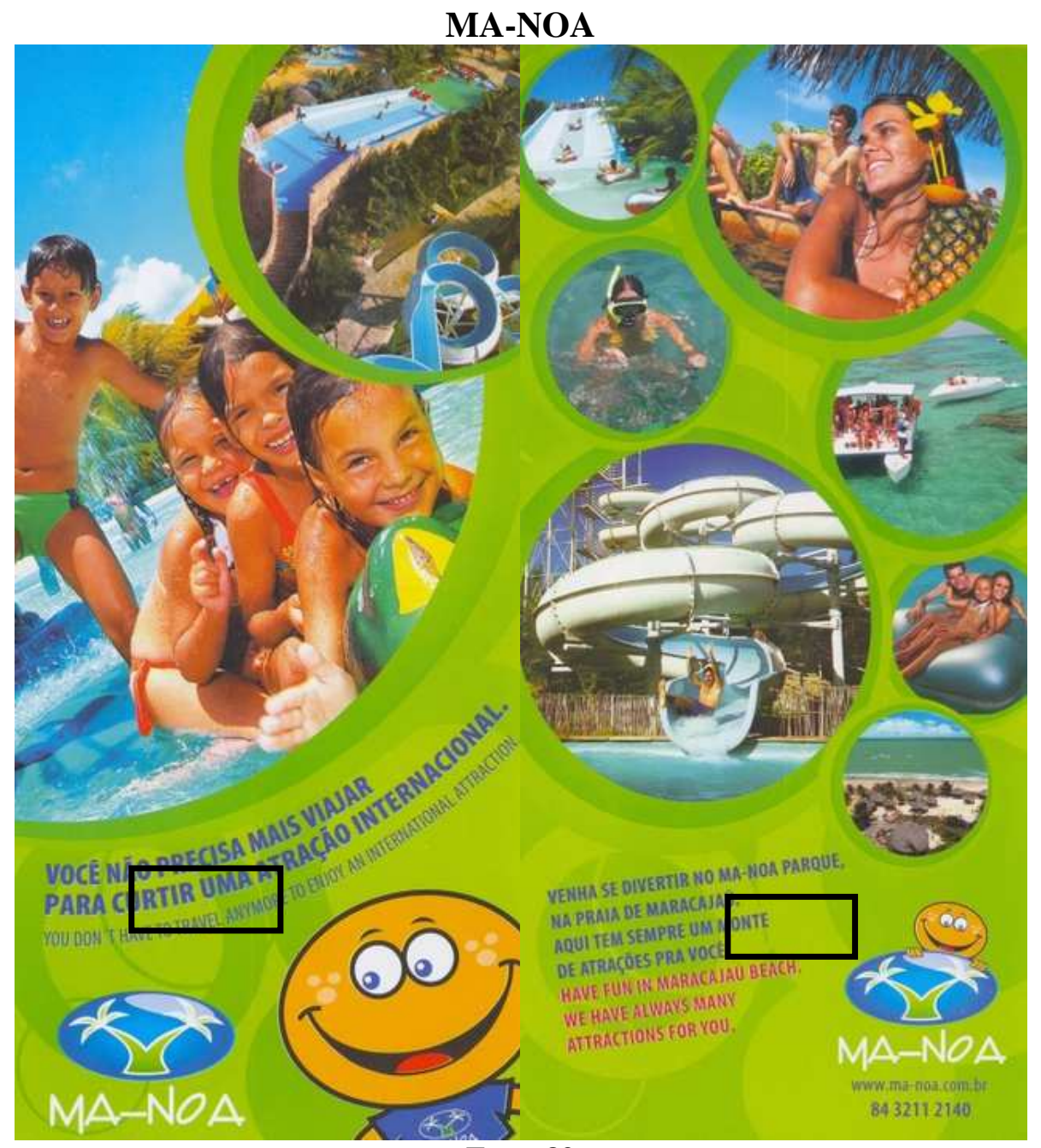

Texto 89

Nuestro anuncio afirma en su componente expandido que no necesitas viajar para aprovechar una atracción internacional. Ven a divertirte en el Ma-noa parque. En la playa de Maracajaú. Aquí hay siempre muchas atracciones para ti. Este texto publicitario tiene una decodificación muy accesible y casi de carácter universal. Su lenguaje escrito está permeado por términos coloquiales o del registro lingüístico oral, como por ejemplo, el lexema "curtir" que coloquialmente en el portugués de Brasil significa aprovechar, pasárselo bien. Es un vocablo usado con mucha frecuencia en la jerga juvenil y de las urbes. Otro uso léxico que también podemos destacar en este mismo texto es el lexema "monte", que coloquialmente significa muchos o muchas en portugués brasileño. También es usado con mucha frecuencia en el registro oral de la lengua en contextos informales.

Como se puede constatar, en el componente visual de este anuncio solo hay personajes prototípicos jóvenes, quizás para que no haya incongruencia entre el léxico adoptado en 
el anuncio de esta publicidad turística y su contenido visual. Así, el Ma-noa, parque de atracciones acuáticas anunciado, aparece como un facilitador de la vida de sus clientes en potencia cuando dice que "no necesitas viajar más para pasártelo muy bien (curtir) en una atracción internacional", y luego invita a sus clientes con "ven al Ma-noa parque, en la playa de Maracajaú. Aquí hay siempre muchas (un monte) atracciones para ti". No se habla de precios, simplemente "invita" a sus clientes por medio de un lenguaje de fácil decodificación y que presenta una determinada proximidad con su público.

Para que el discurso publicitario pase del hacer creer (fiabilidad) al hacer hacer (acto de compra), necesita poseer un alto nivel de fiabilidad. Según Adam \& Bonhomme (2000:34), "el discurso publicitario debe ser lo bastante creíble como para suscitar tal creencia y, al mismo tiempo, la ausencia de toda refutación de lo que afirma". Si volvemos al texto anterior, podemos ver la verosimilitud de lo que se anuncia, lo que hace que este sea un texto fiable. Además, la propia marca Ma-noa aporta confianza al interlocutor.

A continuación podemos ver el texto 90 , por medio del que se presenta un paseo de barco y buceo para los aficionados de este deporte acuático. El texto publicitario se limita a tratar del mismo tema del inicio al fin de la publicidad para transmitir todas las informaciones que el interlocutor puede necesitar.

João Anzanello Carrascoza en su libro A Evolução do Texto Publicitário (1999) trata los aspectos del texto publicitario. Este autor defiende que el texto debe presentar unidad, es decir, tratar del inicio (título) al final, con fidelidad, el mismo tema. Este mismo autor defiende que el texto debe presentar una estructura cíclica, en el sentido de que debe empezar y terminar en el mismo punto de partida. 
MARACAJAÚ DIVER

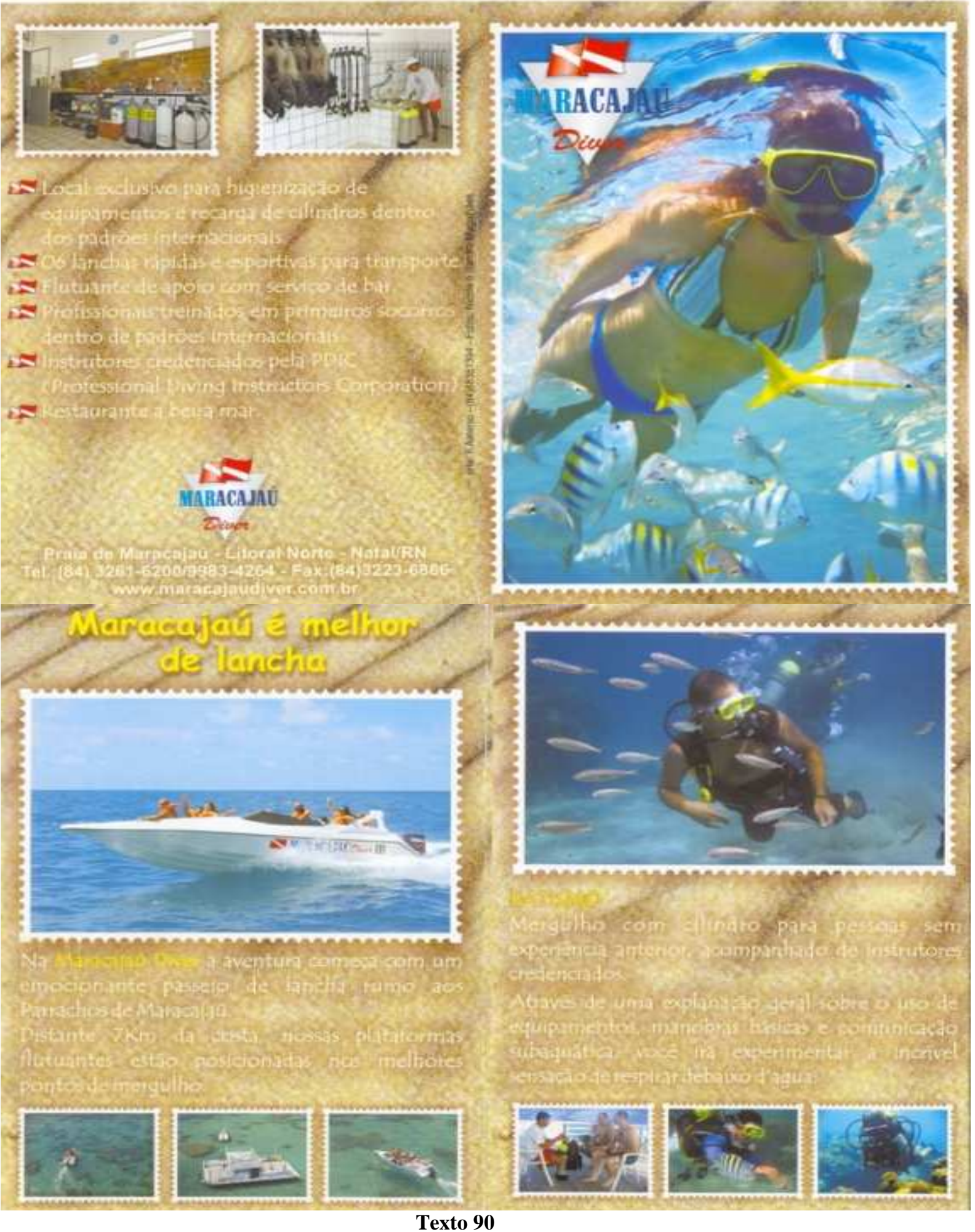

Carrascoza (1999:32) compara esta característica con una serpiente que se muerde a la propia cola y añade que "el texto, en círculo cerrado, evita el cuestionamiento y busca 
llevar al lector a conclusiones definitivas". ${ }^{59}$ Eso es lo que podemos contemplar en el anuncio expuesto arriba. El texto publicitario, como una forma de perpetuación de la retórica, puede hacer uso de las figuras de lenguaje, como ya hemos visto anteriormente. El uso de este recurso retórico en la publicidad tiene la finalidad persuasiva y el objetivo de añadir significado al mensaje publicitario, que puede desempeñar los más diversos tipos de funciones de lenguaje.

Además, en un mismo mensaje publicitario se pueden encontrar todas las funciones del lenguaje (referencial, emotiva, conativa o imperativa, fática, metalingüística, estética o poética) a la vez, pero, probablemente, se dará el predominio de una sobre las demás. En este anuncio que presentamos a continuación, se usa la metáfora como uno de los recursos retóricos, y el propio texto se encarga de explicar el significado de la expresión metafórica utilizada. Además, la secuencia textual predominante es la descriptiva, aunque tenga una finalidad claramente argumentativa y persuasiva, propias del discurso publicitario.

En este contexto se pueden destacar algunas funciones del lenguaje que normalmente predominan en un texto de carácter publicitario. Tales funciones serían la conativa, la fática y la función poética. La primera tiene relieve por centrarse en el interlocutor, ya que "el texto publicitario es deliberativo, pretende aconsejar, siendo natural que prevalezca la función conativa, centrada en el interlocutor" (Carrascoza, 1999:39) ${ }^{60}$; la segunda, por establecer contacto directo con el lector; y la tercera, por cuidar de los aspectos estéticos del texto. Este texto publicitario presenta la "Pousada Castanheira" como un lugar idílico en el que hospedarse en la playa de Ponta Negra, ubicada en Natal. Es más, afirma: "tu casa de playa en Natal".

\footnotetext{
${ }^{59}$ En la fuente original: "O texto em circulo fechado evita o questionamento e objetiva levar o leitor a conclusões definitivas".

${ }^{60}$ En la fuente original: “O texto publicitário é deliberativo, objetiva aconselhar, é natural que prevaleça a função conotativa, centrada no interlocutor".
} 
POUSADA CASTANHEIRA

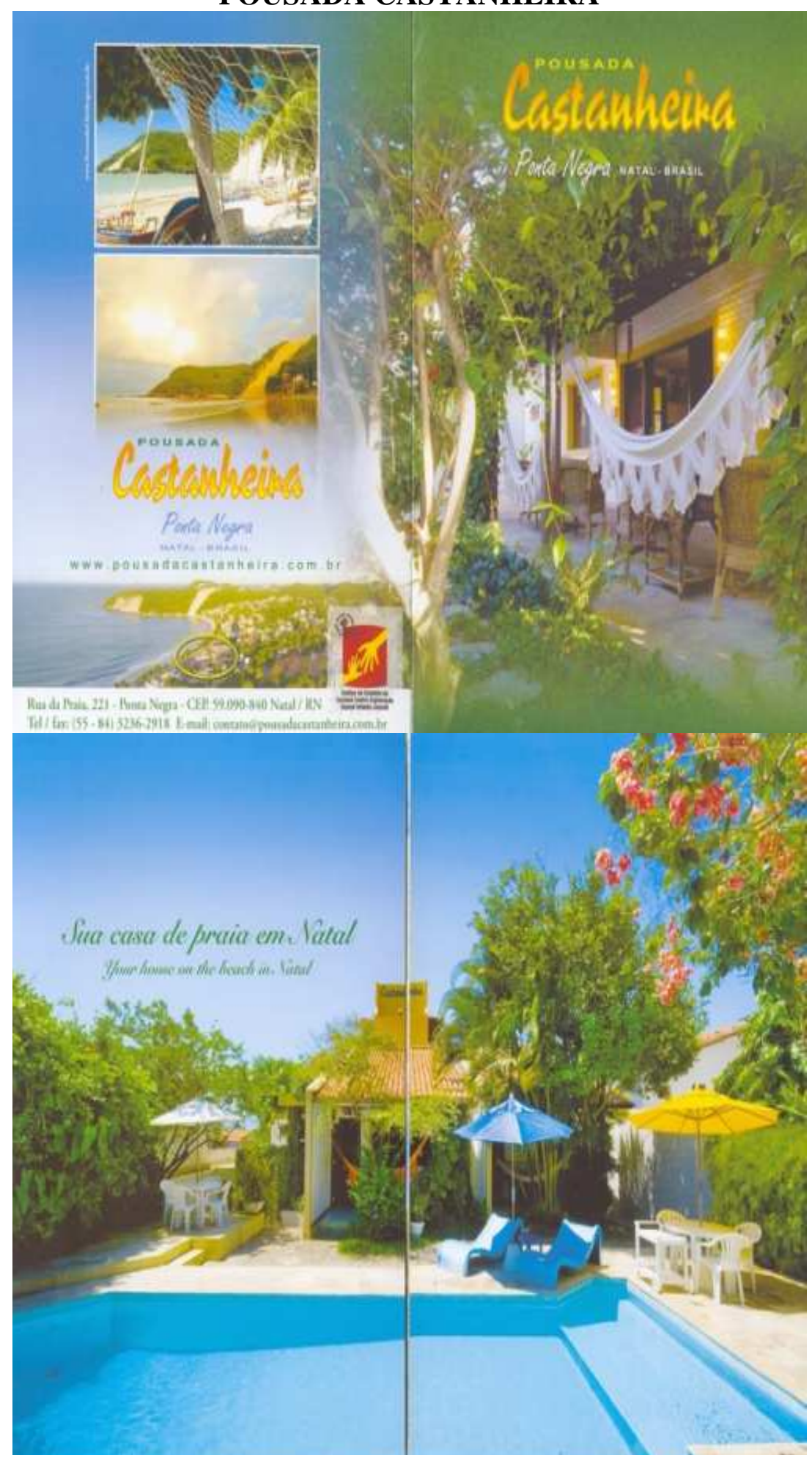




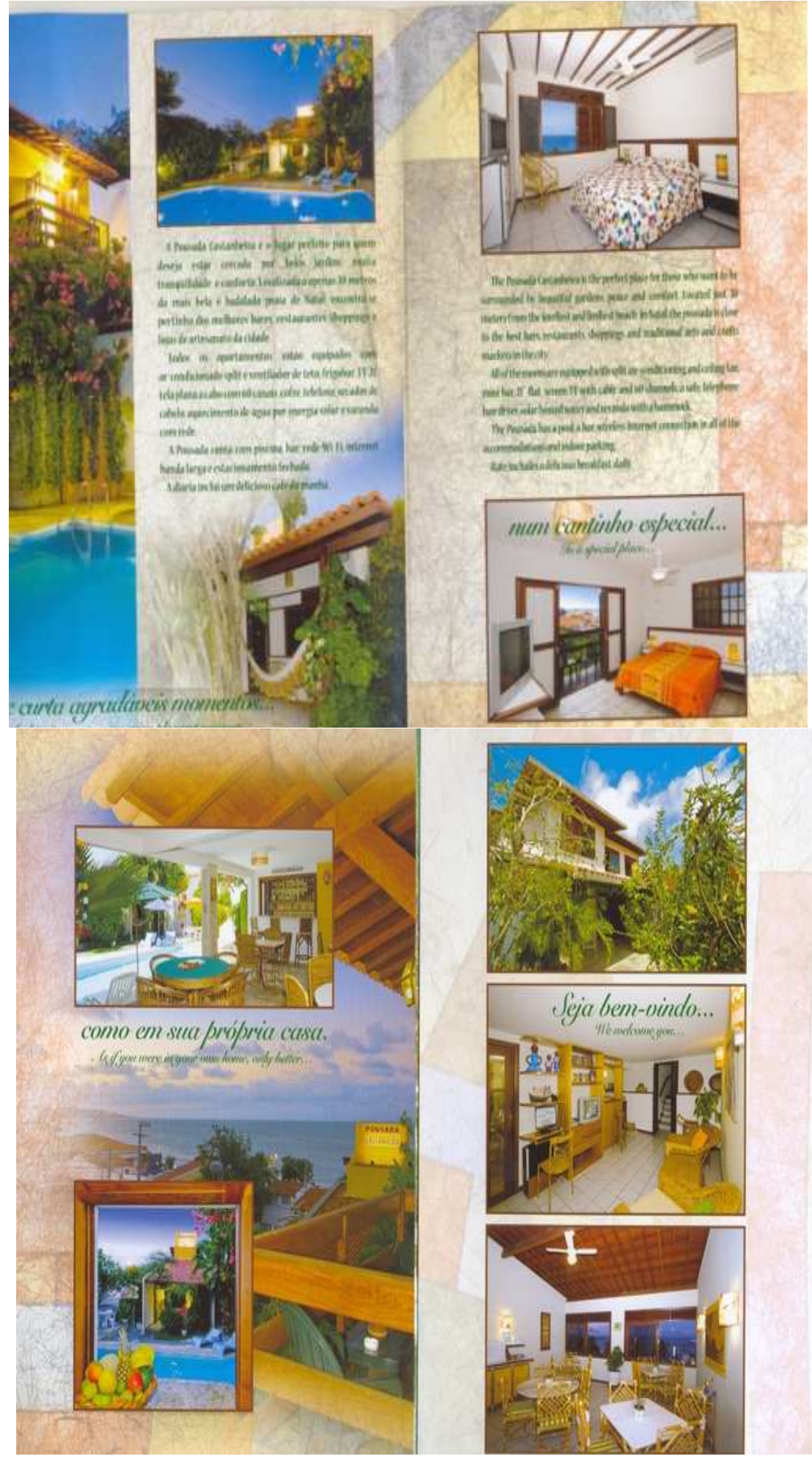

Texto 91

Luego presenta todo lo que uno dispone en este hostal, su organización, su tranquilidad, su confort y sencillez. Después, aclara la metáfora inicial que define este hostal como tu propia casa de playa a partir de la comparación "como en tu propia casa", es decir, el huésped estará tan a gusto en ese lugar como si estuviera en su propia casa. 
Desde un punto de vista formal, en su macroestructura figura la descripción del "Castanheira Pousada", ubicada en la playa de Ponta Negra. La progresión temática de este texto puede ser definida como de progresión de tema constante. La persona del discurso presente es la inscripción del "você", en portugués de Brasil, que tiene la fuerza semántica del "tú” en español, presentando así un carácter de proximidad entre el emisor y el destinatario.

El acto de habla locutivo consiste en el discurso constituido por el lenguaje verbal escrito y el lenguaje visual para presentar la "Pousada Castanheira" al interlocutor del mensaje; la fuerza ilocutiva consite en la descripción del producto turístico ofertado y su ubicación, que funcionan como estrategia de persuasión publicitaria; y el efecto perlocutivo tiene como finalidad recibir del interlocutor la confirmación en forma de un acto de compra.

En el componente expandido del texto en cuestión consta que: La "Pousada Castanheira" es el lugar perfecto para los que desean estar rodeados por bellos jardines, mucha tranquilidad y confort. Ubicada a solamente 30 metros de la playa más bella de Natal, está cerca de los mejores bares, restaurantes, centros comerciales y tiendas de artesanía de la ciudad. Todos los apartamentos [...]. Este sitio también posee piscina, bar, wi-fi, internet y aparcamiento cerrado. La diaria incluye un desayuno тиу rico.

Ese texto pertenece al género del discurso publicitario y desde un punto de vista de la tipología textual posee una secuencia dominante de texto argumentativo, ya que la descripción funciona más bien como un recurso persuasivo. En la textura discursiva están presentes los elementos deícticos y el mantenimiento del referente se da por procedimiento léxicos y gramaticales. En su selección léxica figuran los sintagmas presentados a continuación: lugar perfecto, desean, rodeados, bellos jardines, mucha tranquilidad, confort, solamente, playa, más bella, Natal, cerca, mejores bares, restaurantes, centros comerciales, tiendas de artesanía, piscina, bar, wi-fi, internet, aparcamiento cerrado, incluye, desayuno y muy rico. O sea, un léxico muy positivo.

El producto visual consiste en la propia imagen de las instalaciones de "Castanheira Pousada", cuyo mensaje manifiesto es de un lugar elegante, tranquilo y confortable y el 
mensaje latente transmite la idea de un lugar en el que uno estará tan a gusto que se sentirá en su propia casa en la playa como afirma el eslogan en este anuncio: "tu casa de playa en Natal".

\section{Características textuales}

El objetivo primordial de la publicidad es llamar la atención del público para convertirlo en posible cliente. Eso condiciona la preocupación por la elaboración de este tipo de mensajes para el que se hace uso, según Asunción Escribano (2006:60-61), de "una serie de recursos literarios con la finalidad de llamar la atención del lector, incitarle a que continúe leyendo y convencerle, en el caso de la publicidad, de que compre el producto". En base a esto, el texto publicitario adquiere algunas características peculiares de las que hablaremos a continuación.

Además, los mensajes publicitarios intentan ser registrados en los recuerdos de su público, así que la creatividad y la presentación de lo novedoso son estrategias básicas para sorprender la audiencia. Como afirma Asunción Escribano (2006:64), "los mensajes publicitarios buscan ser recordados por el receptor y así tienden a elaborarse mensajes breves que se memoricen con facilidad". Eso puede ser corroborado a partir del texto 92 expuesto a continuación.

Desde un punto de vista formal, en su macroestructura figura la descripción del "Quality Suites Natal", la presentación de su localización y sus instalaciones internas y externas, bajo los titulares: Facilidades, Localización y Eventos. La progresión temática de este texto puede ser definida como de progresión de tema constante, ya que tiene como objetivo la máxima descripción del "Quality Suites Natal”.

La persona del discurso presente es la inscripción de la tercera persona del singular que remite al producto turístico anunciado de modo impersonal. El acto de habla locutivo establecido por el texto en cuestión consiste en el discurso constituido por el lenguaje verbal escrito y el lenguaje visual que describen el sitio anunciado y sus servicios; su fuerza ilocutiva consiste en la estrategia de persuasión publicitaria por medio de la descripción del productor turístico ofertado y su ubicación, presentados para persuadir 
al interlocutor del mensaje; y el efecto perlocutivo tiene como finalidad recibir del interlocutor la confirmación en forma de un acto de compra.

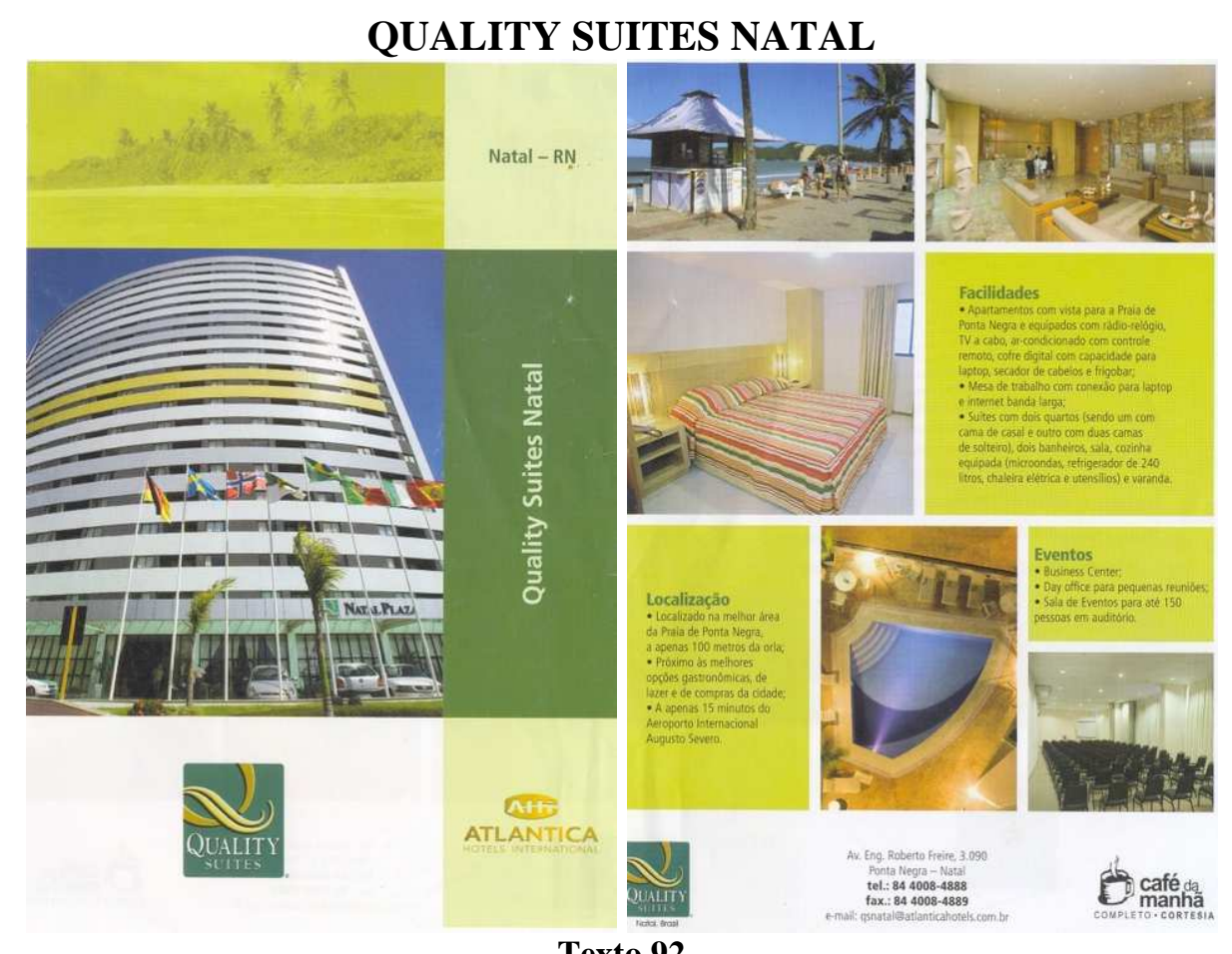

Texto 92

Este texto pertenece al género del discurso publicitario y desde un punto de vista de la tipología textual posee una secuencia dominante de texto argumentativo, ya que la descripción funciona más bien como un recurso persuasivo. En la textura discursiva están presentes los elementos deícticos y el mantenimiento del referente se da por procedimiento léxicos y gramaticales.

El componente expandido del texto 92 dice que: "Quality Suites Natal", una cadena de hotel internacional, está localizado en el mejor sector de la playa de Ponta Negra, a solamente 100 metros de la playa. Cerca de las mejores opciones gastronómicas, de ocio y de compras de la ciudad. A solamente 15 minutos del aeropuerto internacional Augusto Severo. Facilidades [...]. Eventos: Centro de negocio, oficina de reuniones, sala de eventos con capacidad para hasta 150 personas. En la selección léxicas de ese texto figuran sintagmas positivos como: localizado, mejor sector, playa, solamente, cerca, mejores opciones, gastronómicas, ocio, compras, ciudad, aeropuerto, internacional, facilidades, eventos, centro, negocio, oficina de reuniones, sala de eventos, o sea, un léxico propio de la publicidad como ya hemos visto anteriormente. 
El producto visual consiste en la propia imagen del "Quality Suites Natal", sus instalaciones externas, internas y su vista privilegiada del mar. Cuyo mensaje manifiesto coincide con el propio anuncio del producto turístico ofertado y el mensaje latente connota la elegancia, la comodidad, el confort, la tranquilidad y el ambiente relajado de este hotel.

Para Sara Robles Ávila (2005:253), la sencillez del discurso publicitario sumada a la creatividad que debe ser empelada en este tipo de texto no sacrifica su característica de economía lingüística y para ello afirma que el discurso de la publicidad es "fiel al principio de economía lingüística que lo rige, tiende al empleo de una sintaxis poco compleja. La fuerza expresiva que el creativo imprime en este tipo de mensaje se observa en la alta ocurrencia de enunciados interrogativos y exclamativos". El texto presentado anteriormente sirve como un ejemplo de la sencillez y economía lingüística en el discurso publicitario.

El texto publicitario, además de las características textuales de forma general, también posee la particularidad de que en él hay un cuidado vehemente con el significante, que debe llamar la atención del interlocutor a punto de despertar el interés e invitarle a la lectura textual. A este respecto, Juan de los Ángeles (2005:16-18) resalta cinco atributos básicos del lenguaje publicitario para mantener la claridad necesaria en él, a saber:

\section{ATRIBUTOS BÁSICOS DEL LENGUAJE PUBLICITARIO}

\section{1- Naturalidad y sencillez}

\section{2- Orden}

\section{3- Brevedad}

\section{4- Objetividad y concreción}

\section{5- Cohesión y fluidez}

Además, es importante resaltar que el texto publicitario asocia siempre el lenguaje verbal al visual, lo que facilita la decodificación del mensaje de forma más rápida y eficaz. De este modo, la imagen ocupa un papel clave dentro de este tipo textual, 
ayudando al interlocutor a acceder a su mensaje central. Todo eso sirve para reafirmar el hecho de que "en publicidad, menos es siempre más" (Juan de los Ángeles, 2005:17).

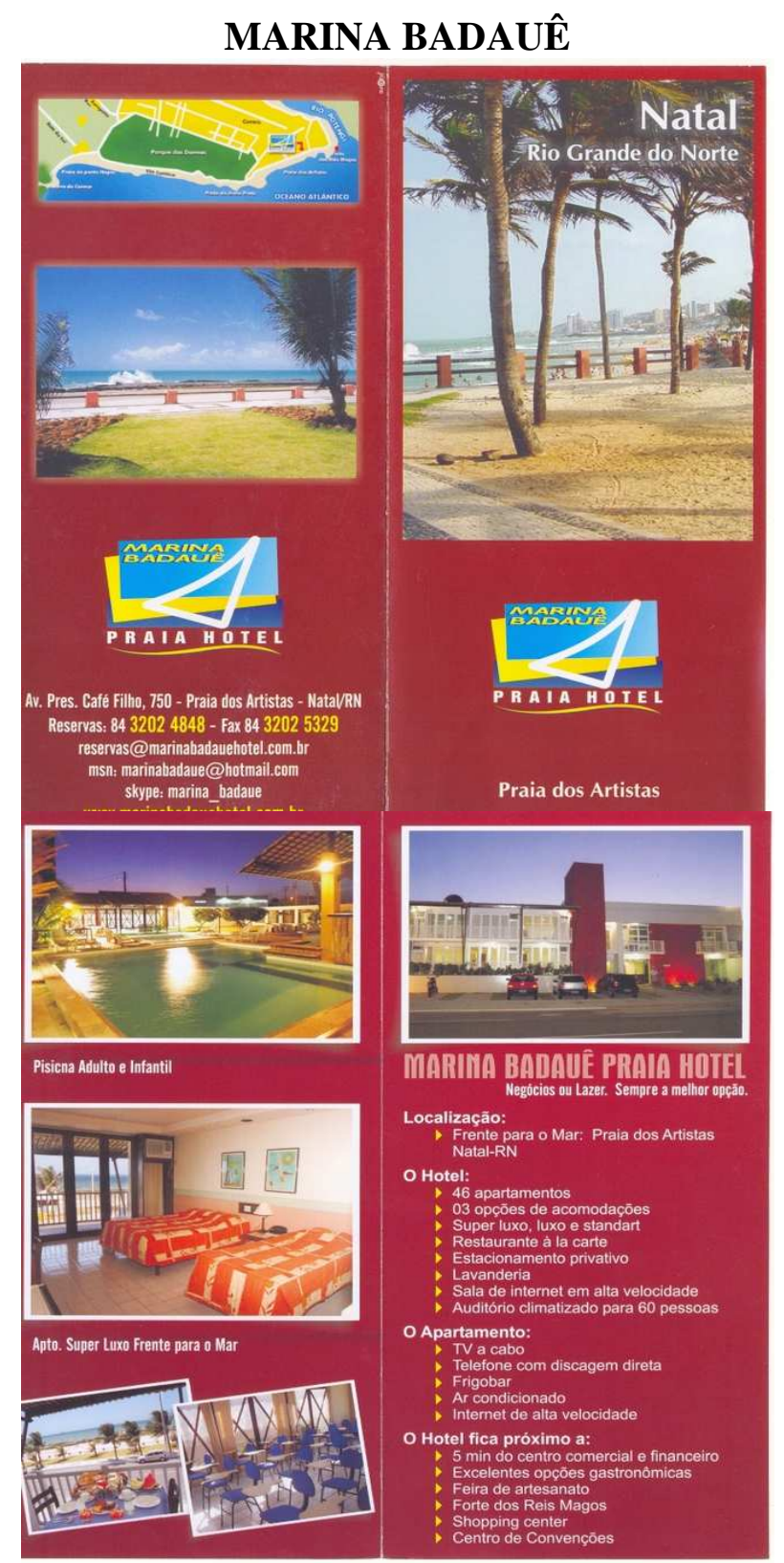

Texto 93

$\mathrm{Al}$ echar un vistazo al texto 93 se puede ver que un $80 \%$ está fraguado por medio del lenguaje visual, mientras solamente un $20 \%$ del texto fue plasmado por medio del lenguaje escrito. Eso auxilia en la descodificación de dicho texto con el mínimo esfuerzo cognitivo. En su macroestructura figura la descripción del "Marina Badauê Praia Hotel" como producto turístico y su progresión temática es de tema constante. 
En el componente expandido de la primera página del texto 93 los enunciados verbales usados para anclar la imagen de portada dice: Natal, Rio Grande do Norte. Marina Badauê Praia Hotel. Praia dos Artistas. Sin mucho esfuerzo cognitivo, el lector de ese anuncio publicitario puede llegar a construir el siguiente texto por medio de inferencias: el Marina Badauê es un hotel que está en la playa, mejor dicho, Praya dos Artistas, ubicada en Natal, capital del estado del Rio Grande do Norte.

Ya en la segunda página del anuncio en cuestión figura que: Marina Badauê Praia Hotel. Ocio o Negocio. Siempre la mejor opción. Localización frente al mar: Praia dos Artista, Natal-RN. El Hotel: 46 apartamentos, 03 opciones de acomodaciones, súper lujo, lujo y estándar, restaurante a la carte, aparcamiento privado, tintorería, sala de internet, sala climatizada con capacidad para 60 personas. El apartamento: [...]. El hotel está cerca de: 5 minutos del centro comercial y financiero, excelentes opciones gastronómicas, feria de artesanía, Forte dos Reis Magos, Centro comercial, Centro de Convenções.

Como se puede constatar, la persona del discurso presente es la inscripción de la tercera persona del singular, usada para indicar el producto turístico de modo impersonal. Este texto pertenece al género del discurso publicitario y desde un punto de vista de la tipología textual posee una secuencia dominante de texto argumentativo, ya que la descripción funciona más bien como un recurso persuasivo.

En la textura discursiva están presentes los elementos deícticos y el mantenimiento del referente se da por procedimiento léxicos y gramaticales. La selección léxica usada en la elaboración del anuncio en cuestión presenta sintagmas como: playa, ocio, negocio, siempre, mejor opción, localización, frente al mar, Natal, hotel, apartamentos, acomodaciones, súper lujo, estándar, restaurante, aparcamiento privado, tintorería, sala de internet, gastronómicas, feria y artesanía.

El producto visual consiste en la propia imagen del "Marina Badauê Praia Hotel", sus instalaciones internas y su vista privilegiada del mar, cuyo mensaje manifiesto coincide con el propio discurso publicitario de este texto y el mensaje latente connota un lugar acogedor, confortable, relajado y de "paraíso tropical". 
A partir de lo visto hasta ahora, hay que decir que el objetivo que tiene el mensaje de la publicidad subordina el texto publicitario a estas características mencionadas anteriormente en virtud de su meta, que es persuadir y convencer sin presionar u obligar al destinatario a nada. A este respecto, Asunción Escribano (2006:153) advirtió que "la finalidad principal de la publicidad (es) atraer la atención del receptor para conseguir incrementar las ventas del producto, que al fin y al cabo, insistimos nuevamente, es la finalidad principal de todo texto publicitario a la que se subordinan los usos que en éste se hacen del lenguaje".

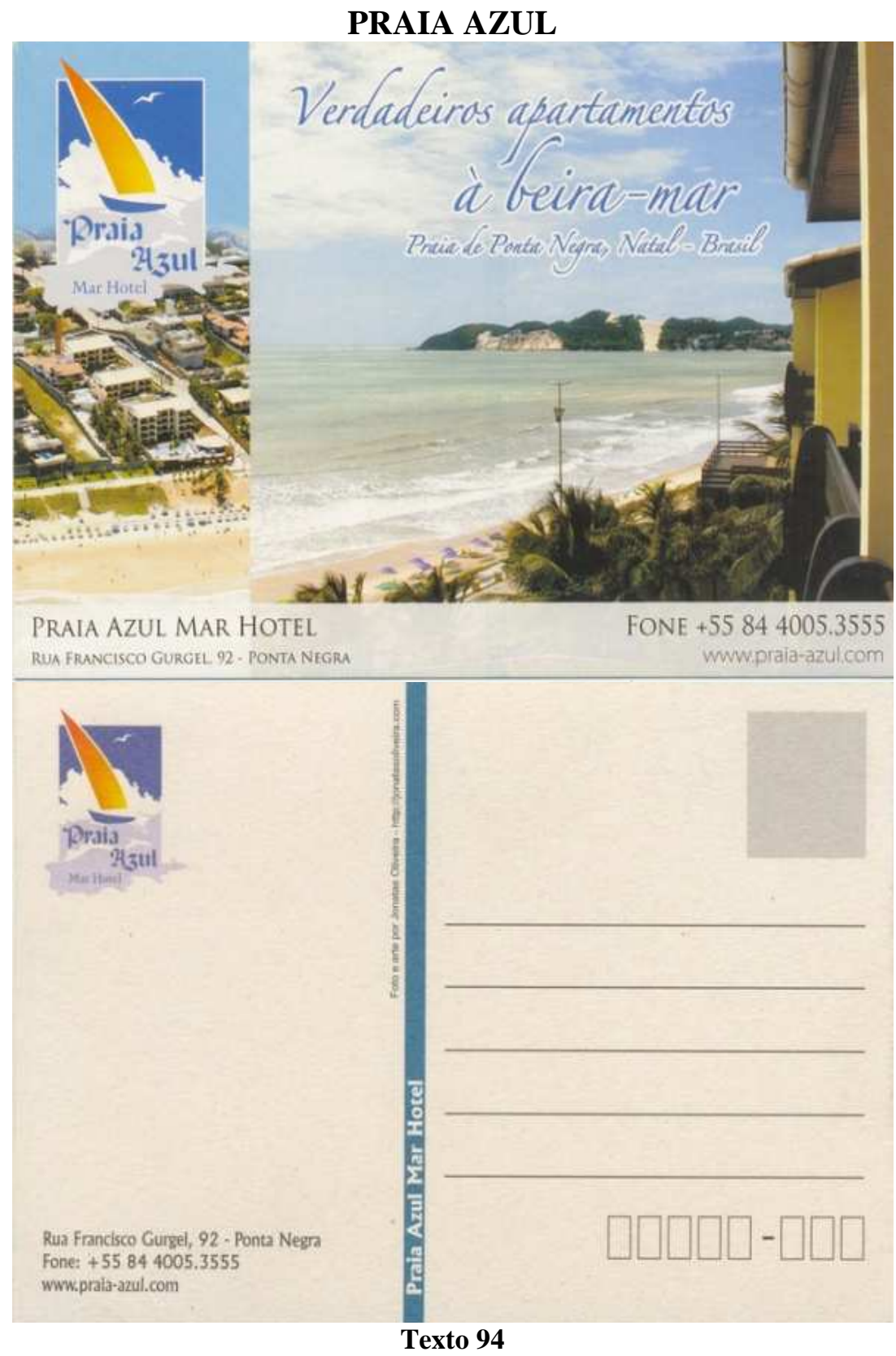


De lo visto hasta aquí hay que concluir que las principales características de un texto publicitario surgen a partir de las necesidades mercadológicas de cumplir con su papel persuasivo en la venta de productos y servicios, lo cual lleva al texto publicitario a acompañar los constantes cambios experimentados por la sociedad contemporánea y a mantener íntima relación con los deseos, miedos y valores de ésta para poder hablar siempre en su "lengua", como ya hemos visto previamente.

Lo que llama la atención del interlocutor y funciona como gancho en el anuncio publicitario presentado anteriormente es el formato: una postal. A partir de eso el Praia Azul Mar Hotel pasa a figurar entre los puntos de interés turístico de Natal ya que está en una postal. En su macroestructura figura la descripción del "Praia Azul Mar Hotel", su dirección y sus formas de contacto. La progresión temática de este texto puede ser definida como de progresión de tema constante y la persona del discurso presente es la inscripción de la tercera persona del plural usada para tratar al producto anunciado de forma objetiva.

Un $90 \%$ del texto 94 está fraguado por medio del lenguaje visual y solamente un $10 \%$ apunta verbalmente que: Praia Azul Mar Hotel, verdaderos apartamentos en frente al mar. El acto de habla locutivo consiste en la presentación descriptiva del producto turístico ofertado y su ubicación; su fuerza ilocutiva es la invitación a que el interlocutor consuma el producto turísticos ofertado y su efecto perlocutivo consiste en la confirmación del lector al hospedarse en el hotel anunciado, o sea, la compra del servicio anunciado.

En el componente expandido del texto en cuestión figura una selección léxica positiva constituida por sintagmas como: Playa, azul, mar, hotel, verdaderos, apartamentos, en frente. Aquí es importante resaltar el lema azul, que describe un color cuyo efecto cromático en el estado de ánimo del interlocutor es de paz, equilibrio y tranquilidad. Además, en portugués brasileño hay una expresión idiomática que consiste en tudo azul (todo azul), cuyo significado equivale a decir que está todo bien.

El producto visual presenta la imagen del logotipo del "Praia Azul Mar Hotel", sus vistas panorámicas y el propio formato del anuncio, ya que es una postal y este hotel, supuestamente, no es un punto de interés turístico de Natal. El mensaje manifiesto de 
este anuncio corresponde a la propia publicidad del producto turístico anunciado y el mensaje latente connota la amplitud del hotel anunciado y su buena localización en frente al mar.

\section{La claridad textual}

Es fundamental la idea de que una de las características textuales básicas debe ser la claridad, porque sin ella el texto resultará incomprensible y a la vez inútil. La publicidad funciona a partir de textos que despierten la atención del interlocutor, que sean claros y de fácil comprensión para que puedan tener persuasión, característica básica del discurso publicitario. Para ello, los publicistas usan todos los mecanismos que la lengua ofrece, de forma que no haya ninguna restricción en relación al uso de elementos gramaticales, léxicos, semánticos, fonológicos, morfológicos y sintácticos. A este respecto, María Victoria Romero Gualda (2005:185) manifiesta que "en los anuncios no parecen existir restricciones gramaticales o léxicas en el empleo del vocabulario". Este concepto de claridad textual es fundamental en la publicidad turística ya que el producto turístico es intangible y la publicidad lo hace existir y lo torna real. 


\section{POR DO SOL DO POTENGI}

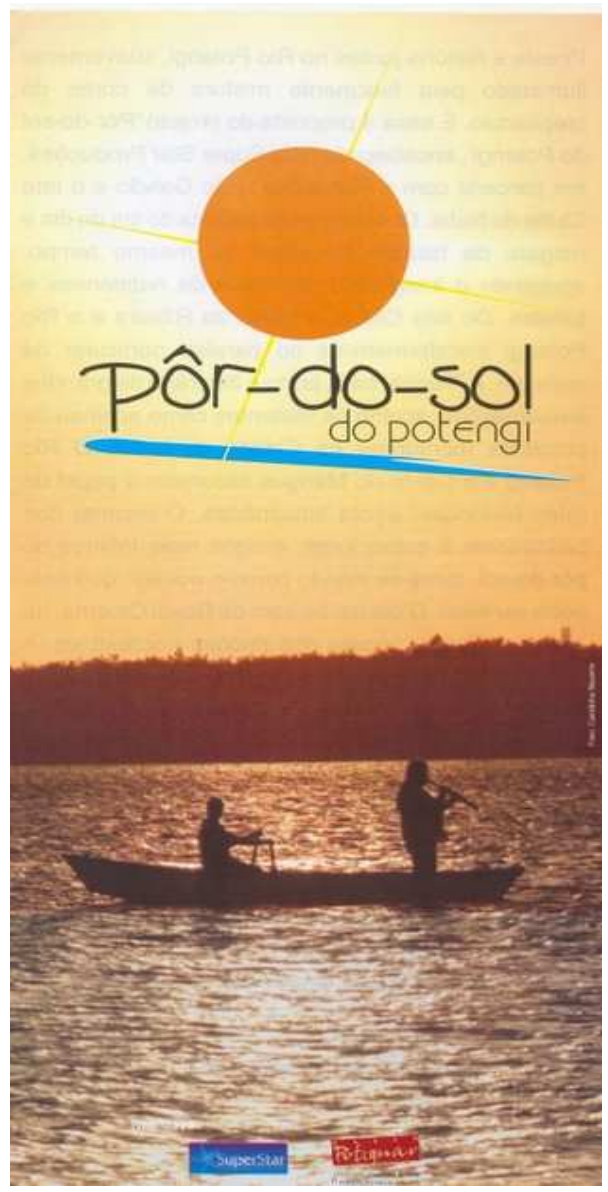

Poesia e história juntas no Rio Potengi, suavemente iluminado pela fascinante mistura de cores do crepúsculo. É essa a proposta do projeto 'Pôr-do-sol do Potengi', encabeçado pela Super Star Produçōes, em parceria com a Fundação Helio Galvão e o late Clube do Natal. Contemplação poética do fim do dia e resgate da história de Natal ao mesmo tempo, aguçando o imaginário simbólico de natalenses e turistas. Do late Clube, o bairro da Ribeira e o Rio Potengi transformam-se no paraiso particular de cada um. A Ribeira, cais, porto e itinerário de grandes embarcaçōes, acolhe os visitantes como acolheu os primeiros moradores da Cidade do Natal. O Rio Potengi e o Canto do Mangue assumem o papel de rotas históricas, agora imaginárias. $\mathrm{O}$ recanto dos pescadores e estivadores, amigos mais intimos do pôr-do-sol, torna-se infinito como o oceano que dele pode ser visto. O dia cai ao som de Royal Cinema, de Tonheca Dantas, poeta dos rincōes nordestinos. A noite começa, com a renovação das expectativas. A Ave Maria de Gounod recebe a lua que surge. E a Serenata dos Pescadores (Praieira), poema de Othoniel Menezes que decanta esses peculiares homens do mar, celebra a Cidade e a vida que recomeça depois do pôr-do-sol. No mais "O Trenzinho do Caipira" de Heitor Villa-Lobos embala os velhos e atuais trens da história potiguar.

Local: late Clube do Natal Data: Terças, Quartas e Quintas

Hora: $17 \mathrm{~h}$

Informaçōes: 3202-4402

Vendas Antecipadas: (III) ATHENAS (84) $3221-2626$

\section{Texto 95}

El texto 95 sorprende por estar constituido por más de 50\% de lenguaje verbal escrito. Ese anuncio tiene en su componente expandido el texto presentado a continuación: Poesía e historia juntas en río Potengi, suavemente iluminado por una fascinante mezcla de colores del crepúsculo. Esa es la propuesta [...]. En lo demás, "O Trenzinho Caipira" de Heitor Villa-Lobos embala los viejos y actuales trenes de la historia potiguar.

Hay algunos recursos usados en la elaboración del texto publicitario como el estereotipo, la sustitución de nombres, la creación de enemigos, apelación a autoridades, además de afirmaciones y repeticiones, todos esos elementos preservan la claridad que debe estar presente en un texto publicitario, como se puede vislumbrar en el texto presentado arriba.

En la macroestructura del texto 95 figura la descripción del "Pôr do Sol do Potengi", la presentación de su localización y las actividades artísticas realizadas en el momento 
crepuscular visto desde el río Potengi. La progresión temática de este texto puede ser definida como de progresión de tema constante. Las personas del discurso presentes son la tercera persona del singular y la tercera persona del plural, usadas para describir el producto anunciado de forma objetiva o más bien impersonal.

Este texto pertenece al género del discurso publicitario y desde un punto de vista de la tipología textual posee una secuencia dominante de texto argumentativo, ya que la descripción funciona más bien como un recurso persuasivo. El acto de habla locutivo establecido por ese texto consiste en el discurso constituido por el lenguaje verbal escrito y el lenguaje visual en descripción del producto turístico ofertado; su fuerza ilocutiva consiste en invitar al interlocutor a realizar ese paseo fluvial por el río Potengi; y el efecto perlocutivo de ese acto de habla es una respuesta positiva por parte del receptor, o sea, la compra de ese servicio turístico.

El producto visual consiste en la propia imagen de la puesta del sol en el río Potengi, con dos hombres en un barco representado ese paseo de forma romántica y uniendo la pescadería a la música. El mensaje manifiesto de ese producto visual consiste en el propio anuncio del producto turístico ofertado en esta publicidad y su mensaje latente consiste en el romanticismo y la nostalgia creada por la imagen de la puesta del sol en un río al son de un clarinete. 
Por lo que se refiere a la creatividad, se puede decir que es una de las características básicas de la publicidad. El factor de la creatividad es fundamental para la publicidad, puesto que como dice Juan de los Ángeles (2005:19), “en el mundo de la publicidad, creatividad es sinónimo de efectividad". Por tanto, la creatividad debe ser sumada a todas las características textuales mencionadas anteriormente. Este mismo autor añade:

\begin{abstract}
Al escribir un texto creativo múltiples factores entran en danza. Todo influye: el acierto en las palabras, los ritmos, el tamaño del (sic.) frases, el sonido, el lugar en el que se coloque una coma o un punto, la oportunidad de escoger un adjetivo, o decidir omitirlo, la originalidad en el uso de las metáforas, o las comparaciones (Juan de los Ángeles, 2005:19-20).
\end{abstract}

Juan de los Ángeles (2005:20-22) también destaca las siguientes seis características básicas de un texto creativo:

\title{
CARACTERÍSTICAS BÁSICAS DE UN TEXTO CREATIVO
}

1- Llama la atención (causa sorpresa, tiene originalidad y/o mantiene relación con los intereses de la audiencia;

2- Crea expectativas;

3- Transmite pasión y entusiasmo;

4- Aporta razones;

5- Es presentado de modo simple;

6- El texto lleva siempre en consideración el receptor y posible consumidor.

Como conclusión de este apartado, Juan de los Ángeles (2005:21) define como un texto verdaderamente creativo el "que consigue captar el interés del lector del principio hasta el final”. Añadiríamos aquí que el texto creativo es el que conquista la atención de la audiencia y además recibe la respuesta esperada de esta audiencia: el consumo del producto o servicio anunciado.

Partiendo del presupuesto de que para que exista el mensaje publicitario este debe estar elaborado a partir de un determinado nivel de creatividad inserta en este tipo textual, la creatividad sería una condición sine qua non en la existencia del discurso publicitario. Por eso hay empresas que se dedican específicamente a la elaboración de textos 
publicitarios que, a través de la especialización que disponen, dan a conocer un determinado producto.

\section{PRAIA AZUL MAR HOTEL}

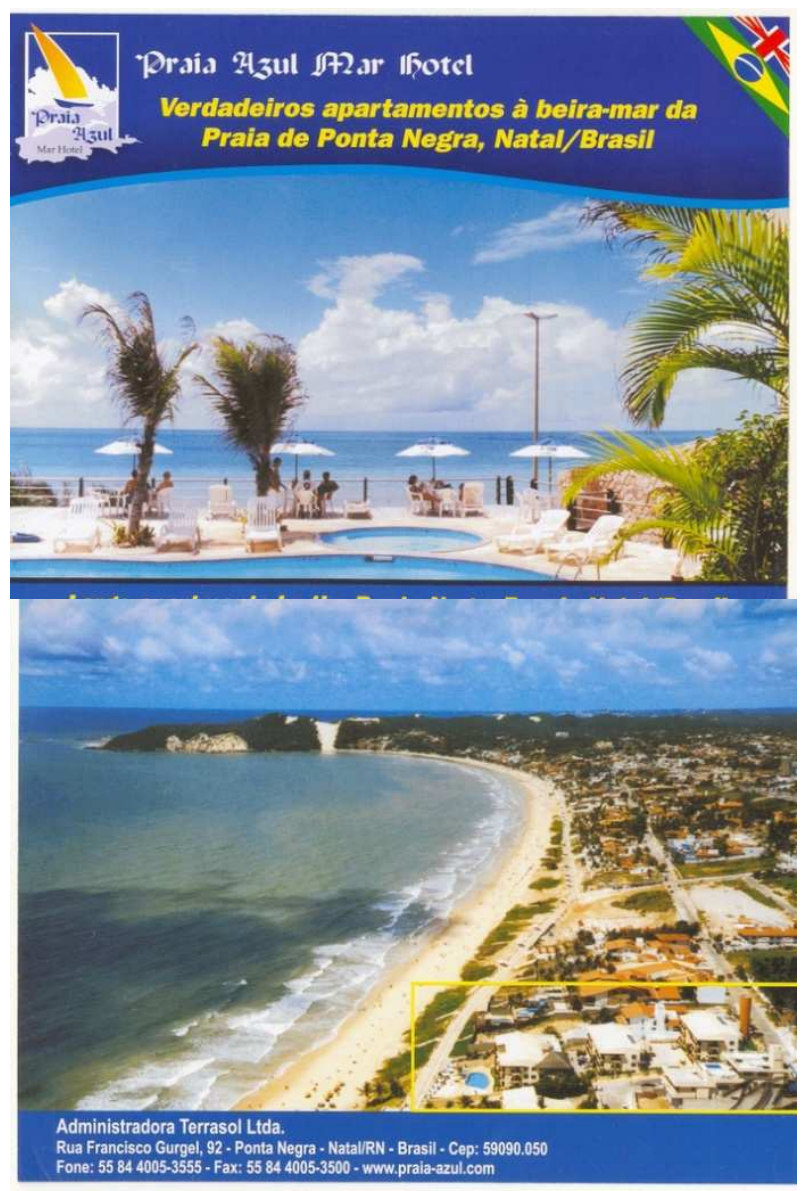




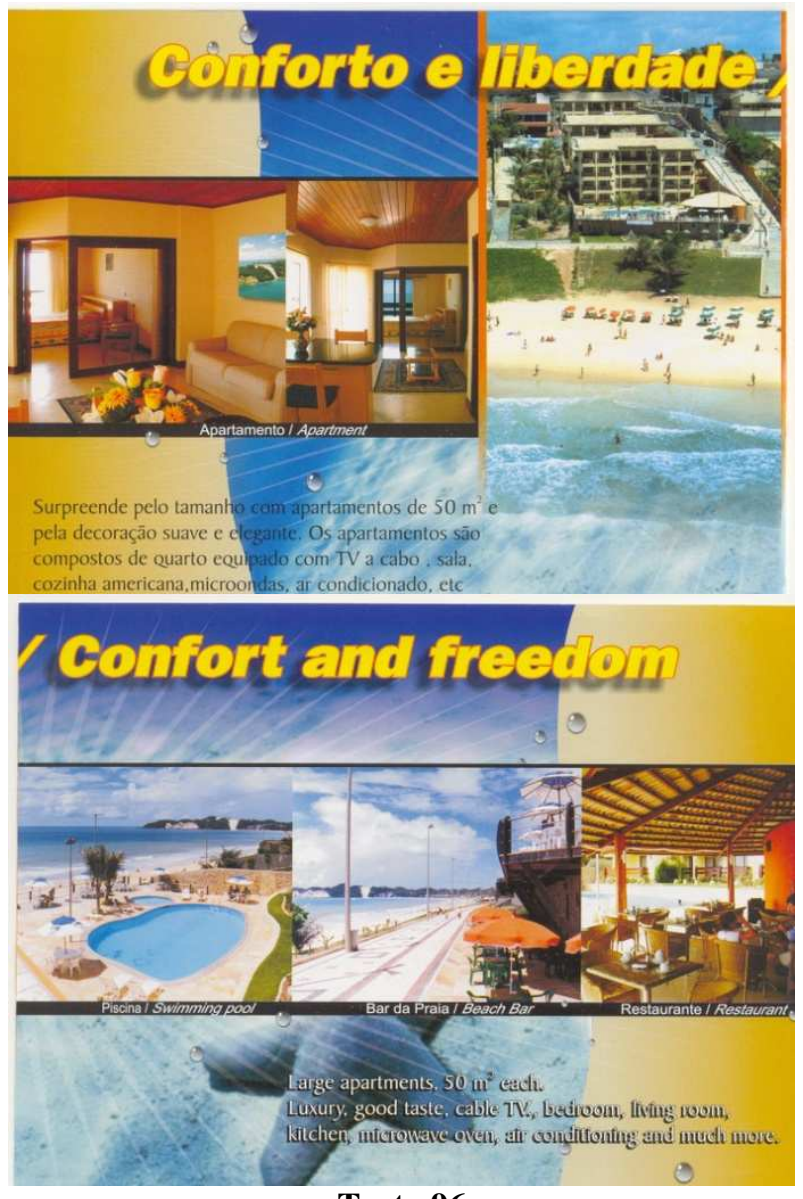

Texto 96

Si el texto presentado anteriormente sorprende al interlocutor por más de mitad ser presentado por medio del lenguaje verbal, el texto 96 sorprende por presentar más de $80 \%$ de su contenido por medio del lenguaje visual. En su macroestructura figura la descripción del "Praia Azul Mar Hotel”, su localización y sus contactos.

En el componente expandido del texto en cuestión se anuncia que: Praia Azul Mar Hotel. Verdaderos apartamentos en frente al mar, en la playa de Ponta Negra, Natal/Brasil. Confort y libertad: sorprende por el tamaño con apartamentos de 50 metros cuadrados y por la decoración suave y elegante [...]. Como se puede ver, la progresión temática de este texto puede ser definida como de progresión de tema constante. La persona del discurso presente es la inscripción de la tercera persona del singular que remite al producto anunciado de forma impersonal.

Desde un punto de vista de la tipología textual, la secuencia dominante del anuncio presentado anteriormente es la argumentativa y el uso de la descripción funciona más bien como un recurso persuasivo. En la selección léxica figuran sintagmas positivos 
como: playa, azul, mar, hotel, verdaderos, apartamentos, en frente al mar, Ponta Negra, Natal, Brasil, confort, libertad, sorprende, tamaño, decoración suave, elegante.

El producto visual del anuncio en cuestión consiste en el logotipo del "Praia Azul Mar Hotel", sus instalaciones externas, internas y las vistas del mar desde este hotel. El mensaje manifiesto es de un hotel amplio y bien ubicado en frente al mar y coincide con el propio texto publicitario del producto anunciado. El mensaje latente connota un gran hotel, elegante y muy confortable.

\section{Articulación del tema en el texto publicitario}

En la elaboración de una campaña publicitaria, según Armando Sant'Anna (2002), se debe elegir un tema y seguirlo con fidelidad, con la finalidad de que el mensaje ejerza más poder de persuasión en la mente humana. En la elección del mensaje para un anuncio publicitario el foco central debe ser el principal aspecto del producto o servicio ofrecido. Para convencer al consumidor, la producción del tema tiene que tomar en consideración el punto de vista del consumidor. Armando Sant'Anna (2002:158) dice que el tema debe ser creado tomando como base factores como:

\begin{tabular}{|c|l|}
\hline \multicolumn{2}{|c|}{ FA CTORES QUE SIRVEN COMO BASE PARA LA CREACIÓN DE UN TEMA } \\
\hline PARA UN TEXTO PUBLICITARIO \\
\hline SEGUMERO & Objetivo de la campaña \\
\hline TERCERO & Función principal de la campaña \\
\hline CUARTO & Argúmulo adecuado a la naturaleza del grupo consumidor \\
\hline
\end{tabular}

Otro paso esencial es la identificación de las necesidades básicas y el interés de los consumidores. Después de la conclusión de esa etapa, se deben desarrollar los medios para que, a través de los factores identificados anteriormente, los posibles consumidores sean estimulados por las principales características del producto o servicio, de las ventajas y beneficios del producto como argumentos fuertes. Para Armando Sant'Anna (2002:158), un buen argumento de ventas es aquel que proporciona mayor satisfacción al consumidor; los competidores no posean o posean en menor escala; no haya sido 
presentado en otros anuncios; y esté relacionado con una necesidad o deseo del consumidor.

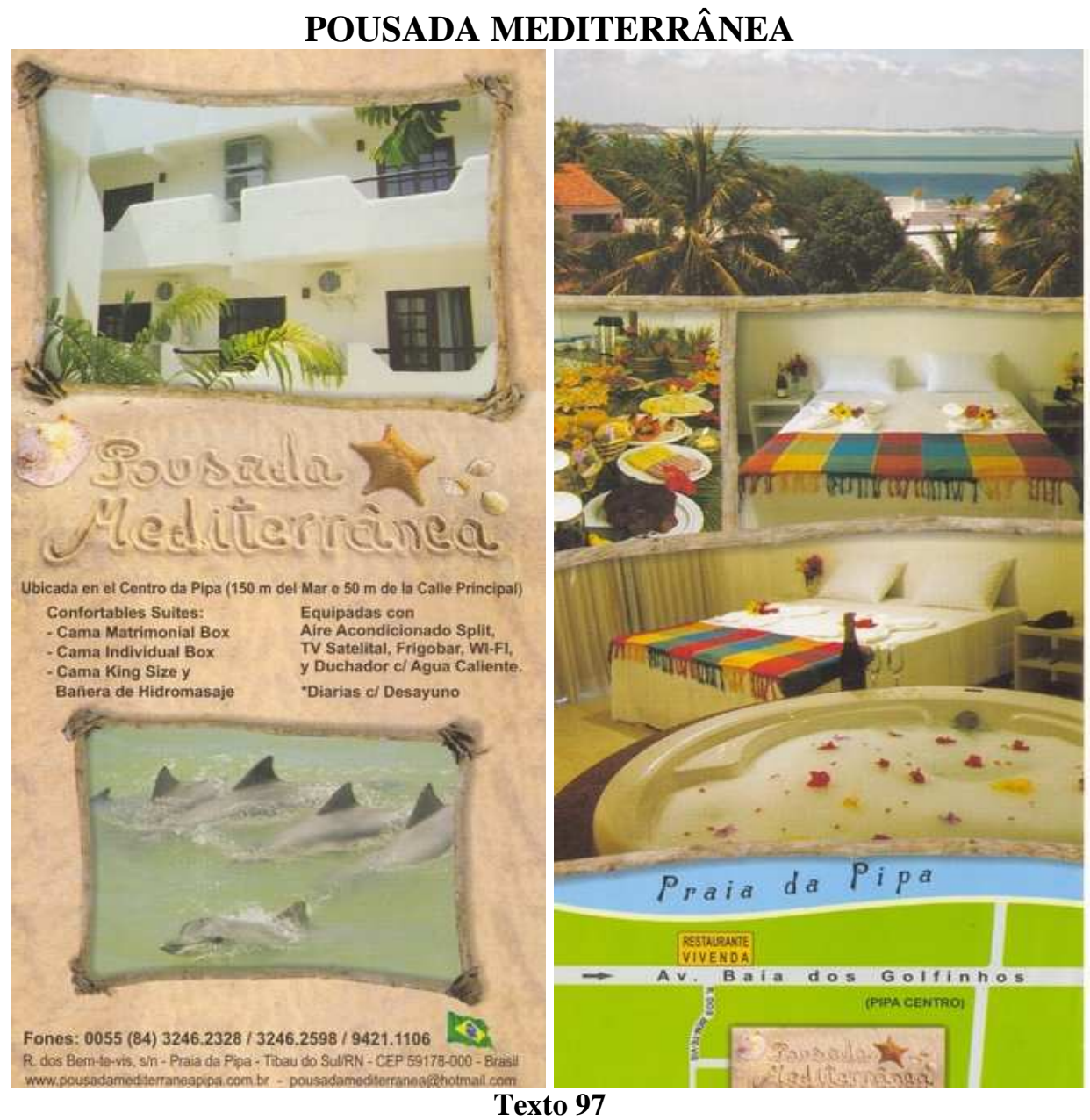

En el anuncio publicitario en forma de folleto de la "Pousada Mediterrânea" está presente el predominio de la economía lingüística, de la sencillez y la objetividad, o sea, el texto se limita a presentar el producto/servicio turístico de la forma más objetiva posible. Con lo cual, si el interlocutor se siente identificado con ese anuncio, tiene todas las informaciones de cómo hospedarse en el establecimiento de hostelería anunciado. La macroestructura de ese texto presenta la descripción de la "Pousada Mediterrânea", sus instalaciones internas y externas, además de sus servicios.

Desde un punto de vista de la tipología textual posee una secuencia dominante de texto argumentativo, ya que la descripción funciona más bien como un recurso persuasivo. En la textura discursiva están presentes los elementos léxicos que agregan un valor positivo al producto turístico anunciado, tales como: centro, confortables y equipadas. Aquí es 
importante mencionar el propio nombre del establecimiento - Mediterránea - que puede remitir muy bien a todos los valores positivos de la cultura mediterránea, incluso al dicho: "la virtud está en el punto medio".

El producto visual consiste en la propia imagen de las instalaciones externas e internas de la "Pousada Mediterrânea", su vista al mar y la imagen de la variedad culinaria que se puede encontrar en esa hospedería. El mensaje manifiesto coincide con el propio anuncio de este sitio y sus calificaciones como producto turístico. El mensaje latente connota la sencillez, el confort, la comodidad, la tranquilidad y la belleza del lugar anunciado.

\section{Características del título}

Armando Sant'Anna (2002:159) afirma que el tema directo contiene un texto razonable que "se dirige a la inteligencia lógica de los hechos, informa, describe el producto, da razón, ventajas, tiene fuertes argumentos de ventas. Directo. Objetivo". Para que sea establecida una coherencia con el título, este tiene que "seleccionar al lector, informar sobre el producto, exponer una ventaja, prometer un beneficio". Además debe ser constituido por elementos textuales como:

1- Una afirmación;

2- Una promesa;

3- Un consejo;

4- Una noticia;

5- Una comparación;

6- Un suspense;

7- Un testimonio;

8- Una pregunta;

9- Una negación.

En ese contexto vale observar que la función de un título en un texto es llamar la atención y despertar el interés del lector, que debe ser seleccionado y detenido por el texto. La mayoría de las veces es el elemento más completo de un anuncio publicitario. 
A través del título, el lector toma la decisión de leer o no un texto, de ahí la importancia del título de un anuncio en la publicidad.

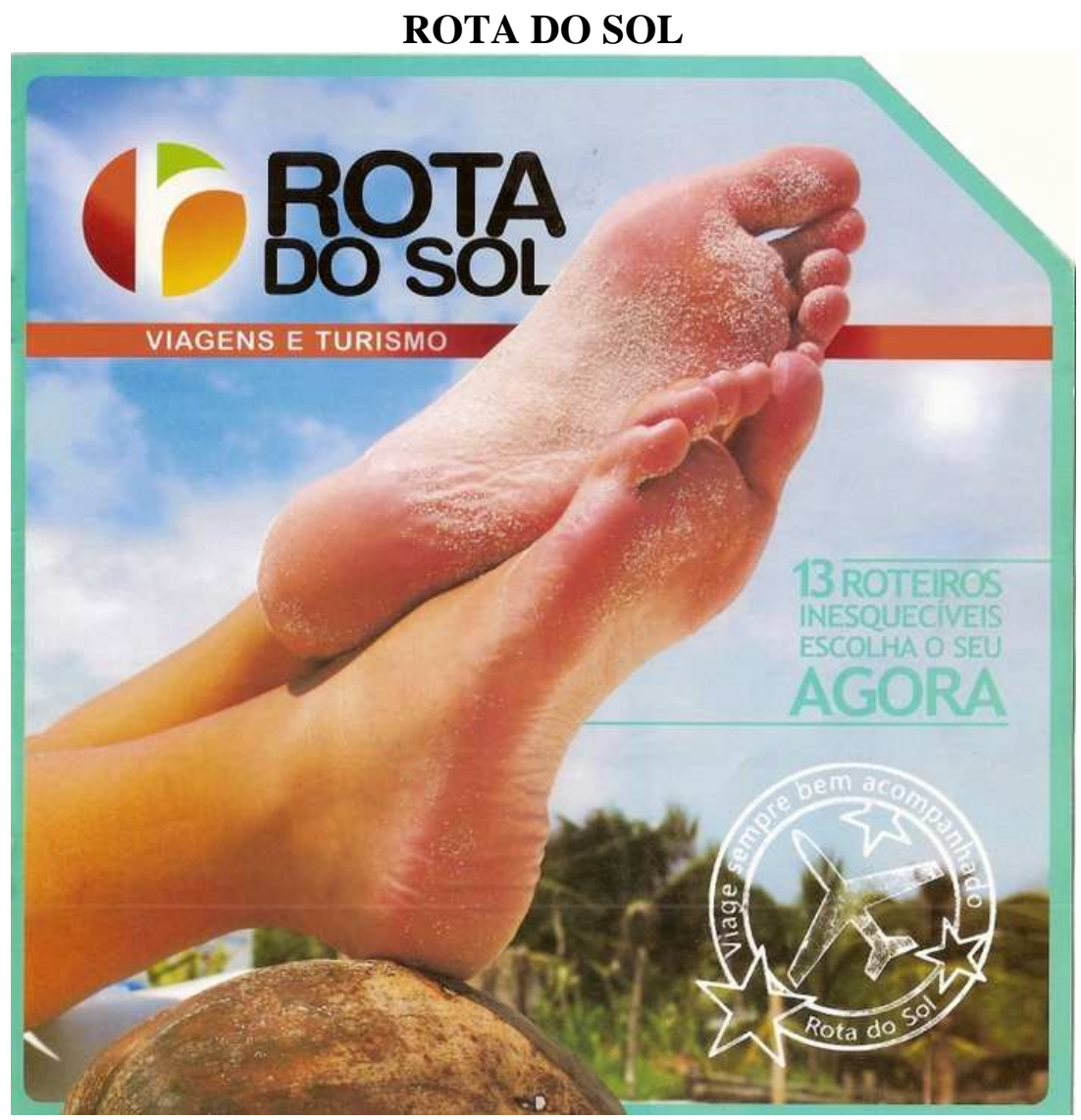

Texto 98

Siguiendo una secuencia de lectura occidental de arriba abajo y de izquierda hacia la derecha el interlocutor del texto 98 puede llegar fácilmente al enunciado presentado a continuación: ROTA DO SOL es una empresa de viajes y turismo, ofrece 13 rutas turísticas inolvidables, en el momento presente, y esa empresa es la mejor compañía para un viaje.

Y como el tamaño de la fuente aporta importancia, no hace falta mucho esfuerzo cognitivo para llegar a la conclusión de que el título "Rota do Sol" tiene más importancia que los otros sintagmas presentes en ese anuncio que, por cierto, está fraguado por medio de una selección léxica positiva como: ruta, sol, viaje, siempre, ahora, inolvidables y bien acompañado. 
La base para la redacción de un texto es la delimitación de su tema y su audiencia. El texto es la representación detallada de lo que fue propuesto por el tema y desarrolla la idea principal del mensaje, presente en todo el anuncio publicitario y que, además, debe convertirse en algo interesante y apetecible, ya que "anunciar consiste en volver interesante, apetecible un producto: crear, en la mayoría de los casos, un valor subjetivo, un valor psicológico que exceda su valor intrínseco o real" (Armando Sant'anna, 2002:161).

En el desarrollo de un texto publicitario se deben tomar en consideración elementos textuales como guión y unidad. Un anuncio se puede presentar de forma razonable o emotiva. El texto razonable está relacionado con el uso de la lógica de los hechos, que contribuyen a persuadir al lector/consumidor por medio de un razonamiento lógico y objetivo, en el que se "informa, describe el producto, enumera las ventajas, justifica los motivos por los que se debe adquirir el producto" (Sant'anna, 1998:162). Sin embargo, como ya hemos visto, en la publicidad contemporánea es bastante común los anuncios más emotivos que razonables.

El texto emotivo intenta persuadir por medio de procesos emocionales despertados en el interlocutor. Este tipo de texto debe ser sugestivo, que intente vender los beneficios del producto, no el producto en sí. Sant'Anna (1998:162) afirma que "la forma razonable se adapta mejor al tema directo, la emotiva al indirecto. En general las dos son usadas en conjunto, con el predominio de uno de ellos".

En la estructura textual, los anuncios publicitarios pueden presentar la estructura de “encabezamiento" o titulares con los que se llama la atención, 'cuerpo' del texto en que se exponen los argumentos persuasivos y 'rúbrica' o cierre" (Martínez, 2000:36), claro que eso no puede ser adoptado como una norma, pero nos sirve de guión como una forma general de ver un texto publicitario. Aun así, es importante tener en cuenta que, como se puede observar a partir de los anuncios publicitarios analizados hasta este punto de nuestro trabajo, no hay una fórmula fija para el texto publicitario. 
El anuncio publicitario necesita ser presentado textualmente de forma atractiva para que conquiste al interlocutor, le despierte curiosidad, le llame la atención desde el inicio hasta el final. De acuerdo con Sant'Anna (1998:163) en el proceso de elaboración de un texto publicitario se deben tomar en consideración algunos aspectos formales como:

\begin{abstract}
El primer párrafo es, generalmente, una ampliación del título. Luego hay una aclaración de las afirmaciones o promesas presentadas en el título o en el primer párrafo. Después, vienen las justificaciones o las pruebas de lo que se dijo, siguiendo, entonces, en caso de que sea necesario, la enumeración de argumentos o ventajas adicionales. Por fin, el cierre o la invitación a la acción: experimente hoy mismo. ${ }^{61}$
\end{abstract}

Esa estructura no es estándar en todo anuncio publicitario, porque dependiendo del tipo de anuncio y de su vehículo de información se pueden encontrar en el texto publicitario elementos como el nombre del producto o servicio anunciado, marca, logotipo, imágenes y un eslogan. En función de la importancia de este último elemento en un anuncio publicitario, abriremos un apartado que trate específicamente del eslogan.

\title{
La polisemia en el texto publicitario
}

Para Rosa Lídia Coimbra, en su obra Jogos Polissêmicos no Discurso Publicitário (2002), el mensaje publicitario tiene como objetivo llamar la atención del receptor y hacer que las informaciones transmitidas sean grabadas en la memoria de la audiencia, también busca persuadirla y convertirla en consumidora.

El juego de palabras en un texto publicitario es una estrategia comúnmente utilizada para captar la atención del lector y para condensar significados en el texto en el que "el máximo de información es condensado en el mínimo espacio posible" (Coimbra, 2002:1).

\footnotetext{
${ }^{61}$ En la fuente original: "O primeiro parágrafo é, geralmente, uma ampliação do título. Segue-se o esclarecimento das afirmativas ou promessas feitas no título ou no primeiro parágrafo. Vêm, depois, a justificativa ou as provas do que se disse, seguindo-se, então, se necessário, a enumeração de argumentos ou vantagens adicionais. Finalmente vem o fecho ou o convite à ação: experimente hoje mesmo".
} 
Esta estrategia de condensación de significados genera la polisemia que "ha sido definida como resultante de la correspondencia de varias acepciones, de acuerdo con diversos contextos, a una misma forma lingüística, sin que se pierda, como homonimia, la noción de que estamos delante del lexema" (Coimbra, 2002:1-2). Esta misma autora presenta tres parámetros para el análisis y la interpretación de los juegos de palabras, a saber:

1- El análisis de los sentidos (prototípico y no prototípico);

2- La Presencia/ausencia de término para el segundo sentido;

3- La relevancia de los sentidos en relación al co-texto.

Estos parámetros pueden ser empleados en niveles semánticos, formales, pragmáticos. Además de ser posible hacer uso de estos elementos para analizar un texto publicitario desde un punto de vista semántico, también es importante destacar el análisis del significado de elementos como frases hechas y dichos en el texto publicitario. Sobre ese aspecto, Claude Hopkins, en su libro A Ciência da Propaganda (1993), orienta sobre cómo ser más específico en un texto publicitario, y para eso se puede evitar el uso de dichos y frases hechas por no ser muy significativos para las personas, ya que "son, como mucho, la simple expresión de lo que se espera" (Claude Hopkins 1993:56). ${ }^{62}$

\subsection{El eslogan en la publicidad}

La marca muchas veces se superpone al producto y llega a nombrarlo hasta el punto de que un producto sin marca o sin nombre no existe. López Eire (1998) aborda la importancia que cobra la marca dentro de la publicidad en el segundo capítulo de $L a$ Retórica en la Publicidad y afirma:

Reflejada en nombre (por vía oral o escrita), icono, logotipo, o estampada sobre los más variados soportes, la marca se convierte en una palabra mágica que se almacena en el depósito de la memoria colectiva y se rememora luego con más facilidad que las palabras ordinarias con las que nos referimos a la realidad, hasta el punto de que se da la paradoja de que en publicidad conocemos y comunicamos mucho mejor las marcas que los productos a los que representan (López Eire, 1998:38).

\footnotetext{
${ }^{62}$ En la fuente original: "São, quando muito, a simples expressão do que se espera".
} 
CAMPOS DO JORDÃO E CALIFÓRNIA

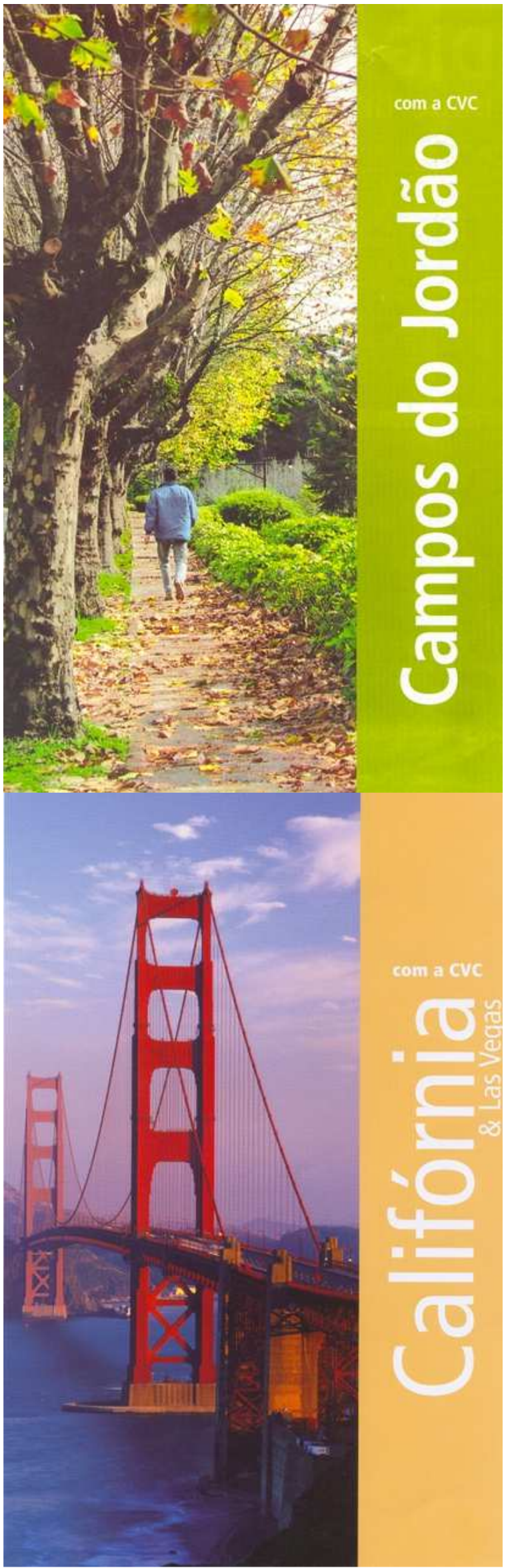

Texto 99 
El eslogan es una fórmula o frase de efecto anterior a la publicidad y sirve como un buen ejemplo del discurso publicitario, con su sencillez y eficacia. Este lema tiene origen gaélico y significa una fórmula concisa y fácil de acordarse. Referente a eso, López Eire (1998:43) afirma que "un buen ejemplo de la eficacia de la extrema sencillez sintáctica o laconismo del lenguaje publicitario es el eslogan".

Un muy buen ejemplo de eslogan es el creado para la operadora de turismo brasileña CVC, que consiste en una marca ya consagrada en el mercado del turismo nacional e internacional, por eso no hace falta mucha explicación sobre esa marca, de ahí se usó como eslogan de una campaña publicitaria entera la fórmula: el nombre del destino turístico + con $C V C$. A partir de esa ecuación podemos vislumbrar eslóganes como: Campos do Jordão con CVC y California \& Las Vegas con CVC, como se puede ver en el texto 99.

El eslogan en la publicidad resume todo lo que se puede decir sobre el texto publicitario y es lo mismo que la frase publicitaria. A partir del principio de economía lingüística, en publicidad, las frases que dicen más con menos palabras valen más. En ese contexto se puede destacar la abundancia de frases hechas en el lenguaje publicitario por su efecto captador de atención, de fácil comprensión y que se memorizan con facilidad. Esas frases funcionan como una práctica cotidiana del lenguaje popular y exponen los aforismos en la publicidad, el giro popular, referencias políticas, sociales y económicas. Ferrer (1994:237) dice que para que un eslogan sea exitoso depende de algunos factores como:

\footnotetext{
El valor unilateral de algunos de ellos en una situación o circunstancia dada. No hay duda de que debe de producir una impresión reveladora de su interés, entre la certidumbre y, a veces, la sorpresa; entre la atención y el asombro. Debe contener la información que revele la función o el beneficio de lo anunciado. Debe ser escrito con sencillez y concisión, independientemente de recrear el sentido de las palabras. Debe alcanzar el segmento del público que corresponde al género de lo anunciado y al perfil del consumidor. Un conjunto de requerimientos que den al mensaje vitalidad e imaginación, fijación y facilidad de recuerdo, compresión y persuasión. Todo ello envuelto en la parábola de la credibilidad.
}

Una de la metas del eslogan es que su mensaje sea memorable, es decir, que quede en la memoria cultural de su público. El eslogan también genera la vida del lenguaje 
publicitario, o sea, sin el eslogan la publicidad no actuaría como un tipo de lenguaje vivo. Ferrer (1994:237) afirma que "el eslogan es una flecha dirigida al blanco. Si en la propaganda cabe el abstraccionismo, la publicidad es lo concreto, sin desperdicio", en fin, consiste en una frase de efecto con objetivos bien definidos previamente.

\section{AIR CANADA}

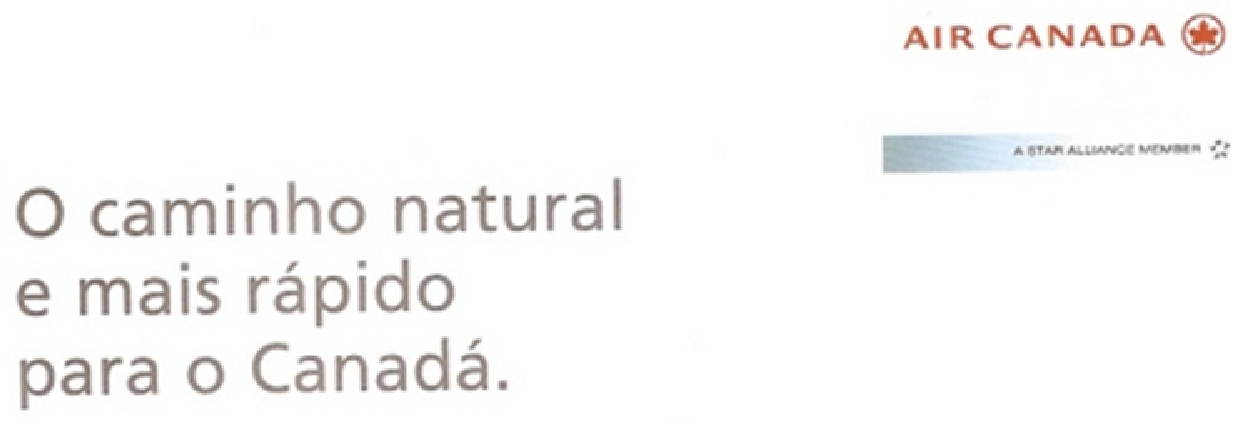

A Air Canada é a única companhia aérea que oferece vóos diários de Săo Paulo a Toronto sem escalas e, também, conexōes imediatas para todo o Canadá e Estados Unidos.

Em Toronto, nossos clientes poderd̆o contar também com vóos non-stop para ir até a Ásia com agilidade.

E para quem năo abre måo do conforto, o renomado serviço Executive Firste oferece um cardápio requintado, vinhos finos e poltronas espaçosas.

Quando pensar em Canadá, pense Air Canada.

wrww.aircanada.com.br

www.skicanada.com.br

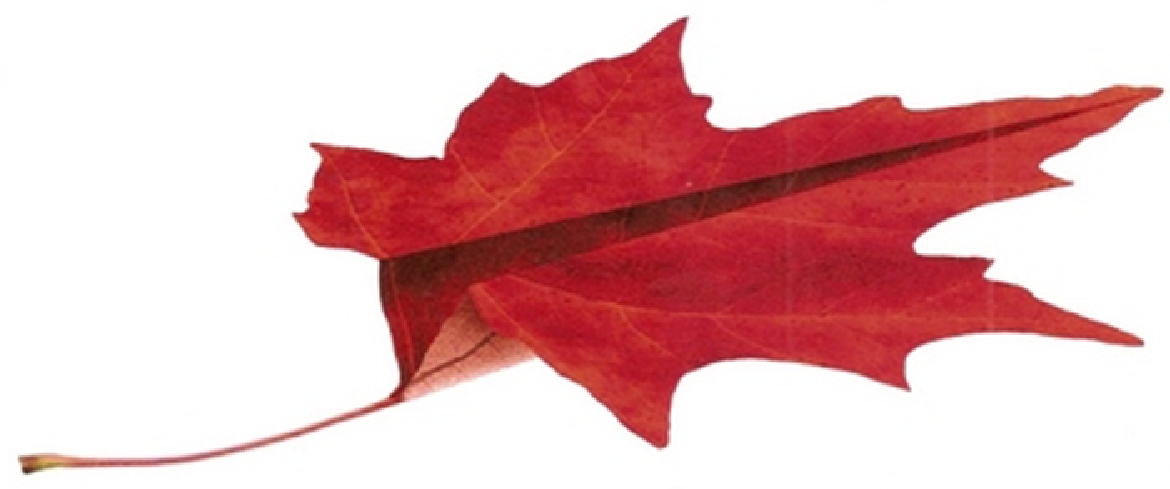

A Air Conyda fol eleita en 2000 a Mehar Companhia Adres do Amirika do Norte por uma pesquiba realizads de empres indegendente Shytrax com mas de 14 milhses de visjantes do mundo inteiro. 
En el eslogán "el camino natural y más rápido para Canadá" resume todo lo que el anuncio de Air Canadá, que hemos presentado arriba, quiere transmitir a sus interlocutores cuando anuncia un vuelo sin conexiones o paradas para Canadá, ofreciendo confianza, seguridad, rapidez y confort. Es interesante observar que en este anuncio el producto ofertado por Air Canadá no aparece en el eslogan, pero si el interlocutor se detiene un poco en el anuncio, al volver a leer la frase "el camino natural y más rápido para Canadâ", automaticamente la mente la complementa con Air Canadá. Con lo cual, podemos decir que este eslogan es muy fácil de ser recordado y el efecto que causa es automático.

Este anuncio ya remite directamente Canadá, ya que es muy semejante a la bandera nacional de este país, con la diferencia de que la hoja del árbol roja está doblada de modo semejante a un avión de papel. Nada más adecuado para anunciar la compañía aérea canadiense. Y ¿por qué alguien volaría por esta compañía? Porque ofrece vuelos directos, porque es una compañía miembro de la Star Aliance y porque fue elegida la mejor compañía aérea de América del Norte en el año del 2007. Esas son las razones que el anuncio presenta para que se elija a la Air Canadá como compañía aérea. Esa publicidad turística es concluida con la frase “cuando pensar en Canadá, piense Air Canadâ", con lo cual no sería difícil establecer esa relación.

Los eslóganes reconocidos como ideales son los que presentan, como el eslogan del anuncio que expondremos a continuación (Tudo novo. Tudo Azul), a la vez sencillez, son memorables y poseen un valor demostrativo. Por eso, hay algunos que se registran en la historia de la publicidad como de gran representatividad y los que se quedan para la historia por presentar un carácter erróneo. Para Ferrer (1994:235) hay un tipo ideal de eslogan, palabra ingresada en el diccionario español en el año de 1992, que presenta las siguientes características:

\footnotetext{
La idealidad publicitaria está condicionada por la realidad del mercado. Quiere decirse que es indispensable contar con él para determinar la funcionalidad práctica de un eslogan. Lo que, a la vez, nos remite a las variables constantes del tiempo y del comportamiento del ser humano. La publicidad, como sabemos, es un fiel reflejo de uno y otro. Sigue sus hábitos, acata sus exigencias; se acomoda a los cambios del lenguaje mismo, según varían los gustos, según las palabras giran en los modismos y aliteraciones del lenguaje genérico de sus particularidades en el de la publicidad.
} 
AZUL

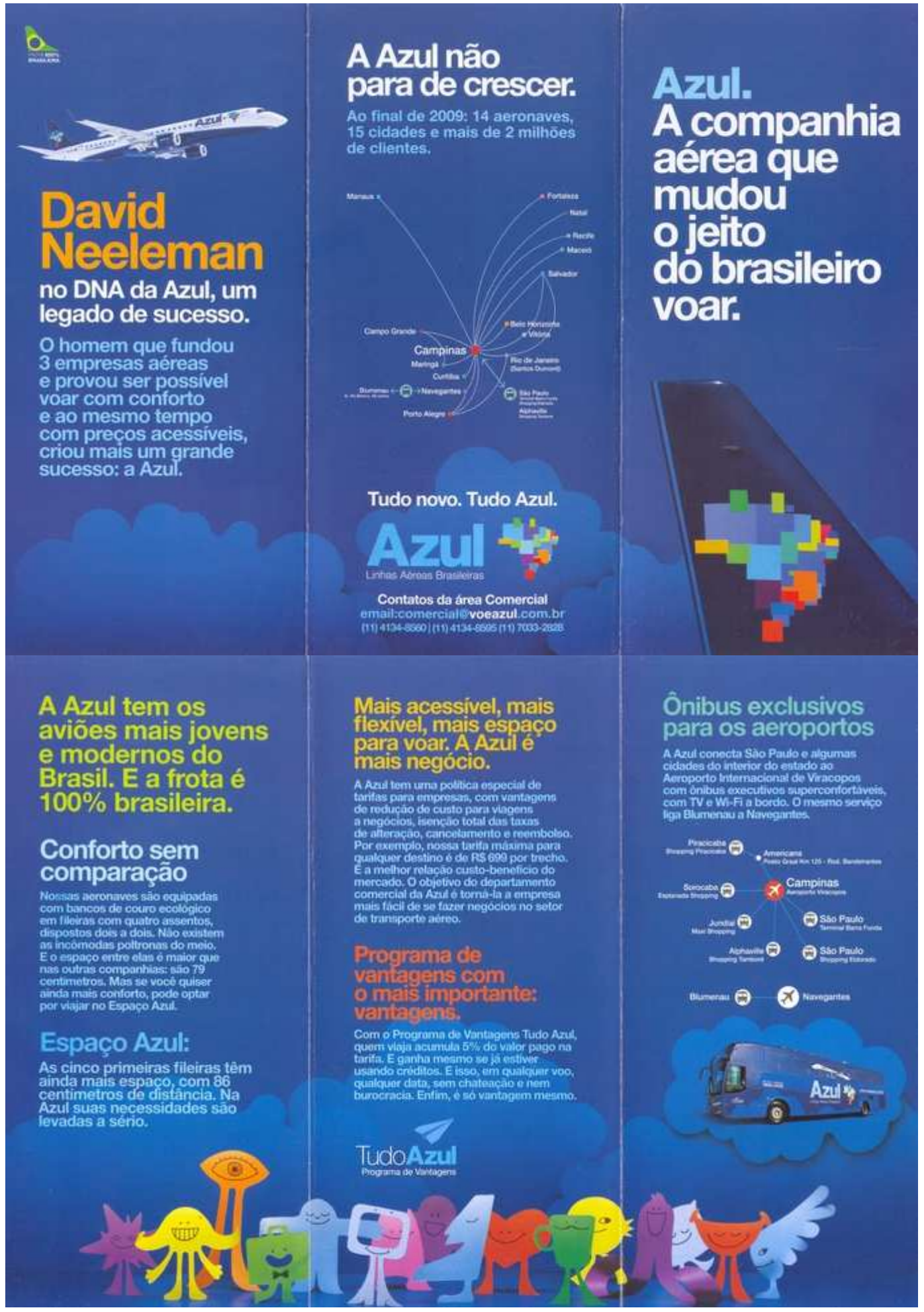

Texto 101

El eslogan también sirve para corroborar el carácter sintético del mensaje publicitario, muy importante en el contexto en el que está inserto. Tomando todavía como ejemplo la publicidad turística presentada anteriormente Todo nuevo. Todo Azul, podríamos 
afirmar que es un eslogan perfecto, pero solo tiene sentido en su contexto porque “Azul" es el nombre de una compañía aérea brasileña y además connota la expresión de que "todo está bien y perfecto", ya que este es el significado de la expresión "tudo azul".

De ese modo "Todo nuevo. Todo Azul", presenta una compañía nueva que está bien, es moderna, confortable, de buena calidad y perfecta. Y lo deja claro por medio del argumento de excelencia usado en los enunciados del texto 101 cuando dice: Azul no para de crecer; Azul. La compañía aérea que cambió el modo brasileño de volar; Azul tiene los aviones más jóvenes y modernos de Brasil; (Azul) Confort sin comparación.

La economía lingüística en los anuncios publicitarios también está directamente vinculada al coste de los espacios que los publican. Para Ferrer (1994:246) "en el lenguaje publicitario, la síntesis se enriquece, experimenta nuevas formas, aligera las cargas orales o escritas de las palabras, maneja sus valores acumulativos de repetición, establece las primeras normas de su economía de coste. Impone su pragmatismo".

El contenido de un eslogan está desarrollado a partir de un principio regido por la economía y el consumo de palabras. El eslogan sintetiza el mensaje que es elaborado a partir de una fórmula comunicativa que tiene como objetivo conquistar la atención del público. Según Ferrer (1994:252) "la síntesis es el corazón del lenguaje de la publicidad que evidencia que el mecanismo económico en que se inserta la publicidad no puede ser ajeno al carácter social de su naturaleza".

El eslogan posee un origen oral y no es muy difícil encontrar características de la literatura oral en un eslogan actual, dado que "el eslogan, por su origen oral, debe tener ritmo, musicalidad. Que se pueda leer tan fácilmente como se dice. Juego de palabras breves, gratas al oído y a la vista, en ese intento tan difícil de conjugar la velocidad del sonido y de la luz; la voz y la imagen entrelazadas" (Ferrer, 1994:252).

Es innegable que debe admitirse que el mercado económico está orientado por y para una sociedad que valora nombres de marcas que necesitan un cierto tiempo para adquirir un determinado relieve en el mercado. Para que una marca conquiste relevancia en el mercado es necesaria la publicidad, la promoción y la información. El nombre de 
la marca va asociado a un logotipo que a su vez servirá como una herramienta clave para la publicidad.

\subsection{La publicidad: un texto híbrido}

Cuando se habla de géneros textuales, el concepto se remite automáticamente a la retórica clásica y a la teoría de la literatura. Según Aristóteles, en la Retórica, los géneros clásicos son forenses o jurídicos; deliberativos o políticos; y epidícticos o de ocasión.

En este sentido, los anuncios serían, entonces, un género discursivo y "constituyen una parte muy importante de lo que se entiende por repertorio comunicativo o capital comunicativo, tanto de los individuos como de los grupos humanos" (Calsamiglia \& Tusón, 2002:263).

Consideramos la publicidad turística como un género discursivo del que forma parte algunos subgéneros como el folleto informativo, el folleto orientativo y destinado a ventas y los folletos-libros, según la clasificación de Manuel Rey (2004), como ya hemos visto en el segundo capítulo de este trabajo de investigación. A partir de nuestro corpus de estudio, proponemos una nueva clasificación de los folletos publicitarios en las siete categorías que presentamos a continuación: folleto orientativo; folleto destinado a ventas; folleto orientativo mixto; folleto libro; folleto libro mixto; folleto publicitario electrónico (CD y DVD); folleto periódico; y folleto revista.

Es importante destacar que la publicidad, comprendida como un arte, es un medio de comunicación social que comunica de una forma especial y también hace uso de un lenguaje especial. El código en el que se apoya el discurso publicitario se aproxima al código del discurso común y, a la vez, al código del discurso literario, pero presenta algunas diferencias singulares en relación a estos dos tipos discursivos. Así, frente al misterio del fenómeno publicitario, el gran desafío de los investigadores es definir y establecer las características específicas del discurso publicitario.

Todavía no ha sido posible identificar todos los problemas que permean este tema y encontrar una solución definitiva, pero es factible, pese a las limitaciones, establecer 
algunas características que distinguen y, a la vez, particularizan el discurso publicitario frente al discurso común y al discurso literario.

Para finalizar, nos gustaría formular la repuesta para nuestra indagación inicial: ¿es la publicidad escrita un texto literario o no literario? A partir de lo que hemos visto sobre el fenómeno publicitario, en muchos casos podríamos considerar el texto publicitario como una verdadera obra de arte literaria, como llegan a afirmar algunos estudiosos, sin embargo, también hay incontables casos en los que la publicidad podría figurar más bien en el grupo de los textos no literarios, así que a partir de ello formulamos nuestro tercer postulado en el que afirmamos que el texto publicitario es un tipo de texto híbrido, siendo así un texto que gravita entre los textos literarios y los textos no literarios.

El texto publicitario posee a la vez un carácter utilitario, en su ámbito informativo, y estético, producto de sus características subjetivas y poéticas, por eso podemos clasificar el texto publicitario como híbrido, como ya hemos visto anteriormente, en el que tiene relevancia su tipo de lenguaje que está caracterizado también por el predominio de la sensibilidad, y por eso presenta una gran variación de estilos. Para Ferrer (1994:236) el lenguaje del texto publicitario "está hecho de percepciones y sugestiones, de equilibrio y excesos."

Por fin, considerando las peculiaridades estilísticas del texto publicitario, se puede decir que este tipo textual es producto de la creatividad y por ello se presenta a través de distintos códigos y canales, de los cuales dispone para la propagación de un mensaje publicitario y con eso cerramos nuestra primera cuestión, quedándonos intentar establecer las especificidades del texto publicitario frente al texto literario y al texto no literario para defender nuestra Teoría del Acto de Comunicación Publicitario. 


\subsection{Semiótica y publicidad turística}

Del mismo modo que la retórica es fundamental para la comprensión del proceso comunicativo en la publicidad, la semiótica también cobra su importancia en el discurso publicitario, puesto que es un tipo discursivo mixto, en el que tanto el lenguaje visual como el escrito se asocian en la producción del sentido y difusión del mensaje, con lo cual la noción de semiótica es imprescindible para el tratamiento del discurso publicitario.

Además, la comprensión del comportamiento del signo visual es muy importante para la publicidad, ya que "el anunciante utiliza la imagen para destacar los atributos del producto, implicar al destinatario o resaltar el mensaje" (Velasquez, 2007:333). En este sentido, la semiótica es uno de los fundamentos para los estudios de la publicidad. También, el dominio visual pertenece al campo de estudio de la semiótica y el dominio mental (tema de estudio de la cognición) están ligados a los conceptos de signo y representación.

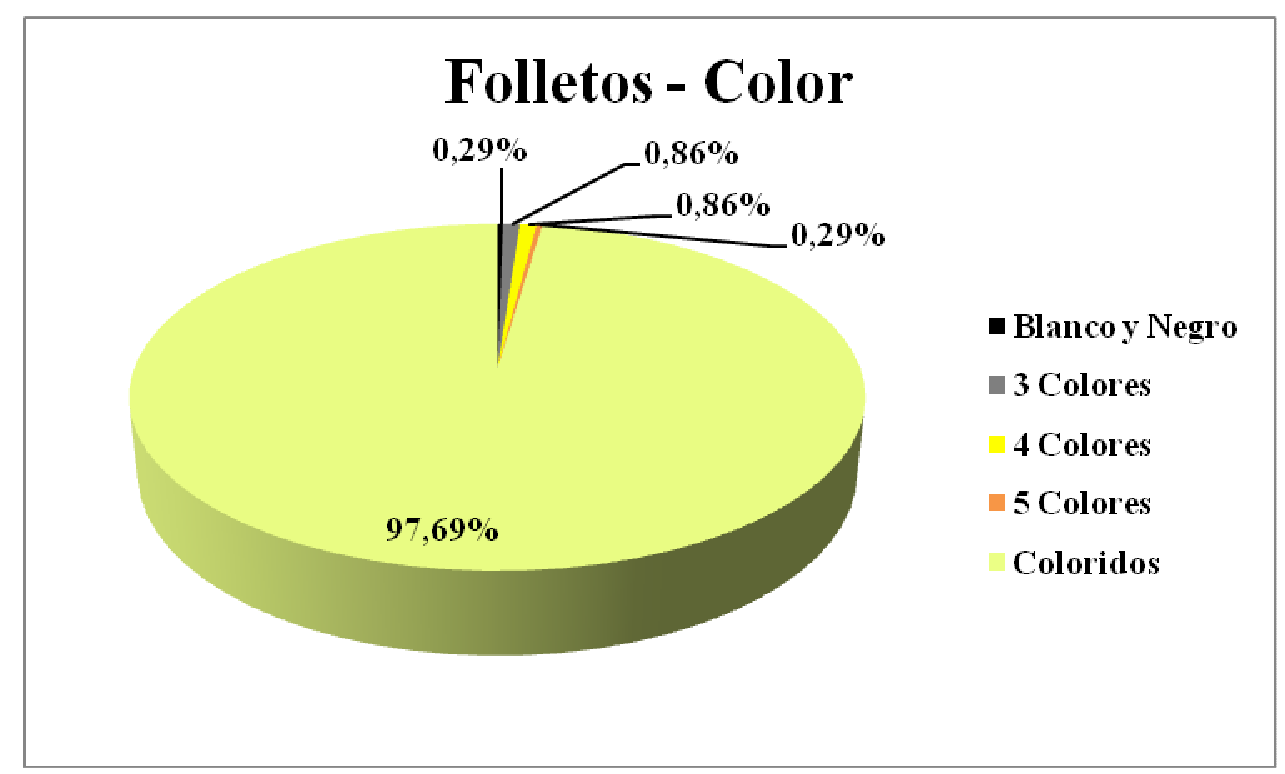

Gráfico 19

En la publicidad turística la imagen tiene un papel fundamental, ya que este tipo de publicidad hace tangible un producto intangible, como hemos visto anteriormente. Si observamos el gráfico de las categorías del uso de colores de la publicidad que forma parte de nuestro corpus de estudio, se puede ver que la gran mayoría de los anuncios en 
la categoría de folletos están presentados en anuncios coloridos, lo mismo para con los folletos mixtos, como se puede ver en el gráfico abajo:

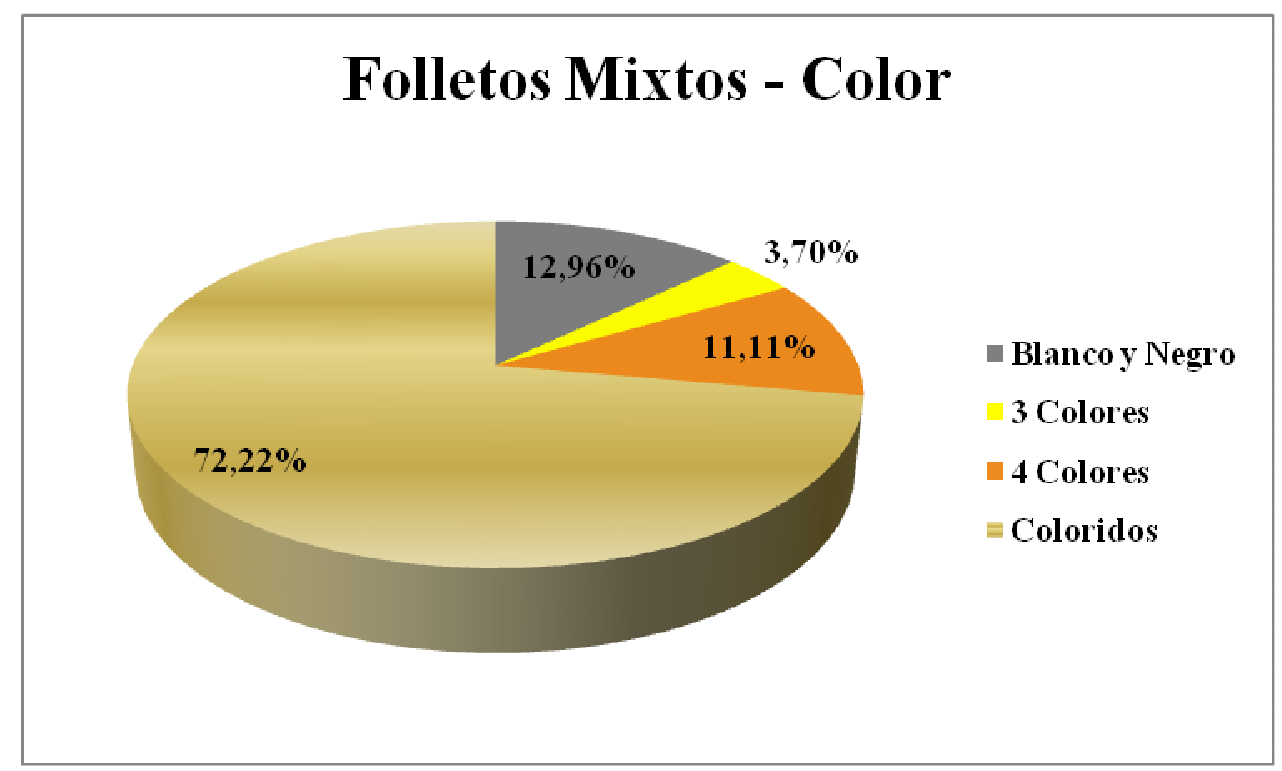

Gráfico 20

Otro hecho que corrobora la importancia del atractivo del lenguaje visual para la publicidad turística es que, en lo que se refiere a las categorías de libros y libros mixtos de nuestro corpus de estudio, todos están impresos en varios colores, pero es importante resaltar que hay un pequeño porcentaje de los libros mixtos que están impresos en solamente 5 colores, como podemos ver en el gráfico a continuación.

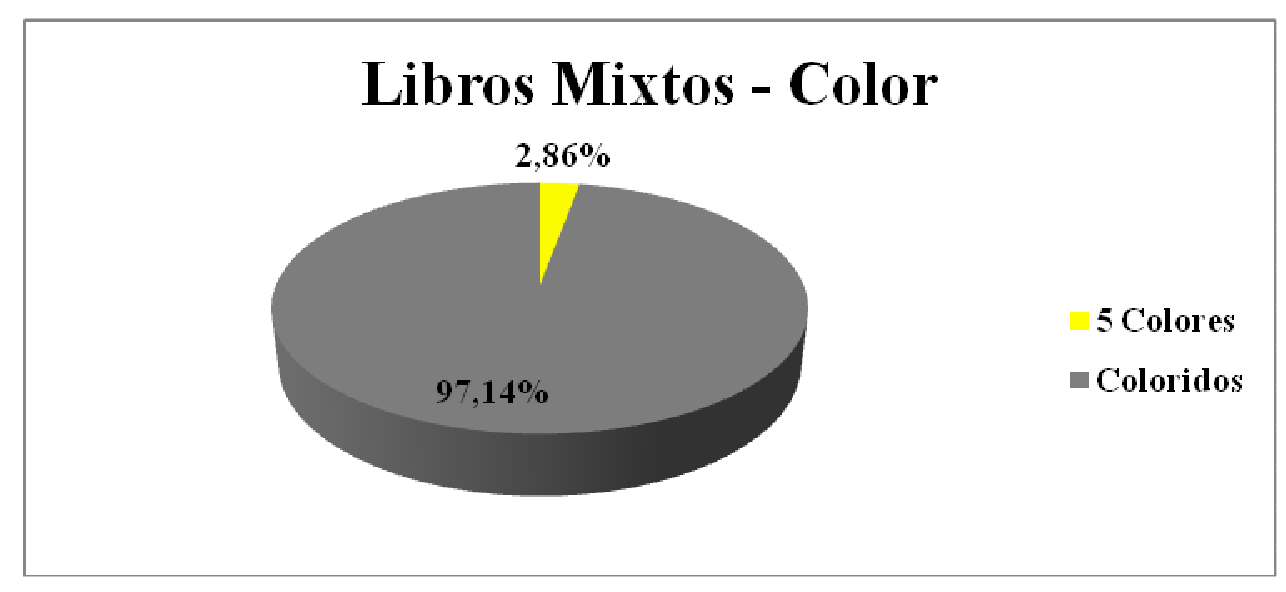

Gráfico 21

El lenguaje visual es uno de los sistemas de comunicación más antiguos y las representaciones visuales pueden ser entendidas como algo cotidiano en la sociedad 
contemporánea, además, influyen enormemente en nuestras vidas, eso corrobora la relevancia de la semiótica en el contexto actual, sobre todo para los estudios del lenguaje publicitario.

La semiología fue establecida como disciplina formal en 1971 cuando se publican los escritos de la teoría general de los signos de Charles Morris. Este investigador fue seguido por Charles Peirce, con su teoría de los signos (1860-1880). Luego por Roland Barthes (1965) y Umberto Eco, autor del Tratado de Semiótica General (1975).

La teoría de la información y la teoría de la comunicación son campos de estudio que analizan cómo se captan y se transmiten los mensajes. El segundo de esos campos analiza los mensajes y su contenido por medio de la semiótica. En las palabras de Acaso (2009:23):

\footnotetext{
El campo de estudio que tiene por objetivo analizar cómo captamos y transmitimos los mensajes es la Teoría de la Información, de la que nace la Teoría de la Comunicación. Mientras que la primera se ocupa de la probabilidad de que los mensajes ocurran, desde la Teoría de la Comunicación se analiza el contenido de los mensajes a través de una rama del conocimiento denominada semiótica o semiología (términos intercambiables que significan lo mismo), que se puede definir como el campo del saber que estudia los signos.
}

Aristóteles postuló que el pensamiento no es posible sin la imagen y, luego, Jung concibió la imagen o la palabra como algo simbólico al representar más que su sentido inmediato. Eso corresponde al inicio de los estudios de la semiótica que, en su origen, era un término empleado como sinónimo de "sintomatología". Más tarde, el uso de este término para designar "la ciencia de los signos, correspondiéndose, en ese sentido a la lógica tradicional, fue propuesto por el filósofo inglés John Locke, en el siglo XVII" (Carlos Vogt, 2006:107). 
CRUZEIROS AMÉRICA DO SUL

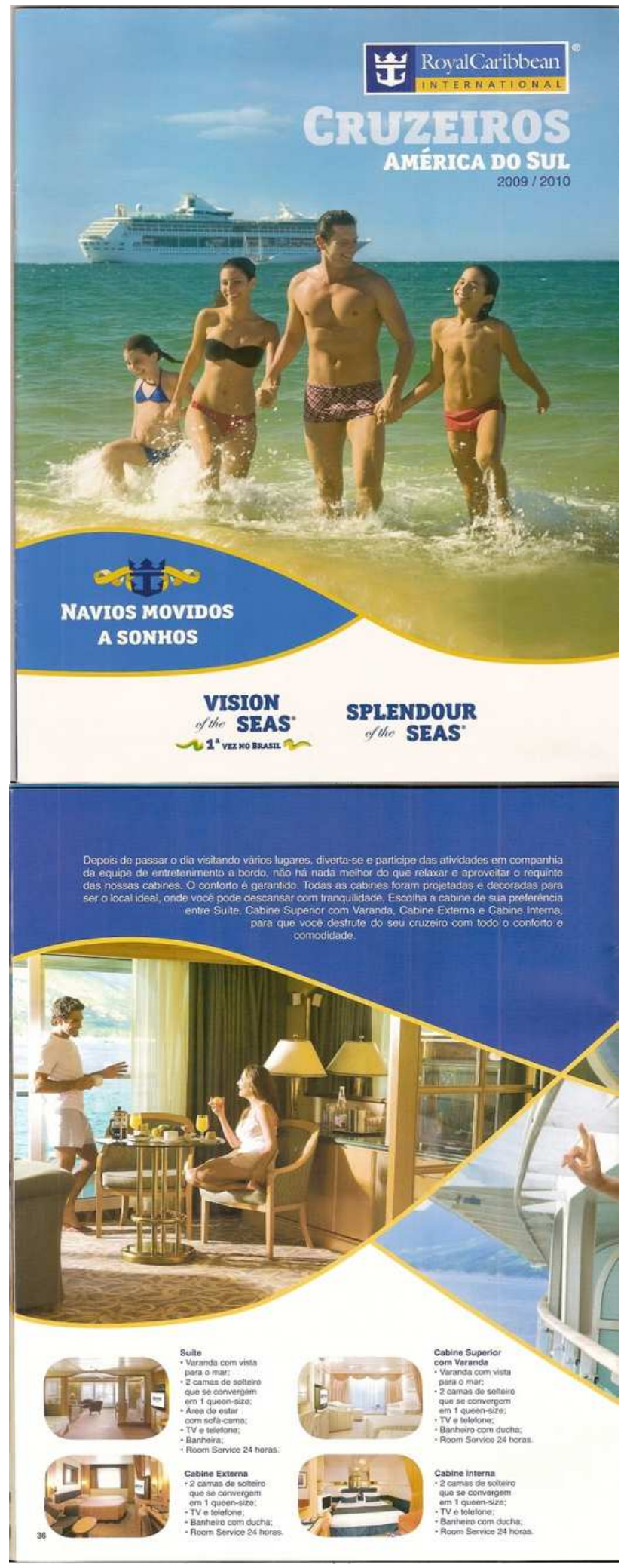



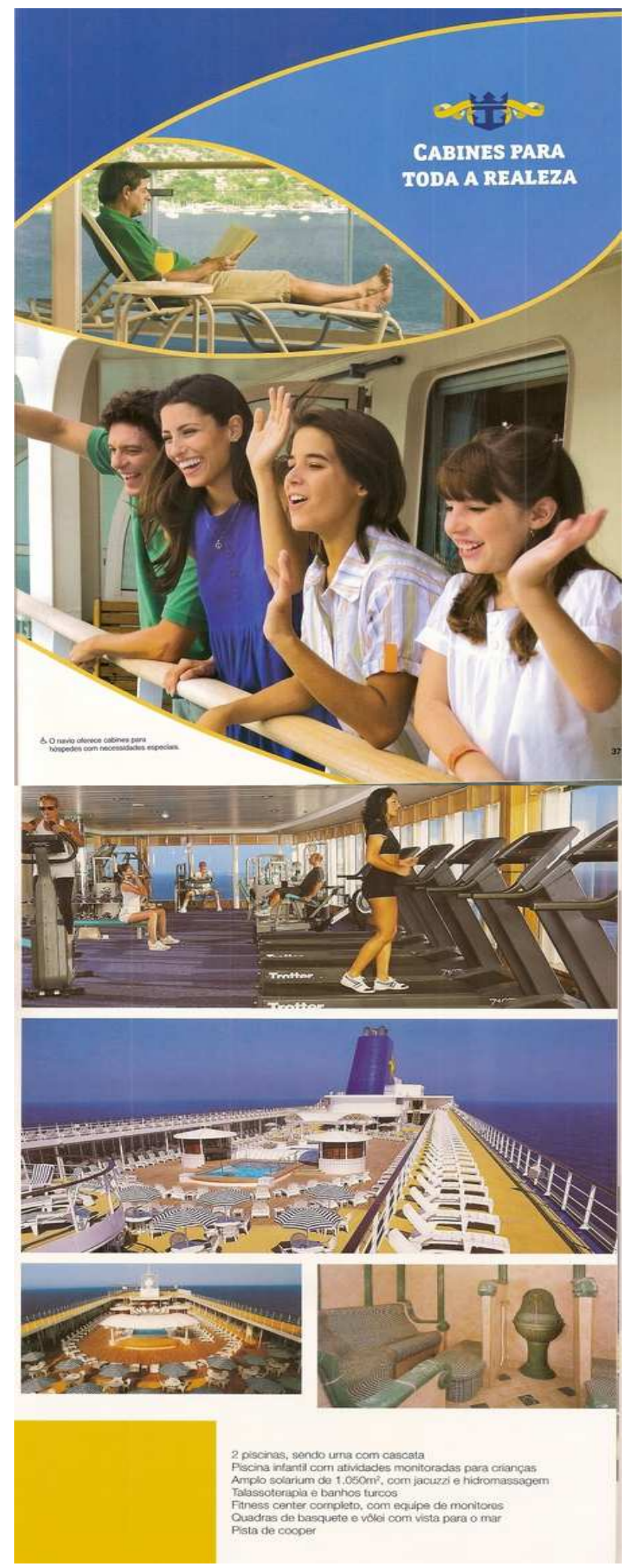

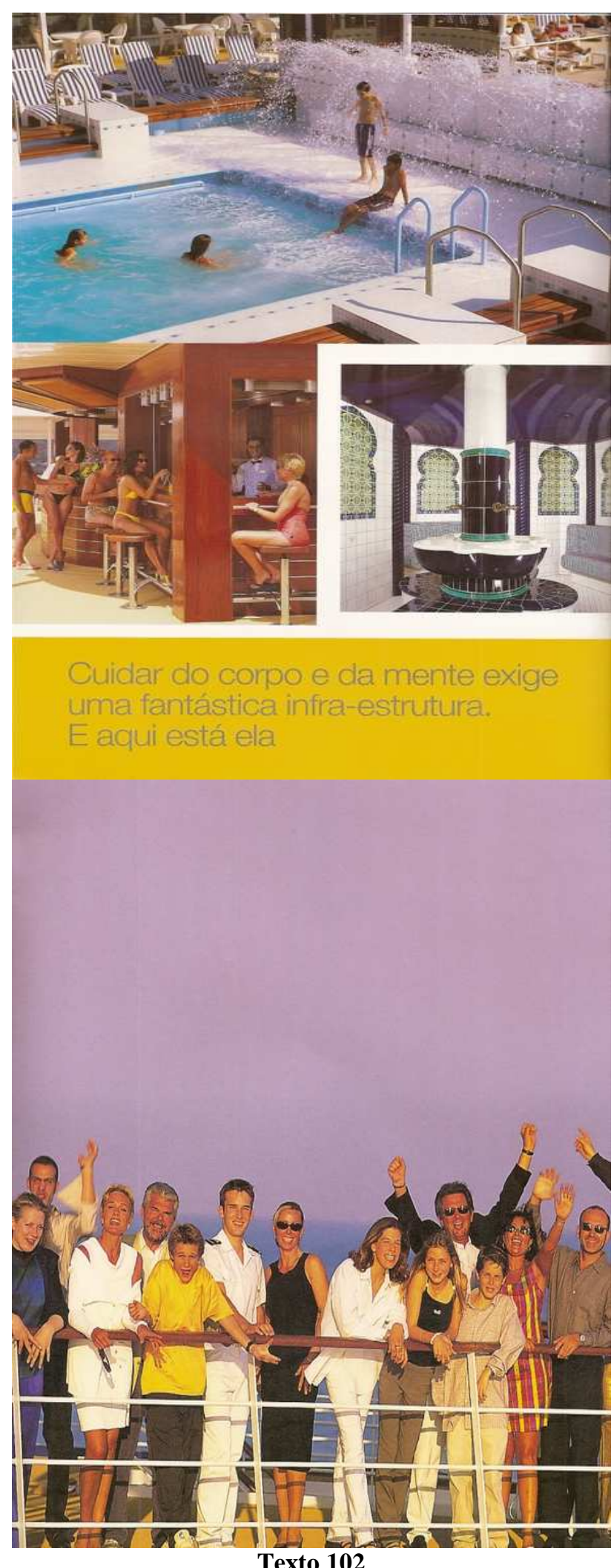

Cuando la semiótica está ya establecida como un nuevo campo del conocimiento, surge la semiología de la imagen o semiótica visual como una suma de los campos de conocimiento de la comunicación visual y la semiótica. Para Acaso (2009:25), la 
semiología de la imagen o semiótica visual es una "rama del saber centrado en los problemas de la comunicación a través del lenguaje visual". En la publicidad turística, el correcto uso de la imagen como parte del texto es fundamental, como ya hemos mencionado anteriormente.

En el anuncio publicitario que presentamos arriba se puede registrar el protagonismo del signo visual asociado al lingüístico. En la primera parte del anuncio, se presentan los personajes que participan del viaje de los "Cruzeiros América do Sul", o sea, una familia formada por 4 personas (muy de nuestro tiempo) y las instalaciones físicas de la parte de las cabinas y suites del navío en el que viaja la familia prototípica del anuncio. El texto en la segunda página resume parte de las connotaciones que el remitente puede inferir a partir de este anuncio, ya que dice que "después de pasar el día de visita a varios lugares diviértete y participa de las actividades con el equipo de entretenimiento [...] el confort es gratis". Realmente, el mensaje visual es de entretenimiento, relajación y mucho confort.

En la segunda parte del anuncio, el lenguaje visual ya no dice quién, cómo y en qué condiciones viajan los tripulantes prototipos de los "Cruzeiros América do Sul", sino cómo pasan el tiempo de ocio y en qué ambientes. Así, presenta las actividades de ocio de la familia y ¿qué más pueden hacer a bordo de este navío? Para contestar a esa pregunta presenta las piscinas, el solárium, en centro de actividades físicas, para modalidades como corrida, fitness, yacusi, baños turcos e hidromasaje.

La tercera parte del anuncio refuerza la idea de la buena estructura física del navío usado en los "Cruzeiros América do Sul" y presenta a los acompañantes de los personajes prototípicos, ya presentados en el anuncio, y claro, muy parecidos a ellos en su buena forma física, estilo elegante y feliz. Y como cierre del anuncio está el enunciado presentado a continuación: cuidar del cuerpo y de la mente exige una fantástica infraestructura. Y aquí está ella. Todo eso refuerza que gran parte, creemos que más de $80 \%$ de la descripción en la publicidad turística está constituida por medio del lenguaje visual. 


\subsection{La imagen en la publicidad turística}

María Acaso, en su obra El Lenguaje Visual (2009), habla de la paradoja de la ausencia de la educación visual en una sociedad en la que la imagen es un elemento presente en el cotidiano de cada individuo. Santaella y Winfried Nöth, por su parte, en la obra Imagen: Cognición, Semiótica y Media (1999), abordan el tema de la imagen y apuntan que la imagen puede ser representada en dos dominios: el visual y el inmaterial.

La representación visual consiste en signos que están en el campo visual, son objetos materiales, como por ejemplo, las pinturas, los diseños y las fotos. La representación mental, a su vez, está constituida por aquellas imágenes que son producidas en nuestras mentes, son las visiones, fantasías e imaginaciones. Para esos autores, ambas representaciones de la imagen están íntimamente relacionadas y están “inextricablemente ligados desde su génesis. No hay imágenes como representaciones visuales que no hayan surgido de imágenes en la mente de aquellos que las produjeron, del mismo modo no hay imágenes mentales que no tengan algún origen en el mundo" (Santaella \& Noöth, 1999:15). ${ }^{63}$

En el caso de esta publicidad turística presentada a continuación, la imagen sirve para describir parte del producto turístico anunciado. La primera página (a la izquierda) actúa como una introducción al anuncio, es decir, presenta de lo que se va hablar en ese folleto; mientras la segunda página (a la derecha) sirve como un cierre o conclusión, o sea, presenta de lo que se ha discurrido en el folleto en cuestión. Es importante resaltar en esta parte de nuestro estudio que este tipo de organización visual del texto publicitario para el turismo es muy común en los folletos libros, folletos libros mixtos e incluso folletos y folletos mixtos.

\footnotetext{
63 En la fuente original: "Inextricavelmente ligados já na sua gênese. Não há imagens como representações visuais que não tenham surgido de imagens na mente daqueles que as produziram, do mesmo modo que não há imagens mentais que não tenham alguma origem no mundo".
} 
ESTADOS UNIDOS E CANADÁ
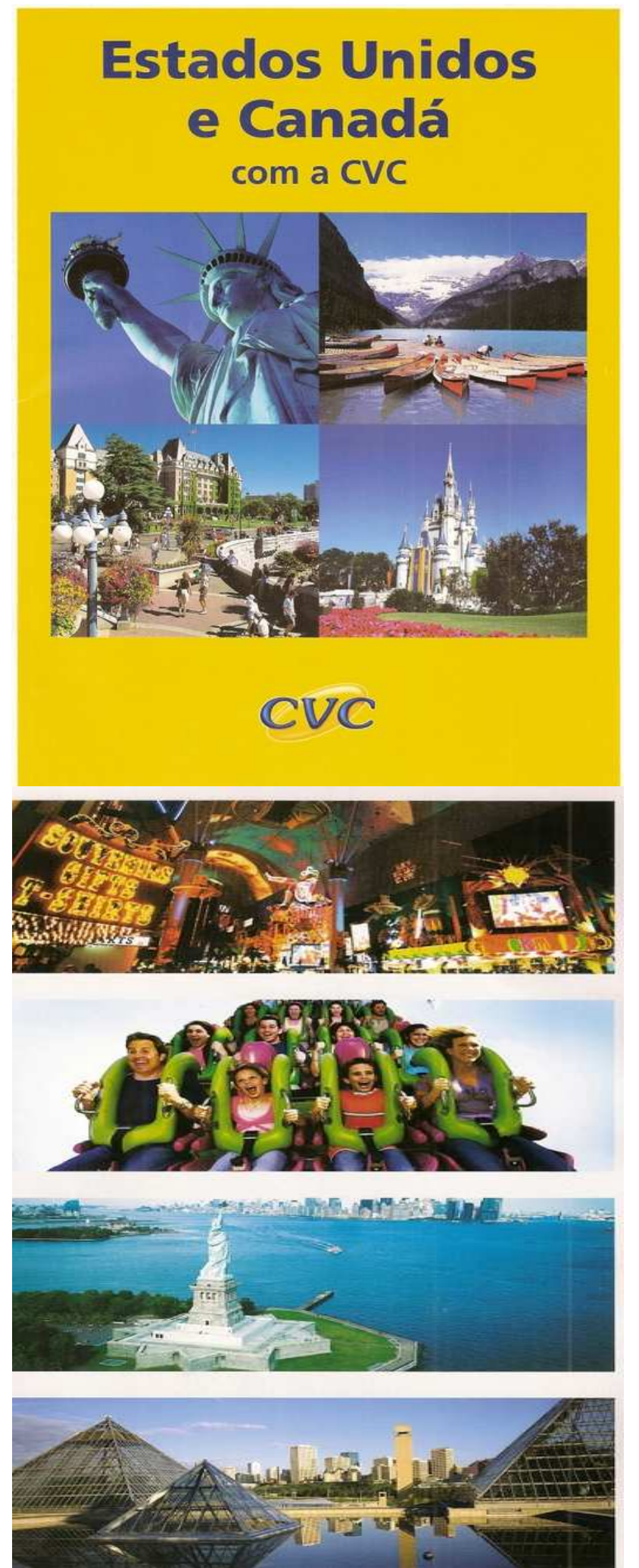

Texto 103

Para Acaso (2009:36), la imagen es una "unidad de representación realizada mediante el lenguaje visual". Esta autora cree que la imagen no reemplaza a la realidad, pero la crea. El producto visual se reparte en dos tipos de funciones: la función representativa se 
opone a la función comunicativa una vez que la primera sirve para representar el mundo, la segunda funciona como mediadora de pensamientos entre interlocutores, en otras palabras, "la primera debe, de acuerdo con esa visión, servir a la representación del mundo; la última a la mediación de pensamientos entre las personas" (Santaella \& Noöth, 1999:18). ${ }^{64}$

Por lo que hemos visto, el proceso de comprender un mensaje visual no es sencillo y para ello hay que comprender primeramente el lenguaje visual y ver que en la misma imagen podemos interpretar mensajes distintos. Para ese proceso de comprensión, es importante la noción de signo que es "cualquier cosa que representa a otra; es decir, un signo es una unidad de representación" (Acaso, 2009:37). Esto queda muy claro cuando usamos la publicidad turística como ejemplo, pues el interlocutor conoce el producto y sus beneficios, principalmente, por medio de la imagen que sustituye el producto real, que por ser inmaterial no puede ser presentado a su posible consumidor, salvo por imagen o la unión del signo visual con el verbal.

Entre los tipos de signos hay tres grandes grupos: la huella o la señal (vestigio visual); el ícono (presenta cierta similitud a lo que representa); y el símbolo (pierde por completo los rasgos de lo que representa). El dominio visual (que pertenece al campo de estudio de la semiótica) y el dominio mental (tema de estudio de la cognición) están ligados a los conceptos de signo y representación, como afirman Santaella \& Noöth, (1999:15): "Es en la difusión de esos dos conceptos donde reencontramos los dos dominios de la imagen, a saber, su lado perceptible y su lado mental, estos unificados en algo tercero, [...] el signo.

La imagen, como es concebida por Barthes (1965), posee tres tipos de mensajes: el lingüístico, el denotado o literal y el connotado o simbólico. La continuidad de los estudios de Barthes sobre la retórica de la imagen es realizada por estudiosos como Péninou (1976) que se basa en las ideas de Jakobson para identificar y clasificar los mensajes establecidos por los Manifiestos Publicitarios.

\footnotetext{
${ }^{64}$ En la fuente original: "A primeira deve, de acordo com essa visão, servir à representação do mundo; a última à mediação de pensamentos entre as pessoas".
} 
En la formación de un concepto de imagen, desde un punto de vista semántico, se debe tener en cuenta dos puntos: la percepción y la imaginación. Dado que "uno describe la imagen directa perceptible o incluso existente. El otro contiene la imagen mental simple, que en la ausencia de estímulos visuales, puede ser evocada" (Santaella \& Noöth, 1999:29). ${ }^{65}$ Además, hay que diferenciar entre imagen mental y la verbal, también la diferencia entre imagen y modelo. Existen varios tipos de imágenes que según la tipología de Mitchell (1986) podrían ser clasificadas como:

\begin{tabular}{|l|l|}
\hline \multicolumn{1}{|c|}{ TIPO DE IMAGEN } & \multicolumn{1}{c|}{ TIPOLOGÍA } \\
\hline IMÁGENES GRÁFICAS & Imágenes dibujadas o pintadas, esculturas; \\
IMÁGENES ÓPTICAS & Espejos, proyecciones; \\
IMÁGENES PERCEPTIBLES & Datos de ideas, fenómenos; \\
IMÁGENES MENTALES & Sueños, recuerdos, ideas, fantasías; \\
IMÁGENES VERBALES & Metáforas, descripciones. \\
\hline
\end{tabular}

\subsection{Publicidad turística: lenguaje escrito y visual}

El código en el que se pautan los mensajes corresponde a un sistema de signos, objetos de estudio de la semiótica. Un mensaje pude ser transmitido por tres sistemas de mensajes distintos, a saber: la comunicación verbal, la comunicación escrita y la comunicación visual. Sin embargo, "la comunicación visual difiere de la comunicación verbal pero funciona igual que la comunicación escrita, aunque lo que verdaderamente las diferencia es que el código que transmite la información es distinto: el lenguaje visual" (Acaso, 2009:24).

Desde un punto de vista del idealismo de Platón el mundo de las ideas estaría formado por dos esferas: la primera sería la palabra y la segunda las imágenes. Para Aristóteles, el pensamiento solo se realizaría con las imágenes. Los epicureistas, a su vez, defienden la idea de que la imagen mental evoca fuertemente la realidad, es decir, las imágenes serían copias icónicas de la realidad. A partir de ello, las ideas y la cognición están

\footnotetext{
${ }^{65}$ En la fuente original: "Um descreve a imagem direta perceptível ou até mesmo existente. O outro contém a imagem mental simples, que na ausência de estímulos visuais, pode ser evocada".
} 
constituidas por imágenes mentales que se originan a partir de la percepción de los sentidos.
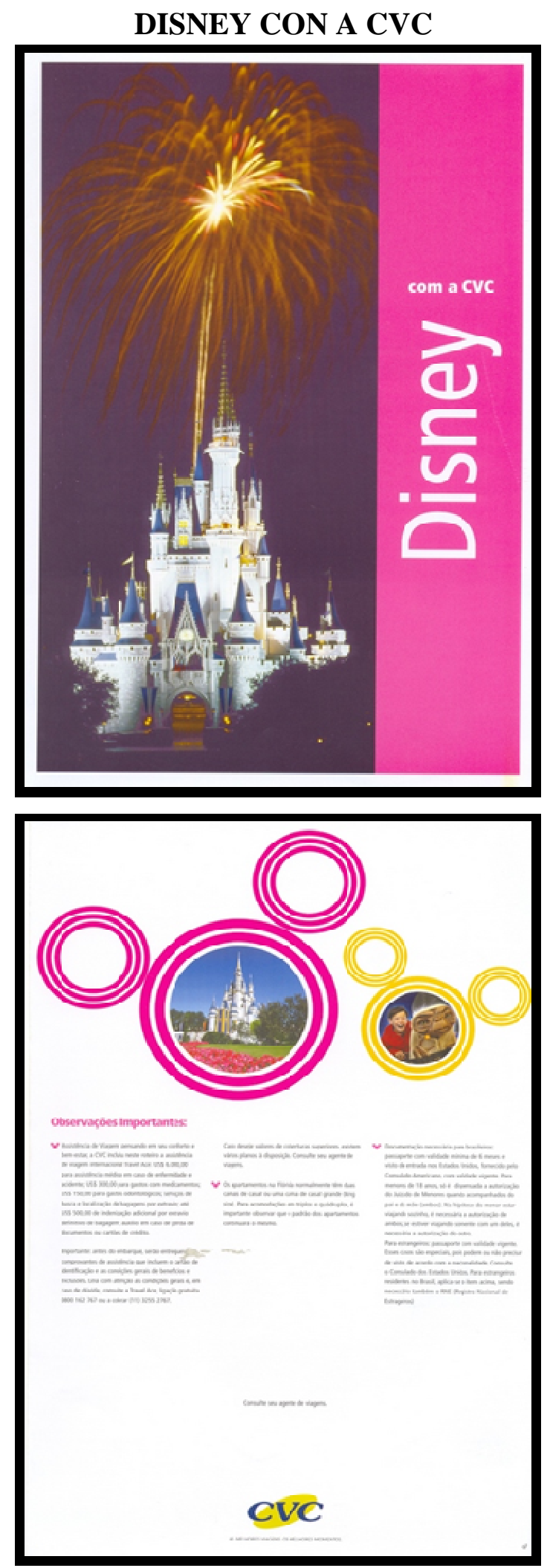

Texto 104 
Tomando eso como base, las imágenes están presentes en la mente humana, son percepciones de lo que se ve, son conocidas como imaginación, ideas y concepción. Quizás por eso se utiliza la imagen como uno de los principales elementos en la publicidad turística, como se puede ver en el texto 104, en el que la comunicación verbal consiste en una pequeña parte del anuncio, mientras un $80 \%$ de este texto publicitario es imagen. Otro punto curioso de este texto es que no hay ninguna imagen que represente a Mikey Mouse, uno de los símbolos de Disney, pero los 3 círculos unidos evocan este símbolo en nuestras mentes, por lo menos en los que disponemos de este conocimiento compartido.

La teoría de la percepción o la Teoría Representativa de la Percepción es defendida por filósofos como Locke y Descartes. En ella "lo que se percibe provoca representaciones internas que tienen una relación de semejanzas con los objetos percibidos sin poseer necesariamente el carácter de imágenes reales" (Santaella \& Noöth, 1999:29). ${ }^{66}$

También en Santaella \& Noöth (1999) vemos que Wittgenstein defiende la teoría lógica del pensamiento imagético en la que afirma que son formadas, en la mente humana, imágenes que corresponden a hechos; que el pensamiento es la imagen lógica de esos hechos; que esas imágenes son modelos de la realidad; y, por fin, que la imagen no está vinculada simplemente al campo visual y mental, sino que forma parte de una relación compleja y abstracta.

Las diferencias entre imagen y lenguaje pueden ser establecidas a partir de su forma de estructura y presentación. Para ello, Goodman (1968:228) estableció cinco criterios llamados de sistema de notación, a saber: disyunción sintáctica (todas las realizaciones de un signo son equivalentes sintácticamente y no deben pertenecer a más de un signo); diferenciación sintáctica finita (la no correspondencia de marcaciones de signos de un sistema de símbolos debe presentar también un significado único); falta de ambigüedad; disyunción semántica; y, por último, diferenciación semántica finita.

\footnotetext{
${ }^{66}$ En la fuente original: "O percebido provoca representações internas que têm uma relação de semelhanças com os objetos percebidos sem, no entanto, possuir necessariamente o caráter de imagens reais".
} 
Para Goodman (1968), el lenguaje, como un sistema, cumpliría los criterios sintácticos, pero no los semánticos. Por otro lado, la imagen no cumple ninguno de esos criterios y actúa mayoritariamente en el campo de la relación afectiva, ya que el lenguaje presenta aspectos de conceptos cognitivos. La imagen motiva y facilita los procesos de aprendizaje porque el lenguaje visual tiene un carácter más universal y cuesta menos descodificarlo, ya que ver requiere menos esfuerzos mentales que la lectura.

La publicidad turística intenta ser universal, ya que muchas operadoras de turismo son multinacionales y producen publicidad de destinos turísticos que sean eficaces para clientes de cualquier parte del mundo, por eso intenta usar un lenguaje lo más universal posible cuya decodificación no necesita de un gran esfuerzo mental, además llama la atención del interlocutor. Quizás esta sea la explicación para una predominancia de la imagen en la publicidad turística.

Juliana Petermann (2006:2) afirma que "es necesario el aprendizaje de la lectura de textos no verbales, determinando algunas reglas y estructuras formales". ${ }^{67}$ Los elementos usados en la elaboración de un texto no verbal como colores, disposiciones gráficas, orden y forma no son elegidos de forma aleatoria, sino que están pensados para producir determinado efecto en el receptor.

Los mensajes visuales deben ser leídos y percibidos con la misma fluidez que un mensaje verbal para que se busque interpretar su significado. Acaso (2009) y Juliana Petermann (2006:8) defienden que "la alfabetización visual urge en una época en la que los textos multimodales predominan y exigen ese perfeccionamiento, tanto para la producción cuanto para la interpretación de dichos textos". ${ }^{6}$ Ese tipo de alfabetización sería muy importante para el estudio de la publicidad como un tipo de texto que está formado por signos visuales y verbales.

\footnotetext{
${ }^{67}$ En la fuente original: "É preciso aprender a ler os textos não-verbais, determinando algumas regras e estruturas formais".

${ }^{68}$ En la fuente original: “A alfabetização visual torna-se urgente em uma época em que os textos multimodais predominam e exigem esse aperfeiçoamento, tanto para a produção quanto para a interpretação de tais textos”.
} 
Existen diversos intentos de conceptulizar la representación, pero son frecuentemente vacíos. Con respecto a ese concepto, Santaella \& Noöth (1999:16) dicen que "el ámbito de su significación está situado entre la presentación y la imaginación, llegando, así, a conceptos semióticos centrales como signo, vehículo del signo, imagen (representación imagética), bien como significación y referencia”. ${ }^{6}$

Las representaciones visuales, de modo general, son predominantes en la vida cotidiana del mundo occidental. Este tipo de representación tiene el carácter de omnipresencia en la actual coyuntura de la sociedad. En palabras de Acaso (2009:113-114):

\begin{abstract}
Las representaciones visuales comerciales son las que predominan en la vida del ciudadano occidental. Si contáramos cuántas imágenes de este tipo vemos (que no contemplamos) a lo largo del día, llegaríamos en torno a 800 imágenes, incluyendo los envases que nos acompañan desde que desayunamos (mantequilla, caja de cereales, envase de café), cuando nos duchamos (gel, champú, cremas variadas), pasando por la publicidad inserta en la prensa o desplegada en el mobiliario urbano de nuestras ciudades. Esta omnipresencia de la imagen comercial es una de las características de la realidad actual; estamos completamente mediatizados por ellas en casi todas las facetas de nuestra vida.
\end{abstract}

La representación puede, todavía, ser estudiada en otros dos ámbitos: el mental (representación interna) y el público (representación externa - el signo). En la publicidad turística desaparece la importancia de la figura del vendedor y el producto tiene que representarse para venderse a su público objetivo o target. Por lo tanto, las representaciones visuales poseen un papel muy importante en este contexto. También, resaltamos que el desdoblamiento del autor es una de las características de las representaciones visuales comerciales, puesto que hay siempre una parte financiadora y otra realizadora o productora. Además, la imagen comercial tiene una elaboración multigrupal, se caracteriza por ser efímera y tener la obligación de presentar la representación de la marca.

\footnotetext{
${ }^{69}$ En la fuente original: "O âmbito de sua significação situa-se entre apresentação e imaginação e estende-se, assim, a conceitos semióticos centrais como signo, veículo do signo, imagem ("representação imagética”) assim como significação e referência".
} 
Con relación a la imagen Barthes (1965), además, hace una distinción entre la imagen connotativa o simbólica y la imagen denotativa o literal. En la representación mental del conocimiento, las ideas, las imágenes y los símbolos constituyen tres pilares fundamentales puesto que las primeras son concebidas como materia mental estructurada; las segundas son representaciones mentales del conocimiento; los terceros son representaciones mentales del conocimiento y corresponde al hecho de que el lenguaje está representado mentalmente en la forma de símbolos.

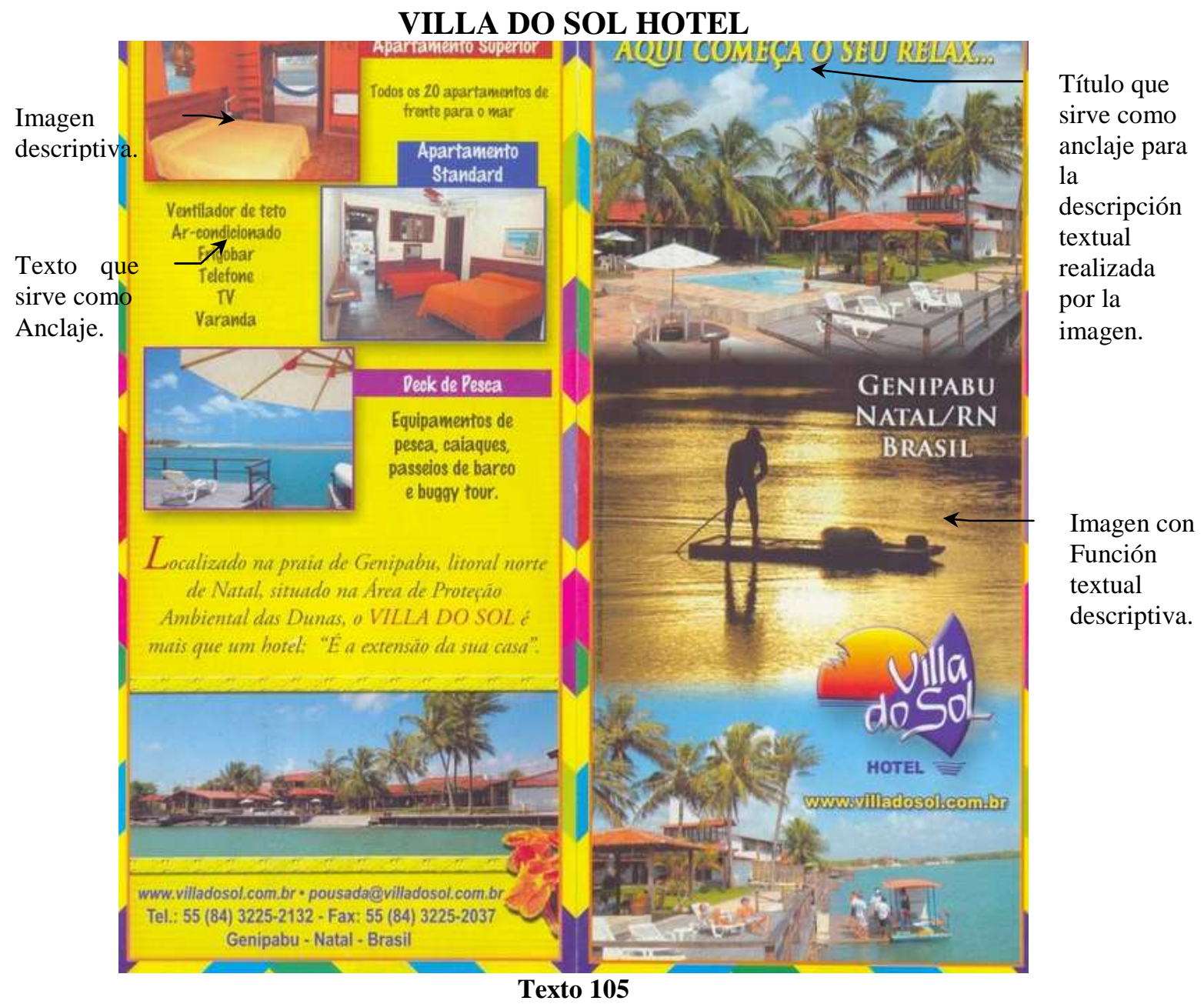

De acuerdo con Luis Celso Piratininga, en su libro Publicidad: Arte o Artificio (1994), el hombre está inmerso en un universo simbólico, por eso es también llamado homo symbolicum. Lo que lleva a ese hombre a tener conciencia de su realidad es el proceso de estimulación de sus órganos sensoriales, como se puede encontrar en Piratininga (1994:9) "(retinas, tímpanos, sensores dérmicos y papilas gustativas y olfativas) 
seguidos de la transformación del resultado de tales sensaciones en imágenes psíquicas internas, que son tomadas como indicadores 'objetivos' de la realidad". 70

Hasta aquí, hemos dicho que la imagen constituye la mayor parte de la publicidad turística que revela mensajes múltiples a través de signos de diversa naturaleza. Martínez (2000:13-24) presenta diversos tipos de mensajes que se caracterizan por los signos empleados. Tales mensajes son lingüístico y de la imagen (icónica o iconográfica). El mensaje icónico "es el mensaje informativo o denotativo de la imagen, centrado en la representación análoga de la realidad", mientras que el iconográfico es más bien connotativo, pues "al ver una imagen publicitaria, también interpretamos una serie de connotaciones superpuestas a la representación”.

La publicidad turística presentada arriba nos transporta al hotel Villa do Sol, en Genipabu, una de las playas más conocidas del litoral norte de Natal. El anuncio en cuestión denota la realidad anunciada por medio de un texto en el que la imagen tiene una función textual descriptiva y el lenguaje verbal tiene una función más bien de anclaje, de complemento de la descripción imagética del producto turístico anunciado.

En la relación establecida entre imagen y texto, el primer elemento puede tener un papel secundario o principal, pues "la imagen puede ilustrar un texto verbal o el texto puede aclarar el sentido de la imagen por medio de un comentario. En ambos casos, la imagen parece no ser suficiente sin texto" (Santaella \& noöth, 1999:53).

Para J.B. Pinho, en Comunicación en Marketing (2006), la información visual es la forma más rápida y eficaz de obtener el proceso de comunicación. El autor defiende el pensamiento visual, pues a través de éste el mensaje transmitido es rápidamente comprendido. Hafer \& White (apud Pinho, 2006:228) tratan de los siguientes motivos de importancia del establecimiento del pensamiento visual: "si quiere tener un mensaje rápidamente comprendido, piense visualmente si desea hablar para todo tipo de persona;

\footnotetext{
${ }^{70}$ En la fuente original: "(retinas, tímpanos, sensores dérmicos e papilas gustativas ou olfativas), seguidos da transformação do resultado de tais sensações em imagens psíquicas internas, as quais então tomamos como indicadores 'objetivos' da realidade".
} 
piense visualmente si desea llamar la atención en nuestro tiempo, con su gran cantidad de propaganda bien elaborada y visualmente orientada". ${ }^{71}$

La eficacia de la comunicación por medio del pensamiento visual es una idea muy de nuestro tiempo, sobre todo, cuando hablamos de publicidad turística, en la que además de crear el producto, la imagen posibilita que este producto exista y sea vendido. Cualquier imagen usada con el objetivo de exponer un mensaje puede ser utilizada como parte ilustrativa de un anuncio, pero siempre con el propósito de llamar la atención para que el texto sea leído, comprendido y tenga credibilidad. La ilustración no es un recurso obligatorio en un anuncio, pero siempre que sea usado tiene que aumentar el rendimiento de las funciones textuales. Sant' Anna (apud Pinho, 2006:228) atribuye las siguientes funciones al uso de las ilustraciones:

\begin{abstract}
Aumenta el índice de atención al anuncio; torna el anuncio más placentero a la vista; induce a la lectura del texto; estimula el deseo por la cosa anunciada; engrandece la cosa anunciada; demuestra o refuerza las afirmaciones realizadas textualmente; identifica el producto o la marca; construye una atmósfera adecuada. $^{72}$
\end{abstract}

En el caso de la publicidad turística, la imagen es más una regla que una excepción, como ya hemos visto anteriormente. Observemos, pues, la publicidad a continuación en la que la imagen define Brasil como el producto turístico anunciado por medio de las chanclas estilo Hawaianas, que es un producto de exportación brasileño, combinadas con el agua de coco verde, que es una bebida muy apreciada en las playas brasileñas.

Además, los colores de las chanclas, del coco, la pajita y el texto remiten a los colores de la bandera de Brasil que son verde, amarillo, azul y blanco. Por último, las dos chanclas unidas recrean el diseño la bandera nacional brasileña. Es decir, todos los

\footnotetext{
71 En la fuente original: "Se você quer ter sua mensagem rapidamente compreendida. [...] b) Pense visualmente se você deseja falar para todos os tipos de pessoas. [...] c) Pense visualmente se você deseja atrair a atenção em nossa época, com a sua grande quantidade de propaganda bem feita e visualmente orientada".

${ }^{72}$ En la fuente original: “1) Aumentar o índice de atenção ao anúncio. 2)Tornar o anúncio mais aprazível à vista. 3) Induzir á leitura do texto. 4) Estimular o desejo pela coisa anunciada. 5) Engrandecer a coisa anunciada. 6) Demonstrar ou reforçar afirmações feitas no texto. 7) Identificar o produto ou a marca. 8) Formar atmosfera adequada".
} 
elementos visuales tienen un significado: remitir a Brasil como un producto turístico internacional.

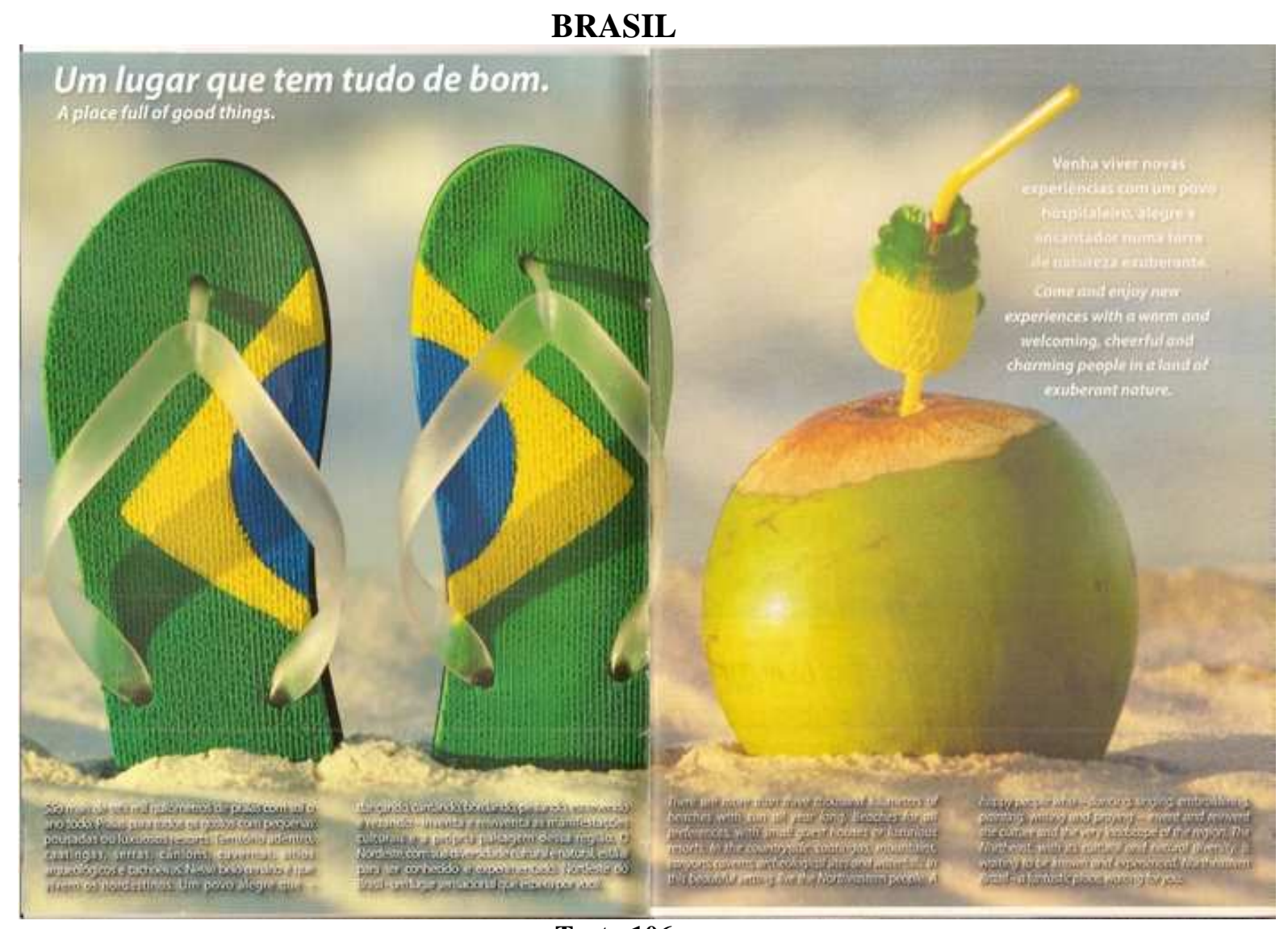

Texto 106

La visión conecta a las personas al mundo circundante. El mundo moderno exige que la comunicación sea realizada de forma rápida y eficaz, lo que torna fundamental el uso de la imagen como elemento dinamizador del mensaje publicitario. Ya Martínez (2000:2224) establece las funciones de lo lingüístico en relación con la imagen de la siguiente forma: función de intriga, función identificadora, función localizadora o de 'anclaje' de mensaje icónico y anclaje del mensaje iconográfico, función complementaria (con fin instrumental o denotativo, con fin connotativo y fin narrativo) y función de trasgresión del código esperado. 


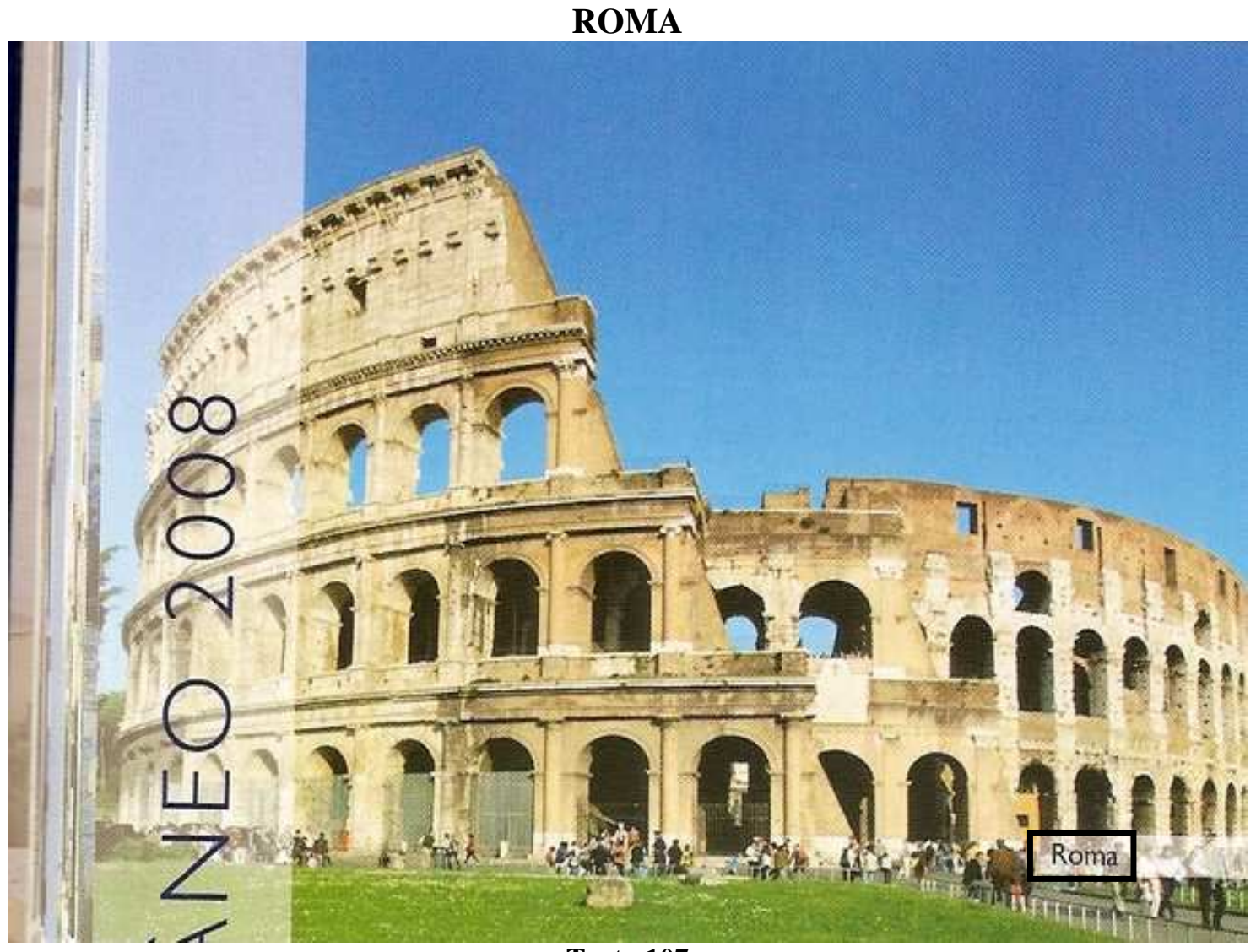

Texto 107

Este anuncio publicitario anuncia la Roma como producto turístico y hace uso del coliseo para representar la capital de Italia. Y para que no quede duda dónde está ubicado este monumento histórico y qué ciudad está siendo anunciada en esa publicidad turística, en el lado derecho del anuncio aparece la palabra "Roma" que tiene una función identificadora, según la clasificación de Martínez (2000).

Juliana Petermann, en su obra Imágenes de la Publicidad: Significaciones y Persuasión (2006), afirma que las imágenes, los sonidos y los textos son los factores organizacionales de la publicidad, y esta tiene como objetivo condicionar al hombre a determinada acción. El texto publicitario es multimodal pues está formado por textos verbales y no verbales, también concentra una gran diversidad de códigos semióticos. 


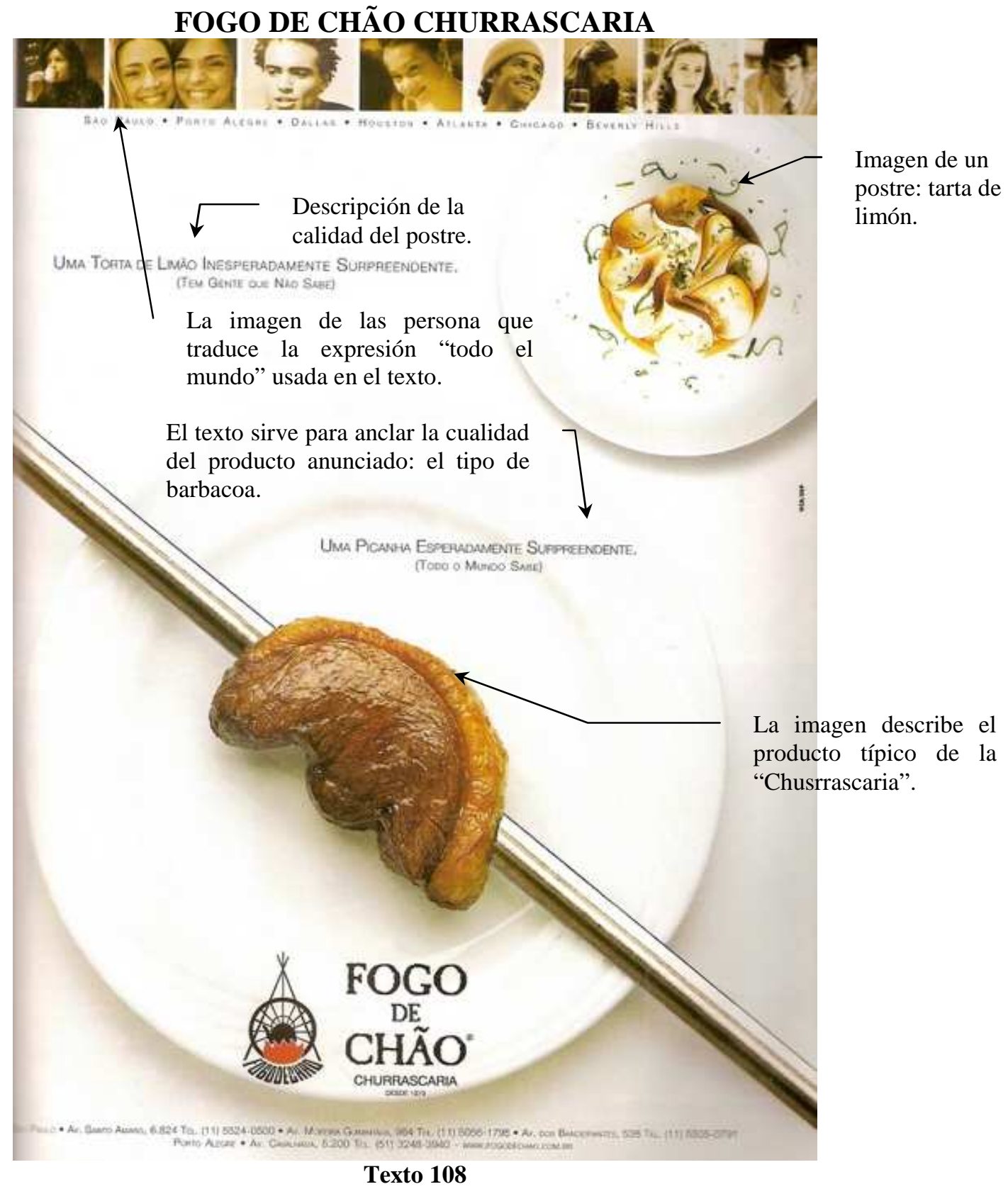

Los elementos de los textos publicitarios (verbales y no verbales) tienen la capacidad de abrigar estrategias de persuasión, pues tienen la función de seducir al lector. El análisis de la imagen ayuda en la percepción de los textos y en la comprensión de sus estrategias. Sin embargo, muchas veces, las estrategias de persuasión pasan desapercibidas por el interlocutor. Veamos la estrategia de persuasión de este anuncio que muestra fotos de personas de lugares distintos del mundo, junto a la imagen del producto anunciado y su respectivo texto. 
El texto publicitario que hemos presentado anteriormente está formado por el lenguaje verbal y el visual, en el que aparecen fotos de personas con características étnicas distintas, y, abajo, nombres de lugares de Brasil y del mundo. Luego, el texto: "una tarta de limón inesperadamente sorprendente (hay gente que no lo sabe)", acompañado de la imagen de la tarta de limón; más abajo, está el texto "una picaña esperadamente sorprendente (todo el mundo lo sabe)" acompañado de la imagen de una picaña, la típica imagen de los rodizios y churrascarías brasileñas.

Este texto resume el anuncio de la churrascaría "Fogo de Chão" y connota la idea de que todo el mundo conoce la buena calidad de la comida de este restaurante y hay gente que todavía desconoce la buena calidad de sus postres. Este mensaje está elaborado de modo que sea fácilmente descodificado. También tiene característica poéticas en el uso del lenguaje cuando adopta el paralelismo como recurso retórico para repetir las estructuras sintácticas: "una tarta de limón inesperadamente sorprendente (hay gente que no lo sabe)" у "una picaña esperadamente sorprendente (todo el mundo lo sabe)".

\section{Retórica visual}

Como derivación directa de la retórica, en 1964 se constató que los mismos recursos retóricos usados en el lenguaje oral y escrito también eran utilizados por el lenguaje visual. Al encontrar esos elementos retóricos en la imagen publicitaria, Barthes acuña el término retórica visual, "por el que se entiende un sistema de organización del lenguaje visual en el que el sentido figurado de los elementos representados organiza el contenido de mensaje" (Acaso, 2009:87).

La retórica de la imagen es la prueba más contundente de que la publicidad es retórica contemporánea. Así, la retórica visual hace uso de los mismos recursos retóricos empleados en el leguaje verbal (oral o escrito) $\mathrm{y}$, tal como hemos presentado anteriormente, "no debemos olvidar que una imagen puede tener varias figuras retóricas a la vez, la mayoría de ellas basadas en la metáfora" (Acaso, 2009:88).

Jacques Durad también relaciona la retórica con la publicidad, porque "si la publicidad tiene interés cultural, se lo debe a la pureza y riqueza de su estructura retórica" (Jacques Durand, 1970:1). No obstante, es cierto que la retórica posee puntos divergentes en 
relación a la publicidad, y esta por su parte tiene sus especificidades que la hacen diferente de la retórica.

TROPICAL TUR

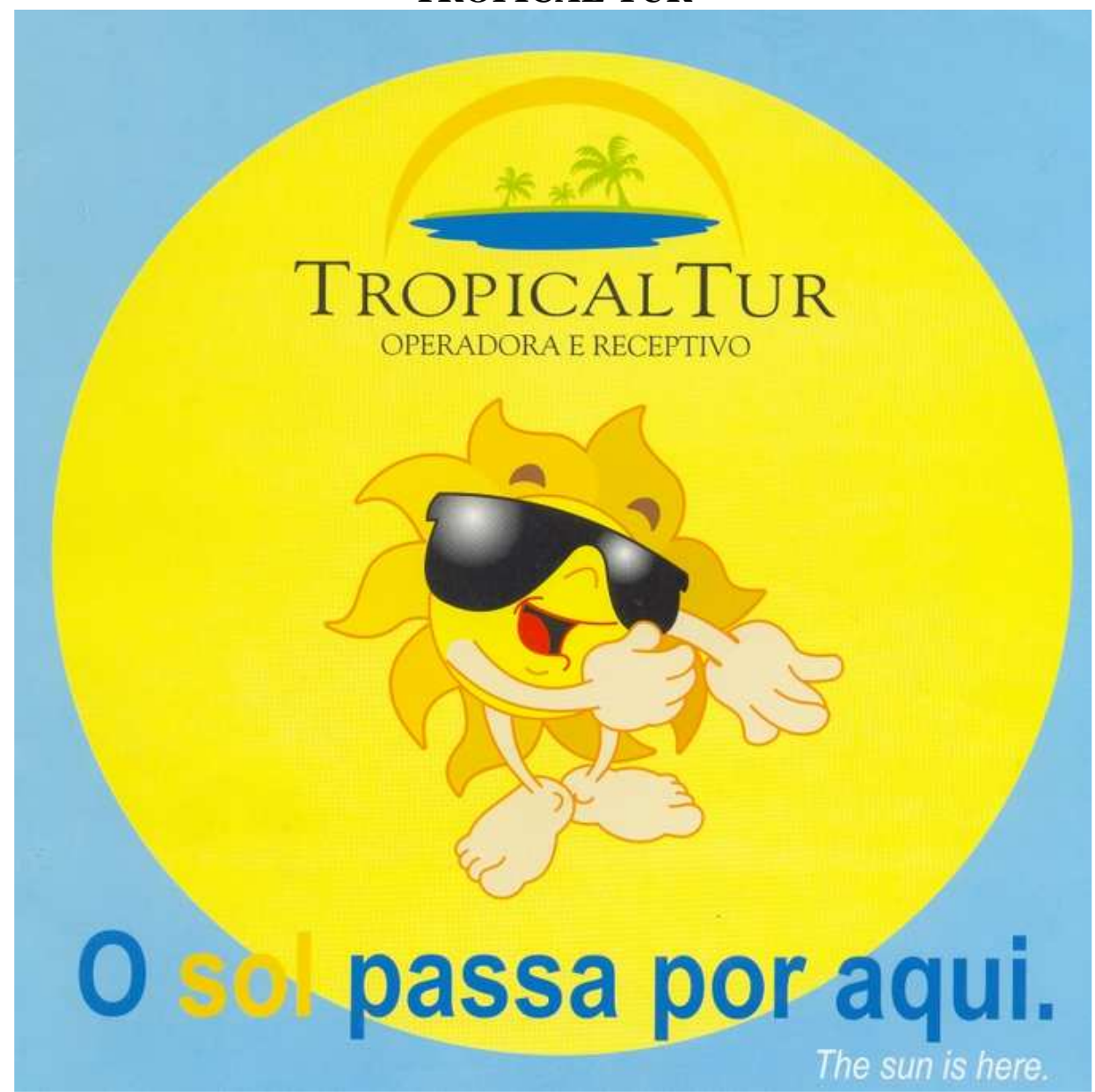

Texto 109

Una de las características indicadoras de la publicística es el uso de múltiples lenguajes que le acercan a la semiótica, como podemos ver en el ejemplo expuesto anteriormente. Sin embargo, desde la dimensión pragmática, el texto publicitario se acerca al discurso retórico. Si observamos este texto, como hemos visto antes, el sol es una imagen cuyo recurso retórico dominante es la personificación o la prosopopeya, ya que el sol es un ser inanimado y por eso no tiene brazos, piernas, pelo, boca, nariz, ojos y no lleva gafas de sol, como un ser humano. 
Dada la importancia de la retórica para la publicidad, López Eire (1998:82) dedica un apartado de su obra a las figuras retóricas recurrentes en el mensaje publicitario. Al hablar de las diferencias entre la retórica y la publicidad, afirma:

\begin{abstract}
Es verdad, sin embargo, que el mensaje publicitario (o acto de habla publicitario) tiene sus peculiaridades exclusivas que lo diferencian de un discurso retórico. Las más importantes son que el mensaje publicitario emplea más de un lenguaje, que es conciso y breve y que es un arma mercadotécnica destinada a dar a conocer un producto y sus excelencias con el objeto de crear demanda de él. El acto de habla retórico al que estamos acostumbrados es más extenso y amplio y no entra por su esencia necesariamente en el mundo moderno del marketing.
\end{abstract}

En nuestra Teoría del Acto de Comunicación Publicitario, concebimos que el acto de habla de la publicidad particulariza el texto publicitario y lo distingue de los textos literarios y de los no literarios, ya que sus componentes se comportan de forma específica. Para López Eire (1998:83), el texto publicitario es semejante al texto retórico porque "desde la dimensión pragmática sí podemos asimilar el texto publicitario a un texto retórico. Ambos buscan la eficacia persuasiva a través de un contexto que es un depósito común de representaciones que hacen posible la interacción entre el emisor y el receptor del mensaje”. Este autor no es el único que concibe la retórica, la semiótica y la pragmática como elementos esenciales al estudio de la publicidad. Según Carlos Vogt (2006:108) "la semiótica para Pierce es sinónimo no solo de la lógica, sino también de la teoría lingüística y debe englobar los tres niveles fundamentales de análisis: el sintáctico, el semántico y el pragmático".

\title{
6.7. Publicidad y pragmática
}

Comprendemos por publicidad un tipo de texto híbrido, es decir, que gravita entre el texto literario y el texto no literario. A partir de esto y todo lo que hemos visto hasta este punto de este trabajo de investigación, los resultados de nuestro estudio tienden a confirmar y sugerir que ciertamente la publicidad turística estudiada posee algunas especificidades que la particularizan frente a los demás tipos textuales.

La conclusión a la que parece estar llegando la investigación es que para un texto sea considerado publicitario hace falta la presencia de cinco características que lo particularicen en relación con los textos literario y los textos no literarios. Estas 
características serían su carácter expresivo (todo lo que se refiere al uso del lenguaje); su carácter comunicativo (todo lo que particulariza el acto de habla publicitario); el carácter retórico (todo lo que se refiere a la elaboración del mensaje persuasivo y la perpetuación de la retórica en el texto publicitario); y, por último, el carácter pragmático, del que hablaremos a continuación.

La comunicación simbólica (verbal e icónica) y la comunicación comercial influyen directamente en la estructura pragmática de la comunicación publicitaria. Por eso, el concepto de pragmática es uno de los pilares de nuestra teoría sobre la comunicación publicitaria en el turismo, ya que defendemos que el discurso publicitario se diferencia del literario y del no literario porque los elementos del acto de habla publicitario tienen algunas especificidades que no se manifiestan en los demás actos de habla. A saber, el emisor es colectivo (empresa anunciante, empresa publicitaria y equipo de publicistas); el mensaje es unilateral y adopta signos distintos (imagen y palabra) que connotan siempre la excelencia de un producto.

Además, la publicidad estudiada establece un comportamiento específico de las tres dimensiones de los actos de habla. Siguiendo la terminología clásica de Austin (1970) podemos afirmar que en la publicidad el acto locutivo (el texto híbrido de la publicidad); el acto ilocutivo (la persuasión inscrita en el texto publicitario); y el acto perlocutivo (el efecto del texto persuasivo del anuncio). En el caso de un anuncio publicitario, la dimensión perlocutiva siempre connota la adquisición de un determinado producto, así que, si el interlocutor no adquiere el producto, podemos decir que no hubo éxito comunicativo. En relación a esto, Adam \& Bonhomme (2000:33) señalan:

Tal duplicidad constitutiva tiene consecuencias directas sobre la estructura pragmática de la comunicación publicitaria. Inspirándonos en la terminología clásica de Austin (1970:109-137), consideremos tres dimensiones de los actos del discurso. Las dos primeras se insertan en la comunicación verbal: la dimensión propiamente locutiva (para nosotros, la producción escrita textual e icónica de un discurso publicitario) y la dimensión ilocutiva (a saber, la fuerza de persuasión inscrita en el anuncio). En cuanto a la tercera dimensión, se abre sobre la comunicación comercial: la dimensión perlocutiva se refiere al éxito (o el efecto) del acto ilocutivo, a las reacciones del lector persuadido o no de comprar el producto. 


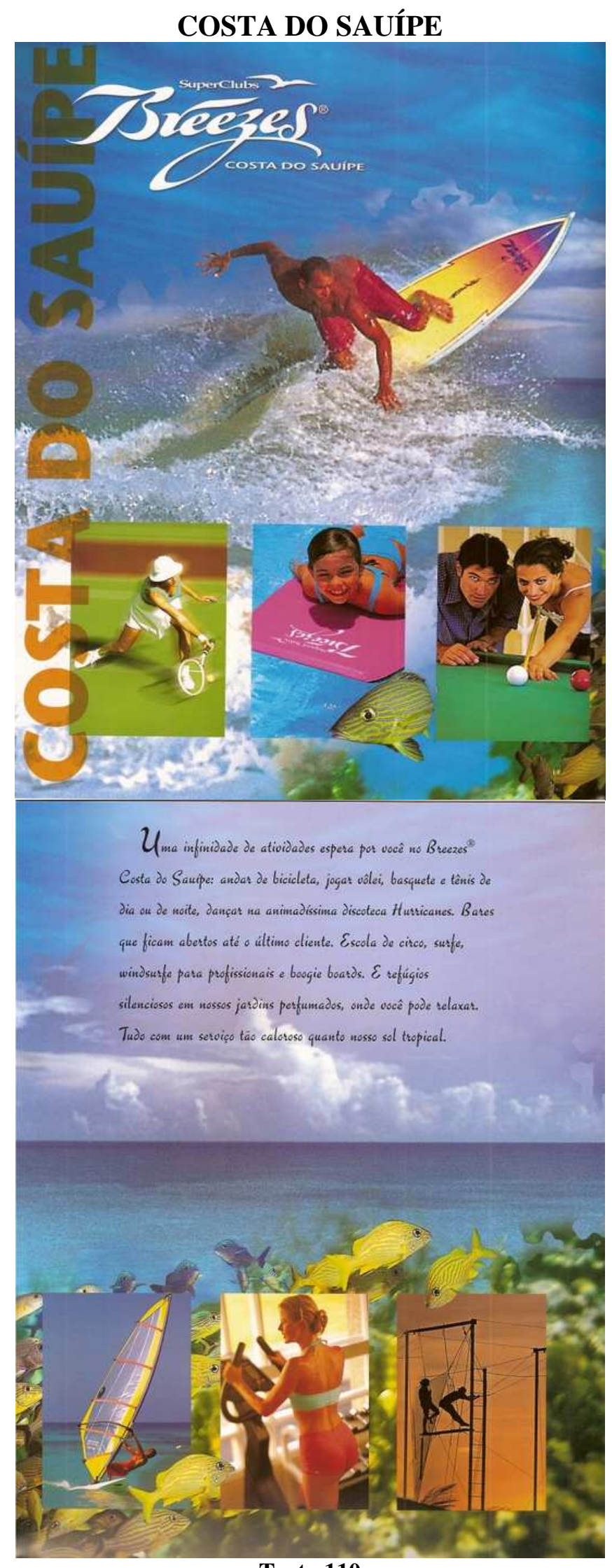

Texto 110

En la dimensión pragmática de la retórica, la comunicación es información y persuasión. En este contexto, López Eire (1998:12-13) concibe la retórica como un arte 
elocuente que se difunde por medio del lenguaje, como una disciplina que tiene sus bases en la pragmática, puesto que el lenguaje mismo tiene una esencia pragmática y un propósito persuasivo dirigido a la sociedad, "cuya estructura, conceptos y usos trata de alterar, modificándolos, sustituyéndolos o simplemente activándolos, ya del todo ya tan solo parcialmente, mediante la información y la persuasión que están contenidas en el proceso de comunicación".

Uniendo la retórica, la publicidad y la pragmática, López Eire (1998:16) asegura que el discurso retórico y el discurso publicitario han de estudiarse desde la perspectiva de la pragmática, "que es la que engloba todas las demás dimensiones de un texto, y que tanto el discurso retórico como el mensaje publicitario son precisamente textos". Eduardo Fernández (2006:55) también relaciona la publicidad y la pragmática y afirma que, la publicidad, de igual modo, "parece haber centrado sus fundamentos en la lingüística en lo que se refiere a la comunicación verbal, en la semiótica, en cuanto al sentido, en la pragmática, en la sociología, en la psicología que ha aportado la investigación de las motivaciones emotivas, etc.". Veamos, pues, el texto 110 bajo una perspectiva pragmática.

La Costa do Sauípe está localiza en el litoral norte de Bahia, en Brasil. En este lugar está ubicado el Club Breezes anunciado en esta publicidad turística. El texto presenta el lugar como perfecto para las vacaciones o para relajar y afirma que: "Hay una infinidad de actividades para ti en Breezes Costa do Sauípe: montar en bici, jugar al vóleibol, al balón mano, al tenis de día o de noche, y bailar en la discoteca. Bares que se quedan abiertos hasta el último cliente. Escuela de circo, surf, windsurf, para profesionales y boogie boards. Y refugios silenciosos en nuestros jardines perfumados, donde puedes relajar. Todo con un servicio tan caluroso cuanto nuestro sol tropical". Este texto va dirigido a deportistas, aficionados al deporte y a los amantes del turismo de sol y playa que busca actividades o simplemente descansar tranquilamente.

Ese texto puede atraer la atención de la gente que busca exactamente este tipo de turismo. Aquí la dimensión locutiva es el texto publicitario que anuncia el Breezes por medio del código mixto (verbal y no verbal), la dimensión ilocutiva es la fuerza persuasiva del texto que no deja duda al interlocutor de que es un lugar perfecto para ir de vacaciones, por último, la dimensión perlocutiva consiste en la compra de este lugar 
como destino turístico, en el caso de la emisión de una respuesta positiva por parte del interlocutor y del suceso de este acto de habla publicitario.

\section{La contribución de la pragmática para la publicidad}

Para Eduardo Fernández (2006:57), estudiar la retórica y la publicidad desde una perspectiva pragmática proporciona otras posibles interpretaciones de esos tipos de discurso, puesto que la pragmática "engloba las dimensiones de un texto, ya que tanto el discurso retórico como el mensaje publicitario son precisamente textos que configuran el acto de habla entre el emisor, el receptor y el contexto", elementos fundamentales en la publicidad turística.

En el acto comunicativo, el sujeto se convierte en una persona social, que crea y mantiene una determinada imagen frente a su interlocutor. "El sujeto hablante como un personaje que se va definiendo en el proceso mismo de la interacción con los otros" (Calsamiglia \& Tusón, 2002:160).

Los componentes de naturaleza material consisten en el emisor, el destinatario, el enunciado y el entorno (contexto o situación espacio-temporal). Es importante resaltar que para Escandell (2008:29) "el destinatario es siempre el receptor elegido por el emisor. Pero no sólo eso: además, el mensaje está construido específicamente para él”. En el caso del discurso publicitario, el emisor es fundamental en su elaboración, aunque está más bien producido para una audiencia que para una única persona.

La orientación pragmática de la publicidad abierta por la lingüística y la eficacia de los mensajes en un acto de habla es muy importante dentro de la publicidad, pues es un tipo de discurso que busca siempre alcanzar su eficacia, es decir, la venta de un producto. Por eso, la publicidad se interesa fuertemente por la retórica porque esta "es el arte que se preocupa y vela por la eficacia comunicativa del lenguaje" (Eire, 1998:19).

Esa orientación pragmática de la publicidad es abordada por Eduardo Fernández (2006:23) y, en sus propias palabras, "la reflexión teórica sobre el lenguaje publicitario ha seguido los cauces en gran medida abiertos por la lingüística, según una clara 
orientación pragmática con la que se busca dar explicación de la realidad de la eficacia del mensaje publicitario".

No cabe duda, por lo tanto, de que el mensaje publicitario está permeado por características pragmáticas desde su génesis, en eso es importante tener en cuenta que "el mensaje publicitario es un breve discurso retórico social con finalidad perlocutiva (o sea, que pretende a toda costa hacerse realidad), provisto de todos los factores pragmáticos propios del discurso retórico" (López Eire 1998:55).

Por esta misma línea de razonamiento, Eduardo Fernández (2006:23/24) también aborda la importancia de las aportaciones de la pragmática para el estudio del lenguaje retórico y publicitario. En las propias palabras de ese autor:

\begin{abstract}
La teoría de la publicidad como un fenómeno moderno ha encontrado en todos estos avances el testigo para asentar una verdadera teoría del lenguaje publicitario. Las aportaciones de la lingüística pragmática que postulan la importancia de los componentes del proceso comunicativo como integrantes del acto del habla hacen depender la comprensión del significado de algo más que unas simples formas verbales; o la superación de una visión inmanentista de contenido del discurso, enriquecida por la lingüística social, la visión del receptor, de sus gustos o condicionamientos sociales del contexto, etc.".
\end{abstract}

Al tratar de la retoricidad del lenguaje vista desde la pragmática, López Eire (1998:15) habla de la importancia de la dimensión pragmática en un acto de habla y dice que las frases fuera de la dimensión de la pragmática se vuelven ambiguas. Además, menciona la importancia del contexto que, según él, "es algo distinto de la situación de la comunicación y tampoco se confunde con el mero código lingüístico gracias al cual se codifican y se descodifican los mensajes que nos enviamos y recibimos en nuestras relaciones y actos de comunicación".

Por último, Adam \& Bonhomme (2000:34) afirman que "el acto ilocutivo dominante de la mayoría de las publicidades es explícitamente constatativo e implícitamente directivo" y exponen que es innegable la complejidad semiótica de la comunicación publicitaria a partir de los siguientes tres puntos:

1- Plano locutivo: discurso constituido por texto e imagen;

2- Plano ilocutivo: objetivo descriptivo, informativo y argumentativo; 
3- Plano perlocutivo: la estrategia de persuasión publicitaria y el acto de comprar.

\section{La cortesía en la publicidad}

Desde el punto de vista de la pragmática, la cortesía también se hace importante en la elaboración del discurso publicitario, puesto que comprende que por medio de principios y comportamientos establecemos relaciones sociales, y, por lo tanto, la percepción de ello repercute en la comunicación.

Como afirma Asunción Escribano (2006:108), las reglas de cortesía "poseen una dimensión cultural importante, puesto que cada sociedad organiza a sus miembros en función de características sociales diversas como la edad, clase social, sexo o posición social." Además, esta misma autora llama la atención sobre la formalidad en la cortesía, que es básica, afirmando que:

\footnotetext{
Tiene enorme rendimiento en la publicidad, ya que en este ámbito comunicativo el emisor ha de conseguir vender el producto a un receptor que, con frecuencia, está expuesto a sobreabundancia de mensajes publicitarios y, por lo tanto, ha desarrollado una enorme resistencia tanto en la atención como en la confianza frente al producto (Asunción Escribano, 2006:109).
}

La cortesía lingüística es estudiada desde una perspectiva pragmática y contribuye a regular un acto comunicativo y mantenerlo. También "puede ser comprendida como un conjunto de normas que regulan el comportamiento de los miembros de una sociedad" (Calsamiglia \& Tusón, 2002:161). El principio de cortesía de Leech (1983) y Brown y Levinson (1987) controla nuestras interacciones: es universal. Tiene que ver con la imagen (face) y con el territorio. La cortesía nos orienta a preservar nuestra imagen y a no amenazar la imagen de los demás ni a invadir su territorio. 
En este capítulo hemos abordado el carácter expresivo de la publicidad, es decir, todo que se refiere a su uso del lenguaje, a su carácter semiótico y pragmático. Nos apoyamos, pues, en este capítulo para decir que la publicitad consiste en un acto de habla específico, pues el emisor, el receptor, el mensaje y el código se comportan de forma distinta de otros tipos discursivos, tales como el discurso literario y el discurso no literario. A partir de ello creemos factible afirmar que un texto puede ser considerado publicitario cuando se dan algunas características y su efecto perlocutivo es la adquisición de un producto. 


\section{Capítulo VII}

\section{CONCLUSIONES}

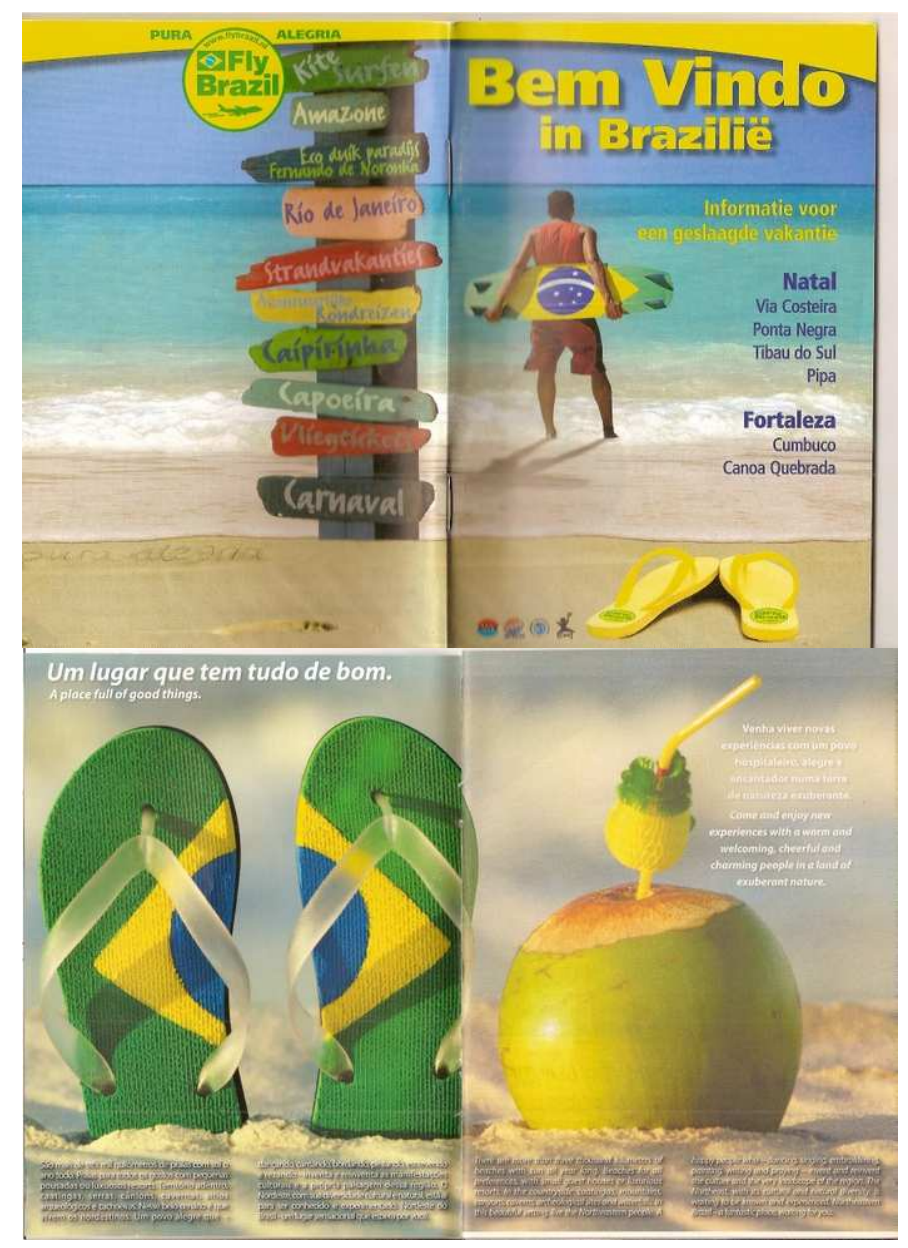

"La publicidad turística no es más que un caso de aplicación de la publicidad general. Aumenta el campo del turismo en el sentido en el que se propone influir en el consumidor induciéndole a utilizar las instalaciones que esta industria pone a su disposición".

(Kurt Krapf) 


\section{CAPÍTULO VII - CONCLUSIONES}

El séptimo y último capítulo de nuestro trabajo de investigación consiste en la presentación de las respuestas a las preguntas planteadas al principio del estudio; y las conclusiones a las que fue posible llegar.

\subsection{La Publicidad Turística}

Hablar de publicidad turística es tocar un tema muy de nuestro tiempo, pues vivimos en un momento histórico en el que los viajes y la publicidad están presentes en los más diversos ambientes o quizás en todos los lugares.

El fenómeno de la publicidad es aún más frecuente cuando se trata de la publicidad turística, ya que este tipo de publicidad torna tangible a un producto inmaterial y, por eso, dentro del campo de la comunicación turística ocupa un lugar fundamental. Kurt Krapf, en La Consumición Turística (1953), dedica la segunda parte de su obra a los elementos constitutivos de la consumición turística que serían: la renta y la demanda turística; el legado histórico; el medio social y, por último, la publicidad, que aparece como uno de las cuatro bases fundamentales para la consumición del producto turístico.

Al estudiar la publicidad turística desde un punto de vista de la lingüística del texto hemos abordado un tema relacionado con la evolución económica, social y cultural de la sociedad contemporánea, ya que esos ámbitos de cualquier sociedad están reflejados en el sector del turismo que tiene un impacto en desarrollo humano, sobre todo, en lo que se refiere a fenómenos pertinentes a la globalización. Para Valdés (2003:13):

\footnotetext{
El sector del turismo resume en si mismo la gran evolución económica y socio-cultural que se presencia en el mundo. Su impacto en el desarrollo de la humanidad va más allá de su papel dinamizador de las economías, pues representa un componente catalizador de la globalización, en el ámbito de la cultura y del intercambio entre las naciones de cualquier latitud.
}

La publicidad cumple, entonces, una función indispensable para el actual mercado económico puesto que informa del mercado y da a conocer a los consumidores la visión 
conjunta de bienes existentes para la consumición. Por eso, es indudable la importancia de la publicidad para el sector turismo.

La comprensión de la publicidad como un fenómeno comunicativo en el que tanto su concepto, su relación con la propaganda, su forma de usar la imagen como signo representativo, su lenguaje, su proceso de comunicación específico y su configuración en forma de un texto híbrido son básicos para el estudio de la publicidad turística, ya que "la publicidad turística no es más que un caso de aplicación de la publicidad general. Aumenta el campo del turismo en el sentido en el que se propone influir en el consumidor induciéndole a utilizar las instalaciones que esta industria pone a su disposición” (Kurt Krapf, 1953:47).

Así, no cabe duda de que el texto publicitario es fundamental para la industria turística porque el turismo, como una actividad económica organizada, solo va a generar beneficios si "existe una infraestructura, una promoción de eventos asociados a un trabajo de marketing para llamar la atención del flujo turístico a la ciudad receptora" Natal (2004:30). Por lo tanto, la industria turística depende directamente de la aplicación de la publicidad como parte de un programa de su marketing.

La linguiística textual, la teoría de la enunciación, la semiótica y el análisis del discurso constituyen cuatro ámbitos distintos de las ciencias del lenguaje que conceptúan el texto bajo distintas perspectivas. Entre estas perspectivas teóricas, el texto publicitario puede ser concebido como una unidad pragmático-comunicativa, puesto que busca el establecimiento de una comunicación. Para Eduardo Fernández (2006:63):

\footnotetext{
En este sentido la publicidad actual encuentra un camino abierto para la utilización de los recursos facilitados por los avances poético-retóricos. Es básicamente, una comunicación persuasiva regida por las normas de la lingüística pragmática en la que los medios para embellecer el discurso son equivalentes a los empleados tradicionalmente en la literatura, pero con la evidente ventaja de que se trata de una expresión viva, estrictamente pragmática de la lengua.
}

El discurso publicitario está anclado en un contexto socio cultural y socio histórico. Por eso es más recomendado hablar de este tipo de discurso desde una perspectiva del análisis del discurso, sin ignorar la contribución de la lingüística textual, la teoría de la 
enunciación y la semiótica. "El análisis del discurso publicitario significa en última instancia, hablar del poder y de la seducción de la imagen como medio de comunicación” (Eduardo Fernández, 2006:52).

La comunicación es una palabra clave para la sociedad postindustrial del siglo XX y XXI, es un evento amplio de que forma parte sus variantes: la información, la propaganda y la publicidad, ésta como una forma de comunicación para la venta de un determinado producto es propia de la sociedad contemporánea. Para Eduardo Fernández (2006:67) "lo que no cabe duda es que el mensaje publicitario existe y se trata de un acto comunicativo". Ya para López Eire y Santiago Guervós (2000:7):

\begin{abstract}
El concepto de publicidad, que es una comunicación para la venta de un producto, se emplea diariamente en la sociedad de producción y consumo masivos o la sociedad de masas en la que vivimos, que - como es bien sabido - es la sucesora de un tipo de sociedad ya añosa y aun centenaria que surgió de la Revolución Francesa y de la Revolución Industrial y experimentó una serie de transformaciones a lo largo de las luchas y reivindicaciones obreras de comienzos de nuestra centuria que la llevaron a convertirse en la sociedad postmoderna de nuestros días.
\end{abstract}

En los años ochenta, surge la hegemonía de las marcas y una década más tarde se deja de producir marcas y se empiezan a producir historias. Sin embargo, a principios del siglo XXI, parece ser que la gente empieza a ser cada vez menos fiel a las marcas. "Indicio de esta fragilidad: marcas que eran símbolo de la prosperidad de las multinacionales en los años noventa han perdido bruscamente su prestigio y su poder comercial” (Christian Salmon, 2007:45).

Desde entonces las marcas se convierten en narrativas, es decir, se pasa del branding al storytelling, como un reflejo de que la gente ya no compra el producto sino una narrativa representada por dicho producto. Respecto a esto, Christian Salmon (2007:57) afirma que "en menos de quince años el marketing ha pasado así del producto al logotipo, y luego del logotipo a la story; de la imagen de marca (brand image) a la historia de marca (brand story)". Eso no quiere decir que los productos y sus marcas ya no existan, sino que han perdido su importancia y con ello su fuerza persuasiva. Referente a la narrativa en la publicidad, Eduardo Fernández (2006:50) afirma que en el mundo de los medios comunicativos, más concretamente el de la publicidad "es un mundo platónico, alejado de la realidad por medio de una serie de procesos de 
simulación capaces de crear falsas realidades, falsas necesidades en las modernas sociedades de consumo".

\subsection{La disposición de capítulos}

Nuestra tesis está estructurada en siete capítulos. El primero posee un carácter introductorio y se ocupa de presentar nuestro tema de investigación. Está dividido en siete apartados: tema y motivaciones; antecedentes del estudio y cuadro referencial; problemas, objetivos e hipótesis; viabilidad y originalidad del estudio; diseño metodológico; esquema del trabajo; y, por último, la conclusión. Trata, por lo tanto, de las cuestiones inherentes al tema elegido como objeto de estudio y de las motivaciones que subyacen a esa elección y a la elaboración de dicha investigación.

El segundo capítulo de nuestro estudio tiene como objetivo establecer las especificidades del producto turístico y mostrar que eso condiciona la producción de la publicidad turística. También defiende la industria del turismo como un elemento de desarrollo socioeconómico en Natal y muestra cómo esa industria puede estar relacionada con el Marketing turístico, con la publicidad y con el análisis del discurso publicitario. Para ello trata cuestiones como la definición del producto turístico, su especificidad y su marketing. Por último presenta cuestiones como la publicidad turística y su análisis según las leyes de la lingüística, más específicamente, el análisis del discurso publicitario.

El tercer capítulo de nuestro trabajo está consagrado a la presentación de nuestro corpus del estudio de caso, la metodología de la investigación empírica adoptada como modelo operacional de procedimiento, el diseño metodológico utilizado en la investigación y nuestra Teoría del Acto de Comunicación Publicitario. Está constituido por doce temas, entre los cuales figuran la metodología y diseño experimental; objetivos e hipótesis; selección del corpus, recogida y tratamiento de los datos; grado de innovación previsto; plan de trabajo y cronograma; investigación bibliográfica y documental; el corpus; reducción de los datos; la tesis; la Teoría del Acto de Comunicación Publicitario; la publicitariedad; y, por último, la conclusión del capítulo. 
En nuestro cuarto capítulo, empezamos el análisis del corpus de estudio y a través de eso defendemos nuestra Teoría del Acto de Comunicación Publicitario. Postulamos aquí que la publicidad y, por consiguiente, la publicidad turística, consiste en un proceso comunicativo del que participan determinados elementos que, sin embargo, se comportan distintamente de otros procesos de comunicación, dadas las especificidades de la publicidad, en especial, de la publicidad turística. Eso es lo que hemos nombrado como el carácter comunicativo del texto publicitario. Así pues, en este capítulo, hemos elaborado nuestra conceptualización de la publicidad turística de modo que sirva para plasmar la premisa de la que partimos de que la publicidad, desde un punto de vista textual, se debe estudiar de modo que se ponga de relieve su concepto, su origen, la relación entre la publicidad y la propaganda, el uso de la palabra en la publicidad, el uso de la imagen en la publicidad, el lenguaje publicitario y su proceso comunicativo específico.

Hemos definido la publicidad turística como un discurso que materializa un producto o servicio y que constituye un acto de comunicación específico. En nuestra tesis de las especificidades del discurso publicitario consisten en que un texto puede ser considerado publicitario cuando se dan algunas condiciones determinadas, entre estas condiciones están los aspectos retóricos del texto publicitario. Por ello, el quinto capítulo de nuestro trabajo presenta los aspectos retóricos como elementos básicos para la comprensión de la publicidad escrita. Mediante esto, intentamos encontrar lo que llamamos aquí las especificidades del discurso publicitario, comprendido como un tipo de discursivo elaborado artísticamente.

La tesis fundamental de nuestra Teoría del Acto de Comunicación Publicitario consiste en afirmar que las características inherentes al discurso publicitario son: el carácter expresivo; el carácter comunicativo; el carácter retórico; el carácter persuasivo; y el carácter pragmático. El sexto capítulo está consagrado, sobre todo, al carácter pragmático de la publicitad turística. Tomando eso como base, hemos empezado con una caracterización del texto publicitario, de modo que todos los aspectos fundamentales para la interpretación de un anuncio sean contemplados. Por último, se han abordado los aspectos semióticos y pragmáticos en el discurso publicitario. 
Finalmente, el séptimo capítulo de nuestro trabajo de investigación consiste en la presentación de las respuestas a las preguntas planteadas al principio del estudio; y las conclusiones a las que fue posible llegar.

\subsection{Las cuestiones estudiadas}

El problema central de nuestra investigación está relacionado con la importancia que la comunicación publicitaria cobra en la sociedad contemporánea, sobre todo en sectores como el turismo. Para tratar este tema hemos partido de las siguientes preguntasproblemas: ¿hay elementos inherentes al discurso publicitario que determinan si un texto es publicitario o no?; ¿qué elementos textuales están presentes en todos o casi todos los textos publicitarios?; ¿hay alguna característica común en la publicidad que defina su grado de "publicitariedad" o que caracterice un texto publicitario como tal?

Con el objetivo de contestar a estas preguntas hemos planteado las cuestiones siguientes: ¿cuál es la importancia del turismo a nivel mundial y local?; ¿cuáles son las especificidades de este producto?; ¿cuáles son las particularidades de la industria del turismo?; ¿cuál es la importancia del marketing y de la comunicación para esa industria?; ¿cómo se constituye la publicidad del producto turístico?; ¿qué se comprende por publicidad?; ¿qué importancia tiene la publicidad en el contexto contemporáneo?; ¿cuáles son las especificidades de la publicidad desde un punto de vista lingüístico?; ¿se pueden identificar elementos comunes a todos los textos publicitarios que los determinen como publicitarios y no como literarios y no literarios?

Partiendo de las cuestiones estudiadas presentadas en el apartado 7.3 fue posible llegar, a través de nuestro trabajo de investigación, a las siguientes conclusiones:

1- Es posible establecer una relación entre el lenguaje publicitario y las teorías lingüísticas;

2- La publicidad es un tipo de producción textual muy presente en la sociedad contemporánea; 
3- La industria del turismo, como otros tipos de campo de la economía comercial, depende directamente de la comunicación, sobre todo de la publicitaria;

4- El turismo, la comunicación turística, la publicidad y la lingüística textual son temas convergentes;

5- Se puede establecer una relación entre la publicidad y el turismo desde un punto de vista de la lingüística;

6- El marketing turístico es una estrategia de mercado que hace uso, sobre todo, de la publicidad;

7- La suma de los conocimientos de campos distintos como la lingüística textual y el marketing enriquece los conceptos a respecto del fenómeno publicitario;

8- La publicidad es una parte del marketing relacionada directamente con la lingüística textual;

9- El marketing establece la relación existente entre la industria turística y el texto publicitario;

10- La publicidad de la industria turística puede ser explicada desde un punto de vista lingüístico.

11- El turismo tiene mucha importancia a nivel mundial, en Brasil y en Natal, además, esto es una tendencia contemporánea;

12- Una de las grandes particularidades de la industria del turismo es que nos enfrentamos a un producto intangible y de eso parte toda la complejidad de este producto;

13- Lo que particulariza la industria del turismo es que se venden productos inmateriales, mejor dicho, una experiencia; 
14- Frente a las particularidades y especificidades de la industria del turismo, el marketing y la comunicación tienen una importancia fundamental para esa industria en virtud de ser la única forma de contacto entre el producto y la demanda;

15- La publicidad del producto turístico se constituye de forma semejante a la publicidad general, siempre llevando en consideración las particularidades de ese producto;

16- La publicidad es un tipo de texto híbrido presentado por medio de los códigos escrito y visual, que establecen un proceso de comunicación distinto a los demás puesto que los componentes del acto de habla publicitario se comportan de forma distinta a los demás procesos comunicativos;

17- La publicidad tiene una gran importancia en el contexto contemporáneo, de modo que forma parte de nuestro cotidiano;

18- Las especificidades de la publicidad comprenden cinco caracteres que la particularizan frente a los demás tipos textuales, a saber: el carácter expresivo (todo lo que se refiere al uso del lenguaje); el carácter comunicativo (todo que particulariza la comunicación en la publicidad); el carácter retórico (todo lo que se refiere a la perpetuación de la retórica en el texto publicitario); el carácter persuasivo (la persuasión en el discurso publicitario); el carácter pragmático (lo pragmático en la publicidad);

19- El aspecto común a todos los textos publicitarios son sus aspectos pragmáticos, es decir, todo lo que particulariza la comunicación publicitaria en su contexto como el enunciado, la enunciación, el enunciador, el enunciatario, el contexto, el código y el vehículo de comunicación;

20- Los elementos que forman parte del acto de comunicación publicitaria determinan un texto publicitario como tal y lo distingue de los textos literarios y no literarios.

A partir de todo lo que hemos visto hasta aquí formulamos lo que hemos nombrado de la Teoría del Acto de Comunicación Publicitario, que consiste en el acto de habla propio del texto publicitario y lo distingue de los demás tipos de textos porque tiene 
siempre como efecto perlucutivo la compra o la adquisición del producto y/o servicio anunciado.

La obra lingüística, recién publicada, Discurso Turístico e Internet (2012) sirve para corroborar la importancia de estudios sobre el discurso turístico en la sociedad contemporánea. Además sirve como una bibliografía básica para una posible continuidad a este trabajo, ya que, a partir de esa referencia bibliográfica, hemos visto que es factible adoptarla como parámetro para adaptar esta tesis a un estudio más cuantitativo de frecuencia léxica mediante el uso de programas como WordSmith Tools (WST) y herramientas como Wordlist de WST. Además de la posibilidad de direccionarla para el estudio del discurso turístico en internet.

Por último, las principales contribuciones de este trabajo son la elaboración de un corpus de textos publicitarios de Natal; el establecimiento de la relación entre el turismo, la publicidad y la lingüística textual; la elaboración de una perspectiva teórica desde la que se debe estudiar el fenómeno de la publicidad desde un punto de vista de la lingüística; la elaboración de un trabajo sobre la publicidad turística desde una perspectiva lingüística de la comunicación social, la creación del término publicitariedad y, por último, la elaboración de la Teoría del Acto de Comunicación Publicitario. 


\section{BILIOGRAFÍA}

ACASO, María (2009). El Lenguaje Visual. Barcelona: Paidós.

ADAM, J.M. \& BONHOMME, M. (2000). La argumentación publicitaria: retórica del elogio y de la persuasión. (Traducción de M. A. Pérez Harguindey y M. Talens). Madrid: Cátedra.

ADAM, J.M. \& CLARA-UBALDINA Lorda. (1999). Lingüística de los Textos Narrativos. Barcelona: Ariel.

ADAM, J.M. (1985). Quels Types de Texts? Le Français dans le Monde.

ADAM, J.M. (1992). Les Textes: Types el Prototypes. Récit, description, argumentation, esplicacition, et dialogue. Praís: Nathan.

AGUSTÍN GUIJARRO, C. y otros. (1991). Análisis Lingüístico de un Texto Publicitario. En Revista de Filología Románica, 9.

ALARCOS LLORACH, Emilio. (1999). Gramática de Lengua Española. Madrid: Espasa.

ÁLVAREZ VALDÉS, Jesus. (2003). Marketing Estratégico e Estratégia Competitiva de Empresas Turísticas: Um Estudo de Cada da Cadeia Hoteleira Sol Meliá. São Paulo: FEA/USP. Tesis Doctoral.

ANDRADE MARCONI, Marina de; LAKATOS, Eva Maria. (2006). Metodologia do

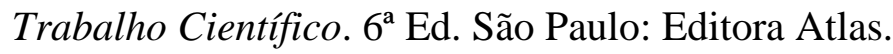

ANDRADE MARCONI, Marina de; LAKATOS, Eva Maria. (2007). Metodologia Científica. $5^{\text {a }}$ Ed. São Paulo: Editora Atlas.

ANDRÉS CASTILLO, David. (2007). El Embalaje Discursivo de la Publicidad: Propuesta Tipológica para el Discurso Publicitario. Tesina.

ÁNGELES, Juan de los. (2005). Lenguaje Publicitario. Barcelona: Ariel.

ANSCOMBRE, J. C. \& DUCROT, O. (1998). La Argumentación en la Lengua. Versión española de Julia Sevilla y Marta Tordesillas. Madrid: Gredos.

ANZANELlO CARRASCOZA, João. (1999). A Evolução do Texto Publicitário. $8^{\mathrm{a}}$ Ed. São Paulo: Futura.

ARISTÓTELES. (2002). Poética. Introducción, traducción, notas y comentario de Antonio López Eire; epílogo de James J. Murphy. Madrid: Istmo.

ARMENGAUD, Françoise. (2006). A pragmática. São Paulo: Parábola Editorial. 
ASSOCIAÇÃO BRASILEIRA DE AGÊNCIA DE VIAGENS (ABAV). Disponible en: http://www.abav.com.br/texto.aspx?id=1\&id_area=1. Acceso en 23 de octubre de 2009.

AUSTIN, J. L. (1962). Cómo hacer cosas con palabras. Barcelona: Paidós.

BARROS GARCÍA, P. (1977) El Lenguaje de la Publicidad. En Español Actual, 33, págs. 1-26.

BARTHES, Roland, (1964) Retóricas de la Imagen, Communication, núm. 4, Francia.

BARTHES, Roland, (1970) Análisis Estructural del Relato, Buenos Aires: Editorial Tiempo Contemporáneo.

BARTHES, Roland, (1972) La Semiología. Buenos Aires: Editorial Tiempo Contemporáneo.

BARTHES, Roland, (1974) El Placer del Texto. Buenos Aires: Siglo XXI Editores.

BARTHES, Roland, (1978) Roland Bartes. Barcelona: editorial Kiros.

BARTHES, Roland, (1978) Sistema de la Moda. Barcelona: Editorial Gustavo Gili.

BARTHES, Roland, (1980) Mitologías. México: Siglo XXI Editores.

BARTHES, Roland, (1985) La Aventura Semiológica. Barcelona: Paiadós.

BARTHES, Roland, (1986) Lo Obvio y lo Obtuso. Barcelona: Paiadós.

BARTHES, Roland. (1970) Retórica de la Imagen, en la semiología. Buenos Aires: Tiempo Contemporáneo, (publicado en francés en 1964).

BARTHES, Roland. (1971) Elementos de Semiología (Traducción: Alberto Méndez) Madrid: Alberto Corazón, D. L.

BARTHES, Roland. (1985) La Aventura Semiológica. París: Ediciones Paidós Comunicación.

BEAUGRANDE, Robert-Alain de \& DRESSLER, Wolfgang Ulrich (2005). Introducción a la Lingüística del Texto. Barcelona: Ariel Lingüística.

BENAVIDES DELGADO, Juan. (1997) Lenguaje Publicitario: hacia un estudio del lenguaje en los medios. Madrid: Síntesis, D. L.

BERNÁRDEZ, E. (1982). Introducción a la lingüística del texto. Madrid: Espasa Calpe.

BETÉS RODRÍGUEZ, Kety. (2005). El Sonido en el Mensaje Publicitario. Lenguaje Publicitario. $1^{\text {a }}$ Ed. Ariel: Barcelona, págs. 113-138.

BLANCO RODRÍGUEZ, Luisa. (2005). Lengua y Grafía. Recursos Fónicos. Lenguaje Publicitario. $1^{\mathrm{a}}$ Ed. Barcelona: Ariel. 
BRITO GARBOGGINI, Frailda. (2005). Ideologias, valores e representação de gênero na Publicidade. In: CONGRESSO BRASILEIRO DE CIÊNCIAS DA COMUNICAÇÃO, 28. Rio de Janeiro. Andis. São Paulo: Intercom. CDROM disponible en: http://hdl.handle.net/1904/17460.

BRITO, Silvana Maria Silva de.(1993). Marketing como instrumento de desenvolvimento do turismo: o caso do Rio Grande do Norte. Monografia apresentada ao departamento de economia (Universidade Federal do Rio Grande do Norte - UFRN) para a obtenção do título de bacharelado em Ciências Econômicas. Natal - RN.

BROWN, G. \& YULE, G. Análisis del Discurso, (1993) Madrid: Visor DL.

BUSTOS GISBERT, José M. (1996). La Construcción de Textos en Español. Salamanca: Ediciones Universidad de Salamanca.

CALSAMIGLIA BLANCAFORT, Helena \& TUSÓN VALLS, Amparo. (1999) Las Cosas del Decir. Manual de Análisis del Discurso. Barcelona: Ariel.

CARVAlHO; Nelly de. (2000). Publicidade: A linguagem da Sedução. São Paulo: Editora Ática.

CASTELlI, Geraldo. (1990). Turismo: Atividade Marcante do Século XX. $2^{\mathrm{a}}$ Ed. Caxias do Sul: EDUCS.

CELSO DE PIRATININGA, Luiz. (1994). Publicidade: arte ou artifício? São Paulo: T.A. Queiroz.

COIMBRA, Rosa Lídia. (2002). Jogos polissêmicos no discurso publicitário, in: Ferreira A. M. (coor.), Presenças de Régio (Actas do $8^{\circ}$ Encontro de Estudos Portugueses). Aveiro: ALAIP, Universidade de Aveiro (ISBN: 972-789-079-2).

CONTEXTO: Revista Acadêmica da Faculdade de Filosofia e Ciências Sociais, v. 3, n.

3, (jan./jul, 2008). - Mossoró, RN: Faculdade de Filosofia e Ciências Sociais.

COOK, Guy. (2001). The Discourse of Advertising. London-New York: Routledge. COOK, Guy (2003). Applied Linguistics. $1^{\text {a }}$ Ed. Oxford: Oxford University Press. CORTÉS RODRÍGUEZ, L. \& CAMACHO ADARVE, Mª M. (2003) ¿Qué es el Análisis del Discurso?. Barcelona: Octaedro.

DEMARTINI GOMES, Neusa. (2003). Publicidade: comunicação persuasiva. Porto Alegre: Sulina.

DIÁRIO DE NATAL. (28/06/2009) Caderno de Economia. Edição de domingo. 
DOMÍNGUEZ GARCÍA, Ma Noemí. (6 de Julio de 2005) Herramientas Teóricas para el Análisis de los Marcadores del Discurso (I). Conferencia Pronunciada en el Curso Superior de Filología Hispánica Pragmática del Español, Universidad de Salamanca.

DUCROT, O. (1984). El Decir y lo Dicho. Buenos Aires: Hachette.

DUNN, S. Watson. (1967). Publicidad. Su Papel en la mercadotecnia. México: UTEHA.

DURÁN, ALFONSO. (1995). Psicología de la Publicidad y la Venta. Barcelona: Grupo Editorial Ceac.

DURAND, Jacques (1970). Retoritique et Image Publicitaire. Comunications, 15. Págs. 70-95.

ECO, Umberto. (1972). La Estructura Ausente. Introducción a la Semiótica. Barcelona: Editorial Lumen.

ECO, Umberto. (1976). Introducción al Estructuralismo. Madrid: Alianza Editorial.

ECO, Umberto. (1992). et al. Análisis de las Imágenes. Barcelona: Editorial Tiempo Contemporáneo.

ECO, Umberto. (1965). Obra Abierta. Barcelona: Seix-Barral.

ECO, Umberto. (1976). Signo. Barcelona: Editorial Labor.

ECO, Umberto. (1976). Tratado de Semiótica General. Milán: Lumen.

ECO, Umberto. (1981). Apocalípticos e Integrados. Barcelona: Lumen.

ECO, Umberto. (2005). Cómo se Hace una Tesis. Traducción de Lucía Baranda y Aberto Clavería Ibáñez. 6ª Ed. Barcelona: Editorial Gedisa.

EMPRESA BRASILEIRA DE TURISMO (EMBRATUR). (2009). Disponible en: http://www.embratur.gov.br/site/br/home/index.php. Acceso en 25 de octubre.

ESCANDEL VIDAL, M. V. (2008). Introducción a la pragmática. Barcelona: Ariel.

ESCRIBANO HERNÁNDEZ, Asunción. (2006). Lengua y Medios de Comunicación. Salamanca: Cervantes.

FERNÁNDEZ GÓMEZ, Jorge David. (2005: 89-112). Eslóganes, Jingles y Otras Frases Felices. Lenguaje Publicitario. $1^{\text {a }}$ Ed. Barcelona: Ariel.

FERNÁNDEZ, Eduardo. (2006) Retórica Clásica y Publicidad (Colección Quintiliano de Retórica y Comunicación). Logroño: Instituto de Estudios Riojanos.

FERRAZ MARTÍNEZ, A. (2000). El Lenguaje de la Publicidad.4ª Ed. Madrid: Arco Libros. 
FERRER RODRÍGUEZ, Eulalio. (1994). El Lenguaje de la Publicidad. México: Fondo de Cultura Económica.

FERRER ROSELLÓ, Clemente. (1996) Comunicación por Objetivos: La Publicidad. Pamplona: EUNSA.

FISCHER, Martina Eva. (2007). A persuasão na perspectiva da publicidade: algumas aproximações iniciais. In Sociedade Brasileira de Estudos Interdisciplinares da Comunicação, 30. Congresso Brasileiro de Ciências da Comunicação. Santos.

FUENTES RODRÍGUEZ, Catalina \& ALCAIDE LARA, E. R. (2002). Mecanismos Lingüísticos de la Persuasión. Madrid: Arco Libros.

FUENTES RODRÍGUEZ, Catalina. (2000). Lingüística Pragmática y Análisis del Discurso. Madrid: Arco Libros.

GIL, Antonio Carlos. (2002). Como Elaborar Projetos de Pesquisa. $4^{\mathrm{a}}$ Ed. São Paulo: Editora Atlas.

GODOI TRIGO, Luiz Gonzaga. (1993). Turismo e qualidade: tendências contemporâneas. $4^{\mathrm{a}}$ Ed. Campinas: Papirus.

GODOI TRIGO, Luiz Gonzaga. (1998). Turismo Básico. 2a Ed. São Paulo: Editora SENAC de São Paulo, (Série Apontamentos Turismo, 26).

GONÇALVES CORRÊA, Manoel Luiz. (2002). Linguagem e comunicação social: visões da lingüística moderna. São Paulo: Parábola.

GREIMAS, Algirdas Julien. (1993). La Semiótica del Texto. Ejercicios Prácticos: Análisis de un cuento de Maupassant. Barcelona: Ediciones Paidós Comunicación.

GUTIÉRREZ ORDOÑEZ, S. (1996). Presentación de la pragmática. Lección inaugural del curso académico 1996-1997. Universidad de León.

GUTIÉRREZ ORDOÑEZ, S. (1997a) Comentario Pragmático de Textos Polifónicos. Madrid: Arco Libros.

GUTIÉRREZ ORDOÑEZ, S. (1997b) Comentario Pragmático de Textos Publicitarios. Madrid: Arco Libros.

HABERMAS, Jürgen. (2003) Mudança Estrutural da Esfera Pública: investigações quanto a uma categoria da sociedade burguesa. Tradução de Flávio R. Kothe. Rio de Janeiro: Tempo Brasileiro.

HALliDAY, Tereza Lúcia. (1999). O que é Retórica? Coleção Primeiros Passos. São Paulo: Brasiliense. 
HASELOFF, O. W. (1969) Kommunikationtheoretische Probleme de Werbung, Handbuch der Werbung. Wiesbaden: Ed. Por k. Ch. Behrens, págs. 157200.

HAUGEN, Einar. (1972) The Ecology of Languaje. Essays by Einar Haugen. California: Standford University Press.

HERNANDO CUADRADO, L.A. (1984) El Lenguaje de la Publicidad. Madrid: Coloquio.

HOPKINS, Claude. (1993) A Ciência da Propaganda. Tradução de José Paulo Paes. $5^{\text {a }}$ Ed. São Paulo: Editora Cultrix Ltda.

ISENBERG, H. (1987: 95-129) Cuestiones Fundamentales de Tipología Textual. In E. Bernárdez. Lingüística del Texto. Madrid: Arco Libros.

JACKOBSON, Roman. (1981) Ensayos de Lingüística General. (Traducción de Josep M. Pujol y Jem Cabanes). Barcelona: Editorial Seix Barral.

JENSEN BRUHN, Klaus. (1997) La Semiótica Social de la Comunicación de Masas. Barcelona: Bosch Casa Editorial.

JORNAL PANROTAS. (2008). Apartado de política: BRASÍLIA Políticas do Turismo. Consulta en 03 y 09 de junio.

KOTLER PHILIP, Armstrong. (2003). Fundamentos de Marketing. México: Pearson Education.

LAGNEAU, Gérard. (1981). A sociologia da publicidade. Tradução de Heloysa de Lima Dantas. São Paulo: Cultrix, Ed. da Universidade de São Paulo.

LAUSBERG, HEINRICH. (1990) Manual de retórica literaria (versión de José Pérez Riesco). Madrid: Gredos.

LEECH, G. (1983) Principles of pragmatics. Londres: Longman.

LEFEBVRE, Henri. (1971) Introducción a la Modernidad. Madrid: Editorial Técnos.

LOPES JÚNIOR, Edmilson. (1997). A Construção Social da Cidade de Prazer: Urbanização turística, Cultura e Meio Ambiente em Natal (RN). Tese Apresentada ao Instituto de Filosofia e Ciências Humanas (IFCH) (Universidade Estadual de Campinas - UNICAMP), para a obtenção do título de Doutorado em Ciências Sociais. Campinas.

LÓPEZ EIRE, Antonio y SANTIAGO GUERVÓS, Javier de. (2000) Retórica y Comunicación Política. Madrid: Cátedra.

LÓPEZ EIRE, Antonio. (2003) La Retórica en la Publicidad. 2a Ed. Madrid: Arco Libros. 
MACHADO, Anna Rachel; LOUSADA, Eliane; ABREU-TARDELI, Lília Santos. (2007). Planejar Gêneros Acadêmicos. $2^{\text {a }}$ Ed. São Paulo: Parábola Editorial.

MACHADO, Anna Rachel; LOUSADA, Eliane; ABREU-TARDELI, Lília Santos.

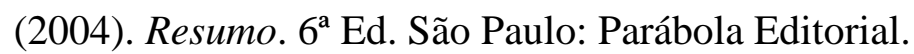

MACHADO, Anna Rachel; LOUSADA, Eliane; ABREU-TARDELI, Lília Santos. (2004). Resenha. $2^{\text {a }}$ Ed. São Paulo: Parábola Editorial.

MANETI DENCKER, Ada de Freitas. (2003.) Métodos e Técnicas de Pesquisa em Turismo. $7^{\text {a }}$ Ed. São Paulo: Futura.

MARCONDES FILHO, Ciro. (2004) O escravo de silêncios: formas de construir e de descontruir sentidos na comunicação: Nova teoria da comunicação II. São Paulo: Paulus.

MARCOS-MARÍN, Francisco (1994). Informática y Humanidades. Madrid: Gredos.

MARCOS-MARÍN, Francisco. (1990). El Comentario Lingüístico. Metodología y Práctica. Madrid: Ediciones Cátedra.

MARCOS-MARÍN, Francisco. (1996). El Comentario Filológico con Apoyo Informático. Madrid: Síntesis.

MARTÍNEZ, Antonio Ferraz (2000). El lenguaje de la publicidad. Madrid: Arco Libros.

MARTINS JR. Joaquim. (2008). Como Escrever Trabalhos de Conclusão de Curso: instruções para planejar e montar, desenvolver, concluir, redigir e apresentar trabalhos monográficos e artigos. Petrópolis: Vozes.

MATOS COSTA, Andréa Leite. (1993) Turismo: Uma Alternativa de Desenvolvimento Para Natal. Monografia Apresentada ao departamento de economia (Universidade Federal do Rio Grande do Norte - UFRN) para a obtenção do título de bacharel em Ciências Econômicas. Natal - RN.

MEENE RUSCHMANN, Doris Van de (1997). Turismo e Planejamento Sustentável: A Proteção do Meio Ambiente. Campinas: Papirus.

MEENE RUSCHMANN, Doris Van de (1999). Marketing Turístico: Um Enfoque Promocional. Coleção turismo. $4^{\mathrm{a}}$ Ed. Campinas: Papirus.

MENNA BARRETO, Roberto. (1978) Criatividade em Propaganda. 12 a Ed. Rio de Janeiro: Editora Documentário.

MESQUITA PRESTES, Maria Luci de (2002). A Pesquisa na Construção do Conhecimento Científico. São Paulo: Respel. 
MINISTÉRIO DO TURISMO. Disponible en:

http://www.turismo.gov.br/turismo/home.html. Acceso en 25 octubre de 2009.

MOLINÉ, Marçal. (1999). La Fuerza de la Publicidad. Madrid: Cuadernos 5 Días.

MOURELLE DE LEMA, M. (1994). El Lenguaje Publicitario. Aproximación a su Estudio. Madrid: Grugalma.

NATAL.(2004). Secretaria Especial de Comércio, Indústria e Turismo: Departamento de Indústria e Comércio. A Evolução Histórica da Sectur no Contexto Sócio-econômica da Cidade do Natal (1968-2004). Natal-RN.

NIETO CALLÉN, Eloísa. (2004). El Español del Turismo. Unversidad de Salamanca. Tesis Doctoral.

ORGANIZAÇÃO MUNDIAL DE TURISMO (OMT). Disponible en: http://www.unwto.org/media/news/sp/press_det.php?id=4951\&idioma=S . Acceso en 25 de octubre de 2009.

ORLANDI, Eni P. (2006). Introdução às ciências da linguagem - Discurso e textualidade/ suzy lagazzi-Rodrigues e Eni P. orlandi (orgs.). Campinas: Pontes Editores.

ORTEGA, Enrique (1997). La Comunicación Publicitaria. Madrid: Pirámide.

PARODI, Giovanni (2010). Lingüística de Corpus: de la Teoría a la Empiría. Editora Iberoamericana Vervuert, Madrid.

PÉNINOU, Georges (1976) Semiótica de la Publicidad. Prólogo Miguel de Moragas. Barcelona: Gustavo Gili.

PETERMANN, Juliana. (2006). Imagens na publicidade: significações e persuasão. Rio Grande do Sul: Unirevista, V. 1, n. 3, julho.

PILLEUX, Mauricio. (2001). Competencia Comunicativa y Análisis del Discurso. Estudios Filológicos. (Valdivia, Chile) No 36, pág. 143-152.

PINHO, J. B. (2006). Comunicação em marketing: Princípios da comunicação mercadológica. $8^{\mathrm{a}}$ Ed. Campinas: Papirus.

PLANTIN, Christian. (2002). La Argumentación. Traducción de Amparo Tusón Valls. $3^{a}$ Ed. Barcelona: Ariel Practicum.

PORTOLÉS, José. (1998). Marcadores del Discurso. Barcelona: Ariel.

PORTOLÉS, José. (2004). Pragmática para Hispanistas. Madrid: Síntesis.

POUND, Ezra. (1991). ABC of Reading. 9 ed. São Paulo: Cultrix. 
PROENÇA FILHO, Domício. (2007). A Linguagem Literária. $8^{\text {a }}$ Ed. São Paulo: Ática (Série Pincípios).

REAL ACADEMIA ESPAÑOLA. (2001). Didáctica de los Discursos Persuasivos: la Publicidad y la Propaganda. Madrid: La Muralla.

REJOWSKI, Mirian. (1996). Turismo e Pesquisa científica: Pensamento Internacional X Situação Brasileira. Campinas: Papirus.

REY, Juan. (1992). La Significación Publicitaria. Sevilla: Alfar.

REYZÁBAL, Ma Victoria. (2002). Didáctica de los Discursos Persuasivos: la Publicidad y la Propaganda. Madrid: La Muralla.

ROBLES ÁVILA, Sara. (2004). Realce y apelación en el lenguaje de la publicidad. Madrid: Arco Libros.

ROBLES ÁVILA, Sara. (2005:225-255). Sintaxis Publicitaria (II) (Lo Oracional). ) Lenguaje Publicitario. Barcelona: Ariel.

ROCA CORREA, David. (2005) El Espacio en el Mensaje Publicitario. Lenguaje Publicitario. Barcelona: Ariel.

RODRÍGUEZ FERNÁNDEZ, Ana María. (2005) Sintaxis Publicitaria (I). Lenguaje Publicitario. $1^{\text {a }}$ Ed. Barcelona: Ariel.

ROMERO GUALDA, María Victoria. (2005). La Palabra en los Mensajes Publicitarios. Lenguaje Publicitario. Barcelona: Ariel.

ROMERO GUALDA, María Victoria. (2005). Texto e Imagen en el Mensaje Publicitario. Lenguaje Publicitario. Barcelona: Ariel.

SALMON, Christian. (2008). Storytelling: La Máquina de Fabricar Historias y Formatear Mentes. Traducción de Inés Bértolo Fernández. Barcelona: Península.

SAMPAIO, Rafael. (1999). Propaganda de A a Z: como usar a propaganda para construir marcas e empresas de sucesso. $2^{\mathrm{a}}$ Ed. Rio de Janeiro: Campus.

SÁNCHEZ CORRAL, Luis. (1991a). Estructuras Semionarrativas en el Lenguaje de los Anuncios. Verba: Anuario Galego de Filoloxia. № 18, págs. 545-567.

SÁNCHEZ CORRAL, Luis. (1991b). Los Marcadores Deícticos en la Publicidad, una Estrategia del Discurso. Lingüística Española Actual (LEA) XIII. Págs. 133-151.

SÁNCHEZ CORRAL, Luis. (1991c). Retórica y Sintáxis de la Publicidad; (Itinerarios de la Persuasión). Publicac. Córdoba: Universidad de Córdoba, D.L. 
SÁNCHEZ CORRAL, Luis. (2001). La Imagen de Marca, Semiótica y Programas Narrativos en La Semiótica Actual. Sevilla: Ed. Alfar, págs. 203-216.

SANT'ANNA, Armando. (2002). Propaganda: teoria, técnica e prática. $7^{\mathrm{a}} \mathrm{Ed}$. São Paulo: Pioneira Thompson Learning.

SANTAELLA, Lúcia \& NÖTH, Winfried (1999). Imagem: Cognição, semiótica, mídia. 2.ed. São Paulo: Iluminuras.

SANTIAGO GUERVÓS, Javier de (2005). Principios de Comunicación Persuasiva. Madrid: Arco Libros.

SANTIAGO GUERVÓS, Javier de (2008). Comentario de Textos Persuasivos. Madrid: Arco Libros.

SEARLE, John (1969). Actos de habla. Madrid: Cátedra.

SECRETARIA DE TURISMO DO RIO GRANDE DO NORTE/SETUR. (2009).

Disponible en: http://www.brasil-natal.com.br/setur_estatisticas.php. Acceso en 25 de octubre.

Secretaria Estadual de Turismo (SETUR). (1996). Natal-RN.

SECRETARIA MUNICIPAL DE PLANEJAMENTO, ORÇAMENTO E FINANÇAS/SECTUR. (2009). Disponible en:

http://turismo.natal.rn.gov.br/paginas/ctd-1.html. Acceso en 25 de octubre.

SOUZA, Itamar.(1999). O Turismo no RN antes da Via Costeira. Diário do RN, n.11.

SPANG, Kurt. Publicidad y Retórica. (2005). Lenguaje Publicitario. $1^{\text {a }}$ Ed. Barcelona: Ariel.

SPANG, Kurt. Repertorio de Recursos Retóricos. (2005). Lenguaje Publicitario. $1^{\text {a }}$ Ed. Barcelona: Ariel.

SPERBER \& WILSON (1986). La relevancia. Madrid: Visor.

TOGNOLLI, Claudio (2001). A Sociedade dos Chavões: Presença e Função do Lugarcomum na Comunicação. São Paulo: Escrituras Editora.

URRY, John. (1996). O Olhar do Turista: Lazer e Viagens nas Sociedades Contemporâneas. Tradução Carlos Eugênio Marcondes de Moura. São Paulo: Studio Nobel, SESC (Coleção megalópolis).

VAN DIJK, Teum A. (1989). La Ciencia del Texto: Un Enfoque Interdisciplinario. Traducción de Sibila Hunzinger. Barcelona: Paidós.

VAN DIJK, Teum A. (1990). Texto y Contexto. Semántica y Práctica del Discurso. Madrid: Cátedra. 
VELA VALLDECABRES, Daniel. (2005) Conocimiento del Destinatario. Dimensión Ética del Mensaje Publicitario. Lenguaje Publicitario. $1^{\circ}$ ed. Barcelona: Ariel.

VELÁSQUEZ GARZA, Hilda. (2007). Condicionantes Culturales de la Publicidad para Hispanos en los Estados Unidos. Tesis Doctoral. Salamanca: Universidad de Salamanca.

VELlOZO, Sérgio Luís. (1969). Teoria Geral da Comunicação Coletiva. Rio de Janeiro: O Cruzeiro.

VIANA DE SÁ, Rosana Bignami (2002). A Imagem do Brasil no Turismo: Construção, desafios e vantagem competitiva. São Paulo: Aleph.

VILARNOVO, Antonio. (2005 Pp 43-63) Aspectos Semióticos de la Publicidad. Lenguaje Publicitario. Ariel: $1^{\circ}$ ed. Barcelona: Ariel.

WOLF, Mauro. (2003). Teorias das Comunicações de massa. São Paulo: Martins Fontes. 
ANEXOS (CD-ROM ADJUNTO)

Anexo: Corpus 